\title{
Design Documentation: Krypton Encapsulation Preconceptual Design
}

Ralph M. Parsons Company

D. A. Knecht (INEL Contact)

October 1994

Lockheed Idaho Technologies Company

PREPARED FOR THE DEPARTMENT OF ENERGY IDAHO OPERATIONS OFFICE

UNDER CONTRACT DE-ACO7-94ID13223 


\section{DISCLAMISR}

Portions of this document may be illegible in electronic image products. Images are produced from the best available original document. 
FOREWORD

This report represents work performed by The Ralph M. Parsons Company under Contract No. DE-AC07-81ID12176 (Task No. 81-3) with the U.S. Department of Energy (DOE), with technical guidance provided by Exxon Nuclear I daho Company, Inc., (ENICO), Idaho National Engineering Laboratory, and by Battelle, Pacific Northwest Laboratories.

This report presents preconceptual designs, process evaluations, and life cycle costing data for comparison of two aiternate candidate processes for encapsulation of Krypton-85 released during reprocessing of commercial irradiated nuclear fuels. 
The following table presents various parameters as identified in this report for comparison of the two alternate candidate processes.

\section{PARAMETER}

1. Process Conditions

2. Process Units

3. Product Form

4. Product Size

5. $\mathrm{Kr}^{85}$ in Process as Gas

6. Product Throughput

7. Required Availability

8. Remote Operations/ Product Batch

9. Processing Time

10. Hrs./Product Batch

11. Building Floor Area

12. Total Air Supply

13. Demand Power

14. Developments Needed

15. Licensing Concerns

16. Capital Costs

a) Improv. to Land

b) Building

c) Equipment Total

17. Energy Consumption
a) Annual
b) Per Product Batch
c) Per Mole of Gas

18. Life Cycle Costs ( 30 years)

a) Initial Investment

b) Energy Cost

c) Operating Manpower

d) Operating Materials

e) Maintenance Mat ls.

f) Insurance Costs

Total Life Cycle Costs 19. Feasibility

$\frac{\text { ION IMPLANTATION/ }}{\text { SPUTTERING }}$

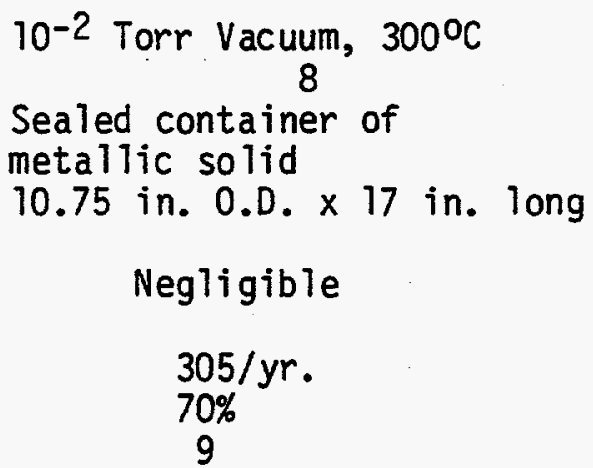

129 hrs.

16 hrs.

$7,138 \mathrm{SF}$

77,000 CFM

$539 \mathrm{KVA}$

1.8 scale-up, remote operation, power supplies, target/substrate assemblies.

60 day lag storage, but may not be needed

$$
\begin{array}{r}
53,100 \\
6,684,400 \\
3,602,500 \\
\hline \$ 10,340,000
\end{array}
$$

$$
\begin{array}{r}
3,880,800 \mathrm{KW}-\mathrm{hr} \\
12,724 \mathrm{KW}-\mathrm{hr} \\
384 \mathrm{KW}-\mathrm{hr}
\end{array}
$$

$$
\begin{array}{r}
\$ 9,306,000 \\
1,935,588 \\
6,639,350 \\
7,648,283 \\
690,568 \\
105,327 \\
\$ 26,430,684
\end{array}
$$

Viable with $5 \mathrm{Yr}$. Development Program
ZEOLITE ENCAPSULATION

14,700 psia, $700^{\circ} \mathrm{C}$

Doubly contained pellets

8.625 in. 0.D. $\times 20$ in. long

$45,000 \mathrm{Ci}$

$600 / \mathrm{yr}$.

$83 \%$

10

12 hrs.

12 hrs.

4,368 SF

6,700 CFM

258 KVA

Commercial scale of equipment, scale-up from tests, $\mathrm{N}$-stamp equipment

60 day lag storage, process vessel

$$
\begin{array}{r}
51,000 \\
5,560,400 \\
4,518,600 \\
\$ 10,130,000 \\
1,857,600 \mathrm{KW}-\mathrm{hr} \\
3,096 \mathrm{KW}-\mathrm{hr} \\
179 \mathrm{KW}-\mathrm{hr}
\end{array}
$$
$\$ 9,117,000$ 926,494
$6,775,860$
$4,094,059$
884,353
103,117
$\$ 21,900,883$
Viable with $5 \mathrm{yr}$.
Development Program 


\section{TABLE OF CONTENTS}

SECTION 1 INTRODUCTION

SECTION 2 GENERAL CRITERIA

SECTION 3 PROCESSES AND EQUIPMENT

3.1 Ion Implantation/Sputtering

3.1.1 Process Description and Equipment

3.1.2 Lag Storage Equipment

3.1.3 Substrate Handling and Sealing

3.1.4 Product Storage and Handling

3.2 Zeolite Encapsulation

3.2.1 Process Description and Equipment

3.2.2 Lag Storage Equipment

3.2.3 Substrate Handling and Sealing

3.2.4 Product Storage and Handing

SECTION 4 BUILOINGS AND BUILDING SERVICES

4.1 I on Implantation/Sputtering

4.1.1 Building Description

4.1.2 Heating and Ventilating

4.1.3 Electrical

4.2 Zeolite Encapsulation

4.2.1 Building Description

4.2.2 Heating and Ventilating

4.2.3 Electrical

SECTION 5 FEASIBILITY EVALUATIONS

5.1 General

5.2 I on Implantation/Sputtering

5.3 Zeolite Encapsulation

5.4 Conclusions

SECTION 6 LICENSIBILITY 
SECTION 7 LIFE CYCLE COSTING ANALYSIS

7.1 Bas is and Approach

7.2 Ion Implantation/Sputtering

7.3 Zeolite Encapsulation

7.4 Conclusions

APPENDICES

A. Drawing List and Drawings

B. Major Equipment List

C. Outline Specifications

D. Calculations

E. Cost Estimates 


\section{SECTION 1}

\section{INTRODUCTION}

U.S. EPA regulations limit the release of Krypton-85 to the environment from commercial facilities after January 1, 1983. In order to comply with these regulations, Krypton-85, which would be released during reprocessing of commercial nuclear fuel, must be collected and stored. Technology currently exists for separation of krypton from other inert gases, and for its storage as a compressed gas in steel cylinders. The requirements, which would be imposed for 100-year storage of Krypton-85, have led to development of processes for encapsulation of krypton within a stable solid matrix. The objective of this effort was to provide preconceptual engineering designs, technical evaluations, and life cycle costing data for comparison of two alternate candidate processes for encapsulation of Krypton-85. This report has been prepared by The Ralph M. Parsons Company for the U.S. Department of Energy.

The general bases for this effort are contained within the Statement of Work for Preconceptual Design, Process Feasibility, and Economic Analys is for Krypton Encapsulation Facilities, December 3, 1980.

Preconceptual designs, process evaluations, and life cycle costing data are provided for facilities utilizing the following alternate processes:

\section{(1) I on Implantation/Sputtering Encapsulation}

(2) Zeolite Encapsulation

Process throughput capacities for the encapsulation facilities considered in this report are based on $110 \%$ of an estimated $17 \times 10^{6}$ curies/year of Krypton-85 released from a plant reprocessing 2000 MTHM/year of LWR fuels. The process gas feed stream is assumed to consist of $2 \%$ xenon, $8 \%$ argon, and $90 \%$ krypton by volume, with Krypton-85 making up $6 \%$ of the total krypton, based on the capabilities of existing technology for cryogenic noble gas separation. The facilities are required to operate 24 hours/day for 300 days/year, with a useful life of at least 30 years.

The process and equipment sizes selected for the alternate encapsulation processes are based only on a viable size basis for the required throughput. No attempt has been made to optimize, either on the bas is of capital or life cycle costs. For either process there is a wide range of combinations of units, sizes, and substrate materials, all of which will satisfy the requirements. Therefore, this report should be used for comparing the two processes only. Optimization studies, as part of a conceptual or preliminary design effort, will better define the actual costs of implementing krypton encapsulation on a commercial scale. 


\section{SECTION 2}

\section{GENERAL CRITERIA}

The following general criteria apply to the preconceptual design of the encapsulation facilities, and are the basis for the process evaluations and life cycle costing data.

1. The encapsulation facility will be a stand-alone facility located in the vicinity of a cryogenic noble gas separation facility as part of a commercial nuclear fuel reprocessing plant.

2. The commercial nuclear fuel reprocessing plant is assumed to be located at the Oak Ridge National Laboratory (ORNL) at Oak Ridge, Tennessee, for cost estimating purposes.

3. All utility services and power will be provided to the encapsulation facility through the reprocessing plant.

4. The design, installation, and operation of the encapsulation facility will conform to the applicable federal nuclear regulations and the applicable federal, state, and local industrial codes and standards. The encapsulation facility will be licensed by the Nuclear Regulatory Commission (NRC).

5. The encapsulation facility will be designed and operated to limit radiation exposure of personnel to "as low as reasonably achievable" (ALARA), in accordance with the requirements of the NRC.

6. The encapsulation facility will be designed, to the extent practical, for remote operation, and for contact maintenance after remote decontamination.

7. The encapsulation facility will include equipment and provisions for storage of up to 60 days operational supply of feed gas.

8. The encapsulation facility will include equipment and provisions to store the encapsulated Krypton-85 due to operation for up to one year.

9. Encapsulated product from the encapsulation facility will be compatible with the storage concepts reported in SAND 80-0122, "Krypton-85 Disposal Program Annual Report, October 1, 1978 to September 30, 1979", based on studies for a spent unreprocessed fuel (SURF) storage facility. 
SECTION 3

PROCESSES AND EQUIPMENT

\subsection{ION IMPLANTATION/SPUTTER ING}

\section{1 .1 PROCESS DESCRIPTION AND EQUIPMENT}

Ion implantation is a process by which gases can be implanted into solids by bombarding the surface of the solid with energetic ions. For positively charged krypton ions, created by collisions between energetic electrons and krypton gas atoms, the depth of implantation amounts to only a few atom layers for ion energies in the keV range.

Sputter deposition is a film growth vapor deposition process in which a substrate is uniformly coated with a solid. The coating is initiated by accelerating positively charged ions to the surface of a target, resulting in sufficient momentum transfer to overcome the binding energy of the target atoms in their lattice.

In combining these processes, a dense thermionically supported plasma is created in the annulus between the target and the substrate. Positively charged krypton ions are accelerated to the target by applying a large negative voltage to the target, so that the krypton ions act as the sputtered ions. The krypton ions are also accelerated to the substrate to implant in the sputtering deposit by applying a lessor negative voltage to the substrate. Implanted krypton ions are entrapped by the growing sputtered deposit. The resulting deposited solid, based on analys is of laboratory scale process deposits, incorporates up to $12.9 \%$ krypton by weight.

The krypton encapsulation facility design (see Appendix D-7) is based on using eight process units. Each unit operates as a batch process, with a calculated processing time of 129 hours, and entraps 34.06 moles (763 liters at standard conditions) of krypton in each deposit. The equipment would operate 24 hours per day, 300 days per year, with a required availability of approximately $70 \%$ while the facility is in operation.

The substrate is a standard 10-inch stainless steel pipe and pipe cap, which, when seal welded after processing, provides containment of the encapsulation deposit. The target is a standard 6-inch steel pipe and pipe cap which is initially coated with 1.30 centimeters of $79 \%$ nickel and $27 \%$ lanthanum by weight, and will result in a 1.0 centimeter thick sputtering deposit. The plasma is initiated by electrons emitted from a tungsten filament in the annulus between the target and the substrate. Cooling water for heat removal during processing is provided to the interior of the target and to the exterior of the substrate. Electrical insulators are provided on a 11 connections and to isolate the target, substrate, and filament from each other. These assemblies will be fabricated, factory tested, and shipped to the encapsulation facility as an assembled unit. A total of 305 assemblies per year are utilized to encapsulate 10,380 moles $(232,500$ liters at standard conditions) of feed gas per year. 
The primary supporting equipment to the process are the power supplies and current limiters and controls for the target, substrate, and filament, vacuum pumps, and cooling systems. A list of major equipment for I on Implanation/Sputtering is given in Appendix B-1.

\subsubsection{LAG STORAGE EQUIPMENT}

The facility is required to include the capability to store up to 60 days operational supply of feed gas $(46,500$ liters at standard conditions). The lag storage equipment is based on storage at 500 psig gas pressure. The equipment consists of a bank of pressure vessels, each constructed of 12-inch Schedule $80 \mathrm{~S}$ pipe by $12^{\prime} 0^{\prime \prime}$ long. A total of eight vessels is required to provide the necessary capacity. The vessels are arranged horizontally in a two wide by four high array. Calculations (see Appendix $\mathrm{D}-3$ ) show that natural convection will remove the heat generated by radioactive decay of Krypton-85, and will maintain the temperature of the stored gas at less than 250 $\mathrm{F}$. Based on ENICO-1081, "Materials Screening Tests for the Krypton-85 Storage Development Program-Final Report", ApriT, 1981, the storage vesse1s wi 11 be constructed of Type $316 \mathrm{~L}$ stainless stee 1 to provide corrosion resistance to rubidium, the decay product of Krypton-85, and compounds of rubidium, and to allow decontamination.

\subsubsection{SUBSTRATE HANDLING AND SEALING}

New target/substrate assemblies are received at the facility and stored in the substrate storage area. A total of 305 target/substrate assemblies are used each year. During processing, shielding is required for the encapsulation deposit, which contains a 1 arge quantity of radioactive krypton, to allow maintenance on other units within the cell. A lead lined shielding assembly is provided which also acts as a cooling jacket around the target/substrate assembly during processing.

New target/substrate assemblies can be installed in the cell either manually or remotely. A shielding assembly is placed on a mini-trailer robo-carrier with the overhead bridge crane which spans the cell. The robo-carrier is a remotely controlled cart and platform lift assembly, with pre-programed positioning capability. A new target/substrate assembly is placed in the shielding assembly, manually or with the use of the bridge crane. The robo-carrier then moves to the appropriate station, and lifts the assembly upward, mating with electrical and piping connections, and locking in position.

After processing, the robo-carrier returns to the processing station, the assembly is remotely unlocked, and is lowered and moved away to the welding station. The bridge crane is used to lift the target/substrate assembly, which now includes encapsulated krypton, and position it for welding. A lid is welded to the target/substrate assembly with a fully remotely operated welder, assisted or maintained by two Model "F" type master-slave manipulators. A shielding viewing window is provided to allow operator supervision of welding.

After welding, the product canister is replaced on the robo-carrier with the bridge crane, and moved to the inspection station. The lid weld is visually inspected through a shielding viewing window. The 
product canister is purged and filled with helium, through a connection provided for this purpose, and the lid weld is helium leak tested. If required, the weld could also be dye penetrant inspected. The remote equipment is assisted or maintained by two Model "F" type master-slave manipulators. The product canister is now ready for storage.

These operations for substrate handling and sealing are not ideal from the standpoint of remote operations, but recognizing that they are performed on an average of only once every 16 hours, and that a more elaborate scheme would be less reliable and considerably more expensive, these operations are considered to be appropriate.

\subsubsection{PRODUCT STORAGE AND HANDLING}

Completed product canisters are stored for up to one year within the facility. The product canister is placed horizontally in a cradle on the robo-carrier. The robo-carrier is moved out of the process cell into the product load-in area, and is positioned and lifts the canister to a pre-selected storage location. A pneumatic piston is used to push the canister into the storage rack.

The storage rack holds product canisters in a horizontal array, to allow cooling by natural convection. Calculations (see Appendix D-5) show that natural convection will remove the heat generated by radioactive decay of Krypton-85, and will maintain the temperature of the stored product at less than $250^{\circ} \mathrm{F}$. The storage rack is $26 \mathrm{ft}$. -0 in. long, and stores canisters in a six by six array, for a total of 468 available storage positions. Product canisters are stored 15 inches on center in the array, with a maximum of 13 canisters in each position.

The storage positions consist of a pair of lines of rollers, one each at 45 degrees in each lower quadrant. The rollers are spaced with two together on 6 inch centers, for a total of 208 rollers at each storage position ( 36 positions). The rollers are constructed of Nitronic 60 material, for decontaminability and non-galling, and are each held in a bracket by a through bolt. The roller/bracket assemblies are mounted on 4 inch angles, (total of 72 , two for each position) which are mounted in a frame of angle columns, (total of 35, in five rows of seven at about $5 \mathrm{ft} .-0$ in. center-to-center). The storage rack, except for rollers, is constructed of $304 \mathrm{~L}$ SS.

Inserted product canisters push other canisters in the same position along the length of the storage rack. Canisters are inserted sequentially by storage position. When the storage rack is filled, the oldest 36 product canisters are exposed at the $f$ ar end of the storage rack. A second mini-trailer robo-carrier, which is also a spare for the process robo-carrier, is used to retrieve the oldest product canisters for shipment to long-term storage. 


\subsection{ZEOLITE ENCAPSULATION}

\subsubsection{PROCESS DESCRIPTION AND EQUIPMENT}

Gases can be entrapped by sintering in solids such as zeolite or vycor which have molecular defects in their structure. Krypton gas can be diffused into the solid, and encapsulated in a structural vacancy when the molecular lattice of the solid substrate is sintered at high temperatures. The encapsulation facility design is based on the use of zeolite $5 \mathrm{~A}$ as the substrate, due to the relatively much higher cost of vycor (see Appendix D-9).

Encapsulation of krypton in zeolite requires high pressure and moderate temperature. The base case utilized for design of the encapsulation facility consists of a working volume of 8 liters loaded with 7,750 cubic centimeters of compacted zeolite $5 \mathrm{~A}$ pellets. The process will operate in a batch sequence, with each batch encapsulating 17.3 moles (387.5 liters at standard conditions) of gas when held at a pressure of 1000 atmospheres $(14,700 \mathrm{psia})$ and $700^{\circ} \mathrm{C}$ for 2 hours. Each batch, including loading, pressurization, heating, processing, cooling, depressurization, purging, and unloading is estimated to take 10 hours. A total of 600 batches per year are utilized to encapsulate 10,380 moles (232,500 liters at standard conditions) of feed gas (see Appendix D-7). Assuming a single unit, the process wi11 operate 24 hours per day, 300 days per year, with a required availability of approximately $83 \%$ while the facility is in operation.

The process equipment is an application of commercial hot isostatic pressing equipment. The pressure vessel is a cooled shell with a capacity of 30 liters (approximately 12 in. dia. $x 16$ in. high), with a top plug. The pressure vessel is estimated to be 6 inches thick. A moveable yoke is used to restrain the plug during operation and to provide partial protection from vessel fragments in the event of a rupture. The interior of the vessel contains electrical heating for the substrate container.

The substrate container is a thin-walled cylinder, constructed of Type $316 \mathrm{~L}$ stainless steel, with a volume of 8.8 1iters (7 in. dia. $\times 14$ in. high). The differential pressure across the container wall is maintained at 50 psig or less by pressurizing the annulus between the pressure vessel and the substrate container with helium.

The primary supporting equipment to the process are compressors and controls for pressurization of the system, vacuum pumps, and cooling systems. A list of major equipment for Zeolite Encapsulation is given in Appendix $B-2$.

\subsubsection{LAG STORAGE EQUIPMENT}

The facility is required to include the capability to store up to 60 days operational supply of feed gas $(46,500$ liters at standard conditions). The lag storage equipment is based on storage at 500 psig gas pressure. The equipment consists of a bank of pressure vessels, each constructed of 12-inch Schedule 80 s pipe by $12^{\prime} 0$ " long. A total of eight 
vessels is required to provide the necessary capacity. The vessels are arranged horizontally in a two wide by four high array. Calculations (see Appendix D-3) show that natural convection will remove the heat generated by radioactive decay of Krypton-85, and will maintain the temperature of the stored gas at less than 2500F. Based on ENICO-1081, "Materials Screening Tests for the Krypton-85 Storage Development Program-Final Report", April, 1981, the storage vesse1s will be constructed of Type 316L stainless steel to provide corrosion resistance to rubidium, the decay product of Krypton-85, and compounds of rubidium, and to allow decontami nation.

\subsubsection{SUBSTRATE HANDLING AND SEALING}

New substrate assemblies are received at the facility and stored in the substrate storage area. A total of 600 substrate assemblies are used each year. During processing, the heavy-wall pressure vessel provides adequate shielding for the encapsulated product, which contains a 1 arge quantity of radioactive krypton. However, personnel will not enter the cell due to the extremely high processing pressure, and danger in the unlikely event of equipment/piping failure.

New substrate assemblies can be installed in the cell either manually or remotely. The overhead bridge crane which services the cell places the assembly in one of two substrate activation furnaces, for drying and preheating. Activation is estimated to take 12 hours. When ready for processing, the vessel yoke is retracted, the vessel top plug is removed, and the bridge crane places the substrate assembly in the Hot Isostatic Press.

After processing, the vessel yoke and plug are again removed. The bridge crane is used to lift the substrate assembly, which now includes encapsulated krypton, and position it for welding. A lid is welded to the substrate assembly with a fully remotely operated welder, assisted or maintained by two Model "F" type master-slave manipulators. A shielding viewing window is provided to allow operator supervision of welding. The substrate assembly is placed in a carbon steel pipe overpack, and a lid is welded to the overpack to form the product canister.

After welding, the bridge crane moves the product canister to the inspection station. The lid weld is visually inspected through a shielding viewing window. The product canister is purged and filled with helium, through a connection provided $f$ or this purpose, and the lid weld is helium leak tested. If required, the weld could also be dye penetrant inspected. The remote equipment is assisted or maintained by two Model "F" type master-slave manipulators. The product canister is now ready for storage.

These operations for substrate handiing and sealing are not ideal from the standpoint of remote operations, but recognizing that they are performed on an average of only once every 12 hours, and that a more elaborate scheme would be less reliable and considerably more expensive, these operations are considered to be appropriate. 
Completed product canisters are stored for up to one year within the facility. The bridge crane places the product canister horizontally in a cradle on a mini-trailer robo-carrier. The robo-carrier is a remotely controlled cart and platform lift assembly, with pre-programed positioning capability. The robo-carrier is moved out of the process cell into the product load-in area, an is positioned and lift's the canister to a pre-selected storage location. A pneumatic piston is used to push the canister into the storage rack.

The storage rack holds product canisters in a horizontal array, to allow cooling by natural convection. Calculations (see Appendix D-8) show that natural convection will remove the heat generated by radioactive decay of Krypton-85, and will maintain the temperature of the stored product at less than $250 \mathrm{O} F$. The storage rack is $26 \mathrm{ft} .-0$ in. long, and stores canisters in a seven by seven array, for a total of 637 available storage positions. Product canisters are stored 12 inches on center in the array, with a maximum of 13 canisters in each position.

The storage positions consist of a pair of lines of rollers, one each at 45 degrees in each lower quadrant. The rollers are spaced with two together on 6 inch centers, for a total of 208 rollers at each position (49 positions). The rollers are constructed of Nitronic 60 material for decontaminability and non-galling, and are each held in a bracket by a through bolt. The roller/bracket assemblies are mounted on 4 inch angles (total of 98 , two for each position), which are mounted in a frame of angle columns (total of 40 , in five rows of 8 at about $5 \mathrm{ft} .-0$ in. center-to-center). The storage rack, except for rollers, is constructed of 304L SS.

Inserted product canisters push other canisters in the same position along the length of the storage rack. Canisters are inserted sequentially by storage position. When the storage rack is filled, the oldest 49 product canisters are exposed at the far end of the storage rack. A second mini-trailer robo-carrier, which is also a spare for the in-cell robo-carrier, is used to retrieve the oldest product canisters for shipment to long term storage. 


\section{SECTION 4}

\section{BUILDINGS AND BUILDING SERVICES}

\subsection{ION IMPLANTATION/SPUTTER ING}

\subsubsection{BUILDING DESCRIPTION}

The Ion Implantation/Sputtering Facility is a rectangular building with overall dimensions of $89 \mathrm{ft} .-0$ in. by $50 \mathrm{ft} .-6$ in. The building is constructed of reinforced concrete for all areas required to survive design basis natural phenomena. Other areas of the building are constructed of reinforced masonry concrete block walls with roofing over metal decking supported by structural steel beams, and are required to survive operating basis natural phenomena. Areas required to survive design bas is natural phenomena are those areas of the building necessary for containment of Krypton-85. Preconceptual drawings of the Ion Implanation/Sputtering Facility are contained in Appendix A. Outline specifications of the facility materials and equipment are contained in Appendix $\mathrm{C}-1$.

The facility is on two levels, with power supplies to the process and heating and ventilating equipment located on the second level, which is $89 \mathrm{ft} .-0 \mathrm{in}$. by $29 \mathrm{ft} .-6 \mathrm{in}$. The total floor area of the facility is 7,138 square feet.

All exterior walls of the building are covered with insulated metal siding. The building roof is an "inverted" type, consisting of asphalt felt layers, insulation, and roofing aggregate.

\subsubsection{Process Ce11}

The Process Cell is $34 \mathrm{ft} .-0$ in. long by $13 \mathrm{ft} .-6$ in. wide by $12 \mathrm{ft} .-0$ in. high constructed of 12 in. thick reinforced concrete walls and ceiling, and a 6 in. thick concrete floor supported by compacted backfill and concrete footings. The cell. is designed to provide shielding from radiation exposure to personnel. Shielding viewing windows are provided for remote operations, substrate inspection, and substrate sealing. An overhead bridge crane services the Process Cell for loading, unloading, and transporting substrate containers.

\subsubsection{Gas Storage Area}

The Gas Storage Area is $16 \mathrm{ft} .-6 \mathrm{in}$. long by 13 $\mathrm{ft} .-6 \mathrm{in}$. wide by $12 \mathrm{ft} .-0$ in. high constructed of $12 \mathrm{in.}$ thick reinforced concrete walls and ceiling and a 6 in. thick concrete floor supported by compacted backfill and concrete footings. The Gas Storage Area is designed to provide shielding for the Lag Storage Equipment, which may contain 60 days operational supply of feed gas, and to provide protection from the accidental rupture of the storage vessels. 


\subsubsection{Interim Product Storage Area}

The Inter im Product Storage Area is $26 \mathrm{ft} .-0$ in. long by $13 \mathrm{ft} .-0$ in. wide by $12 \mathrm{ft} .-0$ in. high constructed of reinforced concrete walls and ceiling and a 6 in. thick concrete floor supported by compacted backfill and concrete footings. The Interim Product Storage Area is designed to provide shielding for encapsulated product due to operation for one year. Shielding hatches are provided for access for maintenance.

\subsubsection{Support Areas}

design are as follows:

Other Support Areas included in the building

(1) Substrate and Container Storage. $19 \mathrm{ft} .-6$ in. long by $15 \mathrm{ft} .-0$ in. wide by $9 \mathrm{ft} .-0$ in. high, constructed of masonry concrete block exterior walls, metal studs and gypsum board interior walls, and suspended plaster ceiling.

(2) Health Office. $13 \mathrm{ft} .-0 \mathrm{in}$. long by $8 \mathrm{ft} .-6$ in. wide by $9 \mathrm{ft},-0$ in. high, constructed of masonry concrete block exterior walls, metal studs and gypsum board interior walls, and suspended acoustical ceiling.

(3) Decontamination Area. $13 \mathrm{ft} .-0$ in. long by $6 \mathrm{ft} .-0$ in. wide by $9 \mathrm{ft} .-0$ in. high, constructed of metal studs and Type " $X$ " gypsum board walls and suspended plaster ceiling, with an enclosed shower with ceramic tile floor and walls.

(4) Operating Gallery. $20 \mathrm{ft} .-6$ in. long by 20 ft. -6 in. wide by $9 \mathrm{ft} .-0$ in. high, constructed of masonry concrete block exterior walls, metal studs and gypsum board interior walls, and suspended acoustical ceiling.

(5) Supervisor's Office. $12 \mathrm{ft} .-0$ in. long by $10 \mathrm{ft} .-0$ in. wide by $9 \mathrm{ft} .-0 \mathrm{in}$. high, constructed of masonry concrete block exterior walls, metal studs and gypsum board interior walls, and suspended acoustical ceiling. Includes an $11 \mathrm{ft} .-0 \mathrm{in}$. 1 ong by $4 \mathrm{ft} .-0$ in. high glass window to the Operating Gallery.

(6) Electrical and HVAC Area. $87 \mathrm{ft} .-0$ in. long by $27 \mathrm{ft} .-6$ in. wide by $12 \mathrm{ft} .-0$ in. high, (second level), constructed of reinf orced concrete floor, walls, and ceiling.

(7) Electrical and Equipment Area. $28 \mathrm{ft.}-6$ in. long by $27 \mathrm{ft} .-6 \mathrm{in}$. wide by $12 \mathrm{ft} .-0 \mathrm{in}$. high, (first level), constructed of reinforced concrete floor, walls, and ceiling.

(8) Product Storage Load-In Area. $13 \mathrm{ft} .-0$ in. long by $8 \mathrm{ft} .-0$ in. wide by $12 \mathrm{ft} .-0 \mathrm{in}$. high, constructed of reinforced concrete floor, walls, and ceiling.

(9) Product Load-Out Area. $15 \mathrm{ft} .-6$ in. long by $13 \mathrm{ft} .-0$ in. wide by $12 \mathrm{ft} .-0 \mathrm{in}$. high, constructed of reinforced concrete floor, walls, and ceiling. 
(10) Restroom and Locker Area. $18 \mathrm{ft} .-6$ in. long by $15 \mathrm{ft} .-0$ in. wide by $9 \mathrm{ft} .-0$ in. high, constructed of masonry concrete block exterior walls, metal studs and Type " $X$ " gypsum board interior walls, and suspended plaster ceiling.

\subsubsection{HEATING AND VENTILATING}

Three Heating and Ventilating Systems are provided for the Ion Implantation/Sputtering Facility. One system services the HVAC and Electrical Equipment Areas. A second system services the non-contaminated operating areas, consisting of the offices, the Operating Gallery, and the Restroom and Locker Area. A third system services the potentially contaminated areas, consisting of the Process Ce11, Gas Storage Area, Inter im Storage Area, Substrate and Container Storage, Product Storage Load-In Area, and Product Load-Out Area. As shown on Drawing V-1, the Heating and Ventilating Systems for the non-contaminated operating areas and for the potentially contaminated areas utilize common supply and exhaust air systems.

The Heating and Ventilating System for the HVAC and Electrical Equipment Areas provides a maximum of $72,000 \mathrm{cfm}$ (summer) and a minimum of $9,000 \mathrm{cfm}$ (winter) through four $25 \%, 15 \mathrm{hp}$ vent fans. Air is exhausted through four 18,000 cfm maximum capacity roof ventilators. Steam unit heaters are provided, with 50,000 Btu/hr. capacity, for space heating.

The Heating and Ventilating Systems for the non-contaminated operating areas and for the potentially contaminated areas are once through air flow systems, designed to maintain confinement zones based on differential air pressure to ensure air flow from less contaminated to more contaminated areas. Ventilation and temperature control will provide a suitable working environment in areas occupied by personnel. Air filtration is employed to reduce potential radioactive contaminants in the effluent to "as low as reasonably achievable" (ALARA) prior to discharge to the environment.

The supply air system, which provides approximately 5,000 cfin to the non-contaminated and potentially contaminated systems, consists of two 100\% (one standby) supply fans. Each supply air plenum includes a tornado shut-off valve, a steam preheat coil, $30 \%$ efficiency roughing and $80 \%$ efficiency pre-filters, backdraft damper, air flow monitor, and flow control damper. $100 \%$ outside air is supplied to the non-contaminated system and the potentially contaminated system.

Approximately $1200 \mathrm{cfm}$ is supplied to the non-contaminated operating areas through a steam heating coil and a refrigerant cooling coil. Approximately $200 \mathrm{cfm}$ is directed to the vestibule, and by infiltration to the Restroom and Locker Area, and is exhausted by exfiltration and by a powered roof ventilator. $1000 \mathrm{cfm}$ is directed to the offices and the Operating Gallery, and is exhausted through the exhaust air system. The offices are maintained at -0.10 in. water gauge air pressure. The Operating Gallery is maintained at $-0.20 \mathrm{in}$. water gauge air pressure. 
Approximately $3800 \mathrm{cfm}$ is supplied to the potentially contaminated areas. Approximately $3200 \mathrm{cfm}$ is supplied directly to the Process Cell through heating/cooling coils. $600 \mathrm{cfm}$ is supplied to the Load-Out Area, the Gas Storage Area, and the Substrate and Container Storage Area, which are maintained at -0.10 in. water gauge air pressure, and then to the Interim Storage Area, which is maintained at -0.25 in. water gauge air pressure, to the Load-In Area, which is maintained at 0.40 in. water gauge air pressure, and to the Process Ce11, which is maintained at 0.60 in. water gauge air pressure.

The exhaust air system, which exhausts approximately 5000 cfm from the non-contaminated and the potentially contaminated systems, consists of two 100\% (one standby) exhaust fans. Each exhaust air plenum includes a flow control damper, a water spray cooling chamber, two stages of high efficiency particulate air (HEPA) filters, a backflow damper, an air flow monitor, a flow control damper, and a constant air radiation monitor. Exhaust air is directed through an exhaust air stack on the facility roof.

\subsubsection{ELECTRICAL}

\subsubsection{Power Distribution}

The Site power for non-critical loads in the Ion Implantation/Sputtering Facility wi 11 be distributed at $13.8 \mathrm{kV}$ to the unit substation (US1). The two $\# 4 / 0,15 \mathrm{kV}, 3$ phase, primary feeders will be provided by Others. The unit substation steps down the voltage to the $277 / 480 \mathrm{~V}$ motor control center, MCC 1 and the split bus motor control center MCC2. Sma 11 loads are supplied power at 120/208V, 3 phase through stepdown transformers.

\subsubsection{Standby Power}

Standby power for critical loads will be distributed at $277 / 480$ volts from the automatic transfer switch in the standby section of motor control center MCC2. The standby section and transfer switch of MCC2 will be seismically qualified.

The critical equipment that requires standby power to ensure availability in the event of a power failure will be connected to the standby section of the motor control center MCC2. The critical process equipment includes an emergency panelboard, ventilation exhaust fans, and certain control functions. The small critical loads will be supplied power through a stepdown transformer. The system voltages will be $277 / 480 \mathrm{~V}, 3$ phase and $120 / 280 \mathrm{~V}, 3$ phase. A power outage occurring ahead of the standby section of MCC2 will momentarily shut down all equipment connected to it.

The automatic transfer from normal power to standby power, and the subsequent manual return to normal power, causes an interruption of services to all loads connected to this system. The fans will be arranged to restart automatically. Lighting and alarm circuit breakers will remain closed through an interruption of service and require no operator action to reset. 


\subsubsection{Lighting}

The lighting levels will be designed for 50 foot candles at work stations, $30 \mathrm{fC}$ in work areas and $10 \mathrm{fc}$ in aisles or corridors in accordance with ERDA 6301. Fluorescent lighting luminaires with energy-saving ballasts and lamps will be utilized in the office and rooms with low ceilings. High pressure sodium fixtures (HPS) with prismatic glass reflectors will be utilized in other locations for energy conservation. Special lighting designed for remote servicing and constructed to permit decontamination will be provided in the cell. The building exterior doorways will be illuminated with wall-mounted HPS fixtures.

Emergency lighting will be provided by fully automatic battery units, wall mounted near doors and stairways. Certain building lighting fixtures will be connected to the emergency lighting panelboard.

\subsubsection{Lightning Protection}

be provided.

Lightning protection with a UL Master Label wi11

\subsubsection{Grounding}

A No. 4/0 AWG soft drawn bare copper ground 10op, with $3 / 4$ inch by 10 foot copper-clad steel ground rods, will be provided. The grounding counterpoise around the building will be connected to the Site duct bank ground.

\subsubsection{Telephone}

The telephone system will be installed in conduit within the building and a 3 inch conduit only will be extended and capped 5 ft outside this building. Telephone cabinets will be provided, as required. The telephone system wiring will be by others.

\subsubsection{Public Address and Intercom}

No intercom or public address is required in the building. A cell monitoring system will be provided.

\subsubsection{Fire Alarm and Evacuation Alarm}

The building fire alarm and evacuation alarm will be compatible with and connected to the Site system. 


\subsection{ZEOLITE ENCAPSULATION}

\subsubsection{BUILDING DESCRIPTION}

The Zeolite Encapsulation Facility is a rectangular building with overall dimensions of $84 \mathrm{ft} .-0 \mathrm{in}$. by $52 \mathrm{ft} .-0$ in. The building is constructed of reinforced concrete for all areas required to survive design basis natural phenomena. Other areas of the building are constructed of reinforced masonry concrete block walls with roofing over metal decking supported by structural steel beams, and are required to survive operating basis natural phenomena. Areas required to survive design bas is natural phenomena are those areas of the building necessary for containment of Krypton-85. Preconceptual drawings of the Zeolite Encapsulation Facility are contained in Appendix A. Outline specifications of the facility materials and equipment are contained in Appendix $\mathrm{C}-2$.

4,368 square feet.

The facility is on one level, with a total floor area of

All exterior walls of the building are covered with insulated metal siding. The building roof is an "inverted" type, consisting of asphalt felt layers, insulation, and roofing aggregate.

\subsubsection{Process Cell}

The Process Cell is $24 \mathrm{ft} .-0$ in. long by $14 \mathrm{ft} .-0$ in. wide by $12 \mathrm{ft} .-0$ in. high constructed of $18 \mathrm{in.} \mathrm{thick} \mathrm{reinf} \mathrm{orced}$ concrete walls and ceiling, with a two-level basement area for location of the Hot Isostatic Press and the Sump Catch Tank, and for use as a pipe chase. The floor of the lower level of the basement area is $9 \mathrm{ft} .-0$ in. below the cell operating level floor. The pipe chase is $2 \mathrm{ft} .-6$ in. wide, with the floor $4 \mathrm{ft} .-0$ in. below the operating level floor. The basement floor is an $18 \mathrm{in.} \mathrm{thick} \mathrm{reinforced} \mathrm{concrete} \mathrm{mat} \mathrm{foundation.} \mathrm{The} \mathrm{operating}$ floor is 12 in. thick reinforced concrete. The Process Cell is designed to provide shielding and to withstand 1PSI overpressure as a result of accidental rupture of the Hot Isostatic Press, and includes metal clad blast-proof doors and blast-proof shielding windows. The estimated maximum overpressure as a result of release of the high pressure gas in the Hot I sostatic Press is 0.80 PSI. Viewing windows are provided for remote operations, substrate inspection, and substrate sealing. An overhead bridge crane services the Process Cell for loading, unloading, and transporting substrate containers.

\subsubsection{Gas Storage Area}

The Gas Storage Area is $16 \mathrm{ft} .-6$ in. 1ong by 15 ft. -0 in. wide by $12 \mathrm{ft} .-0 \mathrm{in}$. high constructed of $12 \mathrm{in}$. thick reinf orced concrete walls and ceiling and a 6 in. thick concrete floor supported by compacted backfill and concrete footings. The Gas Storage Area is designed to provide shielding for the Lag Storage Equipment, which may contain 60 days operational supply of feed gas, and to provide protection from the accidental rupture of the storage vessels. 


\subsubsection{Interim Product Storage Area}

The Inter im Product Storage Area is $26 \mathrm{ft} .-0$ in. long by $13 \mathrm{ft} .-0$ in. wide by $12 \mathrm{ft} .-0$ in. high constructed of $12 \mathrm{in}$. thick reinforced concrete walls and ceiling and a 6 in. thick concrete floor supported by compacted backfill and concrete footings. The Interim Product Storage Area is designed to provide shielding for encapsulated product due to operation for one year. Shielding hatches are provided for access for maintenance.

\subsubsection{Support Areas}

design are as follows:

Other Support Areas included in the building

(1) Substrate and Container Storage. $19 \mathrm{ft} .-6$ in. long by $14 \mathrm{ft} .-6$ in. wide by $9 \mathrm{ft} .-0$ in. high, constructed of masonry concrete block exterior walls, metal studs and gypsum board interior walls, and suspended ceiling.

(2) Health Office. $13 \mathrm{ft} .-0$ in. long by $8 \mathrm{ft} .-0$ in. wide by $9 \mathrm{ft} .-0$ in. high, constructed of masonry concrete block exterior walls, metal studs and gypsum board interior walls, and suspended acoustical ceiling.

(3) Decontamination Area.' $13 \mathrm{ft} .-0$ in. Iong by $6 \mathrm{ft} .-0$ in. wide by $9 \mathrm{ft} .-0 \mathrm{in}$. high, constructed of metal studs and Type " $X$ " gypsum board walls and suspended plaster ceiling, with an enclosed shower with ceramic tile floor and walls.

(4) Operating Gallery. 20 ft. -6 in. long by 15 ft. -0 in. wide by 9 ft. -0 in. high, constructed of masonry concrete block exterior walls, metal studs and gypsum board interior walls, and suspended acoustical ceiling.

(5) Supervisor's Office. $12 \mathrm{ft.}-0$ in. long by $10 \mathrm{ft} .-0$ in. wide by $9 \mathrm{ft} .-0$ in. high, constructed of masonry concrete block exterior walls, metal studs and gypsum board interior walls, and suspended acoustical ceiling. Includes an $11 \mathrm{ft} .-0$ in. 1 ong by $4 \mathrm{ft}$. -0 in. high glass window to the Operating Gallery.

(6) HVAC and Electrical Area. $34 \mathrm{ft},-0$ in. long by $29 \mathrm{ft} .-0$ in. wide by $12 \mathrm{ft} .-0$ in. high, constructed of reinforced concrete floor, walls, and ceiling.

(7) Product Storage Load-In Area. $13 \mathrm{ft} .-0$ in. long by $8 \mathrm{ft} .-0$ in. wide by $12 \mathrm{ft} .-0 \mathrm{in}$. high, constructed of reinforced concrete floor, walls, and ceiling.

(8) Gas Cooling Area. $15 \mathrm{ft} .-0$ in. long by 8 $\mathrm{ft} .-0$ in. wide by $12 \mathrm{ft} .-0$ in. high, constructed of reinforced concrete floor, walls, and ceiling. 
(9) Product Load-Out Area. $13 \mathrm{ft.}-0$ in. long by $11 \mathrm{ft} .-6$ in. wide by $12 \mathrm{ft} .-0 \mathrm{in}$. high, constructed of reinf orced concrete floor, walls, and ceiling.

(10) Restroom and Locker Area. $19 \mathrm{ft.}-0$ in. long by $15 \mathrm{ft} .-0$ in. wide by $9 \mathrm{ft} .-0$ in. high, constructed of masonry concrete block exterior walls, metal studs and Type " $x$ " gypsum board interior walls, and suspended plaster ceiling.

\subsubsection{HEATING AND VENTILATING}

Three Heating and Ventilating Systems are provided for the Zeolite Encapsulation Facility. One system services the HVAC and Electrical Equipment Areas. A second system services the non-contaminated operating areas, consisting of the offices, Operating Gallery, and the Restroom and Locker Area. A third system services the potentially contaminated areas, consisting of the Process Cel1, Gas Storage Area, Inter im Storage Area, Substrate and Container Storage, Product Storage Load-In Area, and Product Load-Out Area. As shown on Drawing V-2, the Heating and Ventilating Systems for the non-contaminated operating areas and for the potentially contaminated areas utilize common supply and exhaust air systems.

The Heating and Ventilating System for the HVAC and Electrical Equipment Area provides a maximum of $4000 \mathrm{cfm}$ through a $1 \mathrm{hp}$ vent $f$ an. Air is exhausted through a $4000 \mathrm{cfm}$ maximum capacity roof ventilator. Steam unit heaters, with 50,000 BTU/hr. capacity, are provided for space heating.

The Heating and Ventilating Systems for the non-contaminated operating areas and for the potentially contaminated areas are once through air flow systems, designed to maintain confinement zones based on differential air pressure to ensure air flow from less contaminated to more contaminated areas. Ventilation and temperature control will provide a suitable working environment in areas occupied by personnel. Air filtration is employed to reduce potential radioactive contaminants in the effluent to "as low as reasonably achievable" (ALARA) prior to discharge to the environment.

The supply air system, which provides approximately 2700 cfm to the non-contaminated and potentially contaminated systems, consists of two $100 \%$ (one standby) supply fans. Each supply air plenum consists of a tornado shut-off valve, a steam preheat coil, $30 \%$ efficiency roughing and $80 \%$ efficiency pre-filters, backdraft damper, air flow monitor, and flow control damper. $100 \%$ outside air is supplied to the non-contaminated system and the potentially contaminated system.

Approximately $900 \mathrm{cfm}$ is supplied to the non-contaminated operating areas through a steam heating coil and a refrigerant cooling coil. Approximately $120 \mathrm{cfm}$ is directed to the vestibule, and by infiltration to the Restroom and Locker Area, and is exhausted by exfiltration and by a powered roof ventilator. $800 \mathrm{cfm}$ is directed to the 
offices and the Operating Gallery, and is exhausted through the exhaust air system. The offices are maintained at $-0.10 \mathrm{in}$. water gauge air pressure. The Operating Gallery is maintained at -0.20 in. water gauge air pressure.

Approximately $1800 \mathrm{cfm}$ is supplied to the potentially contaminted areas. Approximately $1200 \mathrm{cfm}$ is supplied directly to the Process Cell through heating/cooling coils. Approximately $600 \mathrm{cfm}$ is supplied to the Load-Out Area, the Gas Storage Area, and the Substrate and Container Storage Area, which are maintained at $-0.10 \mathrm{in}$. water gauge air pressure, and then to the Interim Storage Area, which is maintained at -2.0 in. water gauge air pressure, to the Load-In Area, which is maintained at -2.20 in. water gauge air pressure, and to the Process Cell, which is maintained at -2.40 in. water gauge air pressure.

The exhaust air sytem, which exhausts approximately 2800 cfm from the non-contaminated and potentially contaminated systems, consists of two 100\% (one standby) exhaust fans. Each exhaust air plenum includes a flow control damper, a water spray cooling chamber, two stages of high efficiency particulate air (HEPA) filters, a backflow damper, an air flow monitor, a flow control damper, and a constant air radiation monitor. Exhaust air is directed through an exhaust air stack on the facility roof.

\subsubsection{ELECTRICAL DESIGN DESCRIPTION}

\subsubsection{Power Distribution}

The Site power for non-critical loads in the Zeolite Encapsulation Facility will be distributed at $13.8 \mathrm{kV}$ to the unit substation (USI). The two \#4/0, $15 \mathrm{kV}, 3$ phase, primary feeders will be provided by others. The unit substation steps down the voltage to the $277 / 480 \mathrm{~V}$ split bus motor control center, MCC1. Small loads are supplied power at $120 / 208 \mathrm{~V}, 3$ phase through stepdown transformers.

\subsubsection{Standby Power}

Standby power for critical loads will be distributed at $277 / 480$ volts from the automatic transfer switch in the standby section of motor control center MCCl. The standby section and transfer switch of MCCl will be seismically qualified.

The critical equipment that requires standby power to ensure availability in the event of a power failure will be connected to the standby section of the motor control center. The critical process equipment includes an emergency panelboard, ventilation exhaust fans, and certain control functions. The small critical loads will be supplied power through a stepdown transformer. The system voltages will be $277 / 480 \mathrm{~V}, 3$ phase and 120/280V, 3 phase. A power outage occurring ahead of the standby section of $\mathrm{MCCl}$ will momentarily shut down all equipment connected to it. 
The automatic transfer from normal power to standby power, and the subsequent manual return to normal power, causes an interruption of services to all loads connected to this system. The fans will be arranged to restart automatically. Lighting and al arm circuit breakers will remain closed through an interruption of service and require no operator action to reset.

\subsubsection{Lighting}

The lighting levels will be designed for 50 foot candles at work stations, $30 \mathrm{fc}$ in work areas and $10 \mathrm{fc}$ in a isles or corridors in accordance with ERDA 6301. Fluorescent lighting luminaires with energy-saving ballasts and lamps will be utilized in the office and rooms with low ceilings. High pressure sodium fixtures (HPS) with prismatic glass reflectors will be utilized in other locations for energy conservation. Special lighting designed for remote servicing and constructed to permit decontamination will be provided in the cell. The building exterior doorways will be illuminated with wall-mounted HPS fixtures.

Emergency lighting will be provided by fully automatic battery units, wall mounted near doors and stairways. Certain building lighting fixtures will be connected to the emergency lighting panelboard.

\subsubsection{Lightning Protection}

be provided.

Lightning protection with a UL Master Label will

\subsubsection{Grounding}

A No. 4/0 AWG soft drawn bare copper ground 1oop, with $3 / 4$ inch by 10 foot copper-clad steel ground rods, will be provided. The grounding counterpoise around the building will be connected to the Site duct bank ground.

\subsubsection{Telephone}

The telephone system will be installed in conduit within the building and a 3 inch conduit only will be. extended and capped 5 ft outside the building. Telephone cabinets will be provided, as required. The telephone system wiring will be by 0thers.

\subsubsection{Public Address and Intercom}

No intercom or public address is required in the building. A cell monitoring system will be provided.

\subsubsection{Fire Alarm and Evacuation Alarm}

The building fire alarm and evacuation alarm will be compatible with and connected to the Site system. 
SECTION 5

FEASIBILITY EVALUATIONS

\subsection{GENERAL}

The purpose of this Section is to discuss and compare the feasibility of developing a viable comercial production scale process for I on Implantation/Sputtering and for Zeolite Encapsulation within the next five years. The bas is for th is evaluation is a discussion of advancements which may be required beyond commercially available state-of-the-art equipment and process components.

\subsection{ION IMPLANTATION/SPUTTERING}

The Ion Implantation/Sputtering process has been developed by Battelle, Pacific Northwest Laboratories, for a wide spectrum of applications and for the specific application of krypton encapsulation. Process equipment has been designed, constructed, and operated by Battelle at laboratory and bench scales. The Encapsulation Facility would use equipment scaled up by only 1.8 over existing operating equipment. The commercial equipment would be somewhat different from laboratory equipment, in that all connections will be at the top of the target/substrate assembly, and that connections will seal automatically/remotely, but these differences are not considered to be serious technical concerns. There is a concern that some of the process equipment, particularly the target/sputtering assemblies, the in-cell sputtering heads, and the current limiters for the power supplies, are not commercially available equipment, nor are they anticipated to be commercially available within five years. These components will require additional development to allow design as special fabrications for a commercial facility.

The estimated cost of target/substrate assemblies is based on development of a source for these special fabrications, which does not presently exist economically or in sufficient production capacity. It is reasonable to assume, however, that a source for target/substrate assemblies could be developed within a five year period.

\subsection{ZEOLITE ENCAPSULATION}

The Zeolite Encapsulation process for encapsulation of krypton has been developed by Exxon Nuclear I daho Company, Inc., I daho National Engineering Laboratory. The process equipment is, with minor modifications, an application of currently available hot isostatic pressing equipment. Laboratory testing has been performed at a small scale, although equipment for the Encapsulation Facility is a commercially available equipment size. Some process components are not now commercially available, such as solenoid operated high pressure valves and control valves. It is reasonable to assume, however, that such components would be available due to normal technological development by the time the Encapsulation Facility is constructed, or suitable alternates, such as air operated high pressure valves which are presently commercially available, would be used. 
The preconceptual design is based on the use of zeolite rather than vycor, although vycor has an apparently higher encapsulation efficiency for krypton, due to the much higher relative cost of vycor. It is conceivable that the production cost of vycor relative to zeolite may decrease, resulting in lower operating cost of the facility.

The estimated equipment costs are based on the application of industrial high pressure codes and standards, as existing commercial equipment is not available in accordance with nuclear codes (e.g. ASME Section III). It is also not anticipated that hot isostatic pressing equipment will be produced to nuclear codes in the future. It is reasonable to assume, however, that if application of nuclear codes and standards is required (see al so Section 6 of this report), a source for such equipment could be developed within a five year period.

\subsection{CONCLUSIONS}

Based on these discussions, either alternate could result in a viable commercial production scale process within five years. No attempt has been made to assess the relative cost of development of the processes. Each process has its own associated risks and concerns. None of the concerns seem to be insurmountable, and the risks associated with each process appear to be of the same relative magnitude. 
SECTION 6

\section{LICENSIBILITY}

The Krypton Encapsulation Facility will be licensed by the U.S. Nuclear Regulatory Commission (NRC), and will comply with the applicable federal regulations and NRC Regulatory guides. Federal regulations 10 CFR Part 50, "Licensing of Production and Utilization Facilities", and 10 CFR Part 100, "Reactor Siting Criteria", will provide the general design criteria for the commercial nuclear fuel reprocessing plant and for the encapsulation facility. Facilities utilizing either of the alternate encapsulation processes should not have difficulty in complying with existing criteria, however, NRC Regulatory Guides for handling and processing waste gases are still in preparation.

A fundamental criterion for the application of more stringent requirements is the consequence of a postulated accident at the site boundary. Since each facility could have as much as $3.74 \times 10^{6}$ Curies of radioactive Krypton-85 in storage (60 days 1 ag storage) the requirements for this portion of the facility may be very stringent, although gas storage pressures are only moderate (500 PSIG). The actual requirements will depend on wind dispersion calculations and other factors for determining site boundary consequences, and since the requirements are identical for the two alternate facilities, these requirements have no impact on a comparative evaluation. Feed gas storage would be required so that a failure of process equipment in the encapsulation facility would not impact continued operation of the balance of the reprocessing plant. Since the Ion Implanation/Sputtering Facility would utilize multiple trains of process equipment, failure of one train would not effect encapsulation production, and equipment for feed gas storage may not be required.

The Ion Implantation/Sputtering Facility should have very few other safety-related components. During processing, the radioactive gas is maintained at a high vacuum, such that very little gas could be released during a postulated accident. Processing radioactive gases in this manner would be preferred from a safety standpoint.

The Zeolite Encapsulation Facility will have as much as 45,000 Curies of radioactive gas at very high pressure $(14,700$ PSIA) contained within the process equipment at a given time. It is likely that the process equipment, particularily the Hot Isostatic Press, would be required to meet high nuclear quality standards as safety-related equipment. Currentiy available commercial equipment, although adequate from an industrial safety standpoint, would require considerable modification to meet nuclear safety requirements. These additional requirements may have an impact on the cost of the Zeolite Encapsulation Facility.

No attempt has been made to assess the relative cost of licensing of the encapsulation facilities. The consequences of a postulated accident at the site boundary, and the resulting requirements which would be imposed are unknown at this time. The Zeolite Encapsulation Facility, however, would seem to require a higher $r$ isk due to the impact of nuclear safety requirements on the ultimate cost of the facility. 

SECTION 7

LIFE CYCLE COSTING ANALYSIS

\subsection{BASIS AND APPROACH}

The Ion Implantation/Sputtering Facility and the Zeolite Encapsulation Facility were evaluated and compared on a life cycle cost basis, following the procedures of the "Life-Cycle Cost Manual for the Federal Energy Management Program," NBS Handbook 135, ("hereinafter referred to as the "Handbook"). In following the Handbook procedures, the total present value of the facility is determined, using a 7 percent per year discount rate for annual costs. For this analysis, a useful life of 30 years with no remaining salvage value was used.

The following cost categories were included in the analysis:

1) Initial Capital Investment

2) Annual Energy Cost

3) Annual Recurring (non-fuel) Costs

a) Operating Manpower Cost

b) Operating Materials Cost

4) Annual Non-Recurring Costs

a) Replacement/Maintenance Materials Cost

b) Insurance Cost

\subsubsection{INITIAL CAPITAL INVESTMENT}

In accordance with the Handbook, all initial capital

investment is assumed to take place at the start of the base year, which is the year in which the analysis takes place. Furthermore, in determining the present value of the initial capital investment, the estimated actual investment is reduced by 10 percent. Therefore, the initial capital investment is 90 percent of the estimated Total Job Cost for the facilities, as shown in Appendix $E$.

\subsubsection{ANNUAL ENERGY COST}

The initial annual cost for energy is determined by the product of the estimated annual energy consumption, and the current regional energy cost. Table $\mathrm{C}-2$ of the Handbook gives $\$ 0.037 / \mathrm{KW}-\mathrm{hr}$. as the current energy cost for the region of Oak Ridge, Tennessee (Region 4). The Handbook estimates the inflation of energy relative to other costs, and 
computes the present value for each annual expenditure using a 7 percent per year discount rate. The sum of present values of annual energy expenditures is the adjusted Uniform Present Worth Factor (UPW*). The Handbook, however, uses a maximum life of 25 years. Following the procedures of the Handbook for 30 years, the UPW*, adjusted for increases in energy costs, is estimated to be 13.48. The present value of the annual energy cost for the life of the facility is then the initial annual cost multiplied by the UPW*. The total life cycle energy cost is shown in Table 7-1.

\subsubsection{ANNUAL RECURRING COSTS}

The present value of annual recurring (non-fuel) costs is determined by multiplying the annual cost in current dollars by the unadjusted UPW. The UPW for a plant life of 30 years, using a 7 percent per year discount rate, is calculated to be 12.41 .

\subsubsection{Operating Manpower Cost}

The determination of life cycle costs for operating manpower is shown in Table 7-2. Operating manpower was estimated in terms of manhours per operating year. The current manpower cost is based on an assumed current rate of $\$ 25 /$ manhour.

\subsubsection{Operating Materials Cost}

The determination of life cycle costs for operating materials is shown in Table 7-3. Attachment 7A provides the details used in determining the current annual cost for operating materials.

\subsubsection{ANNUAL NON-RECURRING COSTS}

Annual non-recurring costs are those costs which vary year-to-year. The present value of a given expenditure during a given year is the expenditure in current dollars, multiplied by the Single Payment Present Worth Factor (SPW). The SPW for each year can be calculated using a 7 percent discount rate. The life cycle cost is then the sum of the present values of the annual expenditures.

\subsubsection{Replacement/Maintenance Materials Costs}

The annual cost for replacement/maintenance materials was estimated as a varying percentage of the initial direct equipment costs. The determination of life cycle costs for rep 7 acement/maintenance materials is shown in Table 7-4.

\subsubsection{Insurance Costs}

The annual cost for replacement insurance of the facility was estimated at 0.3 percent of the replacement value. Replacement value was determined based on the estimated Total Job Cost, shown in Appendix $E$, and using sum-of-the-years depreciation for the life 
of the facility. Insurance costs for liability and damage to the external environment, if any, are assumed to be the same for each facility, and are not included in this analysis. The determination of life cycle costs for replacement insurance is shown in Table 7-5.

\subsubsection{SALVAGE}

The Handbook calls for subtracting the present worth of the salvage value of the facility to determine the total life cycle cost. For this analysis, the salvage value is zero.

\subsection{ION IMPLANTATION/SPUTTER ING}

Life cycle costs for the Ion Implantation/Sputtering Facility are summarized in Table 7-6. The total present value of all included life cycle costs is $\$ 26,430,684$.

\subsection{ZEOLITE ENCAPSULATION}

Life cycle costs for the Zeolite Encapsulation Facility are summarized in Table 7-7. The total present value of all included life cycle costs is $\$ 21,900,883$.

\subsection{CONCLUSIONS}

On a 30 year basis, the total life cycle cost for the Zeolite Encapsulation Facility is $\$ 4,529,801$ less than for the I on

Implantation/Sputtering Facility, or a total savings of $16.5 \%$. Additional investment for initial capital and replacement/maintenance materials (items 1 and 5 in Tables 7-6 and 7-7) is \$4,785 for the Zeolite Encapsulation Facility. Life cycle savings for energy and all other operating and maintenance costs (items 2,3,4, and 6 in Tables 7-6 and 7-7) is $\$ 4,525,016$. The life cycle savings-to-investment ratio is 946 in favor of Zeolite Encapsulation over Ion Implantation/Sputtering. 
TABLE 7-1

LIFE CYCLE ENERGY COSTS

Ion Implantation/Sputtering Zeolite Encapsulation

Estimated Demand

539

258

Power Load, KVA

Load Factor

$85 \%$

$85 \%$

Hours/Year

7,200

7,200

Energy Consumption,

$\mathrm{KW}-\mathrm{Hr} . \mathrm{Nr}$.

$3,880,800$

$1,857,600$

Current (1981) Energy

Cost, \$/KW-hr

0.037

0.037

Current (1981) Annual

Energy Cost

$\$ 143,590$

$\$ 68,731$

Adjusted UPW*

13.48

13.48

Total Present VaTue

of Life Cycle

$\$ 1,935,588$

$\$ 926,494$

Energy Costs 
TABLE 7-2

LIFE CYCLE OPERATING MANPOWER COSTS

Ion Implantation/Sputtering Zeolite Encapsulation

Personnel/Basis

Operators

$2 \times 8 \mathrm{hr} /$ day $\times 300$

days/yr $\times 3$ shifts

Supervisor

$1 \times 8 \mathrm{hr} /$ day $\times 300$ days/yr.

Welding \& Inspection

$1.5 \mathrm{hr} . /$ weld

Janitorial

$2.5 \mathrm{hr} . /$ day $\times 360$

Maintenance

Schedu led

$2 \times 8 \times 60$

Unschedu led

$0.2 \times 8 \times 300$

HP/Fire/Hygiene

$0.75 \times 8 \times 300$

Total Operating

Manpower

Current (1981) Annua 1

Manpower Cost (\$25/MH)

UPW

Total Present Value of

Life Cycle Manpower Costs
74, $400 \mathrm{MH}$

$14,400 \mathrm{MH}$

2,400 MH

$2,400 \mathrm{MH}$

$460 \mathrm{MH}$

$900 \mathrm{MH}$

$900 \mathrm{MH}$

$900 \mathrm{MH}$

$960 \mathrm{MH}$

$960 \mathrm{MH}$

$480 \mathrm{MH}$

$480 \mathrm{MH}$

$1,800 \mathrm{MH}$

$1,800 \mathrm{MH}$

$21,400 \mathrm{MH} / \mathrm{Yr}$.

$21,840 \mathrm{MH} / \mathrm{Yr}$.

$\$ 535,000$

$\$ 546,000$

12.41

12.41

$\$ 6,639,350$

$\$ 6,775,860$ 
TABLE 7-3

LIFE CYCLE OPERATING MATERIALS COSTS

Ion Implantation/Sputtering Zeolite Encapsulation

Current (1981) Annual

Costs of operating

Materials

Substrate/Containers

$\$ 585,000$

Helium

Welding Supplies

Decon Chemicals

Other

Total Current (1981)

Annual Cost of

Operating Materials

UPW

Total Present Value of Life Cycle

Operating Materials Costs

$$
9,800
$$$$
1,500
$$$$
5,000
$$

15,000

$\$ 616,300$

12.41

$\$ 7,648,283$
$\$ 301,700$

7,200

1,000

5,000

15,000

$\$ 329,900$

12.41

$\$ 4,094,059$ 
TABLE 7-4

LIFE CYCLE REPLACEMENT/MAINTENANCE MATERIALS COST

\% of
Yr. $\quad$ Initial
Direct
Equip.

\begin{tabular}{l}
\hline 1 \\
2 \\
3 \\
4 \\
5 \\
6 \\
7 \\
8 \\
9 \\
10 \\
11 \\
12 \\
13 \\
14 \\
15 \\
16 \\
17 \\
18 \\
19 \\
20 \\
21 \\
22 \\
23 \\
24 \\
25 \\
26 \\
27 \\
28 \\
29 \\
30
\end{tabular}

Estimated Annual Costs (1981)

I on Implant./ Zeolite Sputtering Encapsulation
Present Value of Annual Costs

SPW

Ion Implant./ Zeolite

Sputtering Encapsulation

$\begin{array}{lrrrrr}2 & \$ 29,600 & \$ 37,900 & 0.93 & \$ 27,528 & \$ 35,247 \\ 2 & 29,600 & 37,900 & 0.87 & 25,752 & 32,973 \\ 2 & 29,600 & 37,900 & 0.82 & 24,272 & 31,078 \\ 2 & 29,600 & 37,900 & 0.76 & 22,496 & 28,804 \\ 2 & 29,600 & 37,900 & 0.71 & 21,016 & 26,909 \\ 3 & 44,400 & 56,900 & 0.67 & 29,748 & 38,123 \\ 3 & 44,400 & 56,900 & 0.62 & 27,528 & 35,278 \\ 3 & 44,400 & 56,900 & 0.58 & 25,752 & 33,002 \\ 3 & 44,400 & 56,900 & 0.54 & 23,976 & 30,726 \\ 3 & 44,400 & 56,900 & 0.51 & 22,644 & 29,019 \\ 4 & 59,200 & 75,800 & 0.48 & 28,416 & 36,384 \\ 4 & 59,200 & 75,800 & 0.44 & 26,048 & 33,352 \\ 4 & 59,200 & 75,800 & 0.42 & 24,864 & 31,836 \\ 4 & 59,200 & 75,800 & 0.39 & 23,088 & 29,562 \\ 4 & 59,200 & 75,800 & 0.36 & 21,312 & 27,288 \\ 6 & 88,800 & 113,700 & 0.34 & 30,192 & 38,658 \\ 6 & 88,800 & 113,700 & 0.32 & 28,416 & 36,384 \\ 6 & 88,800 & 113,700 & 0.30 & 26,640 & 34,110 \\ 6 & 88,800 & 113,700 & 0.28 & 24,864 & 31,836 \\ 6 & 88,800 & 113,700 & 0.26 & 23,088 & 29,562 \\ 6 & 88,800 & 113,700 & 0.24 & 21,312 & 27,288 \\ 6 & 88,800 & 113,700 & 0.23 & 20,424 & 26,151 \\ 6 & 88,800 & 113,700 & 0.21 & 18,648 & 23,877 \\ 6 & 88,800 & 113,700 & 0.20 & 17,760 & 22,740 \\ 6 & 88,800 & 113,700 & 0.18 & 15,984 & 20,466 \\ 8 & 118,400 & 151,600 & 0.17 & 20,128 & 25,772 \\ 8 & 118,400 & 151,600 & 0.16 & 18,944 & 24,256 \\ 8 & 118,400 & 151,600 & 0.15 & 17,760 & 22,740 \\ 8 & 118,400 & 151,600 & 0.14 & 16,576 & 21,224 \\ 8 & 118,400 & 151,600 & 0.13 & 15,392 & 19,708\end{array}$

Total Present Value of Life Cycle Replacement/ $\$ 690,568 \quad \$ 884,353$ Maintenance Costs 
TABLE 7-5

LIFE CYCLE REPLACEMENT INSURANCE COSTS

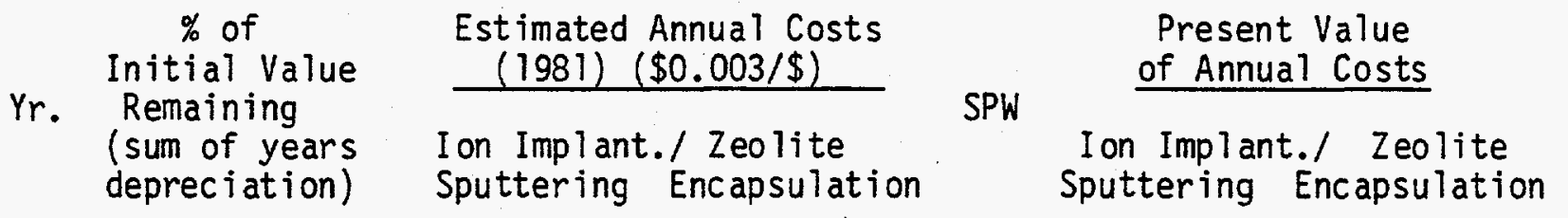

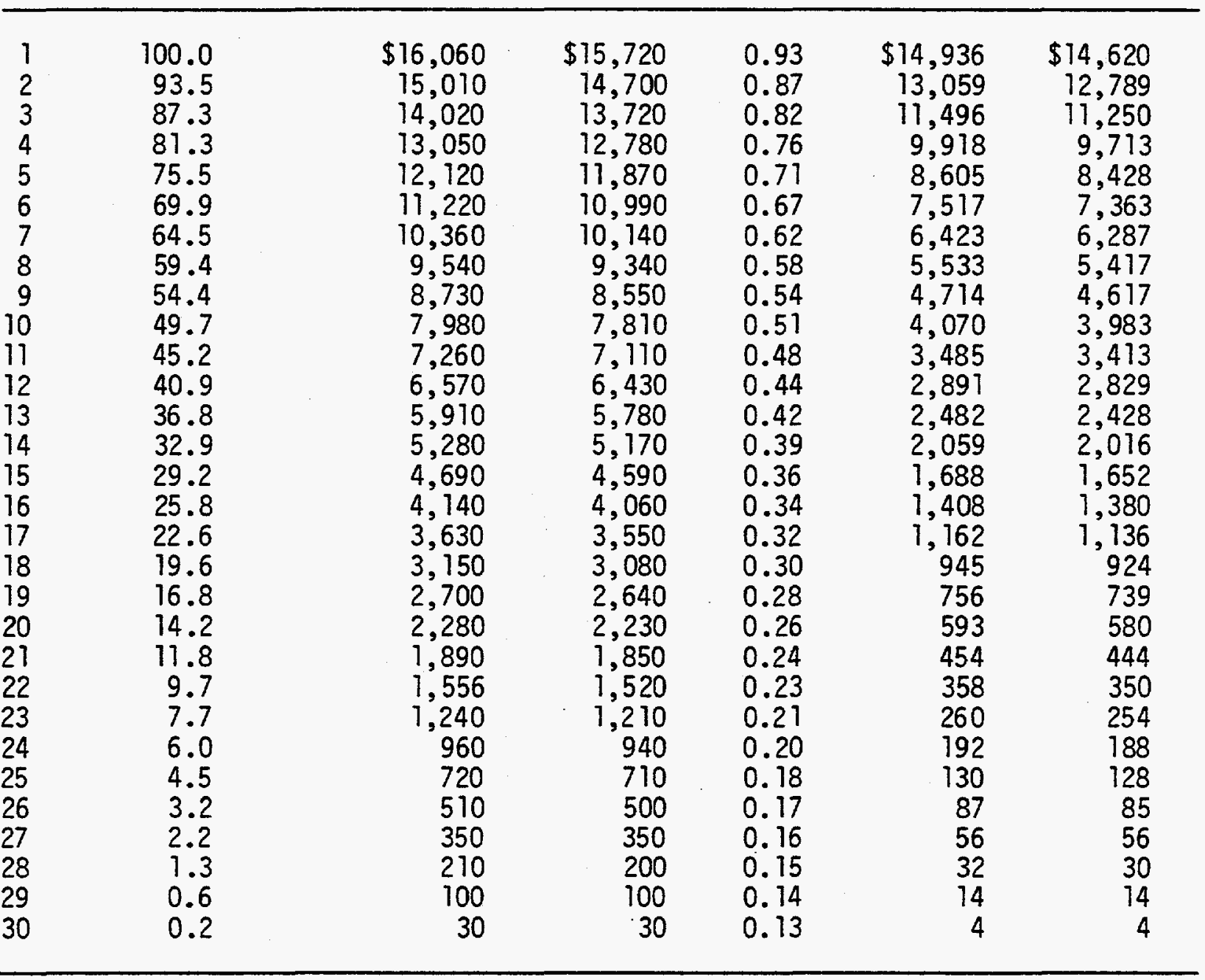

$\$ 105,327 \$ 103,117$ 
TABLE 7-6

ION IMPLANTATION/SPUTTER ING LIFE CYCLE COSTS

1. Present Value of Initial Capital Investment ( $90 \%$ of Total

Estimated Job Cost)

2. Present Value of Life Cycle Energy Costs (Table 7-1)

$1,935,588$

3. Present Value of Life Cycle Operating Manpower Costs (Table 7-2)

4. Present Value of Life Cycle Operating Materials Costs (Table 7-3)

5. Present Value of Life Cycle Rep 1 acement/Maintenance Materials Costs (Table 7-4)

6. Present Value of Life Cycle Replacement Insurance Costs (Table 7-5)

Total Present Value of A11 $6,639,350$ $7,648,283$

Included Life Cycle Costs 
TABLE 7-7

ZEOLITE ENCAPSULATION LIFE CYCLE COSTS

1. Present Value of Initial Capital

Investment $(90 \%$ of Total

Estimated Job Cost)

2. Present Value of Life Cycle

Energy Costs (Table 7-1)

3. Present Value of Life Cycle

$6,775,860$

Operating Manpower Costs

$\$ 9,117,000$

(Table 7-2)

4. Present Value of Life Cycle Operating Materials Costs

(Table 7-3)

5. Present Value of Life Cycle

884,353

Repl acement/Maintenance

Materials Costs (Table 7-4)

6. Present Value of Life Cycle

103,117

Rep 1 acement Insurance

Costs (Table 7-5)

Total Present Value of $A 11$

$4,094,059$

Included Life Cycle Costs

$\$ 21,900,883$ 
ATTACHMENT $7 \mathrm{~A}$

ANNUAL COST OF OPERATING MATERIALS 

RIP

THE RALPH M. PARSONS COMPANY

CALCULATION SHEET

TITLE KRYPTON ENCAPSULATION JOBNO. $6 / 54-3$ DEPARTMENT

SHEET NO

1 or

\begin{tabular}{|c|c|c||c|c|c|c|c|c|c|}
\hline REV & CHECKER & DATE & REV & CHECKER & AUTHOR A. WILKINSON & REV & CHECKER & DATE \\
\hline & & & & & & & & \\
\hline
\end{tabular}

OPERATING MATERIALS (1981\#/YEAR)

SUMMARY

ZEOLITE UNCAP. ION IMPL./SPUT.

SUESTRATE/CONTAINERS

HELIUM

WELDING SUPPLIES

DECOR CHEMICALS

OTHER

TOTAL
$\$ 301,700$

7,200

1,000

5,000

15,000

$\$ 329,900$
$\$ 585,000$

9,800

1,500

5,000

15,000

$\$ 616,300$

AMP-307 (2/78)

PAGE NUMBER 
THE RALPH M. PARSONS COMPANY

CALCULATION SHEET

TITLE KRYPTON ENCAPSULATION

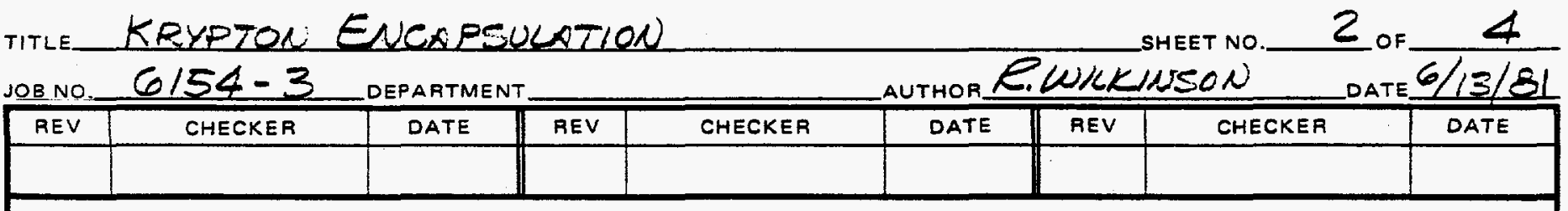

OPERATING MATERIALS

1. zeolite Encapsulation

a. substrate \& cONTAINERS (600/yr.)

1). ZEOLITE ( $\$ 3.35 / L B)$

$$
\begin{aligned}
600 \times 7750 \mathrm{~g} / \mathrm{BATCH}\left(\frac{1}{454}\right) & =10,240 \mathrm{LB} / \mathrm{YR} . \\
& =\$ 34,300
\end{aligned}
$$

2). CONTAINER, $7 \mathrm{~m} . \phi \times 14 \mathrm{~N} .$, T. $3 / 6 L$ S.5. $\times \frac{3}{16}$ "WALL

EST. $135 / E A \times 600=81,000$

3). ENDCAPS $2 @ 7$ IN. OD. $\times \frac{1}{4}$ "

EST $40 / E_{A} \times 2 \times 600=\$ 48,000$

4). OVERPACK O"C.S. PIPEX $16^{\prime \prime}$ LONG w/ PIPE CAPS

EST $\$ 45 / E A \times 600=\$ 27,000$

5). AssemBLY, $4 \mathrm{mH} . \times 30 / \mathrm{mH}^{*} \times 600=\$ 72,000$

6). QA, QC, SHIPPING, ETC.C $15 \%$ \$39,400

TOTAL \$301,700

( $\sim 500$ EA.)

RMP-307 (2/78)

PAGE NUMBER 
$\boldsymbol{A L P}$

THE RALPH M. PARSONS COMPANY

CALCULATION SHEET

TitLE KRYPTON ENCAPSULATION: JOBNO. $\quad 60 / 54-3$ DEPARTMENT

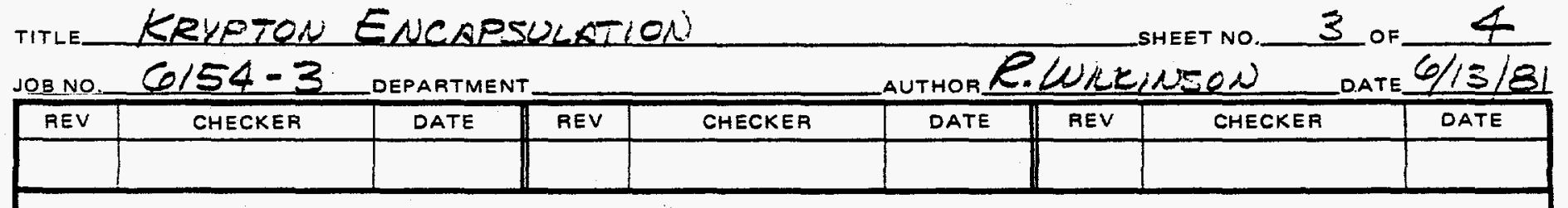

b. Helium (purge $;$ test) est. 3 CF/ Unit EST. $\$ 4 / C F \times 600 \times 3$

c. Welding Supplies (EST.)

d. Devon Chemiencs (est.)

e. Other (EST.)

7,200

1,000

$\$ 5,000$

$\$ 15,000$

2. IOn Implantation/Sputtering

a) Substrate \& Containers (305/yr.)

1). NICKEL $\left(15509 \mathrm{~g} / \mathrm{EA}_{\mathrm{N}} \mathrm{O} .25 / \mathrm{LB}\right)$

$$
\frac{15509}{454} \times 3.25 \times 305=\$ 33,860
$$

2). Lanthanum ( $4123 \mathrm{~g} / \mathrm{l}$ A $\$ 27.30 / \mathrm{LB}$ )

$$
\frac{4123}{454} \times 27.30 \times 305=75,620
$$

3). TARGET (G"STD.WT. C.S. PIPE X 12" LONG WI CAP)

$$
305(8.75+24.20)=10,050
$$

4). SubstrAte (10" Seh.405, T.3/6L SS × 12 "LONg w) CAPS

$$
305(110+280) \quad=\$ 118,950
$$

5). FILAMENT ANOOES (EST)

6). Insulators (EST)

7). Tubing \& Connectors (Est)

8). Fabrication \& Assembly (Est)

$25.2 \mathrm{mH} \times 30 / \mathrm{mH} . \times 305$

9). QA, QC, SH,PPINE, ETC $15 \%$

9,150

\$12,200

$\$ 18,300$

\$230,580

$\$ 76,290$

TOTAL

585,000

$(1920 \in A)$

RMP -307 (2/78)

PAGE NUMBER 
THE RALPH M. PARSONS COMPANY

CALCULATION SHEET

TitLE KRYPTON ENCAPSULATION JOB NO. $6 / 54-3$ DEPARTMENT

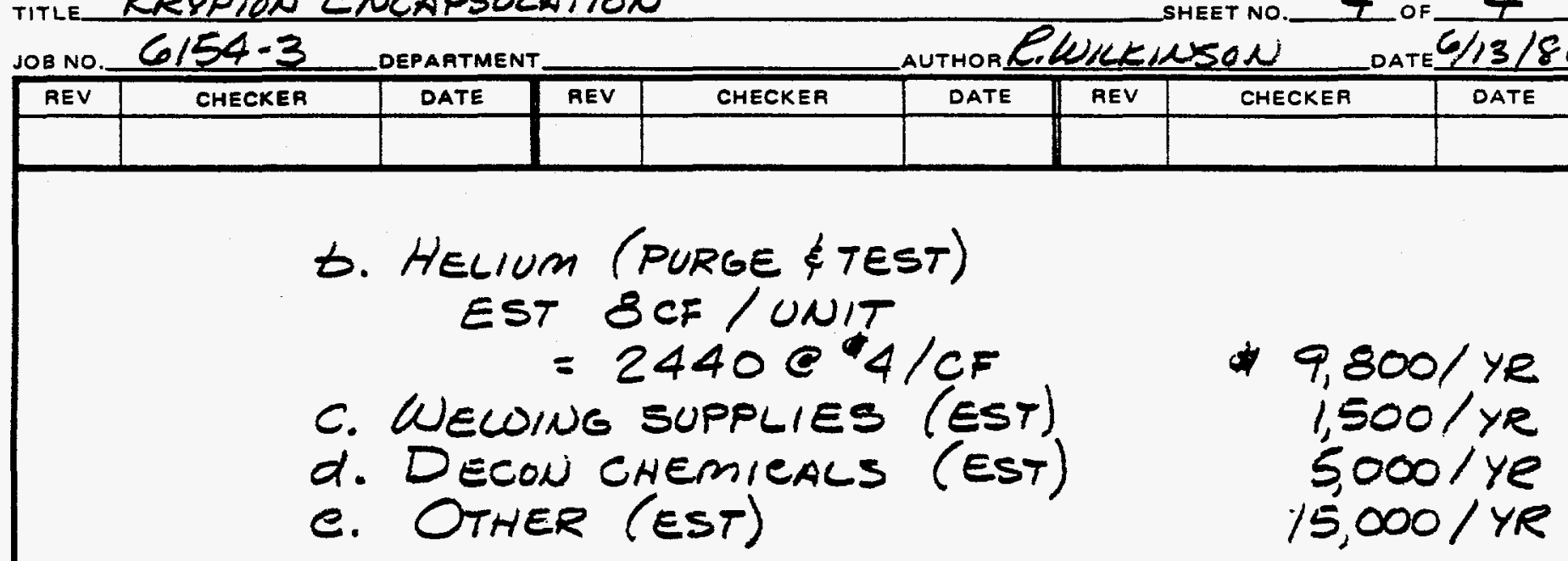

RMP-307 (2/78)

PAGE NUMBER 
APPENDICES

A. Drawing List and Drawings

B. Major Equipment List

C. Outline Specifications

D. Calculations

E. Cost Estimates 

APPENDIX A

DRAWING LIST AND DRAWINGS

Ion Implantation/Sputtering Facility

Dwg. No. 6154-3-II-PR-1

$M-1$

Process Flow Diagram

A-1

$A-2$

$A-3$

$V-1$

$E-1$

$\mathrm{P}-1$

$P-2$

$\mathrm{P}-3$

Piping and Instrumentation Diagram

Ground Floor Plan

Second Floor Plan

Building Sections

HVAC Flow Diagram

Electrical Single Line Diagram

Piping Plan

Piping Isometric

Drainage Plan

Zeolite Encapsulation Facility

Dwg. No. 6154-3-HP-PR-2

$M-2$

$A-4$

A-5

$\mathrm{V}-2$

$E-2$

P-4

$P-5$

$P-6$

$P-7$
Process Flow Diagram

Piping and Instrumentation Diagram

Ground Floor Plan

Building Sections

HVAC Flow Diagram

Electrical Single Line Diagram

Piping Plan

Piping Isometric

Drainage Plan

Lag Storage Tanks 



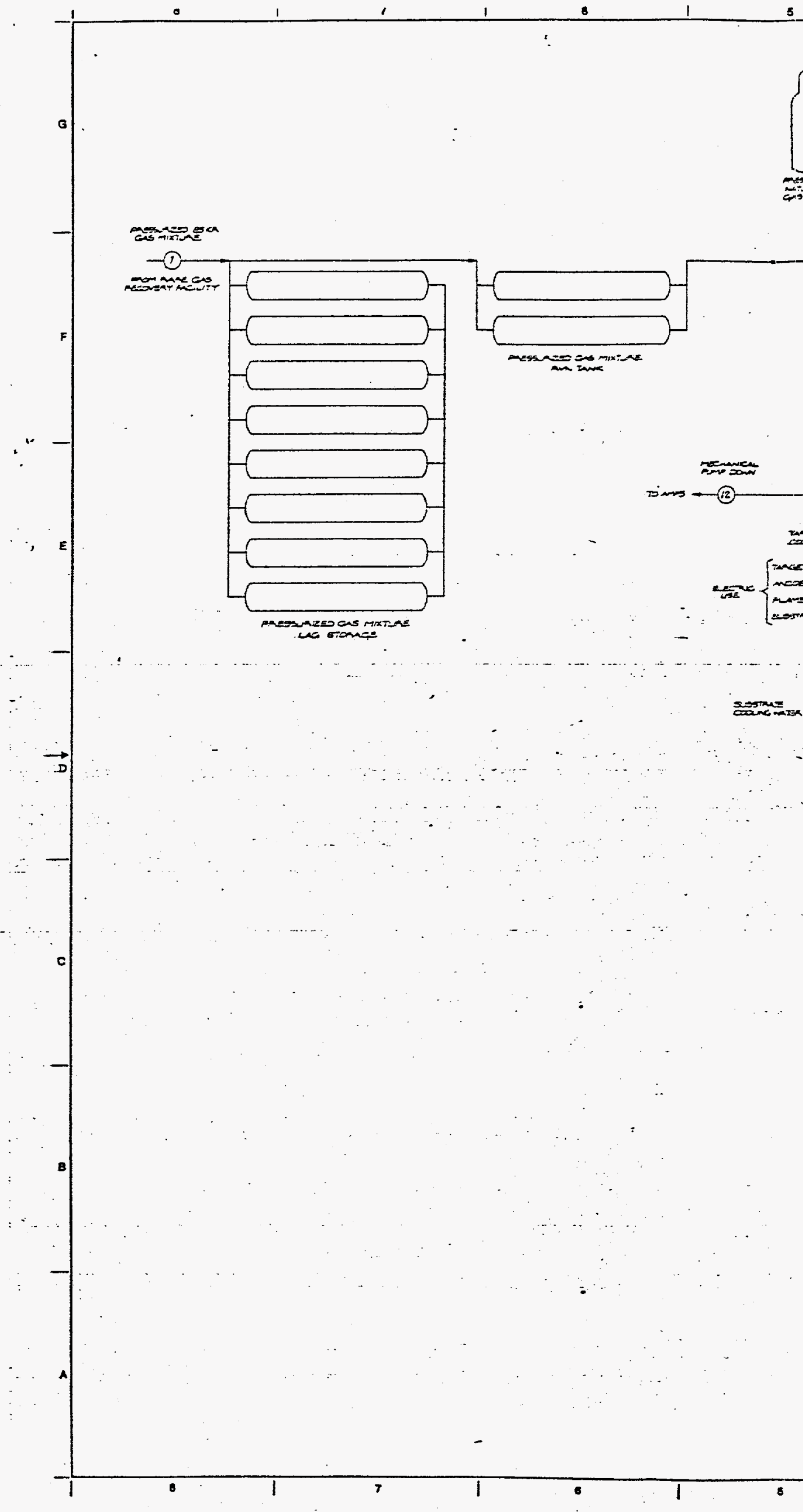




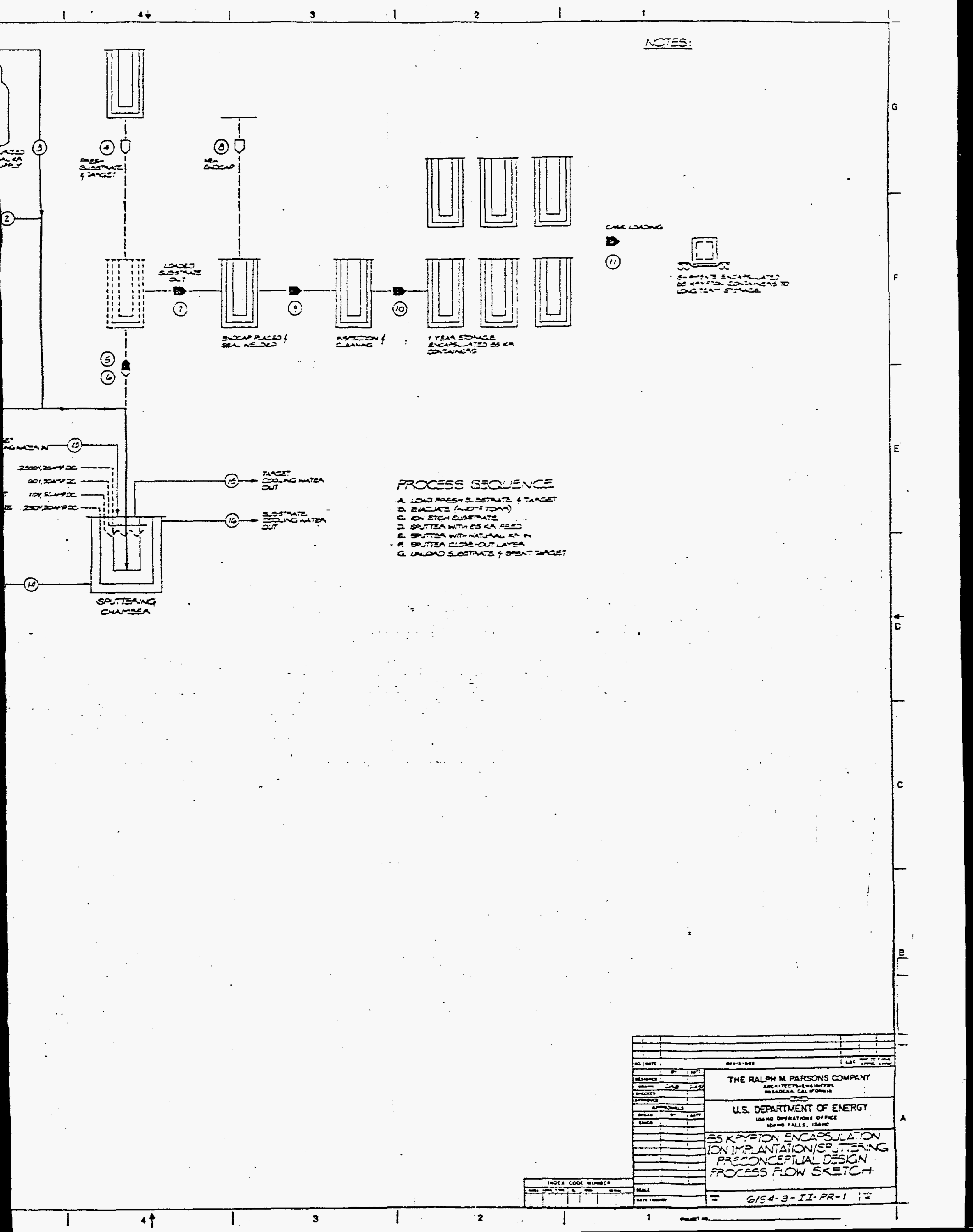




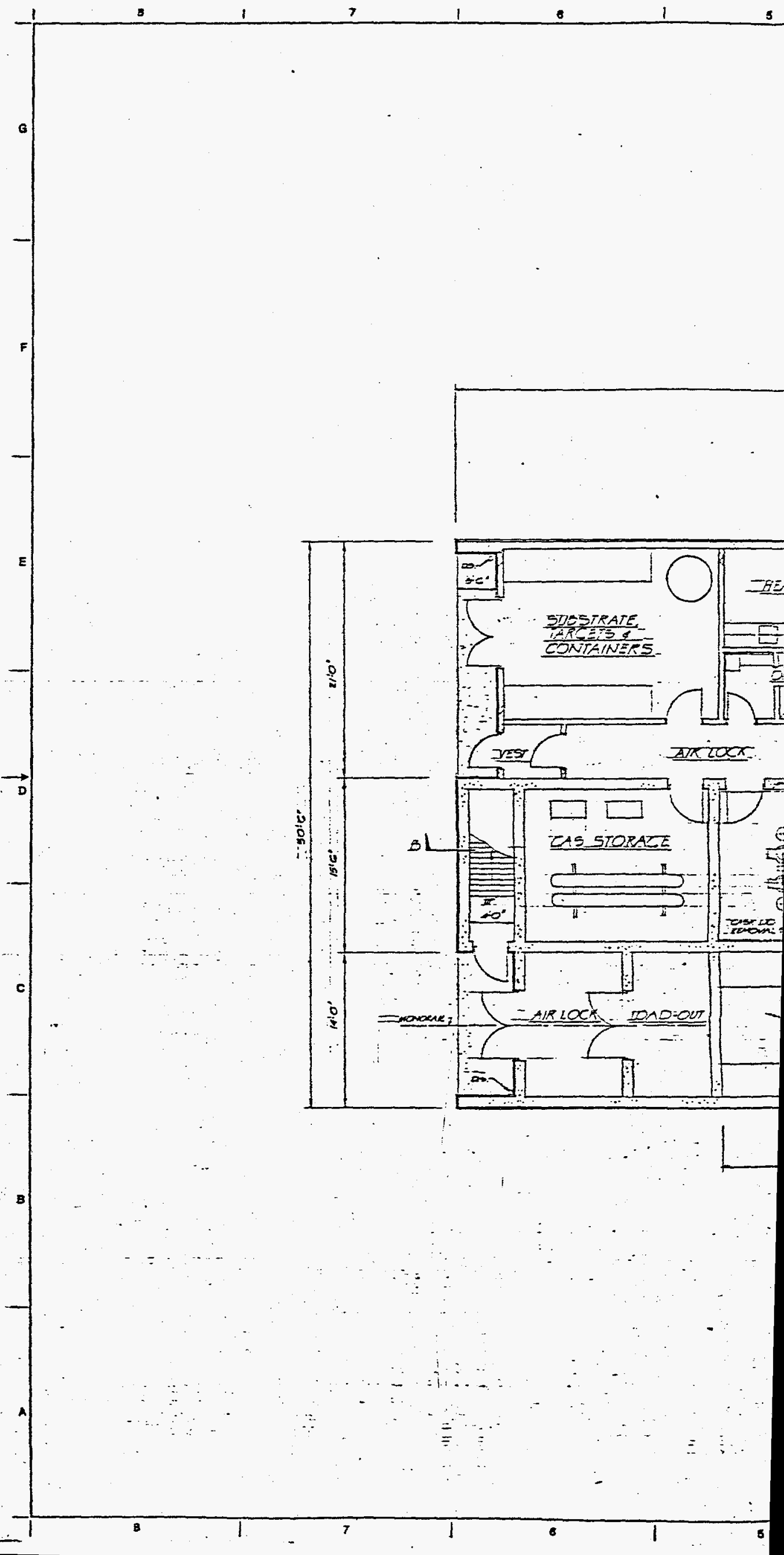




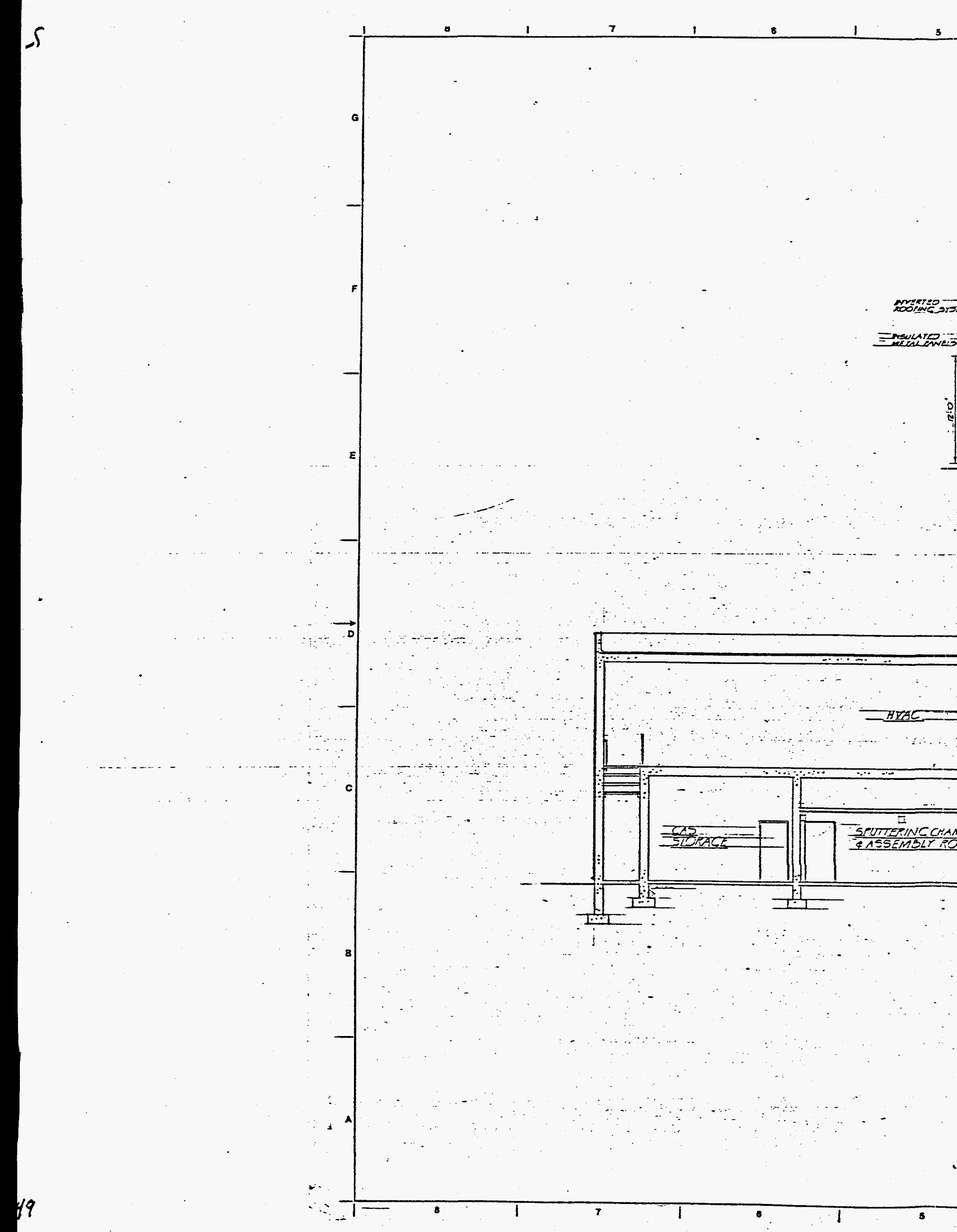




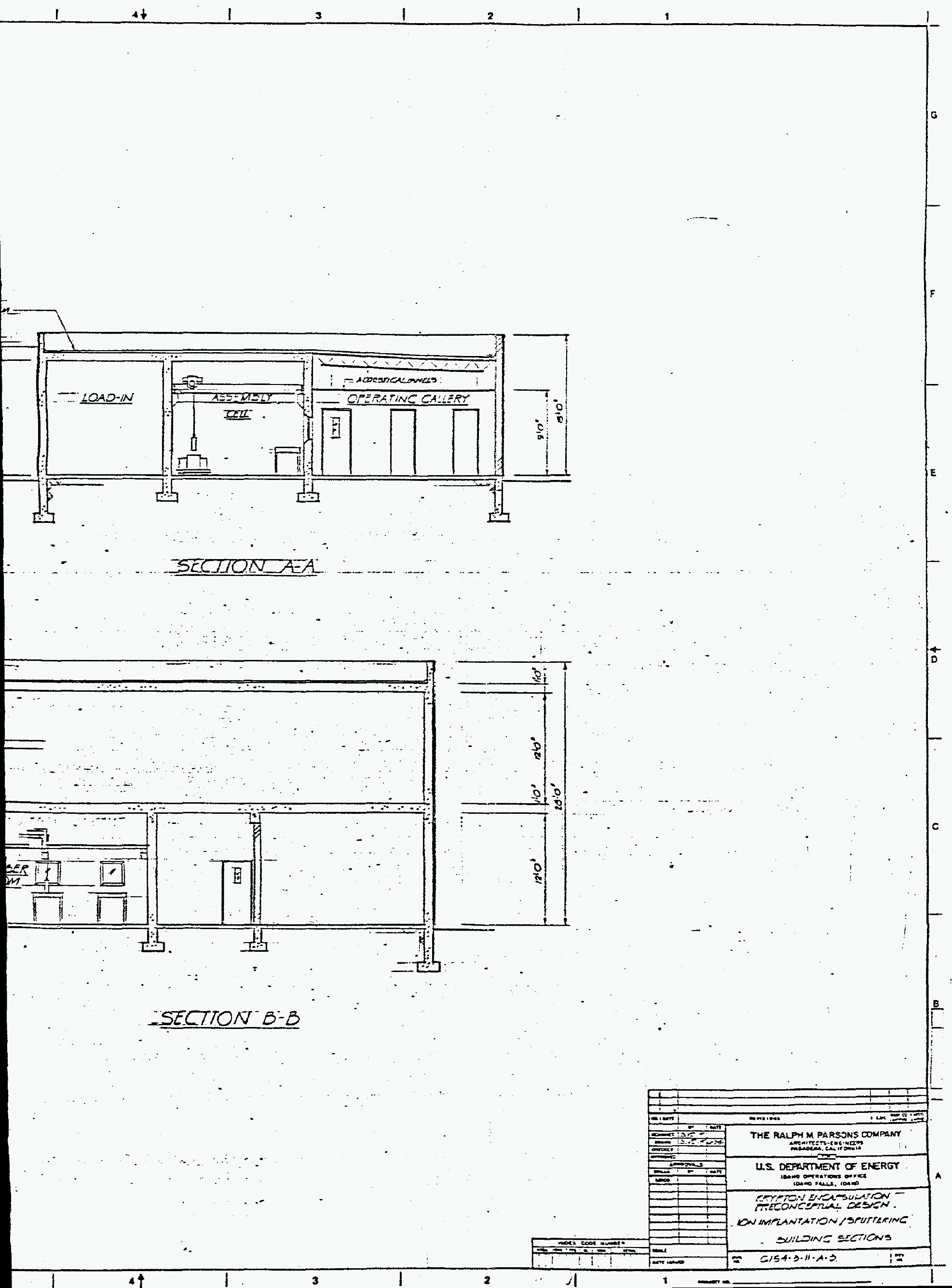




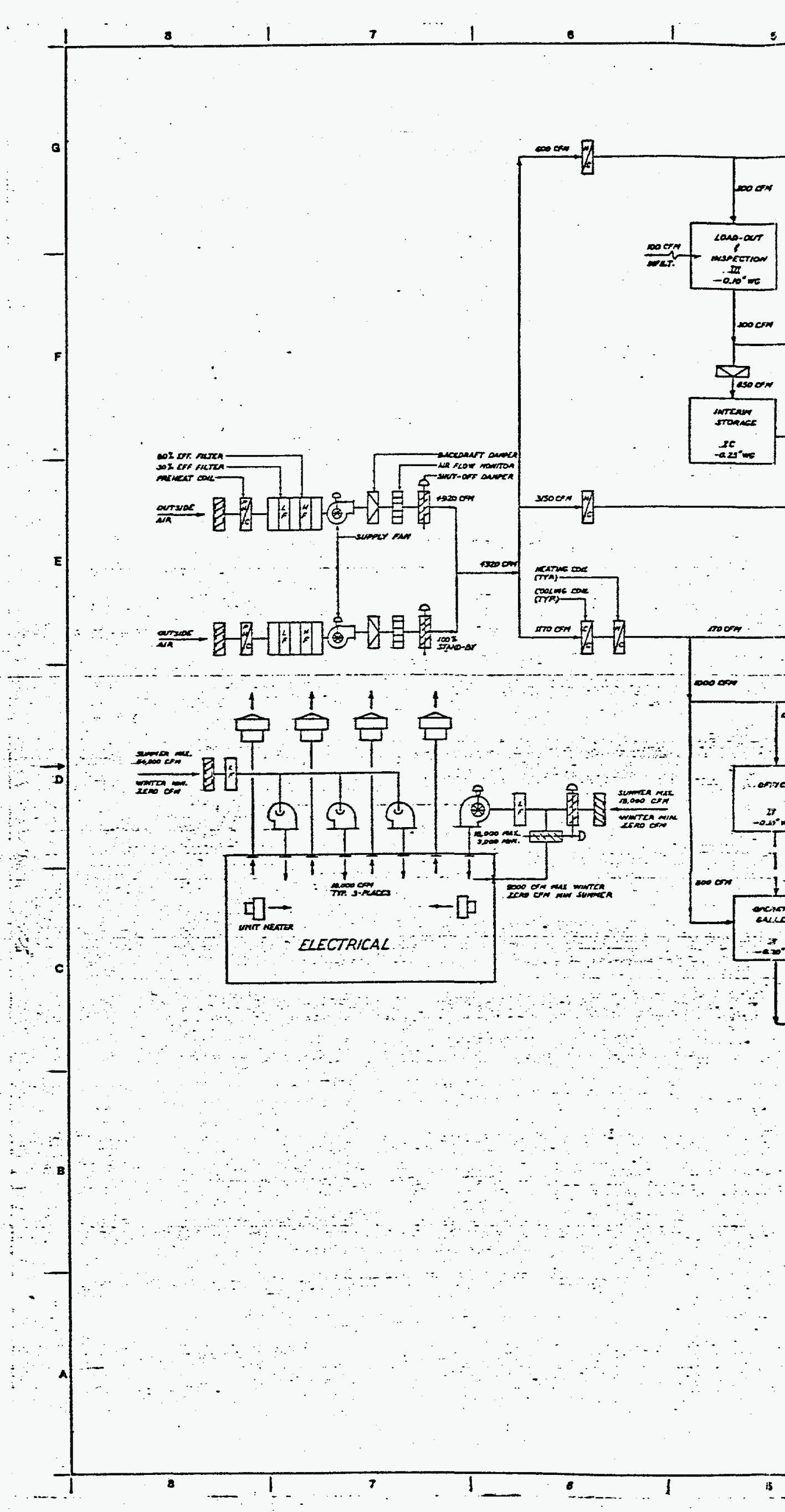



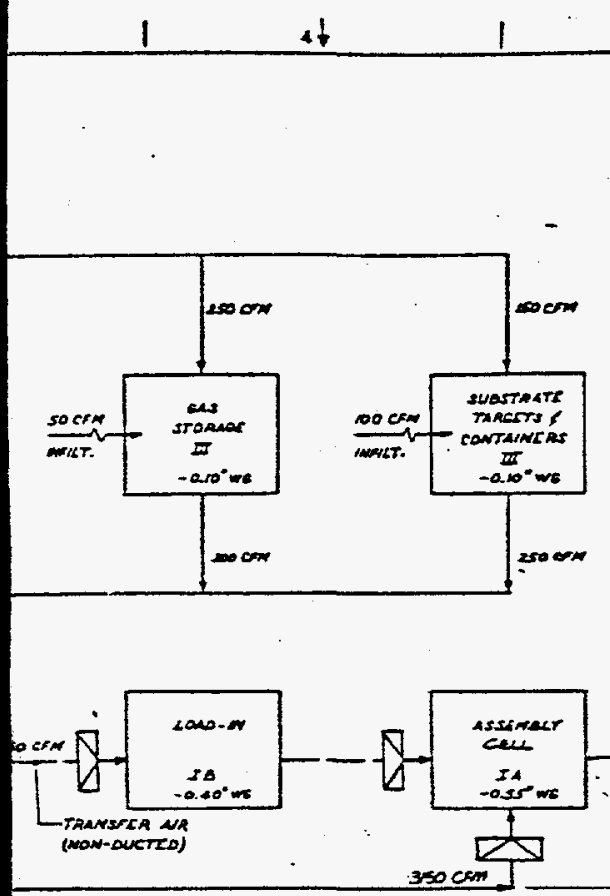

$\because$

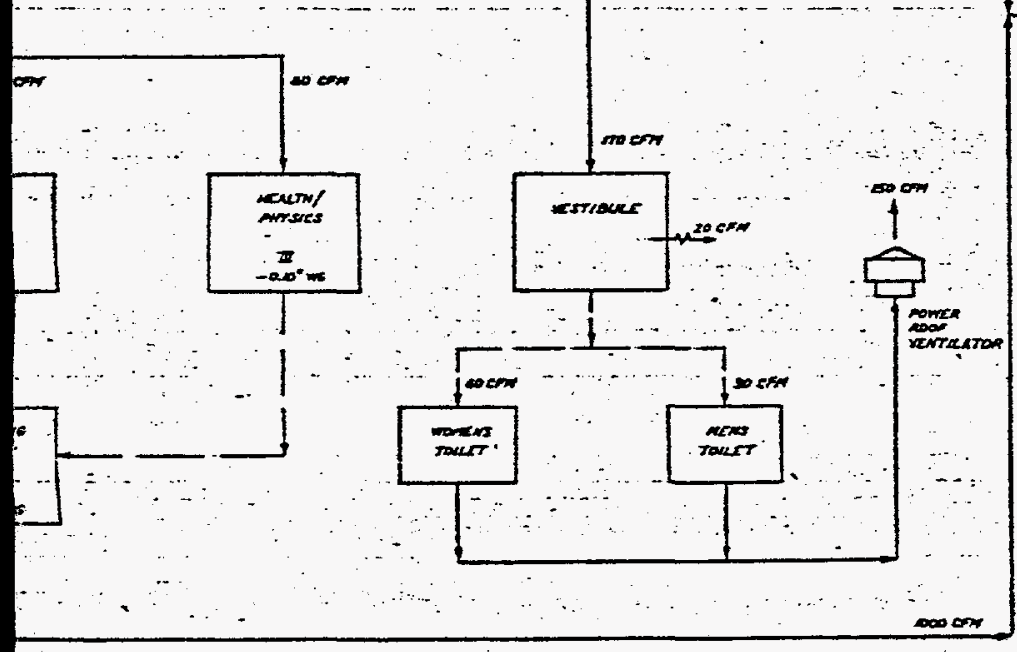

sonar coacm
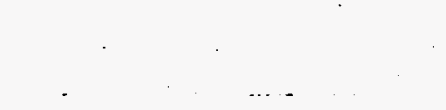


\section{8}

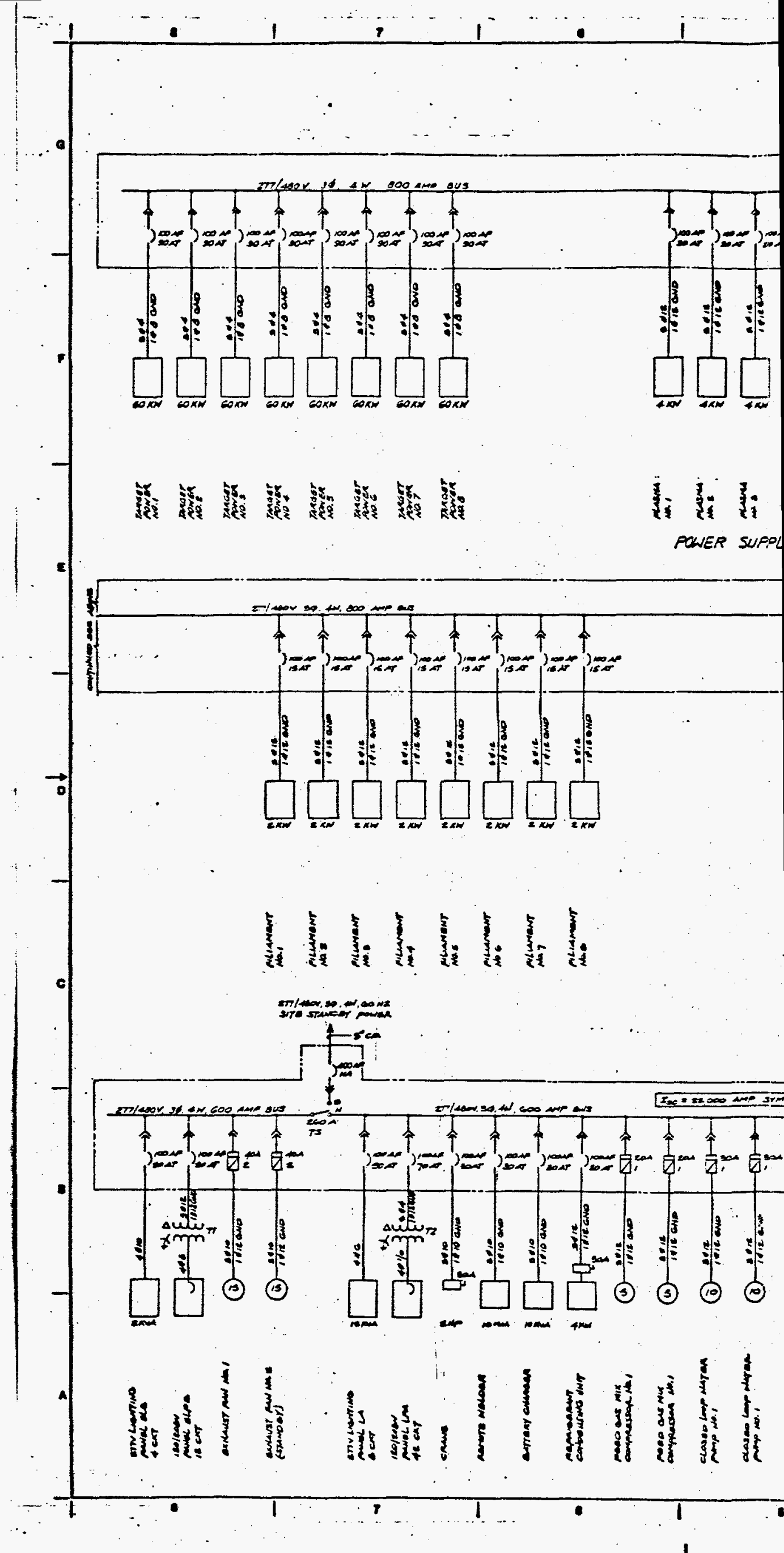




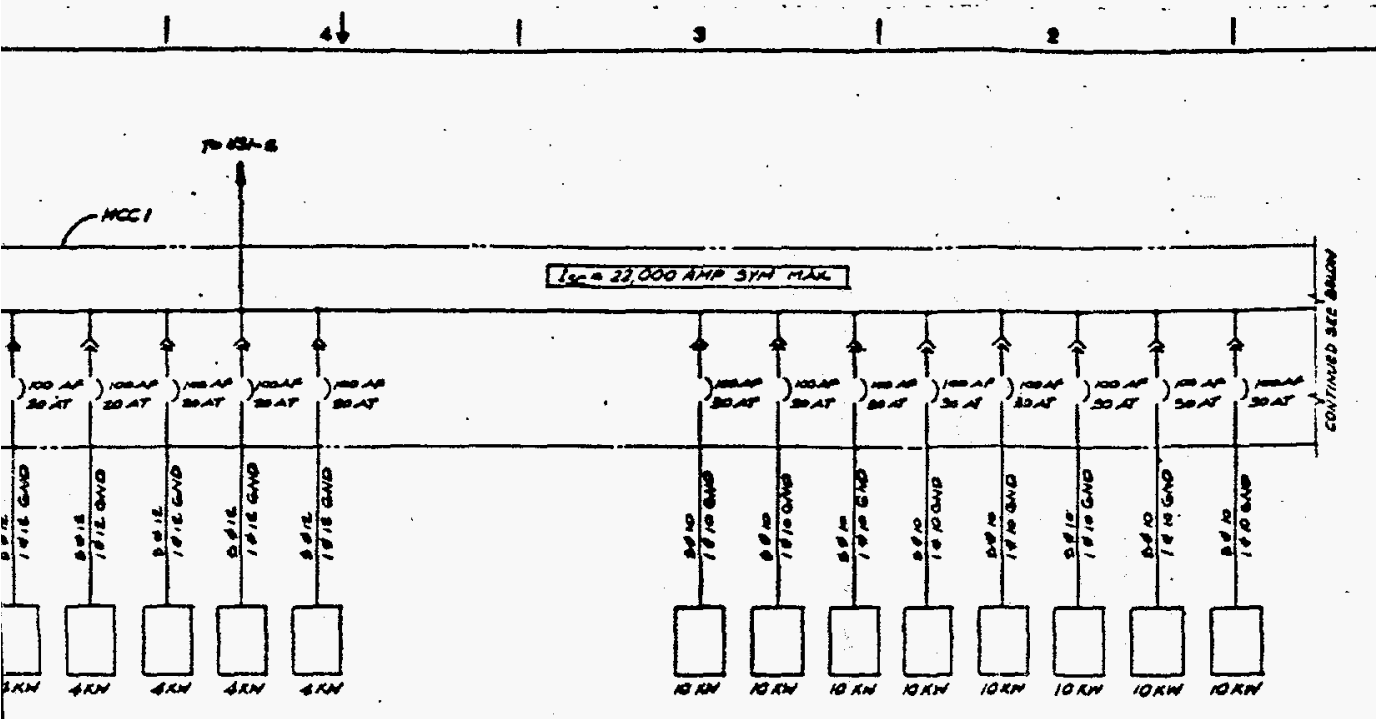

il ES KEF $\Pi$-SCI THRU SCB rimes
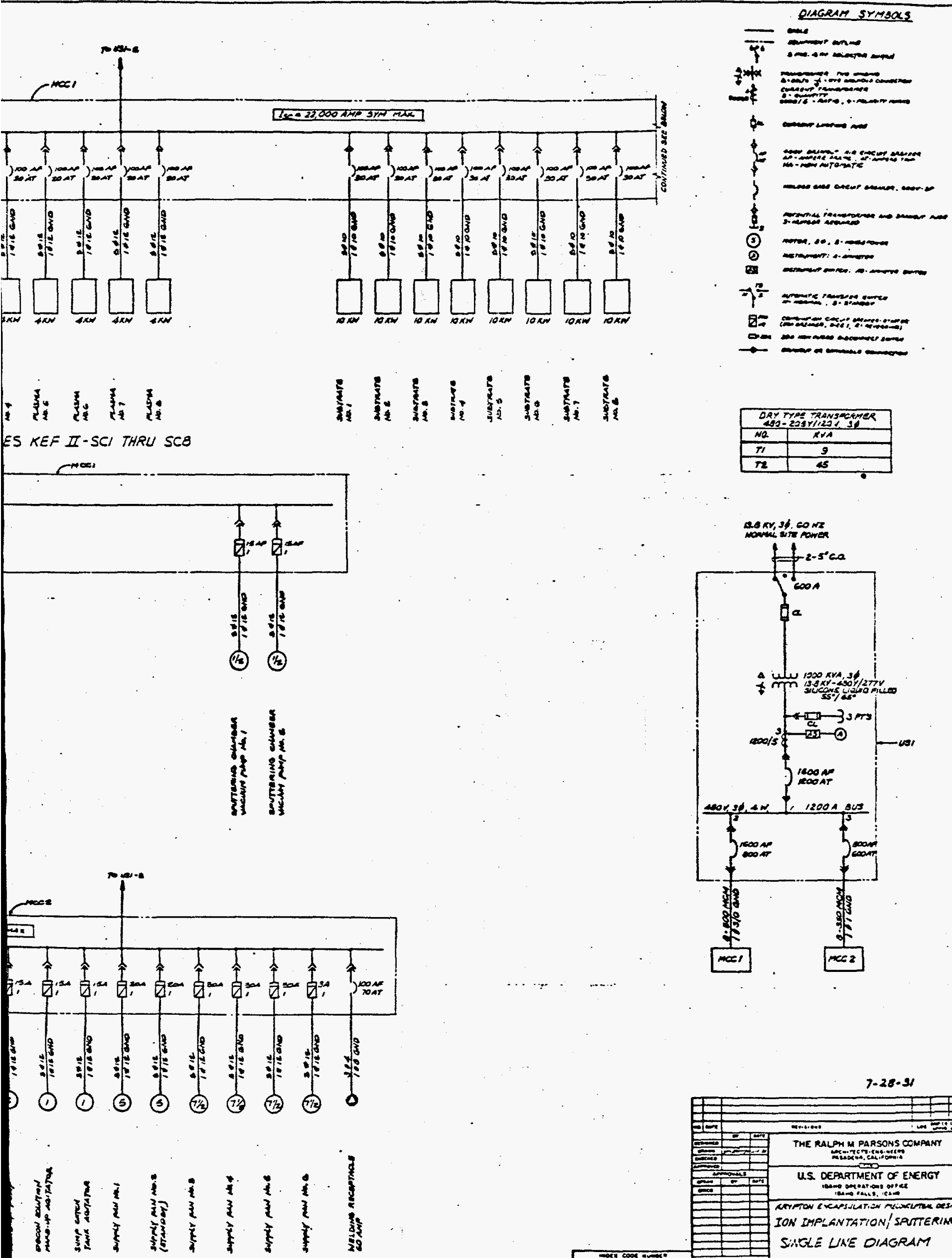

$2-5^{\circ}$

$\cos$ 


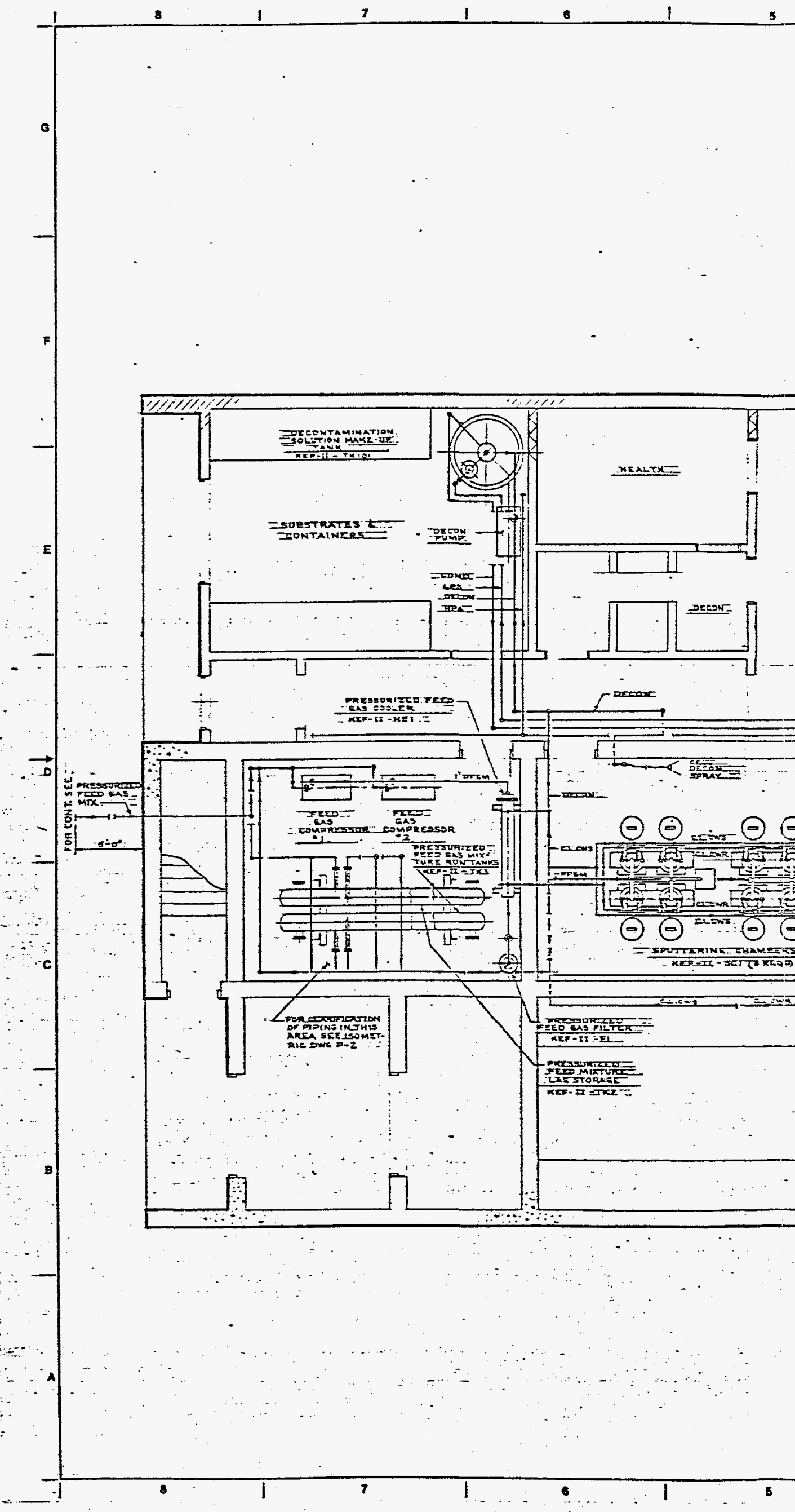




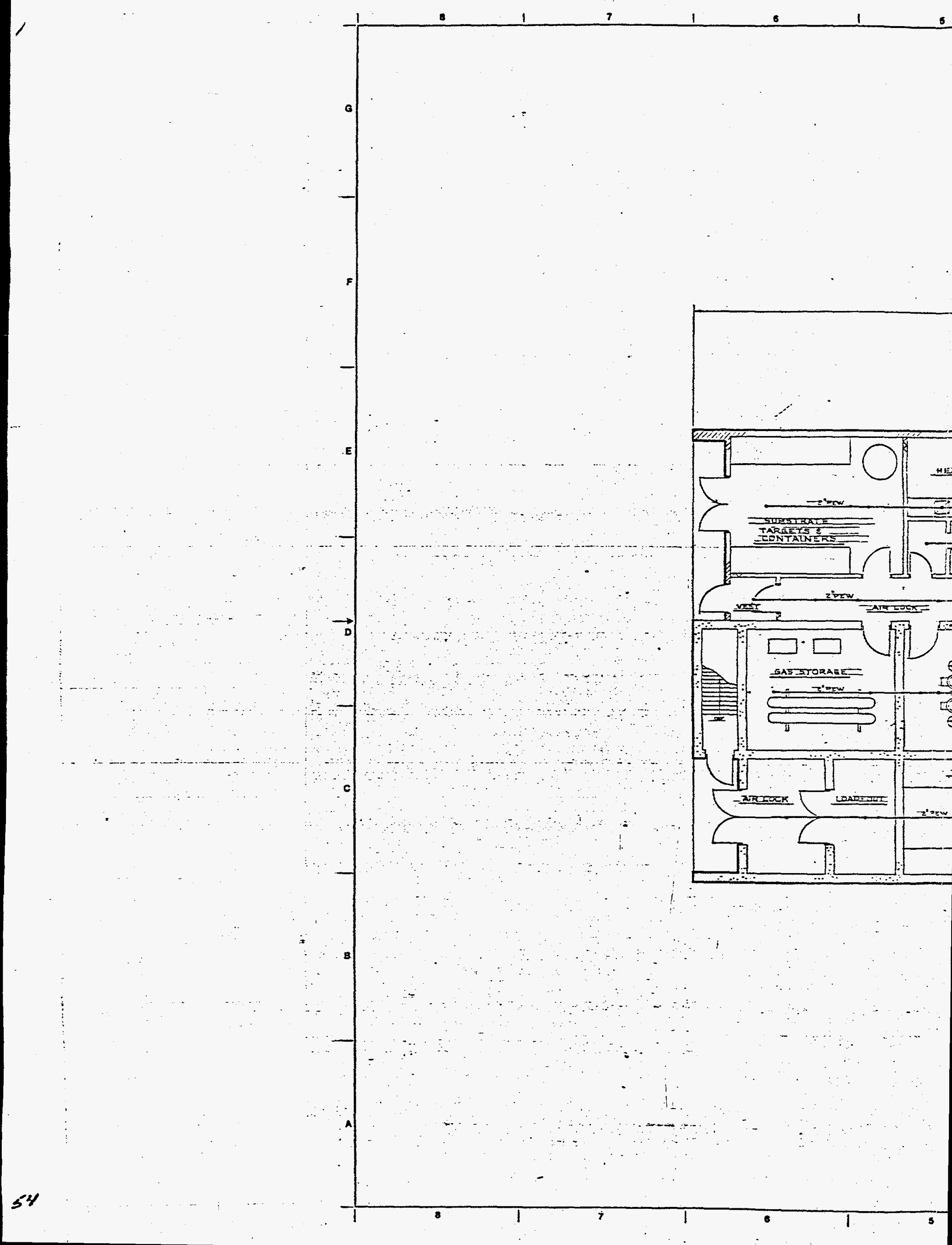




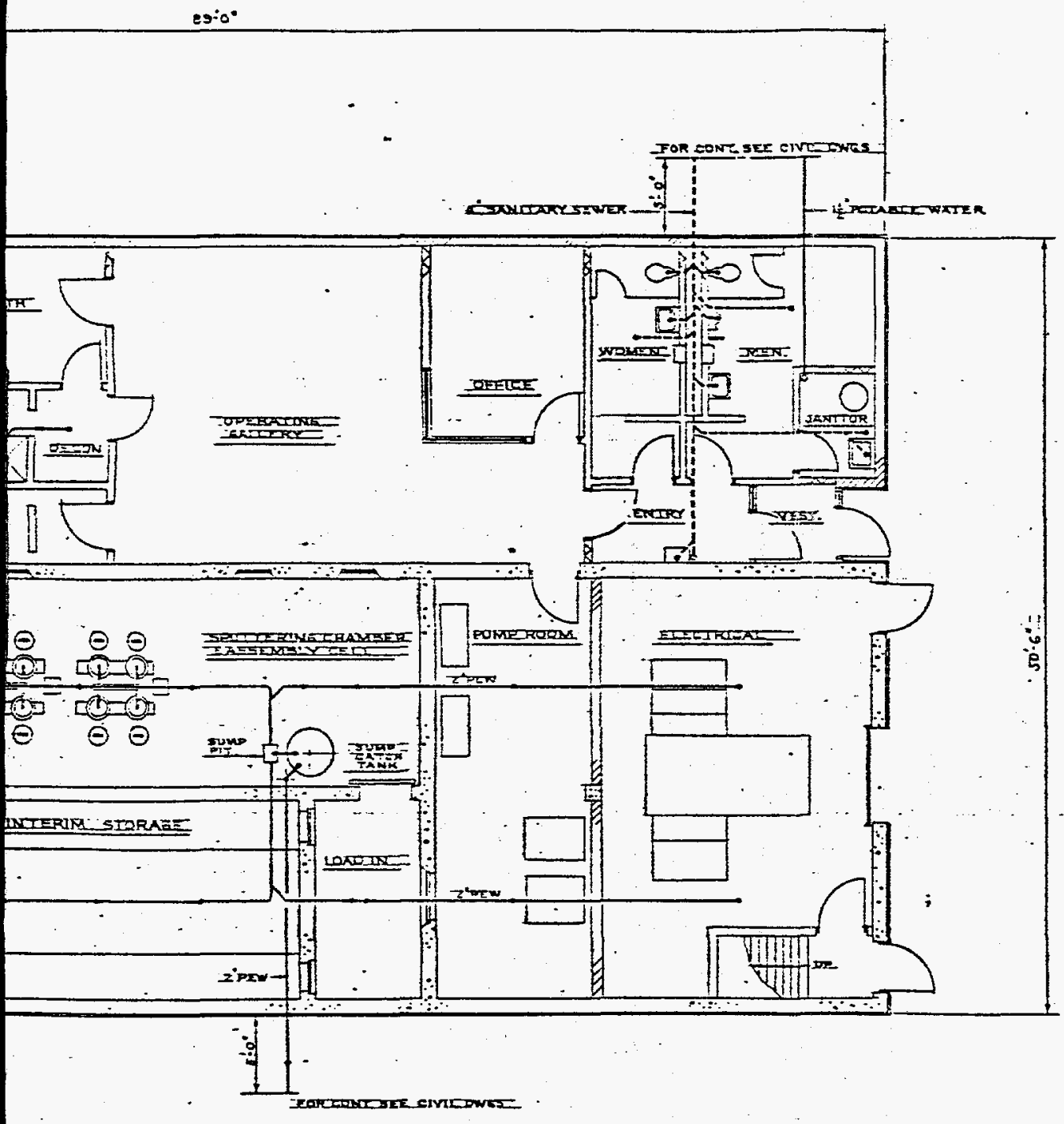



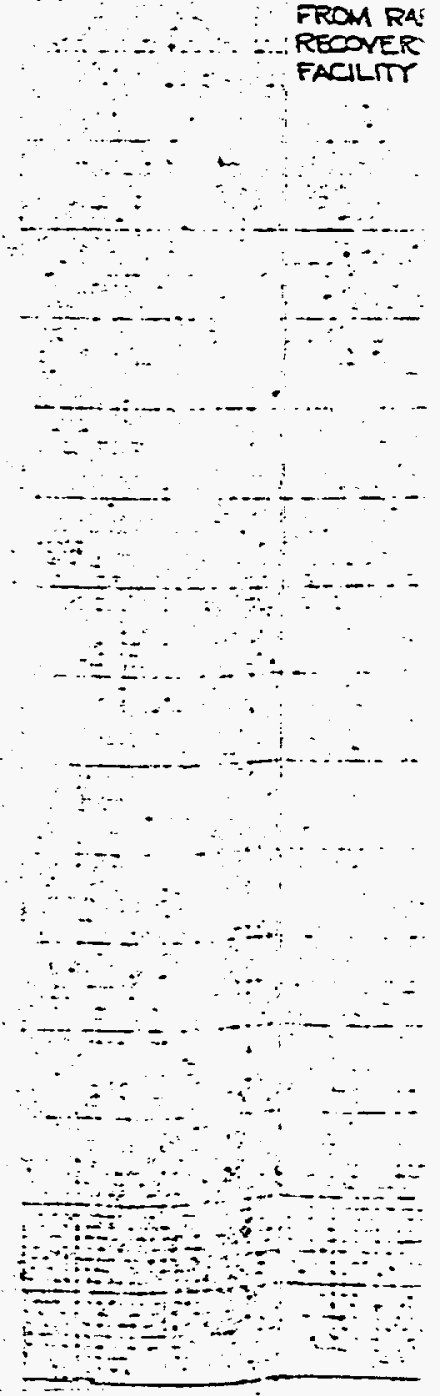


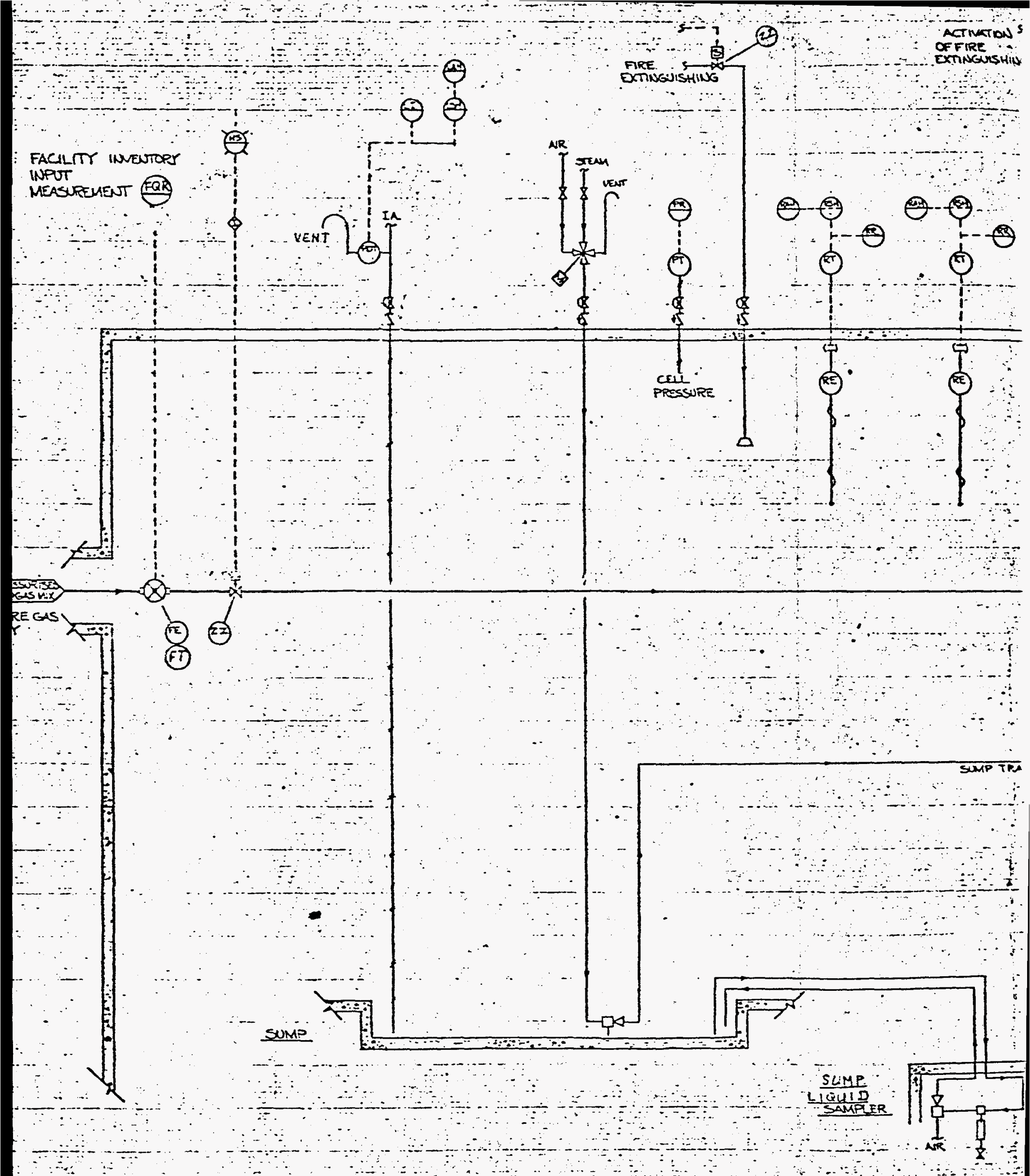


孚

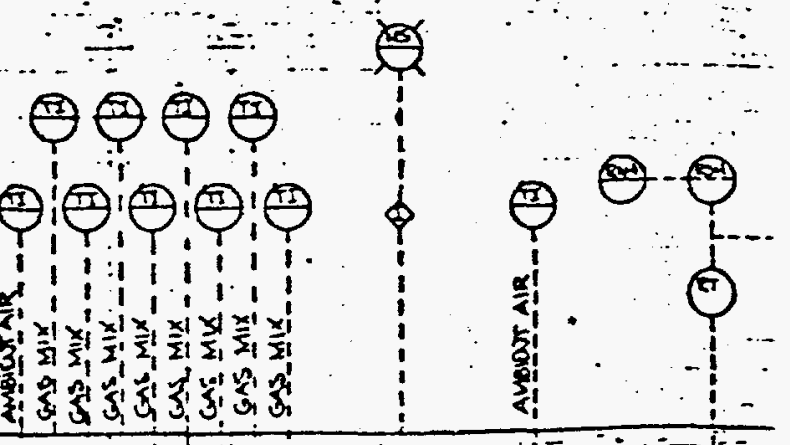

30
1

(1)

$\theta$

$1-\ldots$

+

$-2 i \frac{1}{1}$

1.

1

i.

i

!

$-2$

$-2=2=$

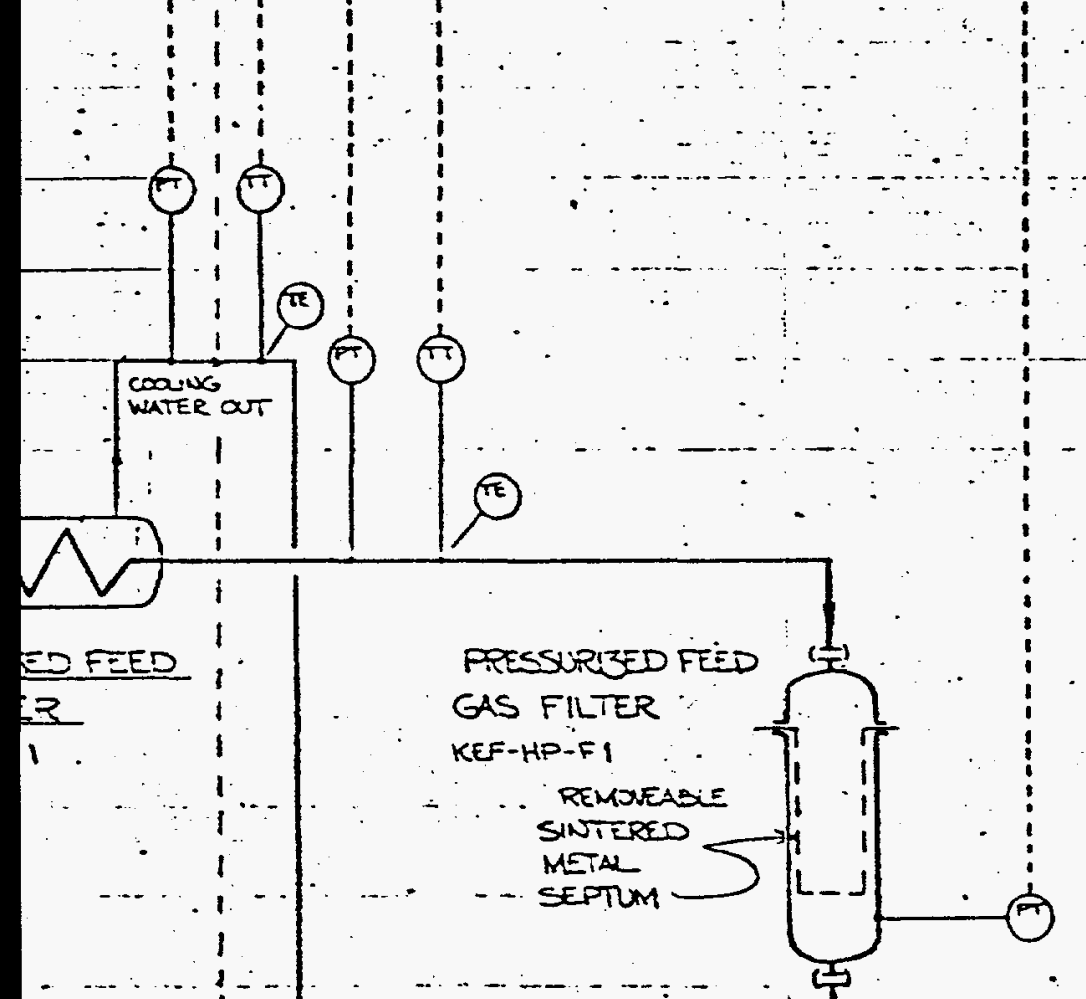

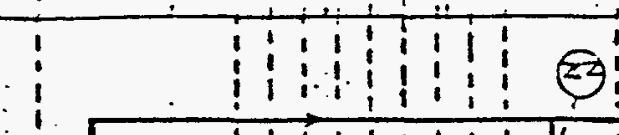

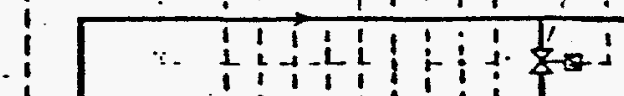

.

i

:

$\because 111.1$

:1 1 1 1

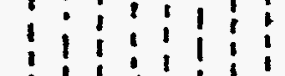

j 1 1 : 1 :

$1: 1: 19: 2$

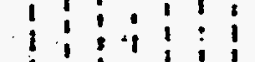

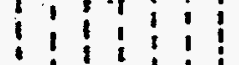

$1110^{1}$

i : 1: i

$1: 1: 11$

1 1 : :

$\begin{array}{lllll} & 1 & 1 & 1 \\ 1 & 1 & 1 & 1\end{array}$

i i i

1! ! !

1: 1

$1: 1$

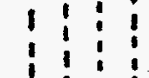

(1)

i $i=T^{5}$

1

$-$

ก)

(1)

(1)-

$\therefore \longdiv { 1 = - 1 = }$

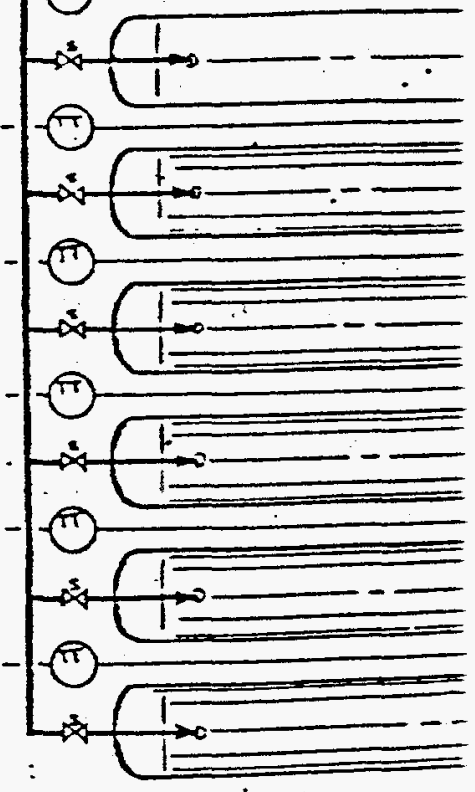

$-C$

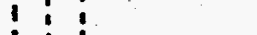

$\begin{array}{ll:c}1 & 1 & 1 \\ 1 & 1 & 1\end{array}$
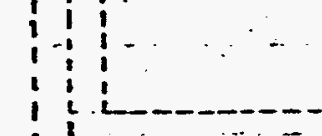

!

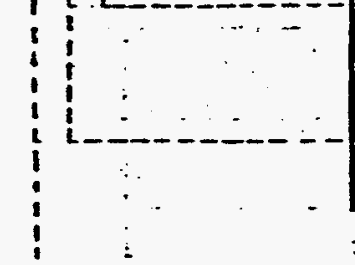

i.

(1)

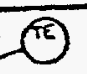

PRESSURTZED FEED GAS MI

$$
\text { KEF-HP TKZ }
$$

CLOSED Loor

contus vatie

cosints.

ar

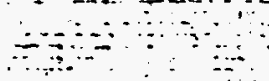




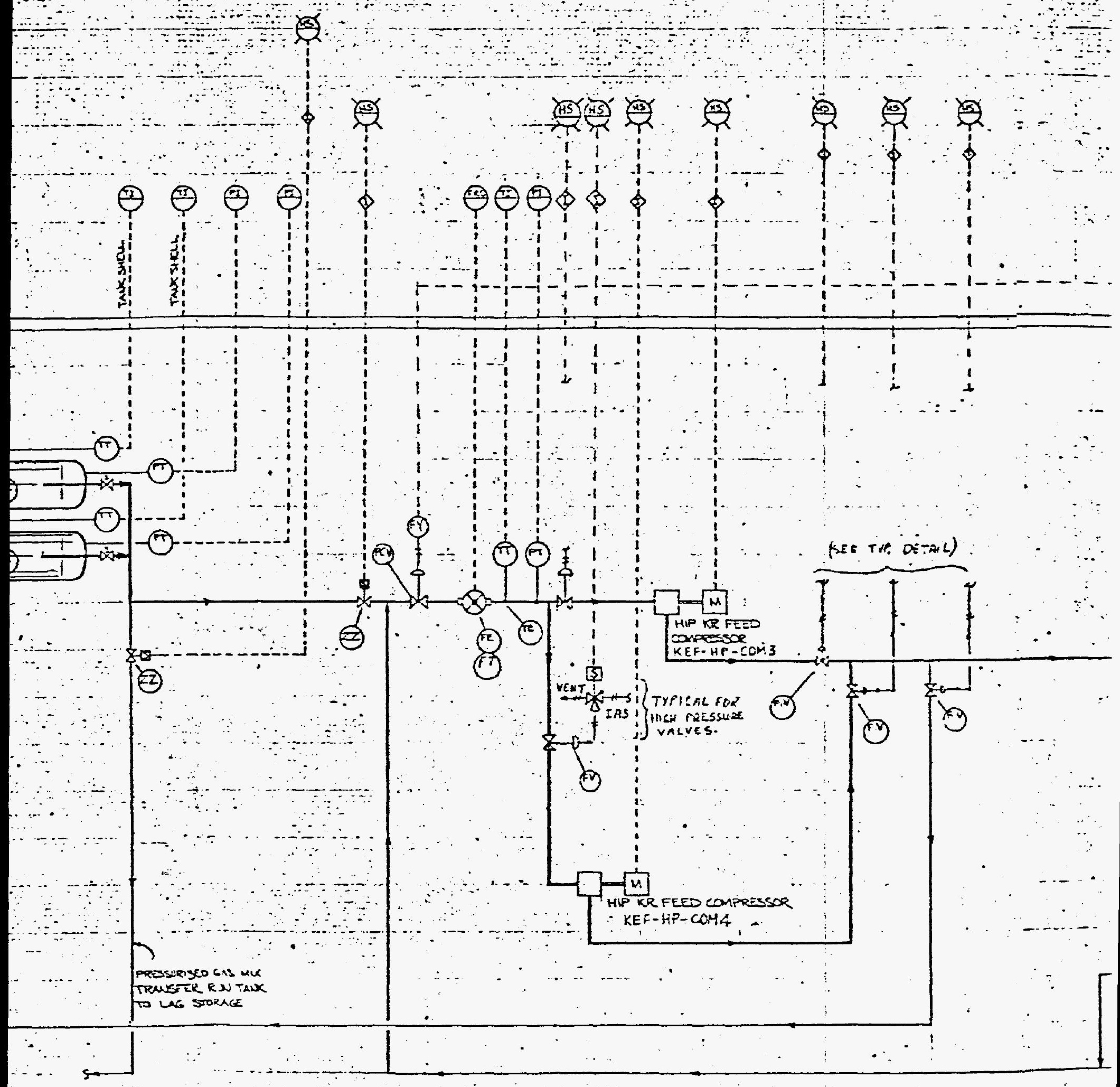




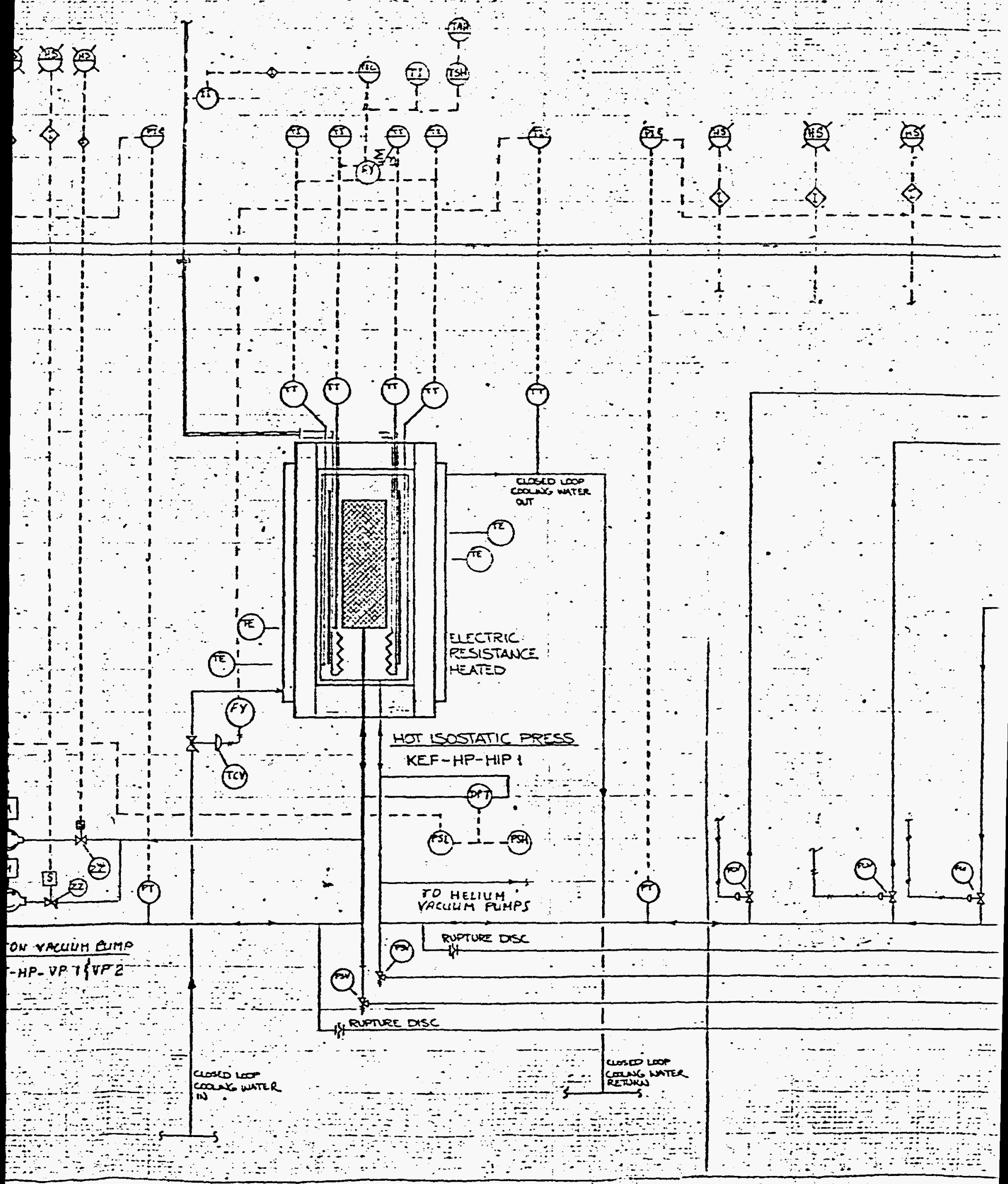




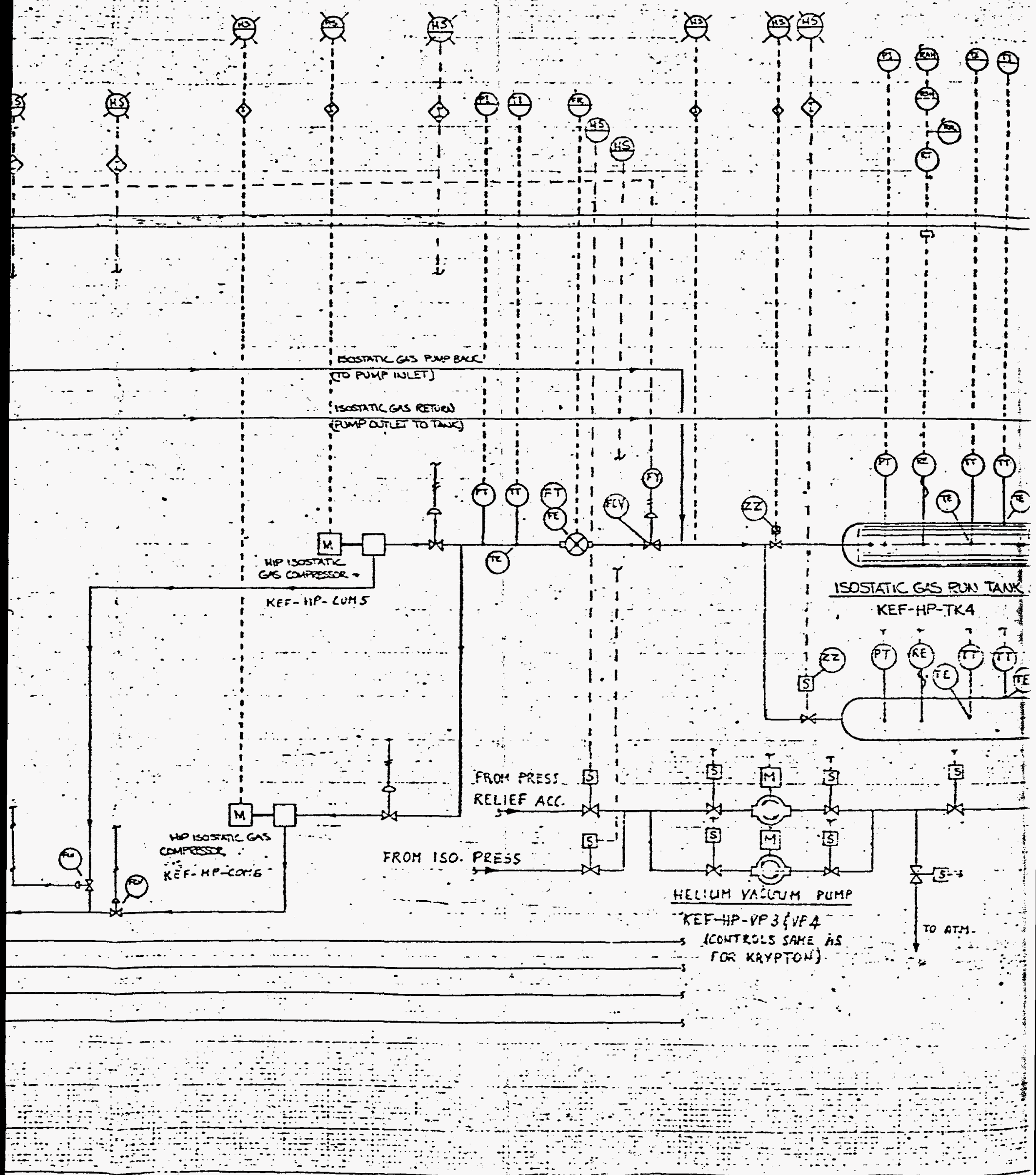




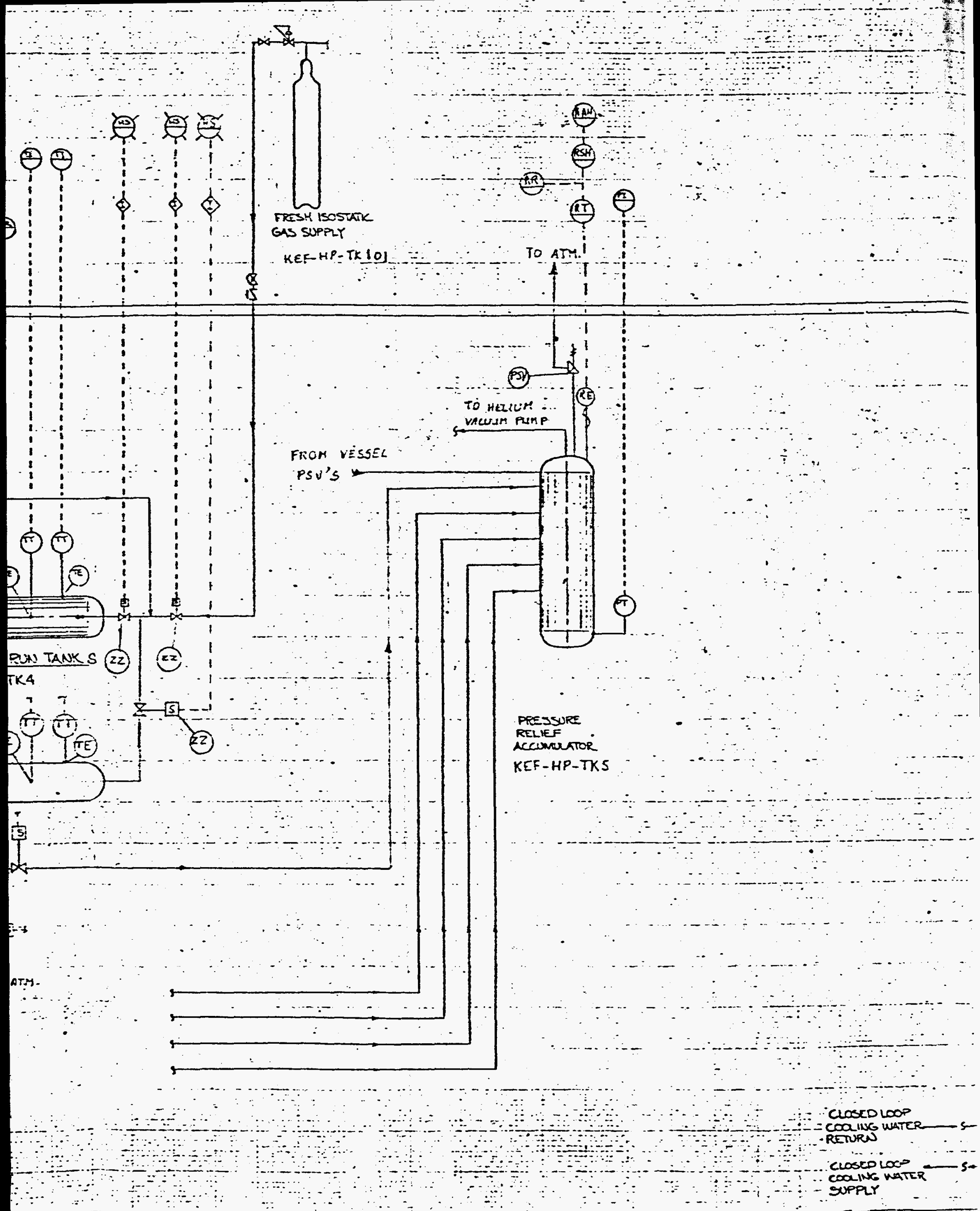




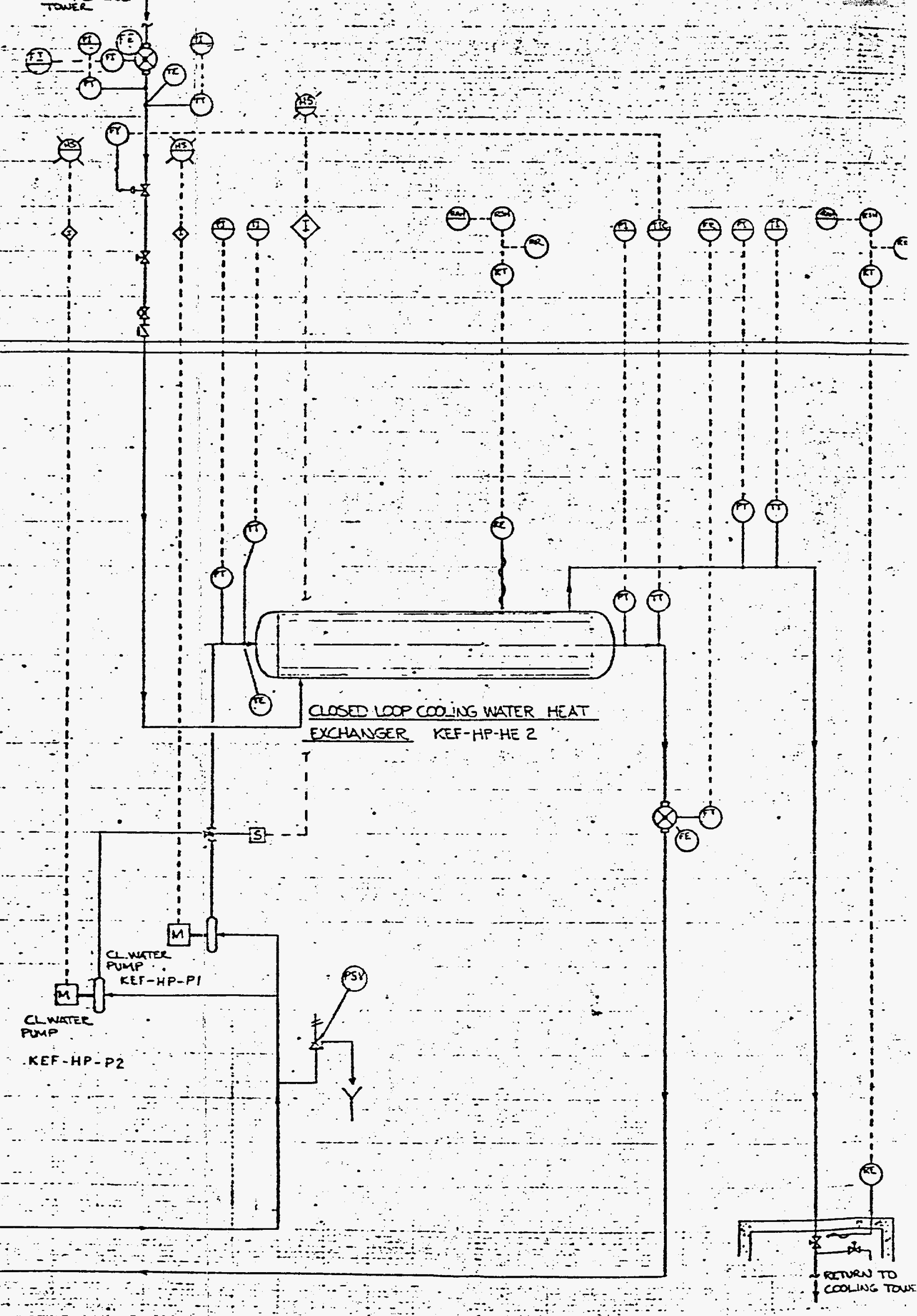




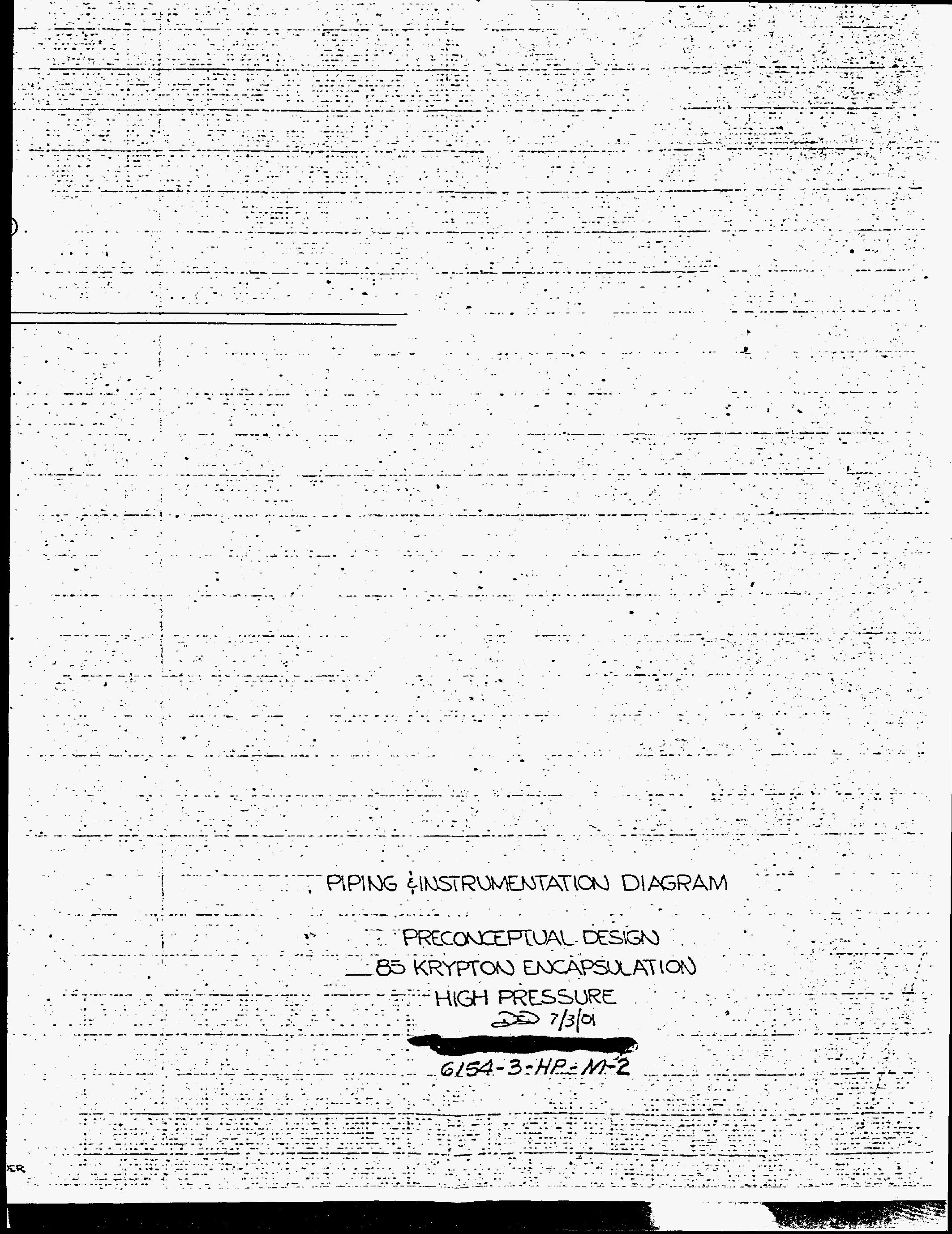




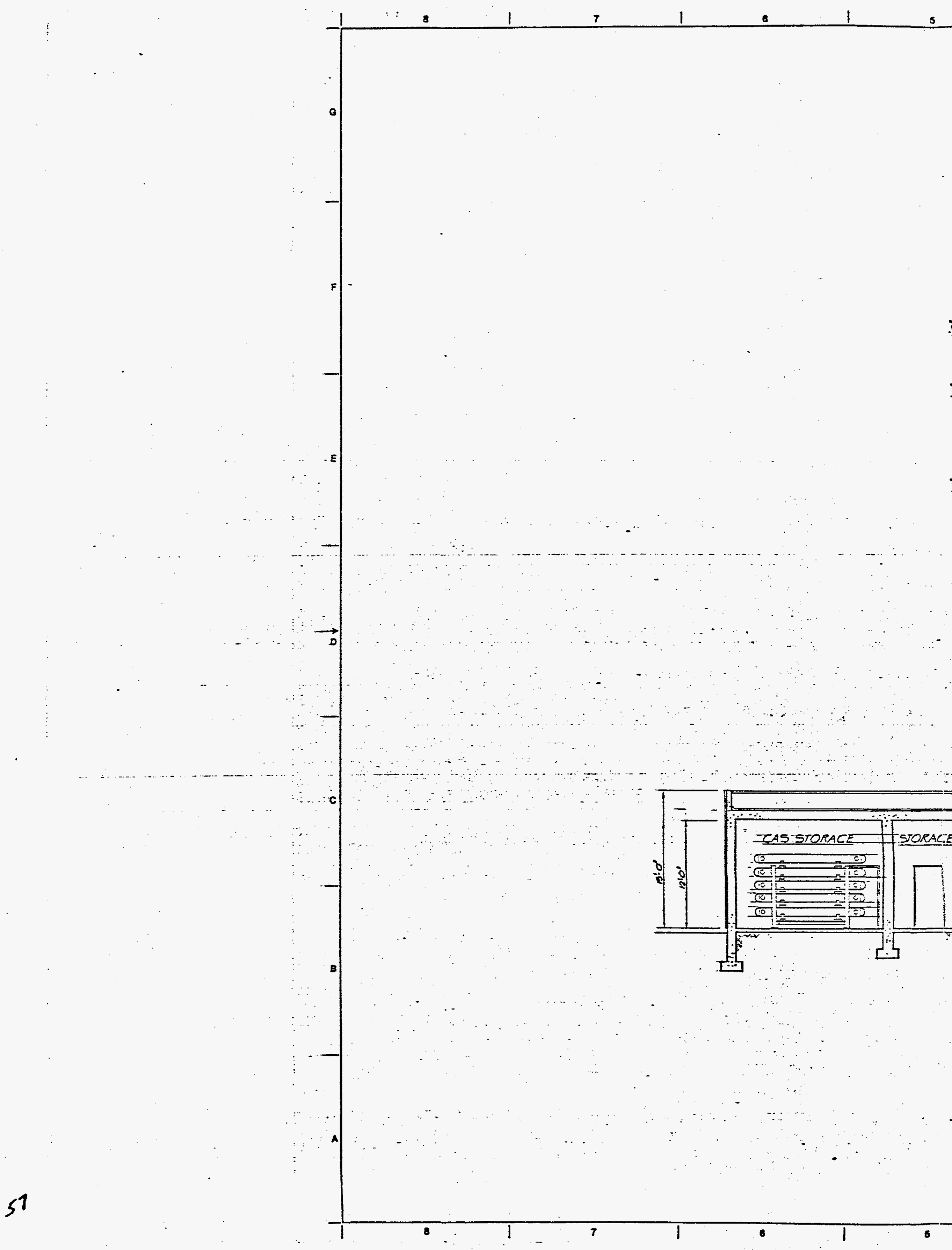




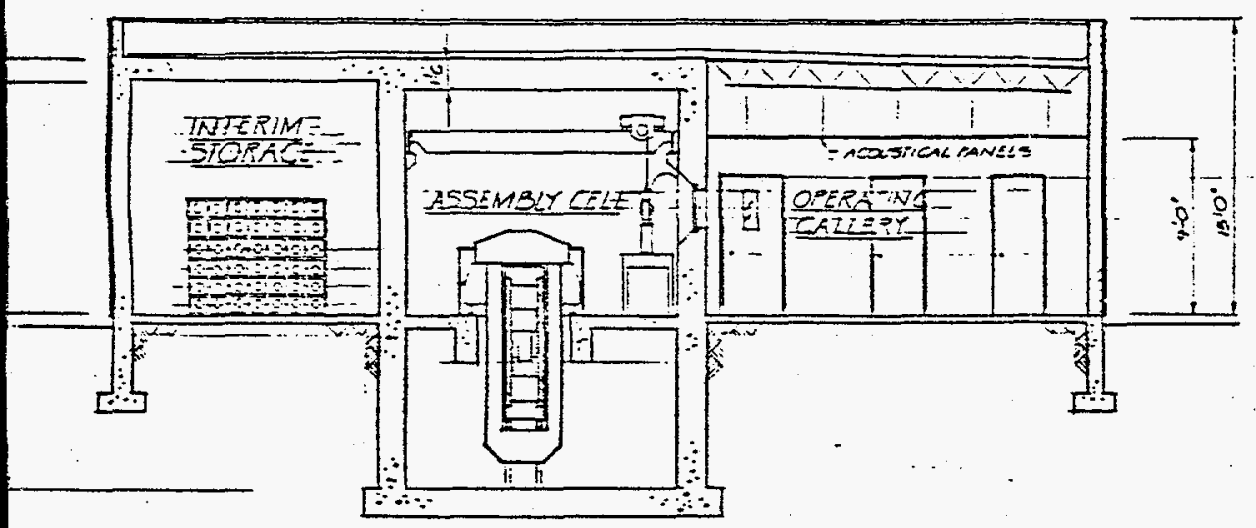

SECTION C-C

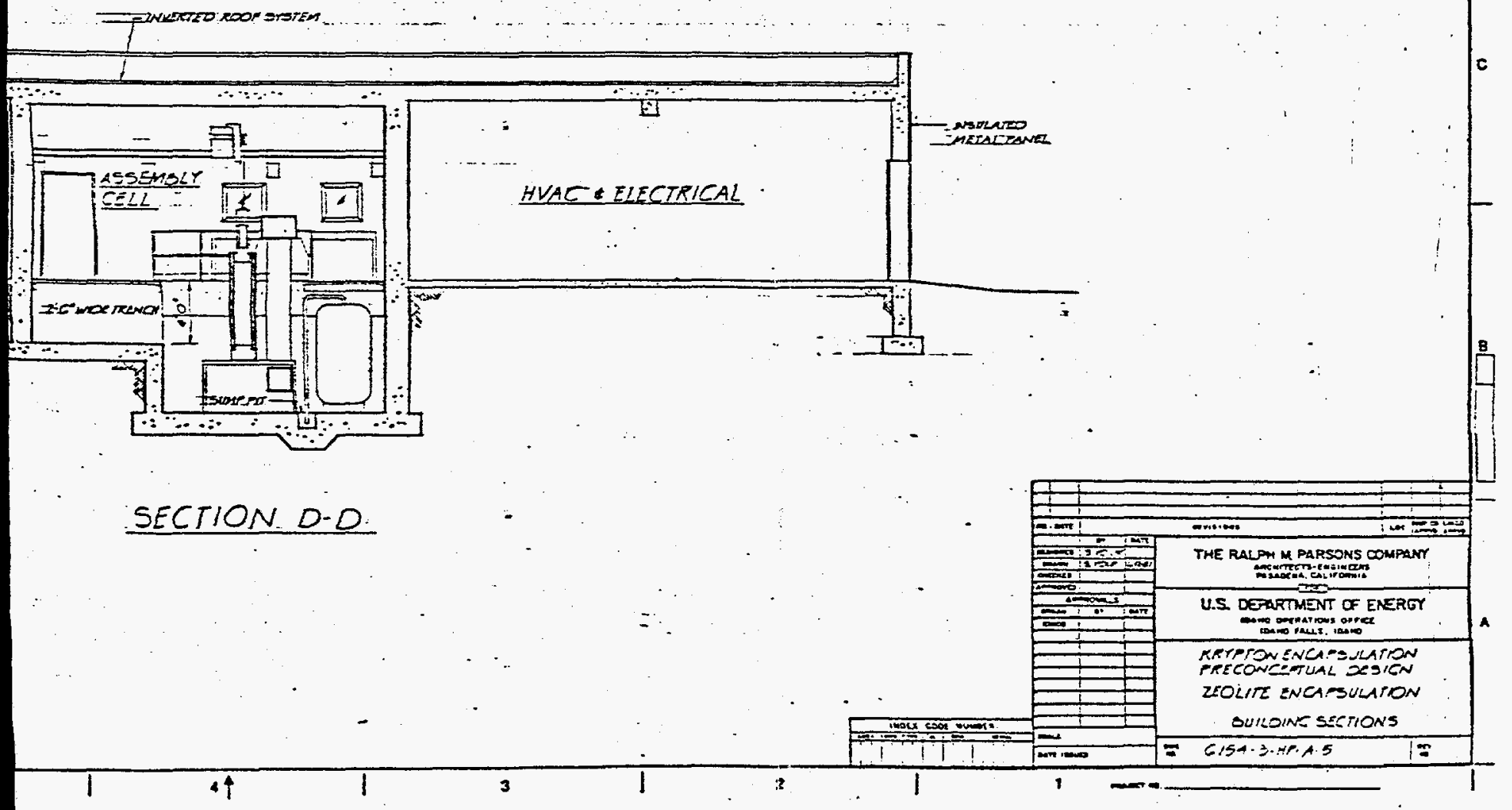




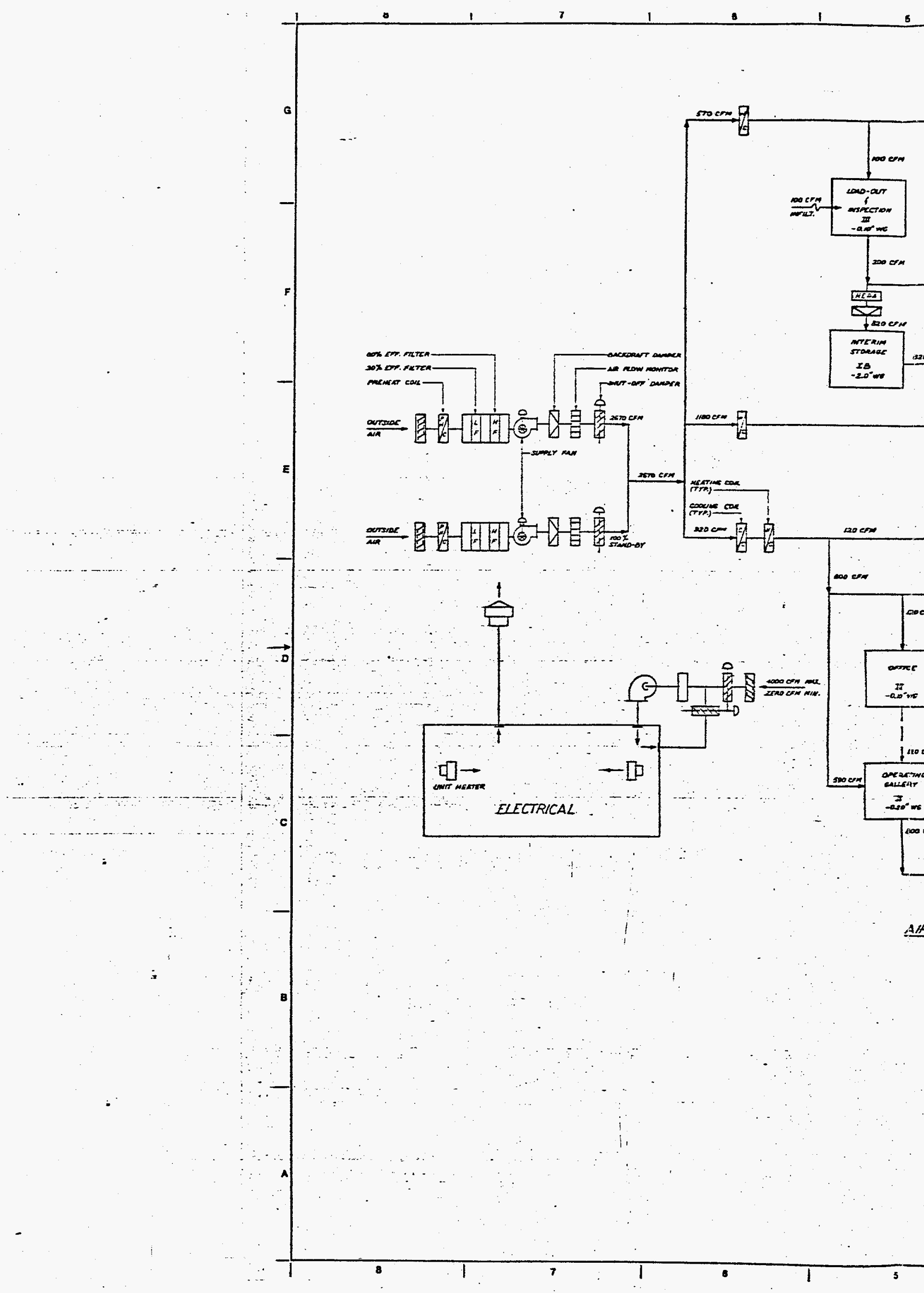




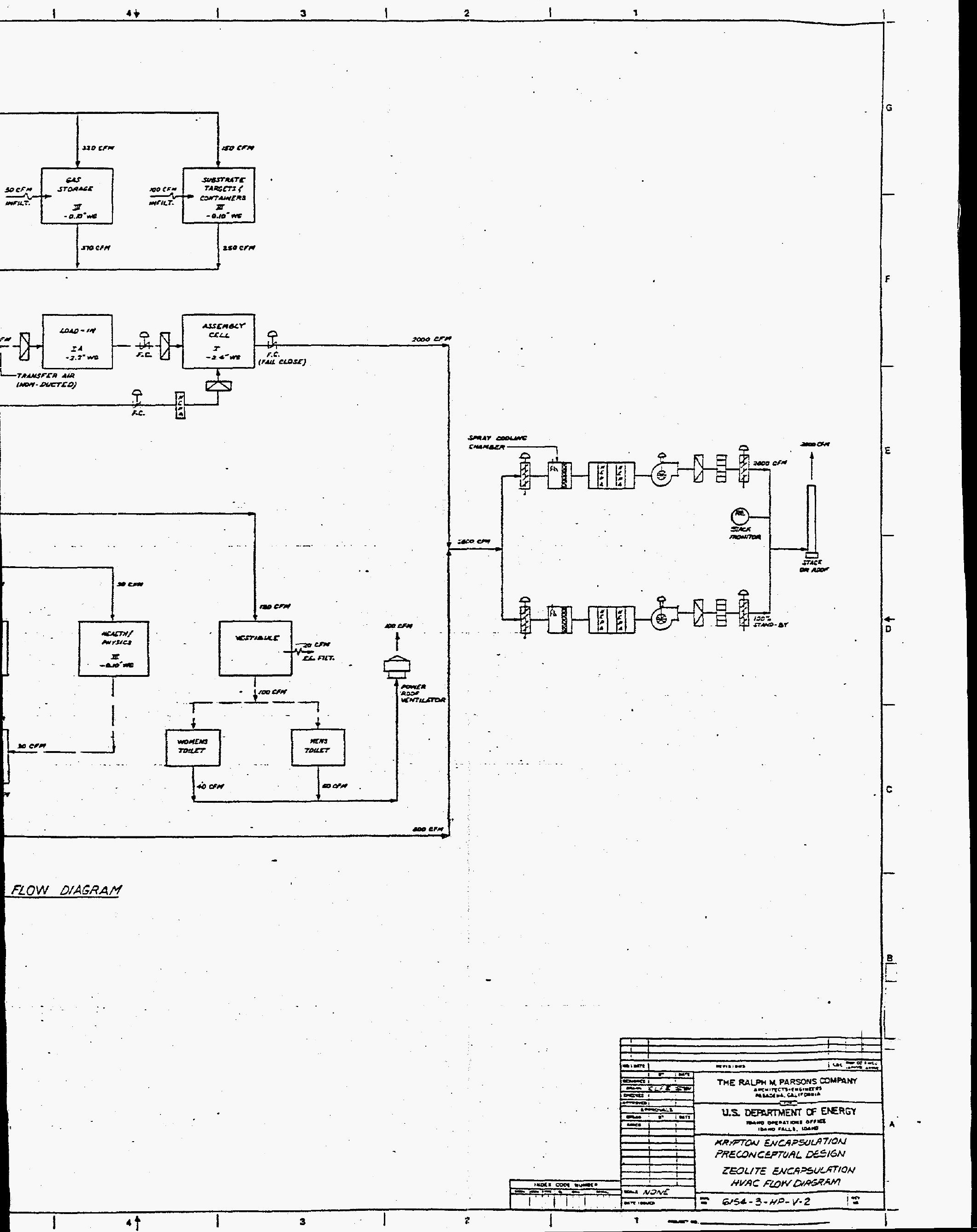




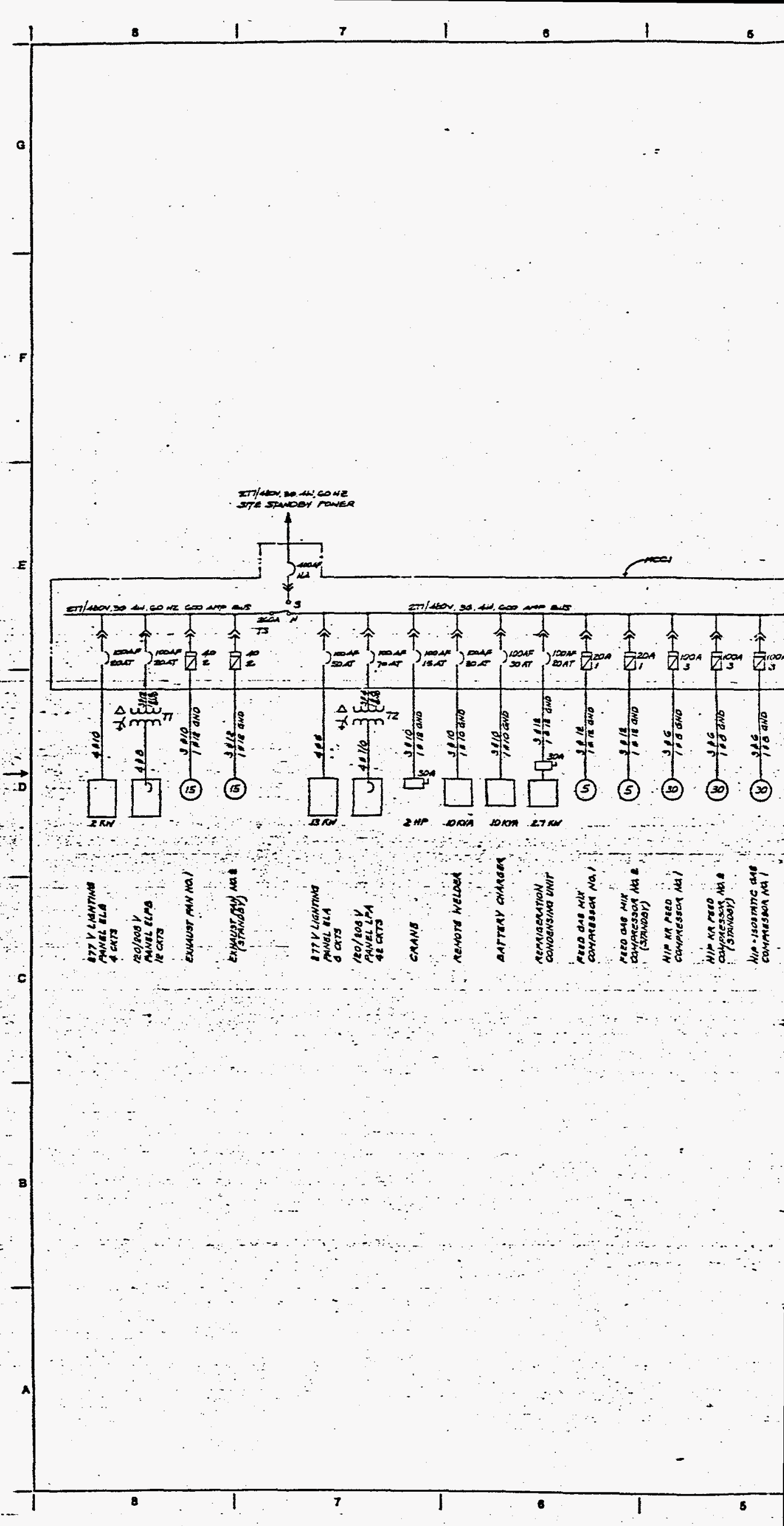




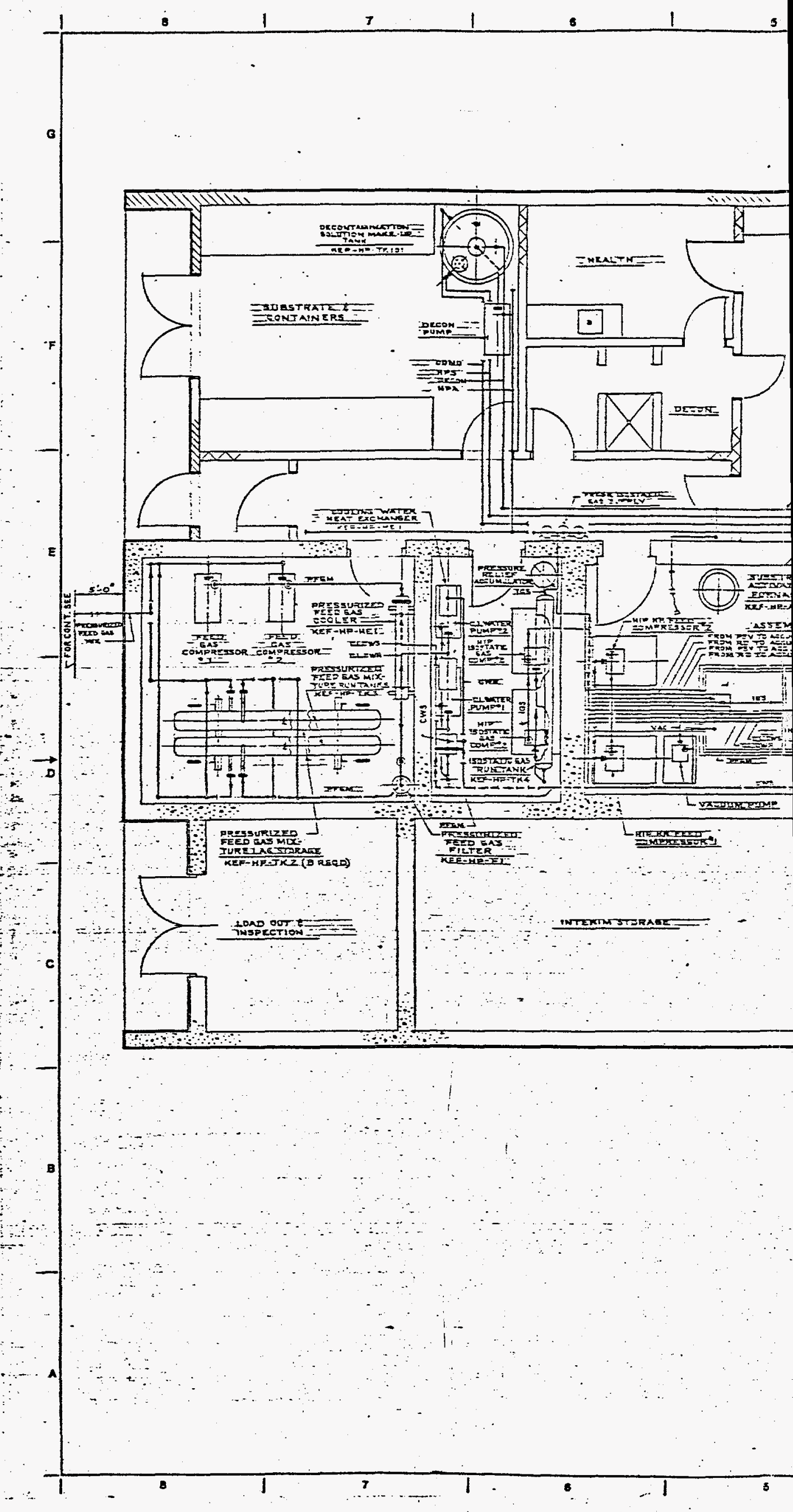



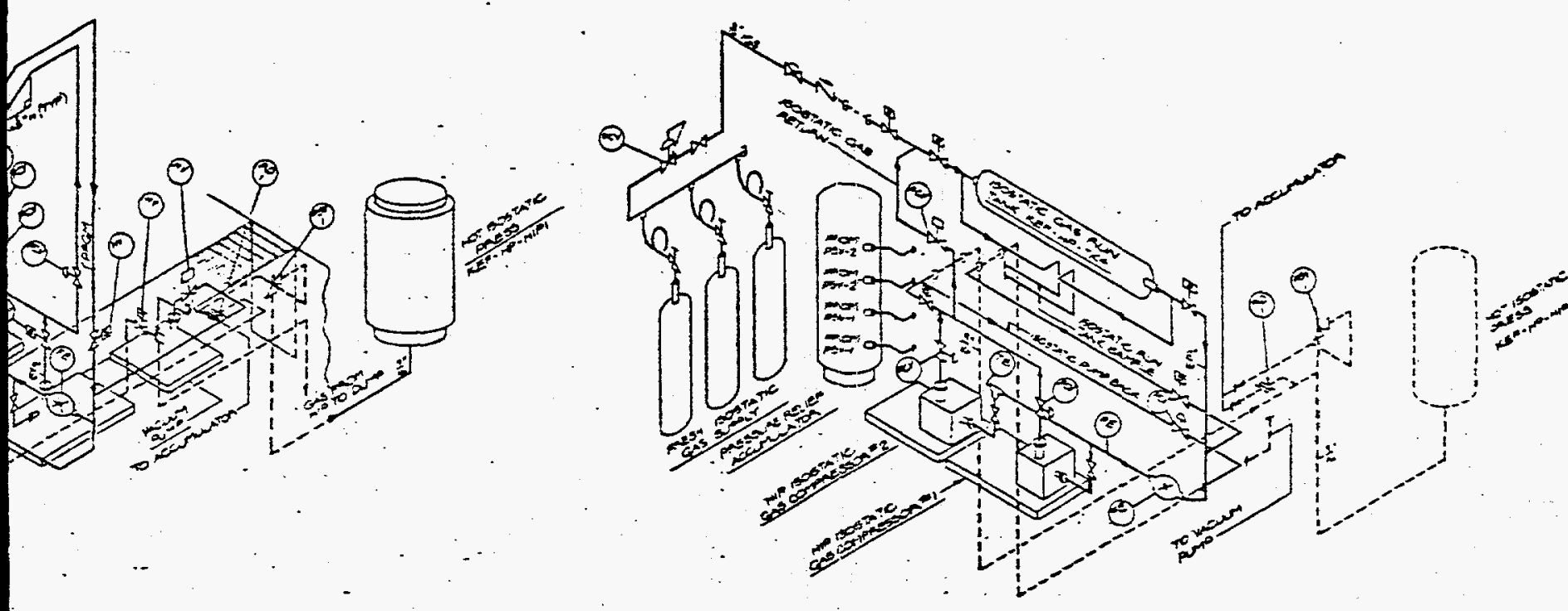

ISOSTATIC GAS SUPOU SISTEM

now 


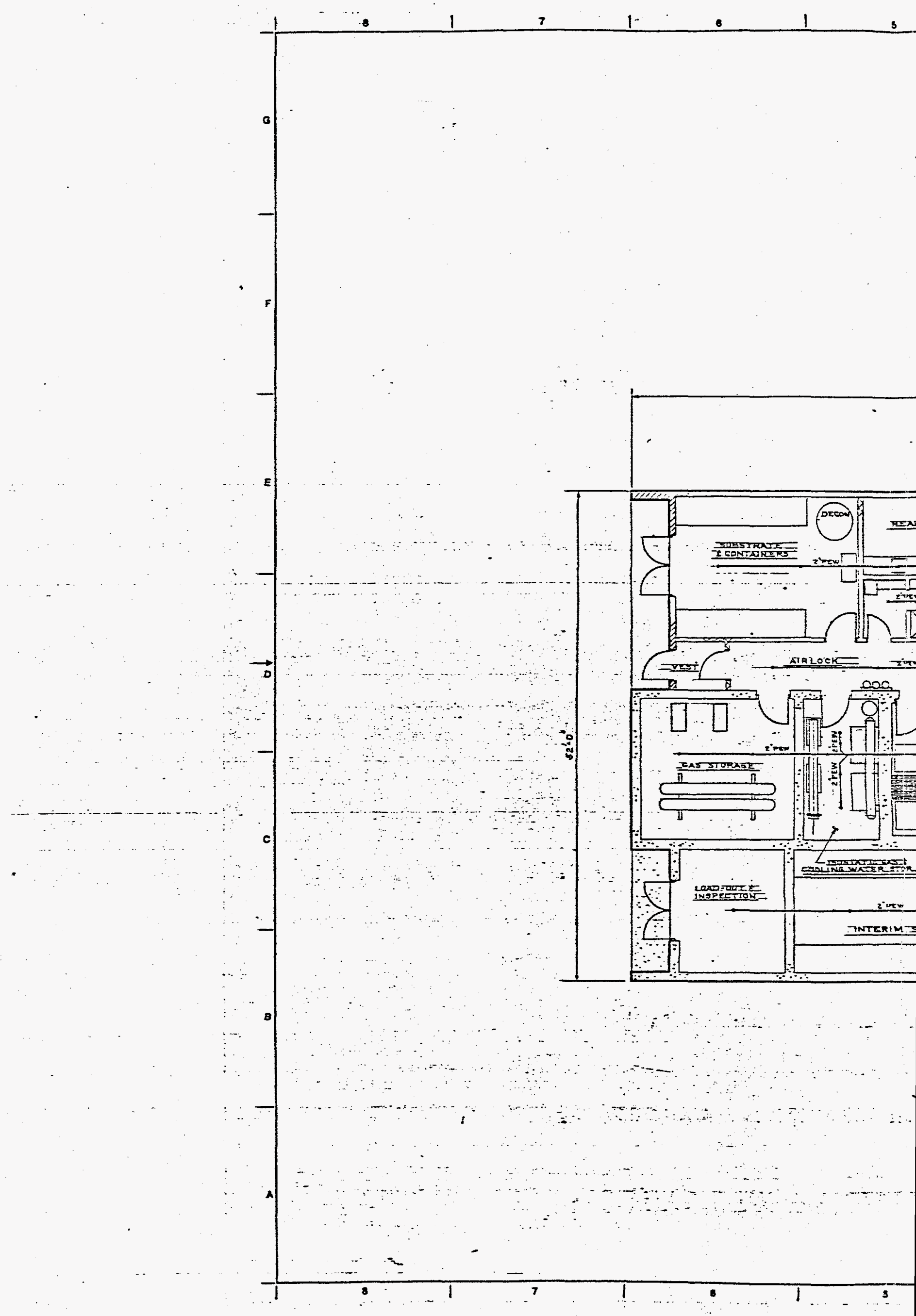




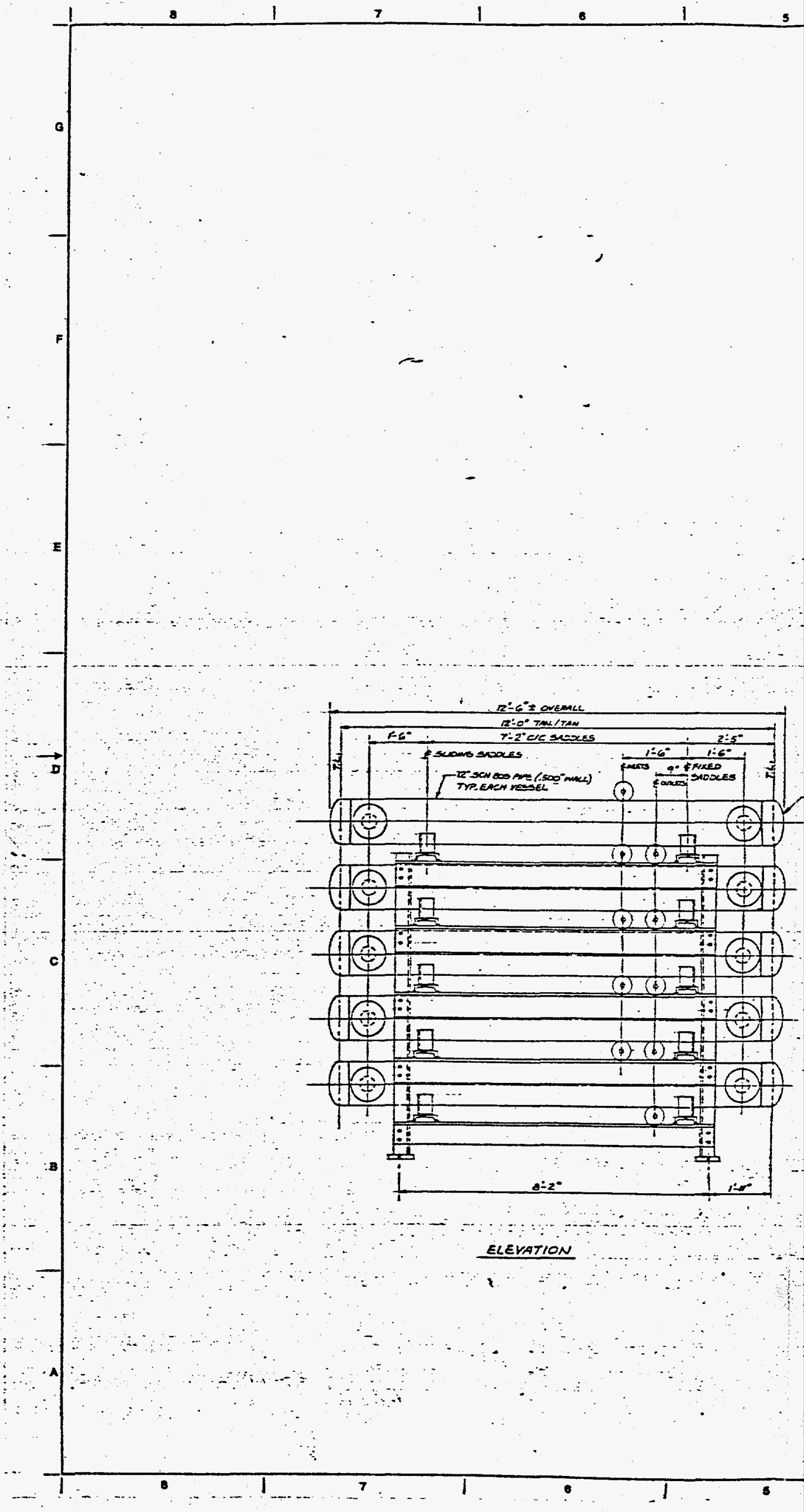




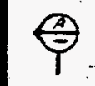

20 sexpos axpes car. Pre cont suos

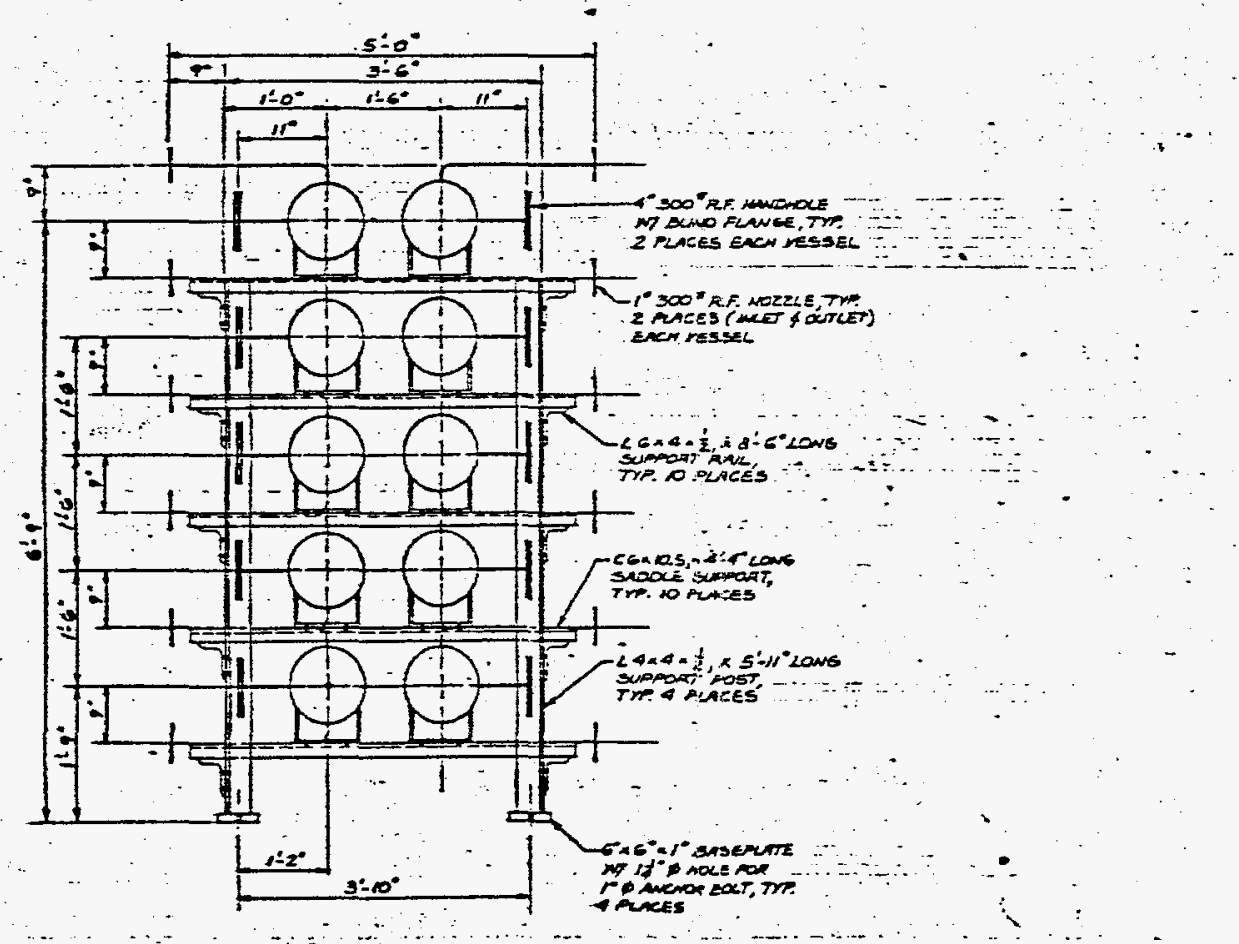




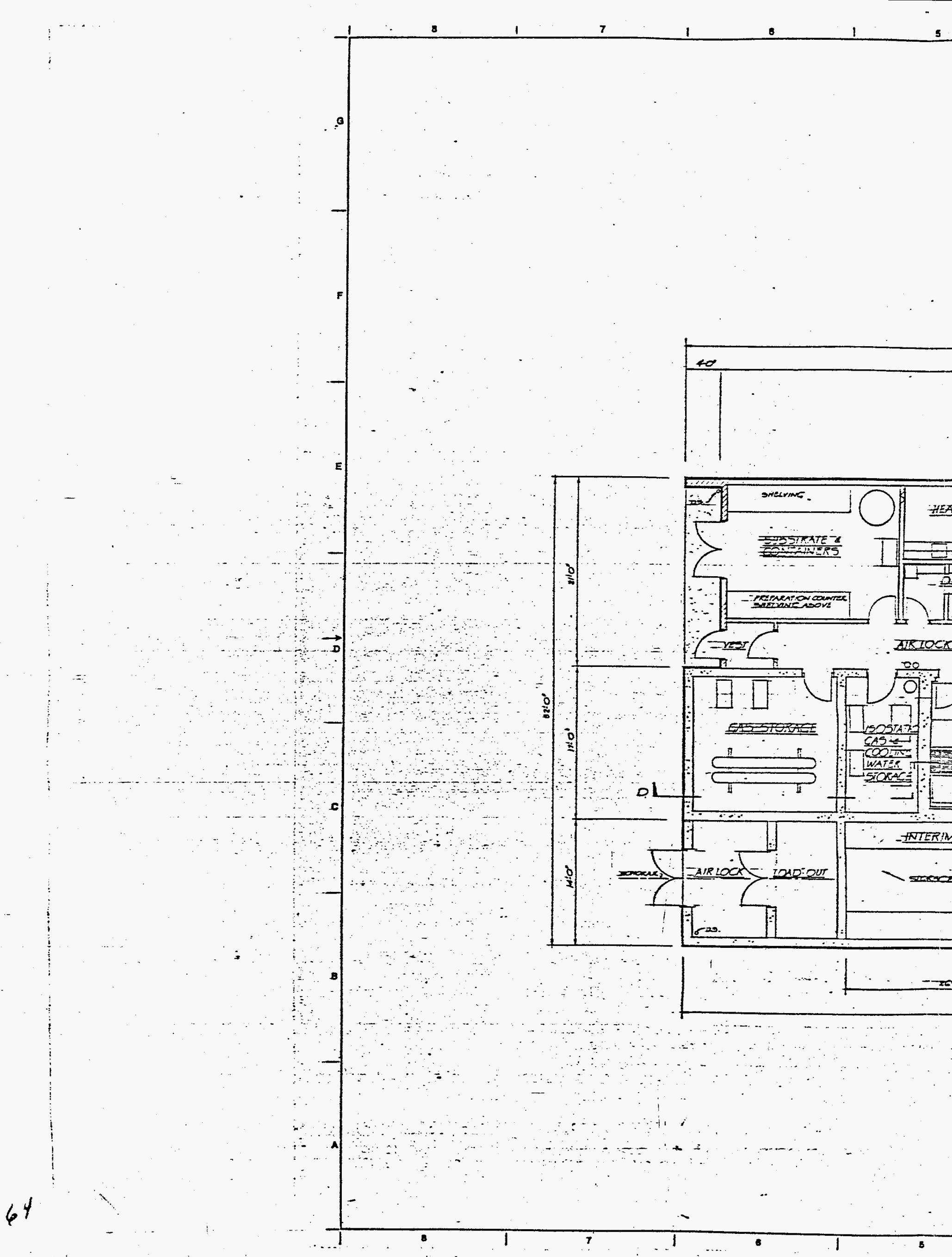


APPENDIX B

MAJOR EQUIPMENT LISTS

B- I ION IMPLANTATION/SPUTTERING

B-2 ZEOLITE ENCAPSULATION

$B-1$ 
APPENDIX B-1

ION IMPLANTATION/SPUTTER ING

MAJOR EQUIPMENT LIST

Equipment No.

KEF-II-TK 1

KEF-II-TK 101

KEF-II-TK2

KEF-II -TK3

KEF-II-TK4

KEF -II -TK5

KEF-II-AGI

KEF-II -AGI01

KEF-II - COMT\&2

KEF-II -P 101

$K E F-I I-P 1 \& 2$

KEF-II-VP $1 \& 2$

KEF-II - VP3\&4

KEF-II-HEI

KEF-II-HE2

KEF - II -F I

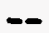

$-$

$-$

$-$

KEF-II-SCI-8
Name

Sump Catch Tank

Decontami nation Solution Make-Up Tank

Pressurize Feed Gas Mixture Lag Storage

Tanks ( 8 required)

Pressurized Feed Gas Mixture Run Tank

Low Pressure Feed Gas Mixture Run Tank

Pressure Relief Accumulator

Sump Catch Tank Agitator

Decontamination Solution Make-Up Tank Agitator

Feed Gas Compressor (2 required)

Decontamination Solution Pump

Closed Loop Cooling Water Pump (2 required)

Sputtering Chamber Vacuum Pump (2 required)

Krypton Vacuum Pump (2 required)

Pressurized Feed Gas Cooler

Closed Loop Cooling Water Heat Exchanger

Pressurized Feed Gas Filter

Sump Liquid Sampler

Sump Catch Tank Liquid Sampler

Sump Eductor

Sump Catch Tank Eductor

Sputtering Chamber ( 8 required) 
APPENDIX B-1 (cont'd)

ION IMPLANTATION/SPUTTERING

MAJOR EQUIPMENT LIST

Equipment No.

Name

Mini-Trailer Robo-Carrier

$5 T / 2-1 / 2 T$ Bridge Crane

Automatic Welder

Leak Detector

Master-Slave Manipulator (4 required)

2T Monorail Hoist 
APPENDIX B-2

ZEOLITE ENCAPSULATION

MAJOR EQUIPMENT LIST

Equipment No.

Name

KEF-HP-TK 1

Sump Catch Tank

KEF-HP-TK 101

Decontamination Solution Make-Up Tank

KEF-HP-TK2

Pressurized Feed Gas Mixture Lag Storage Tanks ( 8 required)

KEF-HP-TK3

KEF-HP-TK4

Pressurized Feed Gas Mixture Run Tanks ( 2 required)

Isostatic Gas Run Tanks (2 required)

KEF-HP-TK 102

Isostatic Gas Supply Cylinders (3 required)

KEF-HP-TK5

Pressure Relief Accumulator

KEF - HP-AG1

Sump Catch Tank Agitator

KEF-HP-AGIOI

Decontamination Solution Make-Up Tank Agitator

KEF-HP-COMT\&2

Feed Gas Mixture Compressors (2 required)

KEF-HP-COM $3 \& 4$

HIP Krypton Feed Compressor (2 required)

KEF - HP-COM5\&6

KEF-HP-P 101

HIP Isostatic Gas Compressor (2 required)

Decontamination Solution Pump

KEF - HP-P $1 \& 2$

KEF-HP-VP $1 \& 2$

Closed Loop Cooling Water Pump (2 required)

Krypton Vacuum Pump (2 required)

KEF - HP-VP $3 \& 4$

Helium Vacuum Pump (2 required)

KEF-HP-HE 1

Pressurized Feed Gas Cooler

KEF -HP-HE2

Closed Loop Cooling Water Heat Exchanger

$K E F-H P-F 1$

Pressurized Feed Gas Filter 
APPENDIX B-2 (cont'd)

ZEOLITE ENCAPSULATION

MAJOR EQUIPMENT LIST

Equipment No.

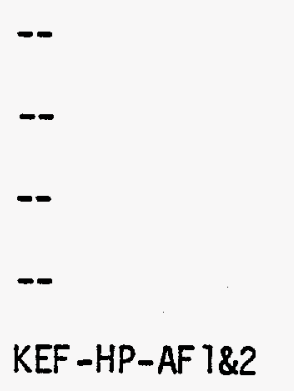

KEF-HP-HIP I

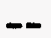

$-\infty$

$-$

$-$

$-$

$-$
Name

Sump Liquid Sampler

Sump Catch Tank Liquid Sampler

Sump Eductor

Sump Catch Tank Eductor

Substrate Activation Furnace (2 required)

Hot Isostatic Press

Mini-Trailer Robo-Carrier (2 required)

5T/2-1/2T Bridge Crane

Automatic Welder

Leak Detector

Master-S1ave Manipulator (4 required)

2T Monorail Hoist 



\section{APPENDIX C}

\section{OUTLINE SPECIFICATIONS}

C-1 ION IMPLANTATION/SPUTTER ING

C-2 ZEOLITE ENCAPSULATION 

APPENDIX $C-1$

ION IMPLANTATION/SPUTTERING OUTLINE SPECIFICATIONS

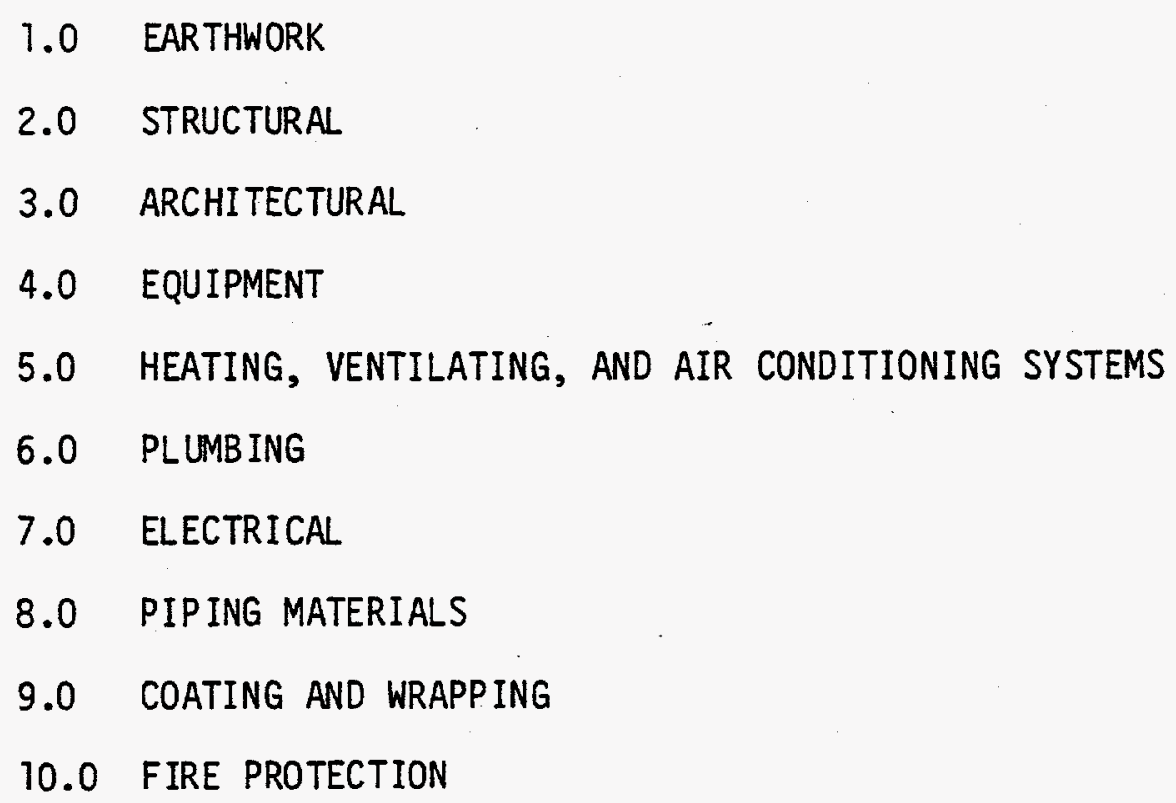

1.0 EARTHWORK

2.0 STRUCTURAL

3.0 ARCHITECTURAL

4.0 EQUIPMENT

5.0 HEATING, VENTILATING, AND AIR CONDITIONING SYSTEMS

6.0 PLUMBING

7.0 ELECTRICAL

8.0 PIPING MATERIALS

9.0 COATING AND WRAPPING

10.0 FIRE PROTECTION 


\section{APPENDIX $C-1$ \\ ION IMPLANTATION/SPUTTERING \\ OUTLINE SPECIFICATIONS}

\section{$1.0 \quad$ EARTHWORK}

Earthwork shall include the removal of all vegetation, trash and debris, and excavation for foundations. Trash and debr is shall be removed to a sanitary land fill. Excavated material suitable for backfilling shall be stock piled on site for later use. Cuts over 4 feet high shall be shored or have side slopes a minimum of $1-1 / 2$ to 1 . Backfilling of excavated areas shall be compacted to 95 percent of maximum dry density in accordance with ASTM D 1557, Method D.

\subsection{STRUCTURAL}

\subsection{CONCRETE}

2.1.1 Applicable Publications. Concrete shall conform to ACI-318, "Building Code Requirements for Reinf orced Concrete", and to the requirements of the following publications of the American Concrete Institute. These publications will be used to the extent they are applicable:

ACI-304 "Recommended Practice for Measuring, Mixing and Placing Concrete"

ACI-305 "Recommended Practice for Hot Weather Concreting"

ACI-306 "Recommended Practice for Cold Weather Concreting"

ACI-308 "Recommended Practice for Curing Concrete"

ACI-315 "Manual of Standard Practice for Detailing Reinforced Concrete Structures"

ACI-347 "Recommended Practice for Concrete Formwork"

2.1.2 Concrete Formwork. Forms shall be constructed to conform, within the tolerances specified, to the required shapes, dimensions, lines, elevations, and positions of the cast-in-place concrete members as indicated. Forms shall be supported, braced, and maintained sufficiently rigid to prevent deformation under load.

2.1.3 Cast-In-Place Concrete. Concrete shall be standard density concrete (150 pounds per cubic foot) unless noted otherwise. The minimum compressive strength of concrete will be 3000 psi at 28 days. Portland Cement shal1 conform to ASTM C150. Reinforcing steel shall conform to ASTM A6 15, Grade 60. Wire mesh for slabs shall conform to ASTM A 185. 
2.1.4 Grout. Grout shall be sufficiently fluid to ensure complete filling of all sections of units or areas requiring grout, but not so thin as to allow segregation of aggregate. All grouting shall be done in accordance with manufacturer's printed instructions. Grout shall be a non-shrink type.

\subsection{METALS}

2.2.1 Applicable Publications. The requirements of the following publications shall be used to the extent they are applicable:

American Institute of Steel Construction (AISC) "Specification for the Design, Fabrication and Erection of Structural Steel for Buildings"

American Institute of Steel Construction (AISC) "Specification for Structural Joints Using ASTM A325 and A490 Bolts"

American Welding Society (AWS) "Structural Welding Code". (AWS D 1.1)

2.2.2 Structural Steel. Structural steel shall conform to ASTM A36. Fabrication and erection shall conform to AISC "Specification for the Design, Fabrication and Erection of Structural Steel for Buildings".

2.2.3 Bolting. Structural steel connections shall conform to "Specification for Structural Joints Using ASTM A325 or A490 Bolts". Structural stainless steel connections shall be similar to structural steel type connections, except that the mechanical properties of the bolts, nuts, and washers shall conform to the latest revision of ASTM A193 for Class 2 , Grade B8, Type 304.

2.2.4 Welding. E308L electrode series shall be used to weld $304 \mathrm{~L}$ stainless steel. Welding shall conform to the AWS Structural Welding Code, AWS 01.1, for carbon steel, to the ASME Boiler and Pressure Vessel Code for stainless steel, and to the requirements of the latest revisions of the following publications to the extent they are applicable:

"Specification for Corrosion-Resisting Chromium and Chromium-Nickel Steel Covered Welding Electrodes", AWS A5.9

"Specification for Corrosion-Resisting Chromium and Chromium-Nickel Steel Welding Rods and Bare Electrodes", AWS A5.9

"Specification for Flux-Cored Corrosion-Resisting Chromium and Chromium-Nickel Steel Electrodes", AWS A5.22

"Specification for Aluminum and Alumionum Alloy Welding Rods and Bare Electrodes", AWS A5.10 
2.2.5 Masonry. Masonry units shall conform to ASTM C90, Grade N, Type I for 8 inch or 12 inch block. Reinforcing steel for masonry construction shall conform to ASTM A615, Grade 60 for deformed billet steel bars.

\subsection{ARCHITECTURAL}

\subsection{WOODS AND PLASTICS}

\subsubsection{Rough Carpentry}

Rough carpentry shal1 be nailers, blocking, striping, and miscellaneous. Any member in contact with concrete or masonry shall be pressure preservative treated.

\subsubsection{Finish Carpentry}

Finish carpentry shall be bult-in wood shelving, cabinets, hardwood shower seats, etc.

\subsection{THERMAL AND MOISTURE PROTECTION}

\subsubsection{Pref ormed Metal Siding}

insulation.

Ribbed siding paneis, 22 gauge, lap type joint with

\subsubsection{Building Insulation}

Building insulation shall be U.L. listed with flame spread under 25 and smoke developed and fuel contributed under 50 . Insulation shall be in thicknesses as indicated on the drawings.

\subsubsection{Inverted Roof System}

Dow Chemical Co., 3-1/2 inch thick styrof oam RM brand insulation shall be placed directly over the roofing membrane.

\section{a. Built up Roofing}

Roofing shall be 3-ply, 20 year bondable type, applied directly over substrate, John-Mansville or equal.

\section{b. Polyester Formed Fabric} loosely over the insulation.

Dow Chemical Co. approved fabric shall be placed

\section{c. Crushed Stone}

A crushed stone ballast of $1-1 / 2$ inch shall be placed over the polyester formed fabric. Stone top covering shail be $3 / 4$ inch to 1 inch in diameter. 


\subsubsection{Sheet Metal}

Parapet flashing, counter flashing, base flashing, and flashing at roof penetrations shall be 24 and 22 Ga galvanized steel.

\subsubsection{Sealants and Caulking}

Sealants and caulking shall be silicone, polysulphide or polyurethane base, non-saf, gun-approved as pourable, selected as best suitable for applicable conditions.

\subsection{DOORS AND WINDOWS}

\subsubsection{Metal Doors and Frames}

Doors and frames shall be standard commercial type, conforming to the Steel Door Institute (SDI) standards as follows:

Doors: Flush panel, seamless; interior doors 18 gauge; exterior doors 16 gauge, galvanized.

Frames: Full welded or knock down construction; interior frames 16 gauge: exterior doors 14 gauge, galvanized.

Fire rated doors and frames, where required, shall conf orm to the requirements of U.L. and shall bear the appropriate label. All interior doors shall have 6 inch $\times 2$ foot wire glass vision lites except doors leading to toilets, lockers and $j$ anitor rooms.

Explosion proof doors shall be able to withstand 1-PSI.

\subsubsection{Finish Hardware}

Finish hardware shall include mortise-type latchsets, locksets, exit devices, hinges, closers, thresholds, flushbolts, pulls, push/kick plates, door holders, and shall be heavy duty as manufactured by Sargent and $\mathrm{Co}$. or equal. Exposed surfaces of hardware shall have a satin finish or as selected. All building exits shall be provided with panic exit devices.

\subsection{FINISHES}

\subsubsection{Metal Studs}

Except as otherwise noted all metal studs shall be 4 inches $\times 20$ gauge, non-bearing screwable type, punched for utility lines, complete with top and bottom runners. 


\subsubsection{Gypsum Board}

Gypsum board shall be $5 / 8$ inch thick tapered edge throughout. Water resistant gypsum board shall be used in toilet rooms and janitors room. Type " $X$ " shall be used in 1-hour fire rated areas.

\subsubsection{Ceramic Tile}

Ceramic tile work shall include regular Portland cement sitting beds and ceramic tile floors, wainscots and walls. Tilework and installation shall conform to the American National Standards Institute (ANSI) and the Tile Council of America (TCA).

\subsubsection{Acoustical Ceilings}

Acoustical ceilings shall be suspended exposed metal "T" grid system with lay-in acoustical units. Exposed "T" members shall be aluminum or steel with applied matte white enamel finish. Acoustical units shall be 24 inches $\times 48$ inches $\times 5 / 8$ inches. Acoustical material shall be U.L. listed with flame spread under 25 and smoke developed and fuel contributed under 50 .

\subsubsection{Cement Plaster}

Cement plaster shall be installed on metal lath and steel framing on walls and ceilings where scheduled, including all necessary trim and accessories.

\subsubsection{Resilient Flooring}

a. Floor coverings in the Decon area, air lock and gallery shall be 200 vinyl chloride, $2 \mathrm{~mm}$ thick flooring as distributed by Dynamit Nobel of America Inc., or approved equal. Material shall be manufactured as a homogenous polywinyl chloride with the pattern and color extending through the butt thickness and shall conform to Federal Specifications SS-T-312, L-F475, and ASTM E84. Material shall have chemical resistance to acids, bases, dye stuffs, and solvents and shall be noncombustible or self-extinguishing. Installation shall be made as a monolithic, seamless floor by heat welding and fusion, or by butt welding edges of material sheets together. Flooring shall be butt welded directly to 6 " high Mipolam flexible vinyl cove.

$$
\text { b. All other areas such as offices and hallways shall }
$$
have vinyl asbestos tile flooring as manufactured by Armstrong Cork Co. or equal. The tiles shall be 12 inches $\times 12$ inches $\times 1 / 8$ inch commercial quality. The base shall be four inches high top set vinyl cove base with pre-formed internal and external corners. 


\subsubsection{Painting}

Except as excluded here in, all surfaces of new work shall be properly prepared, primed, and fin ished, including walls, ceilings, miscellaneous exposed materials, equipment, piping, hangers, conduits, grilles, etc., which normally require painting.

The following items shall not be painted:

- Surfaces receiving a special protective coating

- Concrete floors

- Anodized aluminum, chromed, or stainless metals

- Factory-finished items and equipment

The following items shall be primed or shop-coated

prior to delivery to job site:

- Metal doors and frames

- Structural steel

- Miscellaneous metal work

Paints, primers, and finishes shall be ready-mixed and equal to first-line products as manufactured by:

Devoe and Reynolds, Inc.

Pratt and Lambert, Inc.

E. I. DuPont de Nemours and Co.

Rust-0leum Corporation

Glidden Comp any

Benjamin Moore and Co.

a. Painting Schedule. All painting shall be two coats applied over a primer coat. The primer coat shall be appropriate for the surfaces to be painted and compatible with the types of finish coat used.

\section{b. Interior Surfaces}

Surf ace

Concrete

Galvanized Metal

\section{Finish}

1 coat masonry flock filler 2 coats interior alkyd semigloss enamel

1 coat zinc dust-zinc oxide primer

1 coat interior ename 1 undercoat

1 coat interior alkyd semigloss enamel 
Ferrous Metal

1 coat zinc, iron oxide, alkyd resin-type metal primer

1 coat enamel undercoat

1 coat alkyd semigloss enamel

c. Exterior Surfaces

Surface

Finish

Ferrous Metal

1 coat alkyd-oil resin-type metal primer

2 coats semigloss enamel

GaTvanized Metal

1 coat zinc dust-zinc oxide primer

2 coats semigloss enamel

\subsubsection{Special Coatings}

Special coatings shall be Ameron system decontaminable special protective coating for floors, walls, and ceilings, or equal.

Concrete floors:

Prime sealer

Intermediate coat

Top coat

Concrete Walls:

Prime sealer

Filler

Intermediate coat

Top coat
$\mathrm{Nu}-\mathrm{K} 1$ ad 108

Amercoat 66

Amercoat 66 (2 coats)

Frames:

Structural Stee 1, Decking, Carbon Steel Doors and

$\mathrm{Nu}-\mathrm{K}$ lad 108

$\mathrm{Nu}-\mathrm{K} 1$ ad 114

Amercoat 66

Sea 1 gloss Amercoat 66

Primer

Cleaner (for galvanized)

Intermdiate coat

Top coat

Amercoat 77

Galvaprep

Amercoat 66

Amercoat 66

Protective Coating for Stainless Steel Embedded in

Concrete:

Double coating

Thurmalox 70 


\subsection{SPECIALTIES}

\subsubsection{Metal Toilet Partitions}

Ceiling hung toilet partitions and wall hung urinal screen shall be products of Sanymetal Products or equal, "Century Type" with a baked enamel finish.

\subsubsection{Toilet Accessories}

Toilet accessories shall be products of Bobrick Washroom Equipment $\mathrm{Co}_{0}$, or equal, including:
a. Mirror
b. Soap dispenser
c. Towe 1 dispenser and waste receptacle
d. Sanitary napkin dispenser
e. Toilet tissue dispenser
f. Seat cover dispenser

\subsubsection{Louvers}

Louvers shall be products of Construction Specialties, Inc., or equal, mullion type louvers Model 4100 standard blade or as applicable and shall be constructed of extruded aluminum, 6063-T52 alloy, furn ished with $1 / 2$ inch mesh birdscreen.

\subsubsection{Signs and Directories}

equal.

Signs shall be products of Vomar Products, Inc., or

\subsubsection{Lockers and Benches}

Products, or equal.

Lockers and benches shall be the products of Lyon Metal

a. Lockers. Lockers shall be single tier-type, 12 inches wide, 18 inches deep, 72 inches high with baked enamel fin ish. Lockers shall be curb mounted.

b. Benches. Benches shall be constructed of hardwood seats, fin ished with three coats of plastic sealer mounted on enameled steel pedestals. 
4.0 EQUIPMENT

\subsection{PROCESS EQUIPMENT}

\subsubsection{Sump Catch Tank}

Equipment No. KEF-II-TKI. 42 in. diameter by $6 \mathrm{ft} .-6$ in. tall, constructed of ASME SA-240 Grade 304L stainless steel. Design and fabrication per ASME Boiler and Pressure Vessel Code, Section VIII, Division 1 at 15 PSIG and 100\%F. Capacity shall be 500 gallons.

Equipped with an electric motor driven agitator (Equip. No. KEF-II-AGI) and an internal spray header for decontamination solutions with inlet, outlet, vent, and instrumentation connections and agitator mount.

\subsubsection{Decontamination Solution Make-Up Tank}

Equipment No. KEF-II-TK101. 42 in, diameter by $4 \mathrm{ft} .-0$ in. tal1, constructed of ASME SA-240 Grade 304L stainless steel. Design and fabrication per ASME Boiler and Pressure Vessel Code, Section VIII, Division 1. at 15 PSIG and 200\% F. Capacity shall be 300 gallons. Equipped with an electric motor driven agitator (Equip. No. KEF-II-AG101) and a steam heating coil with inlet, outlet, vent, and instrumentation connections and agitator mount.

4.1.3 Pressurized Feed Gas Mixture Lag Storage Vessels, Pressurized Feed Gas Mixture Run Tank, Low Pressure Feed Gas Mixture Run Tank

Equipment No. KEF-II-TK2 (eight required), KEF-II-TK3 (one required), and KEF-II-TK4 (one required). 12 in. nominal diameter pipe (Sch. 80S) by $12 \mathrm{ft.}-0$ in. long, constructed of ASME SA-312 Grade TP316L stainless steel. Design and fabrication per ASME Boiler and Pressure Vessel Code, Section VIII, Division 1 at 1270 PSIG and 300 F. Capacity shall be 9.5 cubic feet. Equipped with inlet, outlet, and instrumentation connections. The ten vessels shall be stacked two wide by five high in a structural steel frame as shown on Drawing No. P-6.

\subsubsection{Pressure Relief Accumulator}

Equipment No. KEF-II-TK5. 18 in. nominal diameter pipe (Sch. $40 \mathrm{~S}$ ) by $4 \mathrm{ft} .-6 \mathrm{in}$. long, constructed of ASME SA-312 Grade TP316L stainless steel. Design and fabrication per ASME Boiler and Pressure Vesse 1 Code, Section VIII, Division 1 at 500 PSIG and 200\%F. Capacity shall be 8 cubic feet. Equipped with inlet, outlet, and instrumentation connections.

\subsubsection{Feed Gas Mixture Compressor}

Equipment No. KEF-II-COM1\&2 (two required). Single stage, diaphragm type with hydraulic fluid providing the pulsating motion to compress Krypton-85 gas from an inlet pressure of 340 psig at $700 \mathrm{~F}$, to a discharge pressure of 500 psig. Compressor displacement shall be 1 CFM at $400 \mathrm{rpm}$. A triple diaphragm shall be used with a detection system to 
indicate either compressed gas or hydraulic fluid leakage through the diaphragm. Parts in contact with krypton shall be Type 316 stainless steel, other parts may be manufacturer's standard for the application. The compressor shall be electric motor belt driven. Maximum compressor speed shall be $400 \mathrm{rpm}$, electric motor speed shall be $1800 \mathrm{rpm}$. The electric motor shall be $460 \mathrm{~V}, 3$ phase, 60 Hertz. Each compressor and drive sha 11 be assembled and mounted on a structural frame.

\subsubsection{Decontamination Solution Pump}

Equipment No. KEF-II-P101. Centrifugal, horizontal, electric motor driven pump. Motor speed shal1 be 1800 rpm. Parts in contact with decontamination solutions shall be Type 316 stainless steel. Pump capacity sha 11 be $50 \mathrm{gpm}$ with $40 \mathrm{feet} \mathrm{TDH}$.

\subsubsection{Closed Loop Cooling Water Pump}

Equipment No. KEF-II-P1\&2 (two required). Centrifugal, horizontal, electric motor driven pump. Motor speed shall be $1800 \mathrm{rpm}$. Pump material shall be ductile iron. Pump capacity shall be $100 \mathrm{gpm}$ with 60 feet TDH.

\subsubsection{Krypton Vacuum Pump}

Equipment No. KEF-II-VP1\&2 (two required). Cam and piston, compound vacuum pump, capable of displacing 3 CFM minimum at $10^{-2}$ Torr. Metals in contact with the process shall be Type 316 stainless steel. Other materials in contact with the process shall be compatible with Krypton-85. Pump sha 11 be motor driven, single or three phase, 230/460V, 60 hertz. Maximum motor speed shall be 1800 rpm.

\subsubsection{Pressurized Feed Gas Cooler}

Equipment No. KEF-II-HEl. She 11 and tube type heat exchanger with 20,000 BTU/hr. duty. Materials is contact with krypton gas shall be Type 316 stainless steel, other materials may be carbon steel. Design and fabrication per ASME Boiler and Pressure Vessel Code, Section VIII, Division 1, and TEMA R requirements. Design pressure for gas side shall be 600 PSIG, with 200 oF inlet temperature and $1100 \mathrm{~F}$ maximum outlet temperature. Design pressure for water side shall be 100 PSIG, with 95 of inlet temperature.

\subsubsection{Closed Loop Cooling Water Heat Exchanger}

Equipment No. KEF-II-HE2. Shell and tube type heat exchanger with 2,000,000 BTU/hr. duty. Materials shall be carbon steel with admiralty tubes. Design and fabrication per ASME Boiler and Pressure Vessel Code, Section VIII, Division 1, and TEMA R requirements. Design pressure shall be 100 PSIG, with closed loop water inlet temperature $130^{\circ} \mathrm{F}$ and outlet temperature $95^{\circ} \mathrm{F}$, and cooling water inlet temperature $85^{\circ} \mathrm{F}$. 


\subsubsection{Pressurized Feed Gas Filter}

Equipment No. KEF-II-FI. Inlet filter with removable sintered metal element. Filter rating shall be 2 micron with 2 CFM flow and 500 PSIG pressure, with no more than 10 PSI pressure drop. Materials in contact with Krypton-85 sha 11 be Type 316 stainless steel.

\subsubsection{Sump Liquid Sampler \\ Sump Cath Tank Liquid Sampler}

Manually initiated, isolating, plunger type, air powered, solenoid valve actuated liquid sampler.

\subsubsection{Sump Eductor \\ Sump Catch Tank Eductor}

rate, Type 304L stainless steel.

Air or steam operated liquid eductor, $30 \mathrm{gpm}$ transfer

\subsubsection{Sputtering Heads}

(Eight required). Pedestal mounted vertical connector assembiy, in groups of four, with guide pins, remotely operated, insulated connectors for target, substrate, filament, and anode power, target and jacket cooling water supply and return, and gas and air supply, constructed of Type 316 stainless stee 1 .

\subsubsection{Shielded Cooling Jackets}

(Eight required). Lead and Type 316 stainless steel-clad cooling jacket assembly with guide pins, guide holes, and seals to mate with target/substrate assembly and with sputtering head, and with insulated connections for cooling water supply and return.

\subsection{MECHANICAL EQUIPMENT}

\subsubsection{Mini-Trailer Robo-Carrier}

(2 required). Remotely operated, automatically controlled electric cart and platform lift assembly, with vertical and horizontal canister cradles, with pneumatic push/pull piston, and with pre-programed positioning capability.

\subsubsection{In-Ce11 Bridge Crane}

Remotely operated bridge crane with 12-ft. 0-in. span and 5-ton top mounted trolley and hoist, and with two 1/2-ton underslung auxiliary trollies and hoist, as manufactured by Edder Corp. or Approved Equal. 


\subsubsection{Remote Welder}

Fully remote automatic welding station as manufactured by Astro-Arc or Dimetrics Corporation or Approved Equal.

\subsubsection{Leak Detection System}

Fully remote automatic leak detection system with automatically calibrated helium detector.

\subsubsection{Master-Slave Manipulators}

(Four required). Model " $F$ " type master-slave manipulators, for assistance and maintenance of automatic welder and remote leak detection system, as manufactured by Central Research or Approved Equal.

\subsection{HEATING, VENTILATING, AND AIR CONDITIONING SYSTEMS}

\subsection{SUPPLY FANS}

Supply fans shall be single-width, single-inlet, non-overloading centrifugal type with airfoil blades, $V$-belt drive and TEFC motors, AMCA Class II construction, and variable inlet vortex vane damper capacity control. Capacity shall be $5000 \mathrm{cfm}$ at 3-inches $\mathrm{wg}$ static pressure and 5-hp. Fans shall be Buffalo Forge Co. type BL-Aerofoil, size 400, or Approved Equal.

\subsection{EXHAUST FANS}

Exhaust fans shall be designed and constructed to operate continuously prior to, after, but not necessarily during an Operating Bas is Earthquake (OBE). Fans shall be single-width, single-inlet non-loading centrifugal type with airfoil blades, V-belt drive and TEFC motors, AMCA Class III construction, and variable inlet vortex vane damper capacity control. Capacity shall be $5000 \mathrm{cfm}$ at 10 -inches $\mathrm{wg}$ static pressure and 15 hp. Fans shall be Buffalo Forge Co. type BL-Aerofoil, size 365, or Approved Equal.

\subsection{VENT FANS}

Vent fans shall be tubular in-line flow type having an airfoil centrifugal wheel. The fans shall be V-belt driven by a TEFC motor mounted on the tubular fan housing. Capacity shall be $18000 \mathrm{cfm}$ at 1.0-inches $\mathrm{wg}$ static pressure and $15 \mathrm{hp}$. One of the fans shall be provided with variable inlet vortex vane damper capacity control. Fans shall be New York Blower Co. Tubular Acoustafoil type, size T-309, or Approved Equal.

\subsection{POWER ROOF VENTILATORS}

Power roof ventilators shall be low silhouette, all aluminum construction, spun housing type. Fans sha 11 be centrifugal type with direct drive. Capacity shall be $150 \mathrm{cfm}$ at 0.38 inches wg static pressure. 


\subsection{PREHEAT COILS}

Preheat coils shall be 2-row, non-freeze, finned tube, low pressure steam type. Coil capacity shall be $5000 \mathrm{cfm}$ and $315,000 \mathrm{Btu} / \mathrm{hr}$ at 15 psig steam pressure, with $-20 \mathrm{OF}$ entering and $+40 \mathrm{OF}$ leaving air temperatures.

\subsection{HEATING COILS}

Heating coils shall be 1-row, finned tube type designed for modulating control with steam at 15 psig pressure.

\subsubsection{Contaminated Areas}

Heating coil serving the Load-out, Gas Storage, and Substrate areas shall have a capacity of $550 \mathrm{cfm}$ and $25,000 \mathrm{Btu} / \mathrm{hr}$ with $+40^{\circ} \mathrm{F}$ entering and $90 \mathrm{OF}$ leaving air temperatures. Coil face area shall be 1.0 square feet.

Heating coil serving the Process Cell shall have a capacity of $3150 \mathrm{cfm}$ and $85,000 \mathrm{Btu} / \mathrm{hr}$ with $+40_{0} \mathrm{~F}$ entering and $700 \mathrm{~F}$ leaving air temperatures. Coil face area shall be 5.0 square feet.

\subsubsection{Non-Contaminated Areas}

Heating coil serving the Office, Health/Physics, Operating Gallery, and Vestibule shall have a capacity of $1170 \mathrm{cfm}$ and $53,000 \mathrm{Btu} / \mathrm{hr}$ with $+40 \mathrm{OF}$ entering and $+90^{\circ} \mathrm{F}$ leaving air temperature. Coil face area sha 11 be 2.0 square feet.

\subsection{COOLING COIL}

Cooling coil shall be finned tube type for direct expansion refrigerant service. Coil shall be provided with a liquid refrigerant distributor. Coil capacity shall be $1170 \mathrm{cfm}$ and 30,000 Btu/hr. Coil shall have a $f$ ace area of 2.5 square feet and be six rows deep.

\subsection{SUPPLY AIR FILTER BOXES}

Supply air filter boxes shall be the side loading type containing a guide track for prefilters and a separate guide track for high efficiency filters. Prefilters shall have an efficiency of $30 \%$ per ASHRAE Standard 52-76. High efficiency filters shall have an efficiency of $90 \%$ per ASHRAE Standard 52-76. Filter boxes shall be Farr Co. side loading model 3P Universal Glide/Pack with type 30/30 prefilters and type HP-200 high efficiency filters, or Approved Equal. Filter box capacity shall be $5000 \mathrm{cfm}$ and shall have 4-24" $\times 24$ " $\times 4^{\prime \prime}$ prefilters and 4-24" $\times 24$ " $\times 12$ " high efficiency filters. 


\subsection{EXHAUST AIR HEPA FILTER PLENUMS}

Filter plenums shall contain two stages of side loading, bag-out HEPA filters and provisions for remote in-place DOP testing of each HEPA filter. Filter plenums and filters shall be as manufactured by Flanders Filter, Inc. Each plenum shall consist of the following:

1) Upstream first test section, T-I, including DOP injection port, DOP diffusers, and upstream challenge aerosol concentration sample port.

2) First stage of HEPA filters in a model E-4, side loading, bag-out housing.

3) Center combination test section, T-C, including DOP injection port, DOP diffusers, and sample port for measuring first stage downstream sample concentration or second stage upstream sample concentration.

4) Second stage of HEPA filters in a model E-4, side loading bag-out housing.

5) Last test section, T-0, including DOP diffusers and sample port for measuring second stage downstream concentration.

Capacity of each filter plenum shall be $6000 \mathrm{cfm}$. Each filter sha 11 be 24 " $\times 24 " \times 11-1 / 2 "$ and arranged in the plenum 2-wide by 3-high.

\subsection{SPRAY COOLING CHAMBER}

A spray water chamber shall be provided upstream of each exhaust air HEPA filter plenum. Each spray chamber shall be of stainless steel all welded construction. One bank of spray nozzles shall be provided together with moisture eliminators, and drain sump. Capacity shall be 5000 cfm with a face area of 10 square feet.

\section{11 UNIT HEATERS}

Unit heaters shall be horizontal suspended type with steam heating coil, propeller fan, and adjustable discharge air louvers. Capacity shall be $50,000 \mathrm{Btu} / \mathrm{hr}$ with $15 \mathrm{psig}$ steam pressure. Unit heaters shall be Trane Co. model 60-S, or approved equal.

\subsection{AIR COOLED CONDENSING UNIT}

Air cooled condensing unit shall be for split system service and shall include an air cooled condenser, hermetic refrigerant compressor, and automatic control system. The unit shall have a capacity of 30,000 Btu/hr with $5_{5}$ of ambient air. Unit shall be Carrier Corp. model 38GSO42, or approved equal. 


\subsection{PLUMBING}

\subsection{SCOPE OF WORK}

The Contractor shall provide all labor, materials, equipment, and tools necessary for the installation of interior plumbing piping, plumbing fixtures, and plumbing piping extending out to $5 \mathrm{ft}$ from the building where a break is made between plumbing and exterior sewage, drainage, and water piping materials.

following:

The work shall include, but shall not be limited to the

\section{1 .1 System}

Furnishing and installing a complete plumbing system consisting of soil, waste and vent lines and hot and cold water distribution.

\subsubsection{Fixtures, Trim, and Accessories}

accessories.

Furnishing and installing plumbing fixtures, trim and

\subsubsection{Sewer and Water Lines}

Furnishing and installing sewer and water lines from building to $5 \mathrm{ft}-0$ in. outside of building.

\subsubsection{Flashing}

Furnishing and installing flashing and counterflashing for items of this system.

\subsection{MATERIALS OF CONSTRUCTION}

\subsubsection{Waste and Vent}

Above ground 1-1/2 in. and smaller shall be Schedule 40 galvanized steel pipe with coated cast iron drainage type screwed fittings. 2 in. and larger shall be service weight cast iron soil pipe and fittings (Bell and Spigot Type or No-Hub).

\subsubsection{Sewer}

Below grade or slab shall be Bell and Spigot service weight cast iron soil pipe with neoprene compression gaskets to ASTM $C$ 564. Above grade shall be standard weight cast iron Bell \& Spigot or No-Hub. 


\subsubsection{Domestic Hot and Cold Water Piping}

Materials shall be Schedule 40 galvanized carbon steel pipe and fittings to ASTM A 120 with $3001 \mathrm{~b}$ rating. Hot water piping shal1 be insulated.

\subsubsection{Steel Pipe Unions}

type.

Galvanized 300 lb malleable iron, railroad ground joint

\subsubsection{Valves}

Valves shall be gate valves $150 \mathrm{lb}$. Screwed bronze ISRS, Crane No. 431 or Approved Equal, or ball valves $3007 \mathrm{~b}$. Screwed brass with TFE seals, Pacific No. 1-B or Approved Equal.

\subsubsection{Partition Stops}

bibb, with flange.

Repcal B98 or Approved Equal, loose key type, hose

\subsubsection{Strainer \\ Sporlan or Approved Equal.}

\subsubsection{Sleeves}

Sleeves shall be of 24 gauge galvanized iron or steel, for use wherever pipes pass through concrete floors and foundations.

\subsection{PLUMBING FIXTURES}

6.3.1 Water Closet. American Standard No. 2502.011 white vitreous china, siphon jet walT hung, Sloan Royal No. 110 flush valve, white open front seat less cover. J. R. Smith No. 100 carrier.

\subsubsection{Urinal (Mark - UR). American Standard No. 6500.011} white vitreous china, wall hung, SToan Royal NO: 186-11 flush valve with 1-1/4 in. top spud, wall and spud flanges, vacuum breaker, with adjustable floor support.

6.3.3 Lavatory (Mark - L-1). American Standard No. 0350.132 20 by 18 , wa 11 hung, white vitreous china, No. 2248.284 faucet with pop-up drain, No. 2303.063 loose key angle stop supply pipes, No. 4401.014 adjustable P-Trap. Adjustable type concealed lavatory, floor support carrier, with four point locking.

6.3.4 Shower (SH). Sloan Royal No. AC-10 Ac-to-matic with 3 gpm flow control. Stainless steel, built-in mixing valve with $1 / 2$ in. inlet ports. 
nickel bronze strainer.

6.3.5 Floor drain (FD-1). Josam 30000A cast iron body,

6.3.6 Roof Drain (RD). Josam 21000 Series, large dome, bottom outlet with standard clamp ring and gravel stop, gasket, dome, and body and to include deck clamp, drain receiver, and stationary extension collar.

6.3.7 Overflow Drain (OD). Josam 21000-16 Series, large dome, bottom outlet with standard clamp ring and gravel stop, gasket, dome, and body and to include deck clamp, drain receiver, and stationary extension collar.

\subsubsection{Cleanouts (types)}

(1) Ordinary: Zurn A-1305

(2) Floor Type: Zurn Z-1326-1 or Z-1326-10, for setting with top flush and square with floor.

plate.

(3) Wall Type: Zurn with Z-1310 chrome plated cover

6.3.9 Water Hammer Arresters (WHA). Water hammer arresters shall be Zurn Shocktrol 1700 Series, Smith 5000 Series, or Approved Equal.

6.3.10 Roof Drainage. Piping for the roof drainage system will be carb on steel, hot-dipped galvanized, ASTM A53, Gr "B", Std. Wt. threaded ends. Fittings will be 125\# cast iron, ASTM A126, Grade B, hot-dipped gaivanized, threaded ends.

\subsection{EQUIPMENT}

\subsubsection{Electric Water Coolers}

The cooler capacity shall be in accordance with Sunroc Mode1 NSF-8-D or Approved Equal. The cabinet shall be constructed of 19-20 gauge welded stainless steel, with a removable front panel, a stainless steel base, and a Type 300 series stainless steel top. A chrome plated brass hand operated bubbler on a raised mount shall have a built-in pressure regulator. The Contractor shall furnish a reciprocating type hermetically sealed motor compressor with an air cooled condenser and a tube type cooling unit for Type 12 refrigerant, an insulated power cable, and an enclosed, adjustable thermostat. Electrical specifications are 1/4 hp, $115 \mathrm{~V}, 60 \mathrm{~Hz}$, single phase. The cooler shall bear the Underwriters Laboratory (UL) label.

\subsubsection{Electrical Water Heaters}

The heater shall bear the Underwriters Laboratory (UL) label. Each heater shall have a steel glass lined tank with a magnesium anode, 4 bolt $\mathrm{fl}$ ange, inconel sheathed, rod-type heating element with 
pre-wired terminal leads, and immersion type thermostat switching a magnetic contactor(s). The heater shall have a minimum 3 inch glass fiber insulation with a round steel shell. Each heater shall be provided with an ASME rated temperature and pressure relief valve.

\subsection{ELECTRICAL}

This section applies to all electrical equipment and components, which will be used on the I on Implantation/Sputtering Facility. All items are commercially available and shall comply with applicable codes and standards. The power and services required are available from the existing Site utilities. Conduit only will be stubbed out $5 \mathrm{ft}$ from the building for $13.8 \mathrm{kV}$ normal and 480 volt standby power connections.

\subsection{CONDUIT}

All conduit systems shall be UL approved, rigid steel, zinc-coated or 304L seamless stainless steel, Schedule 40 pipe. The minimum conduit size shall be $3 / 4$ in. for power, unless otherwise noted, and $1 / 2$ in. for exposed communication, control and instrumentation. Insulated bushings shall be provided at all terminals, where hubs are not used. Flexible metallic conduit shall be liquid tight. Expansion type conduit fittings shall be used across building expansion joints.

\subsection{WIREWAYS AND AUXILIARY GUTTERS}

Wireways and auxiliary gutters used in dry locations shall be preformed with screw type covers.

\subsection{CABLES, $5 \mathrm{kV}$}

The $5 \mathrm{kV}$ dc target cables shall be No. 8 AWG, non-shielded, single-conductor $C l$ ass $B$, concentric-stranded copper conductors, ethylene-propylene rubber insulation, Okonite Okoguard Okoseal, or equal. Cross-link polyethylene insulation is not acceptable. The $3000 \mathrm{Vdc}$ target system is solidly grounded.

\subsection{BUILDING WIRE, 600 VOLT}

Single conductors for power, lighting, and miscellaneous control shall be 600 volt, code type, 90' C, RHH-RHW, USE, FP 1 with chlorosulfonated, polyethylene jacket for No. 2 AWG and larger, Okonite Okolon, or equal. Type THHN-THWN shall be used for conductors smaller than No. 2 AWG. The minimum control wire size shall be No. 14 AWG, and No. 12 AWG for all other wiring. All conductors shall be stranded copper except that lighting and branch circuits with wiring No. 10 AWG and smaller may be solid. Aluminum wire is not acceptable. 


\subsection{HIGH RADIATION WIRE}

All wiring, single or multi-conductor, within high radiation areas and through shielding walls shall be No. 12 AWG minimum, Class IE, 600 volt wire rated for $10 \% \mathrm{R}$ minimum total integrated dosage, as manuf actured by American Insulated Wire Corp., Boston Insulated Wire and Cable Co., PSC, Div. M.W. Riedel, or The Rockbestos Co. Wiring inside the high radiation areas shall be multi-conductor with a special chlorosulf onated, polyethylene overall jacket suitable for decontamination with water, nitric acid, oxalic acid, and Turco No. 4502.

\subsection{UNIT SUBSTATION, $13.8 \mathrm{KV}$ TO 480 VOLT}

The indoor unit substation shall consist of a three-position, manually operated, $600 \mathrm{amp}, 15 \mathrm{kV}$ primary fused interrupter switch, a silicone insulating fluid transformer, a secondary main and feeder draw-out air circuit breakers. The rating and the equipment quantity shall be as shown on the Single Line Diagrams. The 480 volt breakers shall have static long time (L), short time (S), and ground (G) tripping characteristics. The buses shail be copper with silver plated joints and connections. A manually operated overhead hoist shall be provided to remove the 480 volt air circuit breakers.

\subsection{DISTRIBUTION TRANSFORMERS}

The quiet type distribution, three-phase transformers, rated 480-208Y/120 volt, shall be general purpose dry type in an indoor enclosure and shall have $220^{\circ} \mathrm{C}$ insulation temperature classification and $150^{\circ} \mathrm{C}$ winding temperature rise for $30 \mathrm{kVA}$ and $1 \mathrm{arger}$, and $185^{\circ} \mathrm{C}$ insulation temperature and $115^{\circ} \mathrm{C}$ winding temperature rise for $25 \mathrm{kVA}$ and smaller. Full capacity NEMA standard taps shall be provided on the high voltage winding.

\subsection{MOTORS}

Motors shall be of sufficient size for the duty to be performed. All motors shall have full nameplate horsepower available with a service factor of 1.0 at $3000 \mathrm{ft}$ elevation and 1.15 at sea level. Unless otherwise specified, all motors shall be totally enclosed, and shall have a continuous duty classification based on a $40^{\circ} \mathrm{C}$, ambient temperature of reference. Crane and monorail motors shall be rated for 30 minute intermittant duty. Motors shall be the premium efficiency type. The motors shall have the following factory guaranteed minimum efficiencies in accordance with IEEE 112 Test Procedures and shall have the efficiency index letter stamped on the motor nameplate: 


\begin{tabular}{|c|c|c|c|c|c|}
\hline$\underline{H P}$ & $\%$ Efficiency & $\underline{\mathrm{HP}}$ & $\%$ Efficiency & $\mathrm{HP}$ & $\%$ Efficiency \\
\hline $\begin{array}{ll}1 & \\
1 & 1 / 2 \\
2 & \\
3 & \\
5 & \\
7 & 1 / 2\end{array}$ & $\begin{array}{l}78.5 \\
81.5 \\
81.5 \\
84.0 \\
84.0 \\
88.9\end{array}$ & $\begin{array}{l}10 \\
15 \\
20 \\
25 \\
30 \\
40\end{array}$ & $\begin{array}{l}88.9 \\
89.8 \\
90.6 \\
90.6 \\
91.4 \\
92.0\end{array}$ & $\begin{array}{r}50 \\
60 \\
75 \\
100 \\
125 \\
150\end{array}$ & $\begin{array}{l}92.0 \\
92.0 \\
93.3 \\
93.3 \\
93.3 \\
94.3\end{array}$ \\
\hline
\end{tabular}

The motor insulation shall be Class $\mathrm{F}$ minimum. Motors in high radiation areas shall have $C$ ass $H$ insulation and shall be rated for $2 \times 10^{7} R$ total minimum garma radiation dosage. The high radiation area motors shall be suitably coated in the field with Crouse-Hinds "Corro-Free S-602" Cat. No. ETU2, or equal. The motor voltage rating shall be selected as follows:

$$
\begin{aligned}
& 1 / 2 \mathrm{hp} \text { through } 150 \mathrm{hp}: 460 \text { volt, } 3 \text { phase, } 60 \text { hertz } \\
& 1 / 3 \mathrm{hp} \text { and smaller: } 115 \text { volt, single phase, } 60 \text { hertz }
\end{aligned}
$$

Motors $1 / 4 \mathrm{hp}$ and $1 / 3 \mathrm{hp}$ in a batch process shall be rated 460 volts, 3 phase, 60 hertz. Polyphase motors shall be NEMA Design B minimum, squirrel cage type, having normal starting torque and low starting current; single-phase motors shall be capacitor start type, except that motors rated $1 / 6 \mathrm{hp}$ and less may be split phase type. Gear motors shall be $\mathrm{Cl}$ ass II or III, in accordance with the gear loading requirements. Motors $5 \mathrm{hp}$ and 1 arger shall have full load power factor of 0.85 minimum. Motors $5 \mathrm{hp}$ and 7 arger with a full load power factor less than 0.85 shall be corrected to at least 0.90 , utilizing a power factor corrective device located at the motor. Two-speed motors shall be the two-winding type. Motors connected to the site standby power shall be capable of starting on a voltage reduction of 20 to 30 percent. A copper grounding lug shall be provided in terminal connection box of a 11460 volt, 3 phase motors.

\subsection{STARTERS}

Combination magnetic starters with 120 volt transformer and control shall be provided for 460 volt, 3 phase motors that are $1 / 2 \mathrm{hp}$ through $150 \mathrm{hp}$, and manual starters shall be provided for all 115 volt, single phase motors smaller than $1 / 2 \mathrm{hp}$.

\subsection{MOTOR CONTROL CENTERS}

The motor control center (MCC1) and split bus motor control center MCC2 sha 17 be $277 / 480 \mathrm{~V}, 3$ phase, 4 wire, 60 hertz, free-standing, dead-front, dead-rear, copper bus on 1y, NEMA Class II, Type B wiring consisting of vertical sections containing phase busing, terminals, copper ground bus, wireways, and housing modular plug-in type equipment drawers behind inter locked hinged doors Westinghouse Type Five Star, or equal. The enclosures shall be NEMA 1 . A11 operating handles and controls shall be externally operable. An individual, 480-120 volt control transformer with secondary fuse shall be provided for each motor starter. Each starter shal1 have a HAND-OFF-AUTO selector switch in the cover. The motor control center shall be braced for a minimum of 22,000 ampere symmetrical short circuit. The automatic transfer switch, with solid state control 


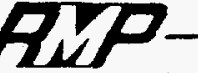

and located in the standby section of the motor control center MCC2, shall be rated $260 \mathrm{amp}, 480$ volt, 3 phase, 3 pole, $60 \mathrm{~Hz}$, and suitable to withstand a 22,000 amp short-circuit fault. Upon power failure, the transfer switch shall automatically start the Site diesel generator system. The return to normal power shall be manual. In the event the standby power fails and normal power is available, the transfer switch shall have an override to transfer automatically to normal power. Two each tandem pilot lights shall be provided to indicate the contact position. The transfer switch shall be ASCO Model 940326099 with accessories 6C, 9A, 9B and 28 , or equal.

\subsection{PANELBOARDS}

The panelboards shall be dead front, copper bus, 4 wire, circuit breaker type. Circuit breakers shall be E Frame minimum and rated for ac or dc operation. The circuit breakers shall have a minimum interrupting rating of 10,000 rms symmetrical amperes for 208 volt panelboards and 14,000 rms symetrical amperes for $277 / 480$ volt lighting panelboards. A ground bus with screw terminals shall be provided. Neutral buses shall be isolated. Enclosures shall be NEMA 1, surf ace mounted. Panelboards of sizes and ratings, as shown on the drawings, shall be provided to serve the ventilating, lighting, and miscellaneous power loads. Ground fault interrupter (GFI) breakers rated $120 \mathrm{Vac}$ only shall be provided, as required by National Electrical Code.

\subsection{RECEPTACLES}

Convenience outlets shall conform with NEMA Standard configuration 5-15R and shall be 3 wire, duplex, grounding type, $120 \mathrm{Vac}, 15$ amp, Hubbell Cat. 5262 , or equal.

Receptacles for 480 volt, 3 phase service shall be 60 amp, 4 pole, 3 wire type, with spring door and combined with a non-fused, heavy-duty, horsepower rated disconnect switch, Crouse-Hinds WSRD 63542 or equal. The mating male plugs shall be Crouse-Hinds APJ 6485, or equal, for 60 amp service.

\subsection{HIGH RADIATION AREA CONNECTORS}

The remote electromechanical manipulator operated, 304 stainless steel, connectors shall be rated for $10^{7} \mathrm{R}$ total integrated dosage minimum and 600 volts. The connector shall be suitably sealed for decontamination with nitric acid, oxalic acid and Turco No. 4502. The receptacle and plug assembly shall be Gulton Lormec Series 9588 and 9405 respectively, or equal.

\subsection{SAFETY SWITCHES}

Safety switches shall be the heavy-duty type, horsepower rated, 600 volt, 3 pole, with current rating and fusing, as shown on the drawings. The enclosure shall be NEMA 1. 


\section{15 TOGGLE SWITCHES}

Toggle switches installed for the control of incandescent, high pressure sodium, and fluorescent lighting luminaires shall be heavy-duty, general purpose, UL approved devices. Toggle switches shall be specification grade, single-pole, Hubbe 11 Cat No. 1221 or 1221-I, or equal.

\subsection{LIMIT SWITCHES}

The non-plug-in limit switches shall be heavy-duty type, 600 volts, 10 amp continuous rating contacts, single pole, double throw (SPDT) or electrically independent double pole, double throw (DPDT). The limit switches shall be Micro Switch Type HDLS Series, or equal.

\subsection{BOXES AND FITTINGS}

Outlet boxes shall be rust-resistant, cast-iron alloy boxes with threaded hubs or bosses for conduit connection. Pullboxes and their covers shall be constructed of galvanized steel.

\subsection{RELAYS}

Control relays shall be magnetically operated relays with $120 \mathrm{Vac}$ coils, and contacts rated for 10 amp inductive at 120 volt continuous duty. Timing relays shall be magnetic relays with an adjustable pneumatic timing mechanism and a minimum 5 amp continuous contact rating.

\subsection{GENERAL LIGHTING}

Commercial type recessed fluorescent luminaires with acrylic lenses and high power factor and energy saving ETL, Class P ballasts and $4 \mathrm{ft}$, cool white, rapid start fluorescent lamps with wattage not to exceed 35 watts shall be used in offices, control room, toilet and similar areas. Ballasts shall not contain PCB capacitors. Industrial type fluorescent luminaires with upward component and porcelain enamel reflectors shall be utilized in other low bay areas. Lighting in the high bay areas shall utilize high pressure sodium (HPS) luminaires. Exterior HPS wall mounted luminaires shall be provided. Special cell HPS luminaires, suitable for remote removal, shall be provided, as required.

The emergency lighting shall be provided by fully automatic 120/277 V supply, lead calcium rechargeable batteries, Holophane Cat. No. M-12-2A-X, or equal.

\subsection{LIGHTNING PROTECTION}

provided.

Lightning protection, complete with UL Master "C" label, shall be

\subsection{GROUNDING}

A No. 4/0 AWG soft drawn bare copper ground 10op with $3 / 4$ in. by $10 \mathrm{ft}$. copper-clad steel ground rods, shall be provided and connected to the Site duct bank ground system. One insulated instrumentation ground bus plate and cable shall 


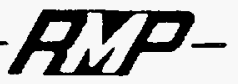

be furnished in the control room. The cable shall be connected to the facility ground system at only one point. The maximum facility ground resistance shall be five ohms. The lowest level of building reinforcing bar shall be grounded. The shielding window liners shall be grounded.

\subsection{CATHODIC PROTECTION}

Cathodic protection shall be provided for all direct buried metallic lines and underground tanks.

\subsection{TERMINAL BOXES}

Control terminal box enclosures shall be NEMA 1 sheet steel construction with hinged door, lock and steel equipment mounting panel(s). Barriers shall be steel, full depth and height, finished the same as the enclosures. The interior of the enclosure shall be finished with white enamel. The exterior shall be painted with color, as directed.

\subsection{TERMINAL BLOCKS}

A1l power and control wiring shall be terminated on accessible terminal blocks. The 600 volt, melamine, rail mounted, terminal blocks shall be Weidmuller Type SAK, or equal. A snap-in preprinted unique wire number marker shall be provided. Hand lettered terminal identification is not acceptable. Terminal connectors shall be the vibration proof, pressure clamp type.

\subsection{TELEPHONE SYSTEM}

Telephone cabinets shall be provided, as required. Conduit only shall be installed in the building, as required. The telephone system wiring will be by 0thers.

\subsection{CELL SPEAKER SYSTEM}

A cell speaker system shall be provided for monitoring audio sounds inside the cell. The system shall consist of a microphone with box mounted on a remotely removable Gulton plug in the cell and connected to a speaker in the control room.

\subsection{FIRE ALARM DETECTION SYSTEM}

The fire detection system shall include control panels, annunciators, initiating devices, signal conduits, and wire necessary for a complete and operational system. The final connection to the Site fire alarm system will be by others. The system shall be Pyr-A-Larm System 3, or equal. The system sha11 consist of a multiplexer and enclosed terminal board, thermal detectors, manual stations, public address speakers, control panel audible devices, remote annunciator and control panels. The detection devices shall be capable of being interchanged without any changes required to the wiring, control panel or to the mounting base. The supervision shall not require additional wires other than the pair used for detection or al arm. The system shall be capable of being expanded at any time up to the maximum capacity of the system. The system shall be capable of 


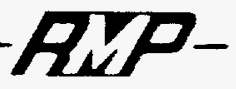

having ionization, thermal, and photoelectric detecting devices, control relays, and manual stations connected across the same pair of wires. The system shall be electrically supervised against both short and open wire faults in the detection circuit, the manual station alarm circuit, and an open in the system alarm and trouble relay coils. An open wiring fault occurring in these circuits shall cause an audible and visual trouble indication at the control panel. A fire alarm signal shall override trouble signals. In the event of a trouble signal resulting from trouble on an initiating zone, a fire signal from another zone shall appear on the panel and remain until the panel is reset, at which time the trouble signal will reappear. Alarm initiating zones shall be as shown on the drawings. A separate switch monitor shall be provided to control waterflow alarms separately from other al arm signals.

\subsubsection{Al arm System}

The system shall function as follows when any sprinkler flow switch operates, or thermal detector in the HVAC fire protection system operates:

A. The main and remote annunciator panel alarm devices shall annunciate audible and visual indicators of a fire alarm.

B. The visible indicator shall indicate the zone location and the device initiating the fire alarm. The audible indicator shall produce the same sound for all fire alarms.

C. An alarm indicating lamp shall light in the base of the HVAC detector initiating the alarm.

D. Panel locks into alarm until manually reset.

E. Exhaust duct detector circuits shall be provided to energize the HVAC fire protection chamber fire water system for HEPA filters.

F. Supply duct detector circuits shall be provided to shut down the supply $f a n(s)$.

G. The alarm shall be manually transmitted as a voice alarm throughout the building over the fire alarm PA speakers.

\subsubsection{Fire Supervisory Signals.}

The supervisory alarm initiating devices shall include post indicator valve (PIV) switches, $O S$ and $Y$ valve switches, dry pipe system low air pressure switches, trouble signals from each of the $\mathrm{Hal}$ on and $\mathrm{CO}_{2}$ systems, and the Pyr-A-Larm Panel system trouble indicators. The supervisory alarm system shall function when any of these devices operate, as follows: 
A. The main control panel shall annunciate audible and visual indicators of a supervisory alarm. The audible indicator shall provide a different sound than the fire alarm audible indicator.

B. The main panel locks the visual alarm indicator on, until manualiy reset. The audible indicator can be silenced by operating the alarm normal switch.

C. The main panel relays the supervisory alarm signal via a separate transmitter to the Site fire supervisory alarm system.

\subsection{EVACUATION ALARM SYSTEM}

The evacuation system shall be completely independent of any other system. Speaker wiring may be installed in same conduit as fire alarm. No voice communication is required. The evacuation alarm system shall include an evacuation al arm panel, supervised public address speakers, initiating devices, a tone generator, signal conduits, and wire necessary for a complete and operational system. The system shall be Pyr-A-Larm System 3, or equal. No voice cormunication is required.

The system shall be electrically supervised against both short and open wire faults in the initiating circuit, the audible al arm circuit, and an open wire fault in the system alarm and trouble relay coils. An open wiring fault occurring in these circuits shall cause an audible and visual trouble indication at the control panel. A short in the initiating circuit and the audible alarm circuit shall cause an audible and visual trouble indicator at the control panel. The evacuation alarm signal shall override the trouble signals. In the event of a trouble signal resulting from trouble on an initiating zone, an evacuation signal from another zone shall appear on the panel and remain until the circuit is reset, at which time the trouble signal will reappear. If a second evacuation al arm signal is initiated after a prior signal has been silenced, the selected evacuation signal shall sound even if the control circuit has not been reset. The evacuation al arm system shall shut off automatically after 5 minutes.

The System 3 evacuation shall also provide the following functions:

A. Receive "ALERT" and "EVACUATION" signals from the Site evacuation system.

B. Provide local building status on "EVACUATION" mode only to the Site evacuation system.

C. Provide alarm signal over two No. 14 AWG wires to the Health Physic office.

D. Provide for remote monitoring of the building trouble status. 


\subsubsection{Local Alarm}

This system shall provide an "ALERT" signal, with the panel mounted front cover switch in the "DOWN" position, consisting of continuous, non-varying audible siren tone or an "EVACUATION" signal, with the switch in the "UP" position, consisting of continuous cyclic audible siren tone the cycle to be "ON" for 5 seconds and "off" for 5 seconds. Each signal shall be initiated by operating any remote and one control room manual alarm switch. Any switch shall initiate the signal, but if more than one is operated at the same time, the switch turned to "EVACUATE" will take precedence over all other switches. Initiation of an "ALERT" or "EVACUATION" signal from any control point within the building shall be shown by an indicating light on the evacuation alarm panel. In addition, an audible panel alarm buzzer shall be actuated. The audible alarm can be silenced by operating the "ALARM-NORMAL" switch to the opposite position but the light shall remain on until all switches or contacts are returned to normal position.

\subsubsection{Site Wide Alarm.}

A separately maintained toggle switch with "Lock-out" pin in the "DOWN" position, located in the control room, shall provide the Site wide alarm system an "ALERT" signal with the switch in the "DOWN" position or an "EVACUATION" signal with the switch in the "UP" position over two No. 14 AWG wires to connection in the Security Building. 


\subsection{PIPING MATERIALS}

\subsection{SCOPE OF WORK}

The Contractor shall provide labor, materials, equipment, and tools necessary to fabricate, test, inspect, document, deliver to the site, field fabricate and/or install, and field inspect and test all piping materials in the quantities defined and as located by the drawings, and in accordance with this specification.

\subsection{OUTLINE SPECIFICATIONS}

The Piping Service Classes to be used are

Class

D

N

P

Q

V

\section{Service}

Process Equipment Waste

High Pressure Steam, Low Pressure Steam, Condensate, High Pressure

Air, Vacuum

Low Pressure Air

Cooling Water Supply And Return

Pressurized Feed Gas 


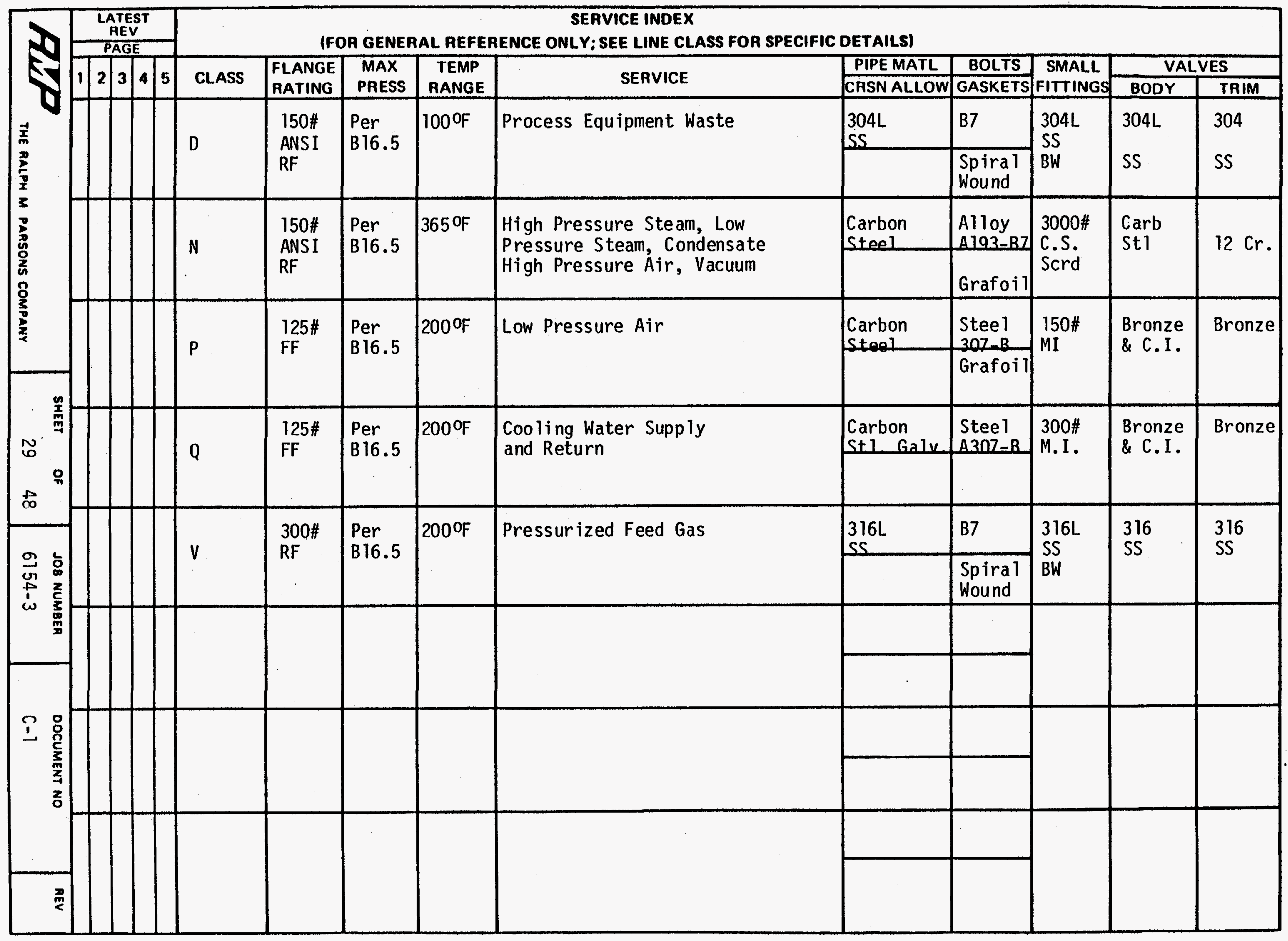




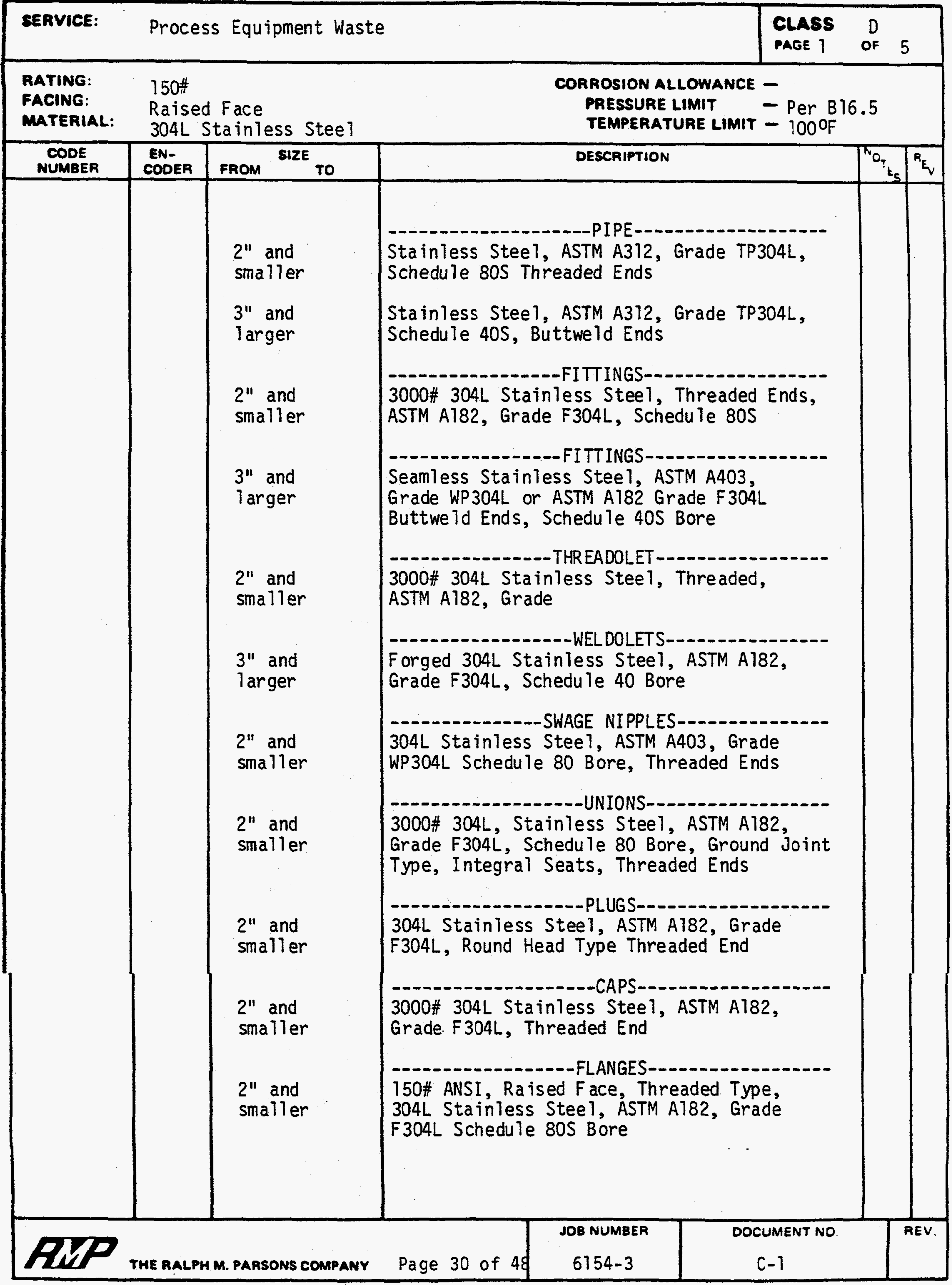




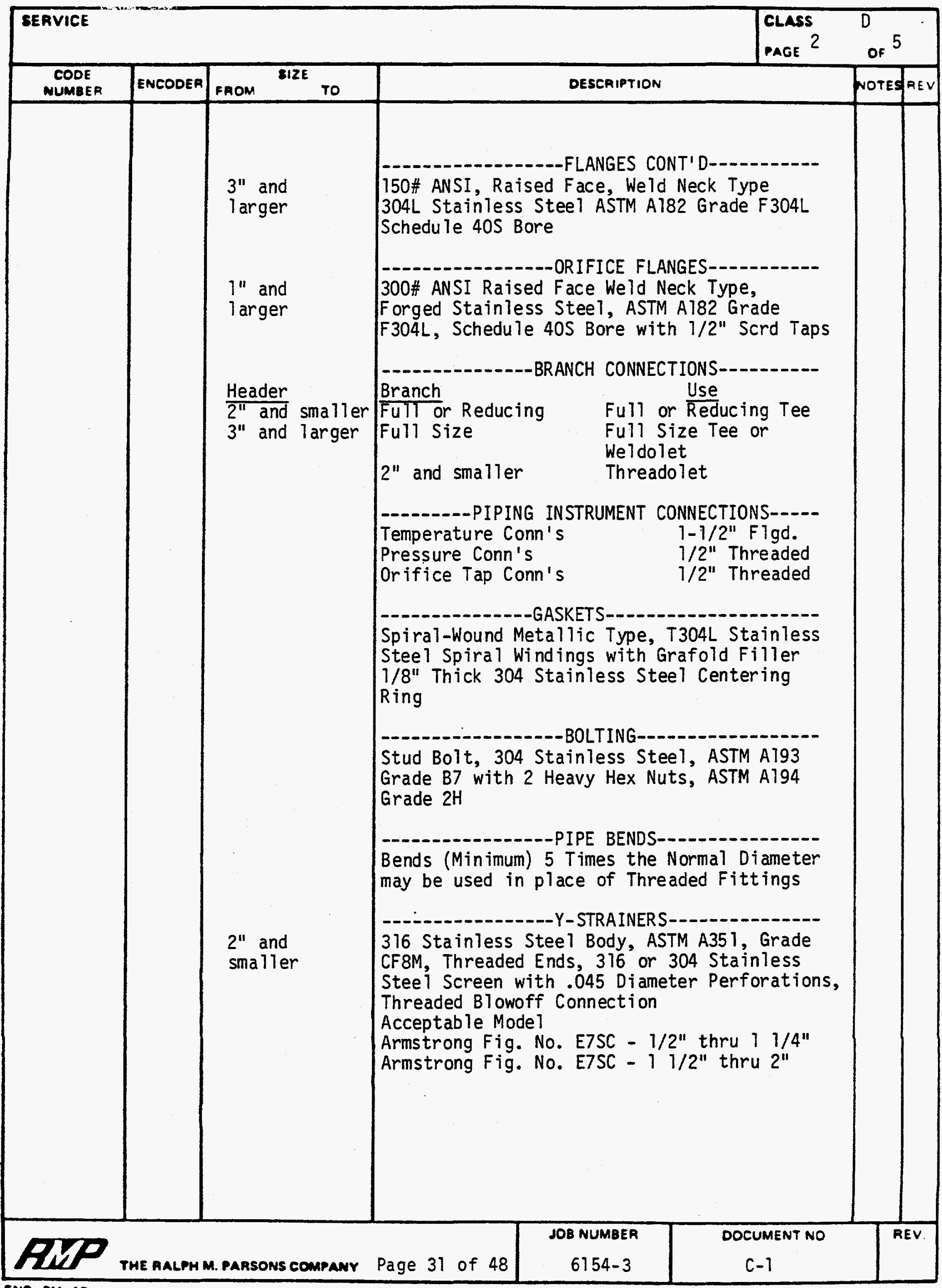




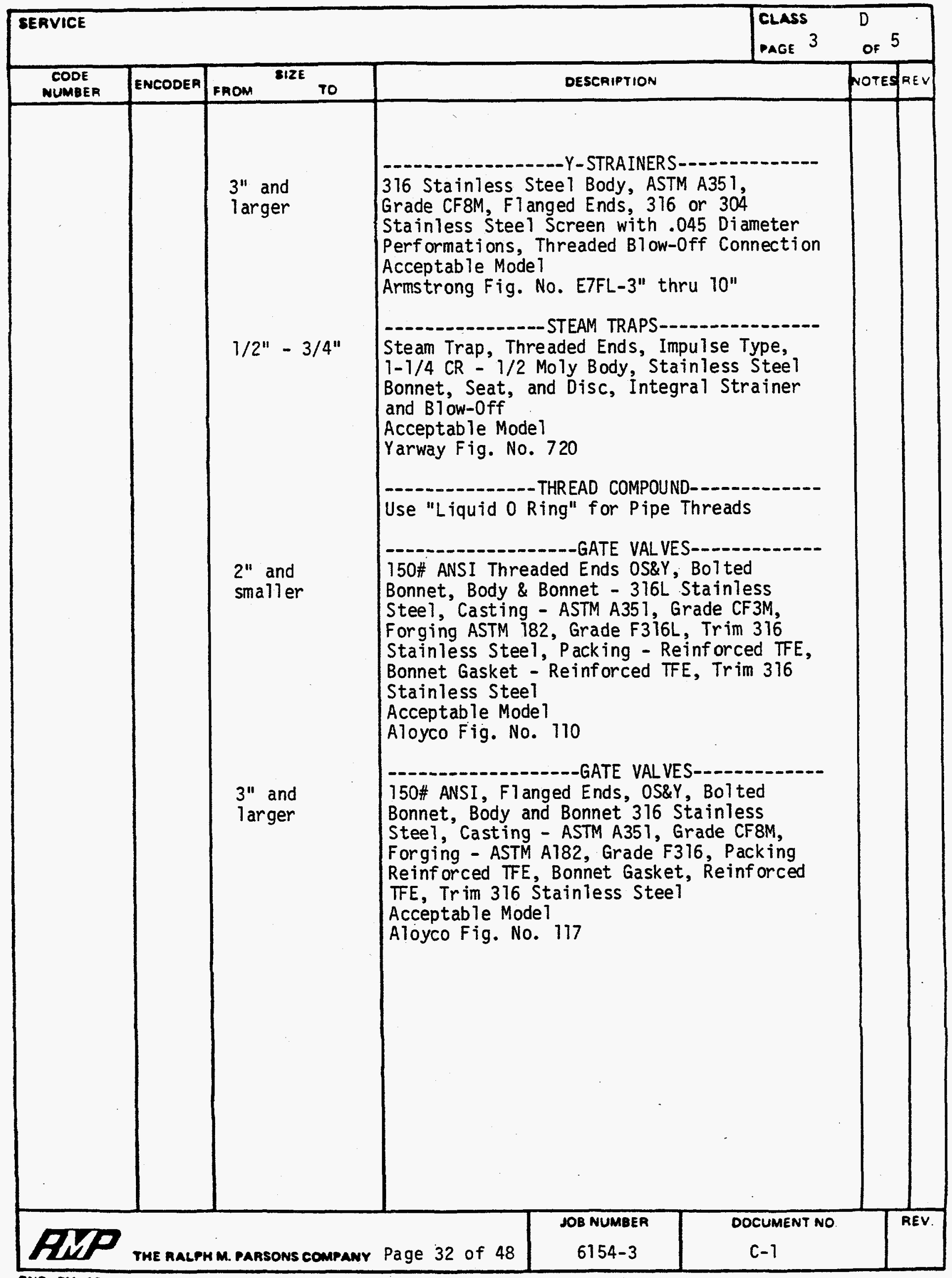




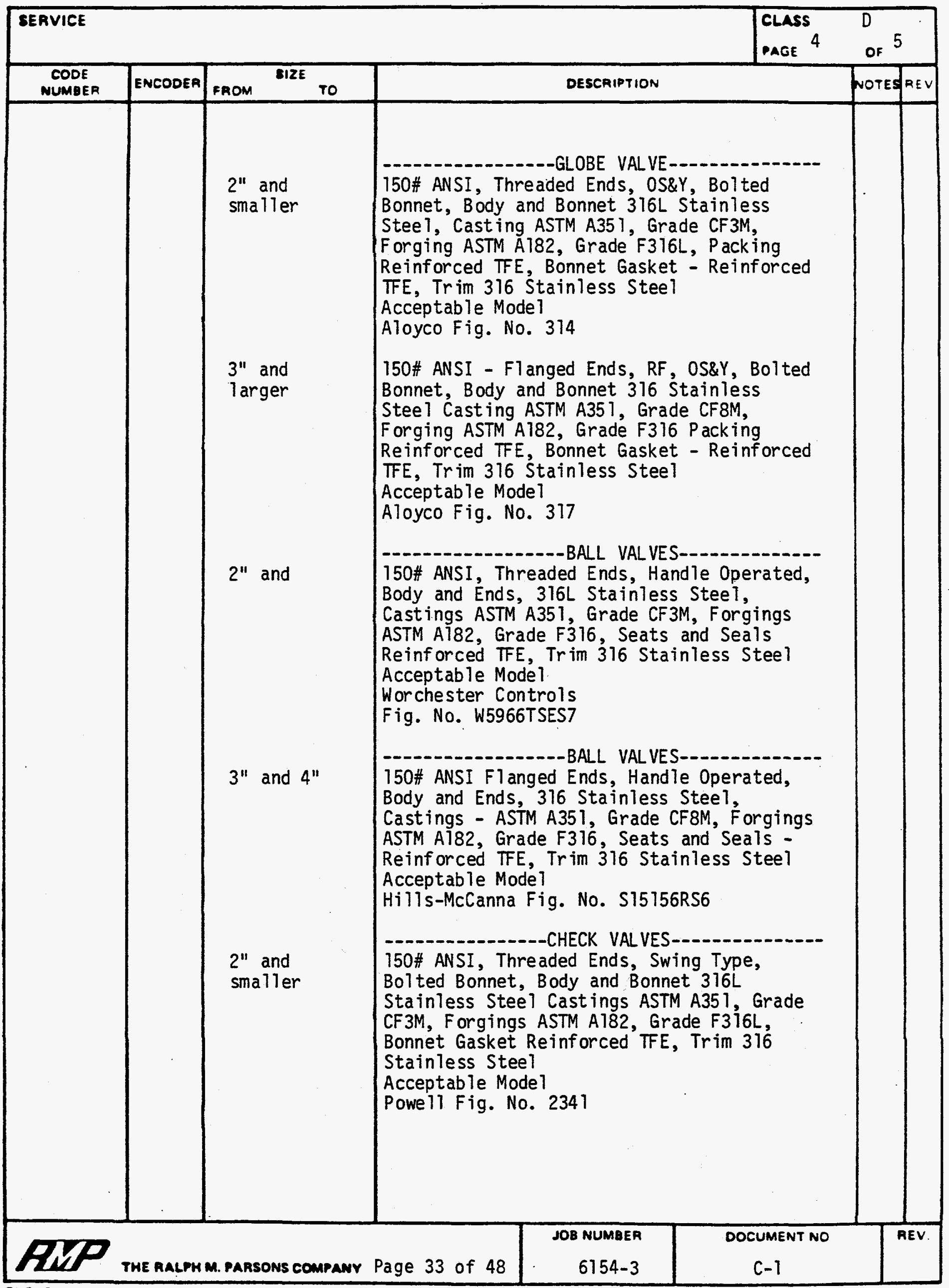




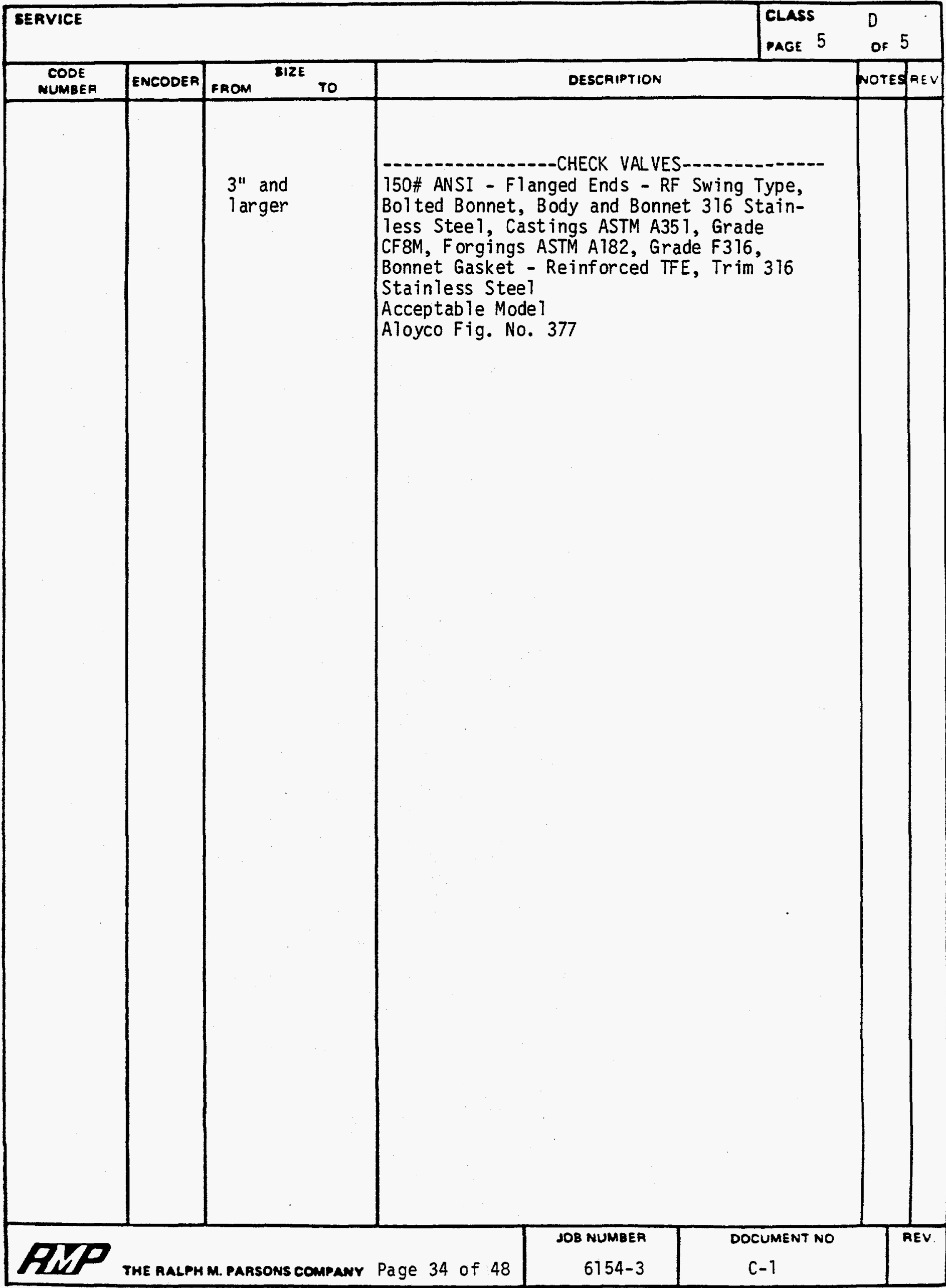




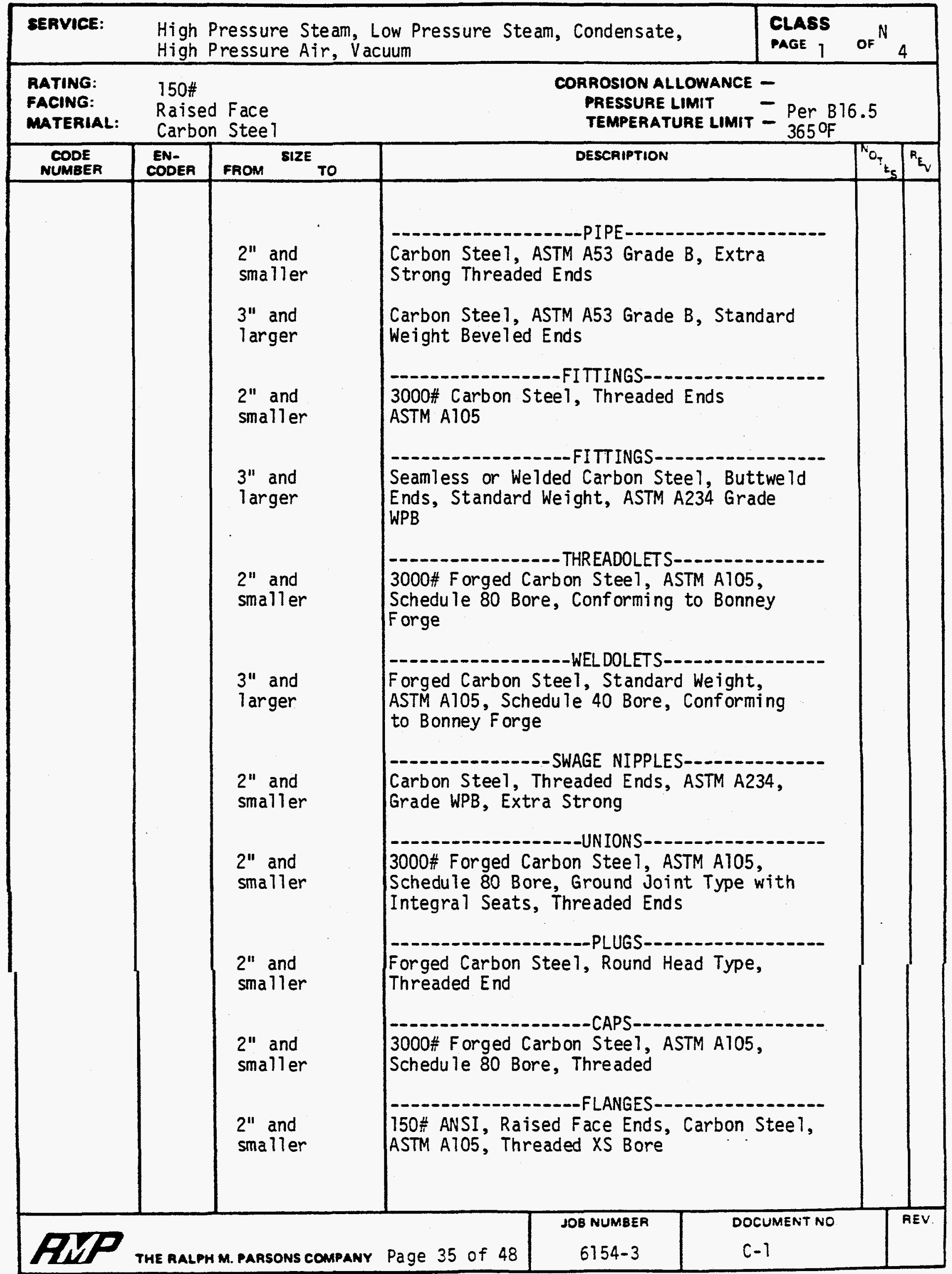




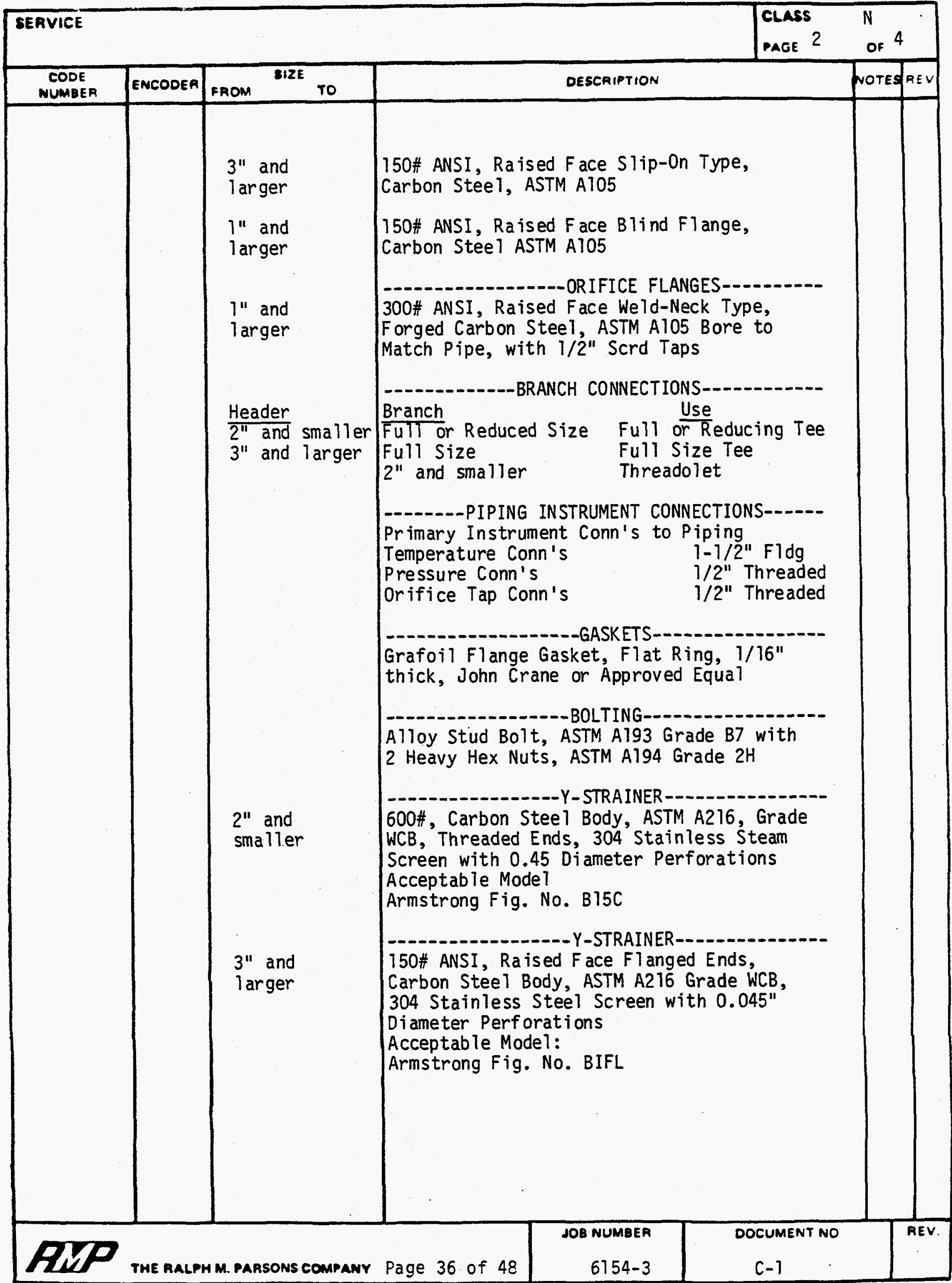




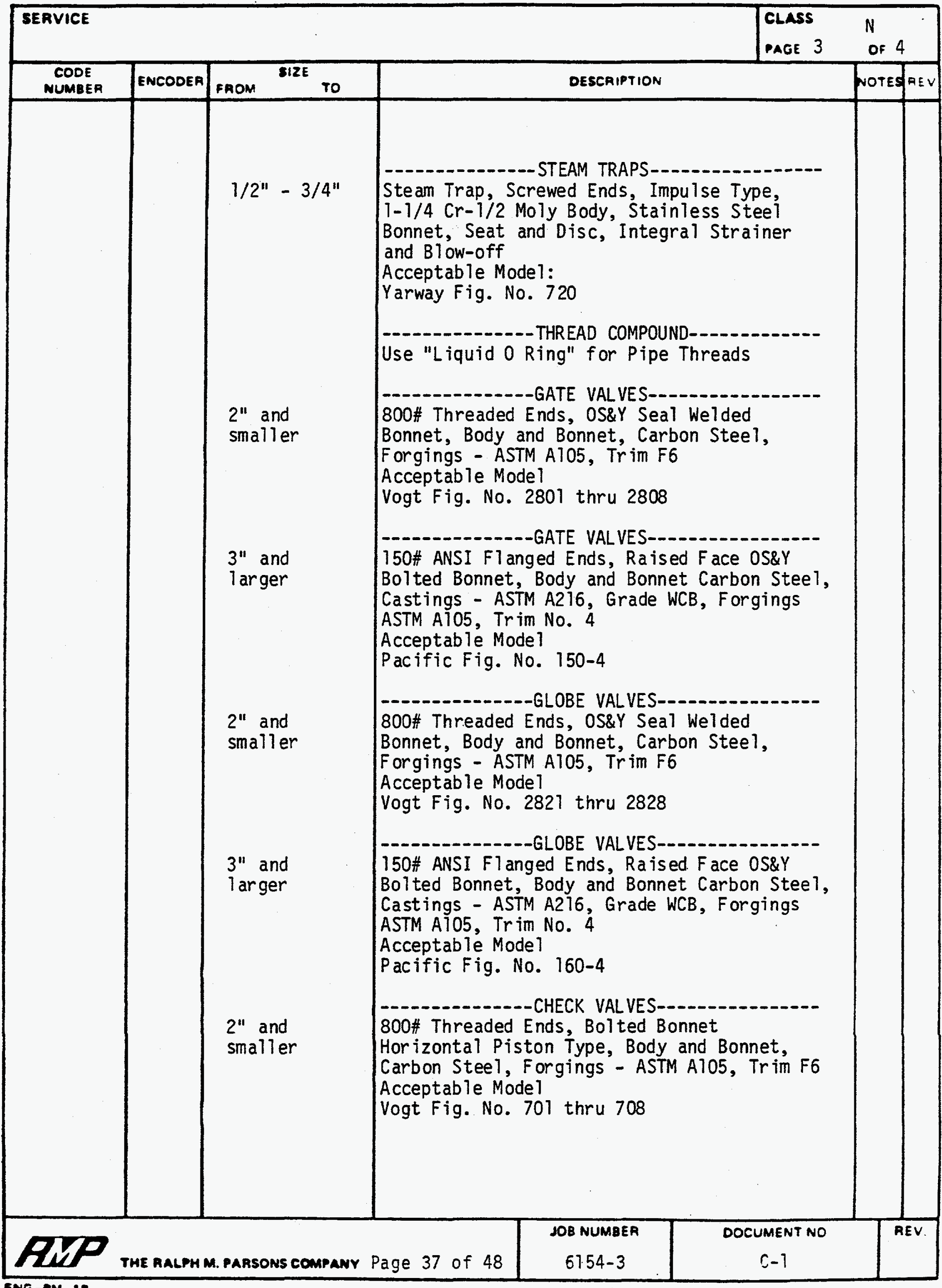




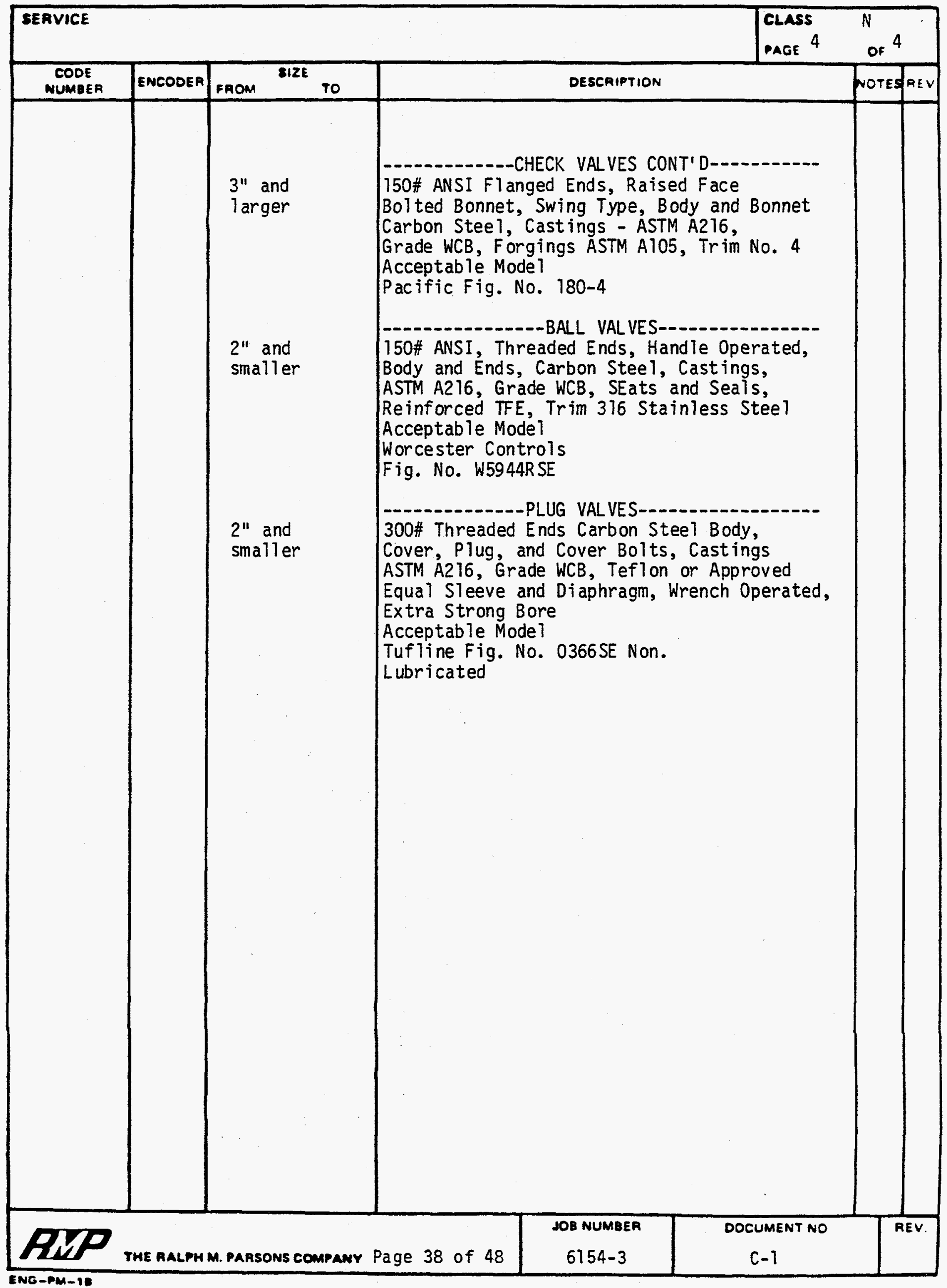


RATING:

FACING:

MATERIAL:

125\#

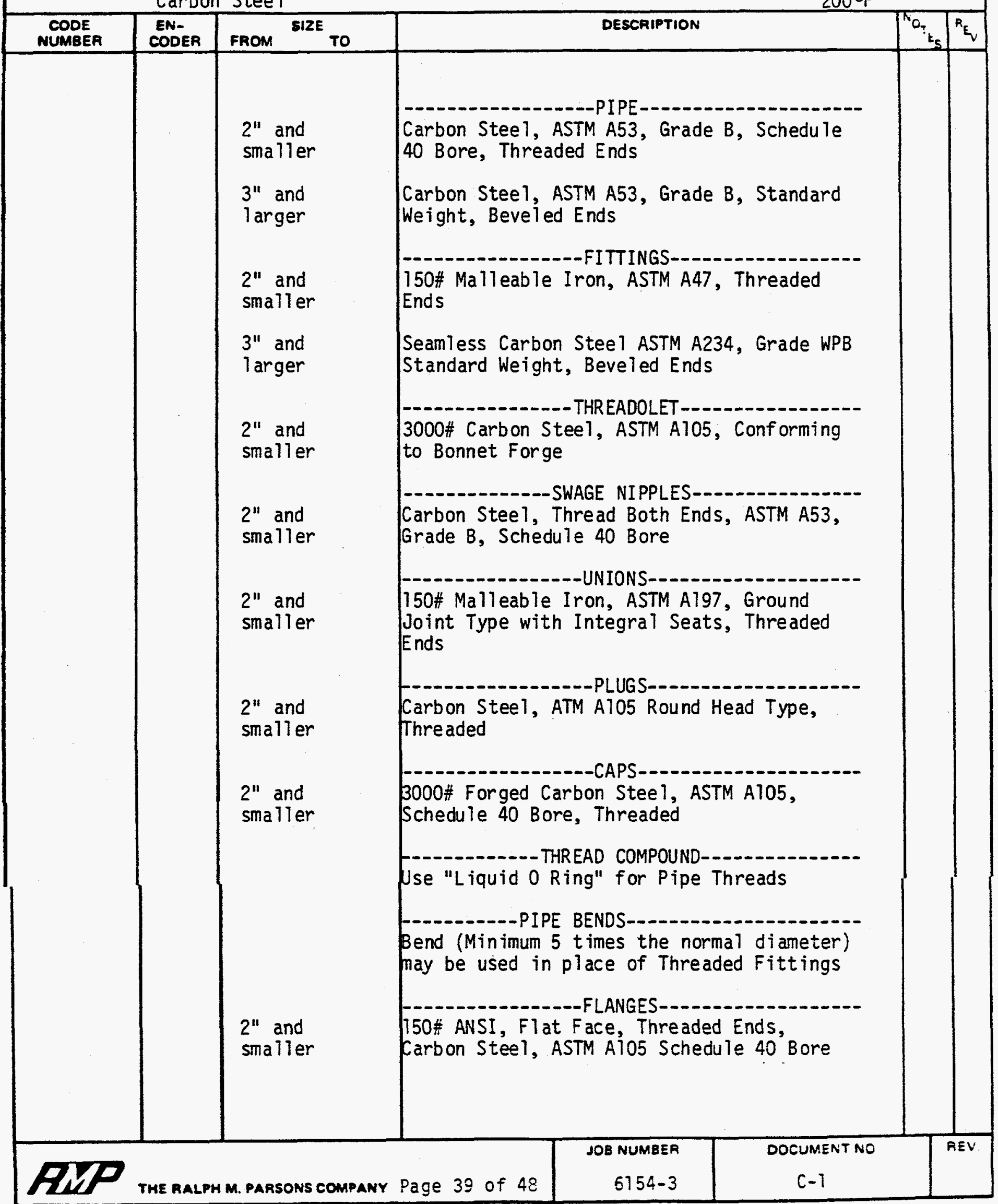

CORROSION ALLOWANCE -

PRESSURE LIMIT - Per B16.1

Flat Face

Carbon Stee

Carbon Stee 1, ASTM A53, Grade B, Schedule

Carbon Stee1, ASTM A53, Grade B, Standard Weight, Beveled Ends

150\# Malleable Iron, ASTM A47, Threaded

Seamless Carbon Steel ASTM A234, Grade WPB THREADOLET

3000\# Carbon Steel, ASTM A105, Conf orming to Bonnet Forge

Carbon Steel, Thread Both Ends, ASTM A53,

150\# Malleable Iron, ASTM A197, Ground Joint Type with Integral Seats, Threaded Ends

Carbon Steel, ATM Al05 Round Head Type,

\section{CAPS}

BO00\# Forged Carbon Steel, ASTM AI05,

-

-PIPE BENDS

Bend (Minimum 5 times the normal diameter) FLANGES 


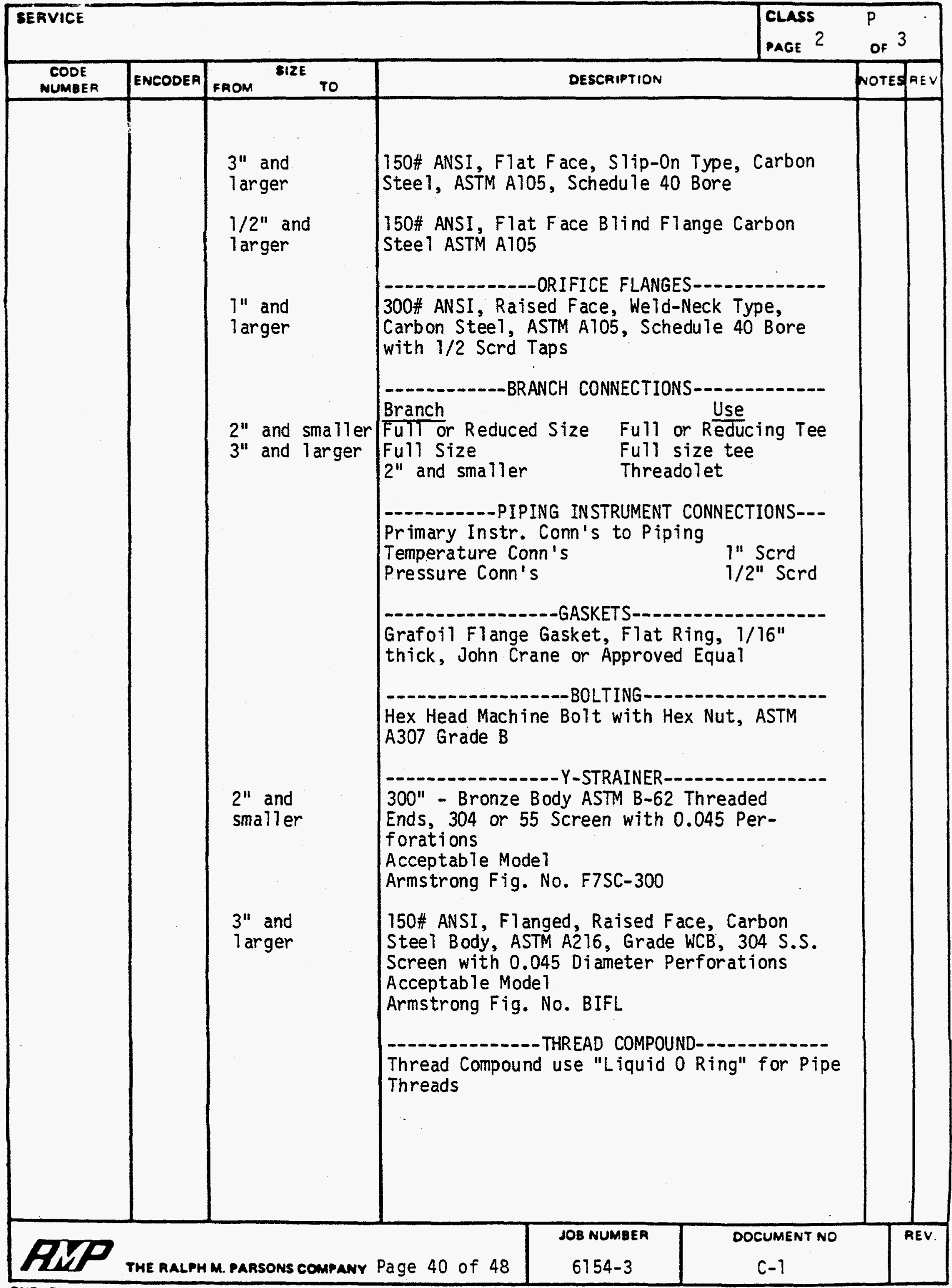




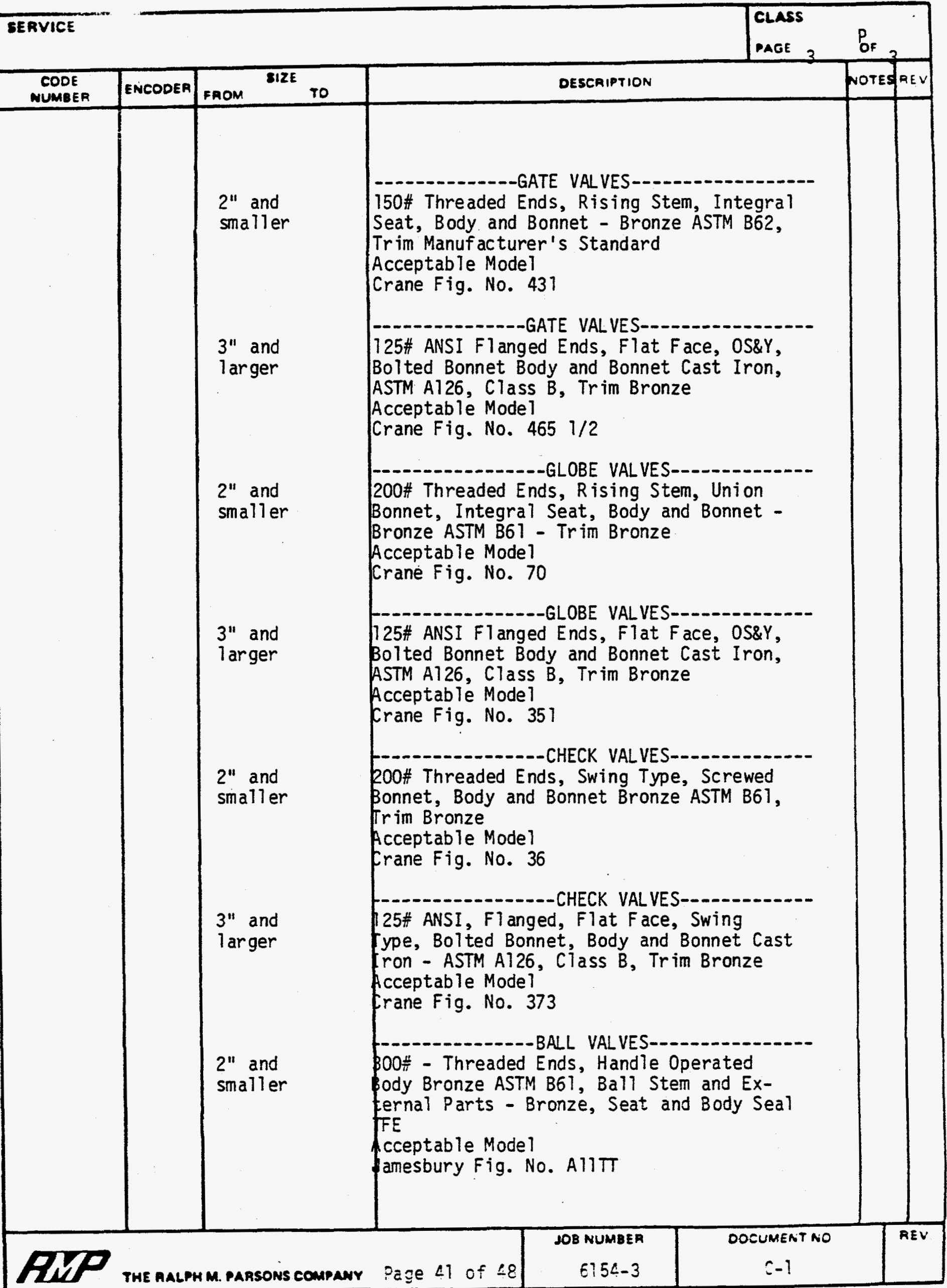




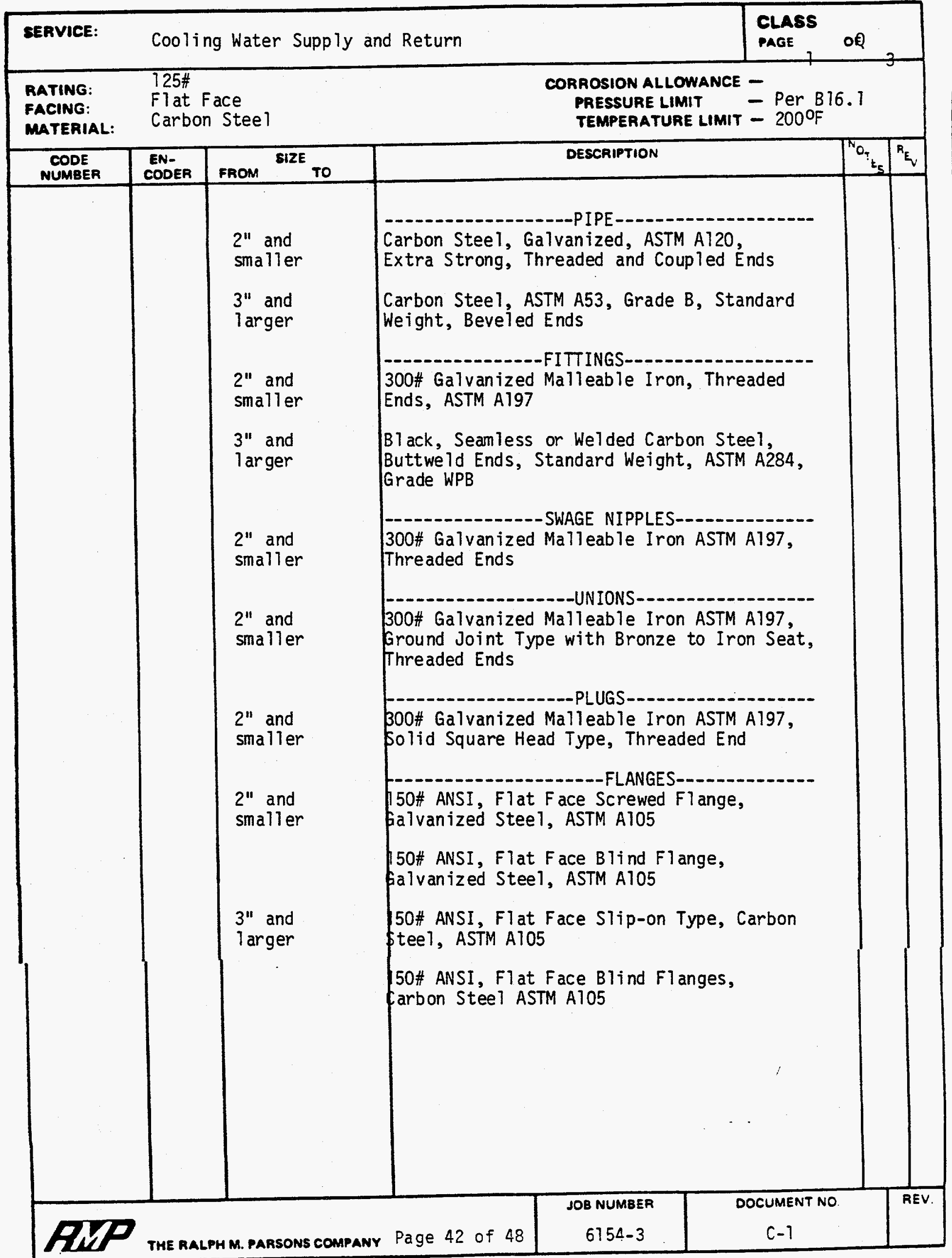




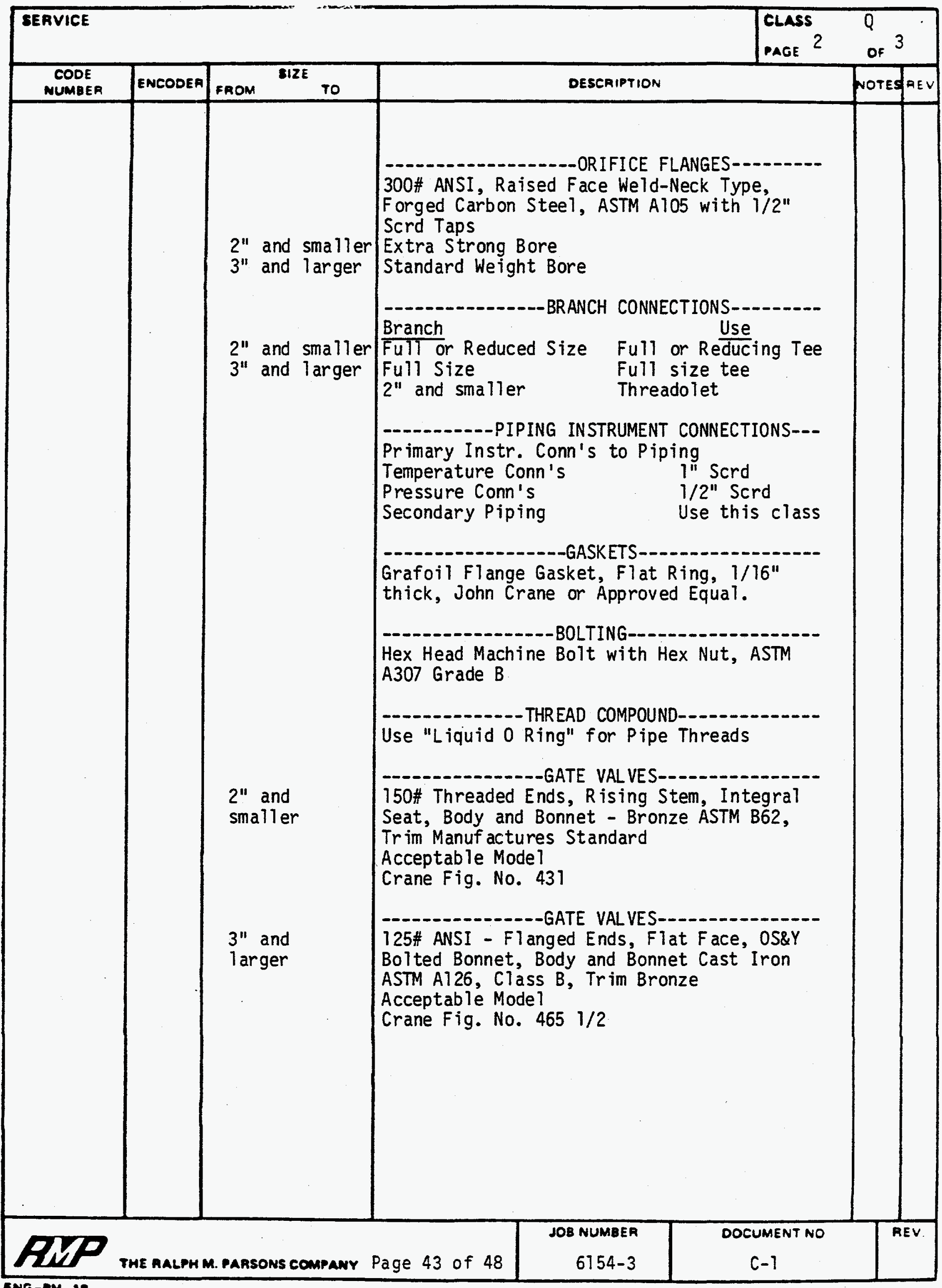




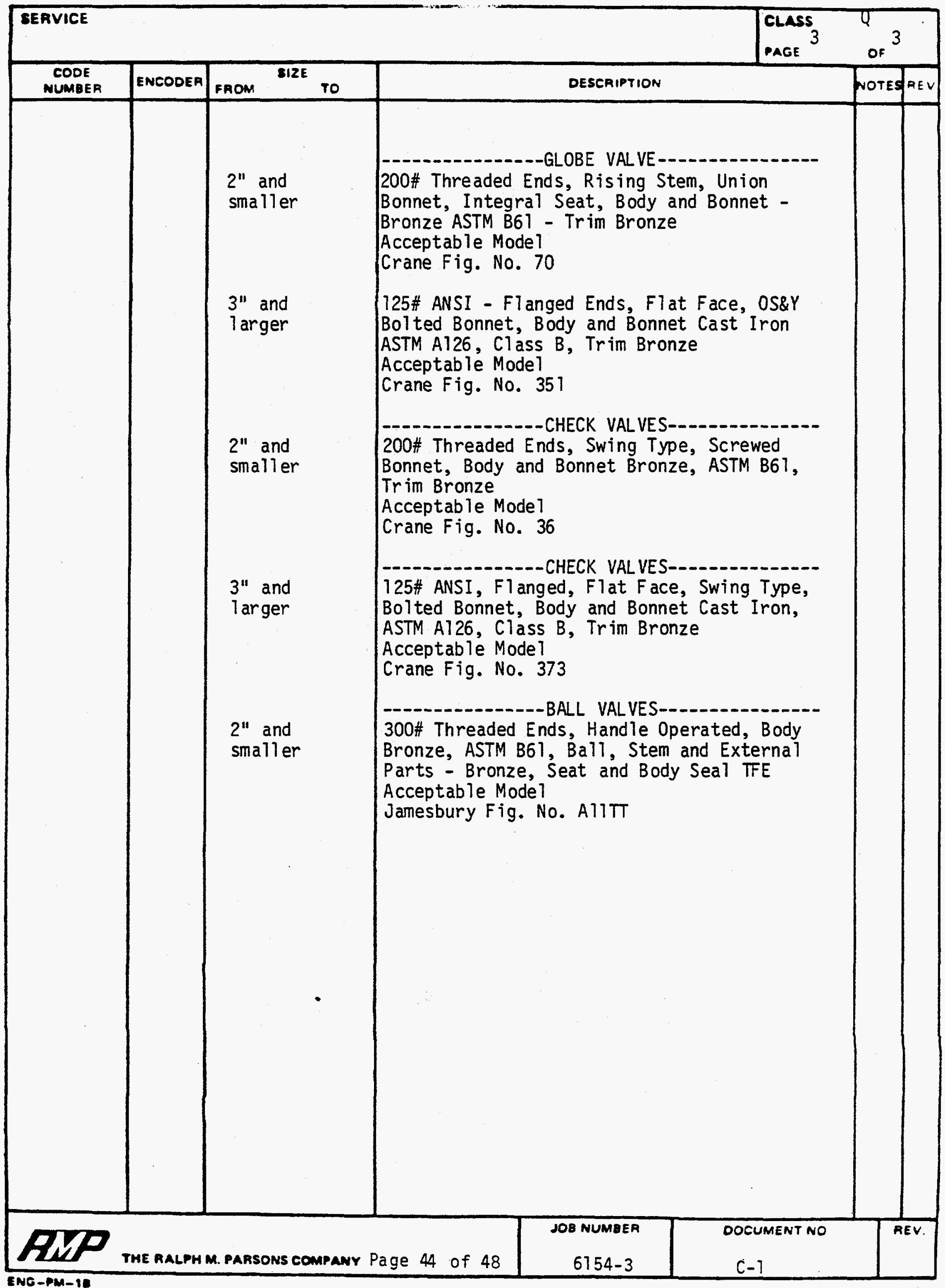




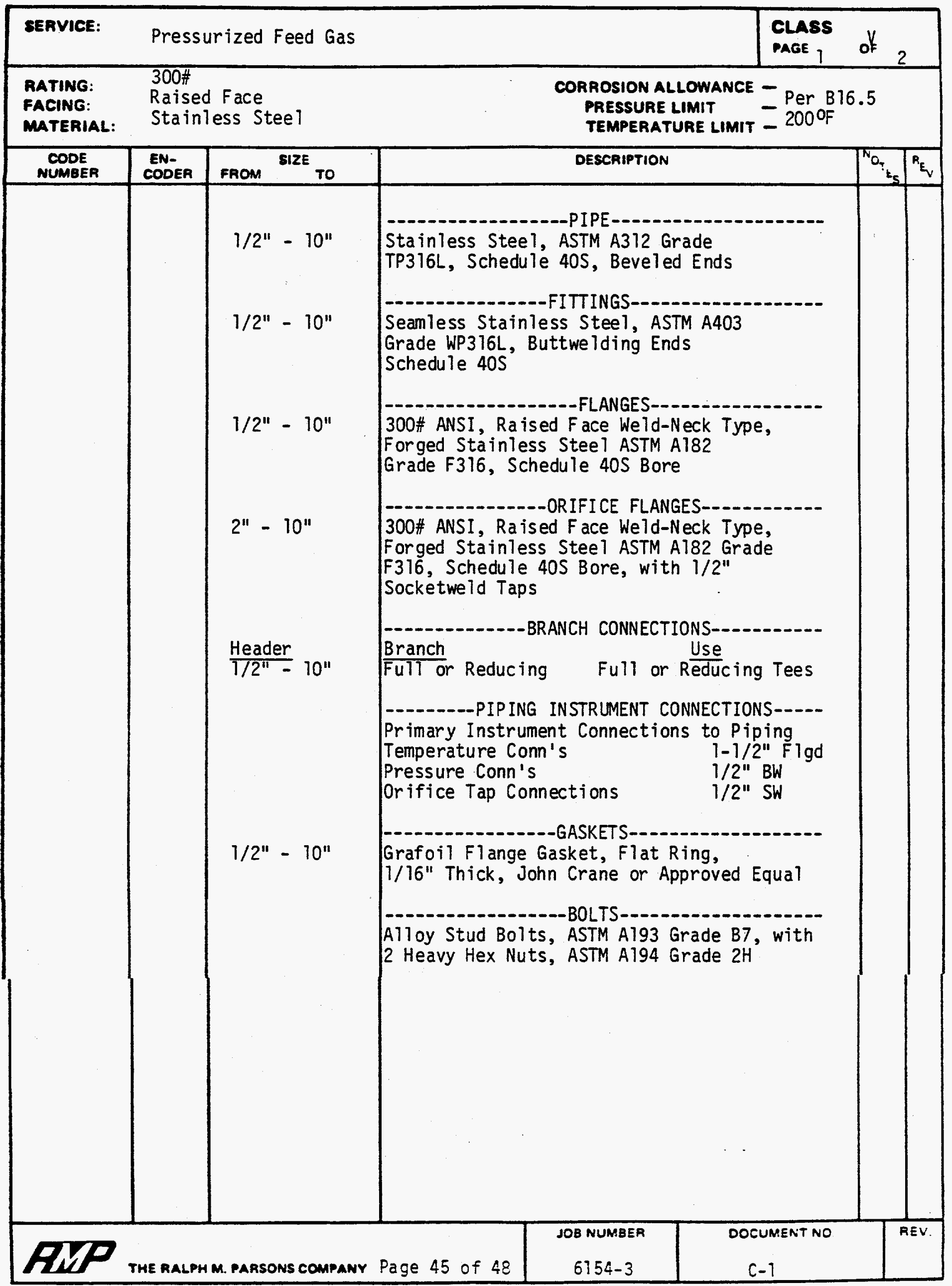




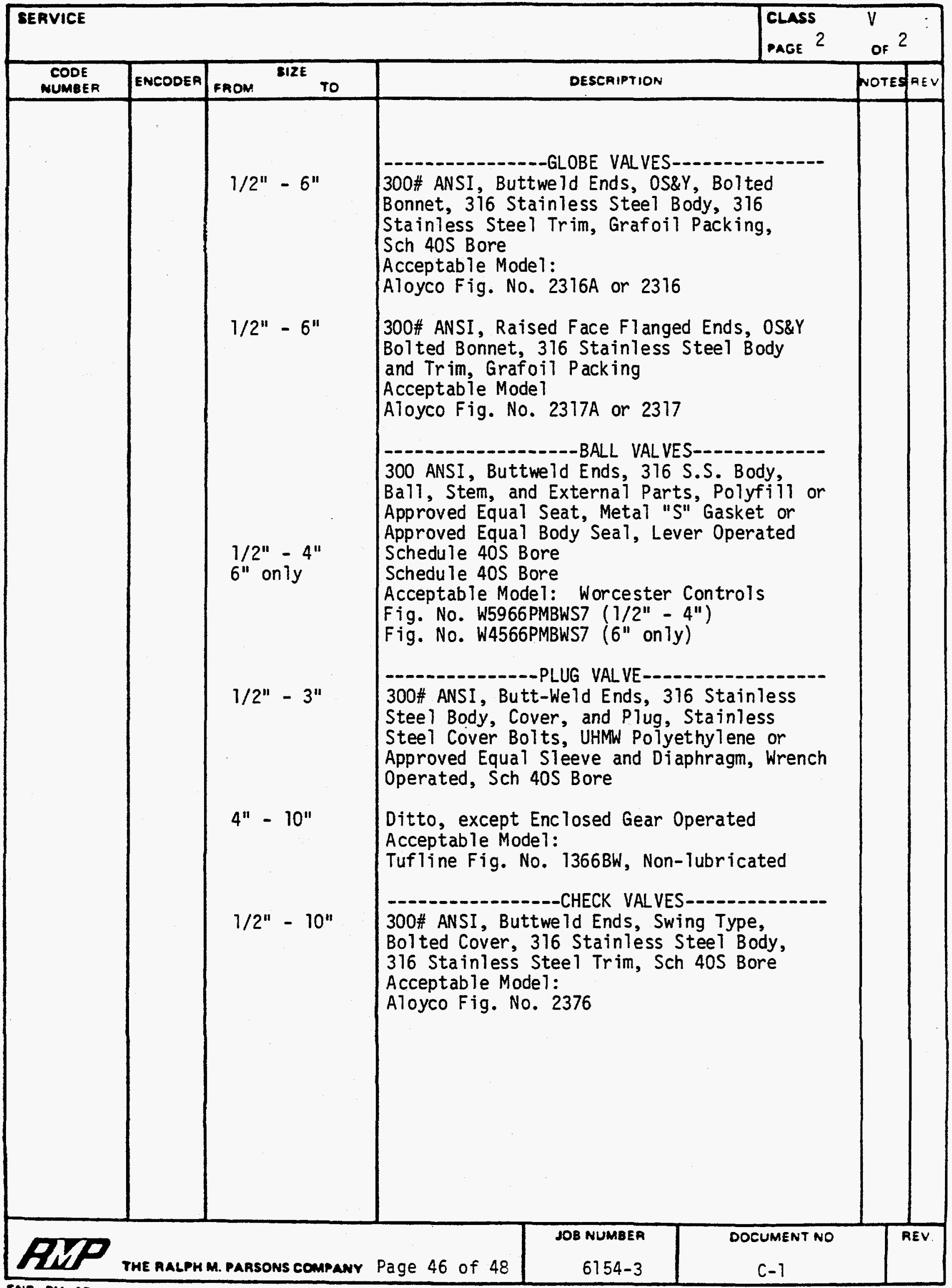




\subsection{COATING AND WRAPPING}

\subsection{SCOPE OF WORK}

The Contractor shall provide all material, labor, equipment, and tools necessary for the preparation and application of corrosion resistant coatings for exterior surfaces of carbon and stainless steel pipe, flanges, valves, and fittings in direct buried service.

\subsection{MATERIALS OF CONSTRUCTION}

The following materials or Approved Equal are acceptable:

\section{MATERIALS}

Tape Primer

Primary Tape

Filler Tap

Joint Tape

MANUFACTURER
Polyken Div
of the
Kendall Co.,
Boston,
Mass.

MFR' S CODE

No. 927

No. 980

No. 931

No. 930

\section{SERVICE TEMPERATURE}

-30 of to $2000^{\circ}$

-30 OF to 200 oF

-30 of to 200 oF

-30 F to $200 \mathrm{OF}$

\subsection{EQUIPMENT}

The pipe wrapping shall be electrically inspected with a Tinker \& Rasor Model AP or APW or Approved Equal holiday detector set at a minimum dc voltage of 150 times the mil thickness of the coating to detect any wrapping flaws.

\subsection{FIRE PROTECTION}

\subsection{SCOPE OF WORK}

This Specification establishes the requirements for the design, fabrication, and installation including furnishing labor, materials, tools, and equipment, and performing operations necessary for engineering, detailing, inspection, testing, documentation, delivery to jobsite and installing Underwriters Laboratories (UL) and/or Factory Mutual (FM) approved automatic fire sprinkler systems, fire hose cabinets, and fire hose racks.

\subsection{MATERIALS OF CONSTRUCTION}

Sprinkler heads for offices and other finished areas shall be UL and/or FM approved, pendant type with ceiling plate, a temperature rating of $212 \mathrm{deg} F$, and a standard 1/2-inch orifice size. Sprinkler heads for all other areas shall be UL and/or FM approved brass upright type, with a standard 1/2-inch orifice size and a temperature rating of 212 deg $F$ except near heat sources where the temperature rating sha 11 be in accordance with NFPA Standard No. 13, Table 3-16.6.4. 
Water flow detectors shall be provided and installed according to NFPA Standard No. 72A. Wiring and conduits shall be provided and installed by the Contractor.

Piping shall comply with the ANSI and ASTM standards. Pipe hangers shall be in accordance with requirements of the Underwriters' Laboratories, Inc., for use in sprinkler systems.

Pipe:

Carbon Stee1, ASTM A 53, Grade B, Standard Weight

Screwed Fittings:

Cast Iron ASTM A 126 conforming to ANSI B16.4 \& B16. 1 or Malleable Iron, ASTM A 197 conforming to ANSI B16.3

F1 anges:

Cast Iron ASTM A 126 conforming to ANSI B16.1

Couplings and Unions:

As per NFPA Standard No. 13

Vaives:

(1) Class 175 WWP Iron Body, Bronze Mounted, OS\&Y Gate Valves for al1 sizes larger than 2 inches

(2) Class 175 WWP Iron Body Swing Alarm Check Valve

(3) Class 175 WWP Iron Body Dry Pipe Valve

\subsection{EQUIPMENT}

\subsubsection{Alarm Check Valves}

The alarm check valves shall be Viking Model F-l Alarm Check Valve with retarding chambers and complete trim packages, or Approved Equal. A water motor gong local alarm shall be included with each wet pipe system.

\subsubsection{Fire Hose Racks, Fire Hose and Extinguisher Cabinets}

Fire hose racks and fire hose cabinets shall be of the surface mounted type and shall be provided and installed at the approximate locations shown on the drawings. All fire hose racks and cabinets shall be installed in compliance with NFPA Standard No. 14 for Class II service and NFPA Standard No. 13 for combined systems. All fire hose cabinets shall be sized to house a 2-1/2 gallon water-type fire extinguisher in addition to the hose and appurtenances. 


\section{APPENDIX $\mathrm{C}-2$}

\section{ZEOLITE ENCAPSULATION OUTLINE SPECIFICATIONS}

\subsection{EARTHWORK}

2.0 STRUCTURAL

3.0 ARCHITECTURAL

4.0 EQUIPMENT

5.0 HEATING, VENTILATING, AND AIR CONDITIONING SYSTEMS

6.0 PLUMBING

7.0 ELECTRICAL

8.0 PIPING MATERIALS

9.0 COATING AND WRAPPING

10.0 FIRE PROTECTION 


\section{APPENDIX C-2 \\ ZEOLITE ENCAPSULATION \\ OUTLINE SPECIFICATIONS}

\subsection{EARTHWORK}

Earthwork shall include the removal of all vegetation, trash and debris, and excavation for foundations. Trash and debr is shall be removed to a sanitary land fill. Excavated material suitable for backfilling shall be stock piled on site for later use. Cuts over 4 feet high shall be shored or have side slopes a minimum of 1-1/2 to 1. Backfilling of excavated areas shall be compacted to 95 percent of maximum dry density in accordance with ASTM D 1557, Method D.

\subsection{STRUCTURAL}

\subsection{CONCRETE}

2.1.1 Applicable Publications. Concrete shall conform to ACI-318, "Building Code Requirements for Reinforced Concrete", and to the requirements of the following publications of the American Concrete Institute. These publications will be used to the extent they are applicable:

ACI-304 "Recommended Practice for Measuring, Mixing and Placing Concrete"

ACI-305 "Recommended Practice for Hot Weather Concreting"

ACI-306 "Recommended Practice for Cold Weather Concreting"

ACI-308 "Recommended Practice for Curing Concrete"

ACI-315 "Manual of Standard Practice for Detailing Reinforced Concrete Structures"

\section{ACI-347 "Recommended Practice for Concrete Formwork"}

\subsubsection{Concrete Formwork. Forms shall be constructed to}

conform, within the tolerances specified, to the required shapes, dimensions, lines, elevations, and positions of the cast-in-place concrete members as indicated. Forms shall be supported, braced, and maintained sufficiently rigid to prevent deformation under load.

\subsubsection{Cast-In-Place Concrete. Concrete shall be standard} density concrete (150 pounds per cubic foot) unless noted otherwise. The minimum compressive strength of concrete wi 17 be 3000 psi at 28 days. Portland Cement shall conform to ASTM C150. Reinforcing steel shall conf orm to. ASTM A615, Grade 60. Wire mesh for slabs shall conform to ASTM A 185. 
2.1.4 Grout. Grout shall be sufficiently fluid to ensure complete filling of all sections of units or areas requiring grout, but not so thin as to allow segregation of aggregate. All grouting shall be done in accordance with manufacturer's printed instructions. Grout shall be a non-shrink type.

\subsection{METALS}

2.2.1 Applicable Publications. The requirements of the following publications shall be used to the extent they are applicable:

American Institute of Steel Construction (AISC) "Specification for the Design, Fabrication and Erection of Structural Steel for Buildings"

American Institute of Steel Construction (AISC) "Specification for Structural Joints Using ASTM A325 and A490 Bolts"

American Welding Society (AWS) "Structural Welding Code (AWS D1.1)

2.2.2 Structural Steel. Structural steel shall conform to ASTM A36. Fabrication and erection shall conform to AISC "Specification for the Design, Fabrication and Erection of Structural Steel for Buildings".

2.2.3 Bolting. Structural steel connections shall conform to "Specification for Structural Joints Using ASTM A325 or A490 Bolts". Structural stainless steel connections shall be similar to structural steel type connections, except that the mechanical properties of the bolts, nuts, and washers shall conform to the latest revision of ASTM A193 for Class 2, Grade B8, Type 304.

2.2.4 Welding. E308L electrode series shall be used to weld $304 \mathrm{~L}$ stainless steel. Welding shall conform to the AWS Structural Welding Code, AWS D1.1, for carbon stee 1, to the ASME Boiler and Pressure Vesse1 Code for stainless steel, and to the requirements of the latest revisions of the following publications to the extent they are applicable:

"Specification for Corrosion-Resisting Chromium and Chromium-Nickel Steel Covered Welding Electrodes", AWS A5.9

"Specification for Corrosion-Resisting Chromium and Chromium-Nickel Steel Welding Rods and Bare Electrodes", AWS A5.9

"Specification for Flux-Cored Corrosion-Resisting Chromium and Chromium-Nickel Steel Electrodes", AWS A5.22

"Specification for Aluminum and Alumionum Alloy Welding Rods and Bare Electrodes", AWS A5.10 
2.2.5 Masonry. Masonry units shall conform to ASTM C90, Grade N, Type I for 8 inch or 12 inch block. Reinforcing steel for masonry construction shall conform to ASTM A615, Grade 60 for deformed billet steel bars.

\subsection{ARCHITECTURAL}

\subsection{WOODS AND PLASTICS}

\subsubsection{Rough Carpentry}

Rough carpentry shall be nailers, blocking, striping, and miscellaneous. Any member in contact with concrete or masonry shall be pressure preservative treated.

\subsubsection{Finish Carpentry}

Finish carpentry shall be bult-in wood shelving, cabinets, hardwood shower seats, etc.

\subsection{THERMAL AND MOISTURE PROTECTION}

\subsubsection{Preformed Metal Siding}

insulation.

Ribbed siding panels, 22 gauge, lap type joint with

\subsubsection{Building Insulation}

Building insulation shall be U.L. listed with flame spread under 25 and smoke developed and fuel contributed under 50 . Insulation shal1 be in thicknesses as indicated on the drawings.

\subsubsection{Inverted Roof System}

Dow Chemical Co., 3-1/2 inch thick styrofoam RM brand insulation shall be placed directly over the roofing membrane.

\section{a. Built up Roofing}

Roofing shall be 3-ply, 20 year bondable type, applied directly over substrate, John-Mansville or equal.

b. Polyester Formed Fabric

loosely over the insulation.

Dow Chemical Co. approved fabric shall be placed

\section{c. Crushed Stone}

A crushed stone ballast of $1-1 / 2$ inch shall be placed over the polyester formed fabric. Stone top covering shall be $3 / 4$ inch to 1 inch in diameter. 


\subsubsection{Sheet Metal}

Parapet flashing, counter flashing, base flashing, and flashing at roof penetrations shall be 24 and 22 Ga galvanized steel.

\subsubsection{Sealants and Caulking}

Sealants and caulking shall be silicone, polysulphide or polyurethane base, non-saf, gun-approved as pourable, selected as best suitable for applicable conditions.

\subsection{DOORS AND WINDOWS}

\subsubsection{Metal Doors and Frames}

Doors and frames shall be standard commercial type, conforming to the Steel Door Institute (SDI) standards as follows:

Doors: Flush panel, seamless; interior doors 18 gauge; exterior doors 16 gauge, galvanized.

Frames: Full welded or knock down construction; interior frames 16 gauge: exterior doors 14 gauge, galvanized.

Fire rated doors and frames, where required, shall conform to the requirements of U.L. and sha 11 bear the appropriate label. All interior doors shall have 6 inch $\times 2$ foot wire glass vision lites except doors leading to toilets, lockers and $j$ anitor rooms.

Explosion proof doors shall be able to withstand 1-PSI.

\subsubsection{Finish Hardware}

Finish hardware shall include mortise-type latchsets, locksets, exit devices, hinges, closers, thresholds, flushbolts, pulls, push/kick plates, door holders, and shall be heavy duty as manufactured by Sargent and Co. or equal. Exposed surfaces of hardware shall have a satin finish or as selected. All building exits shall be provided with panic exit devices.

\subsection{FINISHES}

\subsubsection{Metal Studs}

Except as otherwise noted all metal studs shall be 4 inches $\times 20$ gauge, non-bearing screwable type, punched for utility lines, complete with top and bottom runners. 


\subsubsection{Gypsum Board}

Gypsum board shall be $5 / 8$ inch thick tapered edge

throughout. Water resistant gypsum board shall be used in toilet rooms and janitors room. Type " $X$ " shall be used in 1-hour fire rated areas.

\subsubsection{Ceramic Tile}

Ceramic tile work shall include regular Portland cement sitting beds and ceramic tile floors, wainscots and walls. Tilework and installation shall conform to the American National Standards Institute (ANSI) and the Tile Council of America (TCA).

\subsubsection{Acoustical Ceilings}

Acoustical ceilings shall be suspended exposed metal "T" grid system with lay-in acoustical units. Exposed "T" members shall be aluminum or steel with applied matte white enamel finish. Acoustical units shall be 24 inches $\times 48$ inches $\times 5 / 8$ inches. Acoustical material shall be U.L. listed with flame spread under 25 and smoke developed and fuel contributed under 50 .

\subsubsection{Cement Plaster}

Cement plaster shall be installed on metal lath and steel framing on walls and ceilings where scheduled, including all necessary trim and accessories.

\subsubsection{Resilient Flooring}

a. Floor coverings in the Decon area, air lock and gallery shall be 200 vinyl chloride, $2 \mathrm{~mm}$ thick flooring as distributed by Dynamit Nobel of America Inc., or approved equal. Material shall be manufactured as a homogenous polyvinyl chloride with the pattern and color extending through the butt thickness and shall conform to Federal Specifications SS-T-312, L-F475, and ASTM E84. Material shall have chemical resistance to acids, bases, dye stuffs, and solvents and shall be noncombustible or self-extinguishing. Installation shall be made as a monolithic, seamless floor by heat welding and fusion, or by butt welding edges of material sheets together. Flooring shall be butt welded directly to $6 "$ "high Mipolam flexible vinyl cove.

b. All other areas such as offices and hallways shall have vinyl asbestos tile flooring as manufactured by Armstrong Cork Co. or equal. The tiles shall be 12 inches $\times 12$ inches $\times 1 / 8$ inch commercial quality. The base shall be four inches high top set vinyl cove base with pre-formed internal and external corners. 


\subsubsection{Painting}

Except as excluded herein, all surfaces of new work shall be properly prepared, primed, and finished, including walls, ceilings, miscellaneous exposed materials, equipment, piping, hangers, conduits, grilles, etc., which normally require painting.

The following items shall not be painted:

- Surfaces receiving a special protective coating

- Concrete floors

- Anodized aluminum, chromed, or stainless metals

- Factory-fin ished items and equipment

prior to delivery to job site:

The following items shall be primed or shop-coated

- Metal doors and frames

- Structural steel

- Miscellaneous metal work

Paints, primers, and finishes shall be ready-mixed and equal to first-line products as manufactured by:

Devoe and Reynolds, Inc.

Pratt and Lambert, Inc.

E. I. DuPont de Nemours and Co.

Rust-0leum Corporation

Gli dden Company

Benjamin Moore and Co.

a. Painting Schedule. All painting shall be two coats applied over a primer coat. The primer coat shall be appropriate for the surf aces to be painted and compatible with the types of finish coat used.

b. Interior Surfaces

Surf ace

Concrete

Galvanized Metal

\section{Finish}

1 coat masonry flock filler

2 coats interior alkyd semigloss enamel

1 coat zinc dust-zinc oxide primer

1 coat interior ename 1

undercoat

1 coat interior alkyd

semigloss enamel 
Ferrous Metal

c. Exterior Surfaces

Surface

Ferrous Metal

Galvanized Metal
1 coat zinc, iron oxide, alkyd resin-type metal primer

1 coat enamel undercoat

1 coat alkyd semigloss enamel

\section{Finish}

1 coat alkyd-oil resin-type metal primer 2 coats semigloss ename 1

1 coat zinc dust-zinc oxide primer

2 coats semigloss enamel

\subsubsection{Special Coatings}

Special coatings shall be Ameron system decontaminable special protective coating for floors, walls, and ceilings, or equal.

Concrete floors:

Prime sealer

Intermediate coat

Top coat

Concrete Walls:

Prime sealer

Filler

Intermediate coat

Top coat
Nu-K 1 ad 108

Amercoat 66

Amercoat 66 (2 coats)

Frames:

Structural Stee1, Decking, Carbon Steel Doors and

Nu-Klad 108

Nu-K 7 ad 114

Amercoat 66

Seal gloss Amercoat 66

Concrete:

$\begin{array}{ll}\text { Primer } & \text { Amercoat } 77 \\ \text { Cleaner (for galvanized) } & \text { Galvaprep } \\ \text { Intermdiate coat } & \text { Amercoat } 66 \\ \text { Top coat } & \text { Amercoat } 66\end{array}$

Protective Coating for Stainless Steel Embedded in

Double coating

Thurmalox 70 


\subsection{SPECIALTIES}

\subsubsection{Metal Toilet Partitions}

Ceiling hung toilet partitions and wall hung urinal screen shall be products of Sanymetal Products or equal, "Century Type" with a baked enamel finish.

\subsubsection{Toilet Accessories}

Toilet accessories sha 11 be products of Bobrick Washroom Equipment Co., or equal, including:
a. Mirror
b. Soap dispenser
c. Towe 1 dispenser and waste receptacle
d. Sanitary napkin dispenser
e. Toilet tissue dispenser
f. Seat cover dispenser

\subsubsection{Louvers}

Louvers shall be products of Construction Specialties, Inc., or equal, mullion type louvers Model 4100 standard blade or as applicable and shall be constructed of extruded aluminum, 6063-T52 al1oy, furn ished with $1 / 2$ inch mesh birdscreen.

\subsubsection{Signs and Directories}

equal.

Signs shall be products of Vomar Products, Inc., or

\subsubsection{Lockers and Benches}

Products, or equal.

Lockers and benches shall be the products of Lyon Metal

a. Lockers. Lockers shall be single tier-type, 12 inches wide, 18 inches deep, 72 inches high with baked enamel fin ish. Lockers shail be curb mounted.

b. Benches. Benches shall be constructed of hardwood seats, finished with three coats of plastic sealer mounted on enameled steel pedestals. 


\subsection{EQUIPMENT}

\subsection{PROCESS EQUIPMENT}

\subsubsection{Sump Catch Tank}

Equipment No. KEF-HP-TK1. 42 in. diameter by $6 \mathrm{ft} .-6$ in. tal1, constructed of ASME SA-240 Grade 304L stainless steel. Design and fabrication per ASME Boiler and Pressure Vessel Code, Section VIII, Division 1 at 15 PSIG and 100\% F. Capacity shall be 500 gallons. Equipped with an electric motor driven agitator (Equip. No. KEF-HP-AGI) and an internal spray header for decontamination solutions with inlet, outlet, vent, and instrumentation connections and agitator mount.

\subsubsection{Decontamination Solution Make-Up Tank}

Equipment No. KEF-HP-TK101, 42 in. diameter by $4 \mathrm{ft},-0$ in. ta 11, constructed of ASME SA-240 Grade 304L stainless steel. Design and fabrication per ASME Boiler and Pressure Vessel Code, Section VIII, Division 1 at 15 PSIG and 200\% F. Capacity shall be 300 gallons. Equipped with an electric motor driven agitator (Equip. No. KEF-HP-AG101) and a steam heating coil with inlet, outlet, vent, and instrumentation connections and agitator mount.

\subsubsection{Pressurized Feed Gas Mixture Lag Storage Vessels,} Pressurized Feed Gas Mixture Run Tank, Isostatic Run Tank

Equipment No. KEF-HP-TK2 (eight required), KEF-HP-TK3 (two required), and KEF-HP-TK4 (two required). 12 in. nominal diameter pipe (Sch. 80S) by $12 \mathrm{ft} .-0$ in. long, constructed of ASME SA-312 Grade TP316L stainless steel. Design and fabrication per ASME Boiler and Pressure Vessel Code, Section VIII, Division 1 at 1270 PSIG and $300^{\circ} \mathrm{F}$. Capacity shall be 9.5 cubic feet. Equipped with inlet, outlet, and instrumentation connections. The ten vessels shall be stacked two wide by five high in a structural steel frame as shown on Drawing No. P-6.

\subsubsection{Fresh Isostatic Gas Supply Cylinders}

Equipment No. KEF-HP-TK101, (three required) 9 in. nominal diameter by $4 \mathrm{ft} .4$ in. ta 11 , constructed of carbon steel. Design pressure 2490 PSIG at 100\% . Capacity shall be 1.54 cubic feet each. Assembled with manifold, individual shut-off valves, pressure reducing station, and inlet and outlet pressure indicators.

\subsubsection{Pressure Relief Accumulator}

Equipment No. KEF-HP-TK5. 18 in. nominal diameter pipe (Sch. 80S) by $4 \mathrm{ft} .-6$ in. long, constructed of ASME SA-312 Grade TP316L stainless steel. Design and fabrication per ASME Boiler and Pressure Vesse 1 Code, Section VIII, Division 1 at 900 PSIG and 2000F. Capacity shall be 8 cubic feet. Equipped with inlet, outlet, and instrumentation connections. 


\section{1.6 Feed Gas Mixture Compressor}

Equipment No. KEF-HP-COMI\&2 (two required). Single stage, diaphragm type with hydraulic fluid providing the pulsating motion to compress Krypton-85 gas from an inlet pressure of $340 \mathrm{psig}$ at $700 \mathrm{~F}$, to a discharge pressure of 500 psig. Compressor displacement sha11 be 1 CFM at $400 \mathrm{rpm}$. A triple diaphragm shall be used with a detection system to indicate either compressed gas or hydraulic fluid leakage through the diaphragm. Parts in contact with krypton shall be Type 316 stainless steel, other parts may be manufacturer's standard for the application. The compressor shall be electric motor belt driven. Maximum compressor speed shall be $400 \mathrm{rpm}$, electric motor speed shall be $1800 \mathrm{rpm}$. The electric motor shall be $460 \mathrm{~V}, 3$ phase, 60 Hertz. Each compressor and drive shall be assembled and mounted on a structural frame.

\subsubsection{Decontamination Solution Pump}

Equipment No. KEF-HP-P101. Centrifugal, horizontal, electric motor driven pump. Motor speed shall be 1800 rpm. Parts in contact with decontamination solutions shall be Type 316 stainless steel. Pump capacity sha 11 be $50 \mathrm{gpm}$ with 40 feet TDH.

\subsubsection{Closed Loop Cooling Water Pump}

Equipment No. KEF-HP-P1\&2 (two required). Centrifugal, horizontal, electric motor driven pump. Motor speed shall be $1800 \mathrm{rpm}$. Pump material shall be ductile iron. Pump capacity shall be $100 \mathrm{gpm}$ with 60 feet TDH.

\subsubsection{Krypton Vacuum Pump \\ He lium Vacuum Pump}

Equipment No. KEF-HP-VP 1 \& 2 (two required), and Equipment No. KEF-HP- VP $3 \& 4$ (two required). Cam and piston, compound vacuum pump, capable of displacing 3 CFM minimum at $10^{-2}$ Torr. Metals in contact with the process shall be Type 316 stainless steel. Other materials in contact with the process shall be compatible with radioactive Krypton-85. Pump shall be motor driven, single or three phase, $230 / 460 \mathrm{~V}$, 60 hertz. Maximum motor speed shall be 1800 rpm.

\subsubsection{Pressurized Feed Gas Cooler}

Equipment No. KEF-HP-HE 1. Shell and tube type heat exchanger with $20,000 \mathrm{BTU} / \mathrm{hr}$. duty. Materials is contact with krypton gas shall be Type 316 stainless steel, other materials may be carbon steel. Design and fabrication per ASME Boiler and Pressure Vessel Code, Section VIII, Division 1 , and TEMA $R$ requirements. Design pressure for gas side shal1 be 600 PSIG, with 200 of inlet temperature and $1100 \mathrm{~F}$ maximum outlet temperature. Design pressure for water side shal1 be 100 PSIG, with 95 of inlet temperature. 


\subsubsection{Closed Loop Cooling Water Heat Exchanger}

Equipment NO. KEF-HP-HE2. Shell and tube type heat exchanger with 200,000 BTU/hr. duty. Materials shall be carbon steel with admiralty tubes. Design and fabrication per ASME Boiler and Pressure Vessel Code, Section VIII, Division 1, and TEMA R requirements. Design pressure shall be 100 PSIG, with closed loop water inlet temperature $1300^{\circ}$ and outlet temperature $95 \circ$, and cooling water inlet temperature $85 \mathrm{~F}$.

\subsubsection{Pressurized Feed Gas Filter}

Equipment No. KEF-HP-Fl. Inlet filter with removable sintered metal element. Filter rating shall be 2 micron with 2 CFM flow and 500 PSIG pressure, with no more than 10 PSI pressure drop. Materials in contact with Krypton-85 shall be Type 316 stainless steel.

\subsubsection{Sump Liquid Sampler Sump Catch Tank Liquid Sampler}

Manually initiated, isolating, plunger type, air powered, solenoid valve actuated liquid sampler.

\subsubsection{Sump Eductor \\ Sump Catch Tank Eductor}

rate, Type 304L stainless steel.

Air or steam operated liquid eductor, $30 \mathrm{gpm}$ transfer

\subsubsection{Hot Isostatic Press}

Equipment No. KEF-HP-HIP1. Top loading, single level, graphite, natural convection style hot isostatic pressing furnace with isolated dual gas differential pressure control capability, 30 liter vessel capacity, 8.8 liter container capac ity, with electric internal furnace and water cooled pressure vessel shell. Includes top vessel plug, movable plug yoke, pressure control gas system, feed compressors KEF-HP-COM 3 \& 4 and KEF-HP-COM $5 \& 6$, and vacuum pump. Operating pressure 14,700 PSIG at $700^{\circ} \mathrm{C}, 50 \mathrm{~kW}$ maximum power, 41,000 BTU/hr heat input, design per ASME Boiler and Pressure Vessel Code, Section VIII, Division 1.

\subsubsection{Substrate Activation Furnace}

Equipment No. KEF-HP-AFT (two required). Electric resistance heated furnace with capacity for 8.8 liter substrate container, $40 \mathrm{~kW}$ heat input. 


\subsection{MECHANICAL EQUIPMENT}

\subsubsection{Mini-Trailer Robo-Carrier}

(2 required). Remotely operated, automatically controlled electric cart and platform lift assembly, with vertical and horizontal canister cradles, pneumatic push/pull piston, and pre-programmed positioning capability.

\subsubsection{In-Cell Bridge Crane}

Remotely operated bridge crane with 12-ft. 0-in. span and 5-ton top mounted trolley and hoist, and with two 1/2-ton underslung auxiliary trollies and hoist, as manuf actured by Edder Corp. or Approved Equal.

\subsubsection{Remote Welder}

Fully remote automatic welding station as manufactured by Astro-Arc or Dimetrics Corporation or Approved Equal.

\subsubsection{Leak Detection System}

Fully remote automatic leak detection system with automatically calibrated helium detector.

\subsubsection{Master-S1ave Manipulators}

(Four required). Model "F" type master-slave

manipulators, for assistance and maintenance of automatic welder and remote leak detection system, as manufactured by Central Research or Approved Equal.

\subsection{HEATING, VENTILATING, AND AIR CONDITIONING SYSTEMS}

\subsection{SUPPLY FANS}

Supply fans shall be single-width, single-inlet, non-overloading centrifugal type with airfoil blades, $V$-belt drive and TEFC motors, AMCA Class II construction, and variable inlet vortex vane damper capacity control. Capacity shall be $2670 \mathrm{cfm}$ at 3.0 inches wg static pressure and 3-hp. Fans shall be Buffalo Forge Co. type BL-Aerofoil, size 270, or Approved Equal.

\subsection{EXHAUST FANS}

Exhaust fans shall be designed and constructed to operate continuously prior to, after, but not necessarily during an Operating Bas is Earthquake (OBE). Fans shall be single-width, enclosed radial blade centrifugal type, V-belt drive and TEFC motors, AMCA Industrial Exhauster class. Capacity shall be $2800 \mathrm{cfm}$ at 10 -inches wg static pressure and 10 hp. Fans shall be Buffalo Forge Co. Industrial Exhaust model, size $30 \mathrm{MV}$, or Approved Equal. 


\subsection{VENT FANS}

Vent fans shall be single-width, single-inlet non-overloading centrifugal type with airfoil blades, $V$-belt drive and TEFC motors, AMCA class III construction, and variable inlet vortex vane damper capacity control. Capacity sha11 be $4000 \mathrm{cfm}$ at 1-inch wg static pressure and 1-hp. Fan shall be Buffalo Forge Co. type BL-Aerofoil size 270, or approved equal.

\subsection{POWER ROOF VENTILATORS}

Power roof ventilators shall be low silhouette, all aluminum construction, spun housing type. Fans shall be centrifugal type with direct drive. Capacity shall be $100 \mathrm{cfm}$ at $3 / 8$ inches wg static pressure.

\subsection{PREHEAT COILS}

Preheat coils shall be 2-row, non-freeze, finned tube, low pressure steam type. Coil capacity shall be $2670 \mathrm{cfm}$ and $168,000 \mathrm{Btu} / \mathrm{hr}$ at 15 psig steam pressure, with $-200 \mathrm{~F}$ entering and $+40 \mathrm{OF}$ leaving air temperatures.

\subsection{HEATING COIL}

Heating coils shall be the 1-row, finned tube type designed for modulating control with steam at 15 psig pressure.

\subsubsection{Contaminated Areas}

Heating coil serving the Load-out, Gas Storage, and Substrate areas shal1 have a capacity of $570 \mathrm{cfm}$ and $26,000 \mathrm{Btu} / \mathrm{hr}$ with $+400^{\circ}$ entering and $90^{\circ} \mathrm{F}$ leaving air temperatures. Coil face area shall be 1.0 square feet.

Heating coil serving the Assembly area shall have a capacity of $1180 \mathrm{cfm}$ and $32,000 \mathrm{Btu} / \mathrm{hr}$ with $+40^{\circ} \mathrm{F}$ entering and $700 \mathrm{~F}$ leaving air temperatures. Coil $\mathrm{f}$ ace area shall be 2.0 square feet.

\subsubsection{Non-Contaminated Areas}

Heating coil serving the Office, Health/Physics, Operating Gallery, and Vestibule shall have a capacity of $920 \mathrm{cfm}$ and $41,400 \mathrm{Btu} / \mathrm{hr}$ with +40 of entering and $+90 \mathrm{OF}$ leaving air temperature. Coil face area shall be 1.5 square feet.

\subsection{COOLING COIL}

Cooling coil shall be finned tube type for direct expansion refrigerant service. Coil shall be provided with a liquid refrigerant distributor. Coil capacity shall be $920 \mathrm{cfm}$ and $24,000 \mathrm{Btu} / \mathrm{hr}$. Coil shall have a face area of 2.0 square feet and be six rows deep. 


\subsection{SUPPLY AIR FILTER BOXES}

Supply air filter boxes shall be the side loading type containing a guide track for prefilters and a separate guide track for high efficiency filters. Prefilters shall have an efficiency of $30 \%$ per ASHRAE Standard 52-76. High efficiency filters shall have an efficiency of $90 \%$ per ASHRAE Standard 52-76. Filter boxes shall be Farr Co. side loading model 3P Universal Glide/Pack with type 30/30 prefilters and type HP-200 high efficiency filters, or approved equal. Filter box capacity shall be $2670 \mathrm{cfm}$ and shall have $2-24$ " $\times 24^{\prime \prime} \times 4^{\prime \prime}$ prefilters and $2-24$ " $\times 24$ " $\times 12$ " high efficiency filters.

\subsection{EXHAUST AIR HEPA FILTER PLENUMS}

Filter plenums shall contain two stages of side loading, bag-out HEPA filters and provisions for remote in-place DOP testing of each HEPA filter. Filter plenums and filters shall be as manufactured by Flanders Filter, Inc. Each plenum shall consist of the following:

1) Upstream first test section, T-I, including DOP injection port, DOP diffusers, and upstream challenge aerosol concentration sample port. bag-out housing.

2) First stage of HEPA filters in a model E-4, side loading,

3) Center combination test section, $T-C$, including DOP injection port, DOP diffusers, and sample port for measuring first stage downstream sample concentration or second stage upstream sample concentration. bag-out housing.

4) Second stage of HEPA filters in a model E-4, side loading

5) Last test section, T-0, including DOP diffusers and sample port for measuring second stage downstream concentration.

Capacity of each filter plenum shall be $3000 \mathrm{cfm}$. Each filter shall be $24 " \times 24 " \times 11-1 / 2 "$ and arranged in the plenum 3-wide by 1-high.

\subsection{SPRAY COOLING CHAMBER}

A spray water chamber shall be provided upstream of each exhaust air HEPA filter plenum. Each spray chamber shall be of stainless steel all welded construction. One bank of spray nozzles shall be provided together with mo isture eliminators, and drain sump. Capacity shali be 2800 cfm with a face area of 5.6 square feet.

\section{11 UNIT HEATERS}

Unit heaters shall be horizontal suspended type with steam heating coil, propeller fan, and adjustable discharge air louvers. Capacity shal1 be $50,000 \mathrm{Btu} / \mathrm{hr}$ with $15 \mathrm{psig}$ steam pressure. Unit heaters shall be Trane Co. model $60-5$, or approved equal. 
5.12 AIR COOLED CONDENSING UNIT

Air cooled condensing unit shall be for split system service and shall include an air cooled condenser, hermetic refrigerant compressor, and automatic control system. The unit shall have a capacity of 24,000 Btu/hr with 95 OF ambient air. Unit shall be Carrier Corp. model 38GSO24, or approved equal.

\section{$6.0 \quad$ PLUMBING}

\subsection{SCOPE OF WORK}

The Contractor shall provide all labor, materials, equipment, and tools necessary for the installation of interior plumbing piping, plumbing fixtures, and plumbing piping extending out to $5 \mathrm{ft}$ from the building where a break is made between plumbing and exterior sewage, drainage, and water piping materials.

following:

The work shall include, but shall not be limited to the

\subsubsection{System}

Furnishing and installing a complete plumbing system consisting of soil, waste and vent lines and hot and cold water distribution.

\subsubsection{Fixtures, Trim, and Accessories}

accessories.

Furnishing and installing plumbing fixtures, trim and

\subsubsection{Sewer and Water Lines}

Furnishing and installing sewer and water lines from building to $5 \mathrm{ft}-0$ in. outside of building.

\section{$6.1 .4 \quad$ Flashing}

for items of tinis system.

Furnishing and installing flashing and counterflashing

\subsection{MATERIALS OF CONSTRUCTION}

\subsubsection{Waste and Vent}

Above ground 1-1/2 in. and smaller shall be Schedule 40 galvanized steel pipe with coated cast iron drainage type screwed fittings. 2 in. and larger shall be service weight cast iron soil pipe and fittings (Bell and Spigot Type or No-Hub). 


\subsubsection{Sewer}

Below grade or slab shall be Bell and Spigot service weight cast iron soil pipe with neoprene compression gaskets to ASTM C 564. Above grade shall be standard weight cast iron Bell \& Spigot or No-Hub.

\subsubsection{Domestic Hot and Cold Water Piping}

Materials shall be Schedule 40 galvanized carbon steel pipe and fittings to ASTM A 120 with 300 ib rating.

\subsubsection{Steel Pipe Unions}

type.

Galvanized 300 lb malleable iron, railroad ground joint

\subsubsection{Valves}

Valves shall be gate valves 150 lb. Screwed bronze ISRS, Crane No. 431 or Approved Equal, or ball valves 300 1b. Screwed brass with TFE seals, Pacific No. 1-B or Approved Equal.

\subsubsection{Partition Stops}

bibb, with flange.

Repcal $B 98$ or Approved Equal, loose key type, hose

\subsubsection{Strainer \\ Sporlan or Approved Equal.}

\subsubsection{Sleeves}

Sleeves shall be of 24 gauge galvanized iron or steel, for use wherever pipes pass through concrete floors and foundations.

\subsection{PLUMBING FIXTURES}

6.3.1 Water Closet. American Standard No. 2502.011 white vitreous china, siphon jet wall hung, Sloan Royal No. 110 flush valve, white open front seat less cover. J. R. Smith No. 100 carrier.

\subsubsection{Urinal (Mark - UR). American Standard No. 6500.011} white vitreous china, walT hung, SToan Royal NO. 186-11 flush valve with $1-1 / 4$ in. top spud, wall and spud flanges, vacuum breaker, with adjustable floor support. 
6.3.3 Lavatory (Mark - L-1). American Standard No. 0350.132 20 by 18 , wall hung, white vitreous china, No. 2248.284 faucet with pop-up drain, No. 2303.063 loose key angle stop supply pipes, No. 4401.014 adjustable P-Trap. Adjustable type concealed lavatory, floor support carrier, with four point locking.

6.3.4 Shower (SH). Sloan Royal No. AC-10 Ac-to-matic with 3 gpm flow control. Stainless steel, built-in mixing valve with $1 / 2$ in. inlet ports.

6.3.5 Floor drain (FD-1). Josam 30000A cast iron body, nickel bronze strainer.

6.3.6 Roof Drain (RD). Josam 21000 Series, large dome, bottom outlet with standard clamp ring and gravel stop, gasket, dome, and body and to include deck clamp, drain receiver, and stationary extension collar.

6.3.7 Overflow Drain (OD). Josam 21000-16 Series, large dome, bottom out let with standard clamp ring and gravel stop, gasket, dome, and body and to include deck clamp, drain receiver, and stationary extension collar.

\subsubsection{Cleanouts (types)}

(1) Ordinary: Zurn A-1305

(2) Floor Type: Zurn Z-1326-1 or Z-1326-10, for setting with top flush and square with floor.

plate.

(3) Wall Type: Zurn with Z-1310 chrome plated cover

6.3.9 Water Hammer Arresters (WHA). Water hammer arresters shal1 be Zurn Shocktrol 1700 Series, Smith 5000 Series, or Approved Equal.

6.3.10 Roof Drainage. Piping for the roof drainage system will be carbon steel, hot-dipped galvanized, ASTM A53, Gr "B", Std. Wt. threaded ends. Fittings will be 125\# cast iron, ASTM A126, Grade B, hot-dipped galvanized, threaded ends.

\subsection{EQUIPMENT}

\subsubsection{Electric Water Coolers}

The cooler capacity shall be in accordance with Sunroc Model NSF-8-D or Approved Equal. The cabinet shall be constructed of 19-20 gauge welded stainless steel, with a removable front panel, a stainless steel base, and a Type 300 series stainless steel top. A chrome plated brass hand operated bubbler on a raised mount shall have a built-in pressure regulator. The Contractor shall furnish a reciprocating type hermetically sealed motor compressor with an air cooled condenser and a 


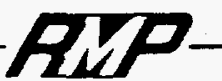

tube type cooling unit for Type 12 refrigerant, an insulated power cable, and an enclosed, adjustable thermostat. Electrical specifications are $1 / 4$ $\mathrm{hp}, 115 \mathrm{~V}, 60 \mathrm{~Hz}$, single phase. The cooler shall bear the Underwriters Laboratory (UL) Tabel.

\subsubsection{Electrical Water Heaters}

The heater shall bear the Underwriters Laboratory (UL) label. Each heater shall have a steel glass lined tank with a magnesium anode, 4 bolt flange, inconel sheathed, rod-type heating element with pre-wired terminal leads, and immersion type thermostat switching a magnetic contactor $(s)$. The heater shall have a minimum 3 inch glass fiber insulation with a round steel shell. Each heater shall be provided with an ASME rated temperature and pressure relief valve.

\subsection{ELECTRICAL}

This section applies to all electrical equipment and components, which will be used on the I on Implantation/Sputtering Facility. All items are commercially available and shall comply with applicable codes and standards. The power and services required are available from the existing Site utilities. Conduit only will be stubbed out $5 \mathrm{ft}$ from the building for $13.8 \mathrm{kV}$ normal and 480 volt standby power connections.

\subsection{CONDUIT}

A11 conduit systems shall be UL approved, rigid steel, zinc-coated or $304 \mathrm{~L}$ seamless stainless steel, Schedule 40 pipe. The minimum conduit size shall be $3 / 4$ in. for power, unless otherwise noted, and $1 / 2$ in. for exposed communication, control and instrumentation. Insulated bushings shall be provided at all terminals, where hubs are not used. Flexible metallic conduit shall be liquid tight. Expansion type conduit fittings shall be used across building expansion joints.

\subsection{WIREWAYS AND AUXILIARY GUTTERS}

Wireways and auxiliary gutters used in dry locations shall be preformed with screw type covers.

\subsection{BUILDING WIRE, 600 VOLT}

Single conductors for power, lighting, and miscellaneous control shall be 600 volt, code type, 900 C, RHH-RHW, USE, FP1 with chlorosulfonated, polyethylene $j$ acket for No. 2 AWG and larger, Okonite Okolon, or equal. Type THHN-THWN shall be used for conductors smaller than No. 2 AWG. The minimum control wire size shall be No. 14 AWG, and No. 12 AWG for all other wiring. All conductors shall be stranded copper except that lighting and branch circuits with wiring No. 10 AWG and smaller may be solid. Aluminum wire is not acceptable. 


\subsection{HIGH RADIATION WIRE}

All wiring, single or multi-conductor, within high radiation areas and through shielding walls shall be No. 12 AWG minimum, Class IE, 600 volt wire rated for $10^{7} \mathrm{R}$ minimum total integrated dosage, as manuf actured by American Insulated Wire Corp., Boston Insulated Wire and Cable Co., PSC, Div. M.W. Riedel, or The Rockbestos Co. Wiring inside the high radiation areas shall be multi-conductor with a special

chlorosulf onated, polyethylene overall jacket suitable for decontamination with water, nitric acid, oxalic acid, and Turco No. 4502.

\subsection{UNIT SUBSTATION, $13.8 \mathrm{KV}$ TO 480 VOLT}

The indoor unit substation shall consist of a three-position, manual1y operated, 600 amp, $15 \mathrm{kV}$ primary fused interrupter switch, a silicone insulating fluid transformer, a secondary main and feeder draw-out air circuit breakers. The rating and the equipment quantity shal1 be as shown on the Single Line Diagrams. The 480 volt breakers shall have static long time (L), short time (S), and ground $(G)$ tripping characteristics. The buses shall be copper with silver plated joints and connections. A manually operated overhead hoist shall be provided to remove the 480 volt air circuit breakers.

\subsection{DISTRIBUTION TRANSFORMERS}

The quiet type distribution, three-phase transformers, rated 480-208Y/120 volt, shal1 be general purpose dry type in an indoor enclosure and shall have $220^{\circ} \mathrm{C}$ insulation temperature classification and $150^{\circ} \mathrm{C}$ winding temperature rise for $30 \mathrm{kVA}$ and 1 arger, and $185^{\circ} \mathrm{C}$ insulation temperature and $115^{\circ} \mathrm{C}$ winding temperature rise for $25 \mathrm{kVA}$ and smaller. Full capacity NEMA standard taps shall be provided on the high voltage wind ing.

\subsection{MOTORS}

Motors shall be of sufficient size for the duty to be performed. All motors shall have full nameplate horsepower available with a service factor of 1.0 at $3000 \mathrm{ft}$ elevation and 1.15 at sea level. Uniess otherwise specified, all motors shall be totally enclosed, and shall have a continuous duty classification based on a $40^{\circ} \mathrm{C}$, ambient temperature of reference. Crane and monorail motors shall be rated for 30 minute intermittant duty. Motors shall be the premium efficiency type. The motors shall have the following factory guaranteed minimum efficiencies in accordance with IEEE 112 Test Procedures and shall have the efficiency index letter stamped on the motor nameplate:

\begin{tabular}{|c|c|c|c|c|c|}
\hline $\mathrm{HP}$ & \% Efficiency & $\mathrm{HP}$ & $\%$ Efficiency & $\mathrm{HP}$ & $\%$ Efficiency \\
\hline $\begin{array}{ll}1 & \\
1 & 1 / 2 \\
2 & \\
3 & \\
5 & \\
7 & 1 / 2\end{array}$ & $\begin{array}{l}78.5 \\
81.5 \\
81.5 \\
84.0 \\
84.0 \\
88.9\end{array}$ & $\begin{array}{l}10 \\
15 \\
20 \\
25 \\
30 \\
40\end{array}$ & $\begin{array}{l}88.9 \\
89.8 \\
90.5 \\
90.5 \\
91.4 \\
92.0\end{array}$ & $\begin{array}{r}50 \\
60 \\
75 \\
100 \\
125 \\
150\end{array}$ & $\begin{array}{l}92.0 \\
92.0 \\
93.3 \\
93.3 \\
93.3 \\
94.3\end{array}$ \\
\hline
\end{tabular}


The motor insulation shall be Class $F$ minimum. Motors in high radiation areas shall have $C l$ ass $\mathrm{H}$ insulation and shall be rated for $2 \times 10^{7} \mathrm{R}$ total minimum gamma radiation dosage. The high radiation area motors shall be suitably coated in the field with Crouse-Hinds "Corro-Free S-602" Cat. No. ETU2, or equal. The motor voltage rating shall be selected as follows:

$1 / 2 \mathrm{hp}$ through $150 \mathrm{hp:} 460$ volt, 3 phase, 60 hertz

$1 / 3 \mathrm{hp}$ and smaller: 115 volt, single phase, 60 hertz

Motors $1 / 4 \mathrm{hp}$ and $1 / 3 \mathrm{hp}$ in a batch process shall be rated 460 volts, 3 phase, 60 hertz. Polyphase motors shall be NEMA Design B minimum, squirrel cage type, having normal starting torque and low starting current; single-phase motors shal 1 be capacitor start type, except that motors rated $1 / 6 \mathrm{hp}$ and less may be split phase type. Gear motors shall be Class II or III, in accordance with the gear loading requirements. Motors $5 \mathrm{hp}$ and larger shall have full load power factor of 0.85 minimum. Motors $5 \mathrm{hp}$ and larger with a full load power factor less than 0.85 shall be corrected to at least 0.90 , utilizing a power factor corrective device located at the motor. Two-speed motors shall be the two-winding type. Motors connected to the site standby power shall be capable of starting on a voltage reduction of 20 to 30 percent. A copper grounding lug shall be provided in terminal connection box of a 11460 volt, 3 phase motors.

\subsection{STARTERS}

Combination magnetic starters with 120 volt transformer and control shall be provided for 460 volt, 3 phase motors that are $1 / 2 \mathrm{hp} \mathrm{through} 150 \mathrm{hp}$, and manual starters shall be provided for all 115 volt, single phase motors smaller than $1 / 2 \mathrm{hp}$.

\subsection{MOTOR CONTROL CENTERS}

The motor control center (MCC1) and split bus motor control center MCC2 sha 11 be $277 / 480 \mathrm{~V}, 3$ phase, 4 wire, 60 hertz, free-standing, dead-front, dead-rear, copper bus on 1y, NEMA Class II, Type B wiring consisting of vertical sections containing phase busing, terminais, copper ground bus, wireways, and housing modular plug-in type equipment drawers behind interlocked hinged doors Westinghouse Type Five Star, or equal. The enclosures shall be NEMA 1 . A11 operating handles and controls shall be externally operable. An individual, 480-120 volt control transformer with secondary fuse shall be provided for each motor starter. Each starter shall have a HAND-OFF-AUTO selector switch in the cover. The motor control center shall be braced for a minimum of 22,000 ampere symmetrical short circuit. The automatic transfer switch, with solid state control and located in the standby section of the motor control center MCC2, shall be rated $260 \mathrm{amp}, 480$ volt, 3 phase, 3 pole, $60 \mathrm{~Hz}$, and suitable to withstand a 22,000 amp short-circuit fault. Upon power failure, the transfer switch shall automatically start the Site diesel generator system. The return to normal power shall be manual. In the event the standby power fails and normal power is available, the transfer switch shall have an override to transfer automatically to normal power. Two each tandem pilot lights shall be provided to indicate the contact position. The transfer switch shall be ASCO Model 940326099 with accessories 6C, 9A, $9 B$ and 28 , or equal. 


\subsection{PANELBOARDS}

The panelboards shall be dead front, copper bus, 4 wire, circuit breaker type. Circuit breakers shall be E Frame minimum and rated for ac or dc operation. The circuit breakers shal1 have a minimum interrupting rating of 10,000 rms symetrical amperes for 208 volt panelboards and 14,000 rms symetrical amperes for $277 / 480$ volt lighting panelboards. A ground bus with screw terminals shall be provided. Neutral buses shall be isolated. Enclosures shall be NEMA 1, surface mounted. Panelboards of sizes and ratings, as shown on the drawings, shall be provided to serve the ventilating, lighting, and miscellaneous power loads. Ground fault interrupter (GFI) breakers rated $120 \mathrm{Vac}$ only shall be provided, as required by National Electrical Code.

\subsection{RECEPTACLES}

Convenience outlets shall conform with NEMA Standard configuration 5-15R and shall be 3 wire, duplex, grounding type, $120 \mathrm{Vac}, 15$ amp, Hubbell Cat. 5262 , or equal.

Receptacles for 480 volt, 3 phase service shall be 60 amp, 4 pole, 3 wire type, with spring door and combined with a non-fused, heavy-duty, horsepower rated disconnect switch, Crouse-Hinds WSRD 63542 or equal. The mating male plugs shall be Crouse-Hinds APJ 6485, or equal, for 60 amp service.

\subsection{HIGH RADIATION AREA CONNECTORS}

The remote electromechanical manipulator operated, 304 stainless steel, connectors shall be rated for $10^{7} \mathrm{R}$ total integrated dosage minimum and 600 volts. The connector shall be suitably sealed for decontamination with nitric acid, oxalic acid and Turco No. 4502. The receptacle and plug assembly shall be Gulton Lormec Series 9588 and 9405 respectively, or equal.

\subsection{SAFETY SWITCHES}

Safety switches shall be the heavy-duty type, horsepower rated, 600 volt, 3 pole, with current rating and fusing, as shown on the drawings. The enclosure shall be NEMA 1.

\subsection{TOGGLE SWITCHES}

Toggle switches installed for the control of incandescent, high pressure sodium, and fluorescent lighting luminaires shall be heavy-duty, general purpose, UL approved devices. Toggle switches shall be specification grade, single-pole, Hubbe 11 Cat No. 1221 or 1221-1, or equal.

\subsection{LIMIT SWITCHES}

The non-plug-in limit switches shall be heavy-duty type, 600 volts, 10 amp continuous rating contacts, single pole, double throw (SPDT) or electrically independent double pole, double throw (DPDT). The limit switches shall be Micro Switch Type HDLS Series, or equal. 


\subsection{BOXES AND FITTINGS}

Outlet boxes shall be rust-resistant, cast-iron alloy boxes with threaded hubs or bosses for conduit connection. Pullboxes and their covers shall be constructed of galvanized steel.

\subsection{RELAYS}

Control relays shall be magnetically operated relays with $120 \mathrm{Vac}$ coils, and contacts rated for 10 amp inductive at 120 volt continuous duty. Timing relays shall be magnetic relays with an adjustable pneumatic timing mechanism and a minimum 5 amp continuous contact rating.

\subsection{GENERAL LIGHTING}

Commercial type recessed fluorescent luminaires with acrylic lenses and high power factor and energy saving ETL, Class $P$ ballasts and $4 \mathrm{ft}$, cool white, rapid start fluorescent lamps with wattage not to exceed 35 watts shall be used in offices, control room, toilet and similar areas. Ballasts shall not contain PCB capacitors. Industrial type fluorescent luminaires with upward component and porcelain enamel reflectors shall be utilized in other low bay areas. Lighting in the high bay areas shall utilize high pressure sodium (HPS) luminaires. Exterior HPS wall mounted luminaires shall be provided. Special cell HPS luminaires, suitable for remote removal, shall be provided, as required.

The emergency lighting shall be provided by fully automatic 120/277 V supply, lead calcium rechargeable batteries, Holophane Cat. No. M-12-2A-X, or equal.

\subsection{LIGHTNING PROTECTION}

provided.

Lightning protection, complete with UL Master "C" label, shall be

\subsection{GROUNDING}

A No. 4/0 AWG soft drawn bare copper ground loop with $3 / 4$ in. by $10 \mathrm{ft}$. copper-clad steel ground rods, shall be provided and connected to the Site duct bank ground system. One insulated instrumentation ground bus plate and cable shall be furnished in the control room. The cable shall be connected to the facility ground system at only one point. The maximum facility ground resistance shall be five ohms. The lowest level of building reinforcing bar shall be grounded. The shielding window liners shall be grounded.

\subsection{CATHOOIC PROTECTION}

Cathodic protection shall be provided for all direct buried metallic lines and underground tanks. 


\subsection{TERMINAL BOXES}

Control terminal box enclosures shall be NEMA 1 sheet steel construction with hinged door, lock and steel equipment mounting panel(s). Barriers shall be steel, full depth and height, finished the same as the enclosures. The interior of the enclosure shall be finished with white enamel. The exterior shall be painted with color, as directed.

\subsection{TERMINAL BLOCKS}

All power and control wiring shall be terminated on accessible terminal blocks. The 600 volt, melamine, rail mounted, terminal blocks shall be Weidmuller Type SAK, or equal. A snap-in preprinted unique wire number marker shall be provided. Hand lettered terminal identification is not acceptable. Terminal connectors shall be the vibration proof, pressure clamp type.

\subsection{TELEPHONE SYSTEM}

Telephone cabinets shall be provided, as required. Conduit on ly shall be installed in the building, as required. The telephone system wiring will be by Others.

\subsection{CELL SPEAKER SYSTEM}

A cell speaker system shall be provided for monitoring audio sounds inside the cell. The system shall consist of a microphone with box mounted on a remotely removable Gulton plug in the cell and connected to a speaker in the control room.

\subsection{FIRE ALARM DETECTION SYSTEM}

The fire detection system shall include control panels, annunciators, initiating devices, signal conduits, and wire necessary for a complete and operational system. The final connection to the Site fire alarm system will be by Others. The system shall be Pyr-A-Larm System 3, or equal. The system shall consist of a multiplexer and enclosed terminal board, thermal detectors, manual stations, public address speakers, control panel audible devices, remote annunciator and control panels. The detection devices shall be capable of being interchanged without any changes required to the wiring, control panel or to the mounting base. The supervision sha11 not require additional wires other than the pair used for detection or alarm. The system shall be capable of being expanded at any time up to the maximum capacity of the system. The system shall be capable of having ionization, thermal, and photoelectric detecting devices, control relays, and manual stations connected across the same pair of wires. The system shall be electrically supervised against both short and open wire faults in the detection circuit, the manual station alarm circuit, and an open in the system alarm and trouble relay coils. An open wiring fault occurring in these circuits shall cause an audible and visual trouble indication at the control panel. A fire alarm signal shall override trouble signals. In the event of a trouble signal resulting from trouble on an initiating zone, a fire signal from another zone shall appear on the panel and remain until the panel is reset, at which time the trouble signal will 
reappear. Alarm initiating zones shall be as shown on the drawings. A separate switch monitor shall be provided to control waterflow alarms separately from other alarm signals.

\subsubsection{Alarm System}

The system shall function as follows when any sprinkler flow switch operates, or thermal detector in the HVAC fire protection system operates:

A. The main and remote annunciator panel alarm devices shall annunciate audible and visual indicators of a fire alarm.

B. The visible indicator shall indicate the zone location and the device initiating the fire alarm. The audible indicator shall produce the same sound for all fire alarms.

C. An alarm indicating lamp shall light in the base of the HVAC detector initiating the alarm.

D. Panel locks into alarm until manually reset.

E. Exhaust duct detector circuits shall be provided to energize the HVAC fire protection chamber fire water system for HEPA filters.

F. Supply duct detector circuits shall be provided to shut down the supply fan(s).

G. The alarm shall be manually transmitted as a voice alarm throughout the building over the fire alarm PA speakers.

\subsubsection{Fire Supervisory Signals.}

The supervisory alarm initiating devices shall include post indicator valve (PIV) switches, OS and $Y$ valve switches, dry pipe system low air pressure switches, trouble signals from each of the $\mathrm{Ha}$ ion and $\mathrm{CO}_{2}$ systems, and the Pyr-A-Larm Panel system trouble indicators. The supervisory alarm system shall function when any of these devices operate, as follows:

A. The main control panel shall annunciate audible and visual indicators of a supervisory alarm. The audible indicator shall provide a different sound than the fire alarm audible indicator.

B. The main panel locks the visual alarm indicator on, until manually reset. The audible indicator can be silenced by operating the alarm normal switch. 
C. The main panel relays the supervisory alarm signal via a separate transmitter to the Site fire supervisory al arm system.

\subsection{EVACUATION ALARM SYSTEM}

The evacuation system shall be completely independent of any other system. Speaker wiring may be installed in same conduit as fire alarm. No voice communication is required. The evacuation alarm system shall include an evacuation al arm panel, supervised public address speakers, initiating devices, a tone generator, signal conduits, and wire necessary for a complete and operational system. The system shall be Pyr-A-Larm System 3, or equal. No voice comunication is required.

The system shall be electrically supervised against both short and open wire faults in the initiating circuit, the audible alarm circuit, and an open wire fault in the system alarm and trouble relay coils. An open wiring fault occurring in these circuits shall cause an audible and visual trouble indication at the control panel. A short in the initiating circuit and the audible alarm circuit shall cause an audible and visual trouble indicator at the control panel. The evacuation alarm signal shall override the trouble signals. In the event of a trouble signal resulting from trouble on an initiating zone, an evacuation signal from another zone shall appear on the panel and remain until the circuit is reset, at which time the trouble signal will reappear. If a second evacuation alarm signal is initiated after a prior signal has been silenced, the selected evacuation signal sha11 sound even if the control circuit has not been reset. The evacuation alarm system shall shut off automatically after 5 minutes.

The System 3 evacuation shall al so provide the following functions:
A. Receive "ALERT" and "EVACUATION" signals from the Site evacu- ation system.
B. Provide local building status on "EVACUATION" mode only to the Site evacuation system.
C. Provide alarm signal over two No. 14 AWG wires to the Health Physic office.
D. Provide for remote monitoring of the building trouble status.

\subsubsection{Local AT arm}

This system shall provide an "ALERT" signal, with the panel mounted front cover switch in the "DOWN" position, consisting of continuous, non-varying audible siren tone or an "EVACUATION" signal, with the switch in the "UP" position, consisting of continuous cyclic audible siren tone the cycle to be "ON" for 5 seconds and "off" for 5 seconds. Each signal shall be initiated by operating any remote and one control room manual alarm switch. Any switch shall initiate the signal, but if more than one is operated at the same time, the switch turned to "EVACUATE" will take precedence over all other switches. Initiation of an "ALERT" or "EVACUATION" signal from any control point within the building shall 
be shown by an indicating light on the evacuation alarm panel. In addition, an audible panel alarm buzzer shall be actuated. The audible alarm can be silenced by operating the "ALARM-NORMAL" switch to the opposite position but the light shal1 remain on until all. switches or contacts are returned to normal position.

\subsubsection{Site Wide Alarm.}

A separately maintained toggle switch with "Lock-out" pin in the "DOWN" position, located in the control room, shall provide the Site wide alarm system an "ALERT" signal with the switch in the "DOWN" position or an "EVACUATION" signal with the switch in the "UP" position over two No. 14 AWG wires to connection in the Security Building. 


\subsection{PIPING MATERIALS}

\subsection{SCOPE OF WORK}

The Contractor shall provide labor, materials, equipment, and tools necessary to fabricate, test, inspect, document, deliver to the site, field fabricate and/or install, and field inspect and test all piping materials in the quantities defined and as located by the drawings, and in accordance with this specification.

\subsection{OUTLINE SPECIFICATIONS}

The Piping Service Classes to be used are

\section{Class}

D

N

$\mathbf{P}$

Q

U

V

\section{Service}

Process Equipment Waste

High Pressure Steam, Low Pressure Steam, Condensate, High Pressure Air, Vacuum

Low Pressure Air

Cooling Water Supply And Return

High Pressure Gas

Pressurized Feed Gas 


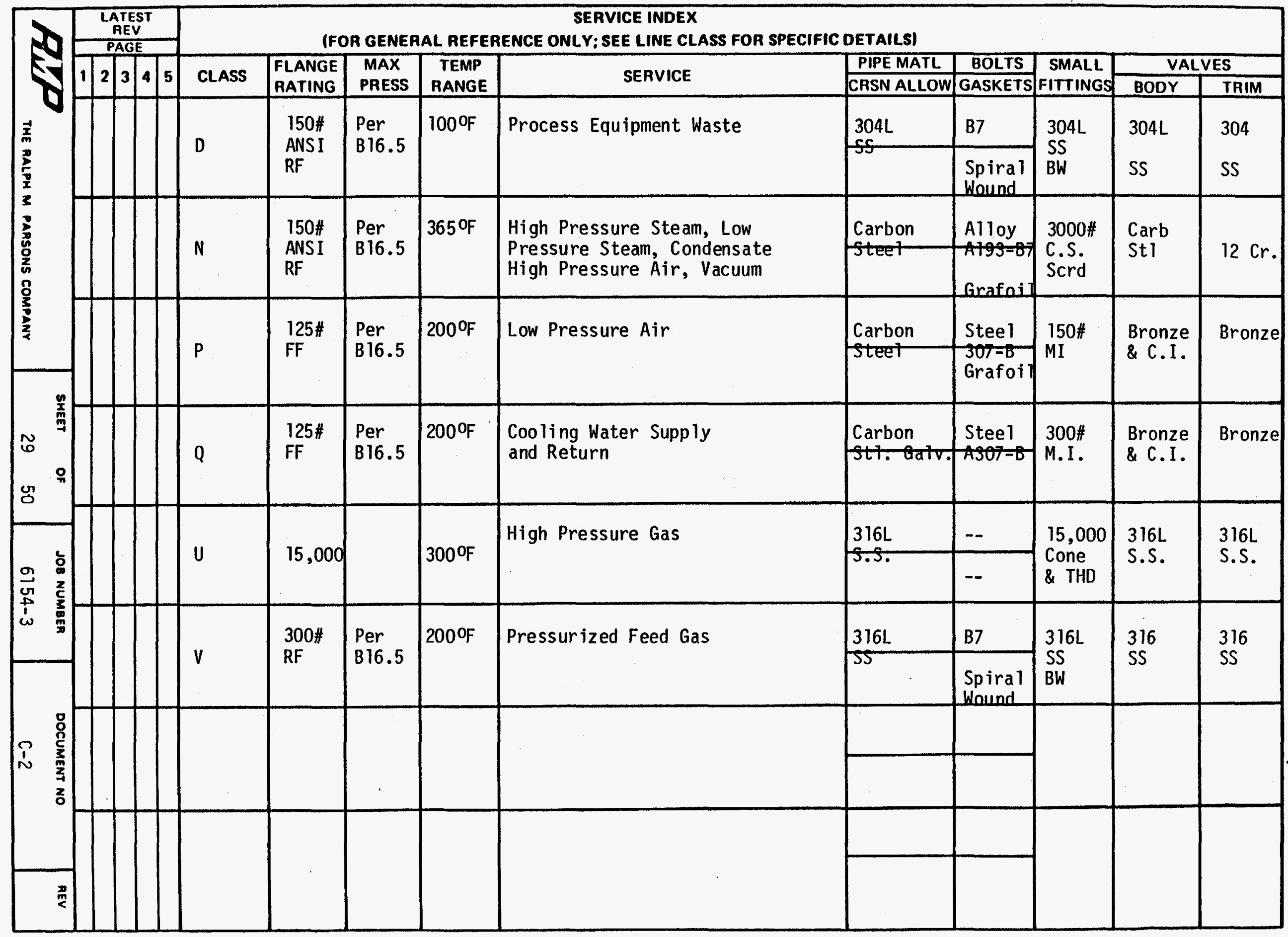




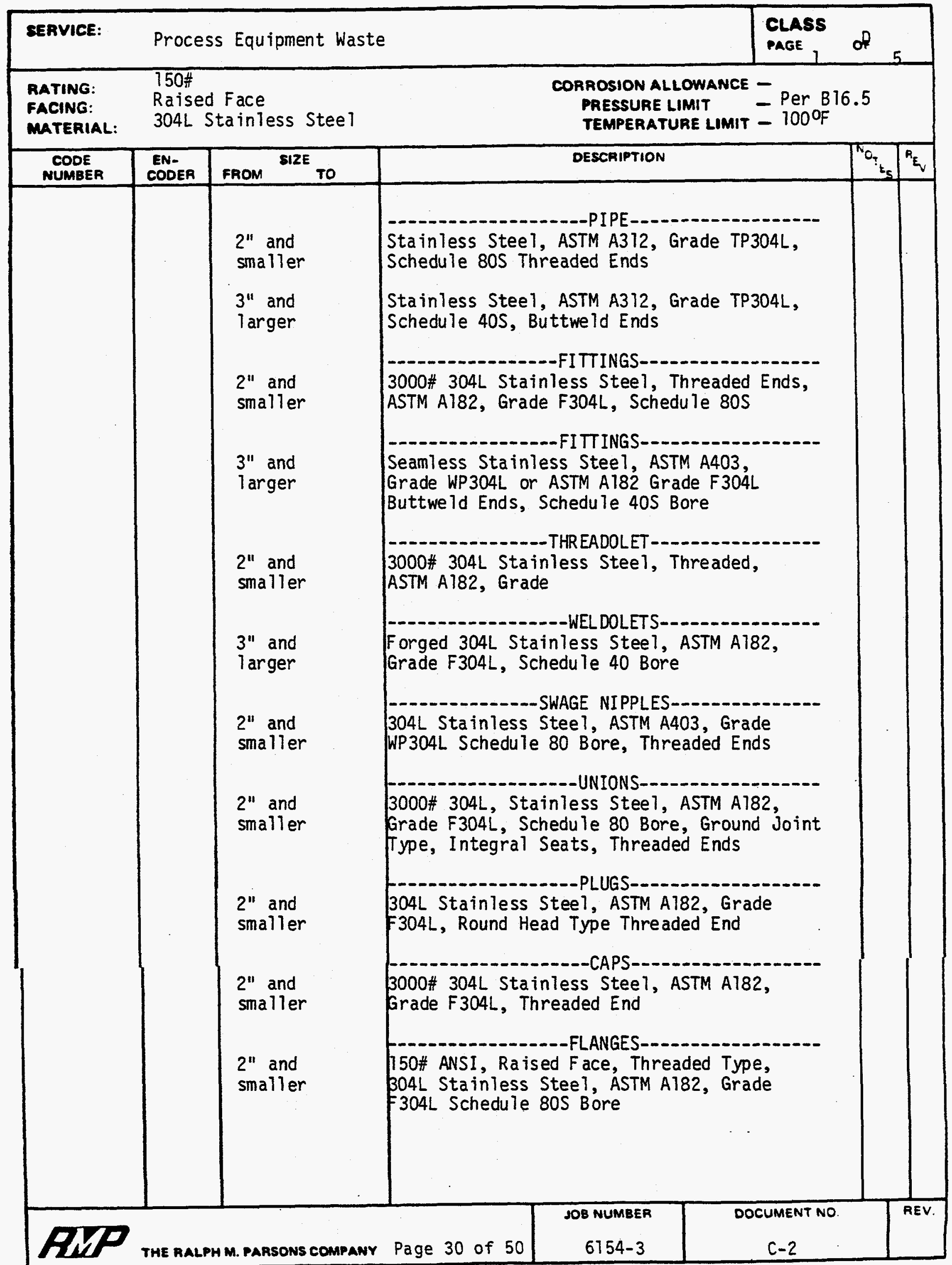




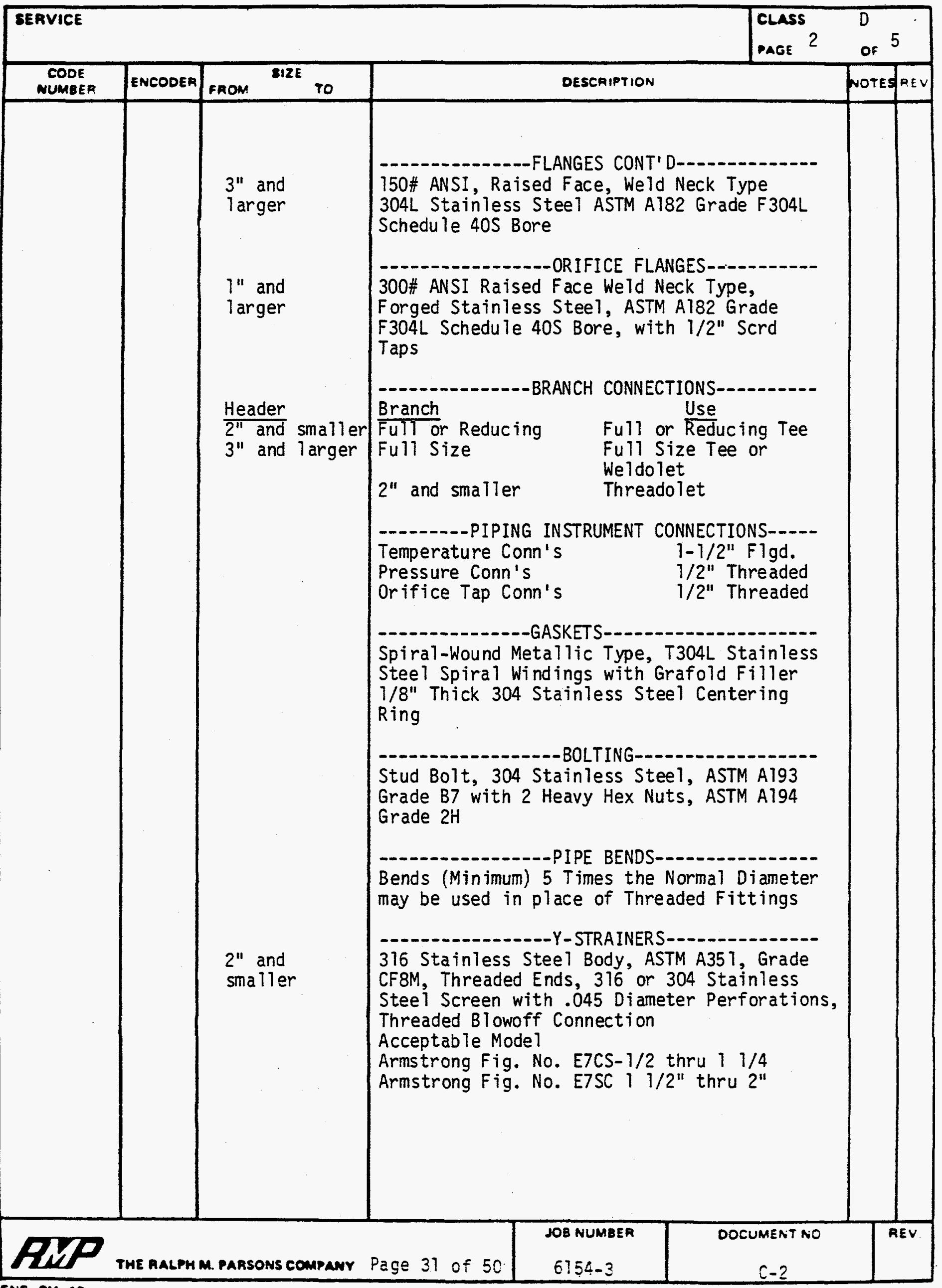




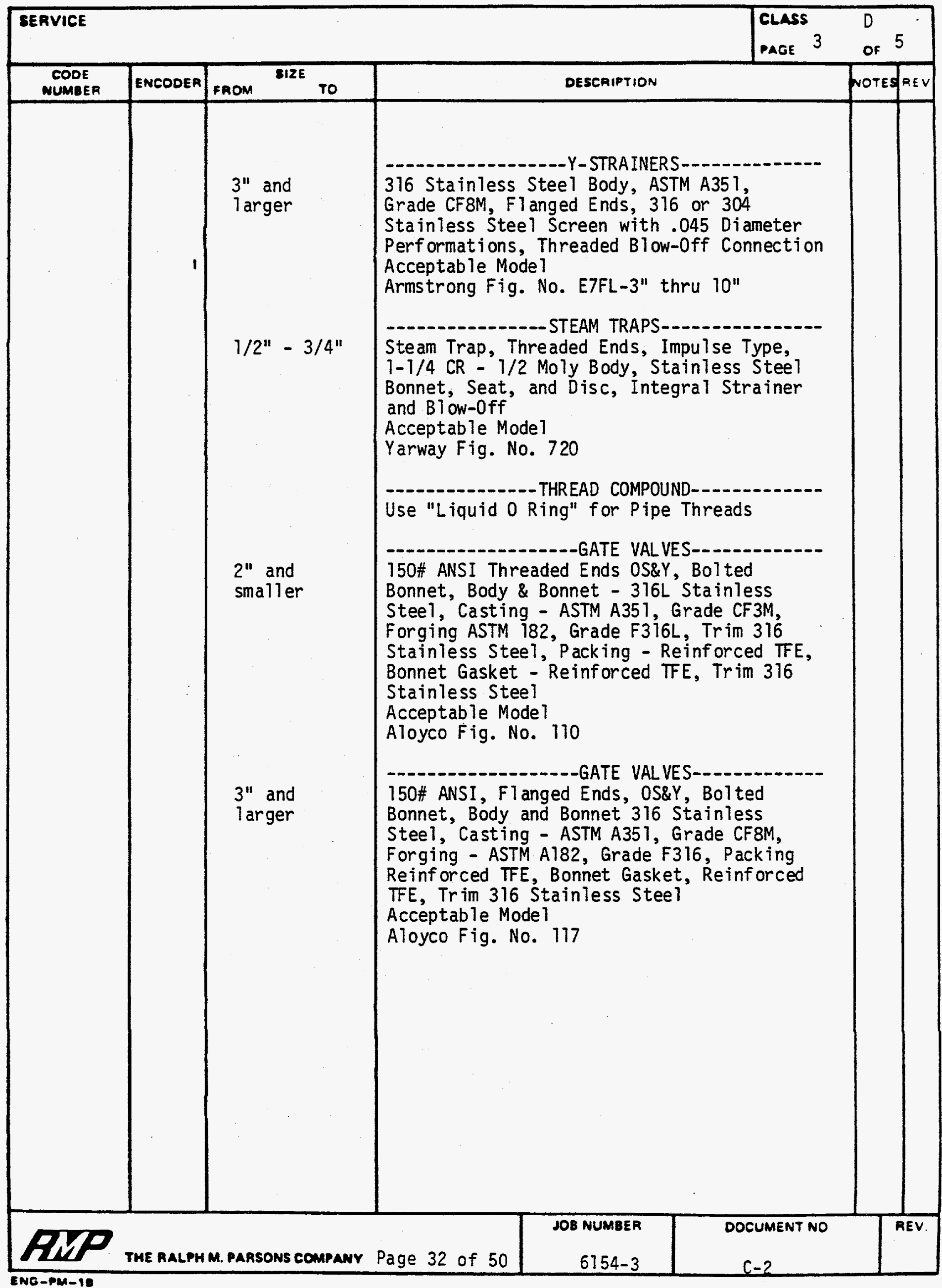




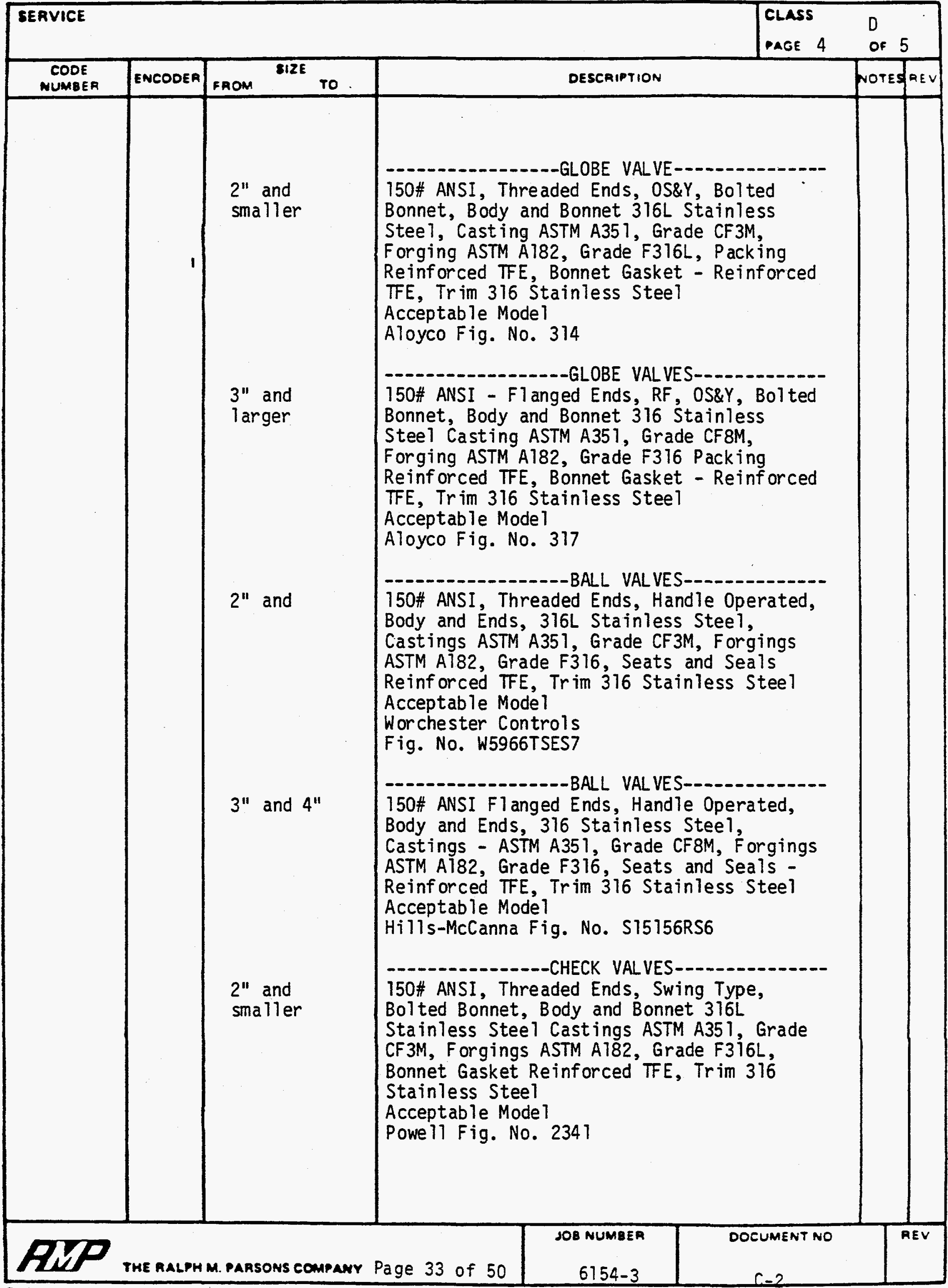




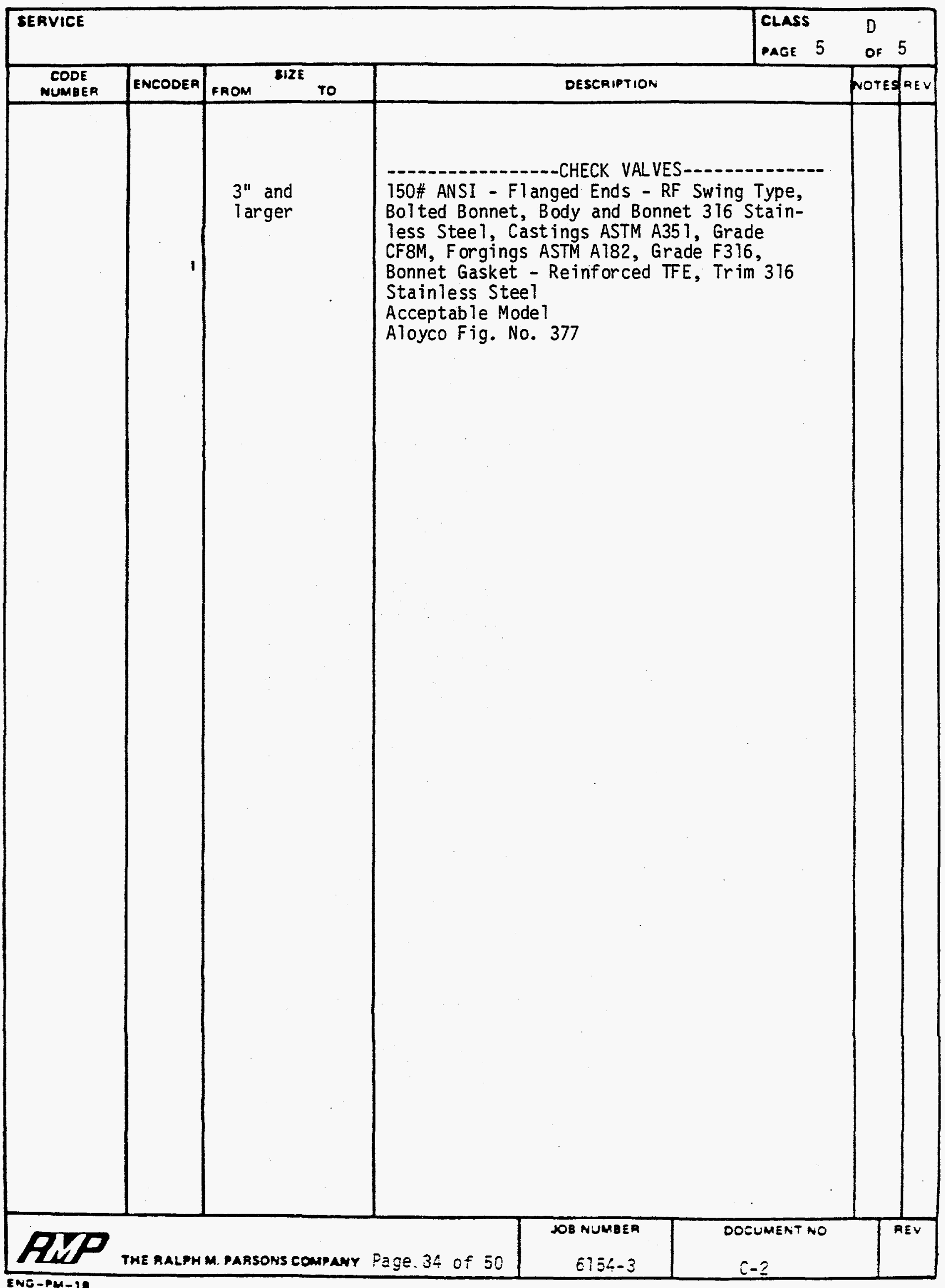




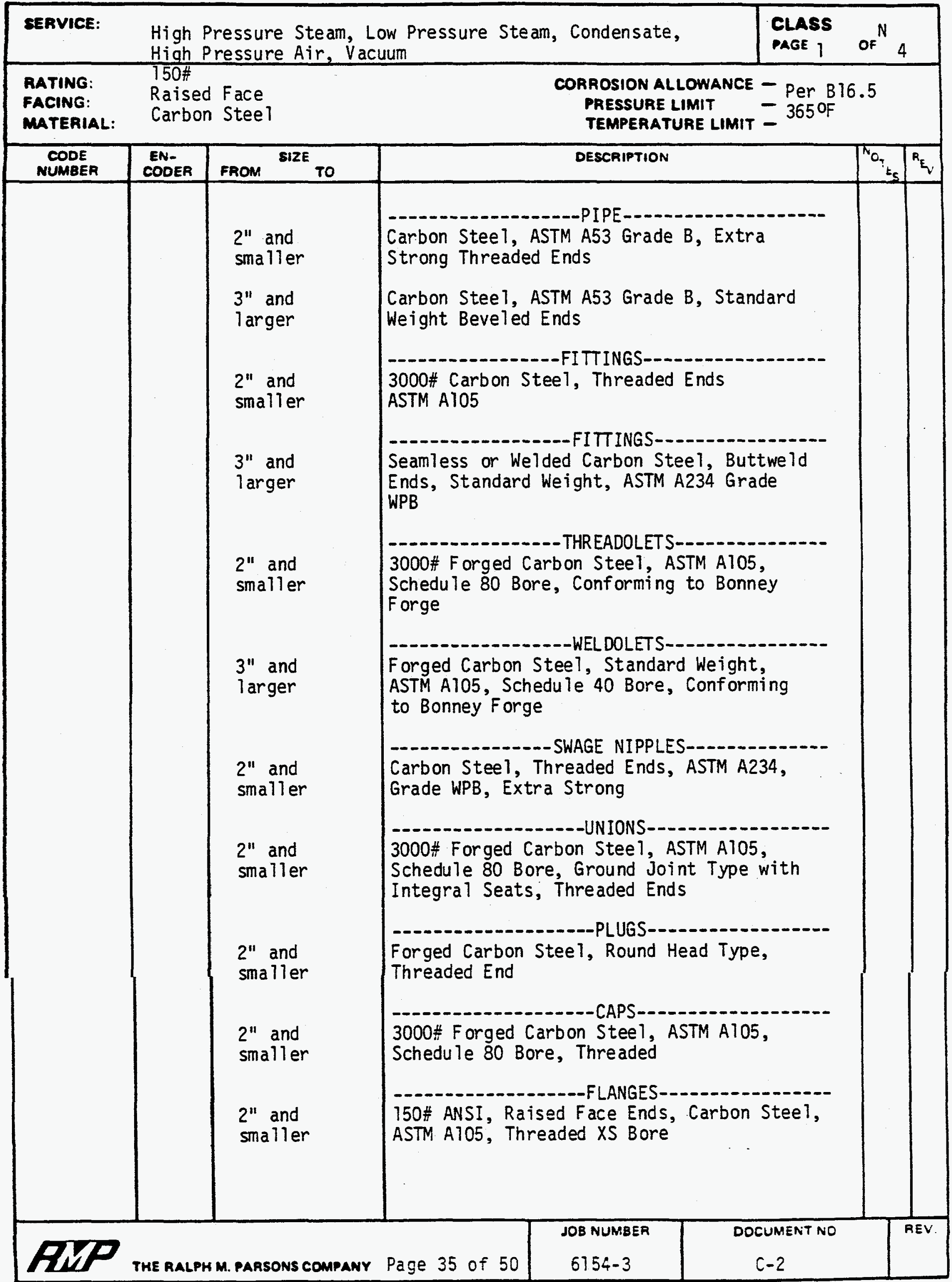




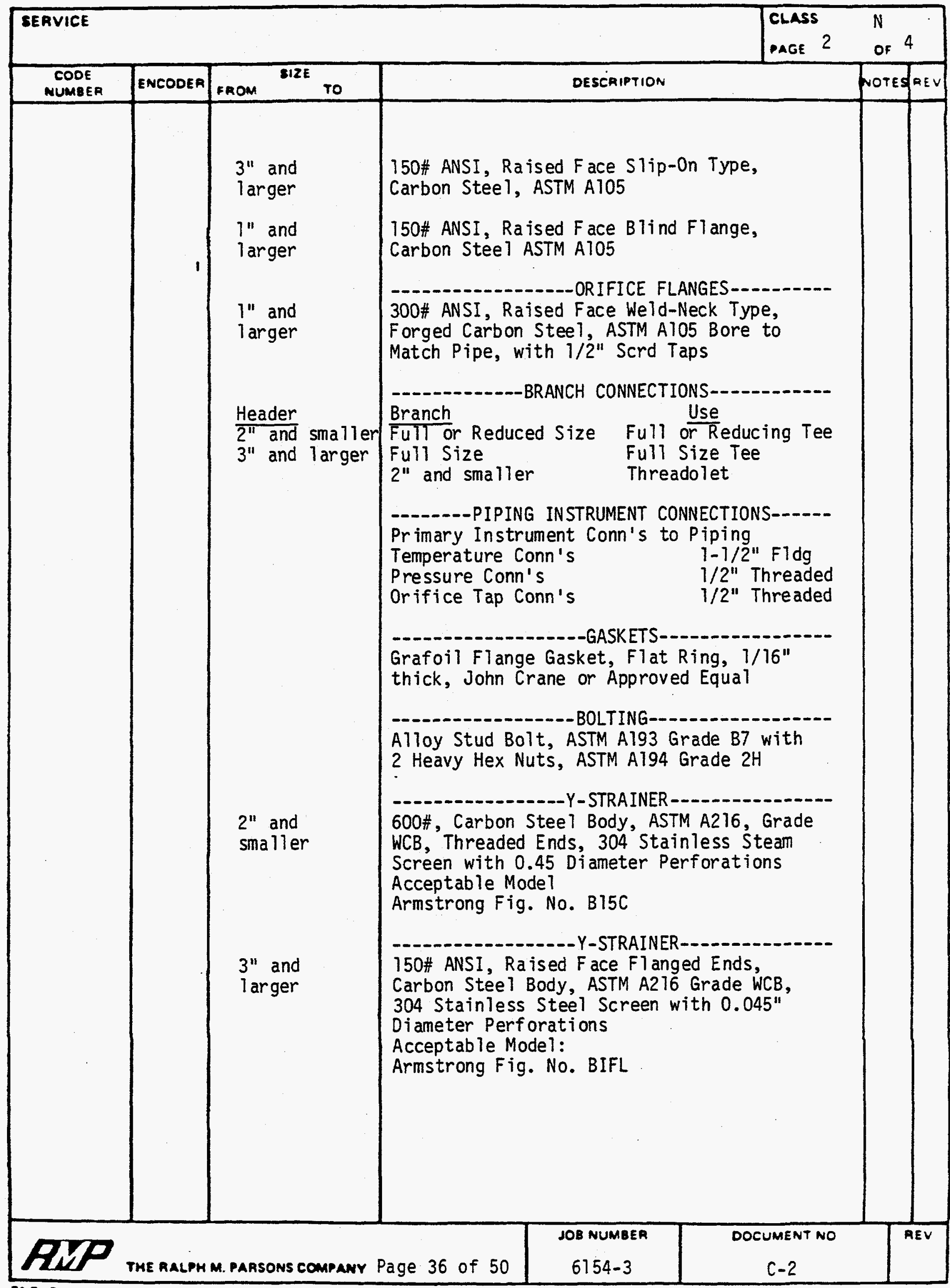




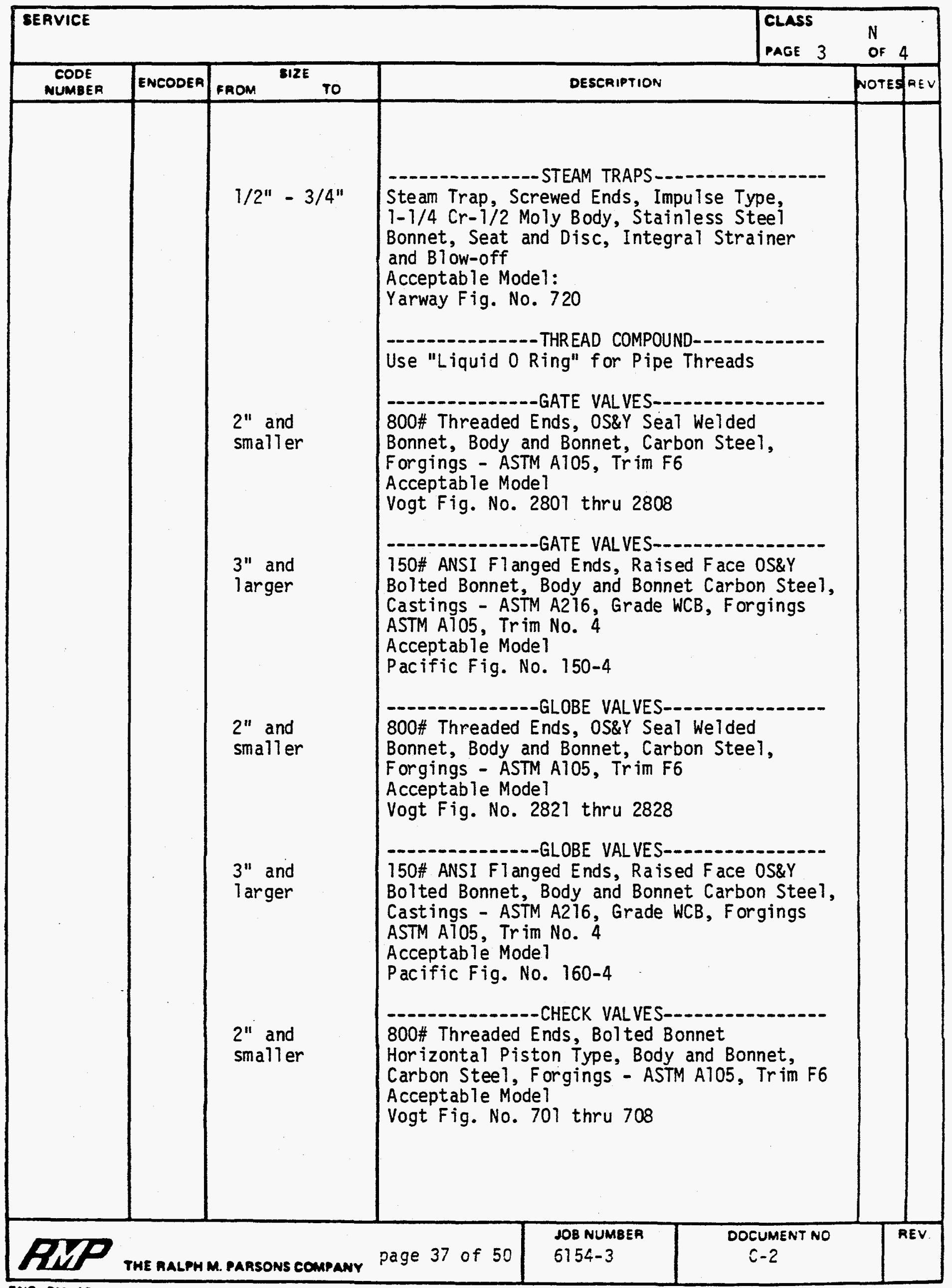




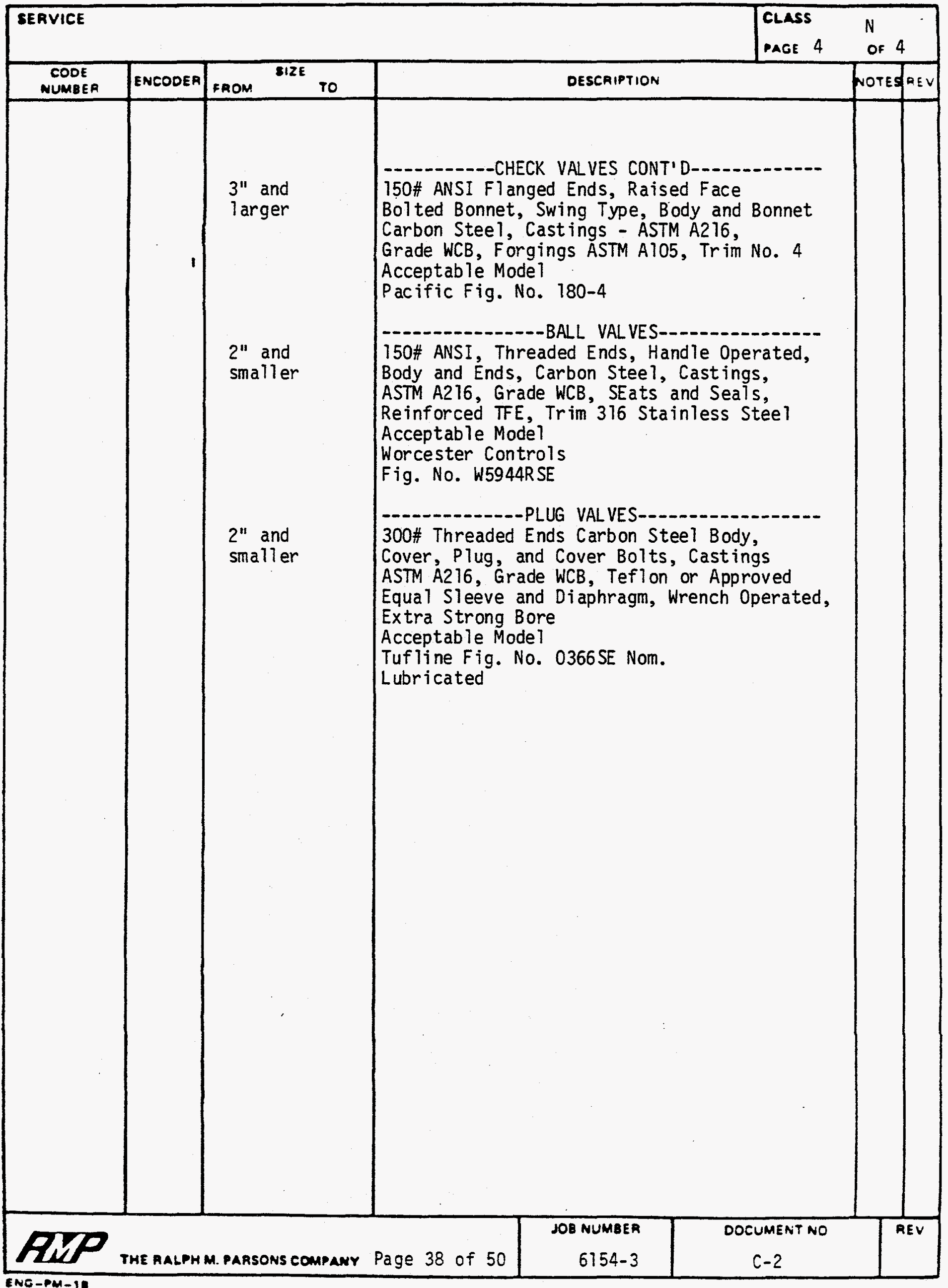




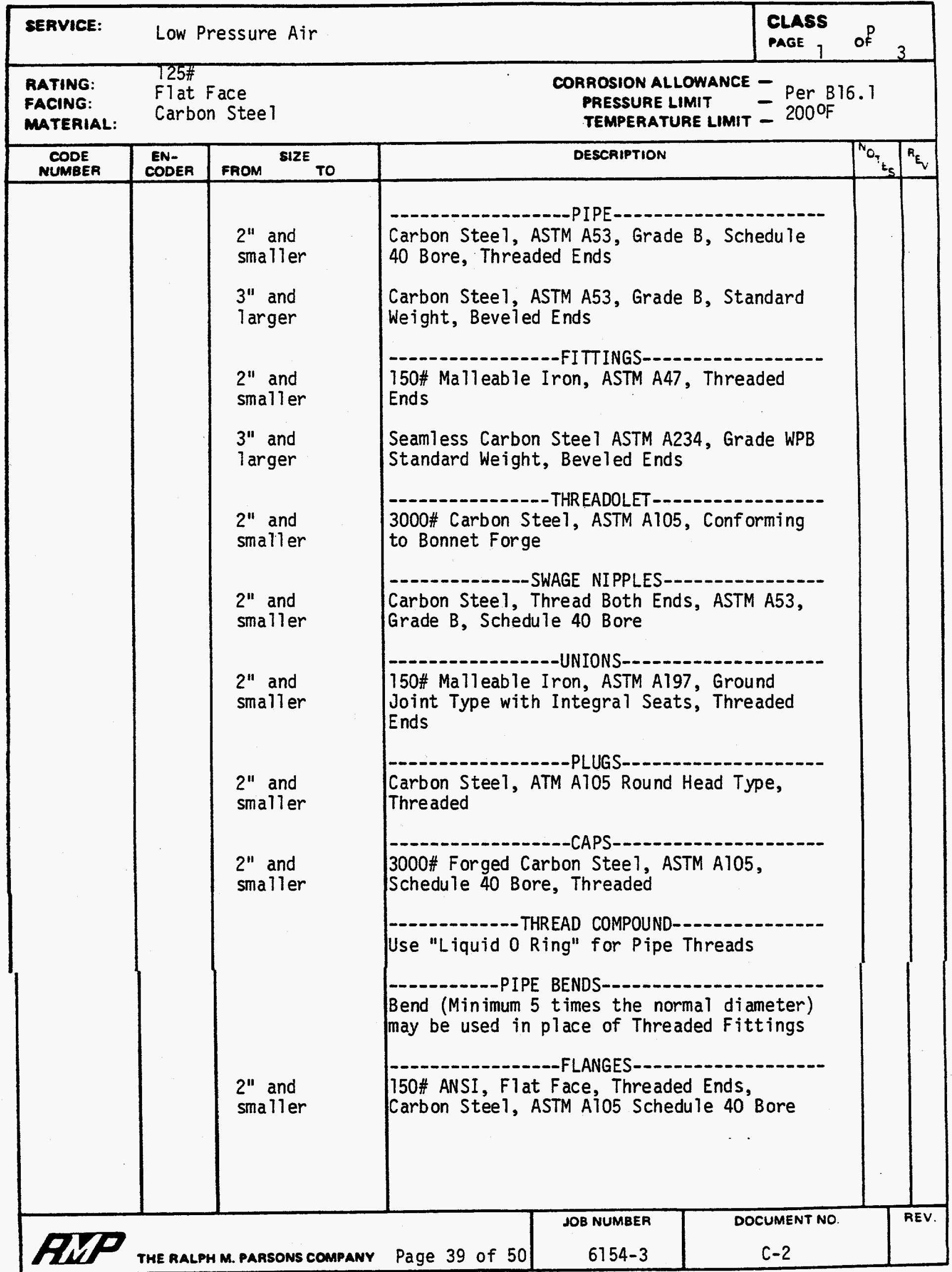




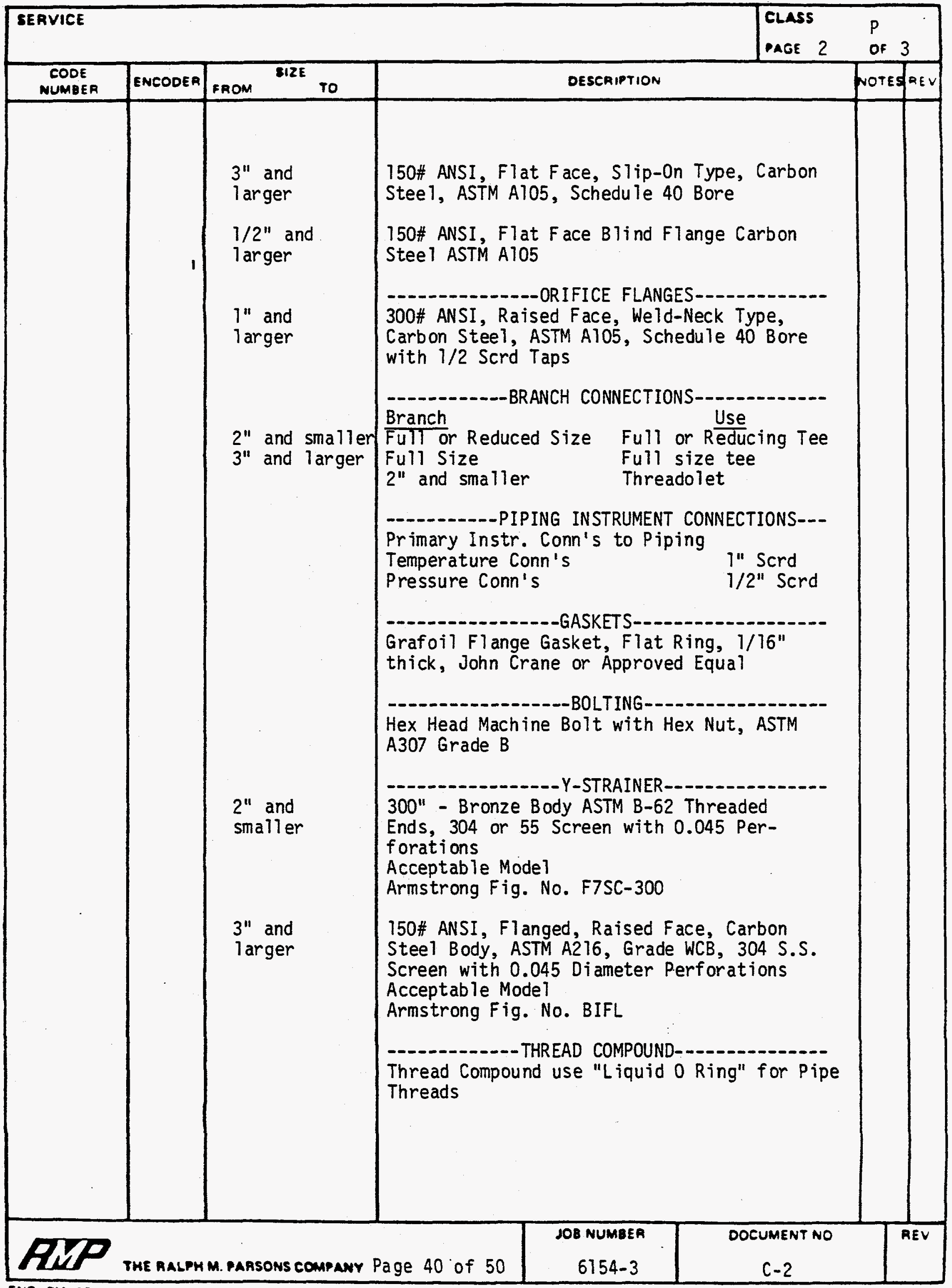




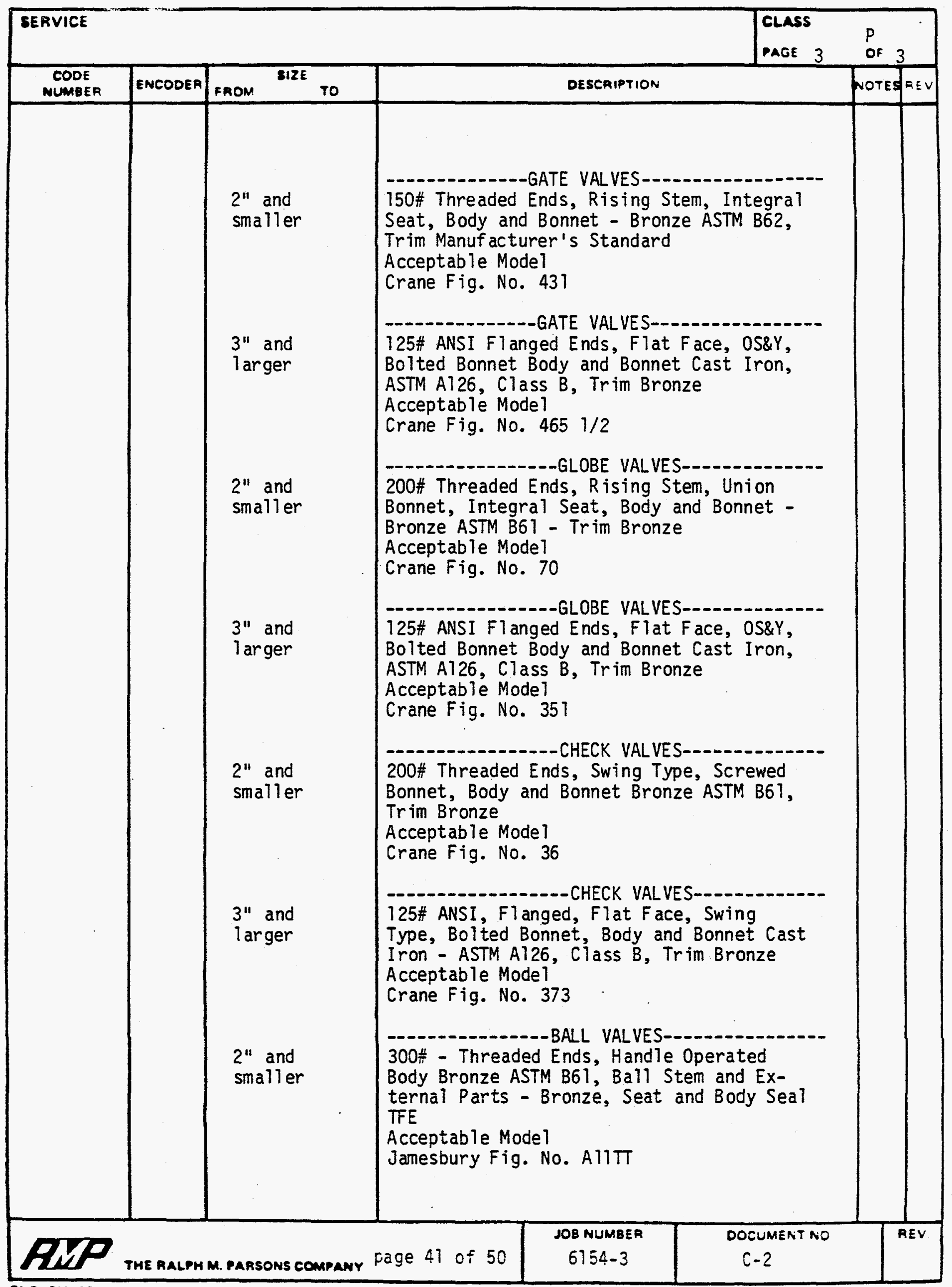




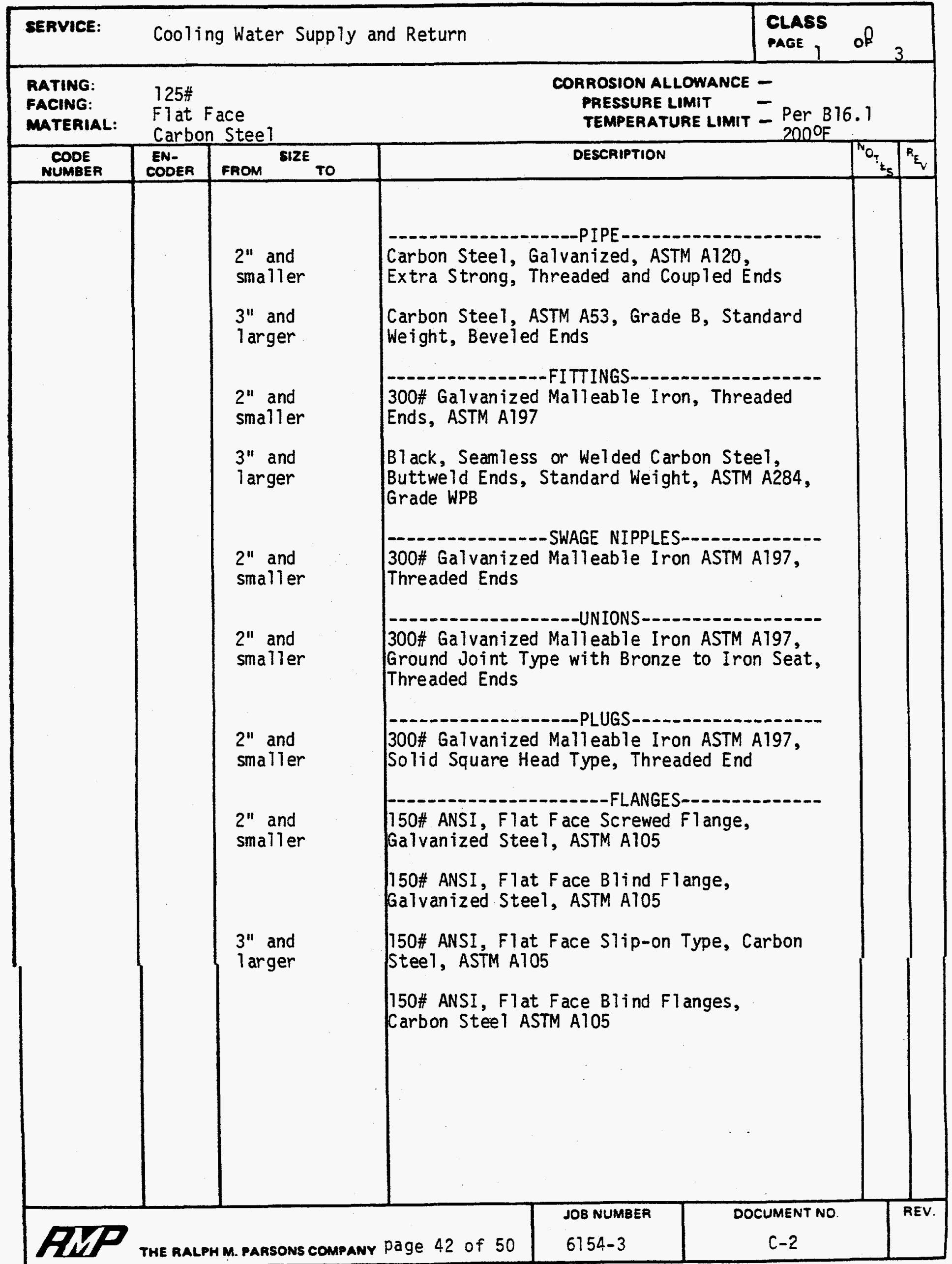




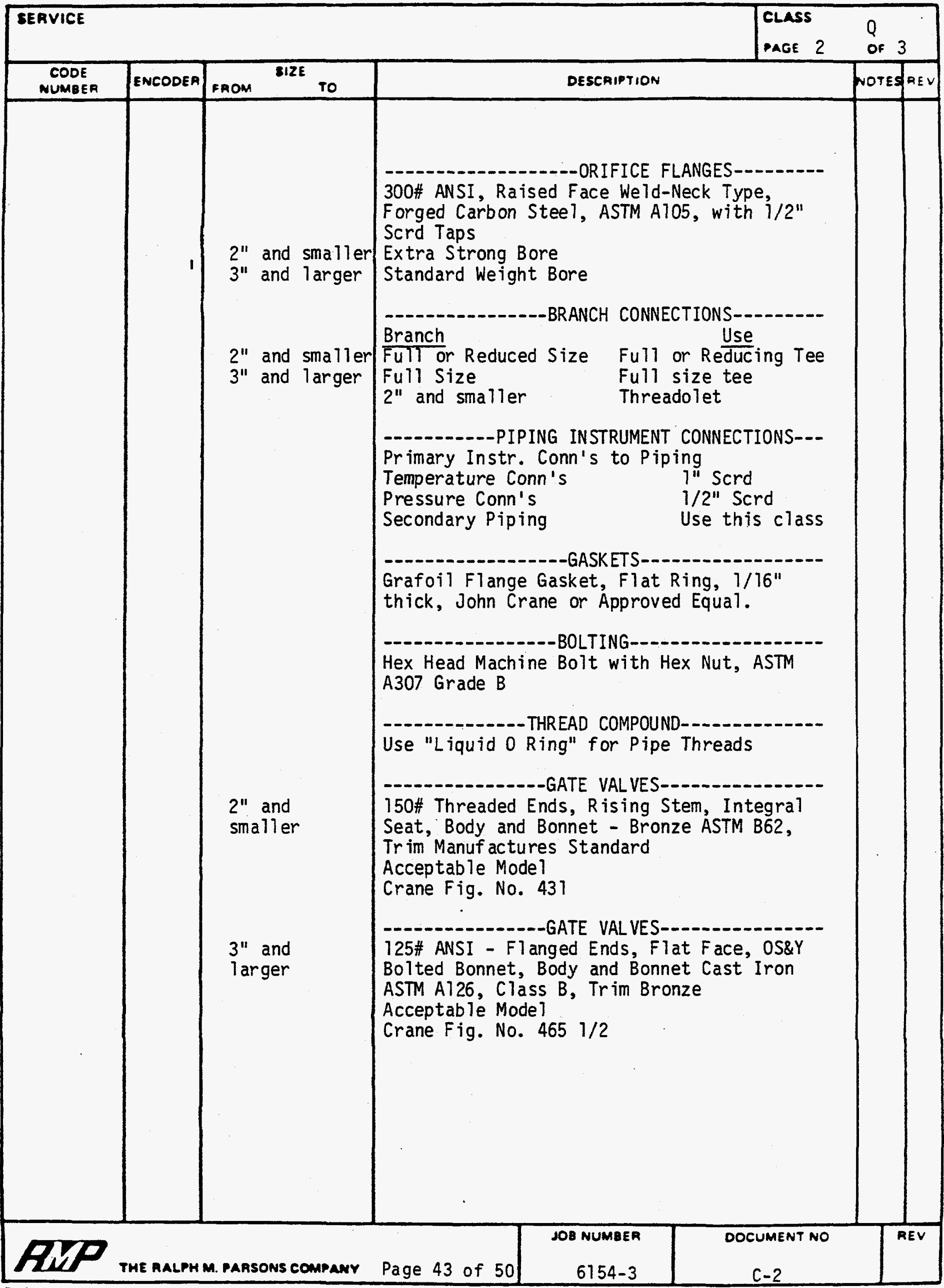




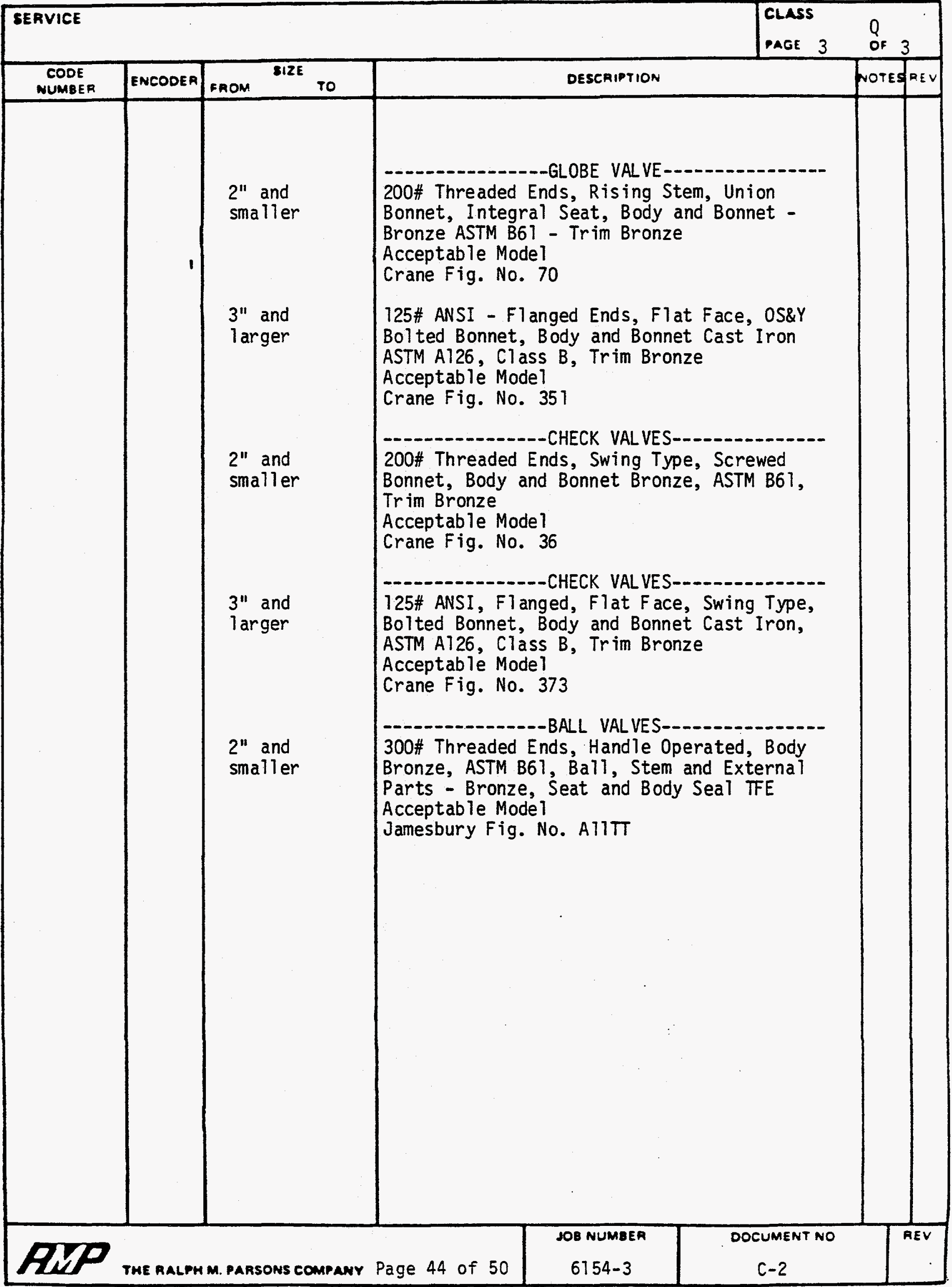




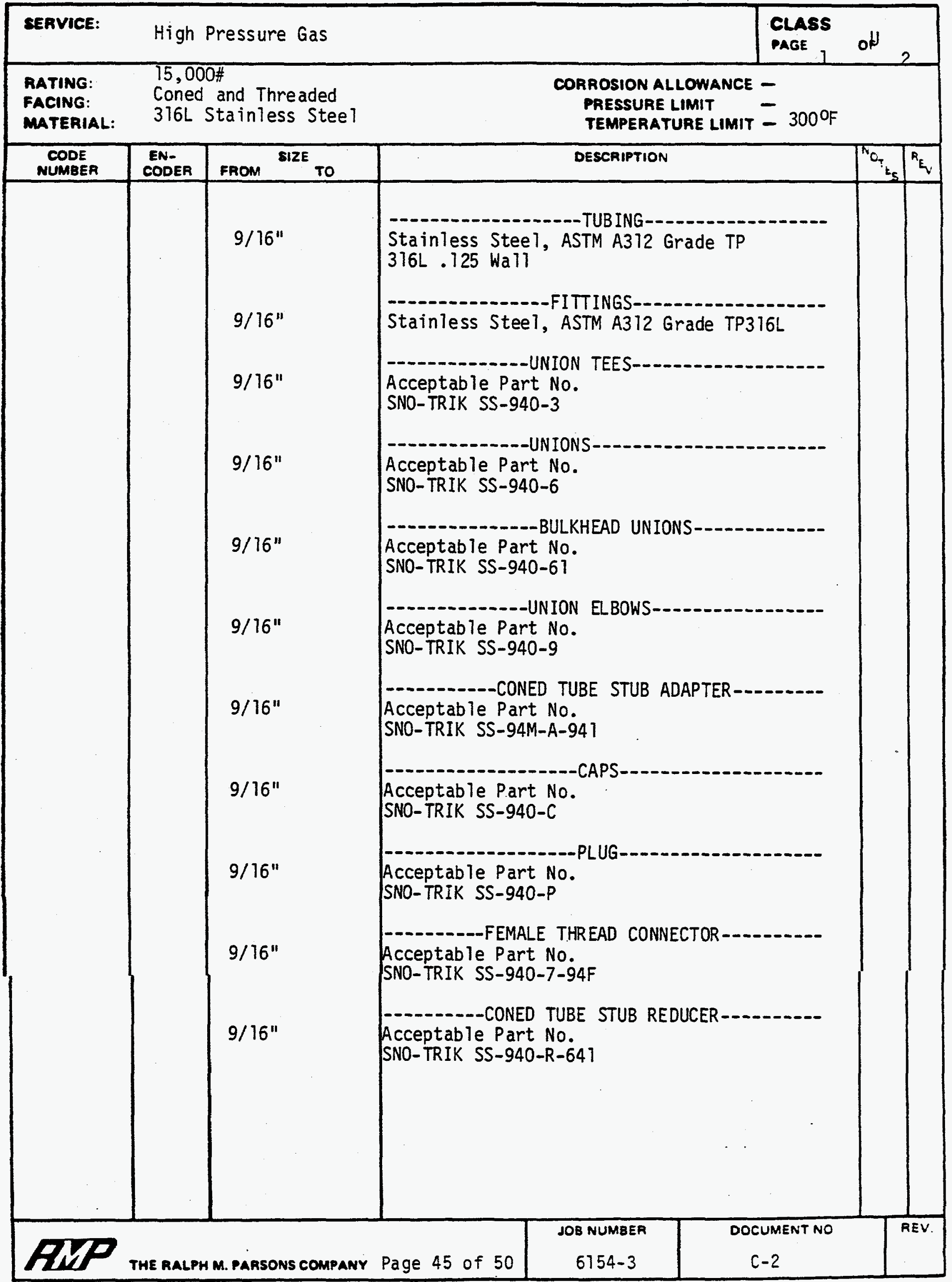




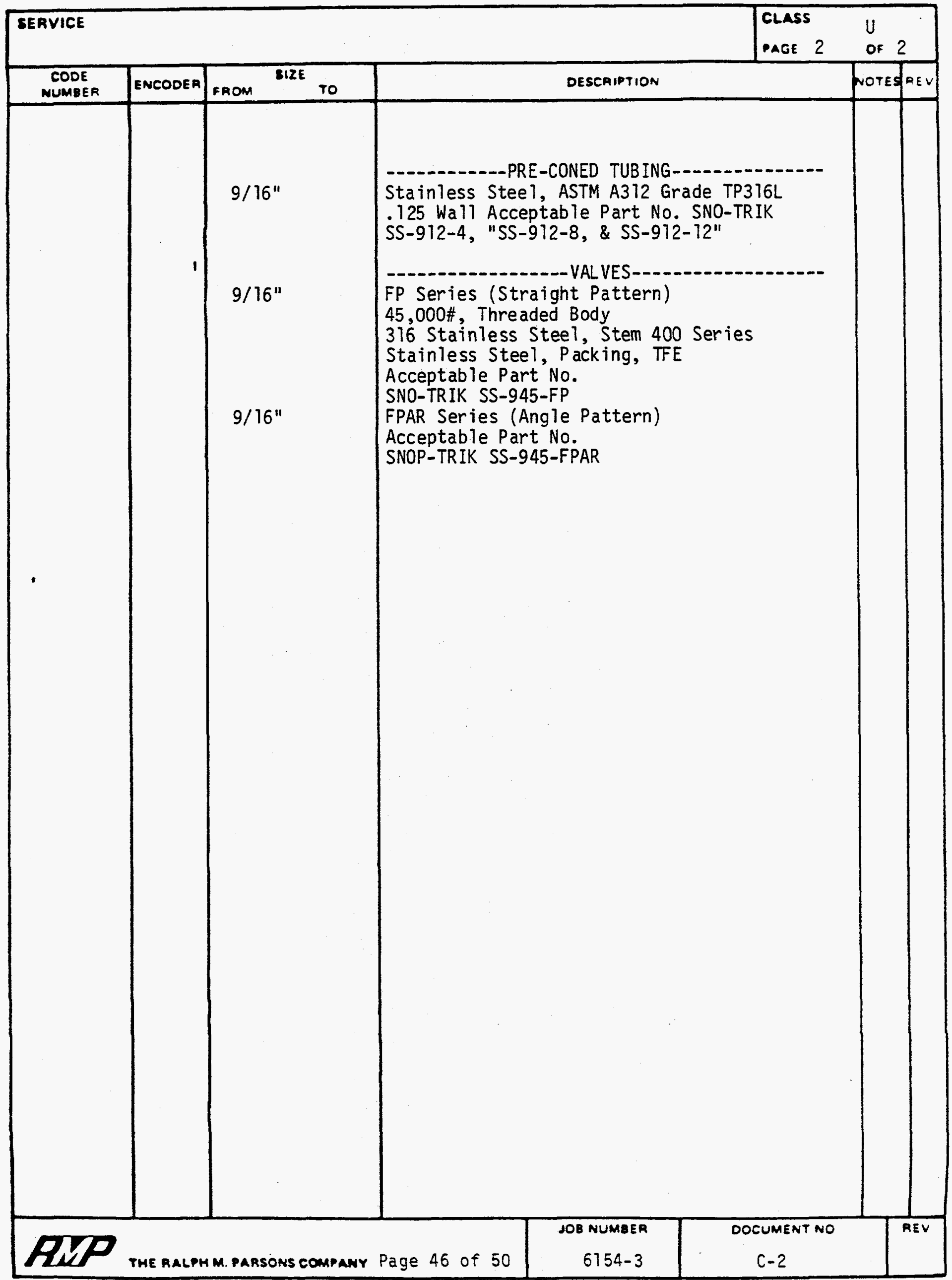




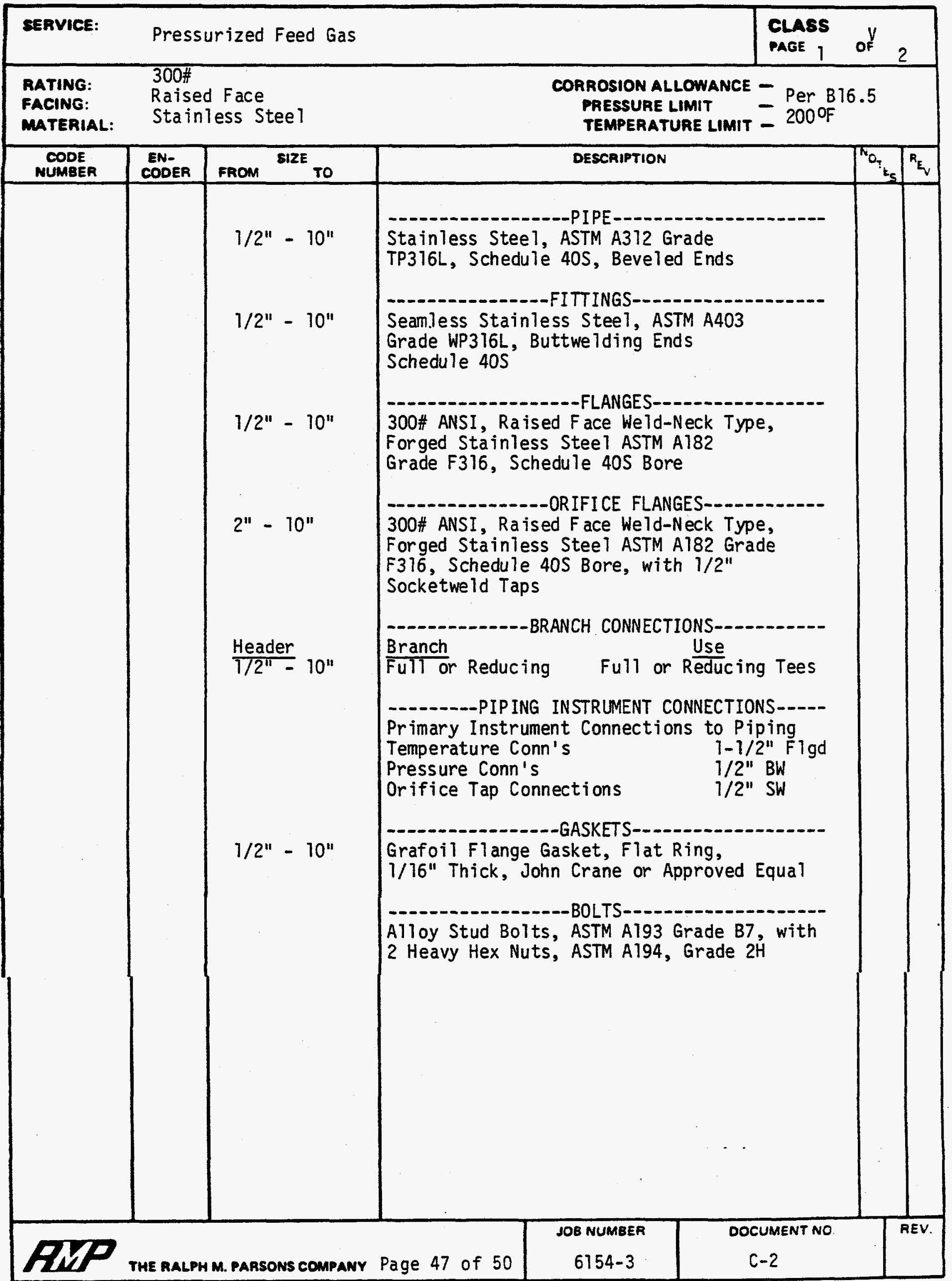




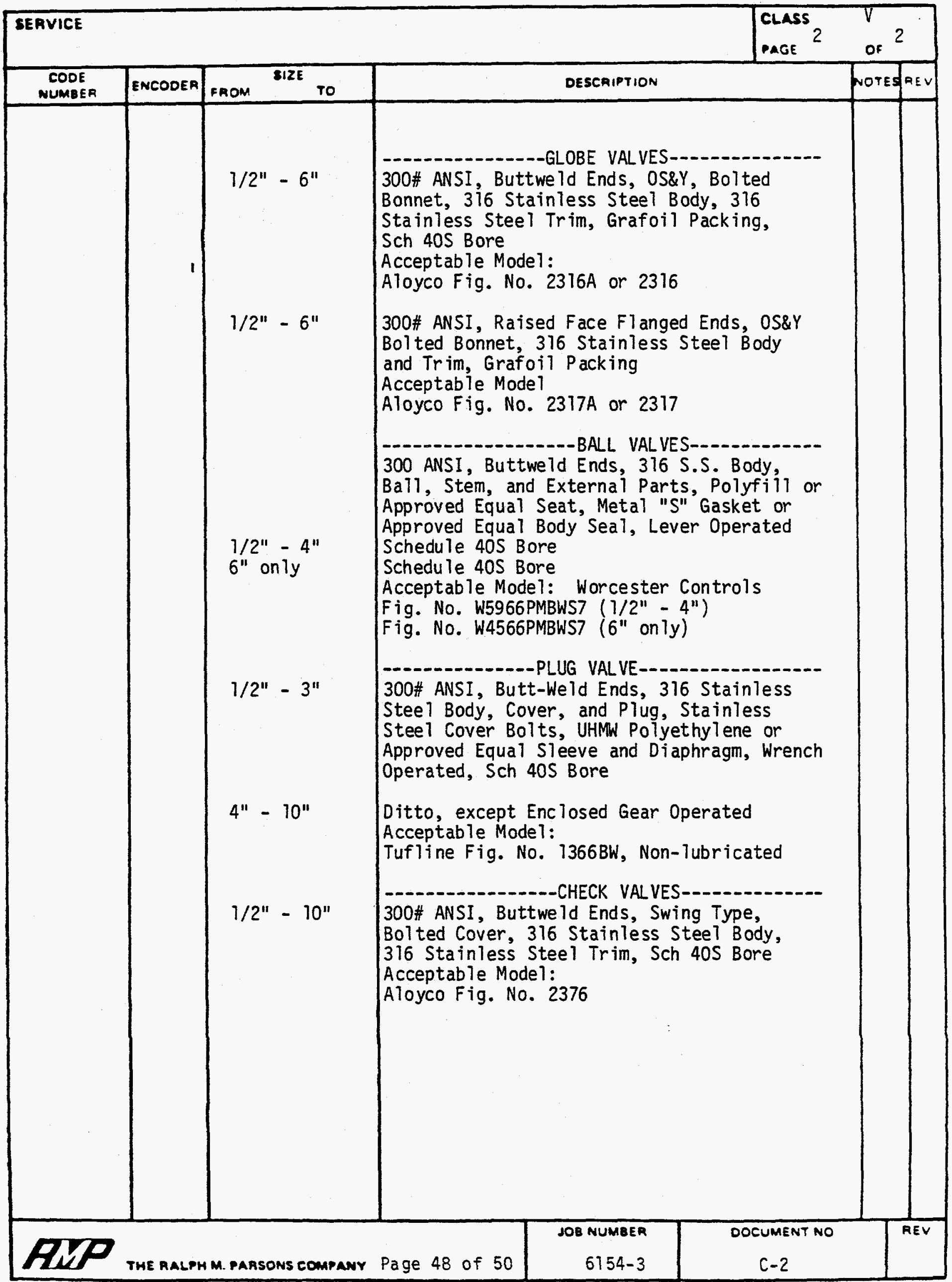




\subsection{COATING AND WRAPPING}

\subsection{SCOPE OF WORK}

The Contractor shall provide all material, labor, equipment, and tools necessary for the preparation and application of corrosion resistant coatings for exterior surfaces of carbon and stainless steel pipe, flanges, valves, and fittings in direct buried service.

\subsection{MATERIALS OF CONSTRUCTION}

The following materials or Approved Equal are acceptable:

\section{MATERIALS \\ Tape Primer \\ Primary Tape \\ Filler Tap \\ Joint Tape}

\section{MANUFACTURER}

Polyken Div

of the

Kendall Co.,

Boston,

Mass.

\section{MFR'S CODE}

No. 927

No. 980

No. 931

No. 930

\section{SERVICE TEMPERATURE}

-30 OF to 200 OF
-30 OF to 200 OF
-30 OF to 200 of
-30 OF to 200 OF

\subsection{EQUIPMENT}

The pipe wrapping shall be electrically inspected with a Tinker \& Rasor Model AP or APW or Approved Equal holiday detector set at a minimum dc voltage of 150 times the mil thickness of the coating to detect any wrapping flaws.

\subsection{FIRE PROTECTION}

\subsection{SCOPE OF WORK}

This Specification establishes the requirements for the design, fabrication, and installation including furnishing labor, materials, tools, and equipment, and performing operations necessary for engineering, detailing, inspection, testing, documentation, delivery to jobsite and installing Underwriters Laboratories (UL) and/or Factory Mutual (FM) approved automatic fire sprinkler systems, fire hose cabinets, and fire hose racks.

\subsection{MATERIALS OF CONSTRUCTION}

Sprinkler heads for offices and other finished areas shall be UL and/or FM approved, pendant type with ceiling plate, a temperature rating of $212 \mathrm{deg} F$, and a standard 1/2-inch orifice size. Sprinkler heads for all other areas shall be UL and/or FM approved brass upright type, with a standard 1/2-inch orifice size and a temperature rating of $212 \mathrm{deg} F$ except near heat sources where the temperature rating shall be in accordance with NFPA Standard No. 13, Table 3-16.6.4. 
Water flow detectors shall be provided and installed according to NFPA Standard No. 72A. Wiring and conduits shall be provided and installed by the Contractor.

Piping shall comply with the ANSI and ASTM standards. Pipe hangers shall be in accordance with requirements of the Underwriters' Laboratories, Inc., for use in sprinkler systems.

Pipe:

Carbon Stee1, ASTM A 53, Grade B, Standard Weight

Screwed Fittings:

Cast Iron ASTM A 126 conforming to ANSI B 16.4 \& B16.1 or Malleable Iron, ASTM A 197 conforming to ANSI B16.3

Flanges:

Cast Iron ASTM A 126 conforming to ANSI B16.1

Couplings and Unions:

As per NFPA Standard No. 13

Valves:

(1) Class 175 WWP Iron Body, Bronze Mounted, OS\&Y Gate Valves for all sizes larger than 2 inches

(2) Class 175 WWP Iron Body Swing Alarm Check Valve

(3) Class 175 WWP Iron Body Dry Pipe Valve

\subsection{EQUIPMENT}

\subsubsection{Alarm Check Valves}

The alarm check valves shall be Viking Model F-l Alarm Check Valve with retarding chambers and complete trim packages, or Approved Equal. A water motor gong local alarm shall be included with each wet pipe system.

\subsubsection{Fire Hose Racks, Fire Hose and Extinguisher Cabinets}

Fire hose racks and fire hose cabinets shall be of the surface mounted type and shall be provided and installed at the approximate locations shown on the drawings. All fire hose racks and cabinets shall be installed in compliance with NFPA Standard No. 14 for Class II service and NFPA Standard No. 13 for combined systems. All fire hose cabinets shall be sized to house a 2-1/2 gallon water-type fire extinguisher in addition to the hose and appurtenances. 
APPENDIX D

CALCULATIONS

GENERAL

D-1 Krypton-85 Radiolytic Heat Generation

D-2 Rubidium Oxidation

D-3 Lag Feed Storage

ION IMPLANTATION/SPUTTER ING

D-4 Equipment Sizing

D-5 One-Year Product Storage

D-6 Electric Power Costs

ZEOLITE ENCAPSULATION

D-7 Equipment Sizing

D-8 One-Year Product Storage

D-9 Substrate Costs

D-10 Vessel Rupture 



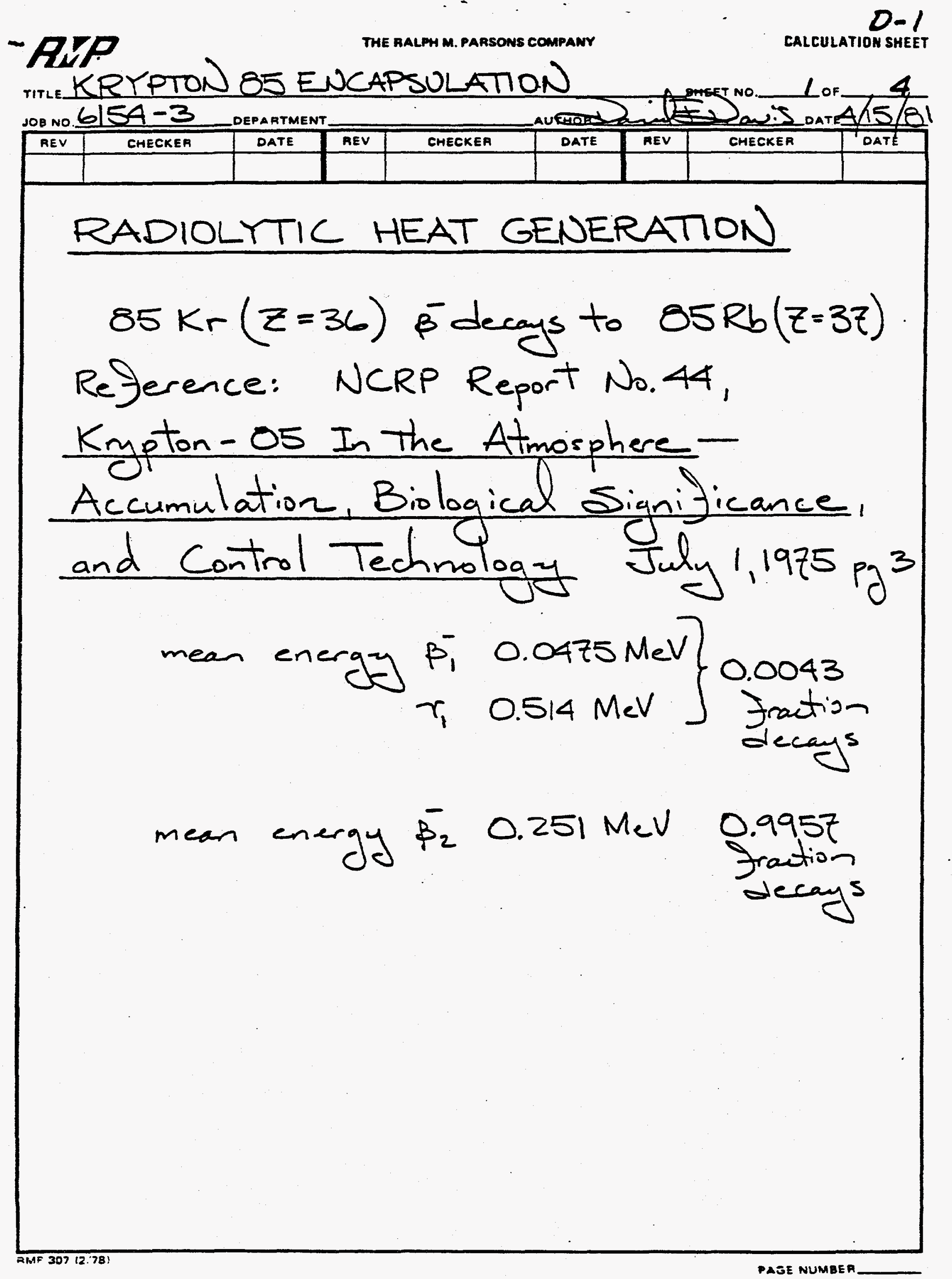




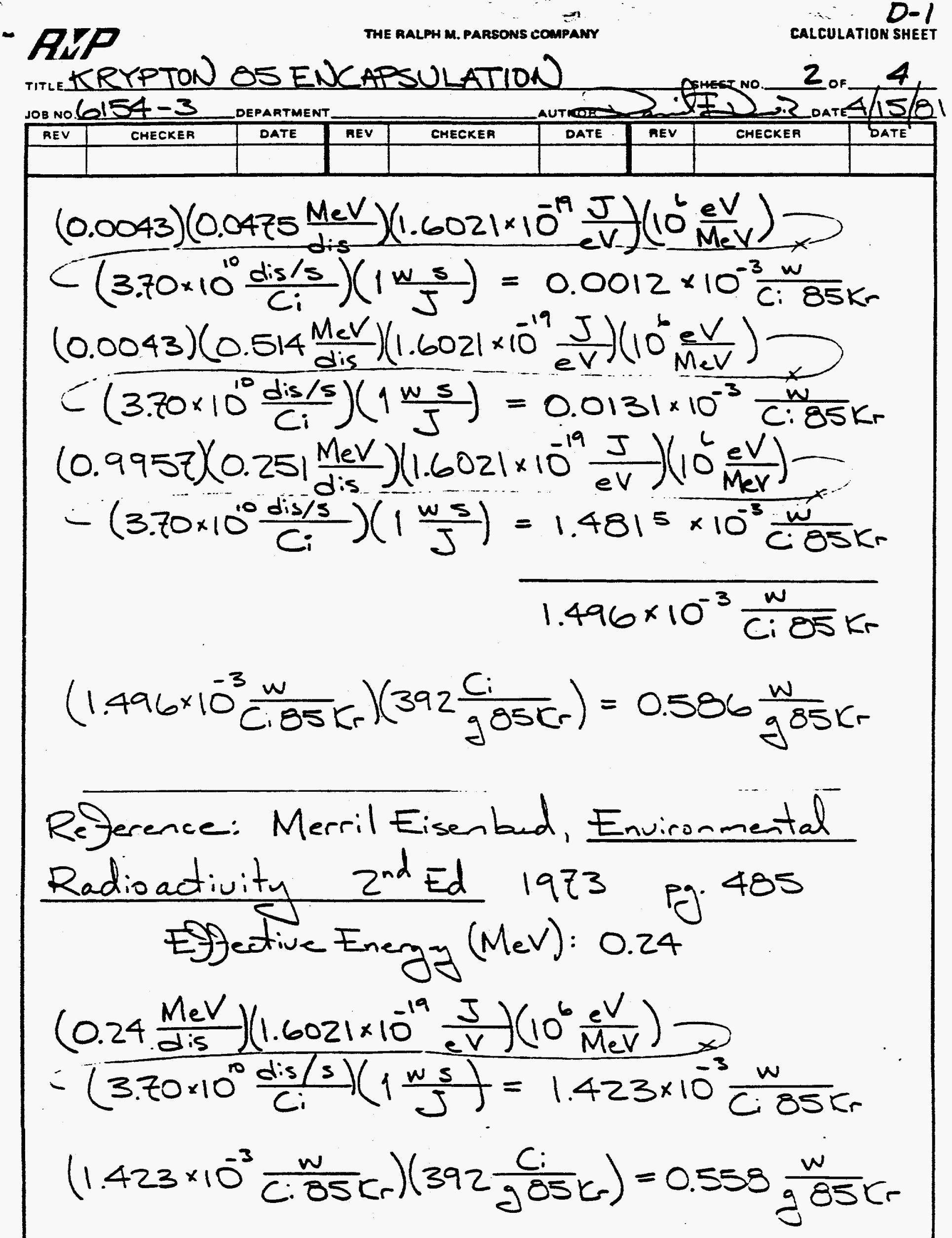


- RIP

D- 1

TITLE KRYPTON 85 ENCAPSULATION

CALCULATION SHEET

JOB No. $6154-3$

DATE

DATE

3 of

Reference: A. B. Christensen, Physical

Properties and Heat Transfer Characteristics

of Materials for Krypton-85 Storage,

ICP-1128, Sept 197z, pg 3

average decay energy $0.24^{\circ} \mathrm{MeV}$

$$
\begin{aligned}
& \frac{\left(0.246 \frac{\mathrm{MeV}}{\mathrm{dis}}\right)\left(1.6021 \times 10^{-19} \frac{\mathrm{J}}{\mathrm{eV}}\right)\left(10^{6} \frac{\mathrm{eV}}{\mathrm{MeV}}\right)}{\left(3.70 \times 10^{10} \frac{\mathrm{dis} / \mathrm{s}}{\mathrm{Ci}}\right)\left(1 \frac{\mathrm{ws}}{\mathrm{J}}\right)=1.458 \times 10^{-3} \frac{\mathrm{w}}{\mathrm{Ci} 85 \mathrm{Kr}}} \\
& \left(1.450 \times 10^{-3} \frac{\omega}{C .85 K_{r}}\right)\left(392 \frac{C_{i}}{g 05 K_{r}}\right)=0.572 \frac{\omega}{g 85 t}
\end{aligned}
$$

Reference: SENumn \&WA Reardon, The Formation and Decay of Selected Isotopes, BNWL-487, January 1967.

$$
\sim 0.53 \frac{w}{g^{85 k}}
$$


- $\boldsymbol{R} \boldsymbol{P} \boldsymbol{P}$

THE RALPH M. PARSONS COMPANY

$D-1$

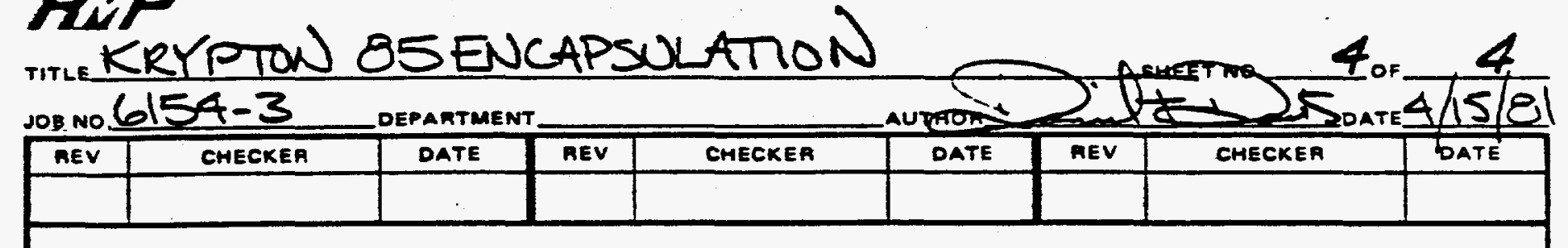

FOR THESE CALCULATIONS

WILL USE:

$$
\begin{aligned}
& 1.458 \times 10^{-3} \frac{\omega}{c i 85 \mathrm{Kr}} \\
& \frac{\left(1.458 \times 10^{-3} \frac{w}{C .055 C}\right)\left(18.7 \frac{M C_{i}}{y}\right)\left(10^{6} \frac{C_{i}}{M C_{i}}\right)}{\left(232.5 \frac{\mathrm{m}^{3}}{y}\right)} \\
& =117.3 \frac{\mathrm{w}}{\mathrm{m}^{3}} \leftarrow \\
& \text { (mª O } \text { O }^{3} \text { lat) THIS is }
\end{aligned}
$$

RADIOLYTIC DECAY HEAT PER CUBIC METER FEED GAS 
ALP

THE RALPH M. PARSONS COMPANY

Calculation Sheet

TIMERRPTON 85 ENCAPSULATION

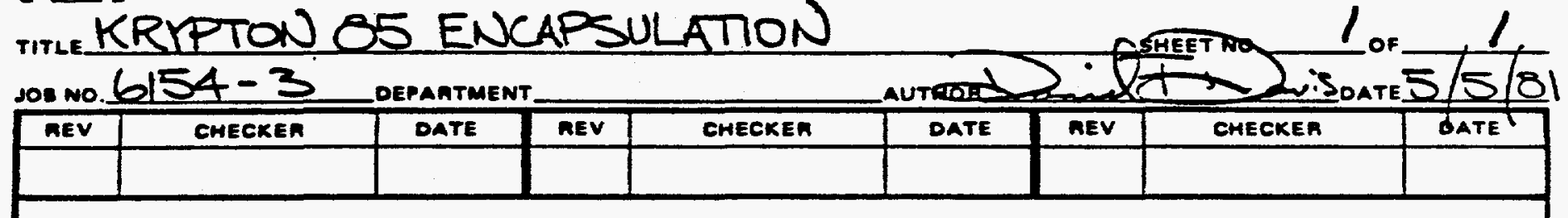

RUBIDIUM OXIDATION

$$
\mathrm{Rb}+\frac{1}{4} \mathrm{O}_{2} \rightarrow \frac{1}{2} \mathrm{Rb}_{2} \mathrm{O}
$$

$85.42 \quad 8.00$

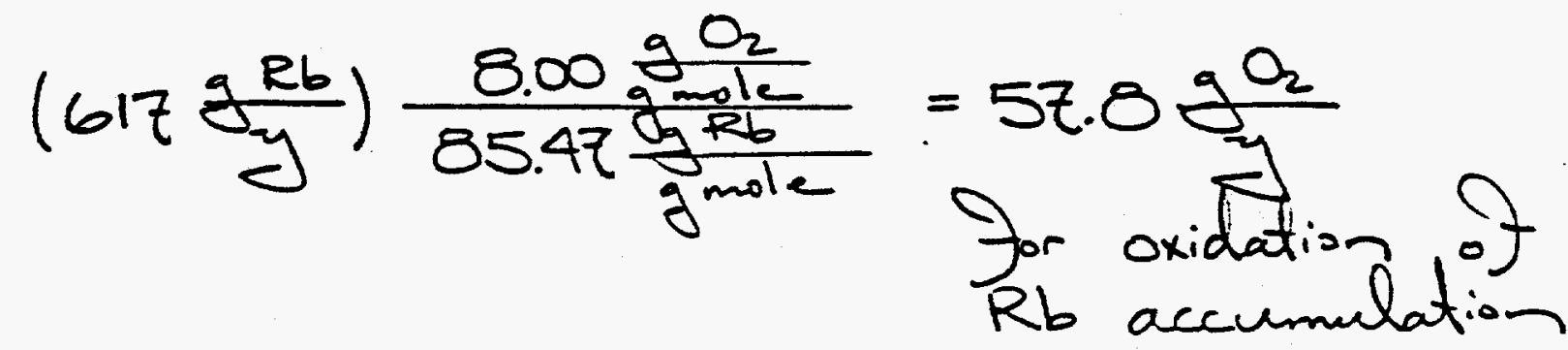

in 60 day log

storage

$$
\frac{\left(232.5 \frac{\mathrm{m}^{3}}{\mathrm{y}}\right)\left(\frac{200}{10^{6}}\right)\left(10^{3} \frac{\mathrm{g}}{\mathrm{f}^{3}}\right)\left(32.0 \frac{\mathrm{gO}_{2}}{22.4 \frac{\mathrm{g}}{\mathrm{gmateO}}}\right)}{20 \mathrm{O}_{2}}=66.4 \frac{\mathrm{O}_{2}}{\mathrm{y}}
$$

200 ppm $\mathrm{O}_{2}$ in Ged gas would provide enough $\mathrm{O}_{2}$ to oxidize $\mathrm{Rb}$ accumulation in lag storage

AMP 307 (2/79)

page number 

AuP

TME RALPH M. PARSONS COMPANY

D- 3 calculation shee

TITLE GRYeTOCL 85 ENCAPSULATIOL

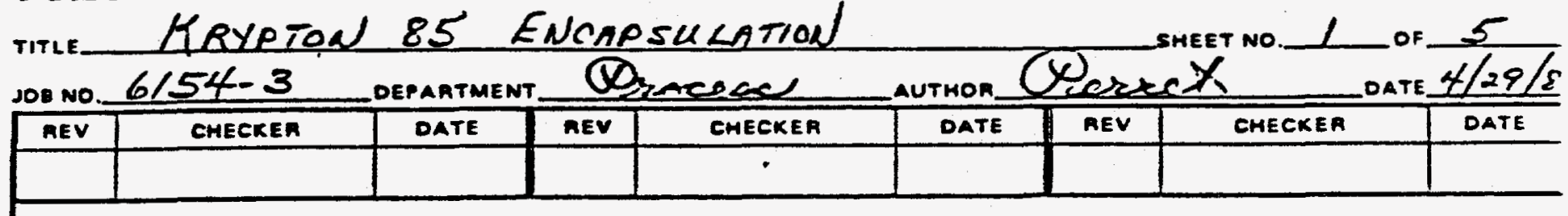

Calculations for Lag Fud Sterage.

Basis: previde 60 day- of ctorage (out of $a=00$ day /ywer operation or) 1/5 the of the emrual prodicction.

Qrevesies calculations gane a rate of 232.5 $\mathrm{m}^{3} / \mathrm{yz}$. with a heat gerecratere of $117.3 \mathrm{w} / \mathrm{m}^{3}$.

$$
\begin{aligned}
& \frac{602}{500 / \mathrm{s}^{2}} 232.5 \frac{\mathrm{m}^{3}}{\mathrm{l}^{2}} \div .028317 \mathrm{~m}^{3} / \mathrm{At}^{3}=1642 . \mathrm{ft}^{3}(1 \mathrm{~atm}, 0 \mathrm{C}) \\
& \frac{60}{300} \times 232.5 \times 117.3 \frac{w}{13 i}=5454.11 \% 1.5 \\
& 5454 W \times 3.413 \frac{B T H / H R}{W}=186 / 5 . B T U / H R \text { HOAT RELERE }
\end{aligned}
$$

Qreleminizy conciderateries suggected use of 12 "

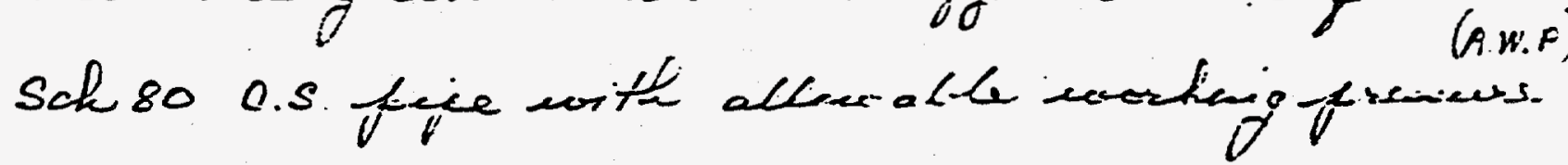

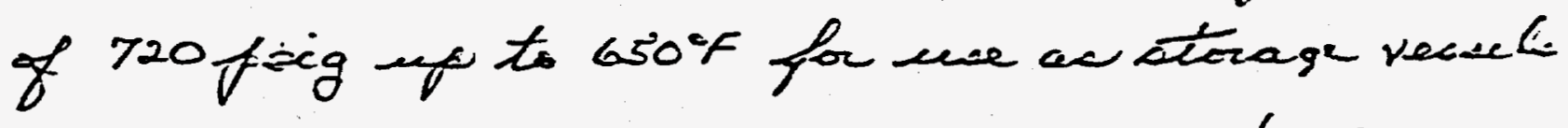

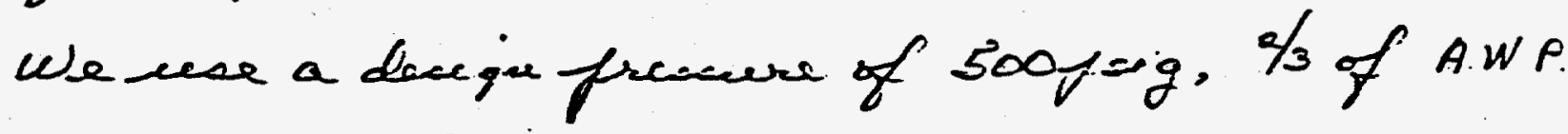
The wall trichissine is $0.682 \mathrm{sm}$. and the can tacined veleme is $0.7056 \mathrm{H}^{3} / \mathrm{ft}$.

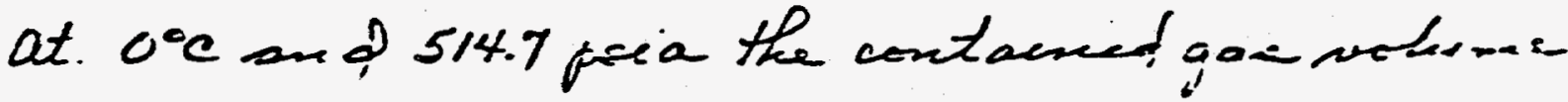
si: 
RLP

THE RALPH M. PARSONS COMPANY

D. 3 calculation shei

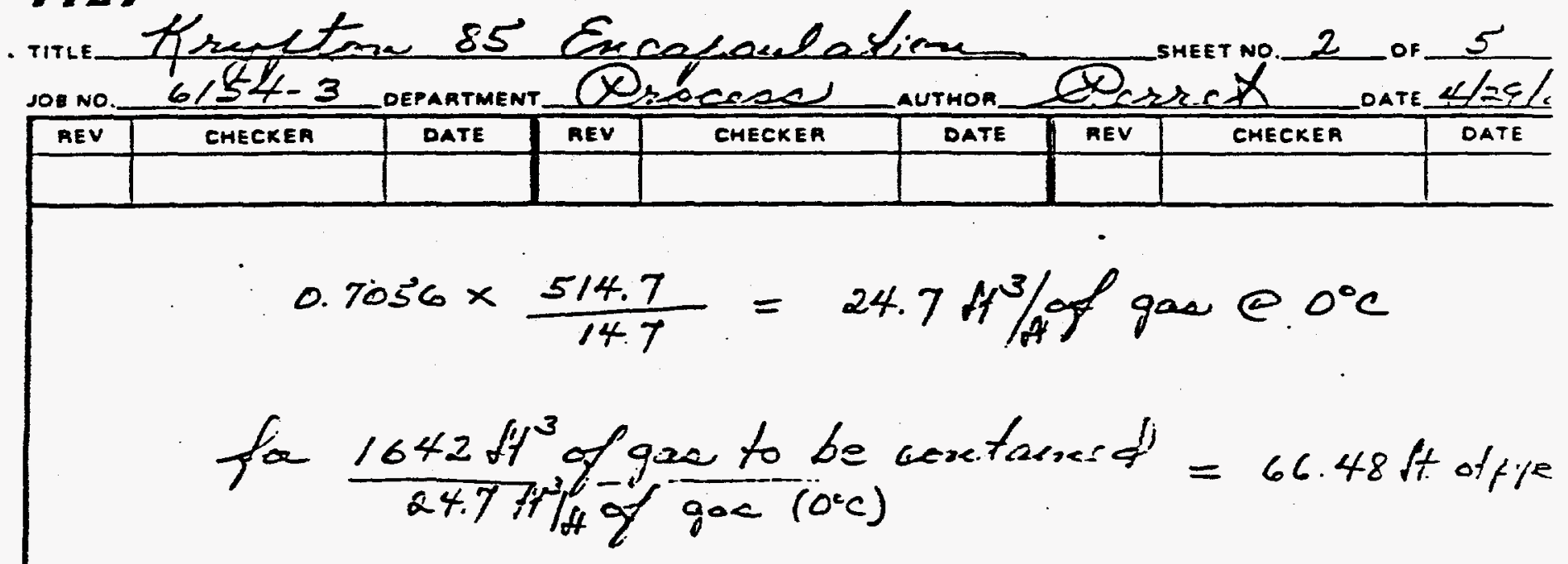

ascuming 80 fiet of thitic as 8-10 ff. sections stacked 2 wide anci thigh, have a space encelifte of $230 "$ wide $\times 60^{\prime \prime}$ high $\times 1.2^{\prime}$ long.

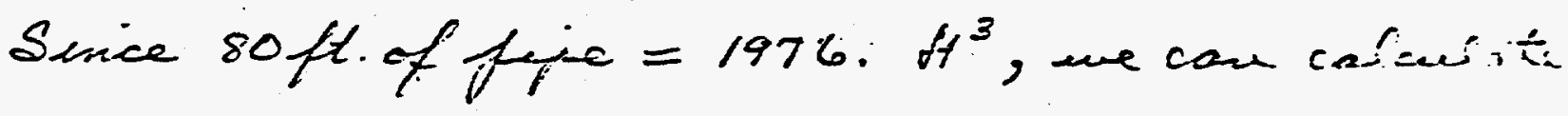

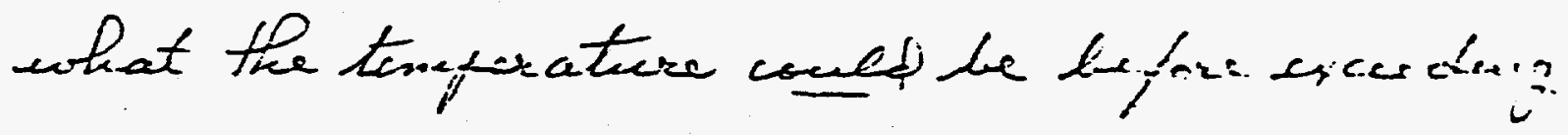
$5 \infty$ fsig.

$$
\begin{aligned}
& 1976 \mathrm{~A}^{3}=\left(\frac{T+460}{492}\right) \times 1642 \mathrm{~A}^{3} \\
& \text { (1ator. T) } \quad\left(1 \mathrm{~atm}, 0^{\circ} \mathrm{C}\right) \\
& T^{\circ} \mathrm{F}=492\left(\frac{1976}{1642}\right)-460=132^{\circ} \mathrm{F} \quad \text { (sect bolow }
\end{aligned}
$$

But howe to remene 18615 BTu/ter thengh a

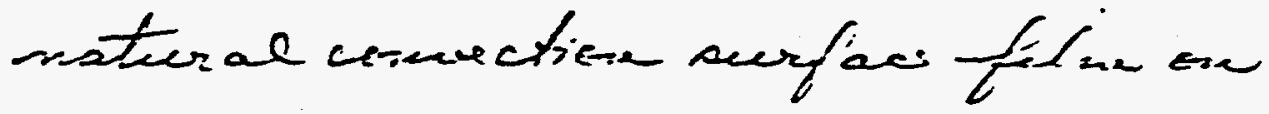

$$
\begin{aligned}
& 80 \text { ft } \times 3.338 \mathrm{rt}^{2} / \mathrm{It}^{\mathrm{t}}=267.04 \mathrm{ft}^{2} \\
& \therefore h_{C} \Delta T=\frac{\dot{Q}}{A}=1 \varepsilon 6 / 5 / 3670 \%=69.71 \frac{0.4 L}{T^{2}-t_{2}}
\end{aligned}
$$

ance, $h_{c} \simeq 0.8$ meed a $\Delta T \simeq 87^{\circ} \mathrm{F}$. S wircose

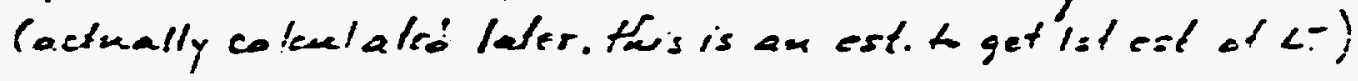


RDP

THE RALPH M. PARSONS COMPANY

D-3calculation Sheet

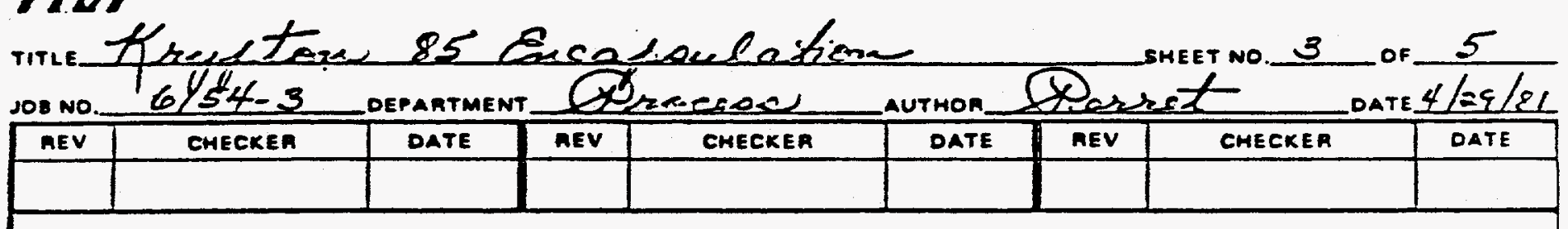

mi $e^{\circ} 90^{\circ} \mathrm{F}$ (max) and ricte $e 110^{\circ} \mathrm{F}$ max. (20\% $\Delta T_{\text {ruse) }}$

$$
\bar{T} \text { (ais) }=100^{\circ} \mathrm{F} \quad T_{s}=127^{\circ} \mathrm{F} \quad T_{g a c} \simeq 200 \% .
$$

We encreace the desegi ficiseuce to

$$
514.7 \text { sian } \times \frac{(200+460)}{(1 \leqslant 2+460)}=573.8 \text { sia }
$$

or $573.8-14.7=560$ psig.

For $T_{s}=187^{\circ} \mathrm{F}, \quad \bar{T}_{\infty}=100^{\circ} \mathrm{F} \quad P_{r}<10^{9} \therefore$ LARINSAR

$$
N_{u}=0.47\left(P_{r} Q_{r}\right)^{1 / 4}
$$

$P_{x}($ ave $)=0.7$

$\nu=\mu / \rho$

$g=32.2 \mathrm{At} / \mathrm{sec}^{2}$

$\eta=\left(\frac{-0183 S_{C F}}{14 E E}\right) \frac{1 b}{111:=t c}$

$\rho=.080816 / \mathrm{ft}^{3}$

$k=.019 \frac{\Delta \pi k}{k+17}$

$$
G_{x}=\frac{g\left(T s-T_{a}\right) L^{3}}{\nu_{0}}
$$$$
G r=\frac{g\left(\frac{T s-T_{0}}{T a}\right) L^{3} \rho^{2}}{\mu^{2}}
$$

$G_{x}=\frac{(32.2)\left(\frac{87 * R}{560 \cdot k}\right)\left(\frac{12.75}{150}\right)^{3}(.0808)^{2}}{(.0183 / 1482)^{2}}$

$G r=0.259 \times 10^{9}$

$N_{u}=\frac{h D}{k}=0.47\left(0.7\left(.259 \times 10^{9}\right)\right)^{k}=54.54$.

$\hbar_{c}=\frac{(019)(54.54)}{\frac{12.75}{12}}=0.975$ 0ive.t. $A: 0_{F}$

$\therefore \Delta T(2)=69.71 / .975=71.48$ is $\Delta T(1) \simeq \varepsilon 7$

Liverne $\left.\Delta \pi^{3}\right)=75 ; h_{c}(2)\left(\frac{75}{87}\right)^{1 / 4} \times 0.975=0.94 \quad \Delta T(3)=7+2^{\circ} \mathrm{F} \mathrm{VV}$ 
THE RALPH M. PARSONS COMPANY

D-3 calculation sheet

REP

D Calculation sheet

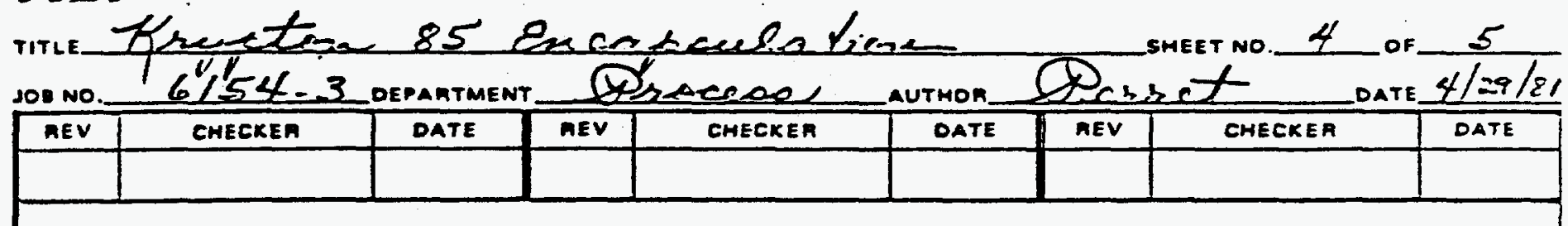

Theiv $\bar{F}_{\text {K. }}=100+75=175^{\circ} \mathrm{F} \quad \bar{T}_{\text {gar }} \cong 250^{\circ} \mathrm{F}$

baced on $h_{c}(i) \simeq h_{c}(0)$

and desigin ficcisure is then:

$$
\left[514.7 \times\left(\frac{250+460}{1.32+460}\right)\right]-14.7 \simeq 600 \text { tsig. }
$$

In crevanig hingth from $10^{\prime}$ to $12^{\prime}$ geviec 500 prig dexign.

Oer Flew:

For $20^{\circ} \mathrm{F}$ reic

$$
\begin{gathered}
\dot{w}=\frac{\dot{Q}}{G_{p} \angle T} \\
\dot{w}=\frac{186 / 5}{(0.25):=0)}=3723 / \mathrm{t} / \mathrm{hr} \\
\text { REQUIRED } \longrightarrow \text { or } 768 \mathrm{ctm} .
\end{gathered}
$$$$
C_{f}=0.25 \mathrm{~B}+\mathrm{u} / \mathrm{ll}
$$

considuring a "íntal" area.

of $30^{\prime \prime} \times 10^{\prime}$ ut tis atect $=251^{\prime 2}$

$$
\begin{aligned}
\vec{v} & =30.7 \mathrm{ft} / \mathrm{min} \\
& =0.5 \mathrm{ft} / \mathrm{sec}
\end{aligned}
$$

$\therefore$ come asisist to notural comir $f^{\prime}=4$, tut not meech

$$
\begin{aligned}
& \frac{D Q 5}{4}=\frac{12.75}{12.0} \times \frac{05 \times 0805}{.0183 / 1482}=3 \% 90 \\
& N_{u}=\frac{h_{D} D}{k}=0.023 R^{.8} P_{r}{ }^{1 / 3}=13.94 \\
& h=\frac{L}{0} \times 13.94=\frac{(.019)(13.94)}{1.75 / 12.0}=0.25^{\prime}
\end{aligned}
$$

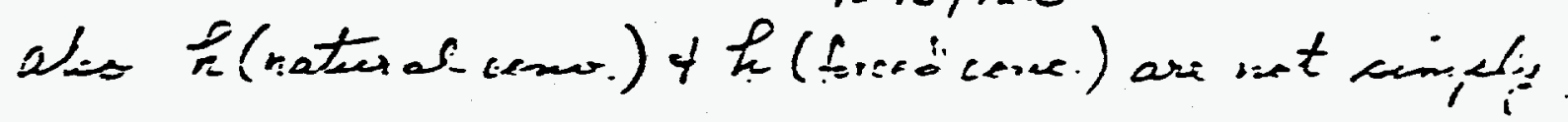


RIP

THE RALPH M. PARSONS COMPANY

D. 3 calculation sheet

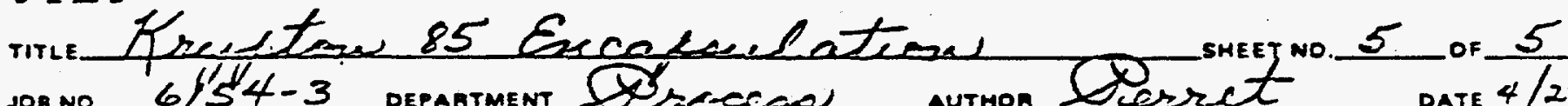

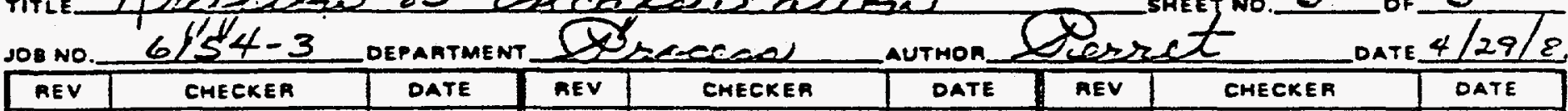

\begin{tabular}{|c|c|c|c|c|c|c|c|c|}
\hline REV & CHECKER & DATE & REV & CHECKER & DATE & REV & CHECKER & DATE \\
\hline & & & & & & & & \\
\hline
\end{tabular}

additive, $h($ total $)<h($ noe. $)+h\left(f_{c}\right)$

d the eniectic

$h, h_{c}(i)$ does rot change, so use $250 \%$ as Foes and $175^{\circ} \mathrm{F}$ as $\bar{T}_{w a c c}$.

R::F.307 (278) 

RIP

THE RALPH M. PARSONS COMPANY

$\sum_{\text {Calculation SHeEt }}$

TITLE $10 N$ IMPLANTATION

JOB NO. $6 / 54-3$ DEPARTMENT

SHEET NO. L OF

3

\begin{tabular}{|c|c|c|}
\hline REV & CHECKER & DATE \\
\hline
\end{tabular}

LEIUSGN DATE G-13-81

\begin{tabular}{|l|l|l|l|l|l|l|l|l|l|}
\hline & CHECKER & DATE & CHECKER & DATE & REV & CHECKER & DATE \\
\hline
\end{tabular}

ION IMPLANTATION/ SPUTTERING EQUIPMENT SIZING

DESIGN PARAMETERS

1. USE 10-INCH PIPE, COMPATIBLE WITH SURF STORAGE

2. $3000 \mathrm{~cm}^{2}$ INITIAL SUBSTRATE AREA

3. $1 \mathrm{~cm}$ THICK DEPOSIT

4. $79 \% N i, 21 \%$ La BY WEIGHT

5. $12.7 \%$ KRYPTON IN DEPOSIT BY WEIGHT

6. SPUTTERING RATE: $7.95 \mathrm{~g} / \mathrm{A}$-NR. $\times 0.009 \mathrm{~A} / \mathrm{cm}^{2}$ $=0.07155 \mathrm{~g} / \mathrm{cm}^{2}$. HR BASED ON INITIAL TARGET SURFACE AREA.

7. DESIGN THROUGHPUT: $232.5 \mathrm{~m}^{3}$ GAS AT STR

8. DEPOSIT DENSITY: $8.0 \mathrm{~g} / \mathrm{cm}^{3}$

A. SUBSTRATE SIZE

10-INEH STD. WT. PIPE (10.02 N. 1.D.) W/ CAP

$$
\begin{aligned}
& \text { CAP SURFACE AREA }=1.084 D^{2}=1.084(10.02 \times 2.54)^{2} \\
& =702.15 \mathrm{~cm}^{2}
\end{aligned}
$$

STRAIGHT LENGTH

$$
L=\frac{(3000-702.15}{\pi \times 10.02 \times 2.54}=28.74 \mathrm{~cm}=11.315^{\prime \prime} \text {, USE } 12^{\prime \prime}
$$

ACTUAL SUBSTRATE AREA $=3139 \mathrm{~cm}^{2}$

B. DEPOSIT VOLUME

$$
\begin{aligned}
& \text { DEPOSIT OD. }=10.02 \times 2.54=25.45 \mathrm{~cm} \\
& \text { DEPOSIT } 1.0 .=23.45 \mathrm{~cm} \\
& V=\frac{\pi\left(25.45^{2}-23.45^{2}\right)}{4} \times 12 \times 2.54+\frac{\pi\left(25.45^{3}-23.45^{3}\right)}{24}=2811 \mathrm{~cm}^{3}
\end{aligned}
$$

RMP-307 (2/78)

PAGE NUMBER 
THE RALPH M. PARSONS COMPANY

Calculation SHEET

TITLE lON lOMPLONTATION

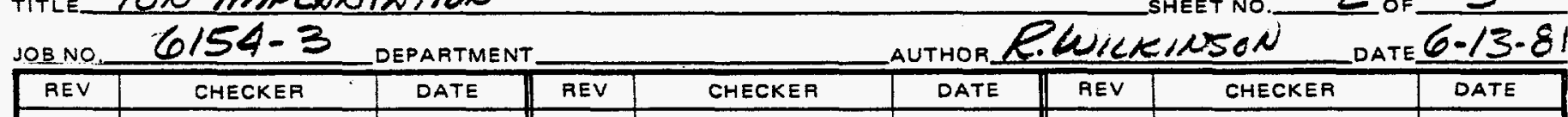

SHEET NO._ZOF_

C. DEPOSIT CONSTITUENTS

$$
\begin{aligned}
& \text { DEPOSIT WEIGHT }=2811 \times 8.0=22488 \mathrm{~g}(10.22 \mathrm{LB}) \\
& \text { ENTRAPPED GAS }=22488 \times 0.127=2856 \mathrm{~g} \\
& \text { NICKEL }(22488-2856) 0.79=15509 \mathrm{~g} \\
& \text { LANTHANUM }(22488-2856) 0.21=4123 \mathrm{~g}
\end{aligned}
$$

D. TARGET VOLUME

NICKEL DENSITY $=8.9 \mathrm{~g} / \mathrm{cm}^{3}$

LANTHANUM DENSITY $=6.15 \mathrm{~g} / \mathrm{cm}^{3}$

$$
\text { VOLUME }=\frac{15509}{8.9}+\frac{4123}{6.15}=2413 \mathrm{~cm}^{3}
$$

E. TARGET SIZE

6 INCH STO. WT. PIPE (6.625" 0.D.) WT CAP

USE $L=11.125^{\prime \prime}$ TO MAINTAIN TARGET TO SUBSTRATE GAP

$$
2413=\frac{\pi\left(0_{0}^{2}-16.8275^{2}\right)}{4} 28.2575+\frac{\pi\left(0_{0}^{3}-16.8275^{3}\right)}{24}
$$

BY TRIAL AND ERROR, USE $D_{0}=19.4275 \mathrm{~cm}$, OR A TARGET THICKNESS OF $1.30 \mathrm{~cm}$.

ACTUAL TARGET VOLUME $=2428 \mathrm{~cm}^{3}$

F. PROCESSING TIME: INITIAL TARGET AREA $=2134 \mathrm{~cm}^{2}$

$$
T=\frac{22488-2856}{0.07155 \times 2134} \cong 129 \text { HRS }
$$

AMP -307 (2/78)

PAGE NUMBER 
ALP

THE RALPH M. PARSONS COMPANY

$0-4$

TitLe lon lomplantation

CALCULATION SHEET

JOBNO. 6/54-3 DEPARTMENT

SHEET NO._ 3 L OF_ 3

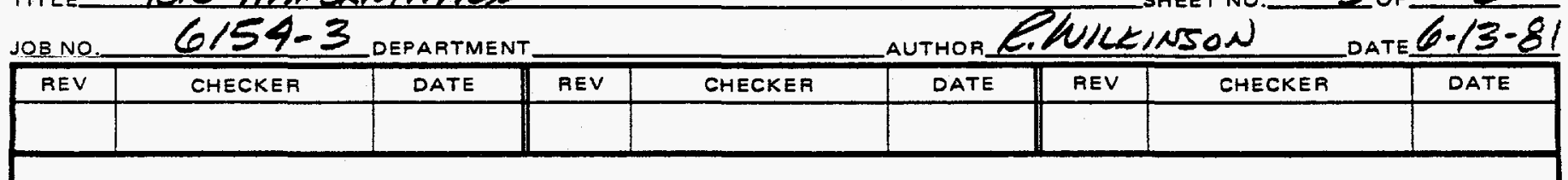

6. ENTRAPPED GAS

$$
\frac{2856 \mathrm{~g}}{83.8 \mathrm{~g} / \text { mole }-K_{r}} \times 22.4 \mathrm{l} / \text { mole }=763 \mathrm{l} / \text { deposit }
$$

H. UNITS REQUIRED

$$
\begin{aligned}
& \frac{232,500 \ell / Y E A R}{763 l / d E P O S I T}=305 \text { DEPOSITS/YEAR } \\
& \frac{305 \times 129}{300 \times 24}=5.57 \text { UNITS MINIMUM, } 24 \text { HRS. DAY, } \\
& 300 \text { DAYS/YEAR }
\end{aligned}
$$

USE 8 UNITS

$$
\text { AVE. UTILIZATION }=\frac{5.57}{8} \cong 70 \%
$$

AMP $-307(2 / 78)$

PAGE NUMBER 
ARP

THE RALPH M. PARSONS COMPANY

D-5 CALCULATION SHEET

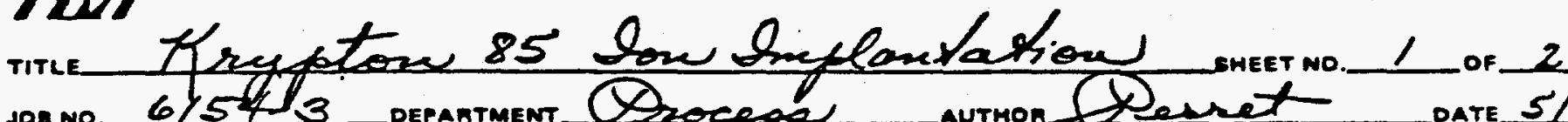

\begin{tabular}{l} 
Jos No. $6 / 54 / 3$ \\
\hline MEV
\end{tabular}

Calculation is for 1-year Product Storage

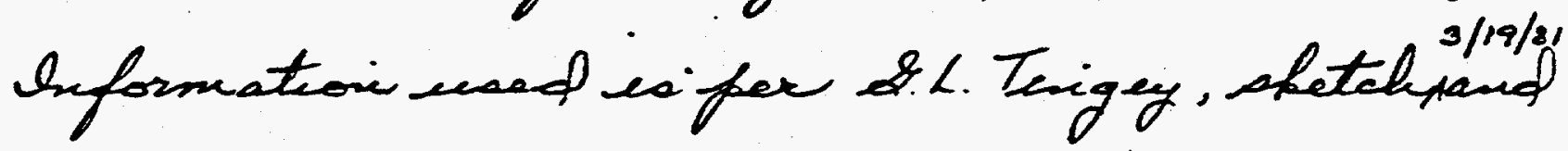
pages 56,57,58 undated.

Sichatrate wall giver as $3000 \mathrm{~cm}^{2}$, demenciosess

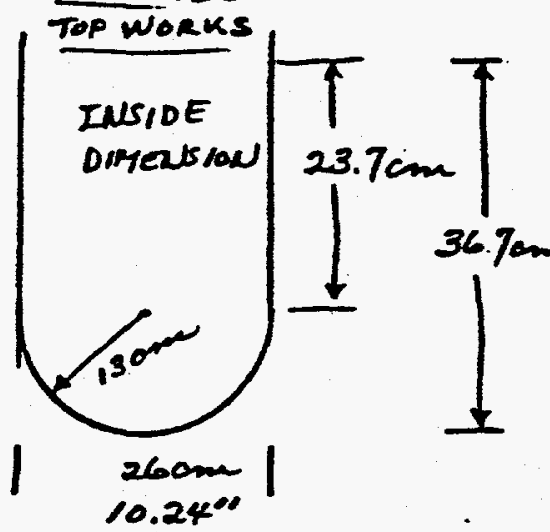
as shown. It is estimated that the areal production, which has a heat release of $5 \times 18615=93075 \frac{B r L}{H R}$. (See prion ales. for lag storage.)

Heat release for unit is $93075 / 435=214 \frac{B T C}{H R}$

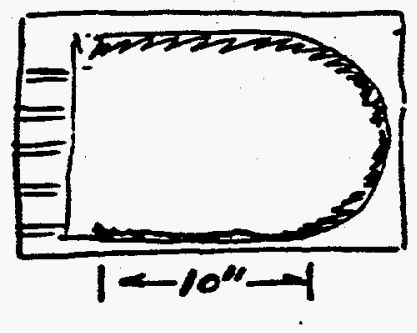

Because of the deposit geometry, assume only $10^{\prime \prime}$ of length are used for heat transfer. $A($ heat tr. $)=10^{\prime \prime} \times 11 \% " \times \pi=2.5 \mathrm{ft}^{2}$

$$
\dot{Q}=\frac{214 \mathrm{BT} / \mathrm{MR}}{2 \cdot 5 \mathrm{fT} \mathrm{T}^{2}}=85.6 \frac{\mathrm{BTe} / \mathrm{HR}}{\mathrm{T}^{2}}=h_{C} \Delta T_{f} .
$$

again from calces. for $\mathrm{lg}$ storage, brow th $=0.98$ 


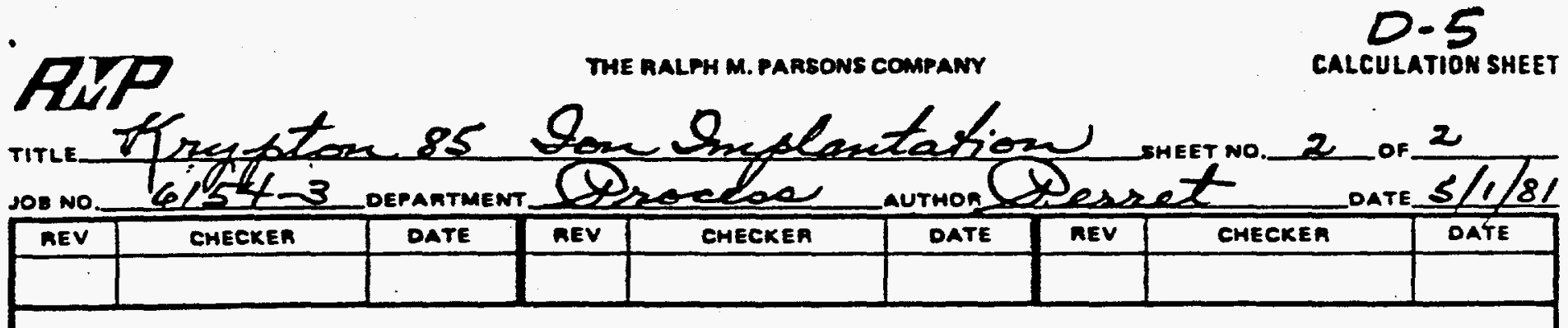

so list est. of $\Delta T_{f}(1)=87^{\circ} \mathrm{F}$. Rationing frei resets (far once $\Delta T$ )

$$
\begin{aligned}
& h_{c} \simeq 0.975\left\{\frac{11.5^{\prime \prime}}{12.75^{\prime \prime}}\right\}^{1 / 4}=0.950 \frac{\mathrm{BPe} / \mathrm{h}_{\mathrm{L}}}{\mathrm{A}^{\prime \prime} \mathrm{OF}}
\end{aligned}
$$

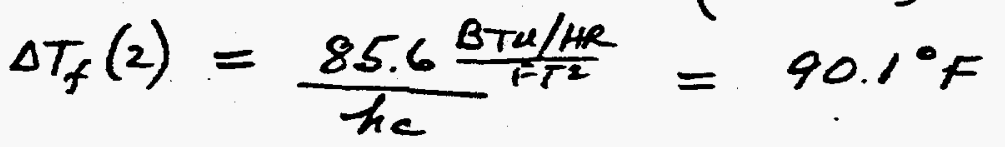

$$
h_{c}(2)=0.975\left\{\frac{11.5}{12.75} \times \frac{90.1}{87}\right\}^{1 / 4}=.9585
$$$$
\Delta T_{f}(3)=89.3^{\circ} \mathrm{F} \simeq \Delta T_{f}(2) \mathrm{N}
$$

Surface $\Delta T$ hess than $90^{\circ} \mathrm{F}$ rise.

assume the resits can be stacked 15" on centers and spaced 24" face to face. A $6 \times 6 \times 13$ array will require $90^{\prime \prime} \times 90^{\prime \prime}$ ore the face $\times 26^{\prime}$ deep. alternate arrangement can he eased and the best fit to overall bldg. geometry will he determined. Same ait loading is required as dotamenied for zeolite encapacelation, $1920 \mathrm{sctm}$.

Floor space for standing there units singh y ore $15^{\prime \prime}$ centers is about $30^{\prime} \times 30^{\prime}$ vs. about $12^{\prime} \times 26^{\prime}$ for above. 


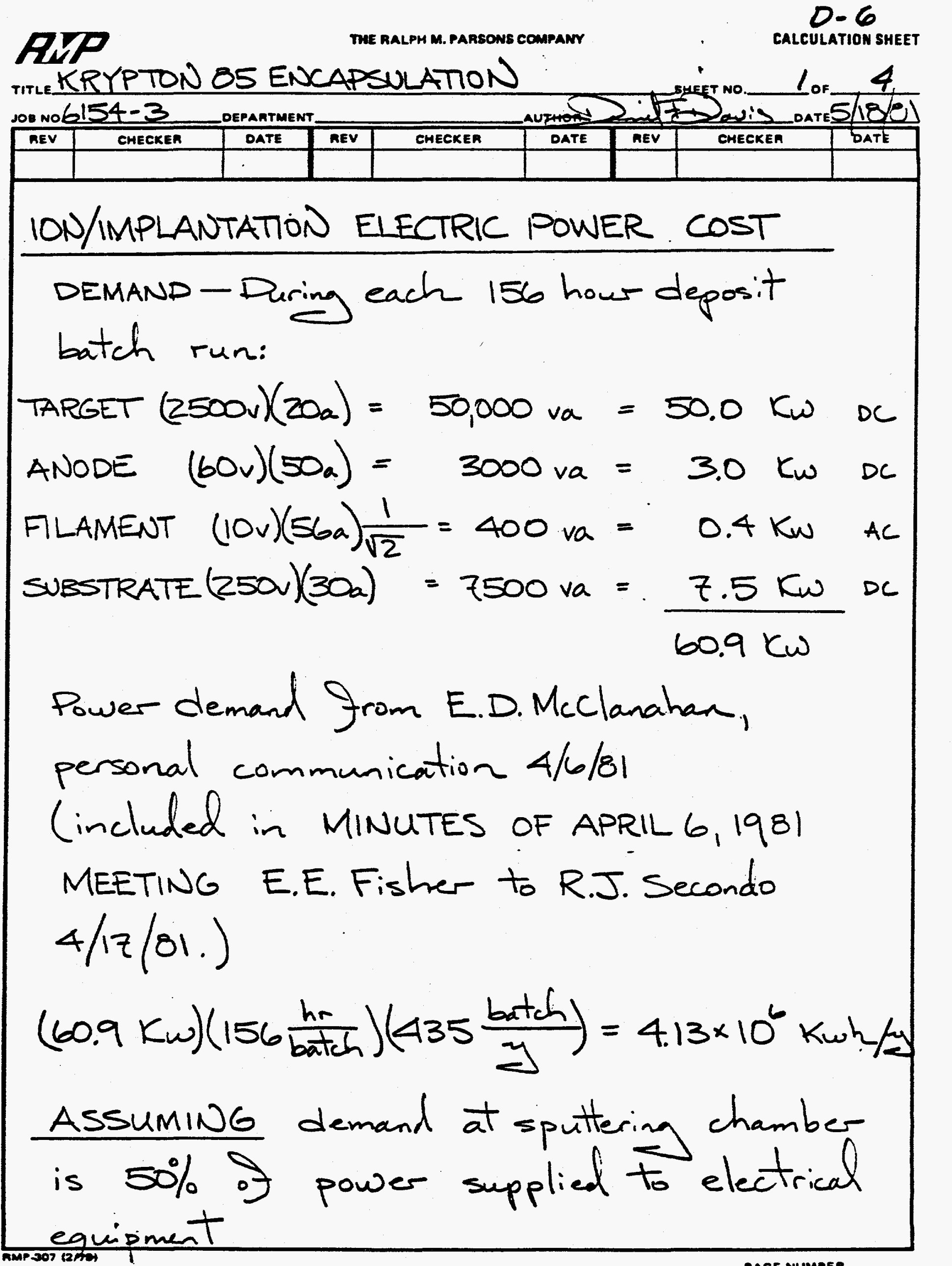




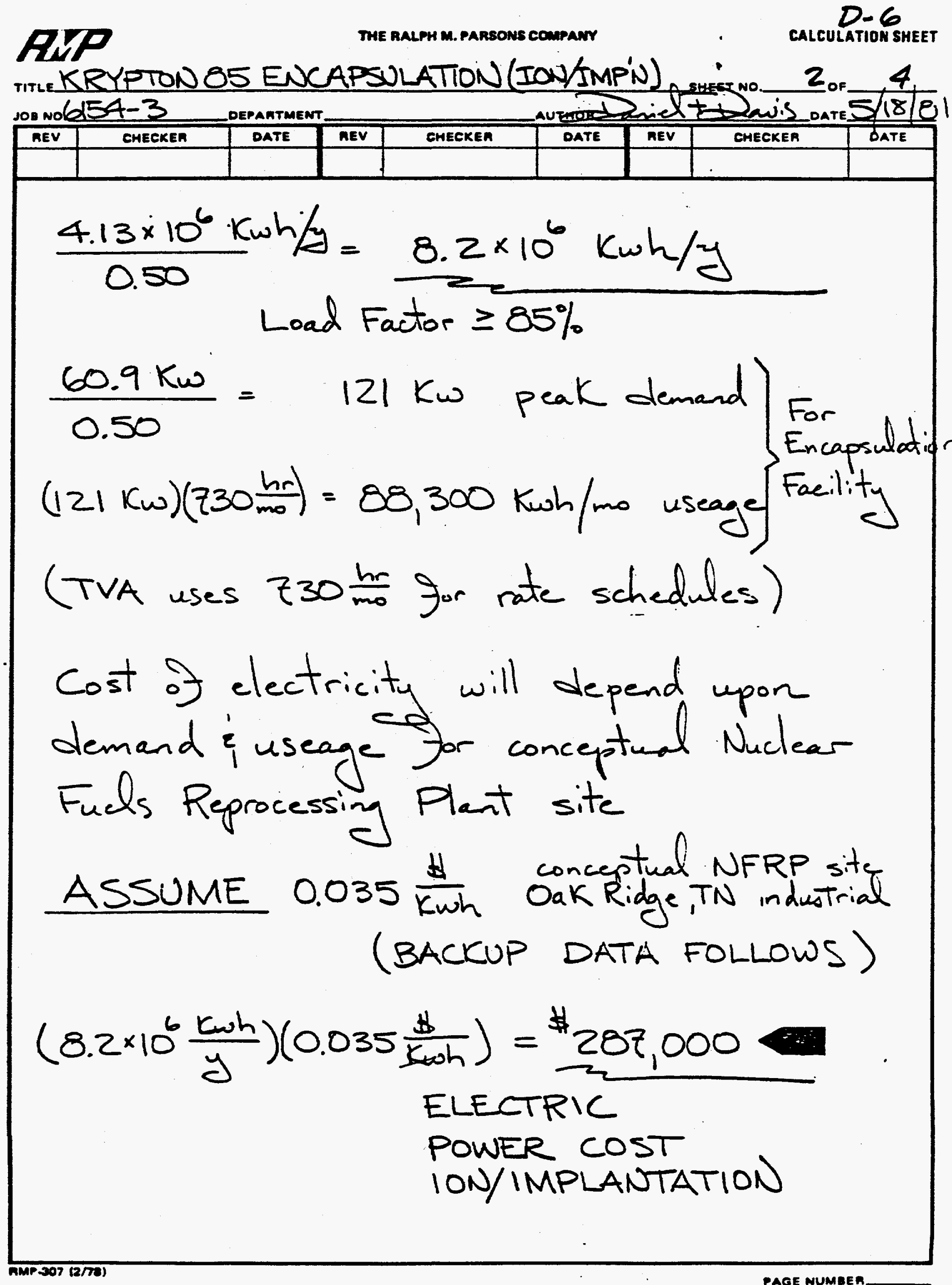




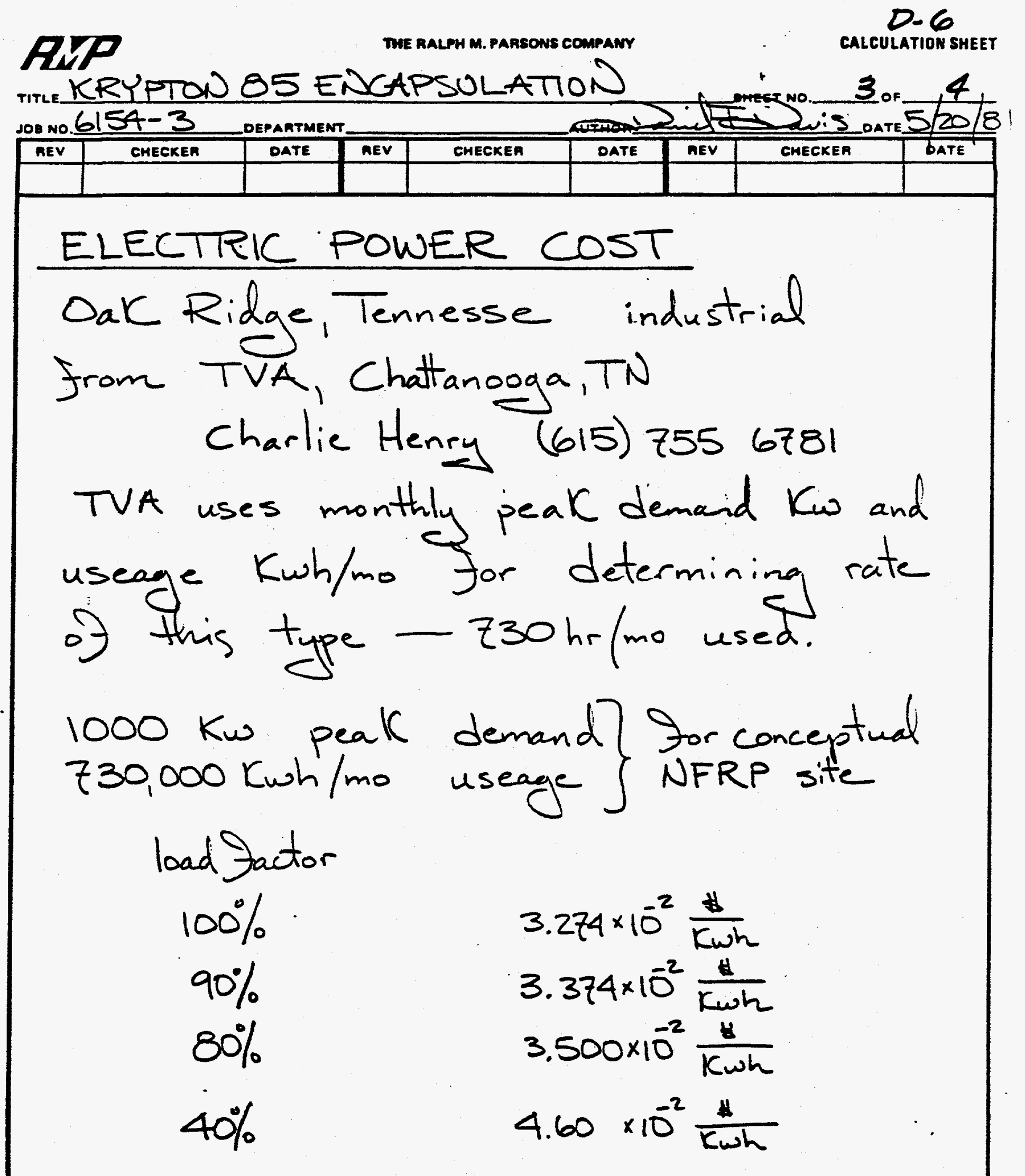


THE RALPH M. PARSONS COMPANY

0.6

CALCULATION SHEET

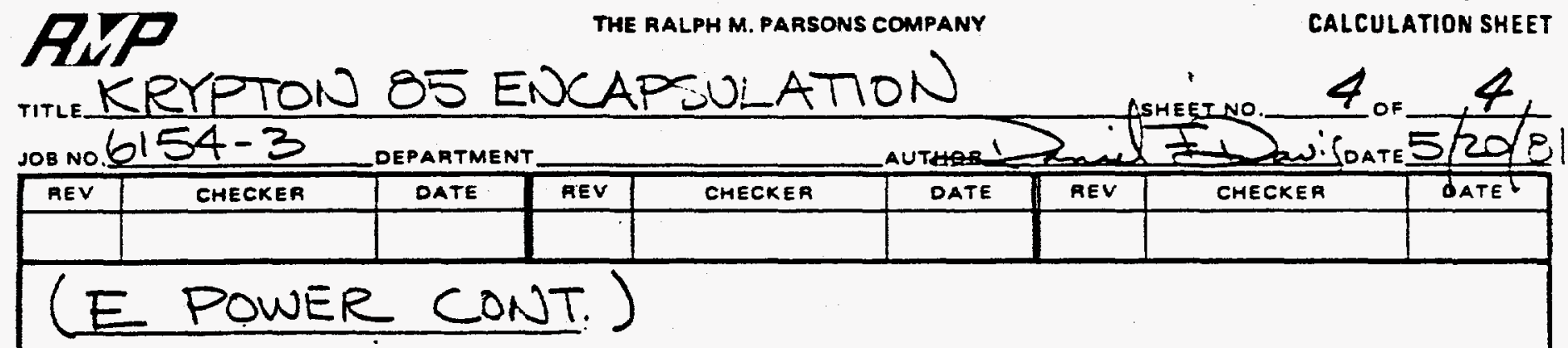

$\left.\begin{array}{c}400 \mathrm{Kw} \text { peak demand } \\ 292,000 \mathrm{Kwh} / \mathrm{mo} \text { usage }\end{array}\right\}$ site

low cost

in Chattanooga

OaK Ridge

high post

District, TVAA

$3.253 \times 10^{-2 \frac{H}{6 w h}}$

$3.271 \times 10^{-2} \frac{H}{k w h}$

$3.458 \times 10^{-2} \frac{1}{k \omega h}$

all at 100\% load factor

AMP $307(2 / 78)$

PAge number R 

TITLERYPTON 85 ENCAPSULATION JOB NO. $6154-3$ DEPARTMENT. \begin{tabular}{|l|l|l|l|l|}
\hline AEV & CHECKEA & DATE & AEV & CHECKER \\
\hline
\end{tabular}

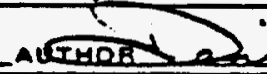

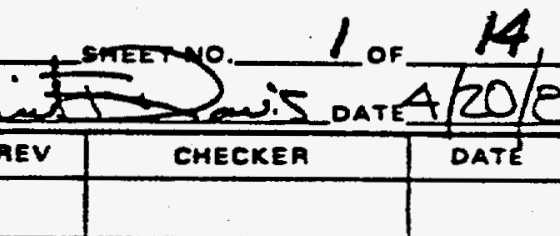

HOT ISOSTATIC PRESS

PHYSICAL DIMENSIONS

TOTAL VOLUME INSIDE PRESSURE VESSEL
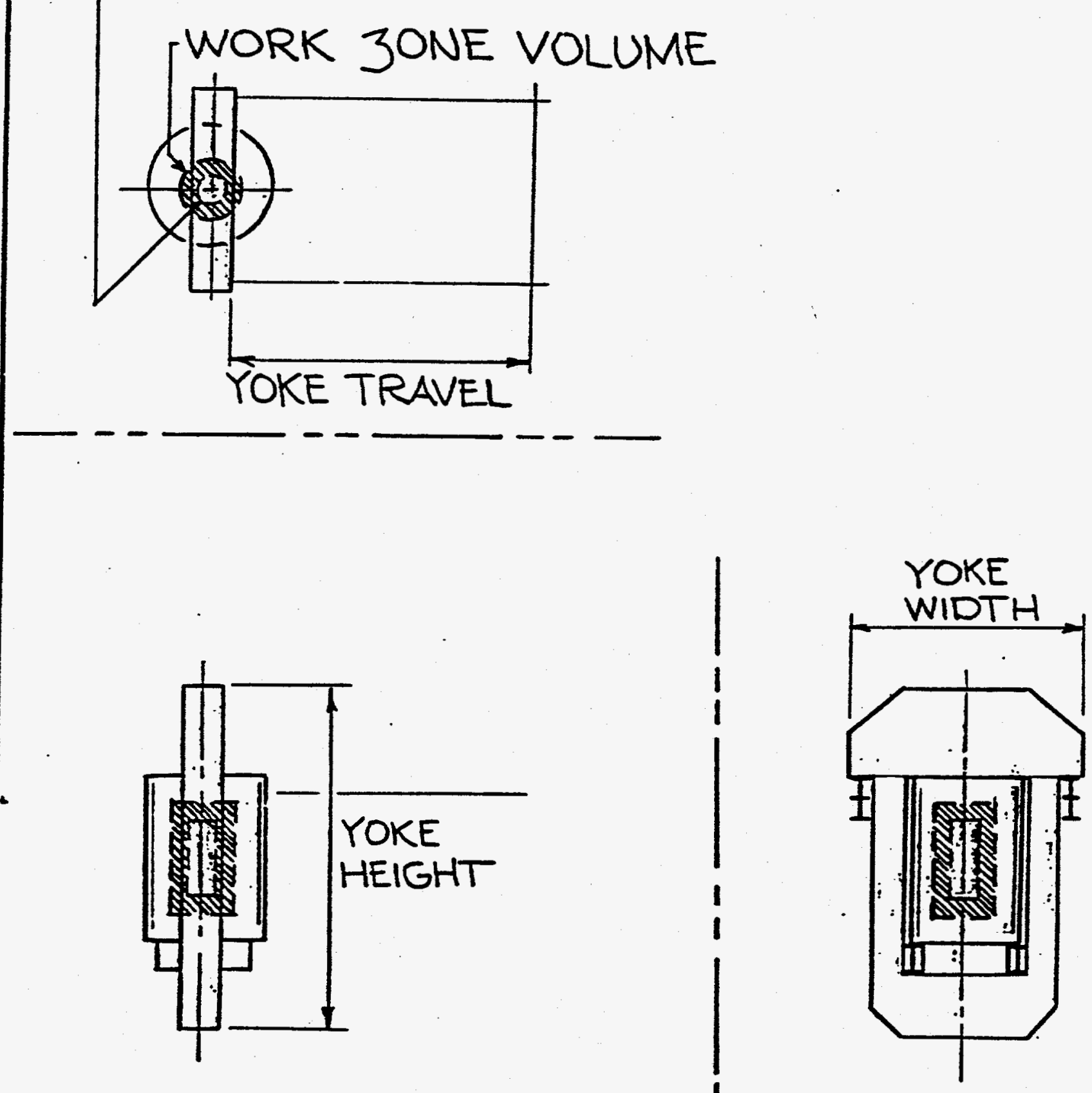


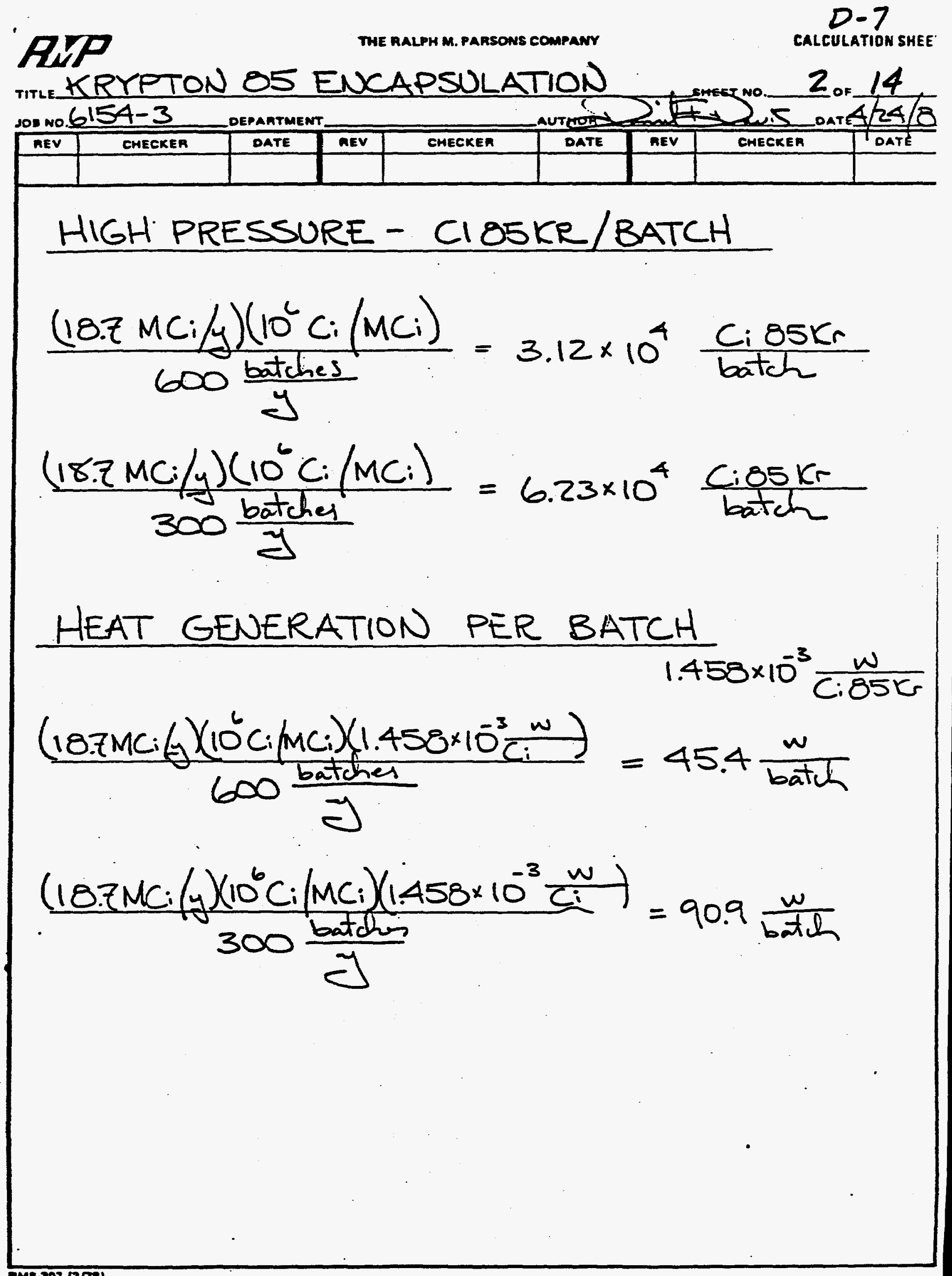


REP

THE RALPH M. PARSONS COMPANY

$D-7$ SETON 85 CAPSULATION

3 or 14

HIGH PRESSURE

VOLUME ENCAPSULATED PER BATCH

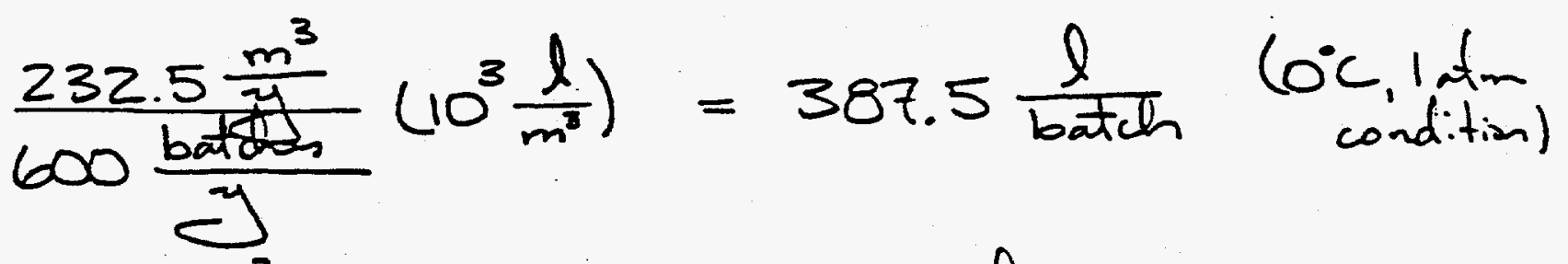

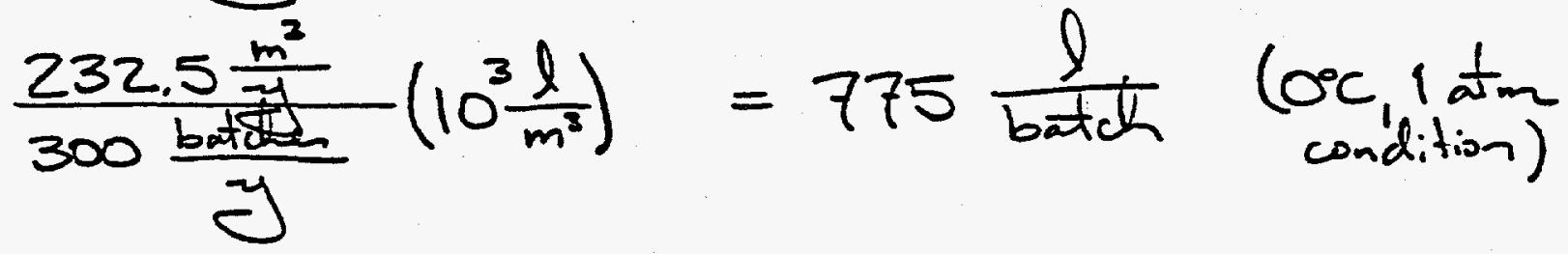

VOLUME GAS SUPPLIED PER

ENCAPSULATION BATCH

600 cycles /y 1000 atm, $700^{\circ} \mathrm{C}$

0.30 traction supplied is encapsulated ATTACHMENT 4, MINUTES OF MEETING KRYPTON OS ENCAPSULATION PRECONCEPTUAL DESIGN JOB NO 6154-3, APRIL 6,1981

$$
\begin{aligned}
& 0.30 S=387.5 \frac{l}{\text { batch }} \\
& S=1291.7 \frac{l}{\text { batch }}
\end{aligned}
$$




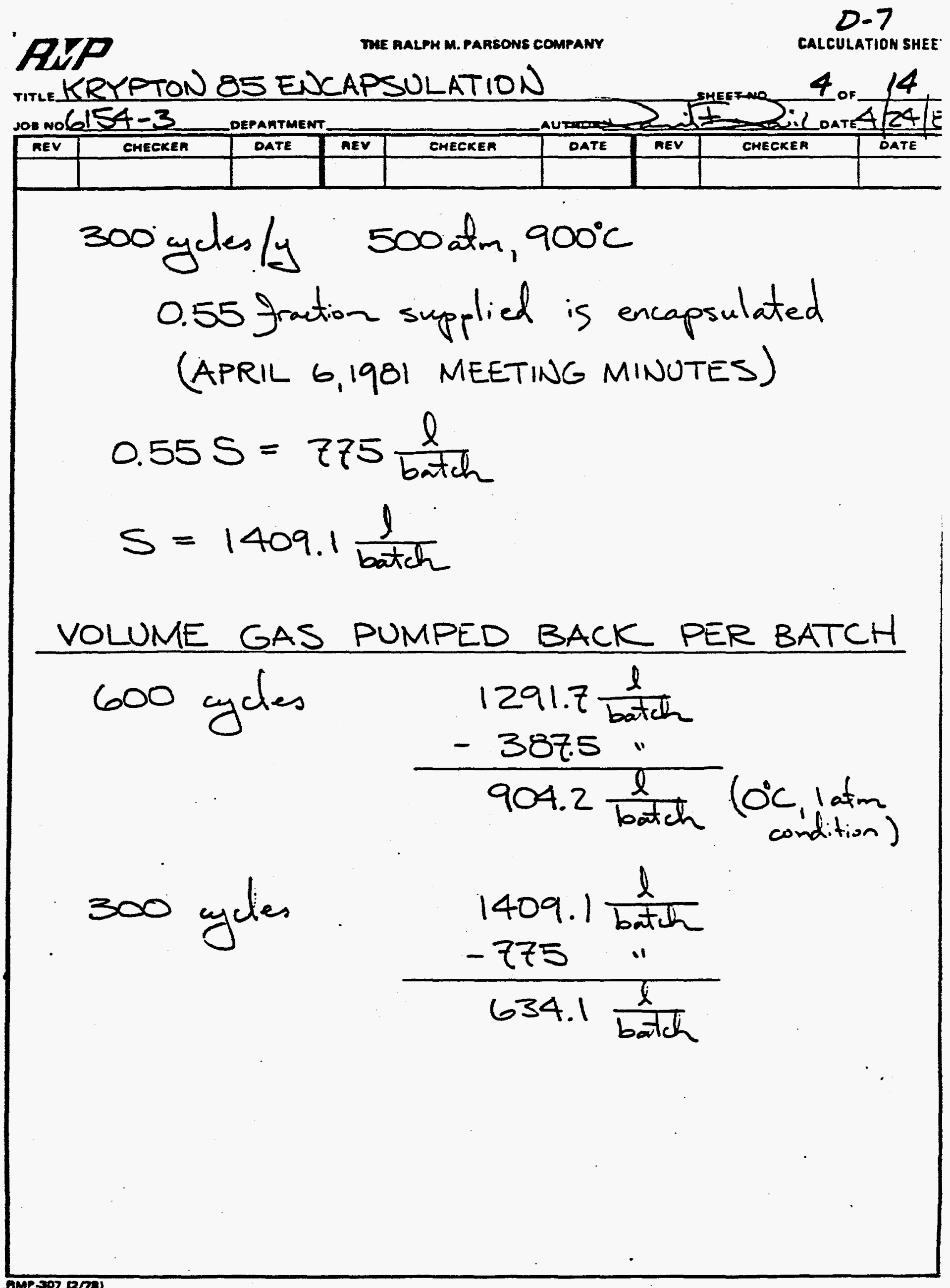




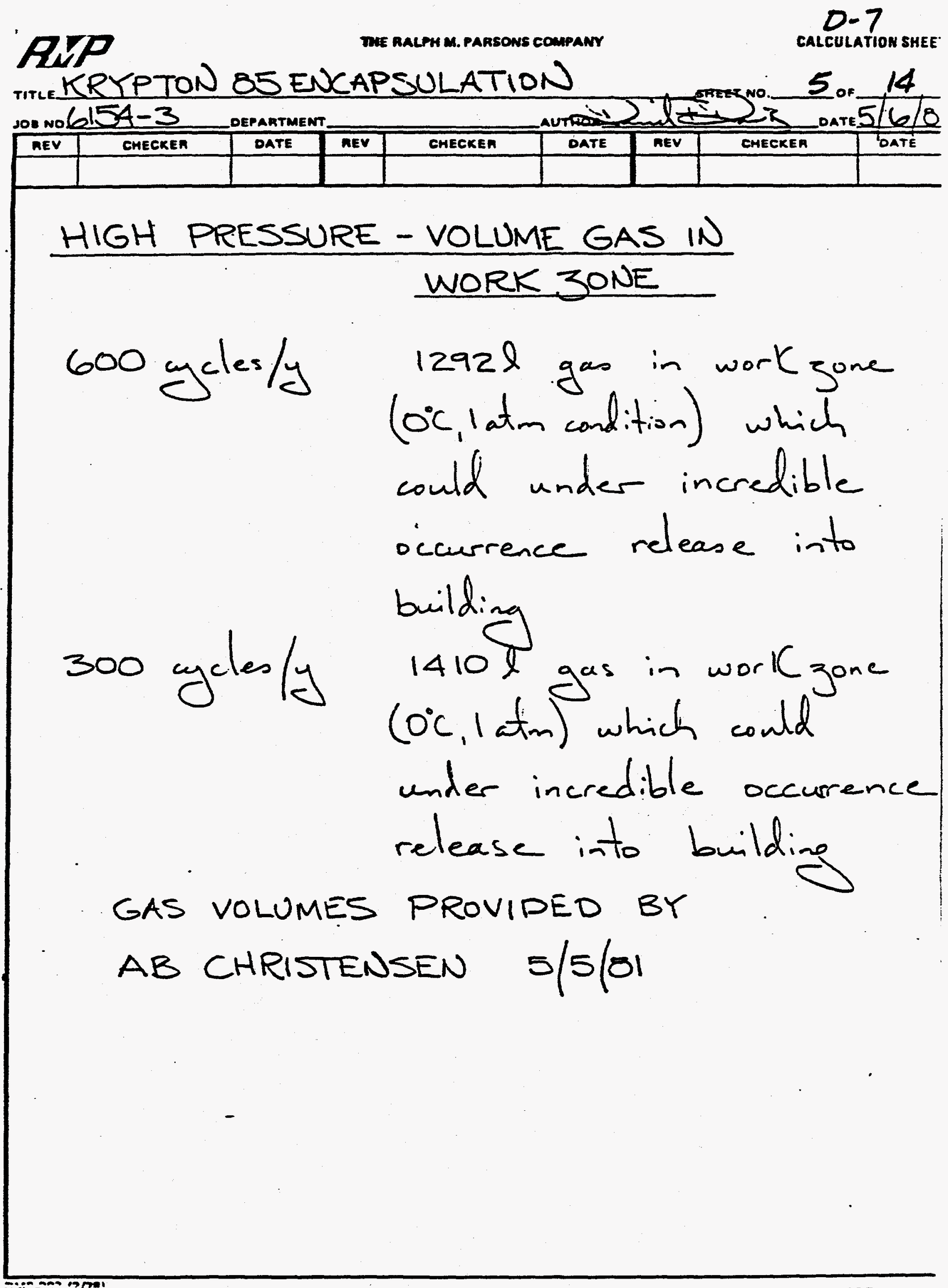




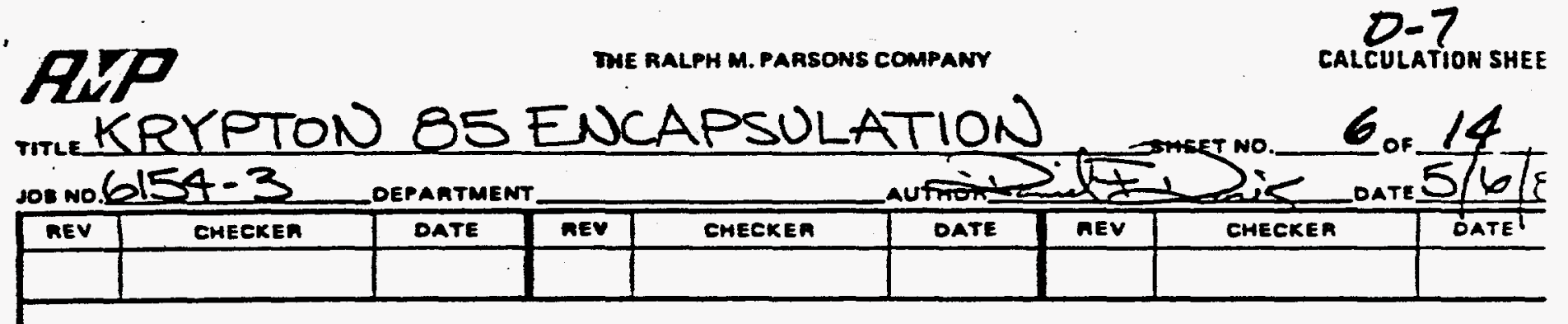

HIGH PRESSURE - VOLUME GAS IN VOID VOLUME

This is gas which provides isostatic pressure

600 ycles/y 58481 gas in void. volume ( $0^{\circ} \mathrm{C}, 1$ atm condition) which could under incredible occurrence release into building

300 cycles /y $7700 \mathrm{l}$ gas in void volume $\left(O^{\circ} \mathrm{C}\right.$, I atm condition) which could under incredible occurrence release into building

GAS VOLUMES PROVIDED BY $A B$ CHRISTENSEN $5 / 5 / 81$ 


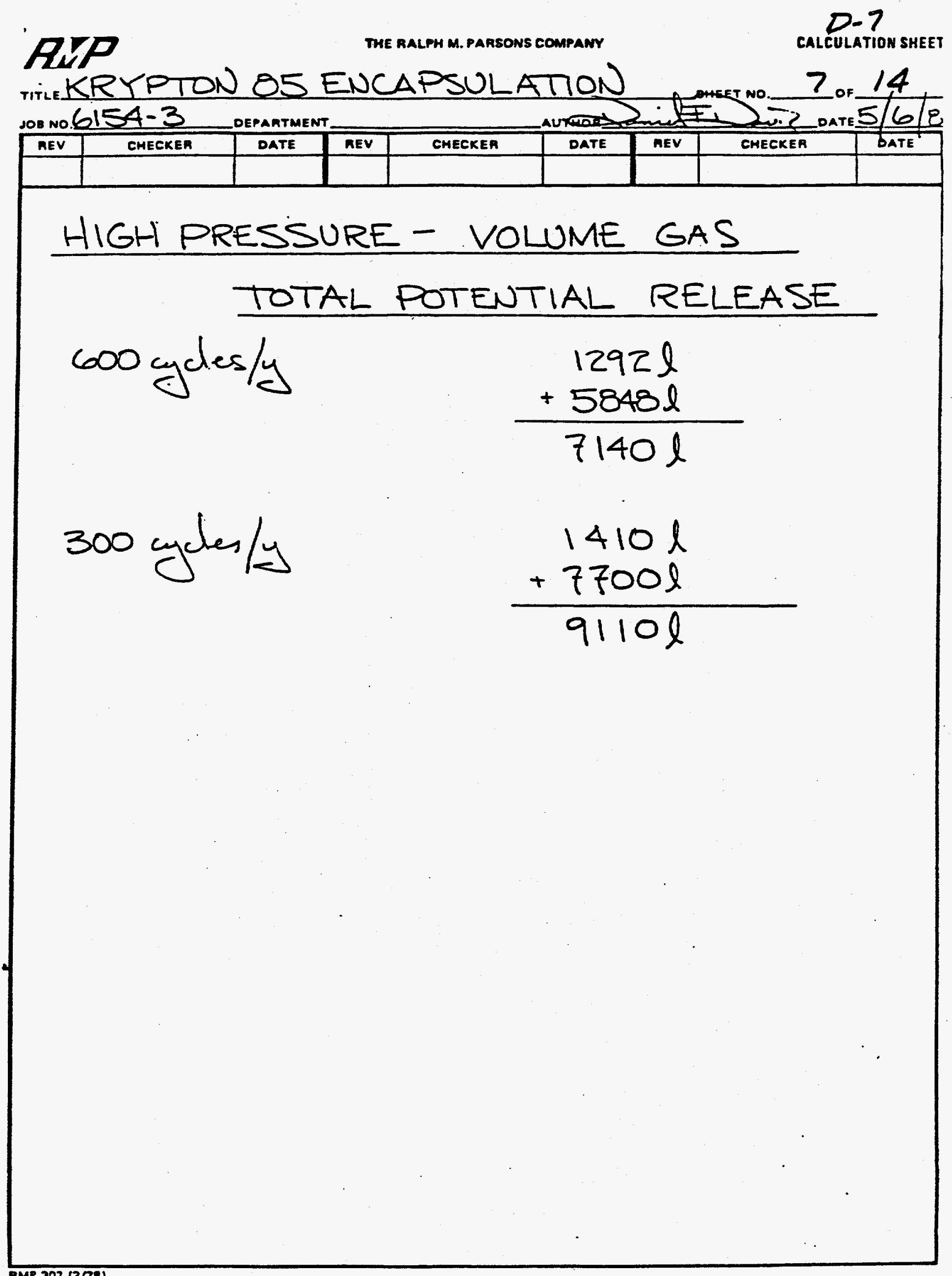




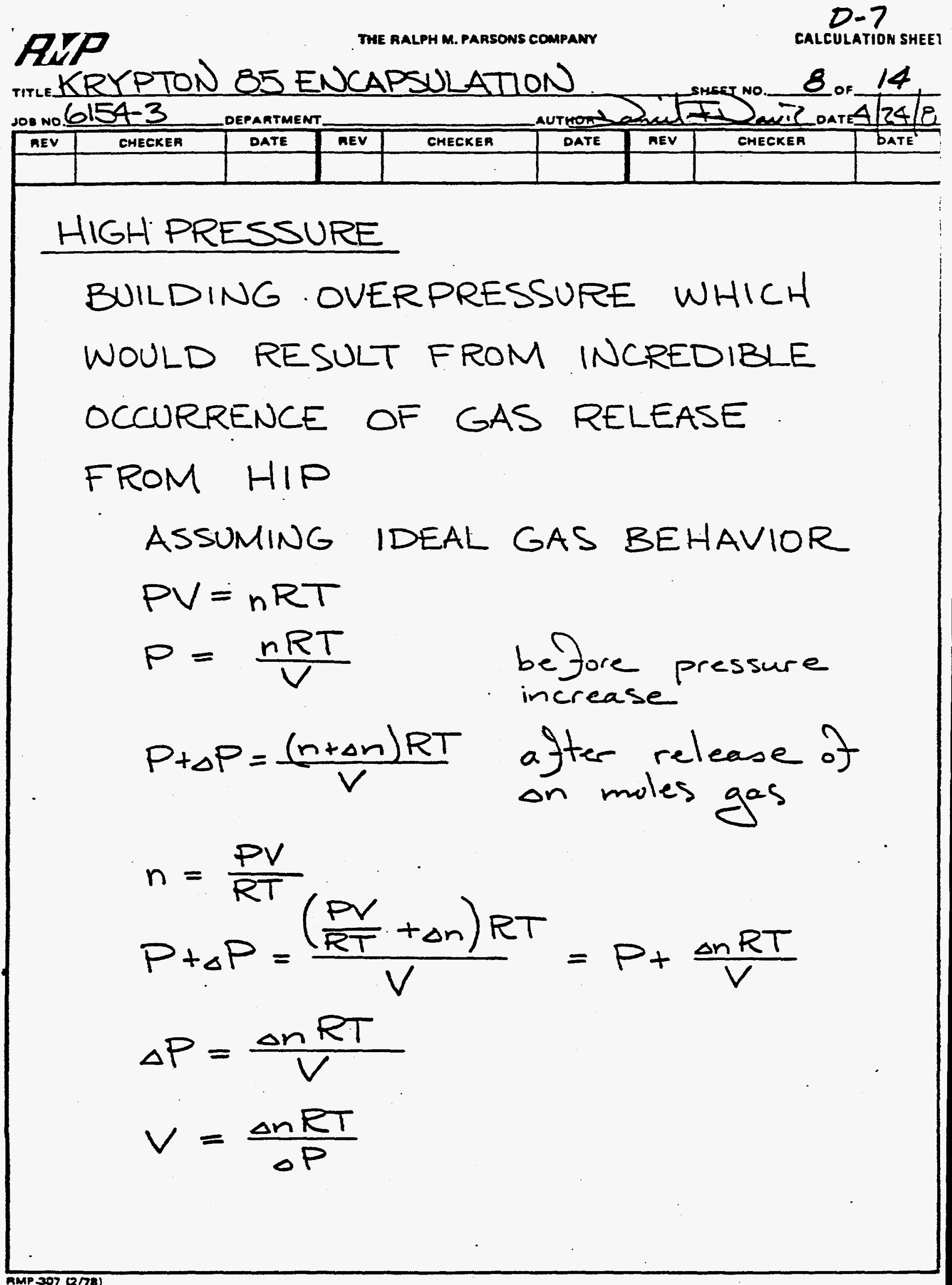




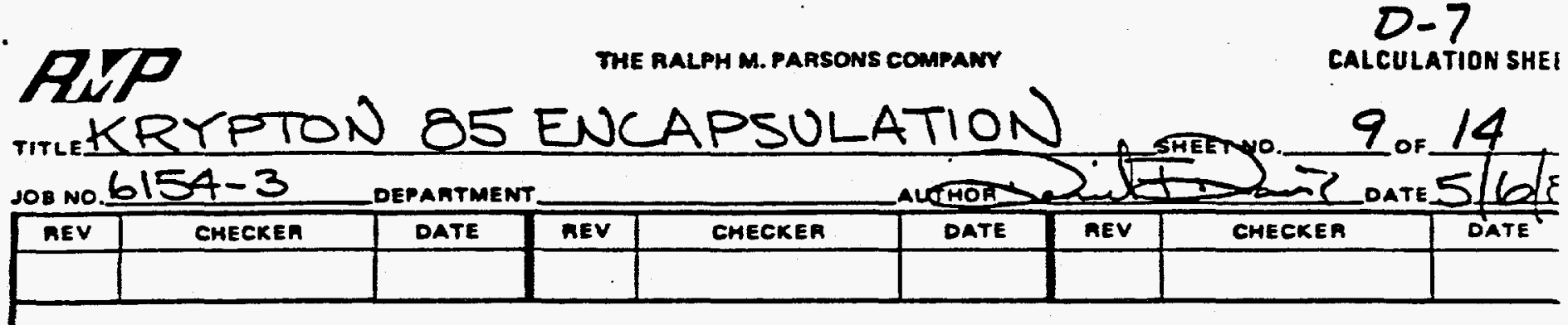

$$
\begin{aligned}
& 600 \text { cycles/y. F140l }\left(0^{\circ} \mathrm{C},\right. \text { lat) gas } \\
& \Delta n=\frac{7140 \mathrm{l}}{22.41 \mathrm{l} g \text { mote }}=319 \mathrm{gmoles} \\
& R=0.08205 \frac{\mathrm{atm} l}{\mathrm{gmule} \mathrm{L}^{\circ}} \\
& \text { ASSUME before pressure increase } \\
& T_{n} \quad n \text { moles at } 290^{\circ} \mathrm{K}\left(25^{\circ} \mathrm{C}\right) \\
& T_{\text {on }} \text { on moles at } 973^{\circ} \mathrm{K}\left(700^{\circ} \mathrm{C}\right) \\
& C_{p}=\text { constant } \\
& \text { NOTE: THIS } \\
& n C_{p}(T-298)=\triangle n C_{p}(973-T) \text { ASSUMES GAS } \\
& \text { EXPANDED FROM } \\
& T=\frac{298 n+973 \Delta n}{n+\Delta n} \\
& \text { AT ZOOm } \\
& n=\frac{P V}{R T_{n}}=\frac{(1) \mathrm{V}}{(0.08205)(298)}=0.0409 \mathrm{~V} \\
& T=\frac{12.19 V+973 \Delta n}{0.0409 V+\Delta n}
\end{aligned}
$$




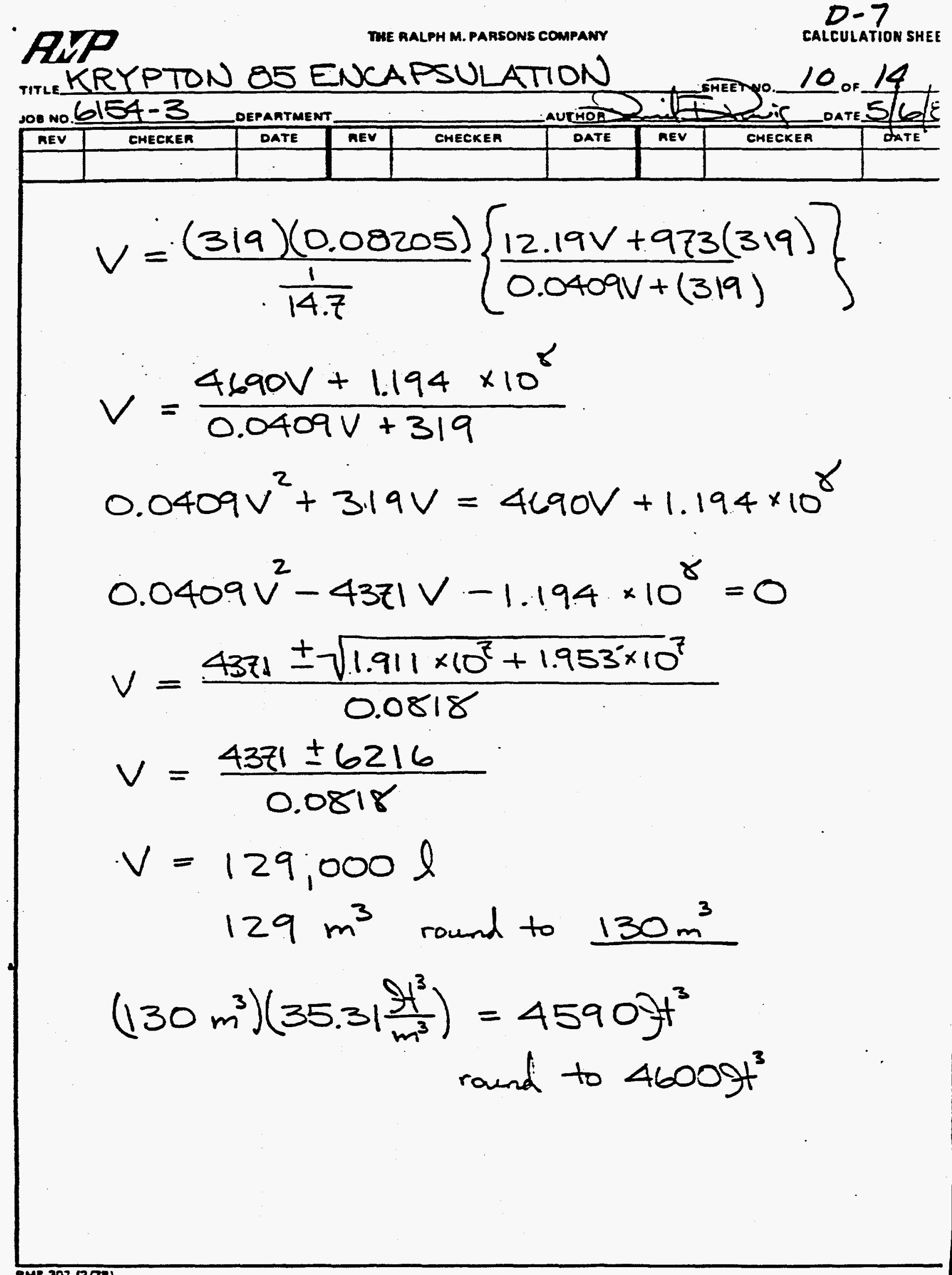




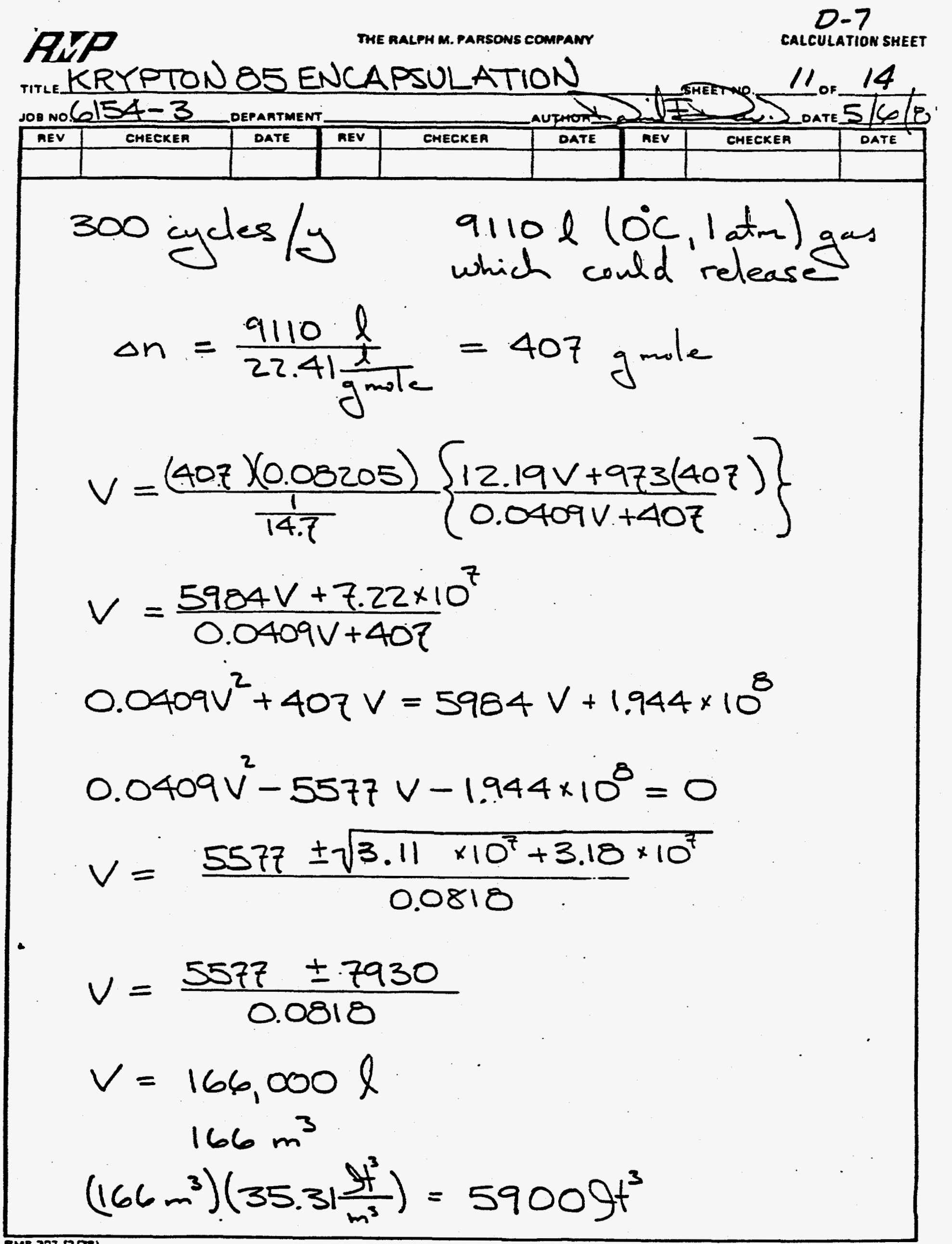




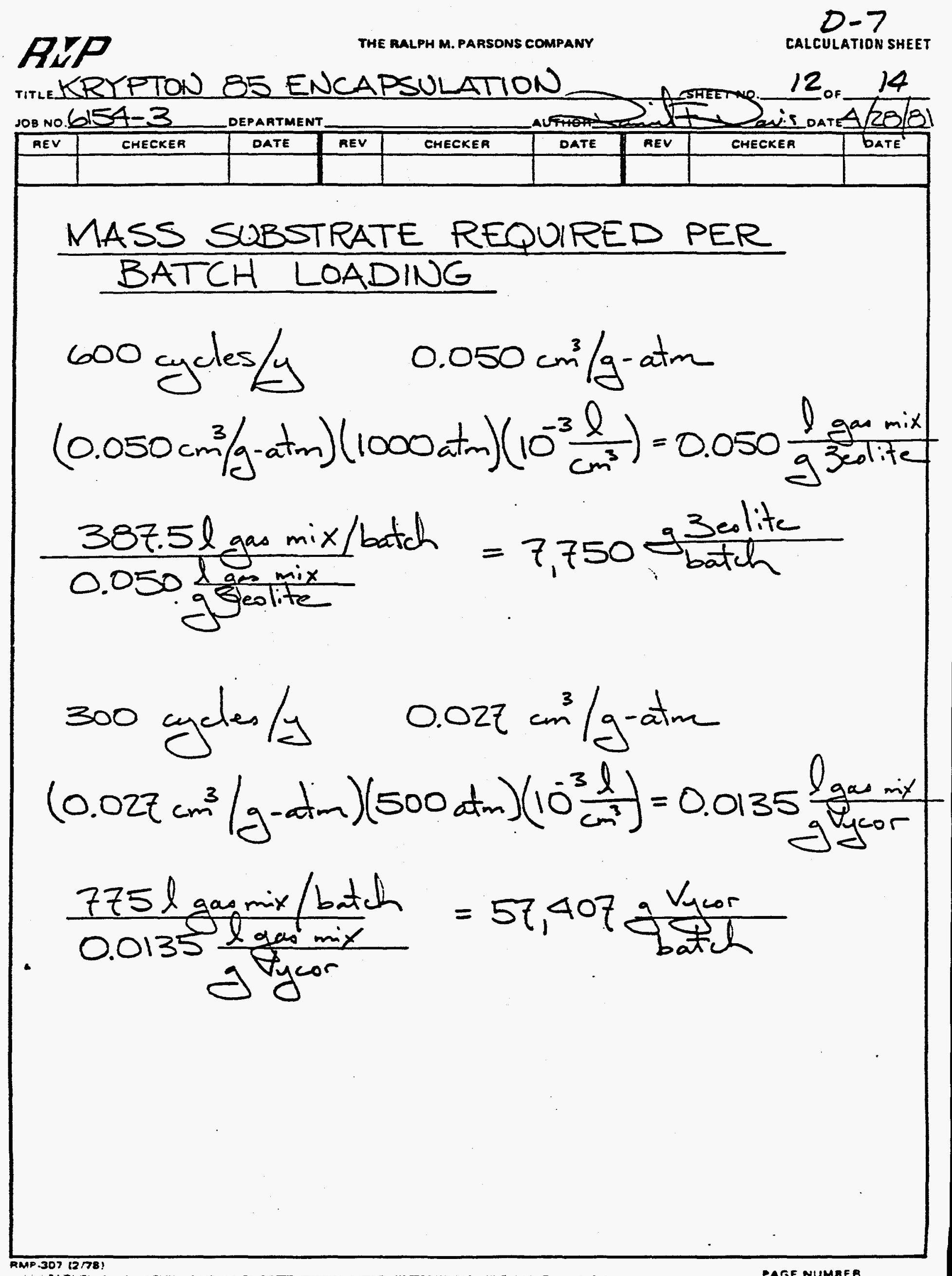




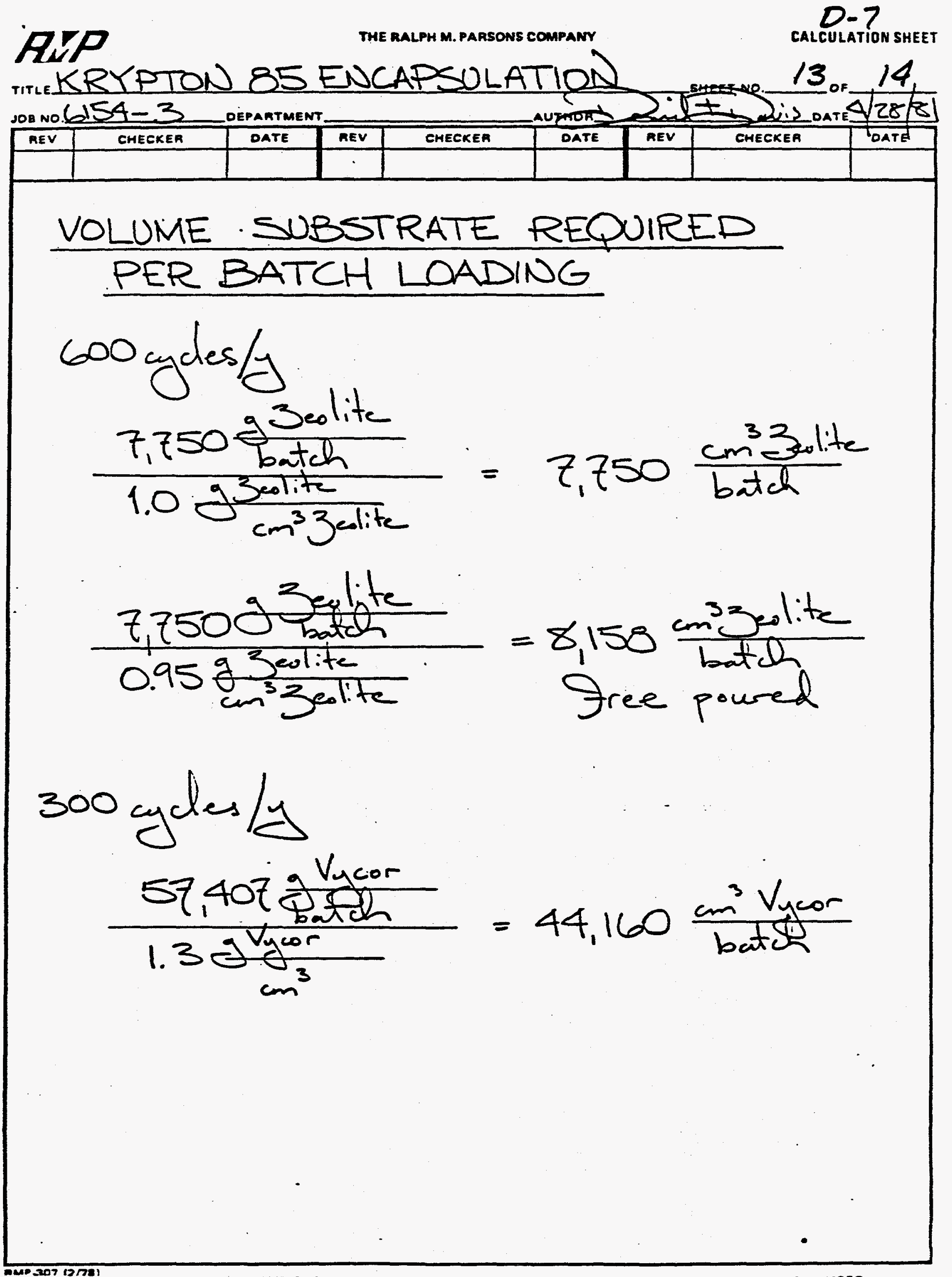




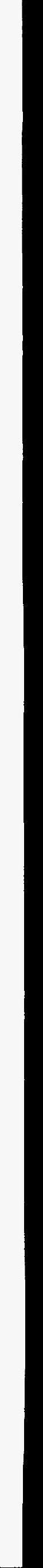




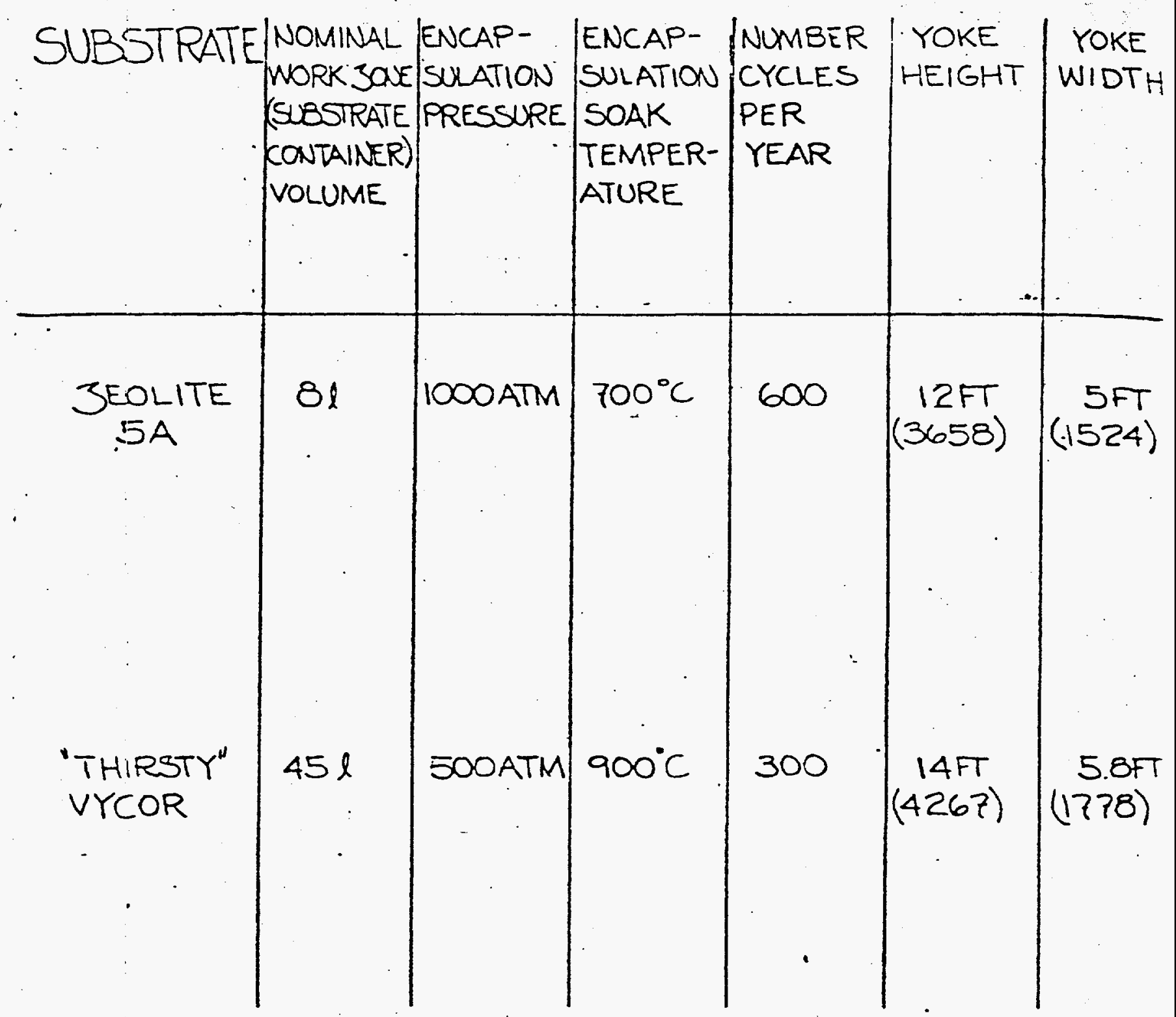

2 PRESSURE VESSEL INSIDE DIMENK CAPSULE, FURNACE, HEAT SHIELD SUCH THAT NOMINAL TOTAL VOLUME FILLED WITH GAS 



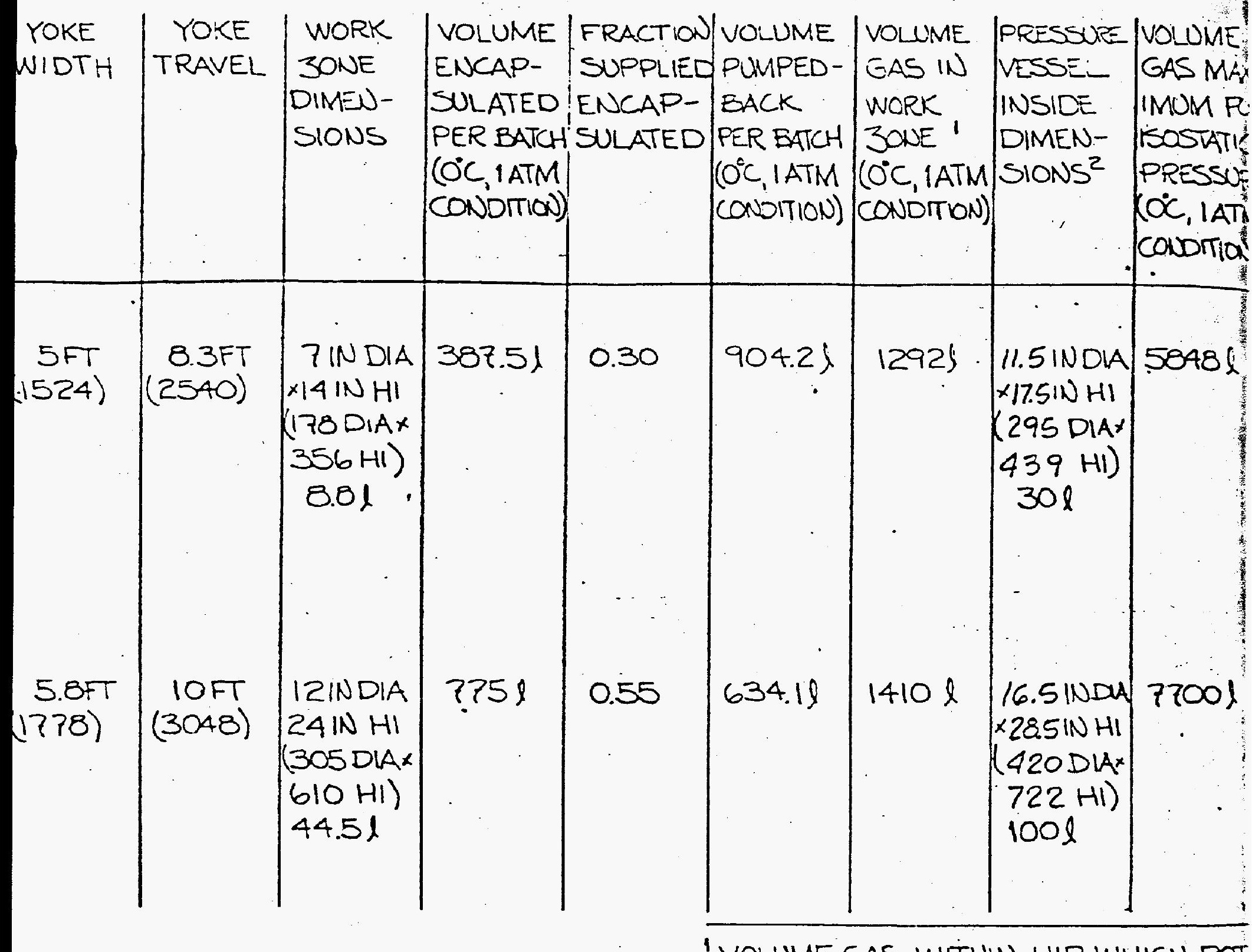

DIMENSIONS ARE OCCUPIED BY HELD $\dot{E}$ INTERNAL FEATURES PLUME IS ONLY PARTIALYY
'VOLUME GAS WITHIN HIP WHICH POT 3 VOLUME GAS WITHIN HIP WHICH IS 4 WORK 3 ONE PLUS VOID VOLUME GAS 5. VOUME OF BUILDING WHICH WOULC 14.7 PSIA TO 15.7 PSIA IN EVE ${ }^{\circ} \mathrm{CM}^{3}$ FEED EXPRESSED AT $0^{\circ} \mathrm{C}, 1$ 



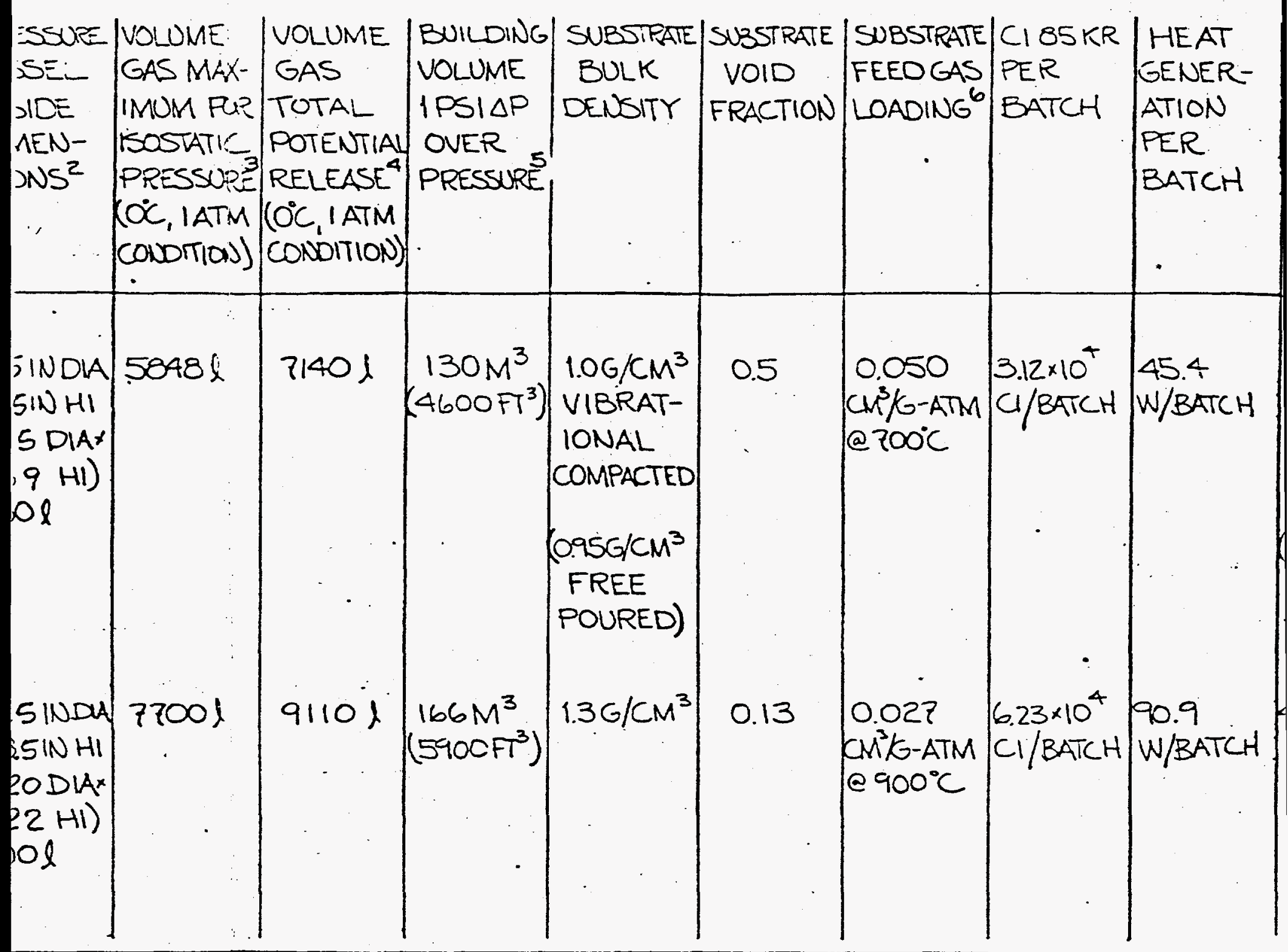

HIP WHICH POTENTIALLY COULD RELEASE FROM WORK $3 O N E$ HIP WHICH IS PROVIDING ISOSTATIC PRESSURE ID VOLUME GAS WHICH POTENTIALLY COULD RELEASE: WHICH WOULD INCREASE IN STATIC PRESSURE FROM ? PSIA IN EVENT OF HIP TOTAL POTENTIAL RELEASE SLD AT OC, IATM CONDITION

DESIGN PARAMETERS

PRECONCEPTUAL DESIGN 85 KRYPTON ENCAPSULA HIGH. PRESSURE 6154-3 5/6/8 



$$
\begin{aligned}
& \text { 18)9/s } \\
& \exists \text { Jans } \\
& \text { Nol } \forall \forall \text { TnSd } \forall \\
& \text { NDIS3O } \\
& \text { Sd } \exists \perp \exists W
\end{aligned}
$$

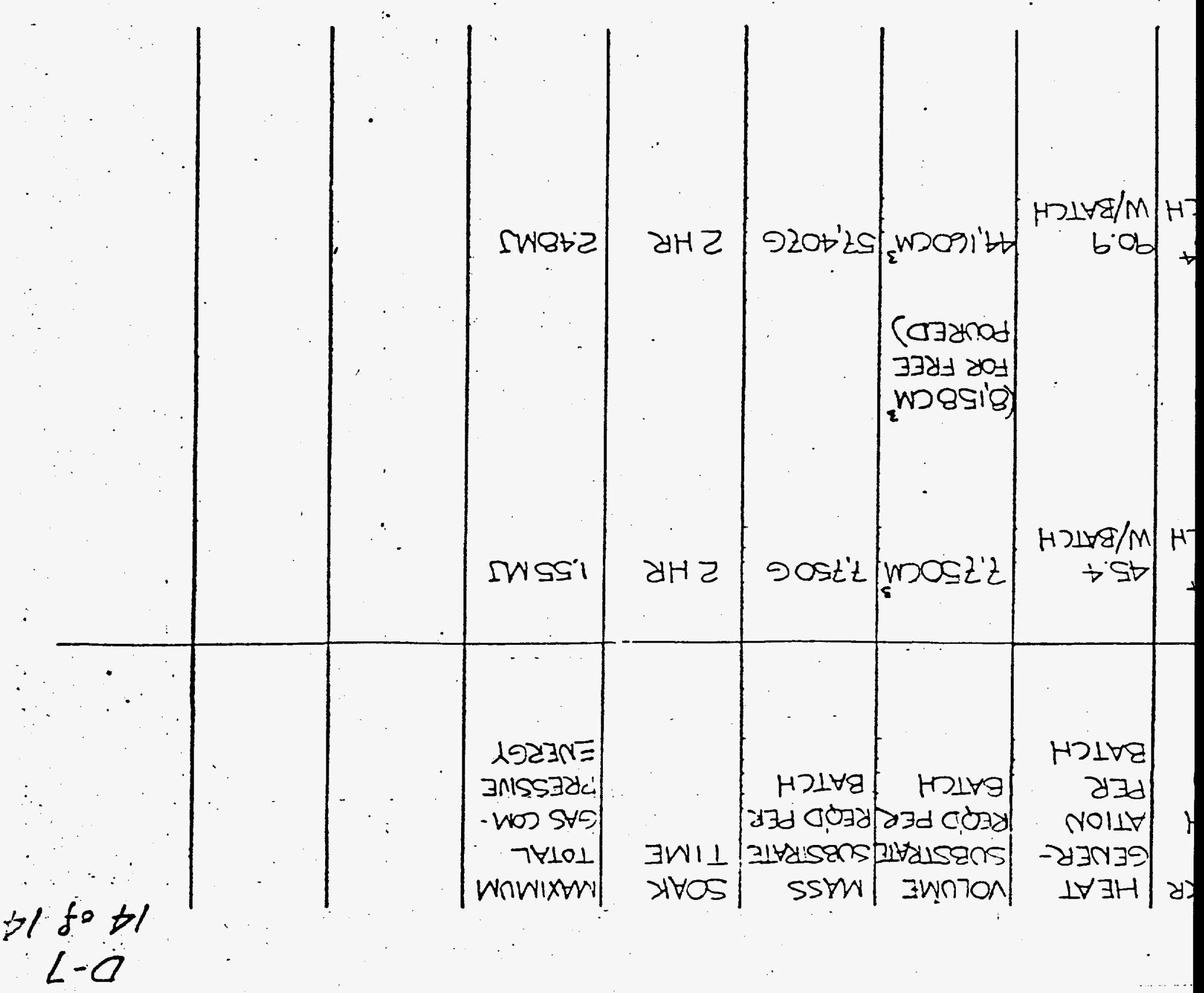





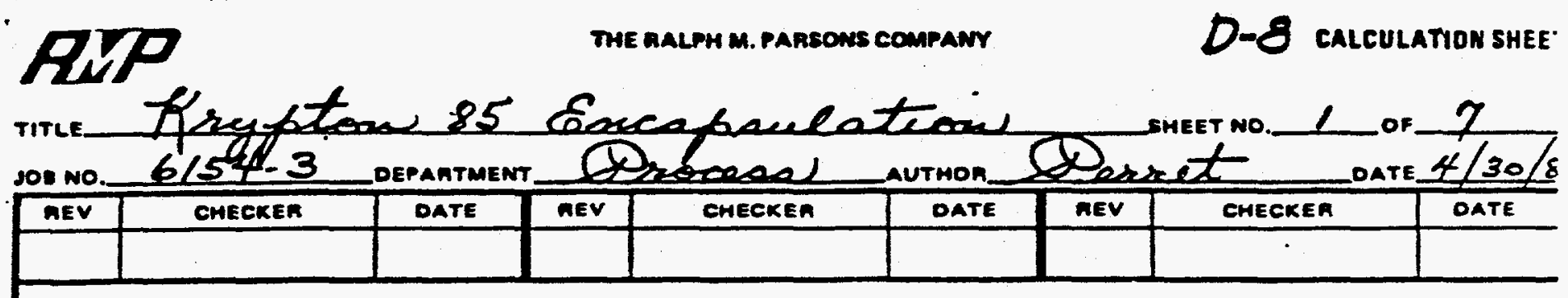

Calculations for I year Product Storage

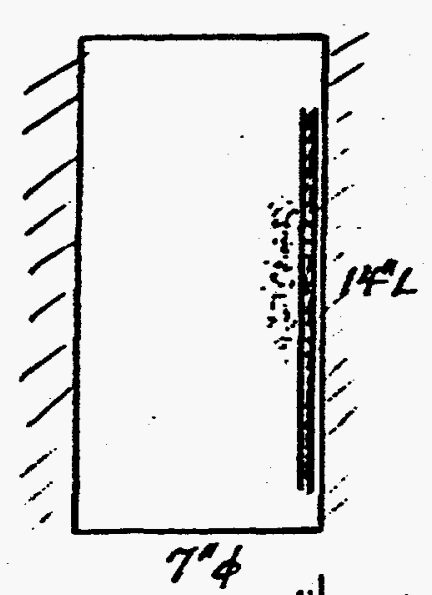

For 600 unite fer year case of to (high pressure) necapacalation in zeolite, the working wolver is given as $7 " \phi \times 14$ "high Assume a "/ i"gap between canned substrate

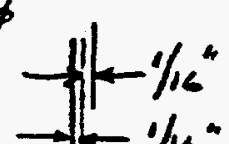
and ard walls, and " $/ 16$ " walls for caw.

$\rightarrow-1 / 16$

$$
\begin{aligned}
\therefore 0.0 \text {. of can } & =7.000-2(.0625)=6.875^{\prime \prime} \\
& \text { x.0. of can }=6.875-2(.0625)=6.750^{\prime \prime}
\end{aligned}
$$

$\begin{aligned} \text { contained vol. }=\frac{4.75^{2} \pi}{4} \times 19.75^{\prime \prime} & =492 \mathrm{in}^{3} \\ & =8.063 \mathrm{~L}\end{aligned}$ to contain $7.750 \mathrm{~L}$ of zeolite.

For a $1 / 1$ "wall of 304 ss., $6.875^{\circ} 0.0$. E $400 \%$, A.W.P $=173$ \% choose a standard pipe size and a minisicem gap for an "over pack". Std type minimizes cost, menimiem gap meniminged $\Delta T$ arose the gas gap. Using an $8^{\prime \prime}$ sch 120 over pack 8.625"0.0. $\times 7.187^{\prime \prime} 7.0$, $60.7 \mathrm{lbs} / \mathrm{At}$ of bough, howe

$$
\frac{7.187-6.875}{2}=0.156^{\circ} \mathrm{gop}
$$


ALP

THE RALPH M. PARSONS COMPANY

0.8

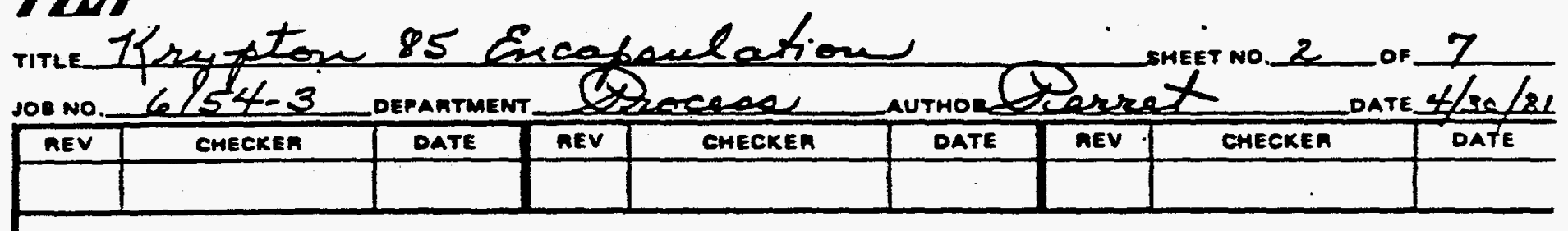

For pure conduction: $\frac{k}{L} \Delta T=\frac{\dot{Q}}{A}$

avi e $300^{\circ} \mathrm{F} \quad k=0.019 \mathrm{BTH} / \mathrm{he}-\mathrm{AH}-\mathrm{F}$

then $\frac{h}{L}=0.019 \times \frac{12}{0.156}=1.46 \frac{\text { ATufhe }}{H^{2.6}}$

For 600 cans fer year:

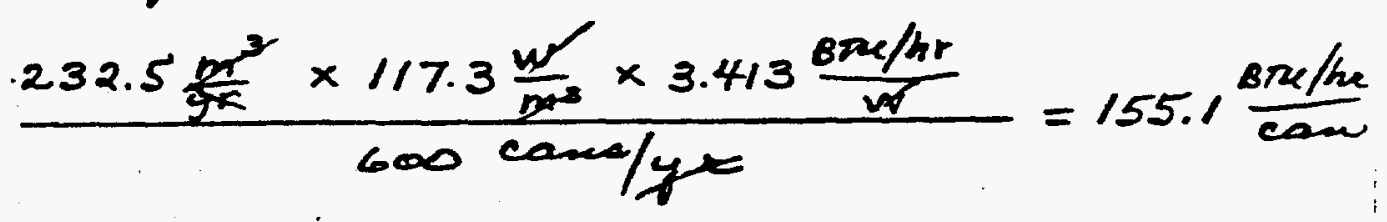

Unrig the curved surface org:

$$
\begin{aligned}
& \bar{A}=\pi \bar{D} L=\frac{\pi \times 6.9 .3^{4} \times 18.875^{\circ}}{144}=2.10 \mathrm{~A}^{2}
\end{aligned}
$$

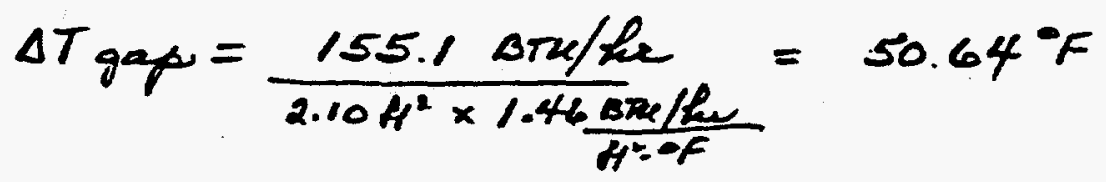

$$
\begin{aligned}
& \bar{D}=7.884
\end{aligned}
$$

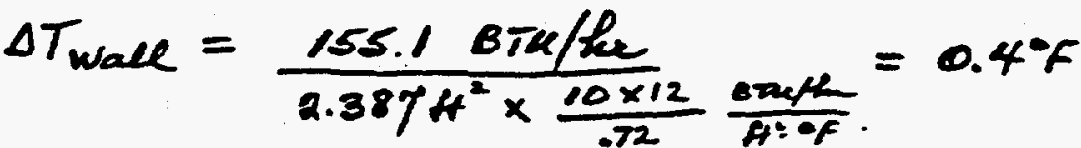

$$
\begin{aligned}
& \Delta T_{0}=\frac{\dot{Q}}{A k_{c}} \simeq \frac{1551}{2.61 \times 0.9}=16.0{ }^{\circ} \mathrm{F}
\end{aligned}
$$

for grave Tax center here of $300 \mathrm{C}=572^{\circ} \mathrm{F}$

and air $Q 120^{\circ} \mathrm{F}$, total max $\Delta T=452^{\circ} \mathrm{F}$; the total

from above $=117^{\circ} \mathrm{F}=26 \%$ of allowable which

appears reasonable for concentre darin fending 
ARP

THE RALPH M. PARSONS COMPANY

D.8

True Krypton 85 Encapsulation

\begin{tabular}{l} 
jo l no. \\
\hline nev
\end{tabular}

further definition of $\Delta T$ throng zeolite matrix.

To minimize stage of pace consider en array

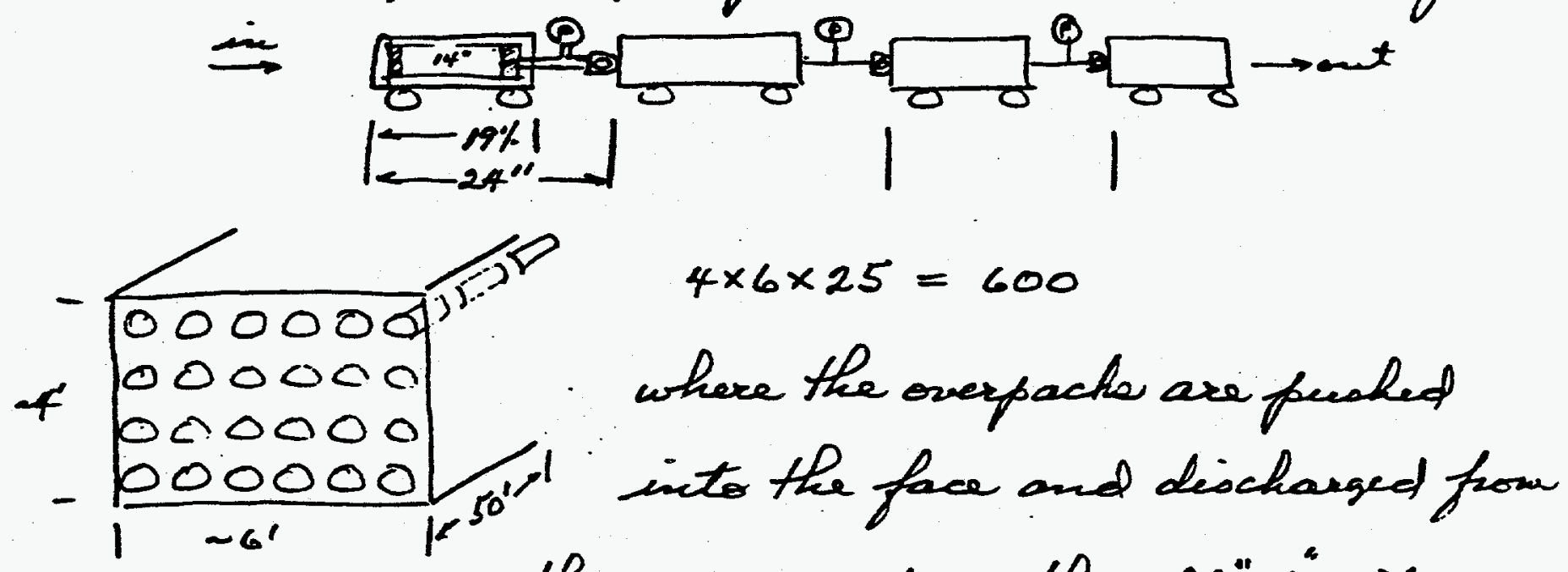

the rear mech as the old" $X$ " file.

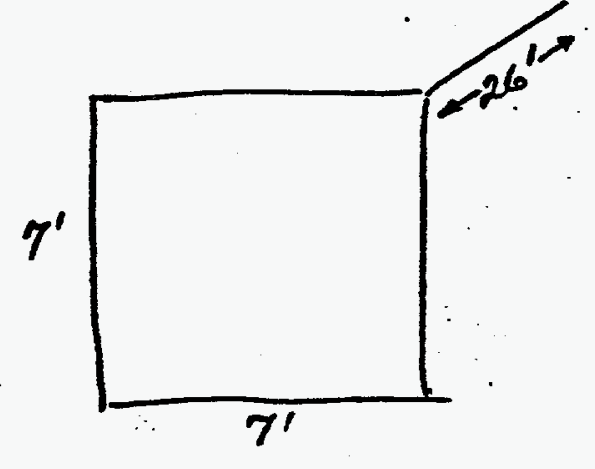

- RACK DIMENSIONS alternately for mos cong act where:

$7 \times 7 \times 13=637$ units

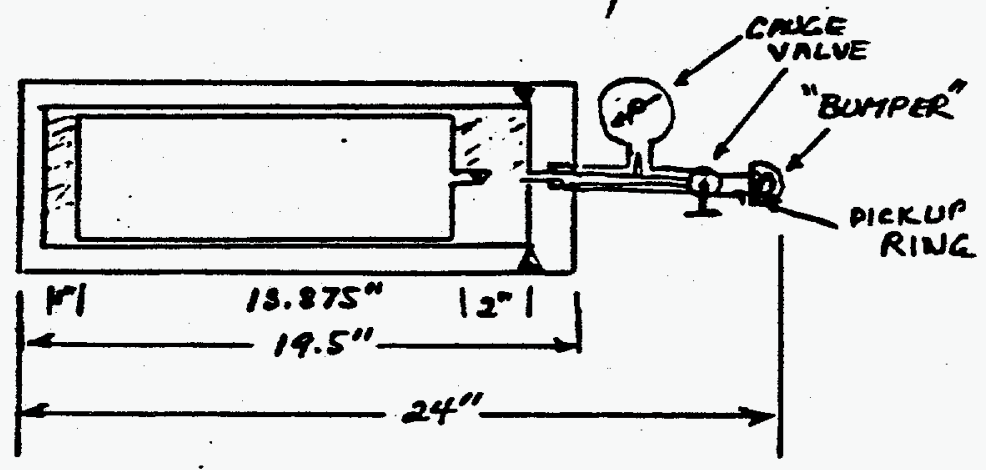

a sch $120-8^{\prime \prime}$ pee of 304 ss e $200^{\circ}$ F has A.W.P. $=3700$ psi

check on ascempition th $\approx 0.9$ :

From calces for log stage $\&_{2}=\frac{g\left(\frac{T_{s}-T_{\infty}}{T_{00}}\right) L^{3} \rho^{2}}{\mu^{2}}$ 
RIP

THE RALPH M. PARSONS COMPANY

vo

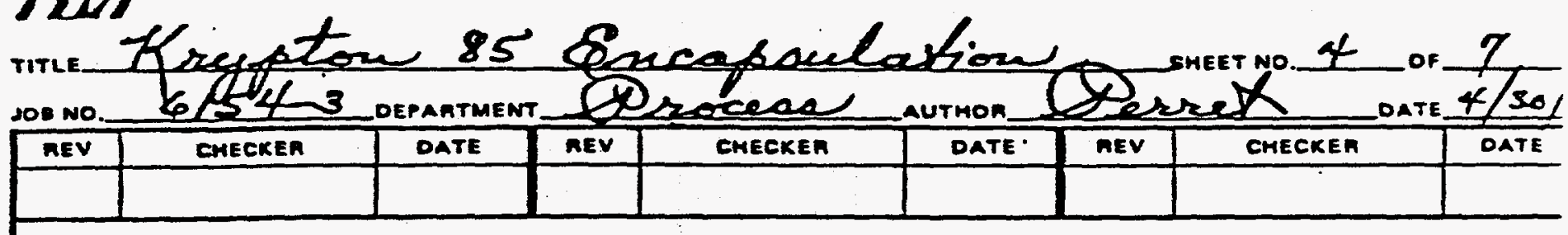

only $T_{s}$ and $T_{\infty}$ and $L=D$ change.

Becanar of large total heat load assume to\% reseniair, $100^{\circ} \mathrm{F}$ to $140^{\circ} \mathrm{F}$ for $\bar{T}_{\infty}=120^{\circ} \mathrm{F}$

$$
\begin{aligned}
& k_{L}=\frac{32.2\left(\frac{66}{560}\right)\left(\frac{8.625}{12.0}\right)^{3}(.0808)^{2}}{(.0183 / 1488)^{2}}=.061 \times 10^{9} \\
& N_{\mu}=0.47(80.78)=37.96 \\
& h_{c}=\frac{.019 \times 37.96}{8.625 / 12}=1.0036
\end{aligned}
$$

Since $h>h$ (sands), correct $T_{s}-T_{0}=66, h \infty \Delta T^{1 / 4}$

$$
\begin{aligned}
& h_{c} \cong 0.97 \quad \Delta T \cong 61 \quad\left(\frac{61}{66}\right)^{1 / 4} \times 1.0036=0.985 \\
& \Delta T=60.3 \mathrm{~V}
\end{aligned}
$$
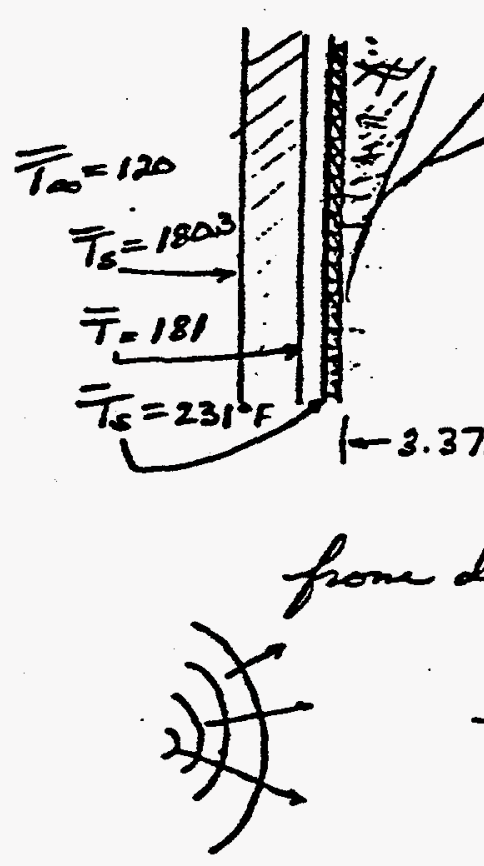

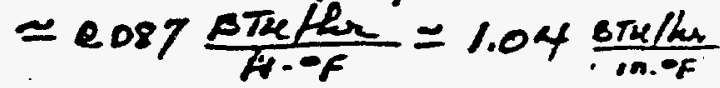

$$
\begin{aligned}
& \frac{Q}{A}<3.375=155.1 / 2.025=76.6 \text { sid } 35.45 \\
& =55.3\left\{\begin{array}{l}
41 \\
42.7
\end{array}\right. \\
& \left.\left.\begin{array}{l}
=31.2 \\
=8.51
\end{array}\right\} \begin{array}{c}
42.7 \\
19.9 \\
42
\end{array}\right) \text { 作 }
\end{aligned}
$$


$D-8$

THE RALPH M. PARSONS COMPANY

calculation She

RIP

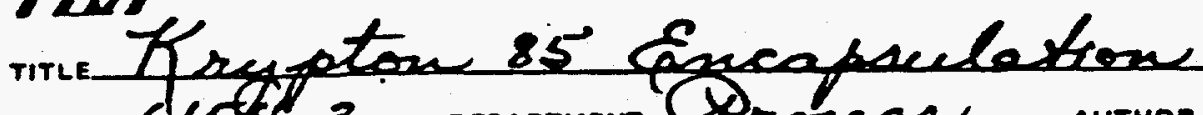

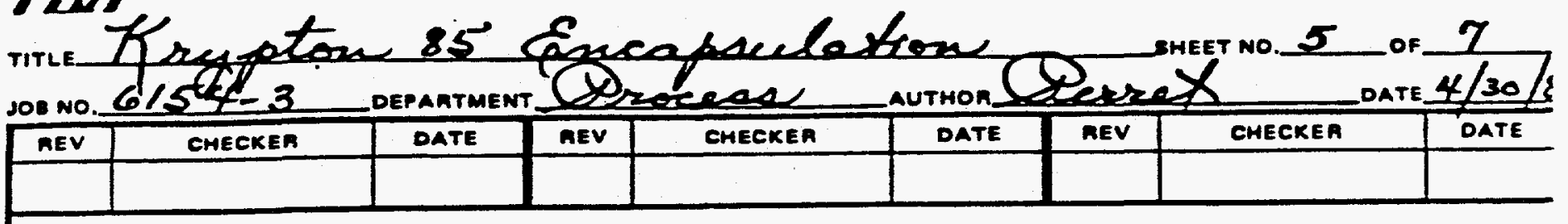

Tor 300 unite per year of "thirsty"

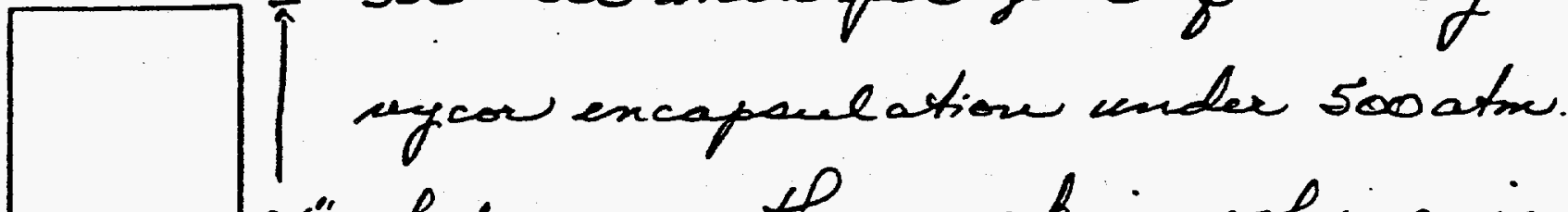
24 " of pressure, the working volume is given as $12 " \phi \times 24$ "dogs.

If in e assume a \%" gap for easy fit and a $1 / 8$ "wail for 100 psi differentiae, the interior volume is $12.00-2 / 10^{\prime \prime}-2 / 8 "=115 / 8 "$ " $2400-2 / 16-2 / 8=235 / 8$ " Long.

$$
v_{0} l=\frac{(115 / 8)^{2} \pi}{4} \times 23 / 8{ }^{\prime \prime}=2507.5 \mathrm{in}^{3}=41.091 \mathrm{~L}
$$

since need $300 \times 44.16 \mathrm{~L}$ of pecos substrate, would need about 330 vessels.

Use 12.5" $\phi$ as work vol. interim $=12.50-3 / 8=12.125^{\prime \prime}$

$$
v e=2727.9 \mathrm{~min}^{3}=44.701 \mathrm{~L} \text {. just about bigenengh }
$$

for $44.16 \mathrm{~L}$ vyaor \& 300 unite.

For er pack was 14 " sch 80 fyi. (12.50"1.0.) for

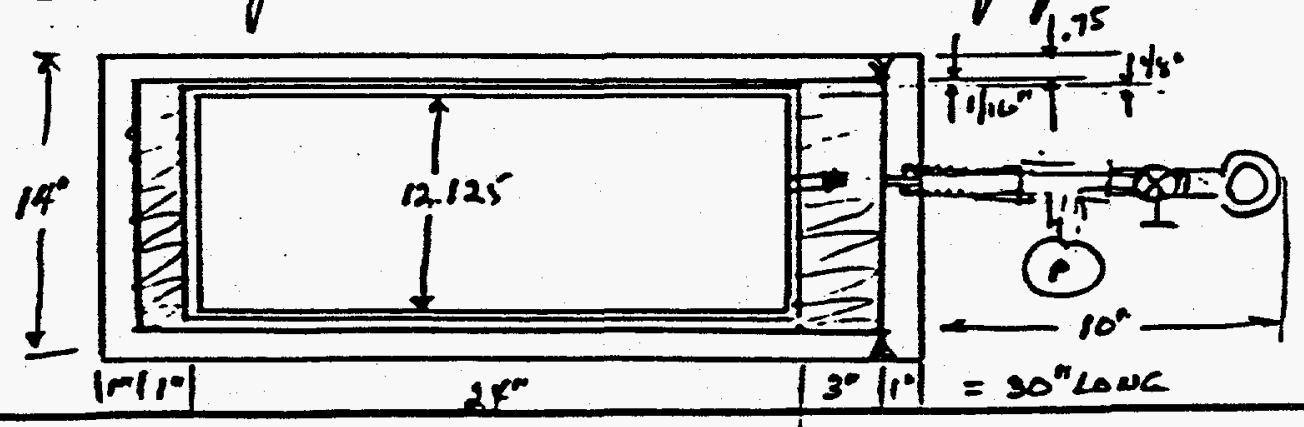


THE RALPH M. PARSONS COMPANY

$0-8$

CALCULATION SHEET

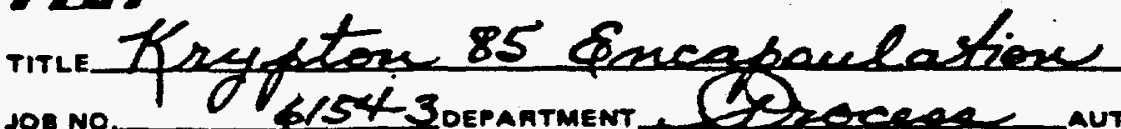

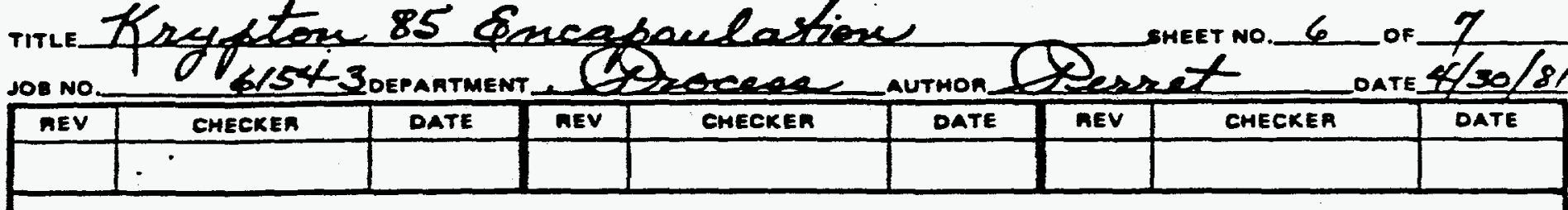

assume 18" on centers, $5 \times 5$ array $\times 12$ deep

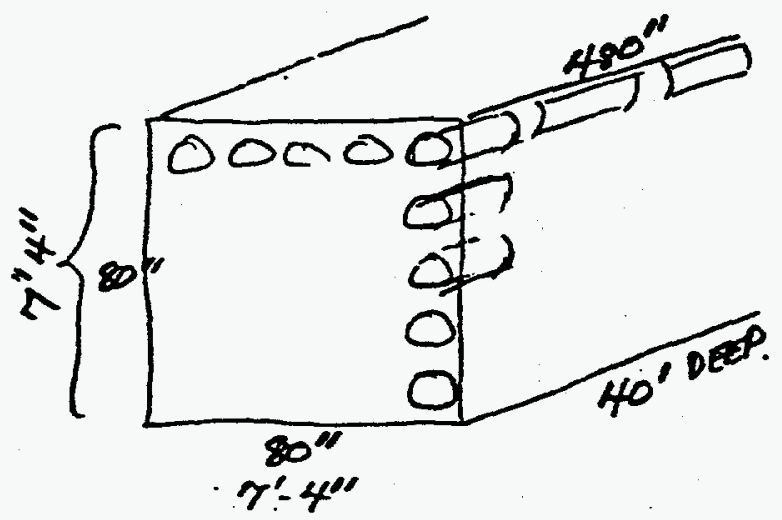

For 300 units hove $2(155.1)=310.2$ Bruter

$$
A_{s}=\pi D L=\pi(12.375)(13.875) / 144=6.446 \mathrm{AH}^{2} ; \dot{Q} / \mathrm{h}=48.1 \frac{\mathrm{sma}}{\mathrm{hrn}}
$$

This compares to $155.1 / 2.10=73.8 \frac{\mathrm{BT} / \mathrm{hr}}{\mathrm{H}^{2}}$ of case 1

$\therefore$ ale $\Delta T^{\prime}$ are proportionately reduced for the internal gas gap and the sue face film.

For the tamp rise in the matrix:

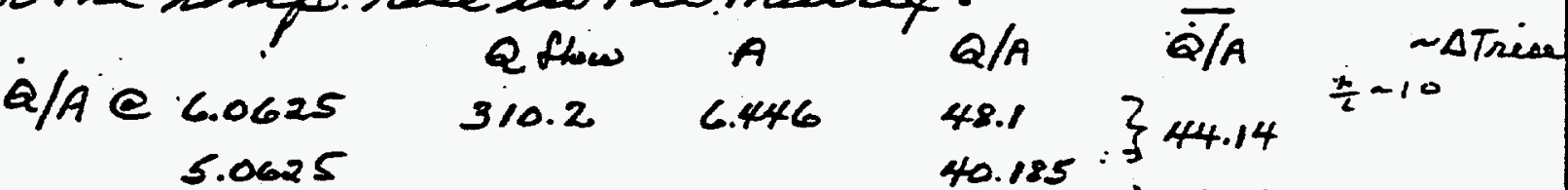

$$
\begin{aligned}
& 4.0625 \\
& 30625 \\
& 32.25\} 86.22 \\
& 2.0625 \text {. } \\
& 1.0625 \\
& .0625 \\
& \begin{array}{l}
24.31 \\
16.37\} 28.28
\end{array} \\
& \begin{array}{ll}
16.37 & \}_{2} \\
8.43 & 20.34 \\
\hline & 12.40
\end{array} \\
& \begin{array}{ll}
8.43 \\
0.496
\end{array} 4 \text { 4.5 } \\
& \Sigma=156^{\circ} \mathrm{F}
\end{aligned}
$$

$\therefore$ Both alternatives look feasible from thermal pewit of kew and it th differences in rescind storage volumes; then the on et difference 
RIP

THE RALPH M. PARSONS COMPANY

DD

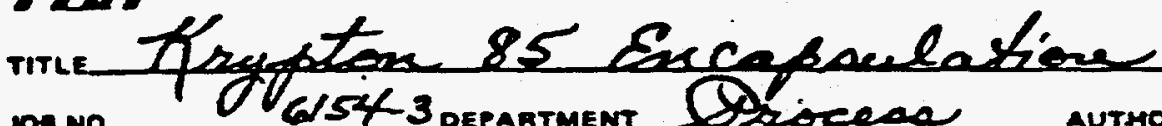

Calculation SHE E

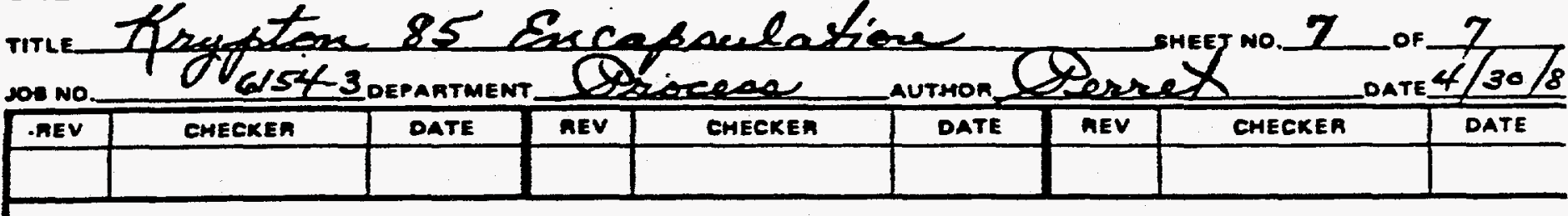

affects to lie in the no. of unite handled and the weights. Based on the preliminary design given above, the small unit weight abut $16516 \mathrm{~s}$ while the larger is aback $40016 \mathrm{~s}$. The effect on requires handling equipment meed to be evaluated.

In either case, for a Hoof tengeratere rise $\dot{W}=\frac{\dot{Q}}{c_{0} \Delta T}=\frac{5 \times 186 / 5}{(0.25)(40)}=2.5 \times 3723 \mathrm{lb} / \mathrm{hr}$ $=1920 \mathrm{ctm}$

to be supplied to the storage area.

$g$ 



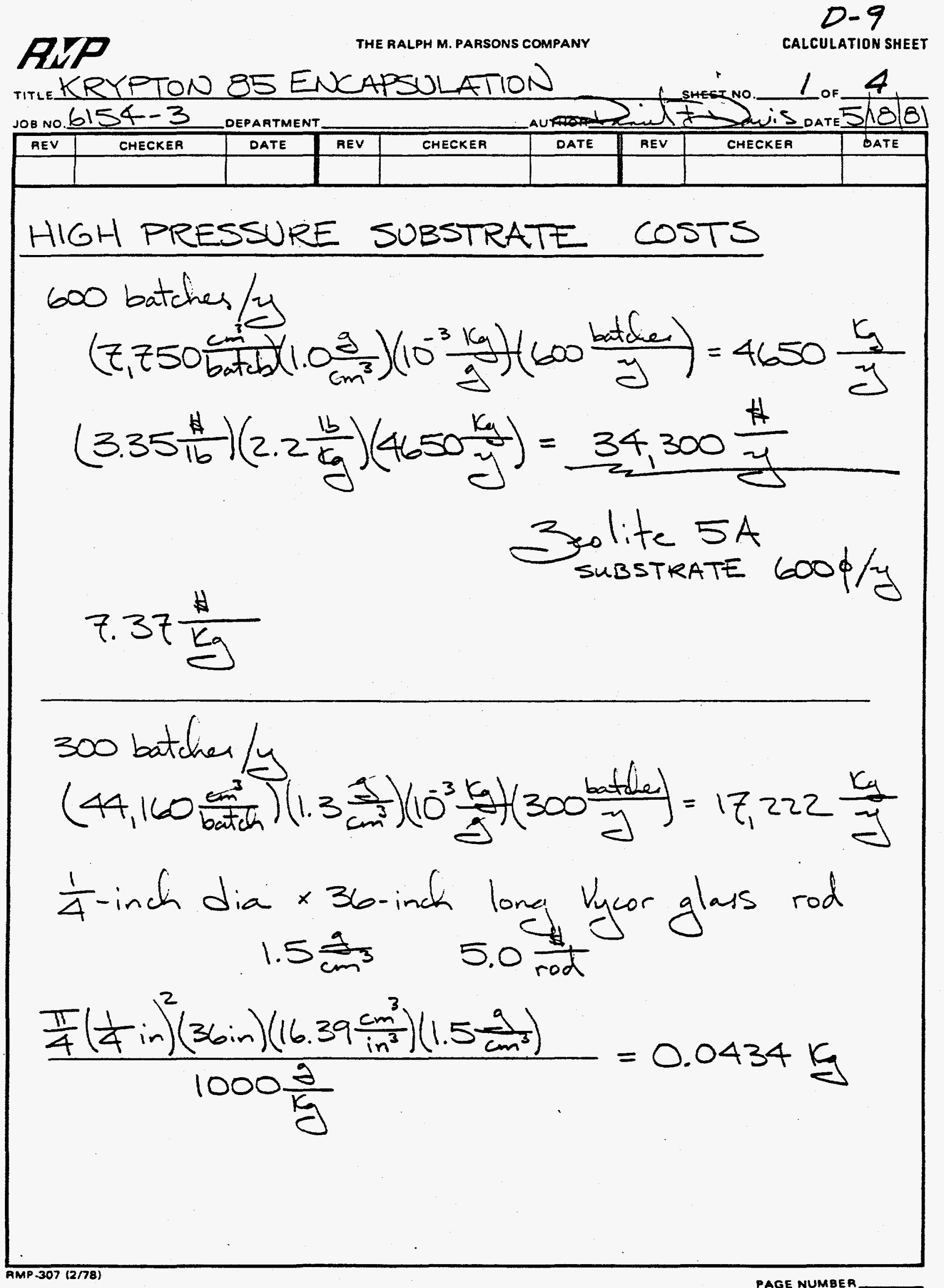




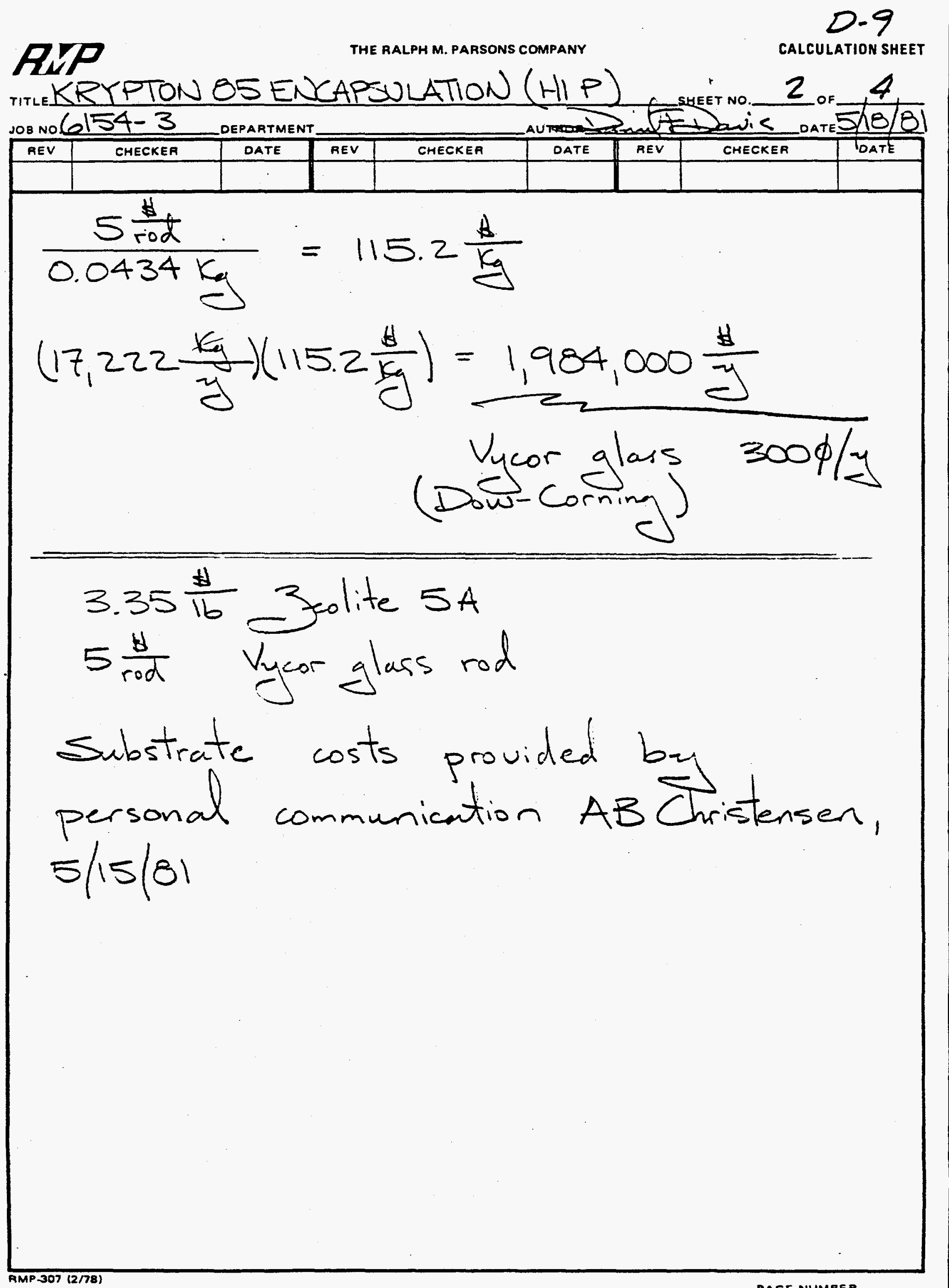




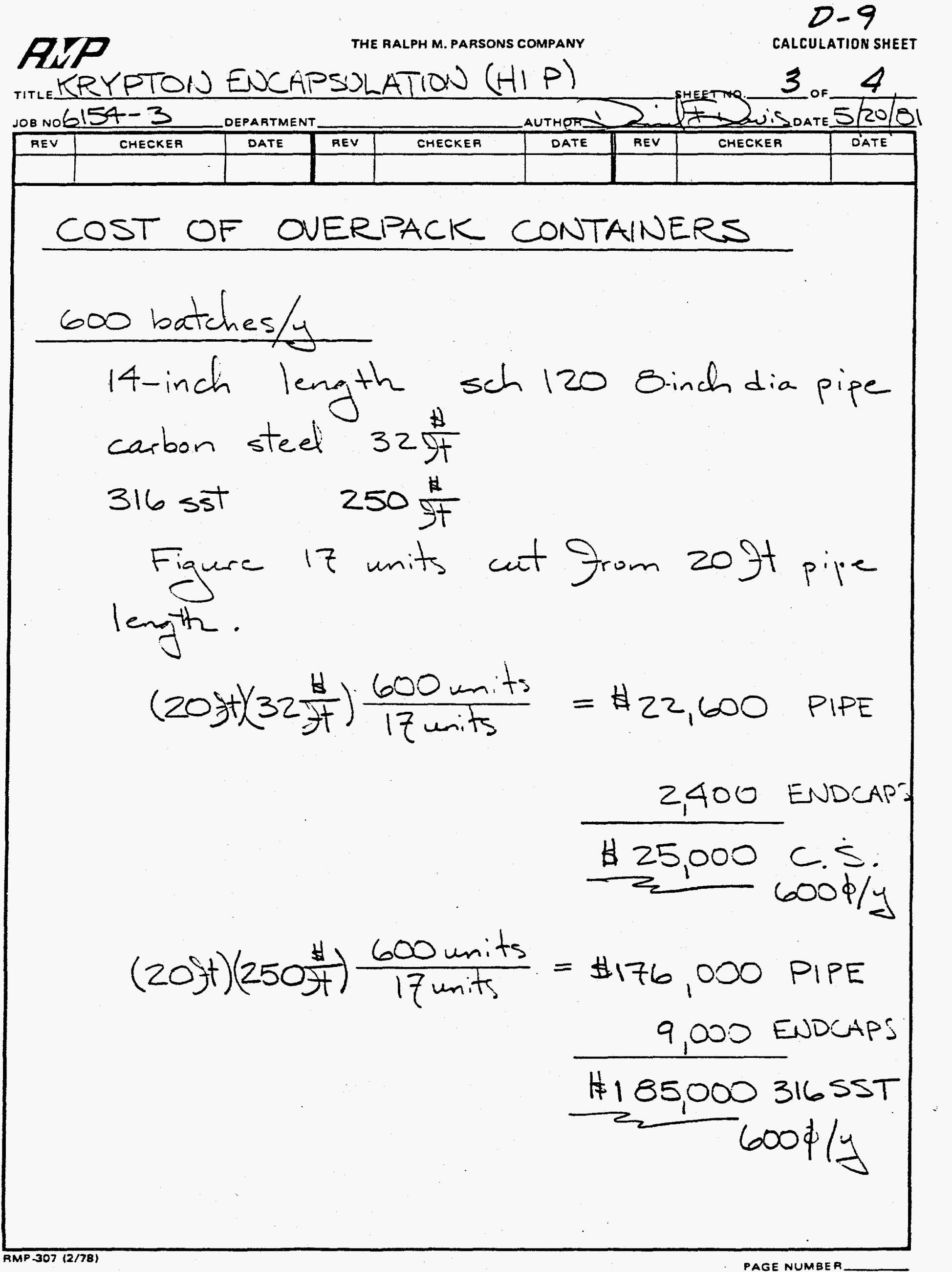




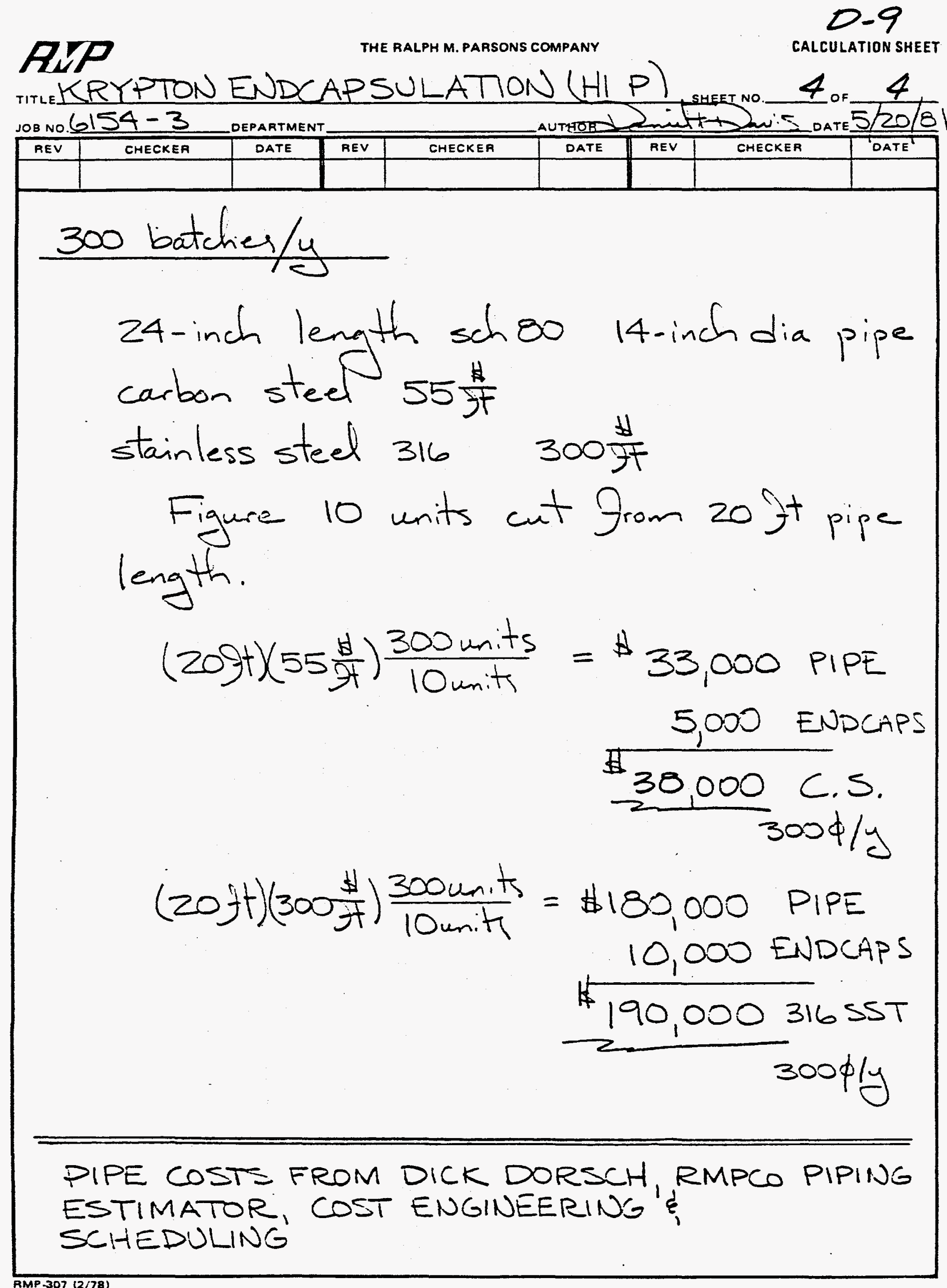


RIP

THE RALPH M. PARSONS COMPANY

$D-10$

CALCULATION SHEET

TITLE VESSEL RUPTURE

SHEET NO. I OF

JOB NO. $6 / 54-3$ DEPARTMENT

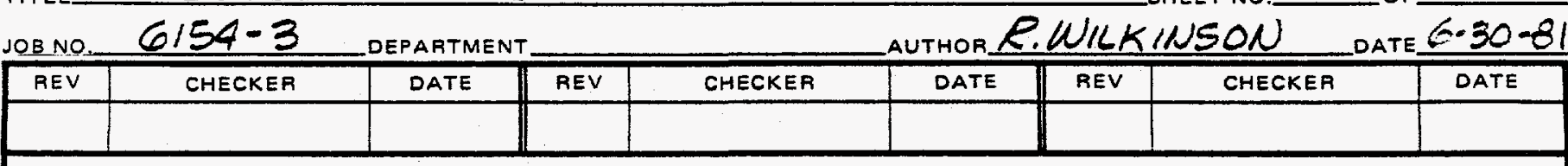

BASED ON PRELIMINARY ASSESSMENTS, AND ON THE CONFIGURATION USED FOR THE PRECONCEPTUAL DESIGN, THE MOST SERIOUS CREDIBLE ACCIDENT FOR THE HOT ISOSTATIC PRESS WOULD BE BRITTLE FAILURE OF THE YOKE UNDER PRESSURE, AND LAUNCHING OF THE TOP PLUG AS A MISSILE. THIS CALCULATION WILL DETERMINE THE MAXIMUM VELOCITY OF THE TOP PLUG, AND THE REQUIRED THICKNESS OF CONCRETE TO CONTAIN THE MISSILE.

CaLCULATIONS ARE bASED ONTHE PROCEDURES USED IN EI VICO 1055, "Preliminary Safety Evaluation of A Commercial- Scale Krypton- 85 En Capsulation FACILITY", September, 1980. For WORST case CALCULATION, ENERGY VALUES ARE BASED ON ARGON GAS PROPERTIES.

$P_{1}=$ PRESSURE PRIOR TO RUPTURE $=1000 \mathrm{ATM}$.

$T_{1}=$ TEMPERATURE PRIOR TO RUPTURE $=700^{\circ} \mathrm{C}=973^{\circ} \mathrm{K}$

$V=$ GAS VOLUME $=7140 \mathrm{l}\left(0^{\circ} \mathrm{C}, \mathrm{ATM}\right)$

$r_{1}=$ SPECIFIC INITIAL VOLUME (PER REOLICH-KWONG EQUATION)

$=103 \mathrm{~cm}^{3} /$ mole

$V_{2}=162.5 \mathrm{~m}^{3}$

$P_{2}$ (ESTIMATED) $=1.055 \mathrm{ATM}$.

$T_{2}$ (ESTIMATED) $=80^{\circ} \mathrm{K}$

$\gamma_{2}=6250 \mathrm{~cm}^{3} /$ mole

AMP $307(2 / 78)$

PAGE NUMBER 
THE RALPH M. PARSONS COMPANY

$D-10$
CALCULATION SHEET

TITLE VESSEL RUPTURE

JOB No. $6 / 54-3$ DEPARTMENT-

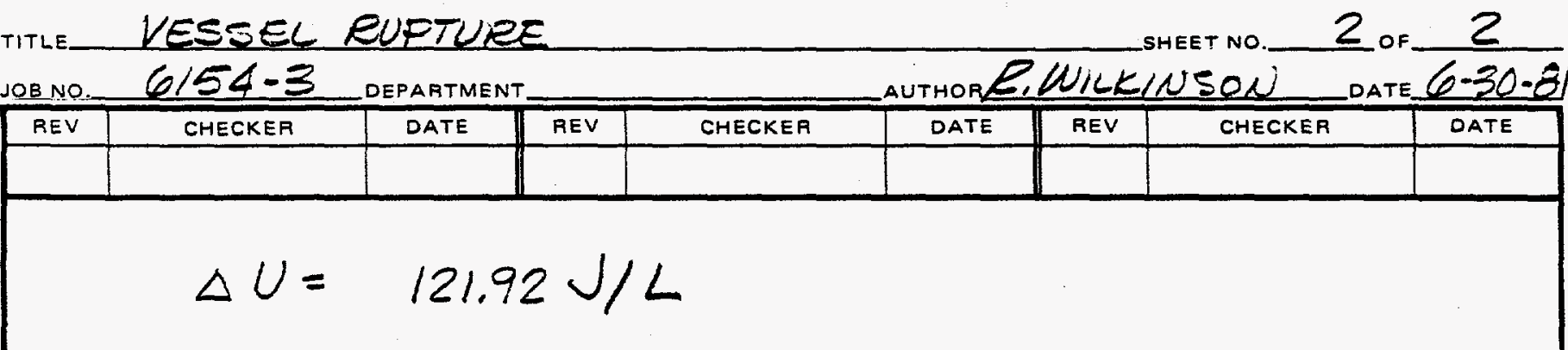

TOTAL ENERGY $=870,540 \mathrm{~J}$

THE Estimated plUG DIMENSIONS ARe $11.5 \mathrm{IN}$. DIAMETER BY $10 \mathrm{~N}$. TH., ESTIMATED WEIGHT $=300 \mathrm{LB}=136 \mathrm{Kg}$

$$
\begin{aligned}
& K . E=0.6 \Delta U=0.6 \times 870,540=522,300 \mathrm{~J} \\
& V_{P}=\left(2 \mathrm{~K} . E / \mathrm{WP}_{P}\right)^{1 / 2}=87.64 \mathrm{~m} / \mathrm{s}
\end{aligned}
$$

THE THICKNESS OF CONCRETE REQUIRED TO STOP THE PLUG is

$$
\begin{aligned}
& t=\frac{6 \times 10^{-4} W_{p}}{A_{p}} L_{0010}\left(1+5 \times 10^{-5} \mathrm{~V}_{p}^{2}\right) \\
& W_{p}=136 \mathrm{~kg} \\
& A_{p}=0.067 \mathrm{~m}^{2} \\
& t=0.172 \mathrm{~m}=6.8 \mathrm{~N} .
\end{aligned}
$$

THEREFORE, THE $18 \mathrm{IN}$. THICK CONCRETE CELL CEILING IS MORE THAN ADEQUATE.

The equivalent explosive energy is

$0.193 \mathrm{Kg} T M T$

0.426 LB TNT

RMP-307 (2/78)

PAGE NUMBER 
$\therefore$

APPENDIX E

COST ESTIMATES

E-1 ION IMPLANTATION/SPUTTER ING

E-2 ZEOLITE ENCAPSULATION 

Krapton Encapsulation Preconeeptual Design PROUECT NAME: ION IMPLANTATION/SPUTTERING FACILITY

pROJEeT No. $61 \overline{54-3}$ ESTIMATE OF COST ACCT. SUMMARY

NO.

\section{DESCRIPTION}

\begin{tabular}{|l|l}
\hline & DIRECT COST \\
\hline 400 & IMPROVEMENTS T \\
\hline
\end{tabular}

400 IMPROVEMENTS TO LANO

500 BUILDING $S$ OTHER STRUCTURES

600 UTILITIES (NOT INCLUDED)

\begin{tabular}{|l|l|}
\hline 700 & EOUIPMENT \\
\hline
\end{tabular}

\begin{tabular}{l|l}
\hline 800 & DEMOLITION \& REMOVALS (NONE) \\
\hline
\end{tabular}

TOTAL DIRECT COST

CONTRACTOR INDIRECTS \& $10 \%$

TOTAL CONSTRUCTION COST

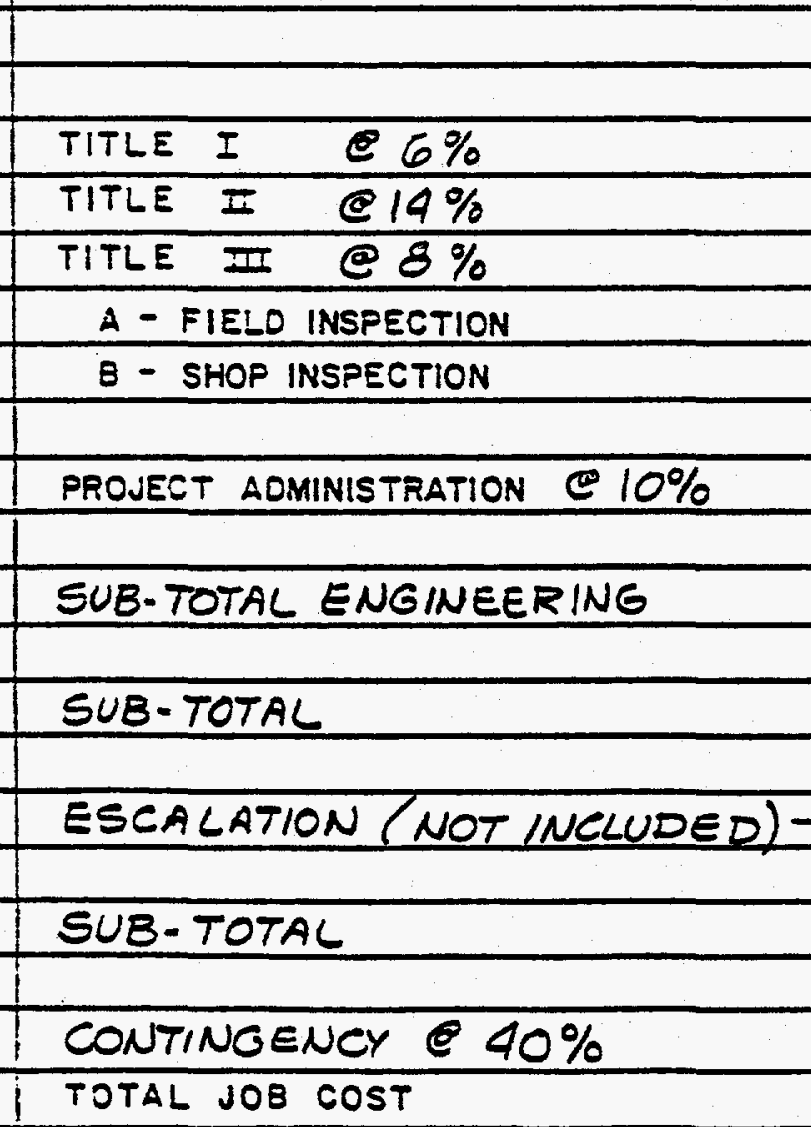

\begin{tabular}{|c|c|c|}
\hline $\begin{array}{c}\text { LABOR } \\
\text { COST } \\
\$\end{array}$ & $\begin{array}{c}\text { MATERIAL } \\
\text { COST } \\
\$\end{array}$ & $\begin{array}{c}\text { TOTAL } \\
\text { COST } \\
\$\end{array}$ \\
\hline 23,000 & 2,000 & 25000 \\
\hline $1,620,000$ & $1,525,000$ & $3,145,000$ \\
\hline & & \\
\hline 215,000 & $1,480,000$ & $1,695,000$ \\
\hline $1,858,000$ & $3,007,000$ & $4,865,000$ \\
\hline & & \\
\hline & & 401,0 \\
\hline & & \\
\hline & & \\
\hline & & 5352000 \\
\hline & & \\
\hline & & 321,000 \\
\hline & & 750,000 \\
\hline & & 428,000 \\
\hline & & \\
\hline & & \\
\hline & & 535000 \\
\hline & & \\
\hline & & $2,034,000$ \\
\hline & & \\
\hline & & $7,386,000$ \\
\hline & & \\
\hline & & \\
\hline & & $7,386,000$ \\
\hline & & \\
\hline & & $2,954,000$ \\
\hline & & $10,340,000$ \\
\hline
\end{tabular}


THE RALPH M. PARSONS COMPANY

ESTIMATE WORKSHEET

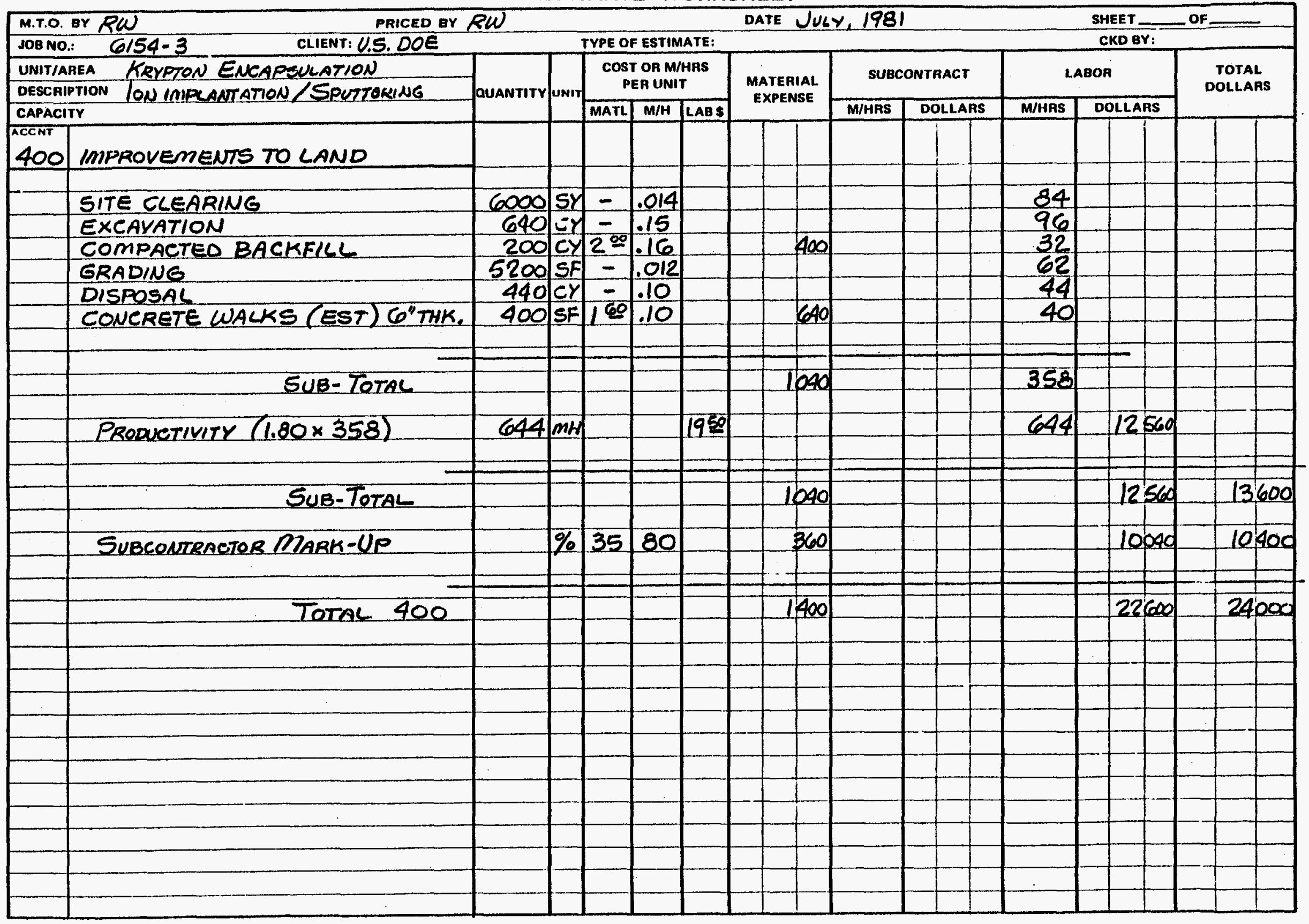


THE RALPH M. PARSONS COMPANY

ESTIMATE WORKSHEET

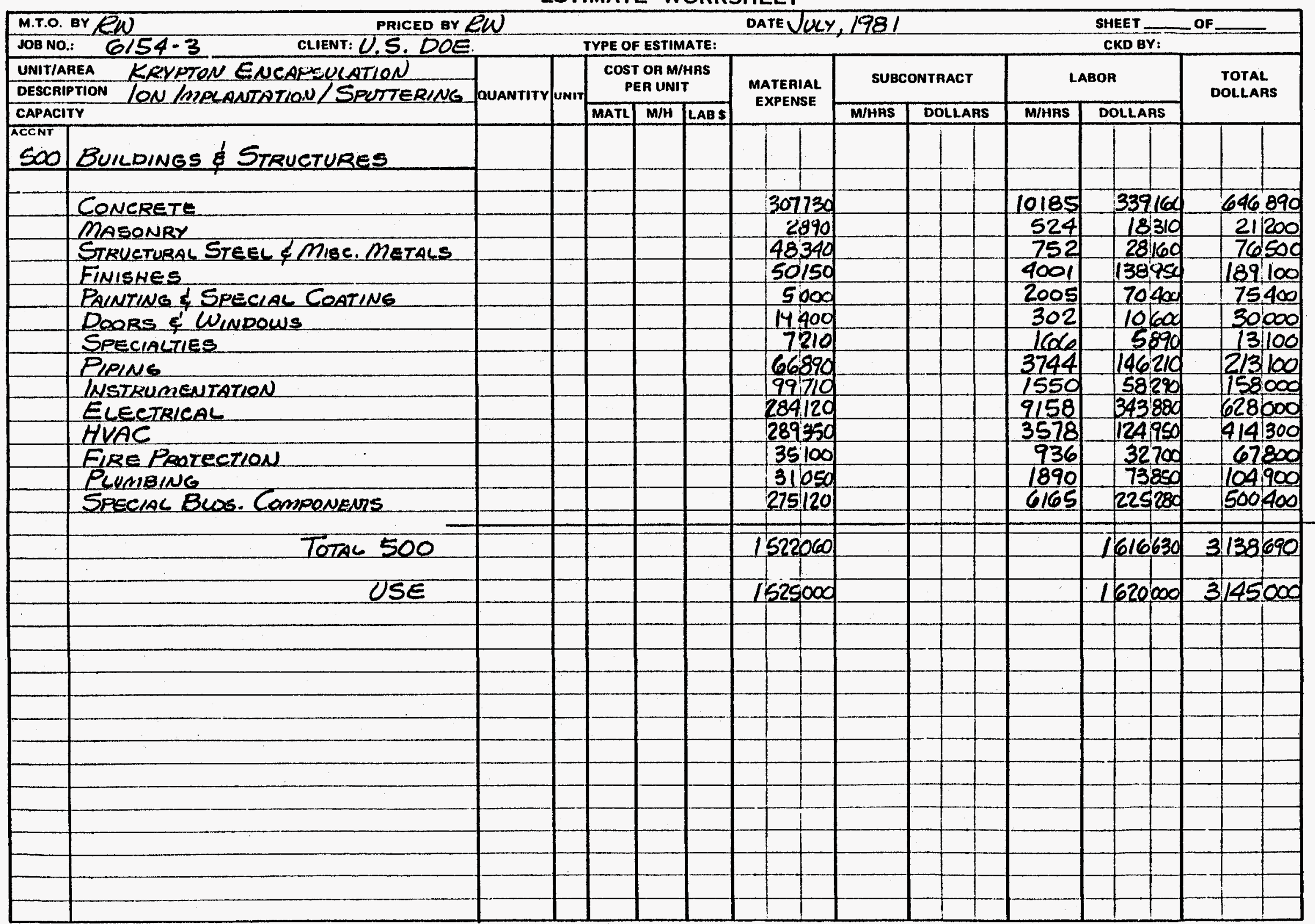


THE RALPH M. PARSONS COMPANY

ESTIMATE WORKSHEET

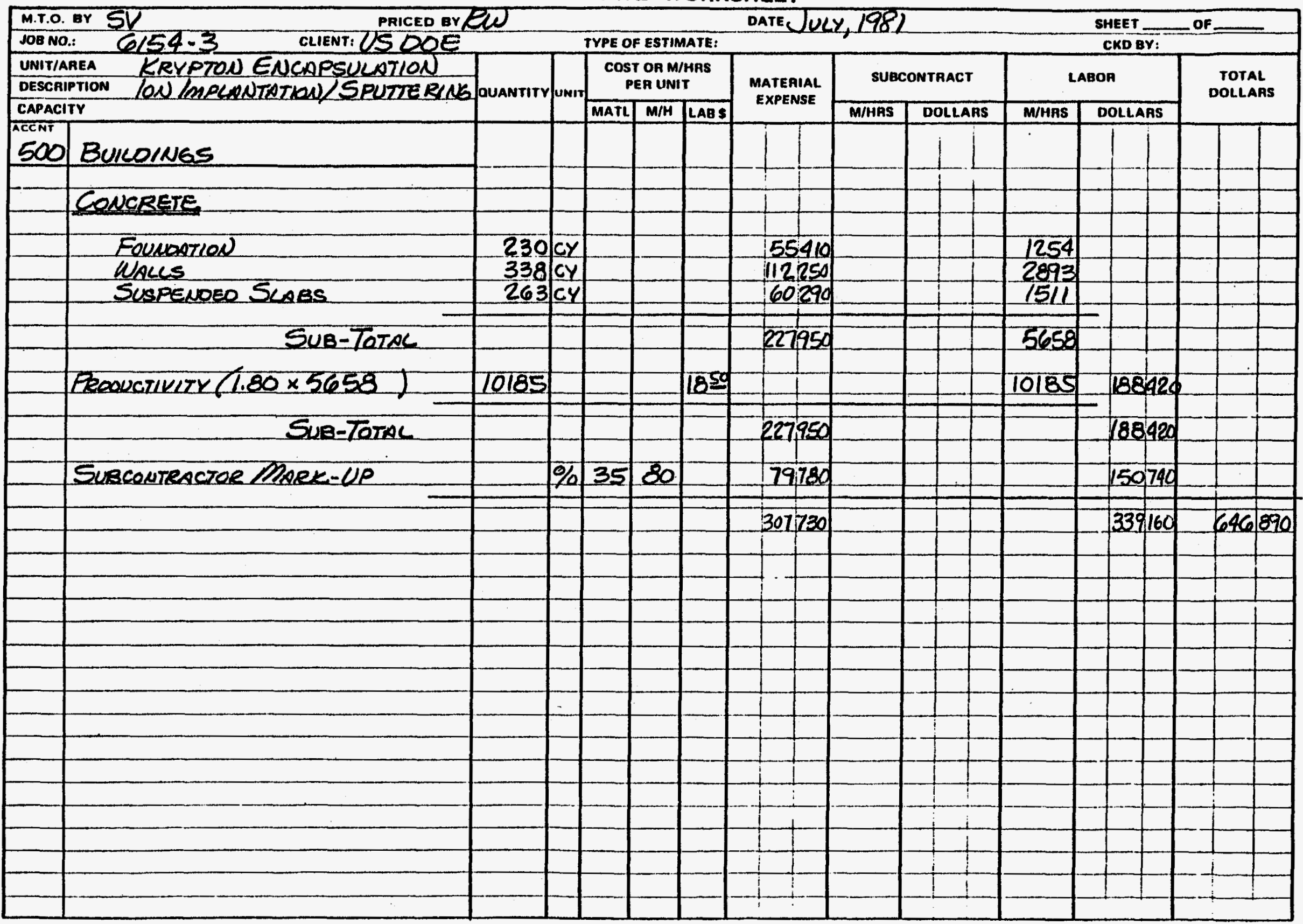


ESTIMATE WORKSHEET

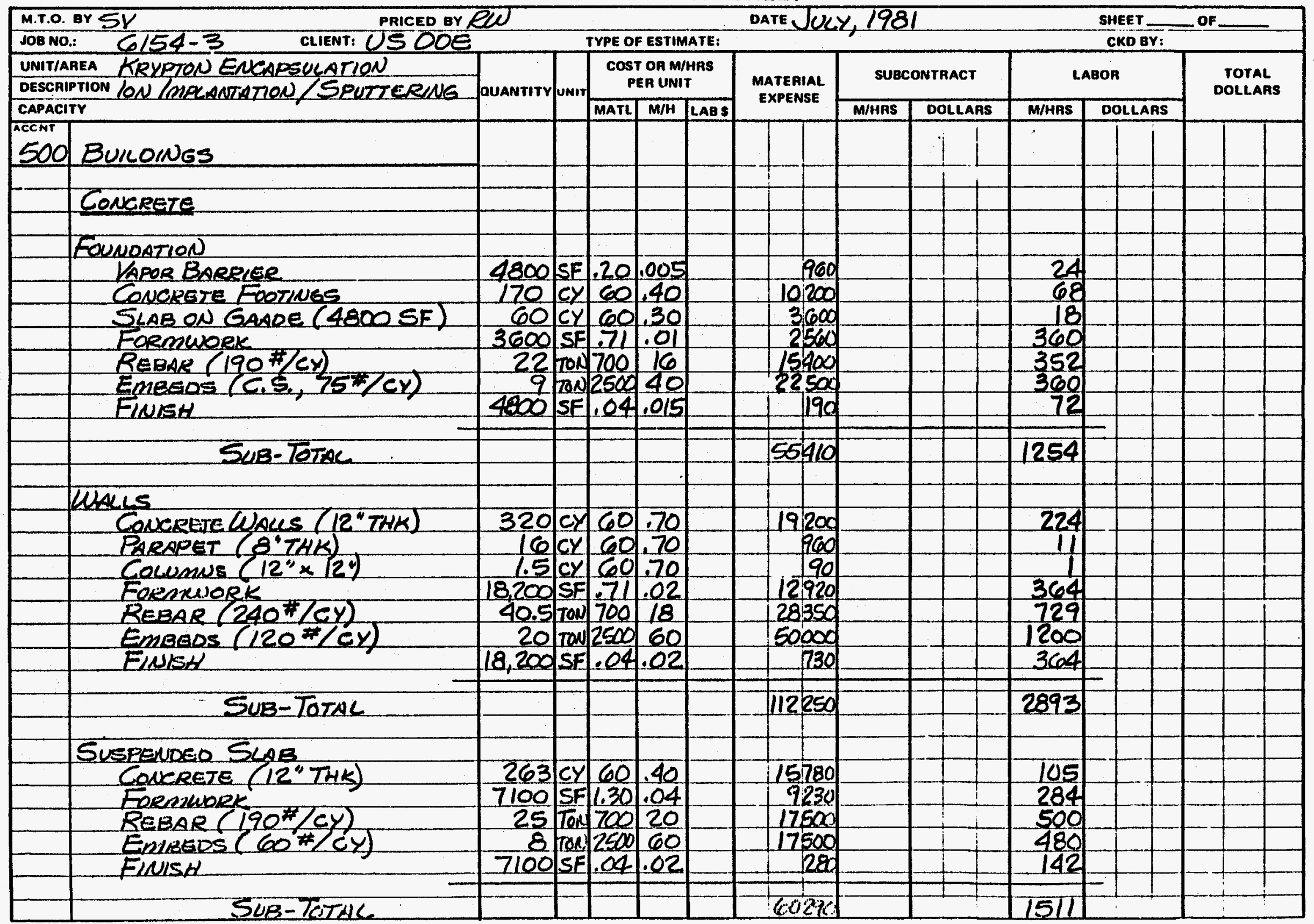


CES $2000-0$

THE RALPH M. PARSONS COMPANY

ESTIMATE WORKSHEET

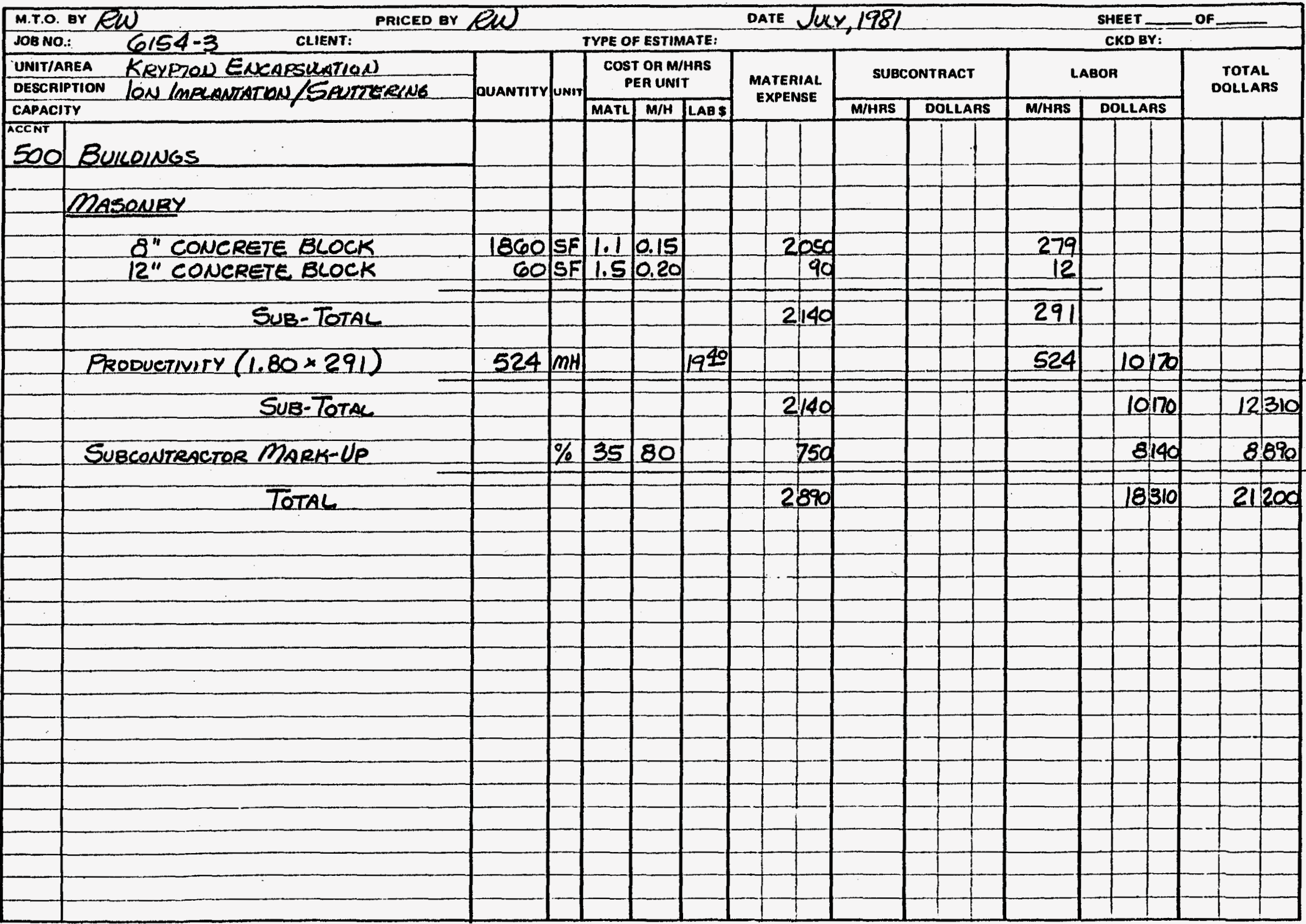


THE RALPH M. PARSONS COMPANY

ESTIMATE WORKSHEET

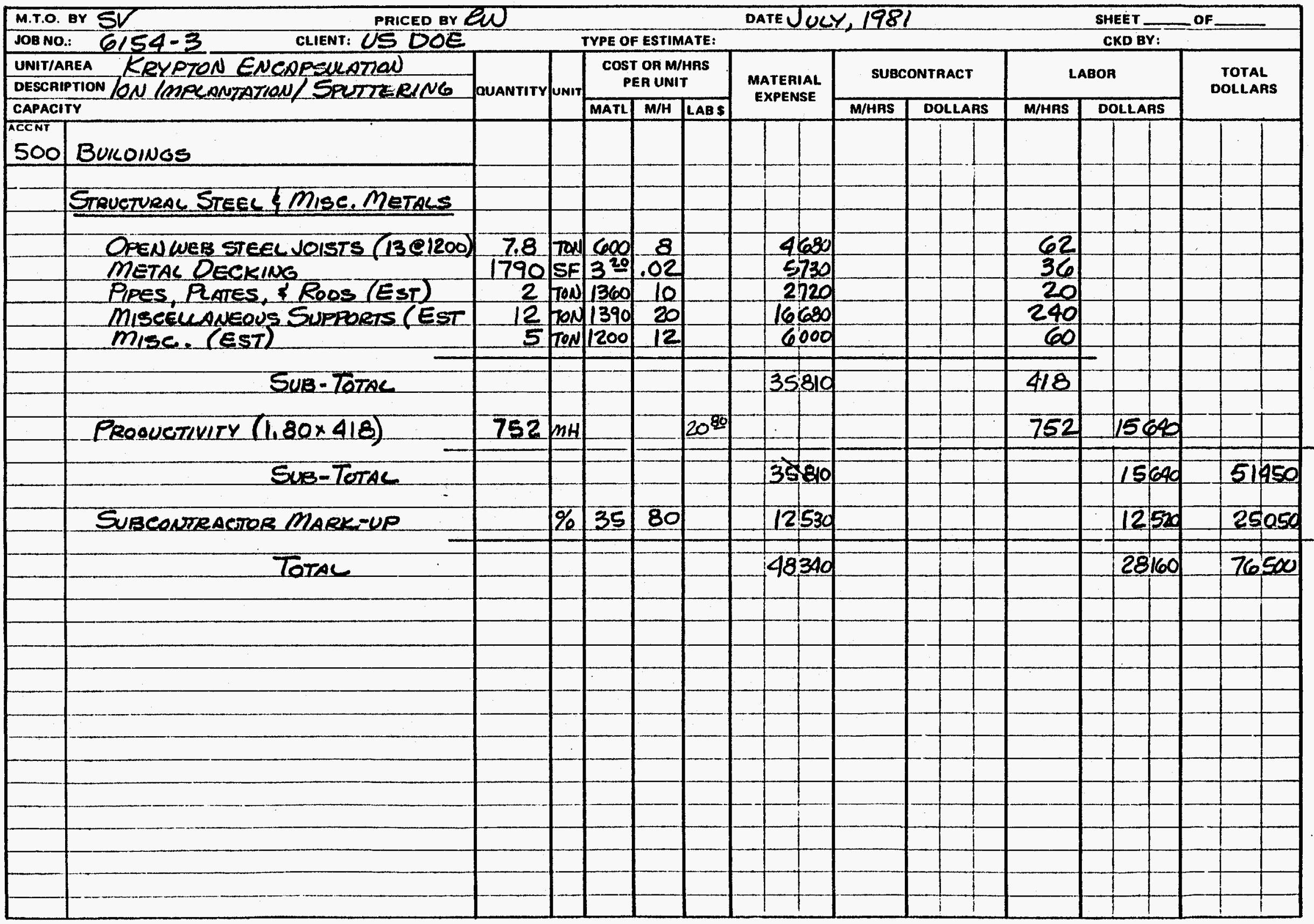


THE RALPH M. PARSONS COMPANY

ESTIMATE WORKSHEET

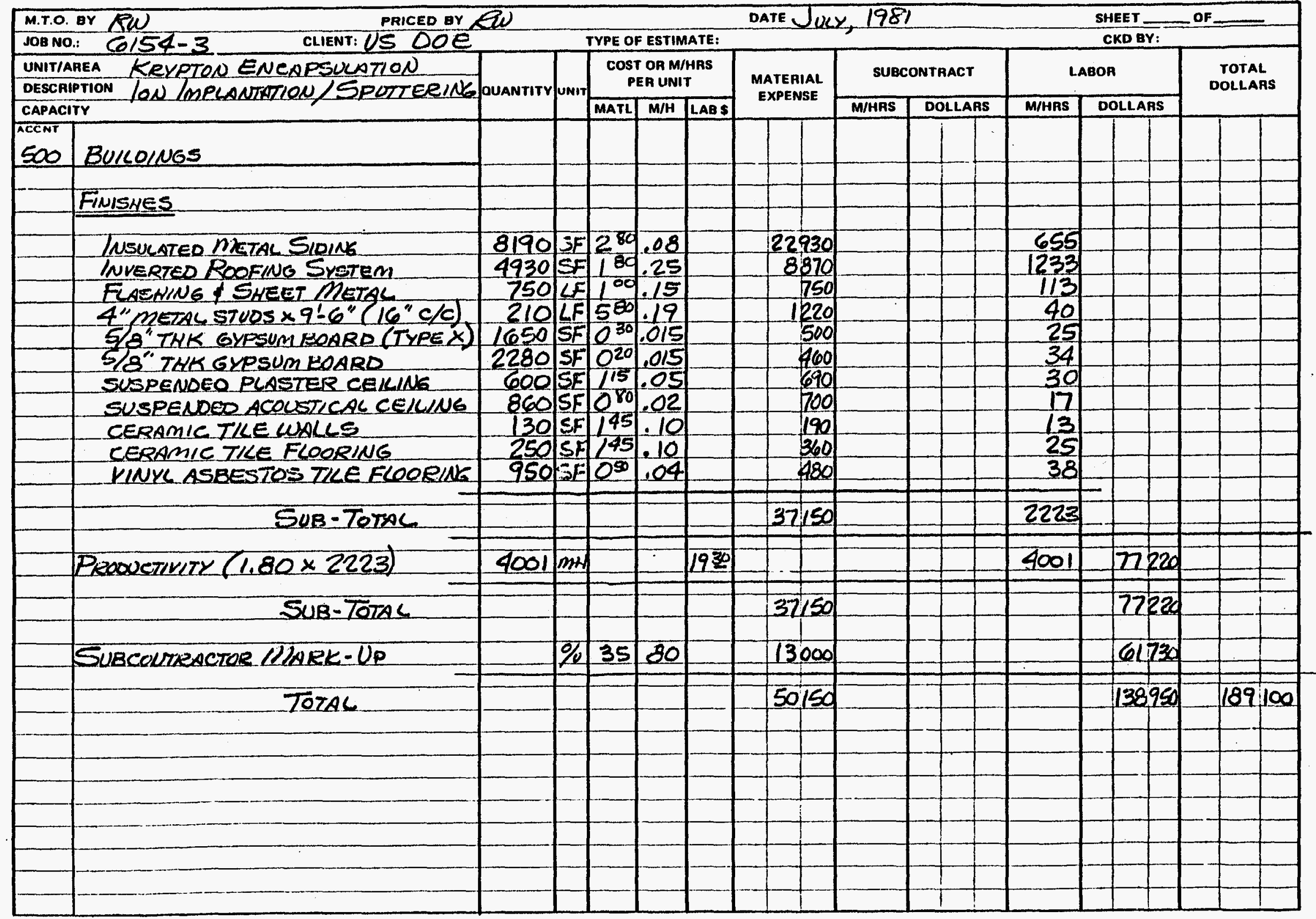


THE RALPH M. PARSONS COMPANY

ESTIMATE WORKSHEET

\begin{tabular}{|c|c|c|c|c|c|c|c|c|c|c|c|c|c|c|c|c|c|}
\hline \multirow{2}{*}{\multicolumn{4}{|c|}{$\begin{array}{ll}\text { M.T.O. BY RLU } & \text { PRICED BYRLU } \\
\text { JOB No.: } & \text { CLIENT: US DO-3 DOE }\end{array}$}} & \multirow{2}{*}{\multicolumn{3}{|c|}{ TYPE OF ESTIMATE: }} & \multirow{2}{*}{\multicolumn{5}{|c|}{ DATE JuKY, 1981}} & \multirow{2}{*}{\multicolumn{6}{|c|}{ SHEET $=$ OF }} \\
\hline & & & & & & & & & & & & & & & & & \\
\hline \multirow{2}{*}{\multicolumn{2}{|c|}{ 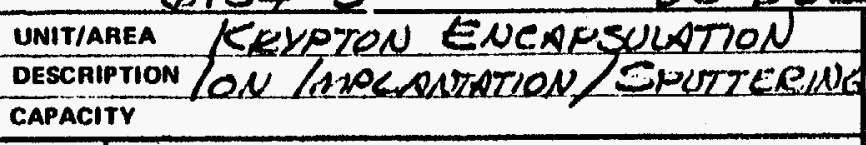 }} & \multirow{2}{*}{ aUANTITY } & \multirow{2}{*}{ unir } & \multicolumn{3}{|c|}{$\begin{array}{l}\text { COST OR M/HAS } \\
\text { PER UNIT }\end{array}$} & \multirow{2}{*}{\multicolumn{2}{|c|}{$\begin{array}{l}\text { MATERIAL } \\
\text { EXPENSE }\end{array}$}} & \multicolumn{3}{|c|}{ SUBCONTAACT } & \multicolumn{3}{|c|}{ LABOR } & \multirow{2}{*}{\multicolumn{3}{|c|}{$\begin{array}{l}\text { TOTAL } \\
\text { DOLLARS }\end{array}$}} \\
\hline & & & & \multirow{2}{*}{\begin{tabular}{|l|l|} 
MATL \\
\end{tabular}} & \multirow[t]{2}{*}{ M/H } & \multirow{2}{*}{ LAB: } & & & \multirow{2}{*}{ M/MAS } & \multicolumn{2}{|c|}{ DOLLAAS } & \multirow{2}{*}{ M/HAS } & \multicolumn{2}{|c|}{ DOLLAAS } & & & \\
\hline 500 & BUILOINGS & & & & & & & & & & & & & & & & \\
\hline & & & - & & $\omega$ & & & & & - & & & - & & & & \\
\hline & FALNTING \& SPRCIAC COATING & & - & & & & & -1 & & - & & & & & & & \\
\hline & & & & & & & & & & & & & & & & & \\
\hline & Pandins & & & & & & & & & - & & & & & & & \\
\hline & Gypsum BOARO & 3930 & 파 & .12 & .03 & & & 470 & & & & 118 & & & & - & \\
\hline & Masel & 1920 & $S F$ & .12 & .05 & & & 230 & & & & 96 & & & & 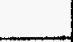 & \\
\hline & Pipina (Est) & 1000 & $S F$ & .12 & .05 & & & 120 & & & & 50 & & & & & \\
\hline & Duetwaek (Est) & 3000 & $S F$ & .12 & .04 & & & 360 & & & & 120 & & & & - & \\
\hline & SPEERIAL CONTING & & & & & & & & & & & & & & & & \\
\hline & Plaster ceillans & 600 & $S F$ & 20 & .05 & & & 120 & & & & 30 & & & & - & \\
\hline & CONCRETE WALLS & 5100 & $\mathrm{SF}$ & .20 & .06 & & & 1020 & & & & 306 & & & & L & \\
\hline & Conerete Flools & 3900 & SF & .20 & .06 & - & & 780 & & & & 234 & & & & & \\
\hline & PIPING (EST) & 1000 & $S F$ & 20 & .06 & & & 200 & & & & 60 & & & & - & \\
\hline & DUCTWORK (EST) & 2000 & EF & .20 & .05 & - & & 400 & & & & 100 & & & & & \\
\hline & 517 & & - & 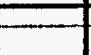 & - & - & & $37 n$ & & & & $1 / 14$ & & & & & \\
\hline & $\operatorname{sab}=10 / \times 1$ & & - & 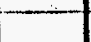 & & & & 2,00 & & & & (4) & & & & & \\
\hline & Psoouctivity $(1.80 \times 1114)$ & 2005 & ant & - & - & 1950 & & - & & - & & 2005 & 39 & 100 & & E & - \\
\hline & $510-T 0 \pi$ & & F & & E- & E & & 3700 & & & & & 29 & & & E & 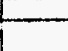 \\
\hline & SUB-10IAC & & & & & & & $2 \pi 0$ & & & & & & & & & \\
\hline & 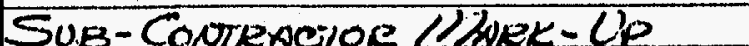 & & \%ा & 35 & 80 & 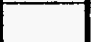 & & 1300 & & & & & & $|300|$ & & & \\
\hline & & & & -2 & 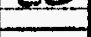 & & - & , & & & & & & $\mp$ & & 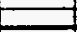 & $=$ \\
\hline & TOTNL & & - & 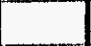 & 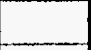 & L & & 5000 & & & 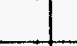 & - & & 1900 & & & 400 \\
\hline & & & & & & - & & & & & & & & & & & \\
\hline & & & t & & & 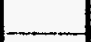 & & & & & & & & & & & \\
\hline & & & 1 & & & & & & & & & & & & & & \\
\hline & & $\ldots$ & $\ldots$ & $\ldots$ & & $\ldots$ & & - & & & & & $\ldots$ & & & & \\
\hline & & & -1 & $-5+2+$ & & - & & & & & & & & & & & \\
\hline & & & $\square$ & & 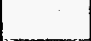 & $-5+2$ & & & & & & & & & & & \\
\hline & & & 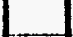 & & & 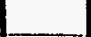 & & & & & & & & & & & \\
\hline & & & & & & & & & & & & & & & & & \\
\hline
\end{tabular}




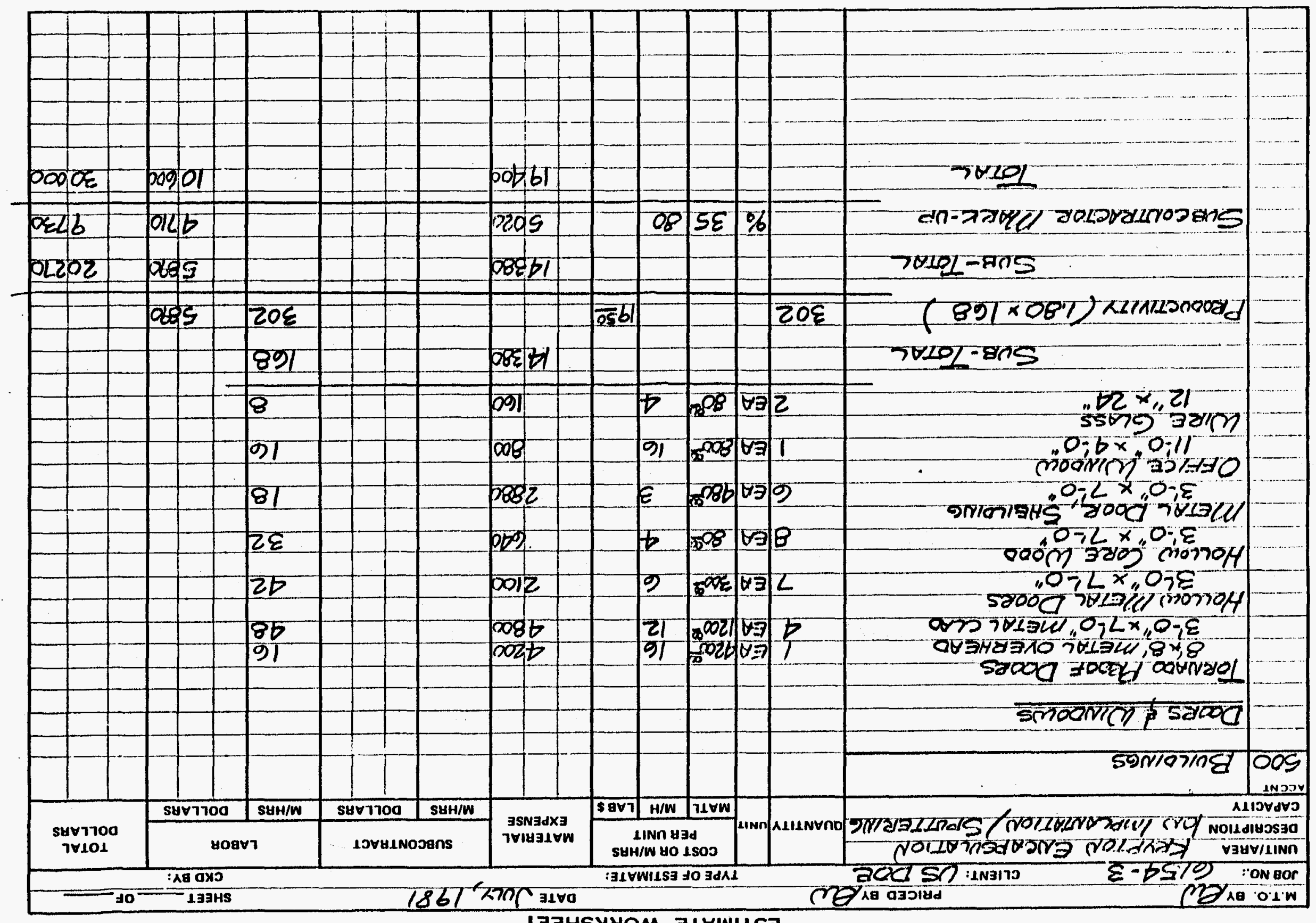

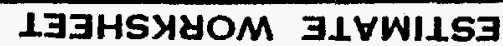

ANYdWOJ SNOSAYd 'W HdרVy $3 H \perp$ 
THE RALPH M. PARSONS COMPANY

ESTIMATE WORKSHEET

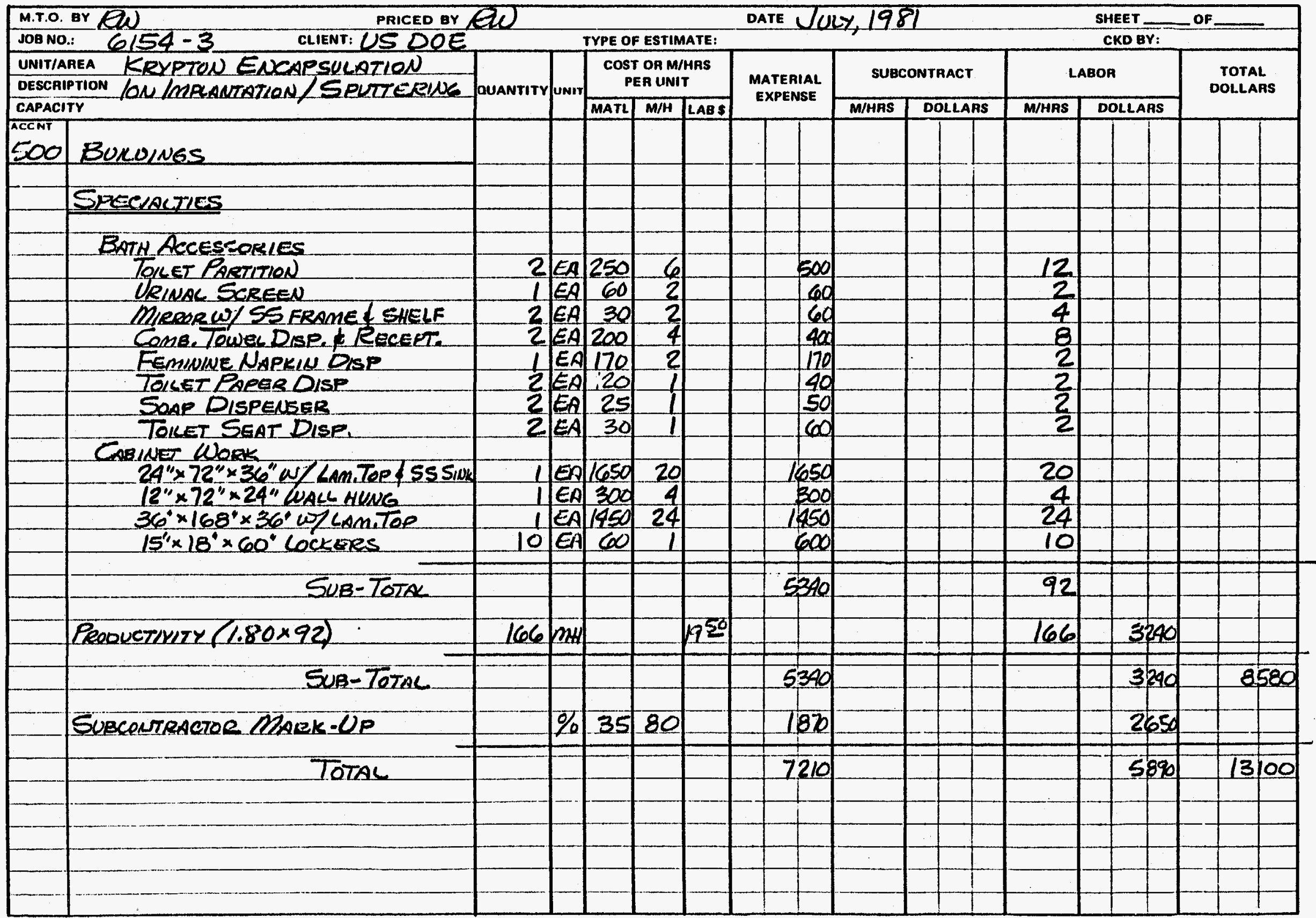


THE RALPH M. PARSONS COMPANY

ESTIMATE WORKSHEET

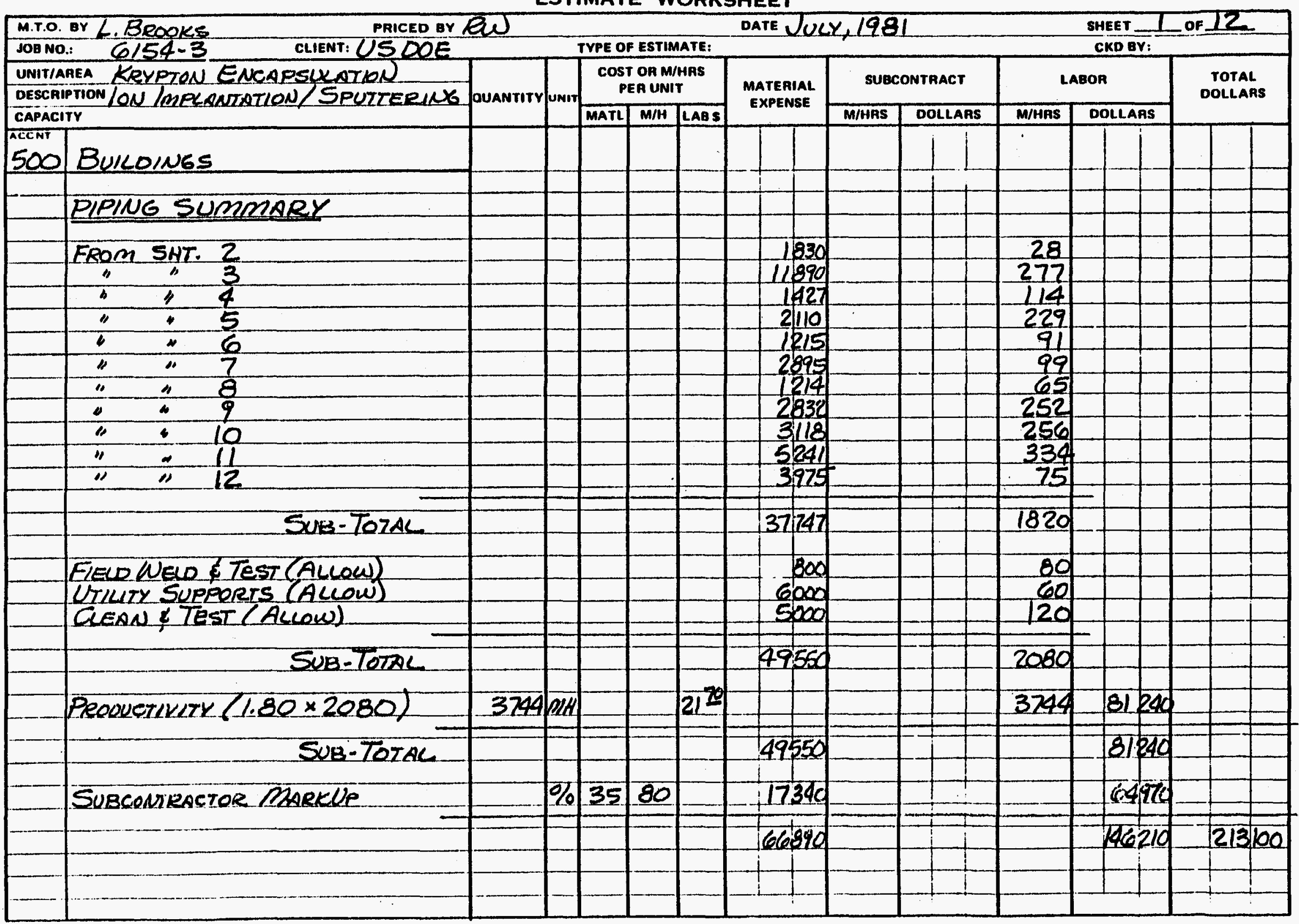


THE RALPH M. PARBONS COMPANY

ESTIMATE WORKSHEET

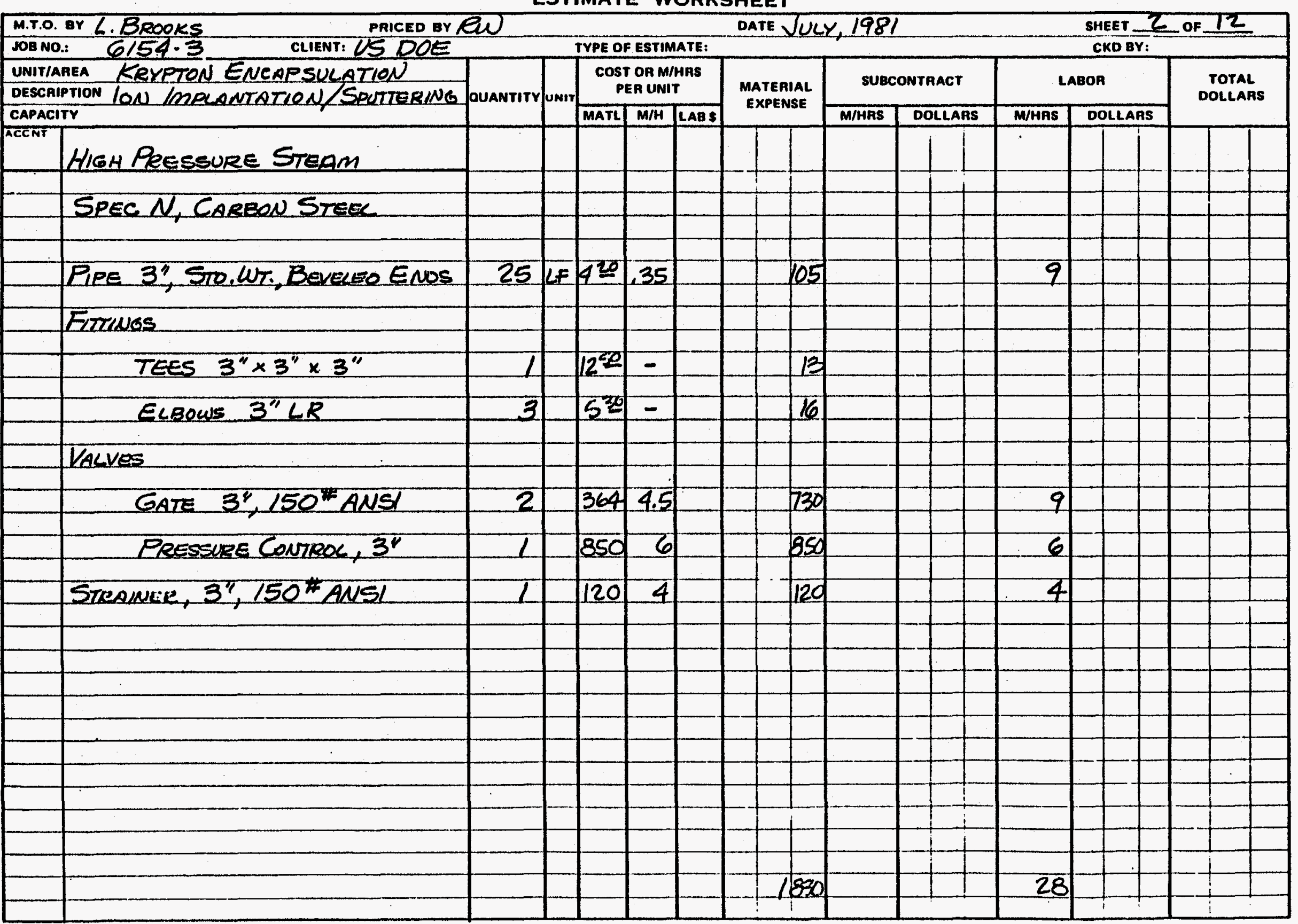


THE RALPH M. PARBONS COMPANY

ESTIMATE WORKSHEET

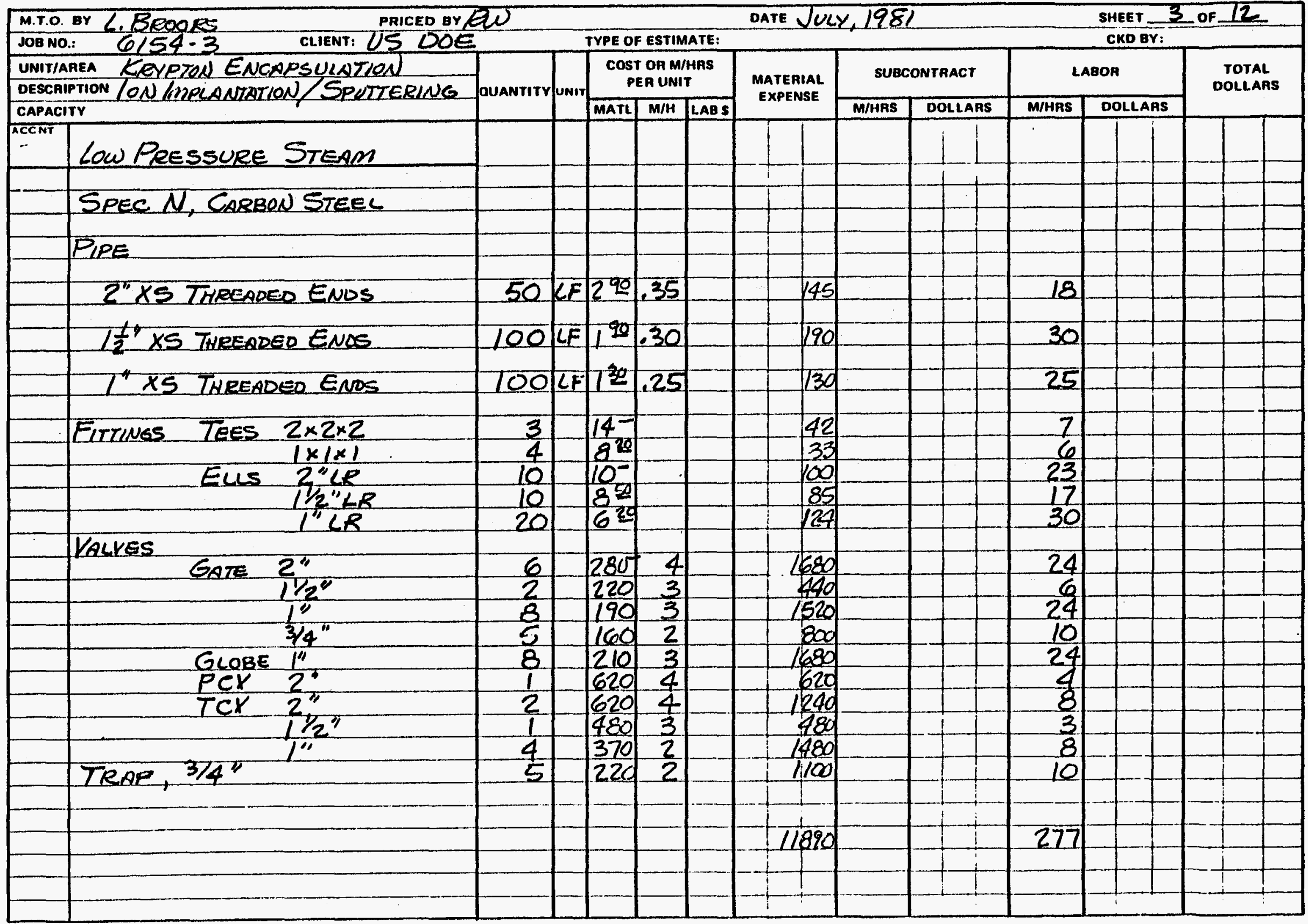


THE RALPH M. PARSONS COMPANY

ESTIMATE WORKSHEET

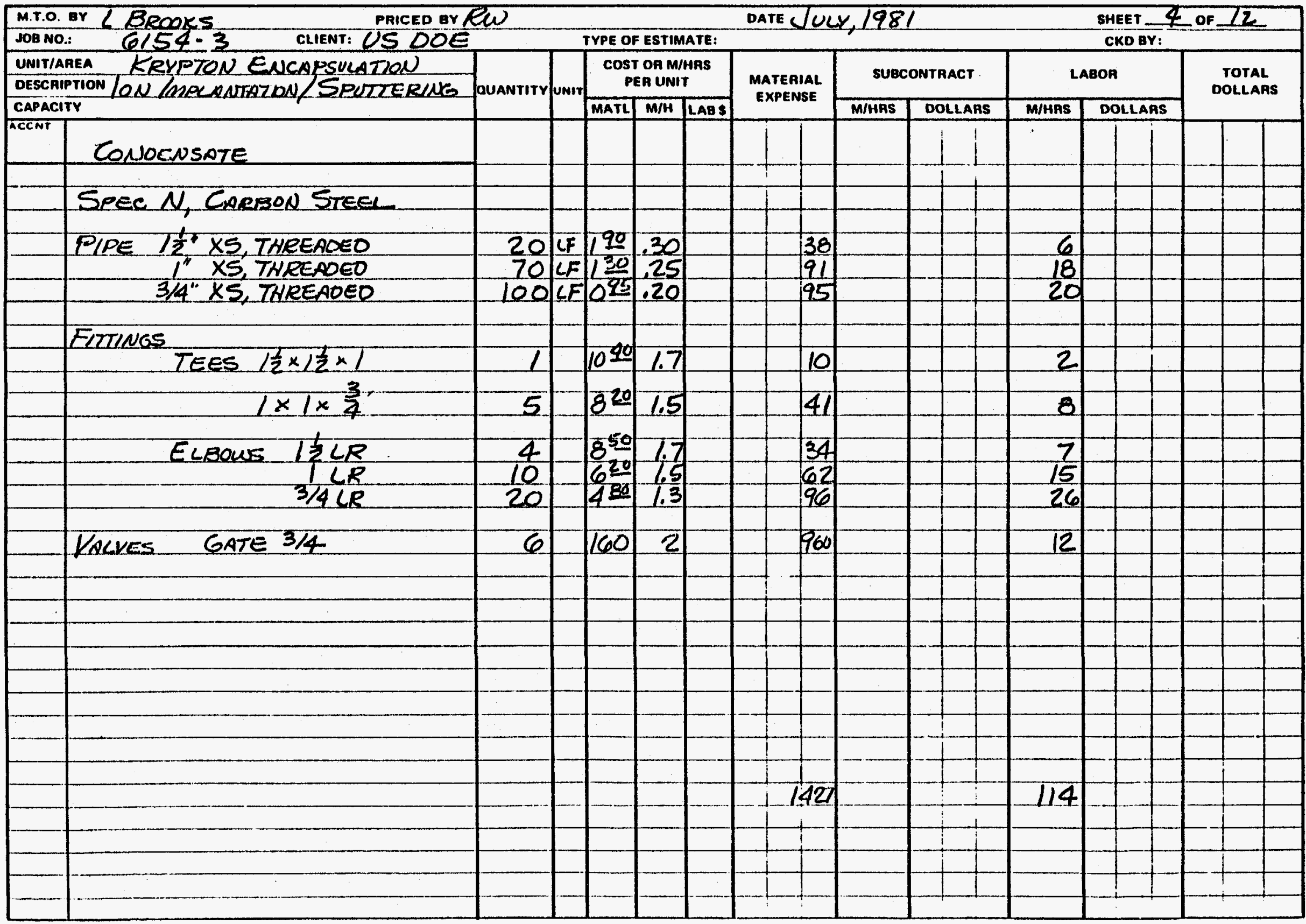




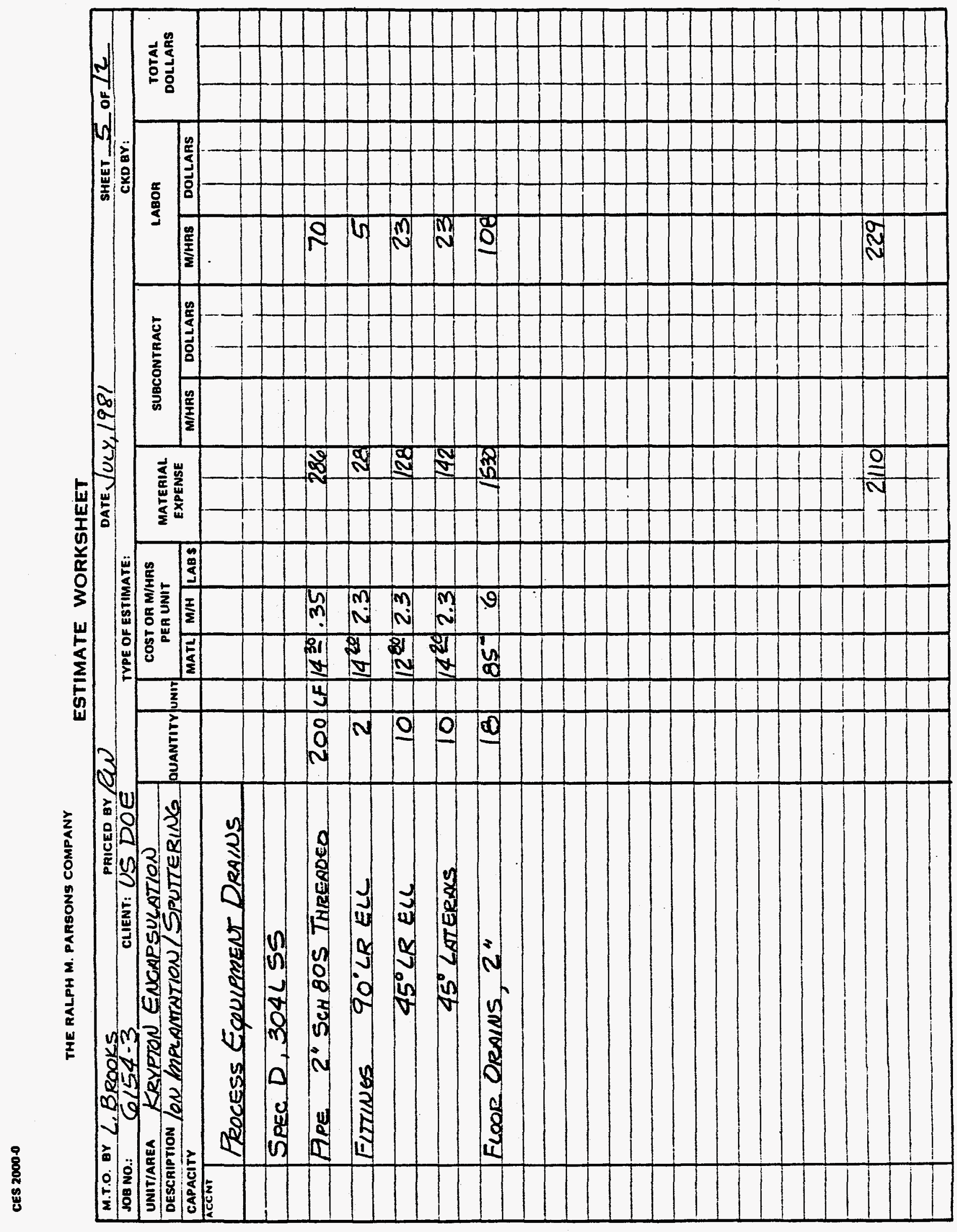


THE RALPH M. PARSONS COMPANY

ESTIMATE WORKSHEET

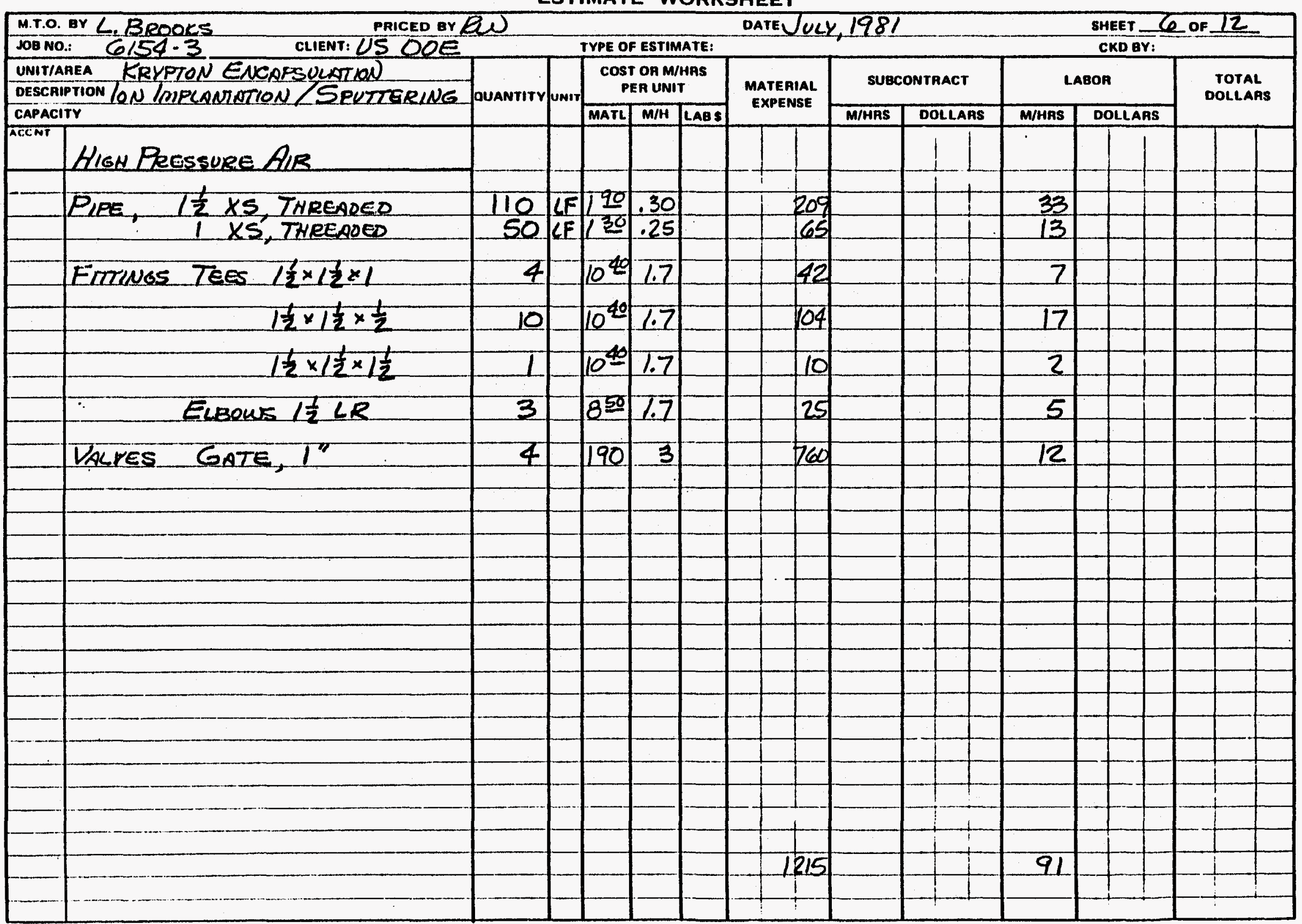


THE RALPH M. PARSONS COMPANY

ESTIMATE WORKSHEET

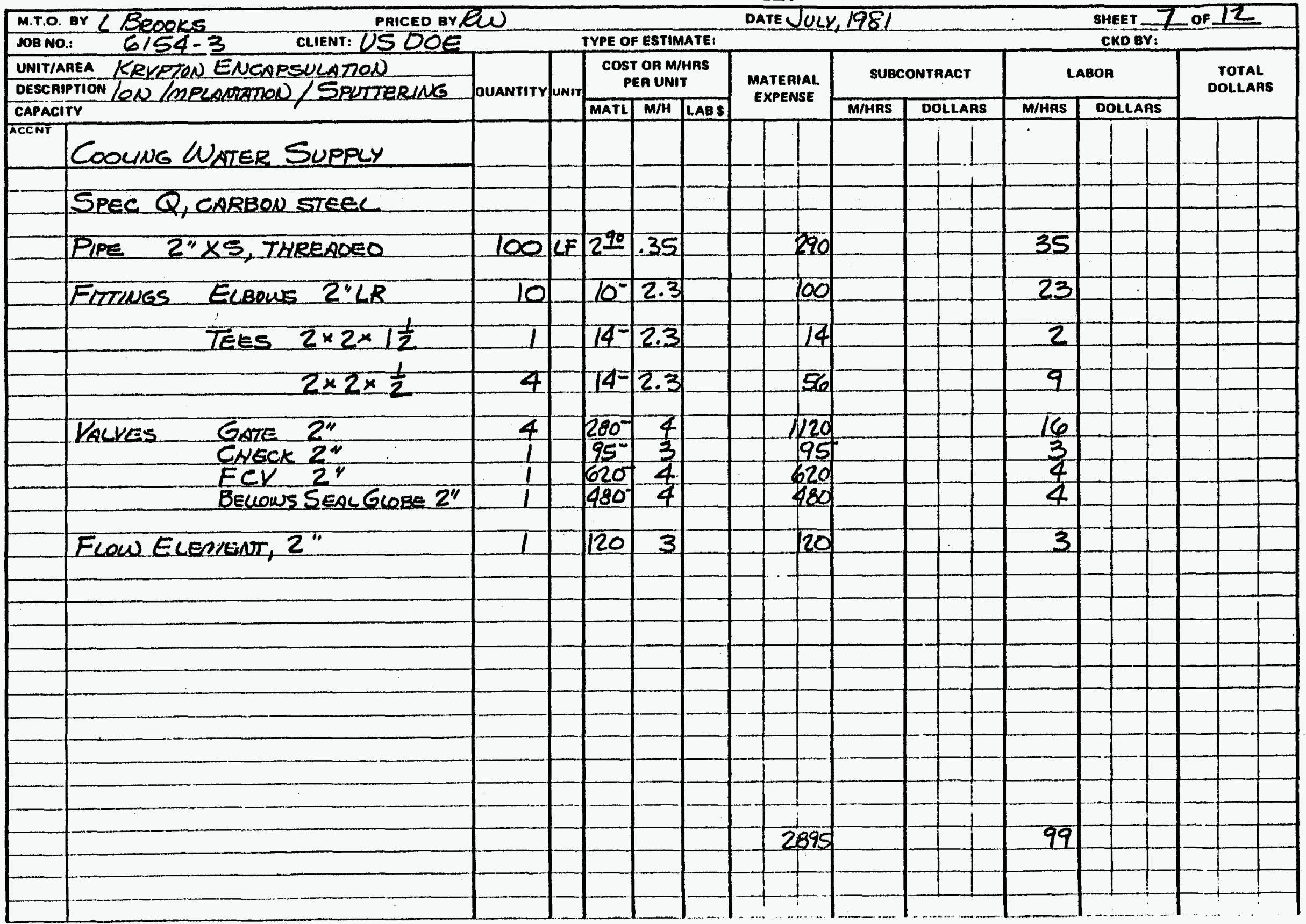


THE RALPH M. PARSONS COMPANY

ESTIMATE WORKSHEET

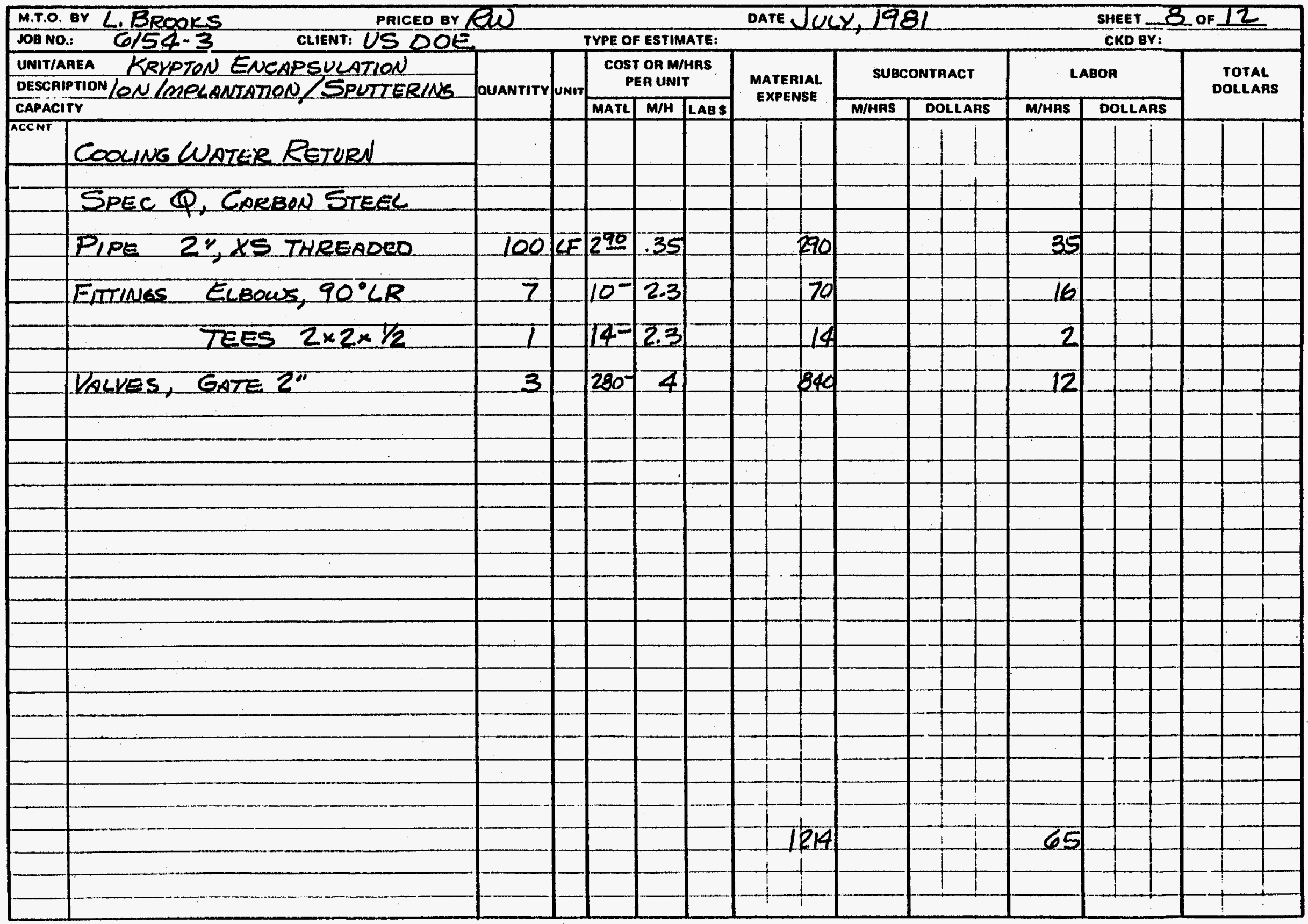




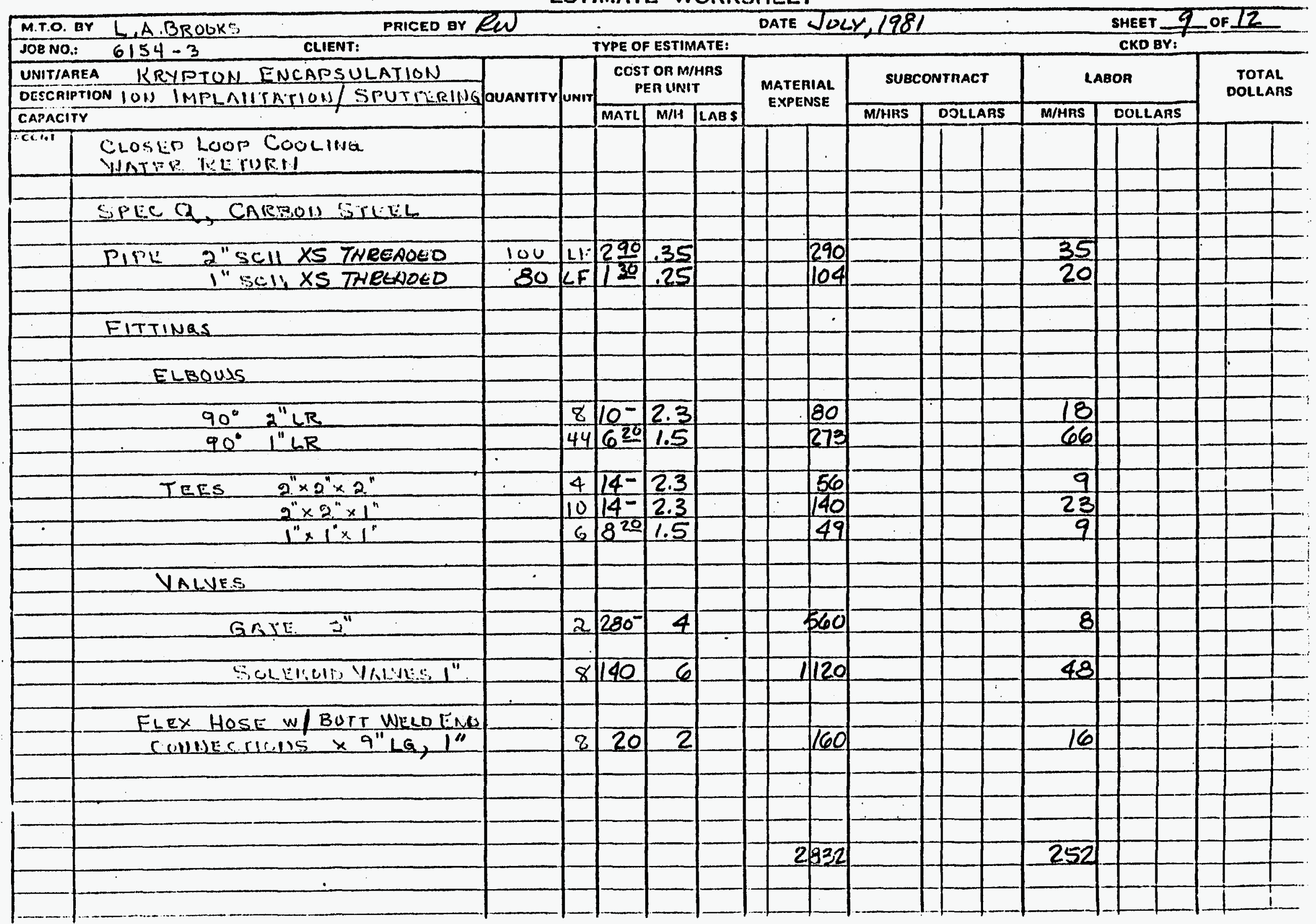


ESTIMATE WORKSHEET

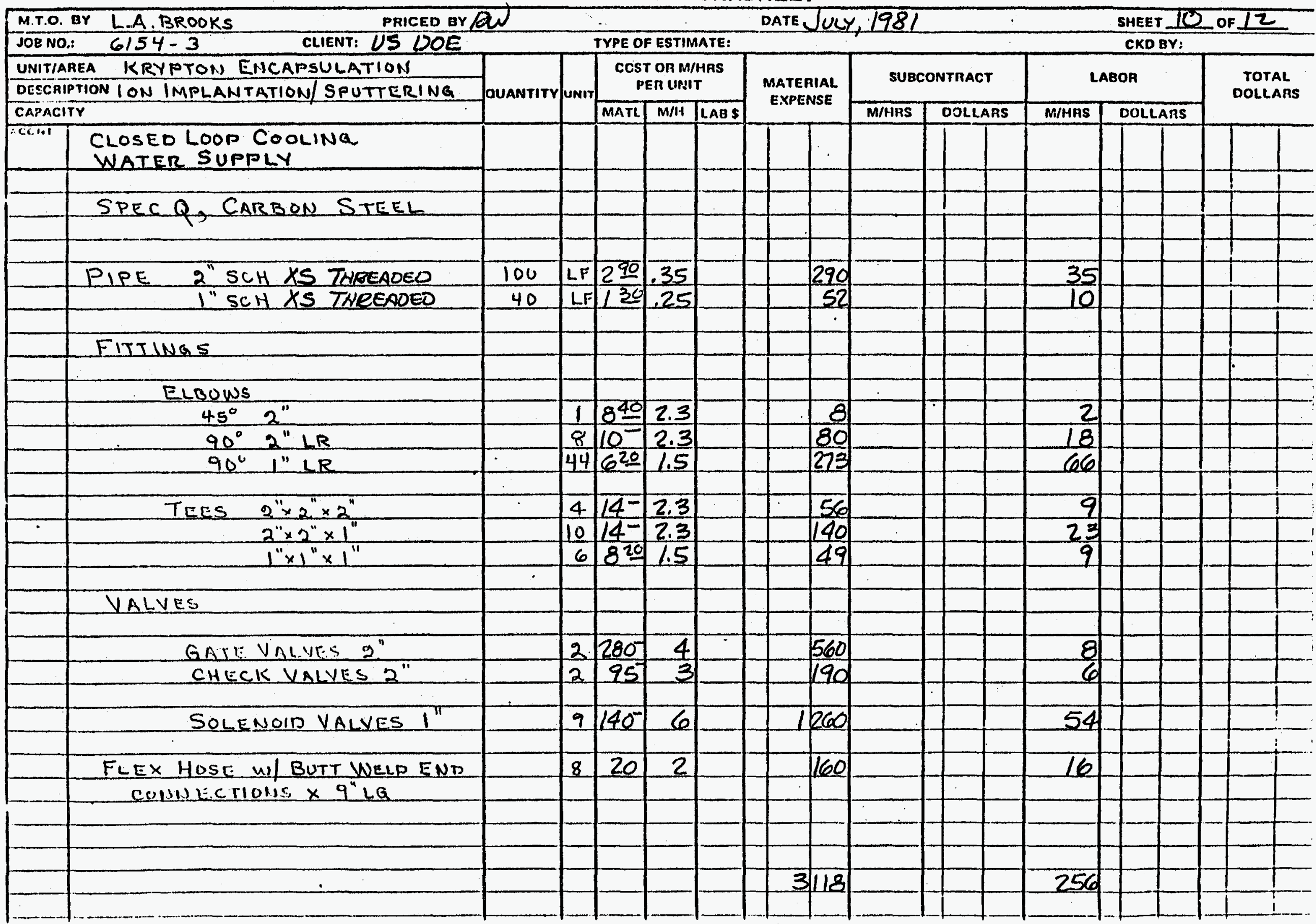


缕

ind

in

(i)

m 9

* ก

m

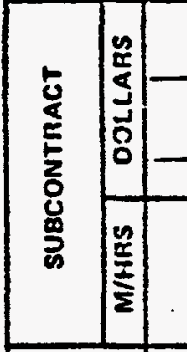

畜

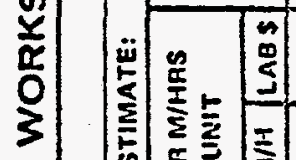

岁

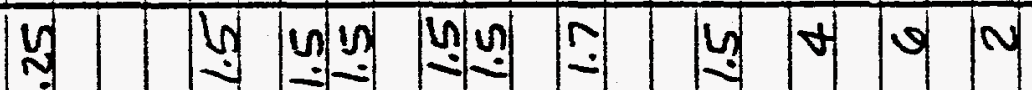

$\sum_{=}^{5}$

w

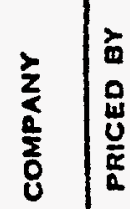

70

$\frac{\bar{z}}{\mathbf{z}}$

ह

榱

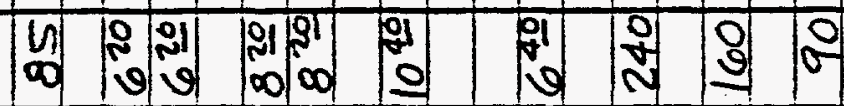

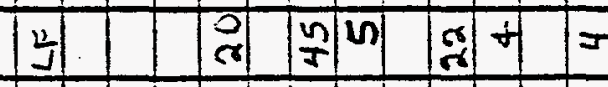

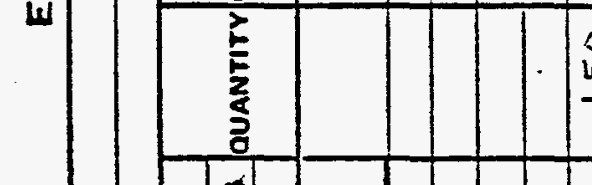

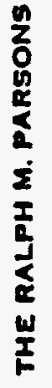

(

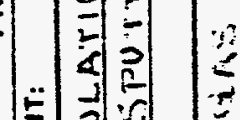

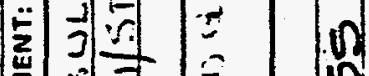

0 वे

뎡븍 :

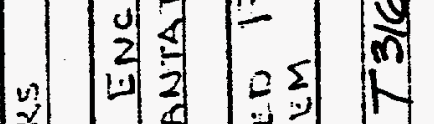

잉 $=4$

일

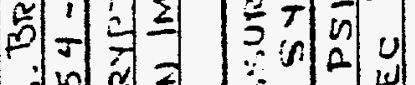

$4 \frac{2}{2}$ 의

z $a^{2}=m n$

$\frac{5}{2} \quad \frac{2}{62}$

言

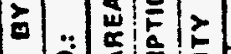

0

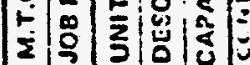




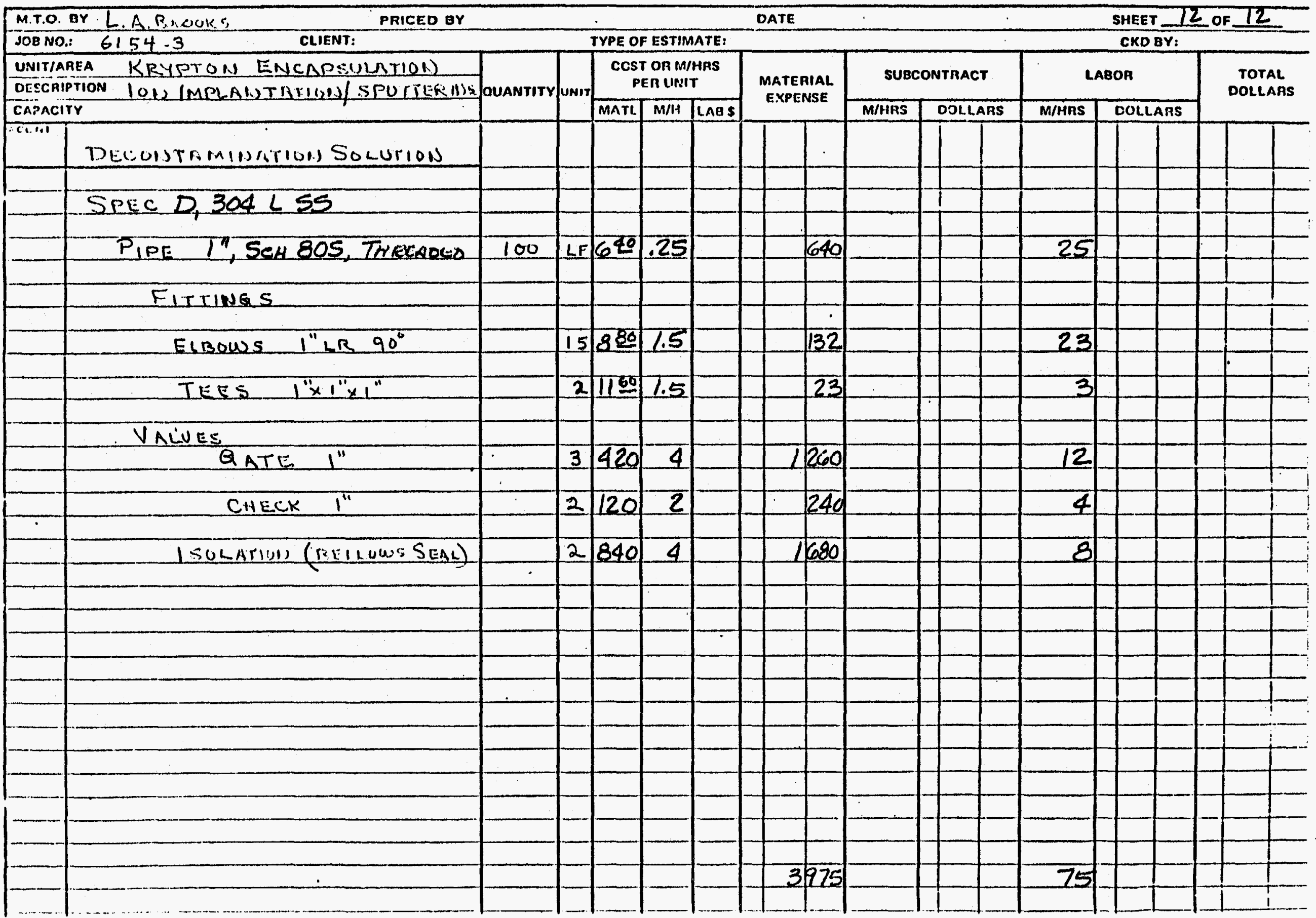


THE RALPH M. PARSONS COMPANY

ESTIMATE WORKSHEET

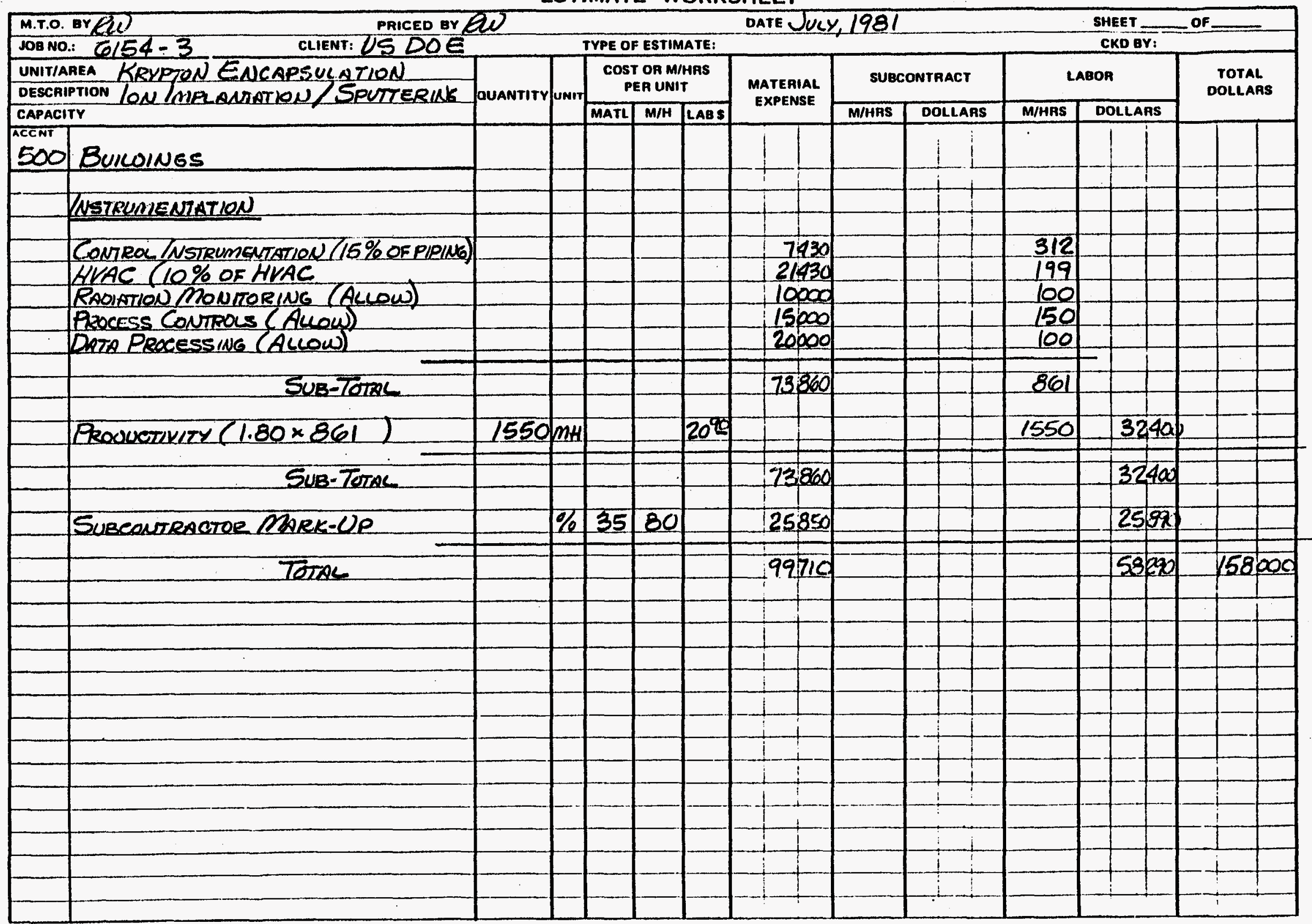




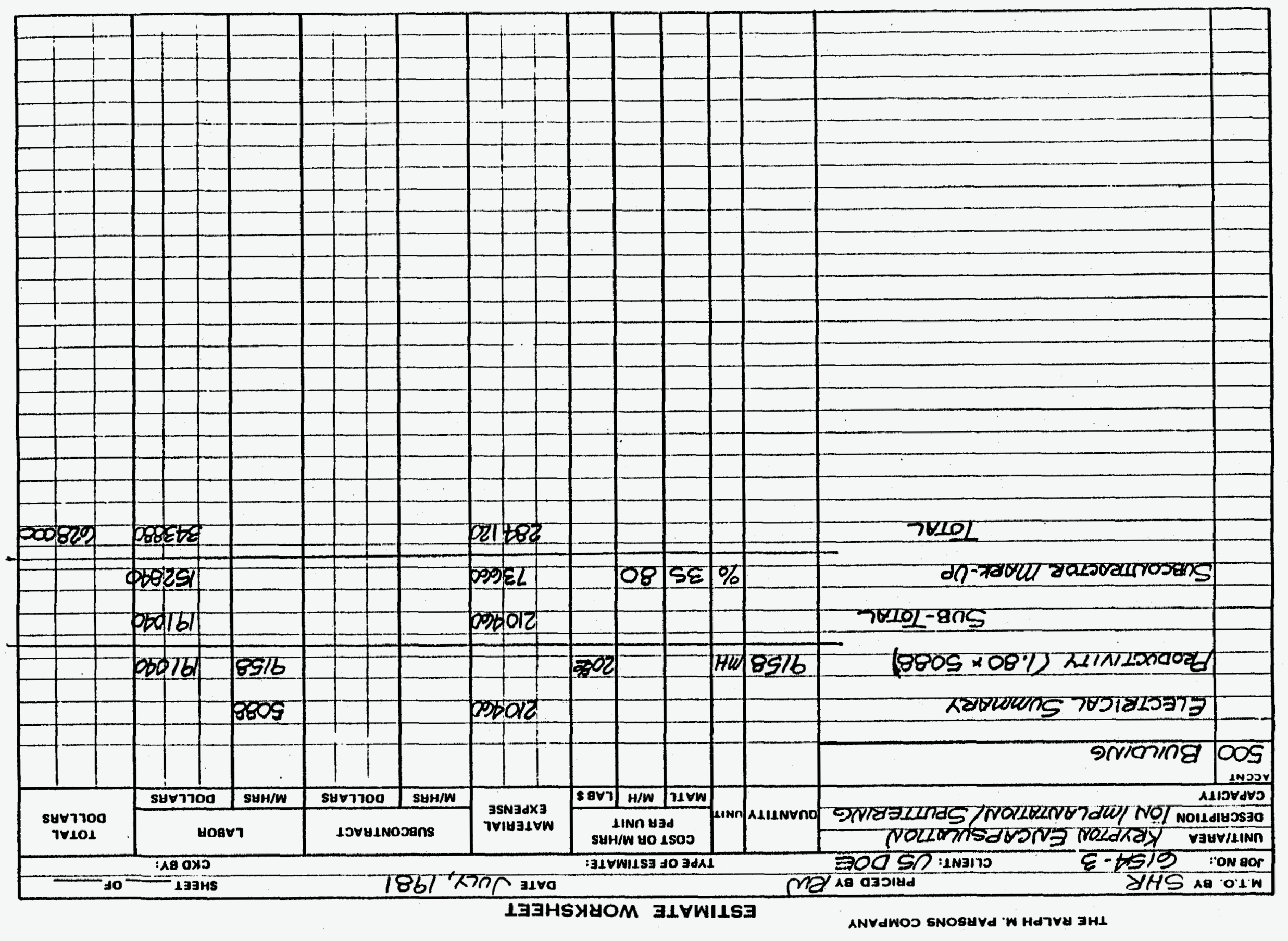

00002530 

THE RALPH M. PARSONS COMPANY

ESTIMATE WORKSHEET

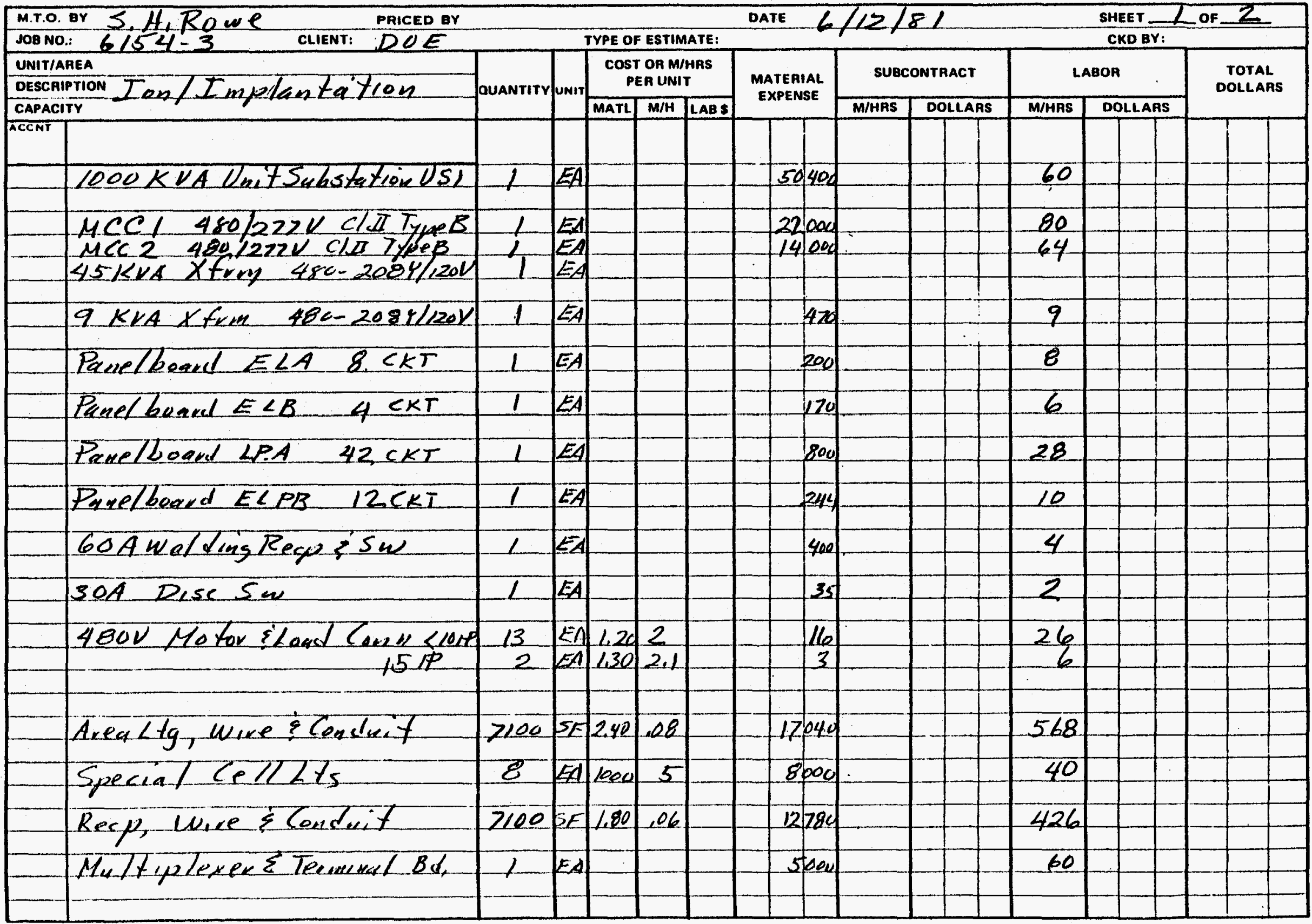


THE RALPH M. PARSONS COMPANY

ESTIMATE WORKSHEET

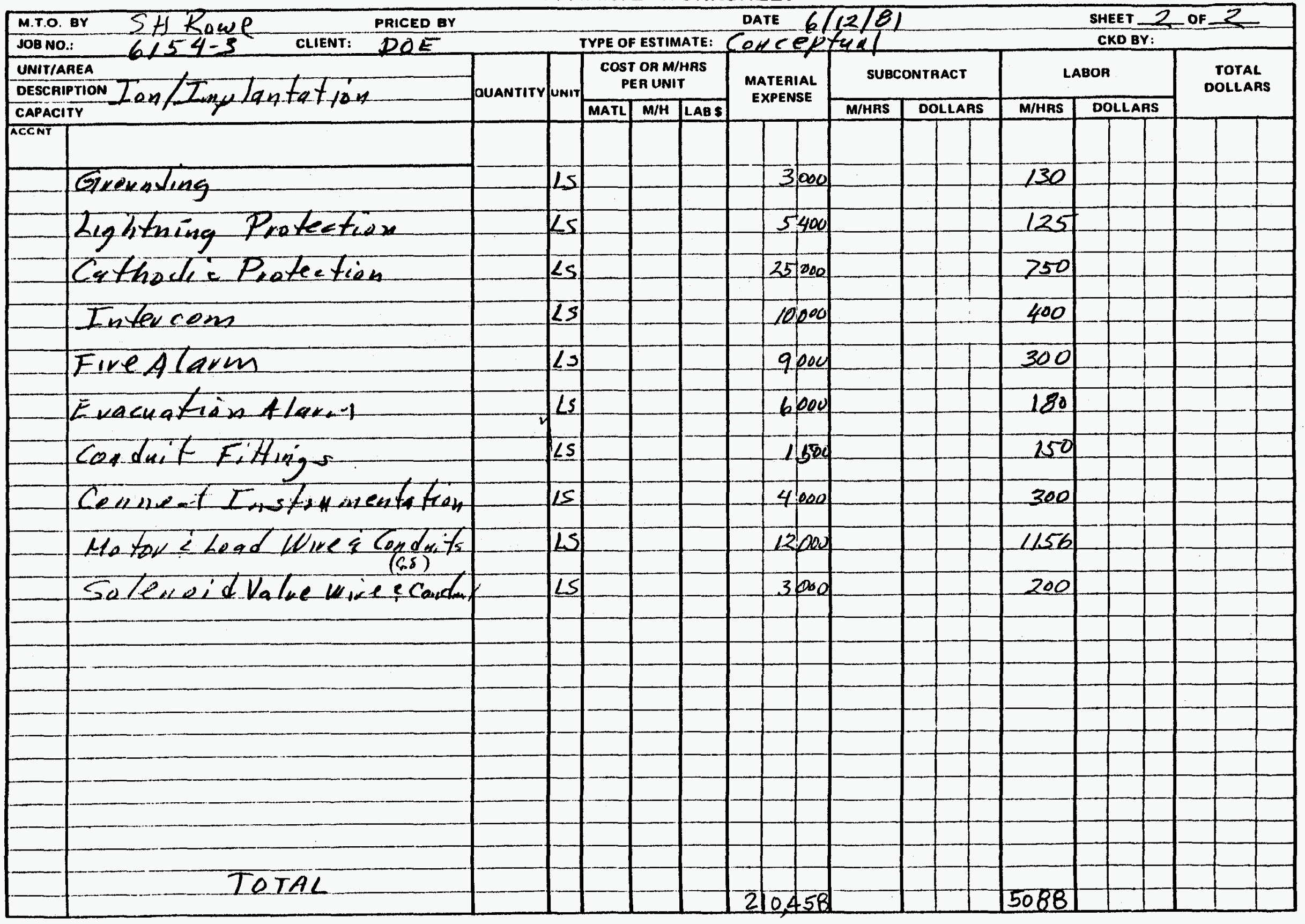


THE RALPH M. PARSONS COMPANY

ESTIMATE WORKSHEET

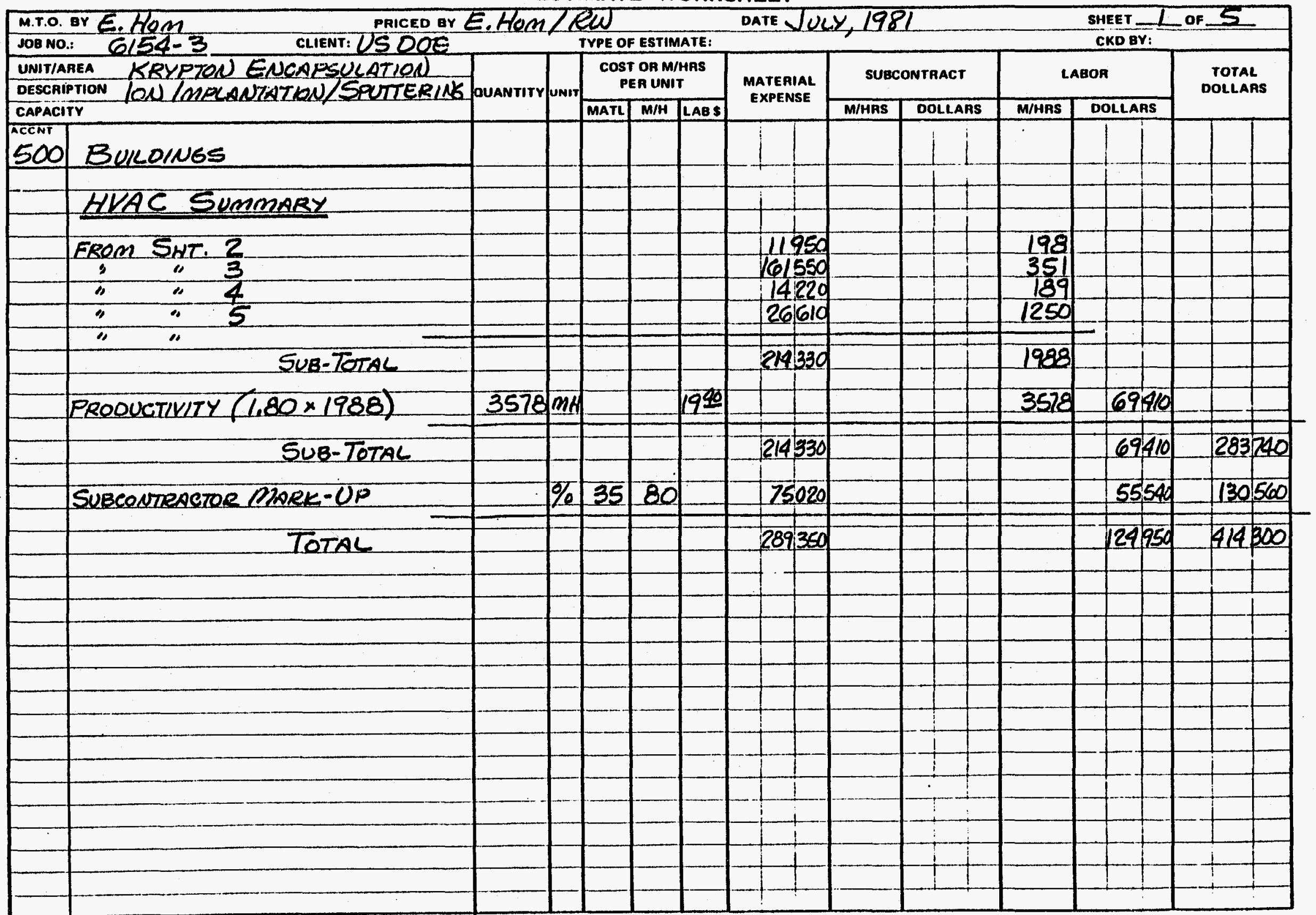



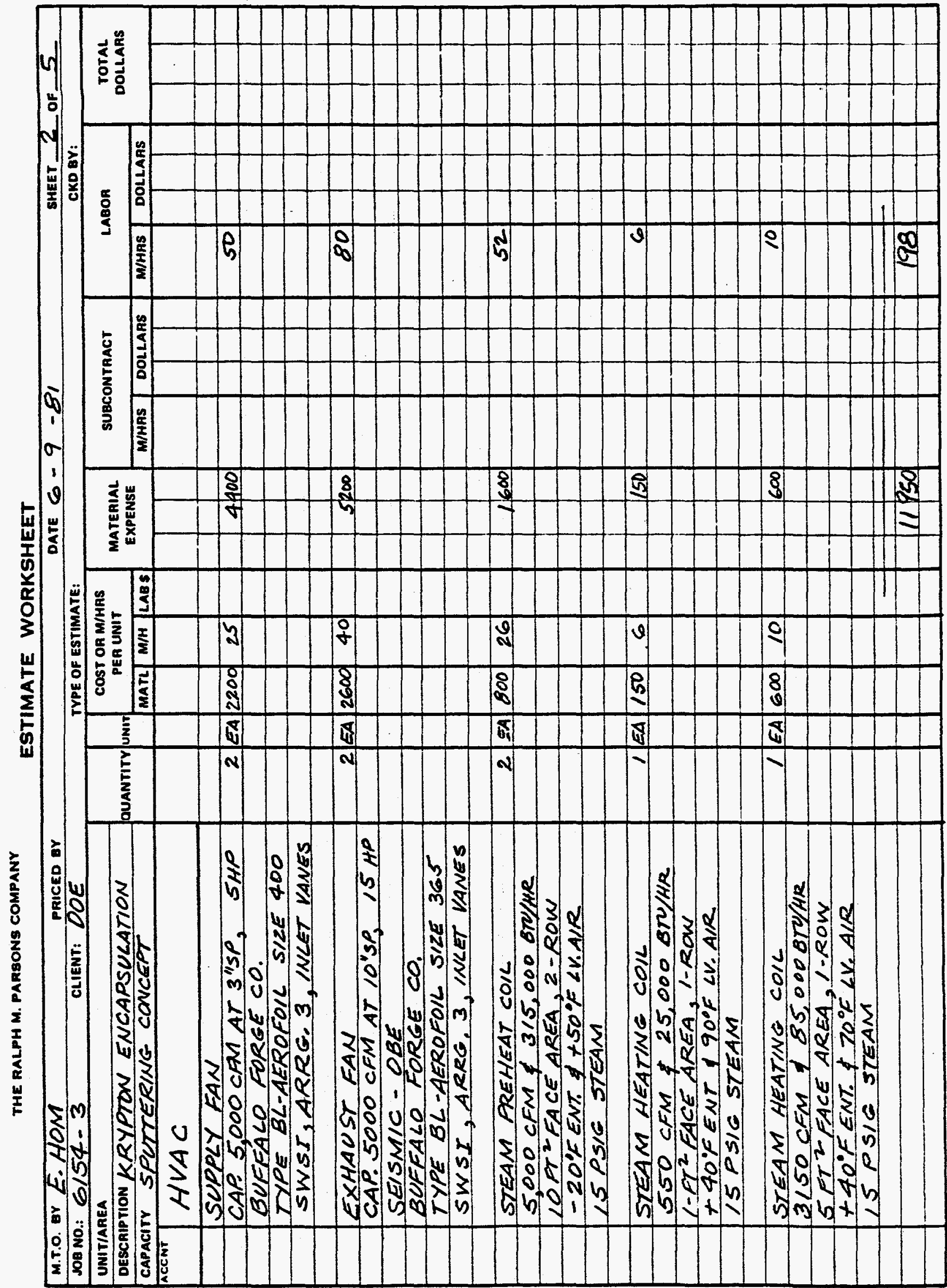
ESTIMATE WORKSHEET

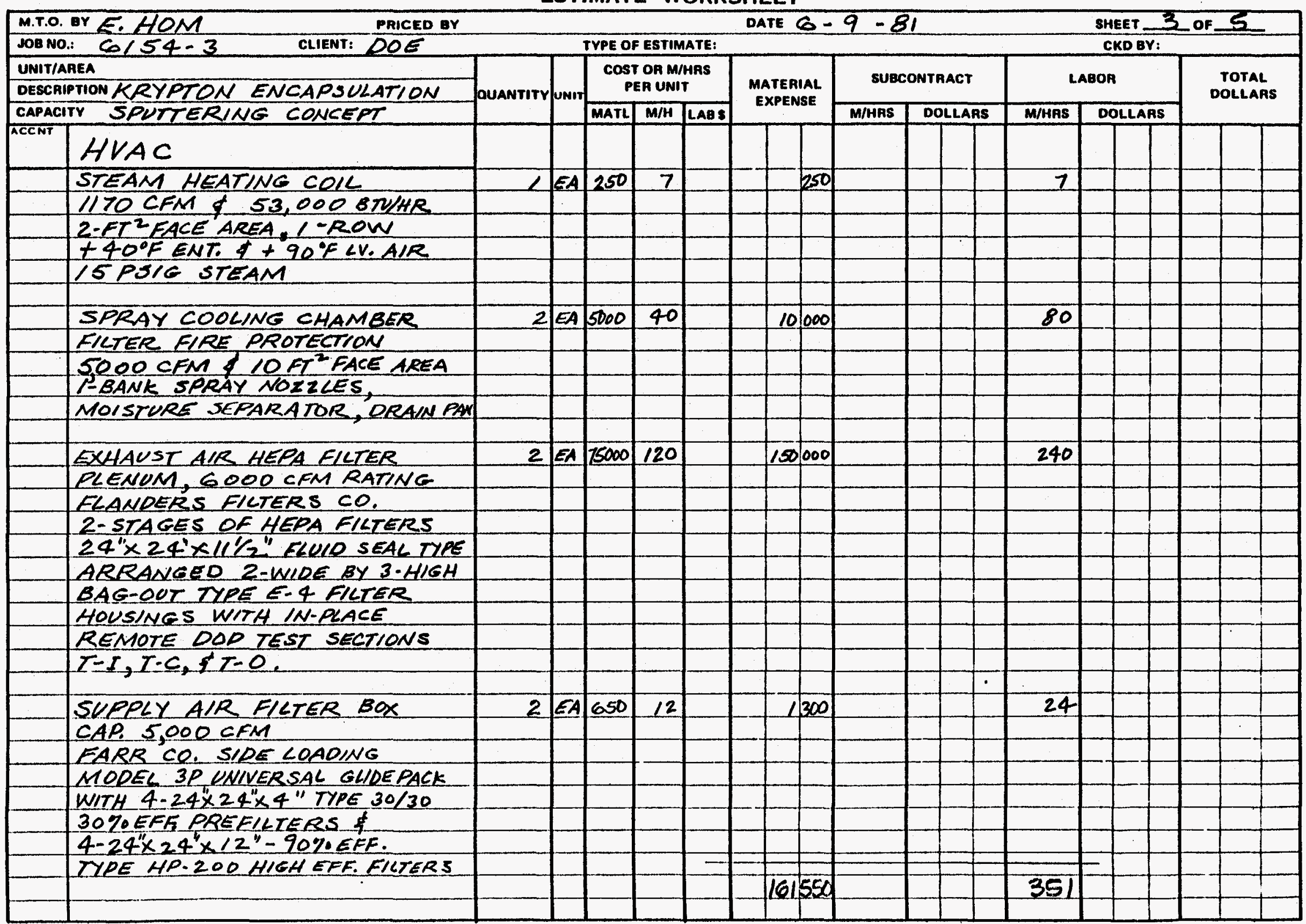


THE RALPH M. PARSONS COMPANY

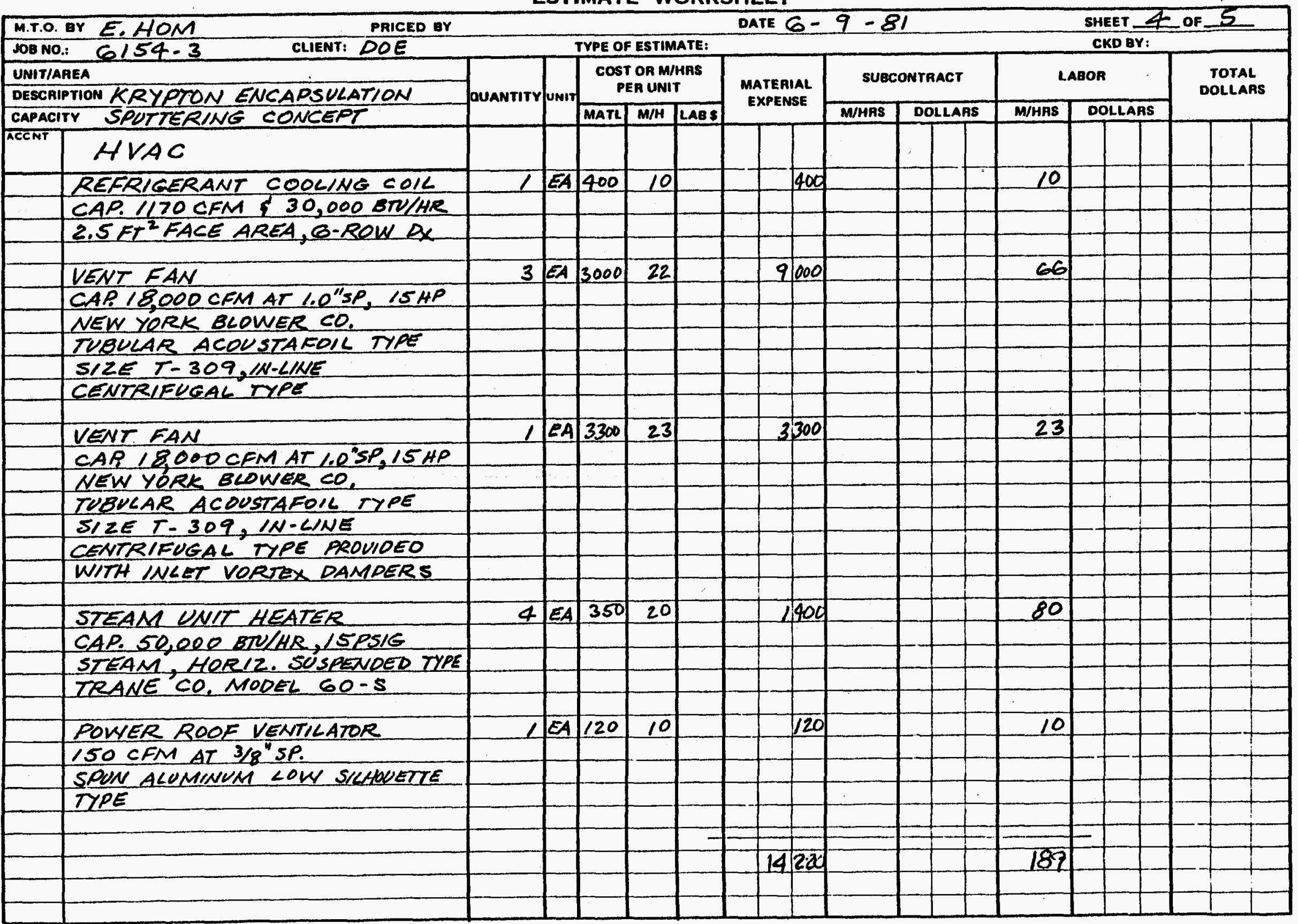

ESTIMATE WORKSHEET 


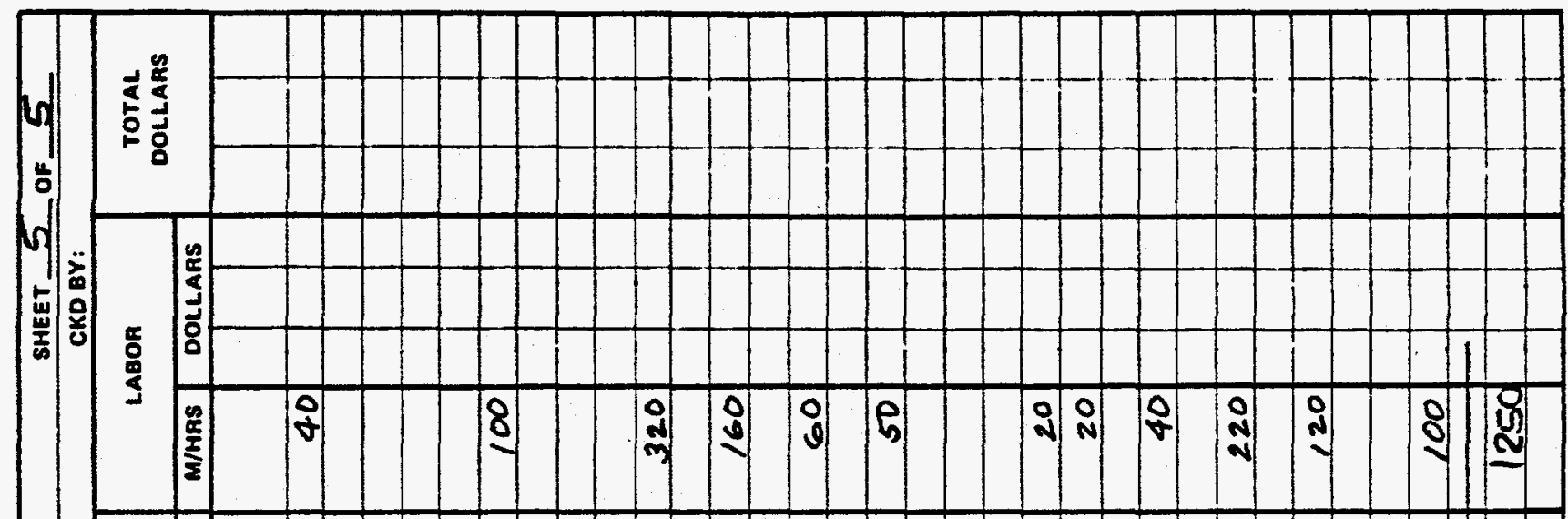

|

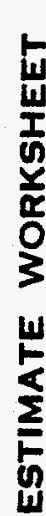

1.

I

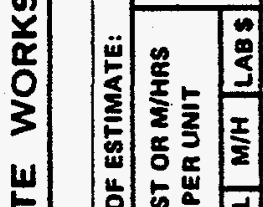

$W$
$\Sigma$
$\Sigma$

8

市

혼

연 8 연

2.

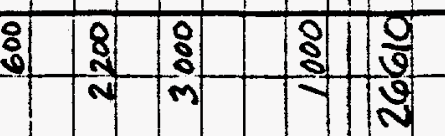

点

.

$\frac{1}{3}+1$

5

产

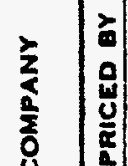

a

3

व

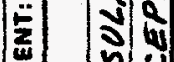

ช

งิ

m

I

$5 \mid \begin{array}{ll}2 \\ 2 \\ 2\end{array}$

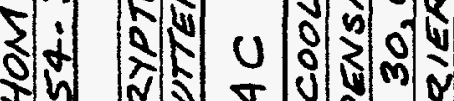

F⿻

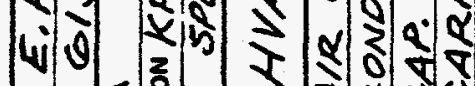

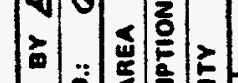

จ v vu

(N) $\quad \frac{0}{0}$

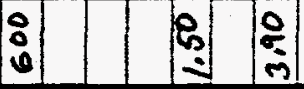

\& 15

$\forall \quad \mid \begin{array}{lll}0 & 0 \\ 0 & 0 \\ 0 & 1\end{array}$

\begin{tabular}{|l|l|lllll|l}
$y$ & $y$ & $y$ & $y$ & $y$ & $y$ & $y$ & $y$ \\
$y$ & $y$ & $y$ & $y$ & $y$ & $y$ & $y$
\end{tabular}
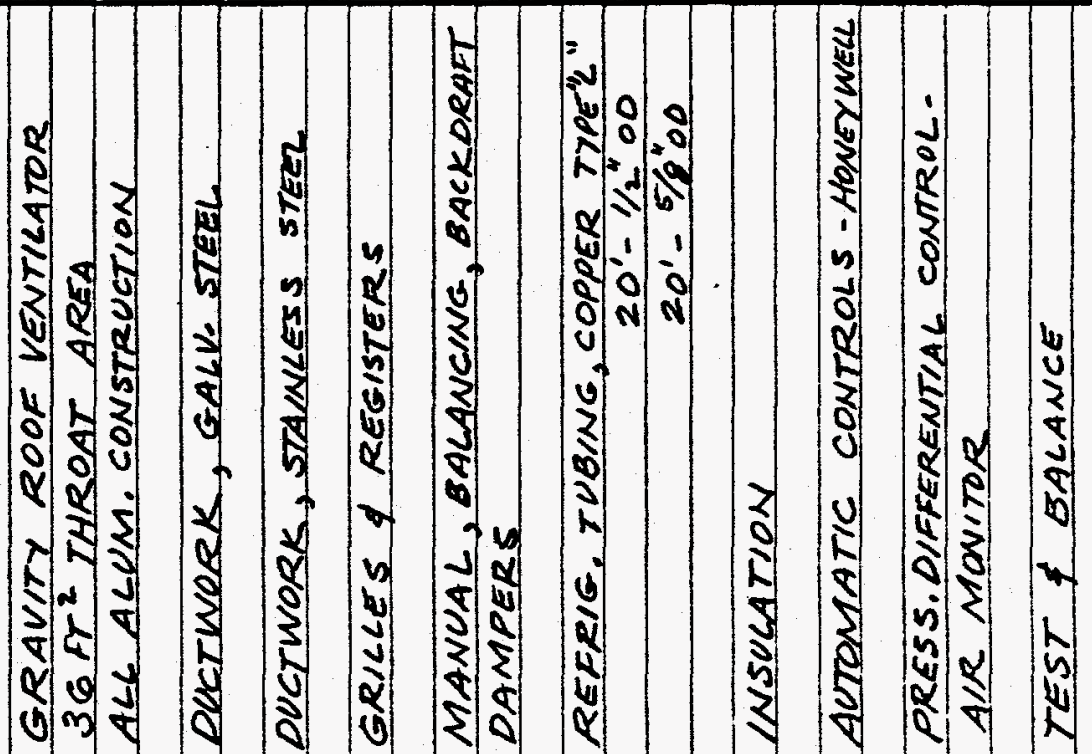
THE RALPH M. PARSONG COMPANY

ESTIMATE WORKSHEET

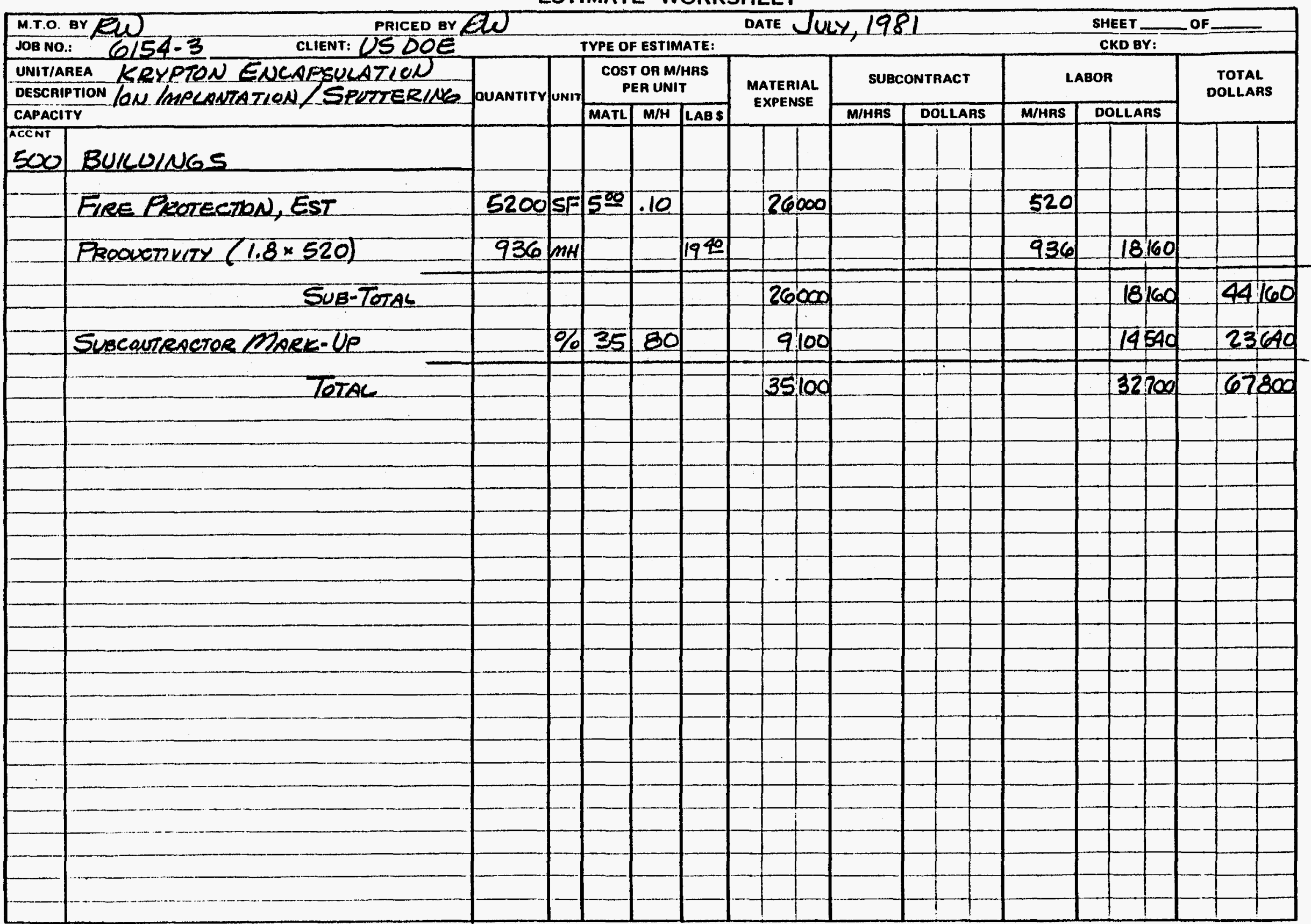


THE RALPH M. PARSONS COMPANY

ESTIMATE WORKSHEET

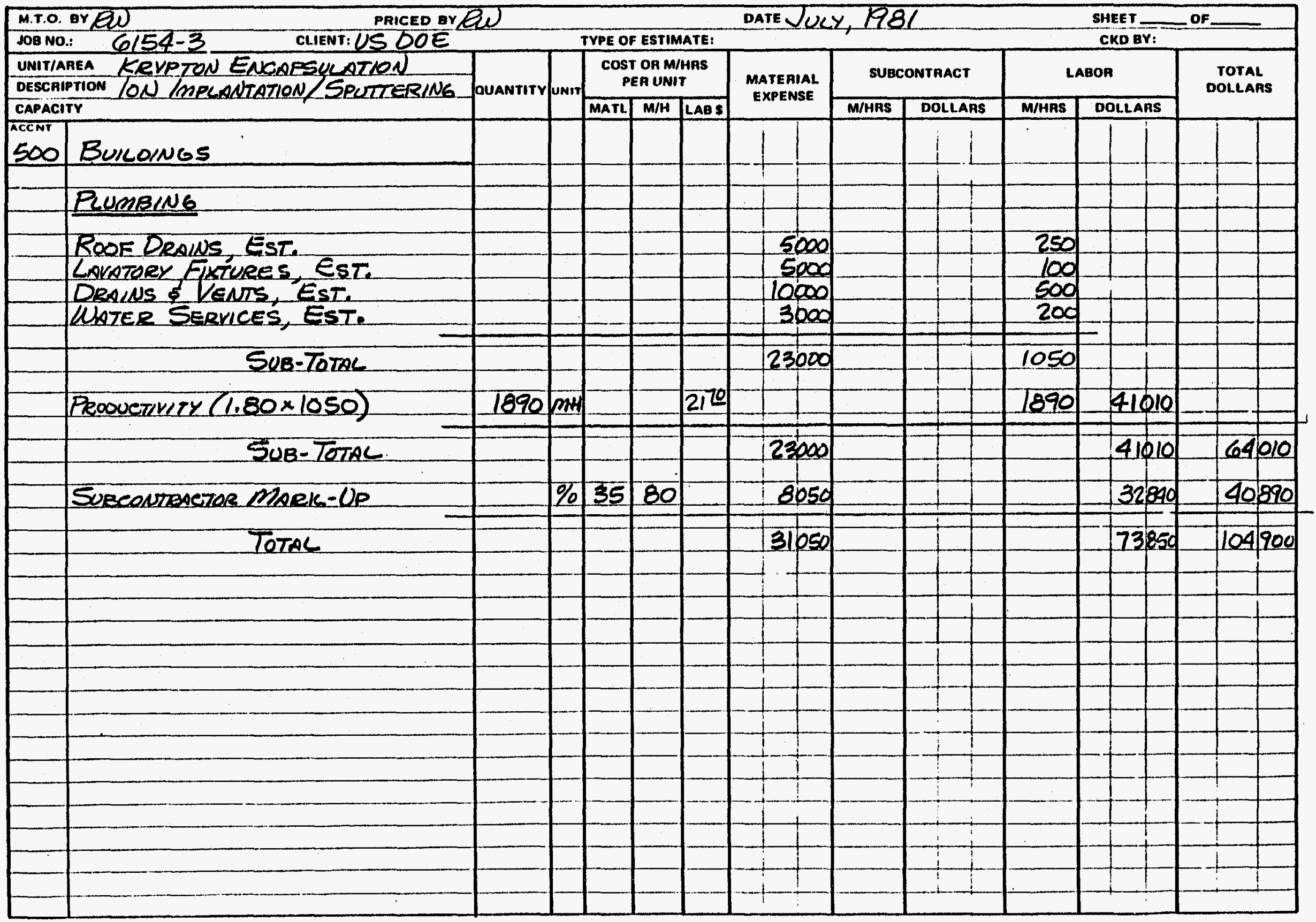




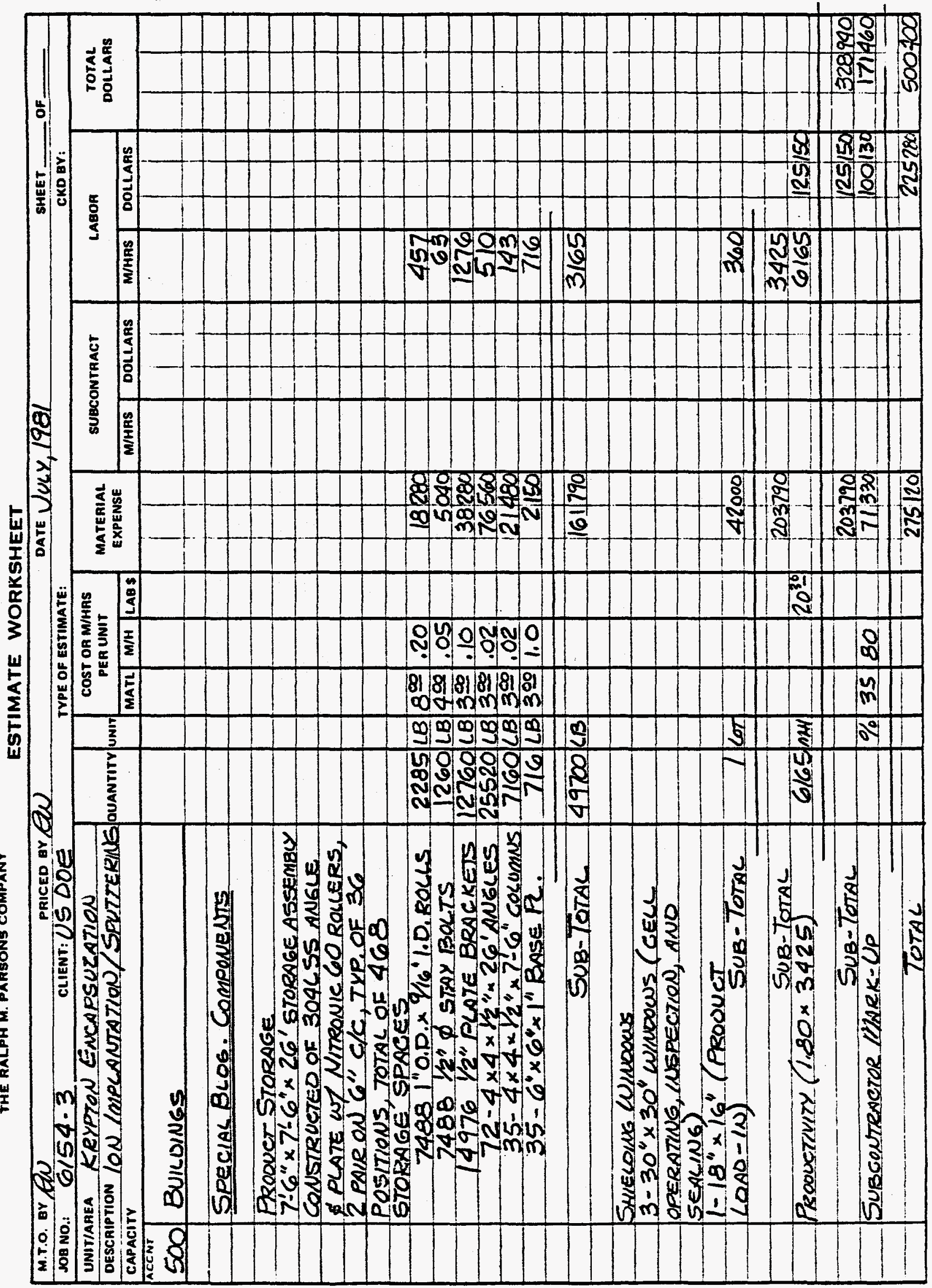




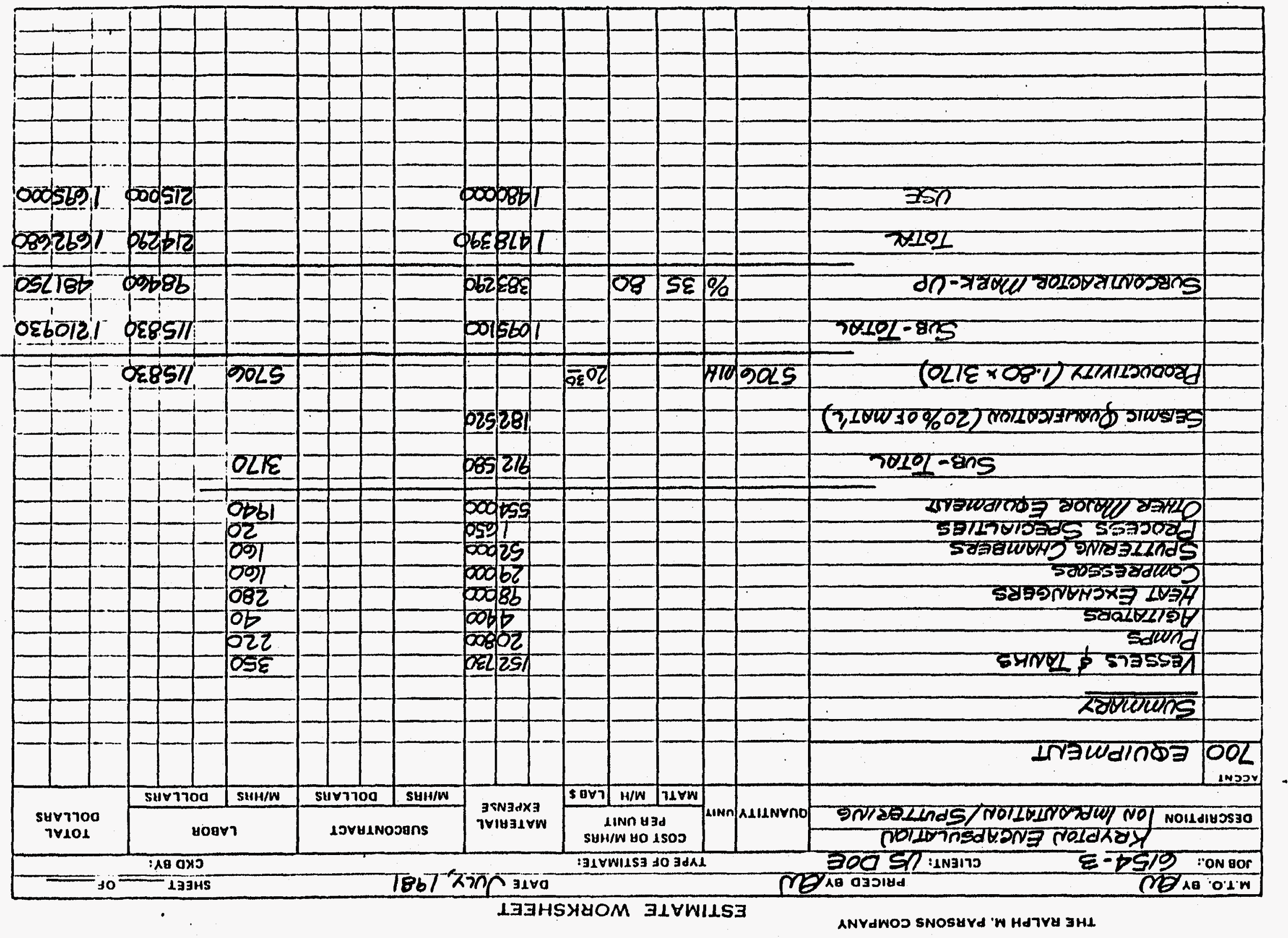




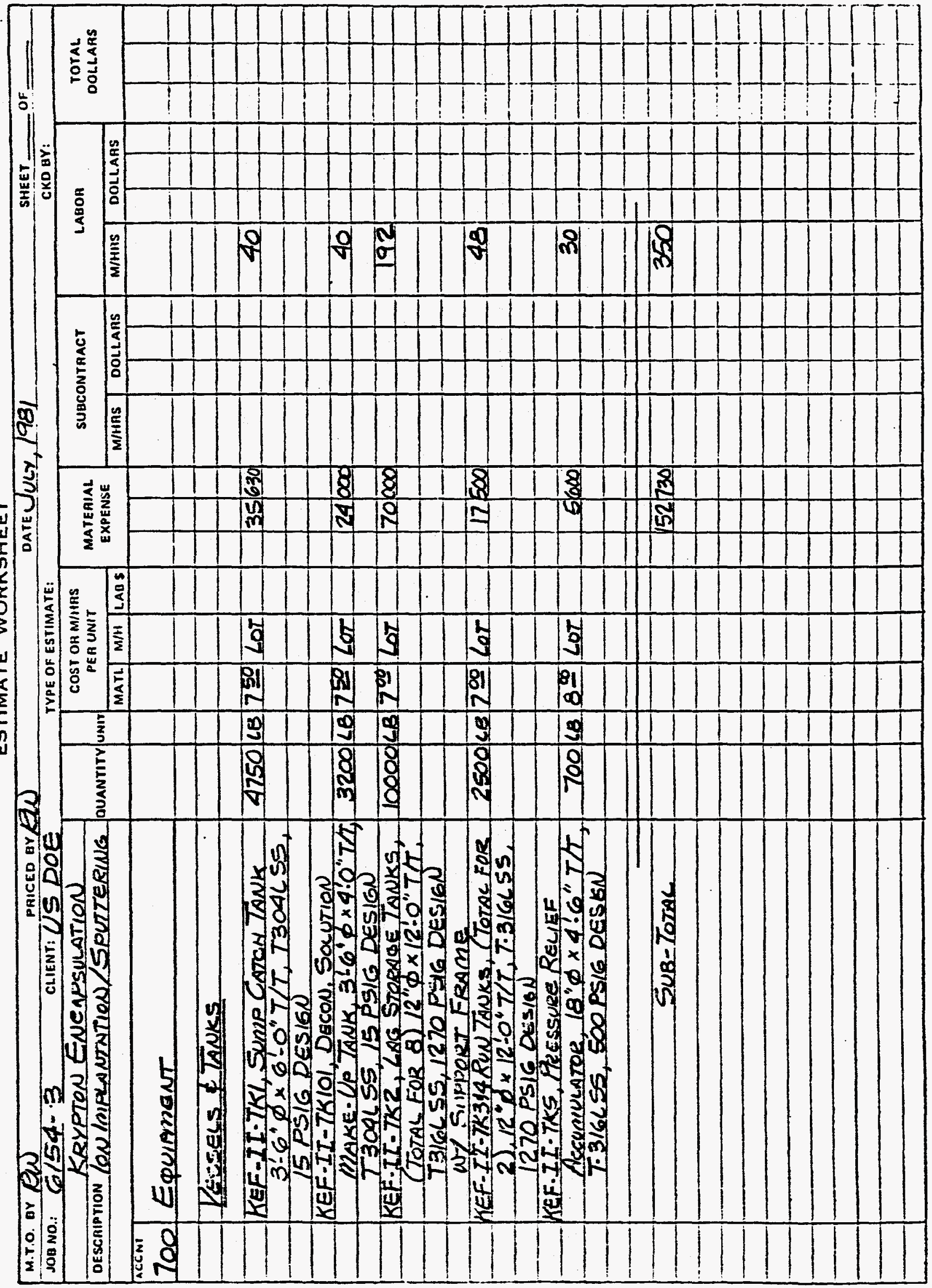



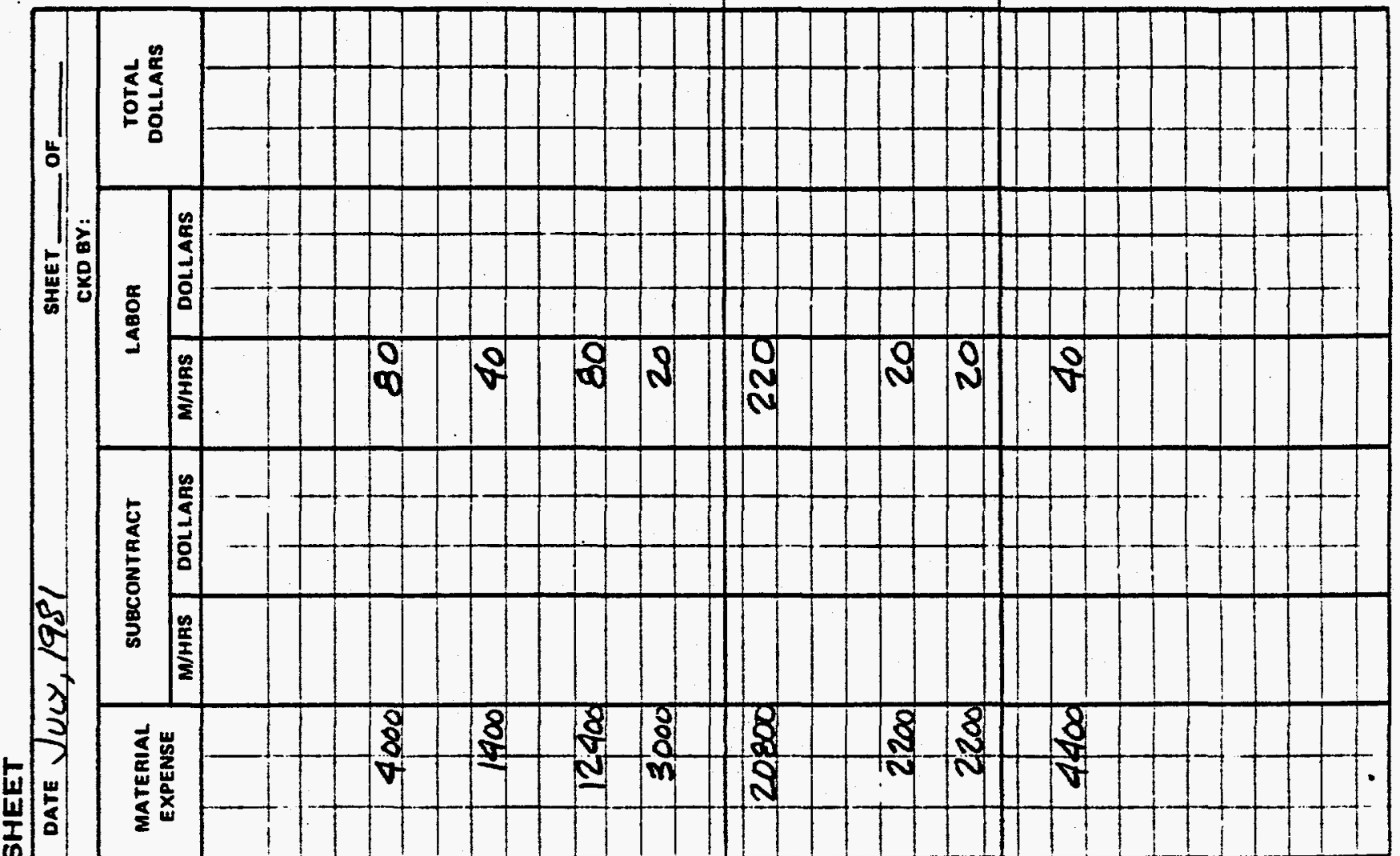

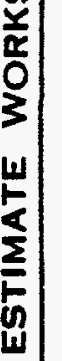

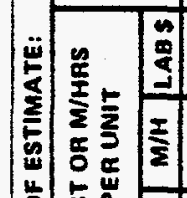

屴

aิ ง

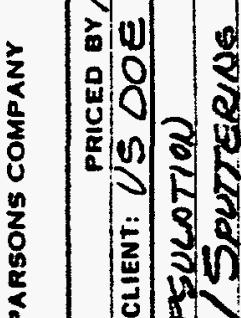

$3{ }^{2}$

$$
\frac{5}{2}
$$

\$

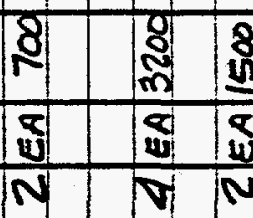

$\checkmark N N$

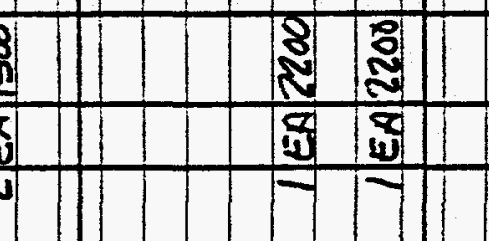

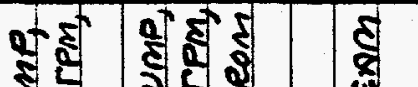

연

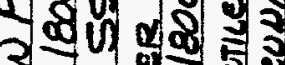

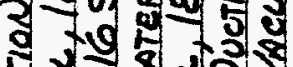

5 สํำ क्षेत्र

ง

ำ 순

ริง

Q บै

告

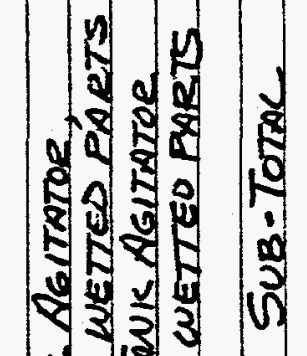

要

$\ln \frac{3}{2}$

5

a

ชี่ง

Jution

von

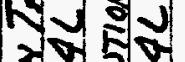

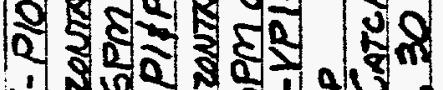

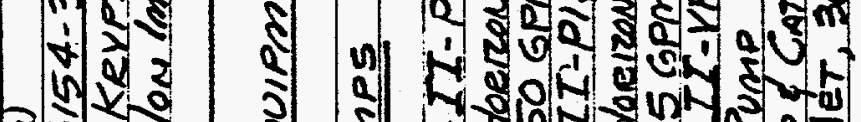

3.

×

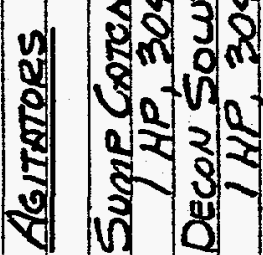

0. $\frac{0}{2}$ 送

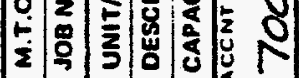


THE RALPH M. PARSONS COMPANY

ESTIMATE WORKSHEET

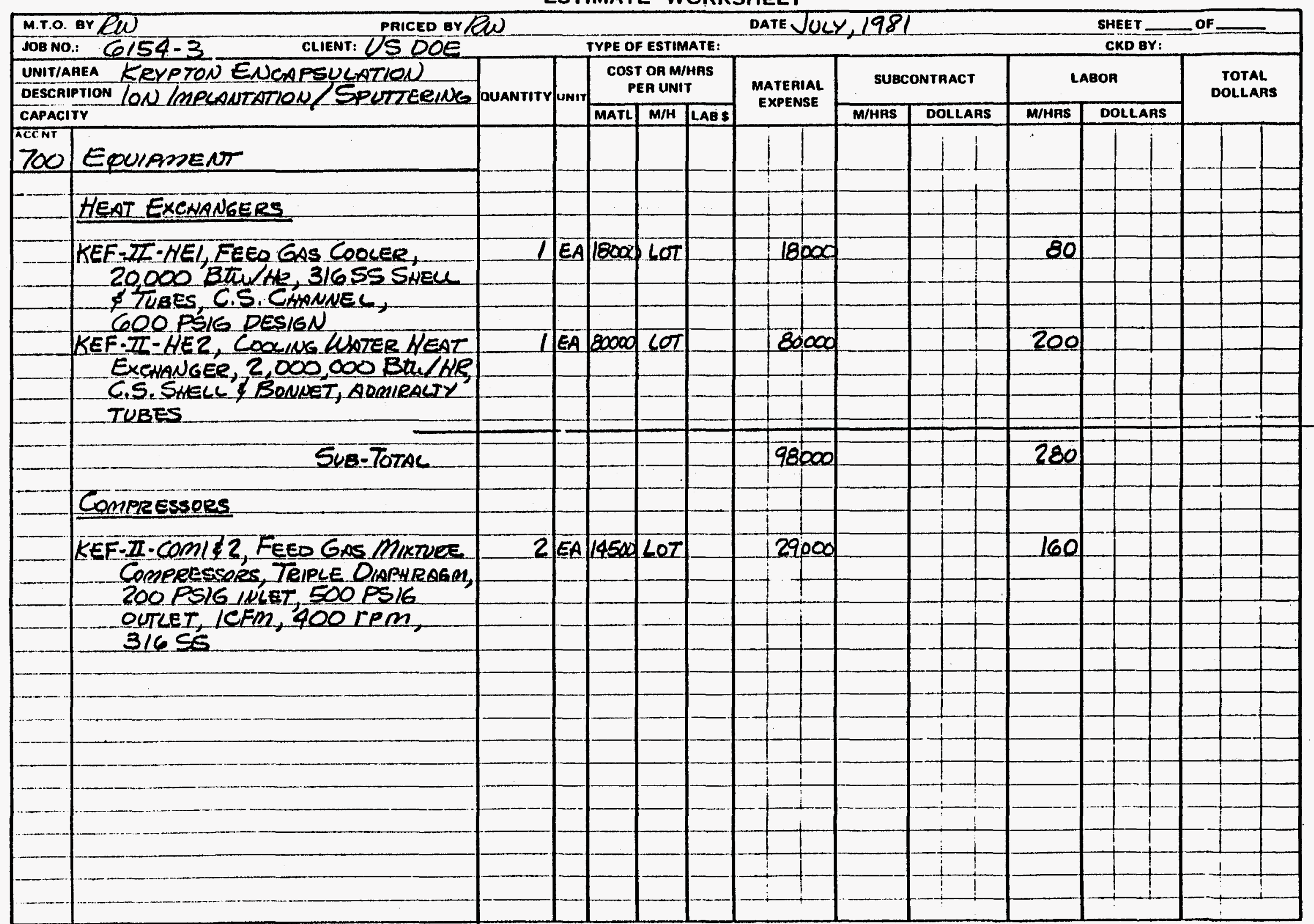




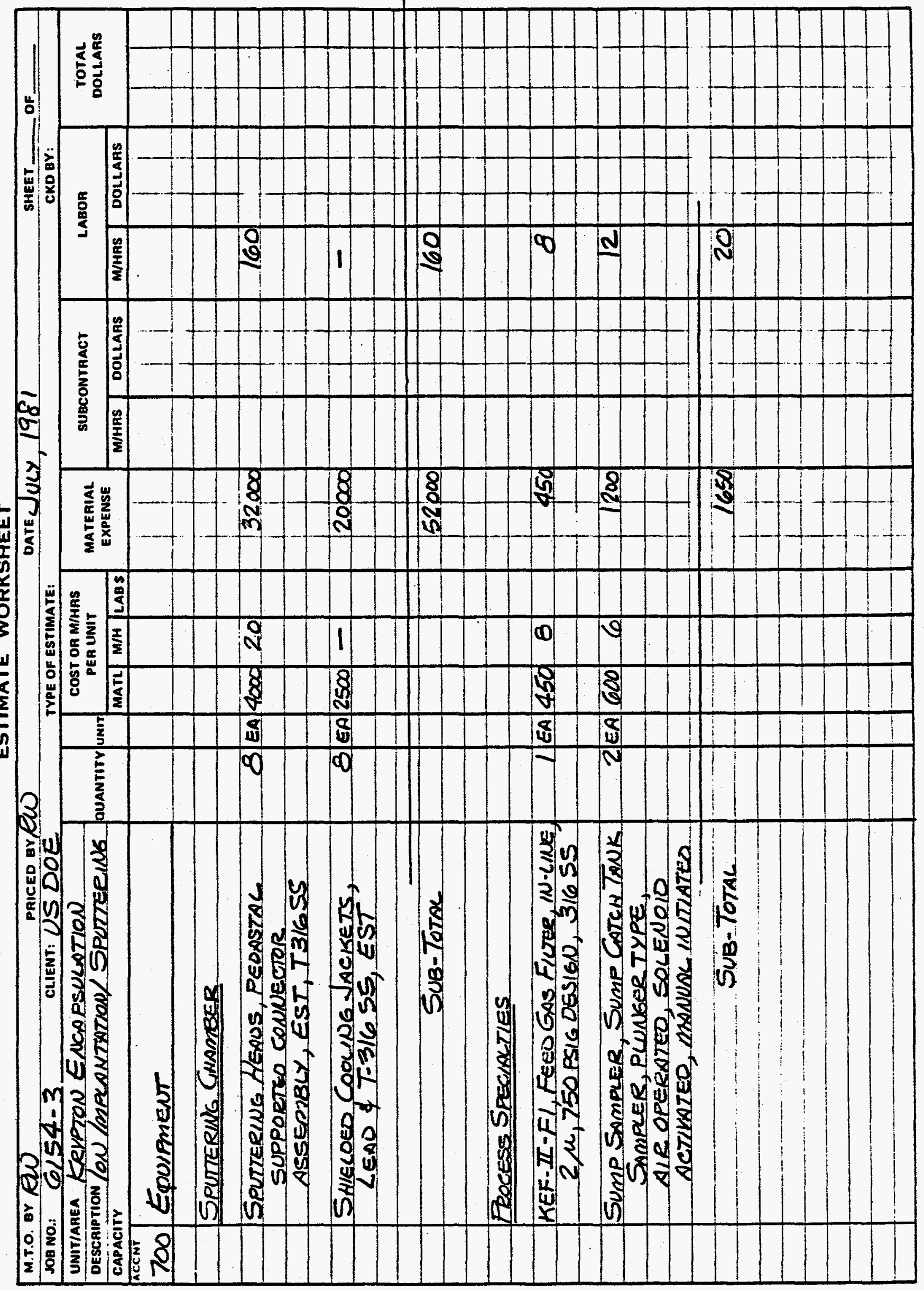




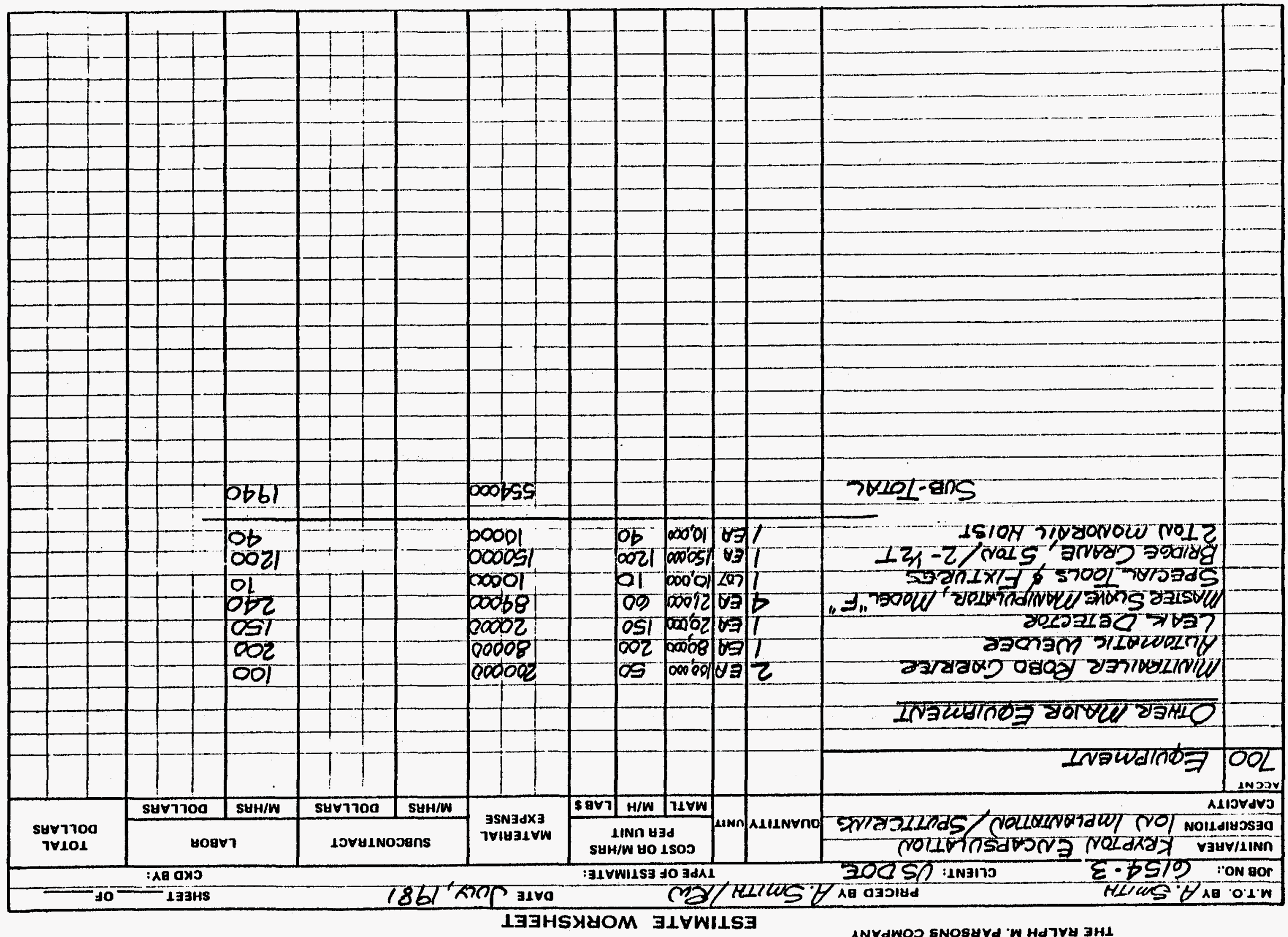


Krypton eneapsulation preconeeptual Desion provect NAME: ZEOLITE ENEAPSULATION FACILITY

PROJECT NO. 6/54-3 SUMMATERY

\begin{tabular}{|c|c|c|c|c|}
\hline $\begin{array}{c}\text { ACCT. } \\
\text { NO. }\end{array}$ & DESCRIPTION & $\begin{array}{c}\text { LABOR } \\
\text { COST } \\
\$\end{array}$ & $\begin{array}{c}\text { MATERIAL } \\
\text { COST } \\
\$\end{array}$ & $\begin{array}{c}\text { TOTAL } \\
\text { COST } \\
\$\end{array}$ \\
\hline & DIRECT COST & & & \\
\hline 400 & IMPROVEMENTS TO LAND & 22,000 & 2,000 & 24,000 \\
\hline 500 & BUILDING $\&$ OTHER STRUCTURES & $1,325,000$ & $1,290,000$ & $2,615,000$ \\
\hline 500 & UTILITIES (NOT IN CLUDED) & $\overline{-}$ & - & \\
\hline 700 & EQUIPMENT & 230,000 & $1,895,000$ & $2,125,000$ \\
\hline \multirow[t]{3}{*}{800} & DEMOLITION \& REMOVALS (NONE) & $=$ & $=$ & $=$ \\
\hline & TOTAL DIRECT COST & $1,577,000$ & $3,187,000$ & $4,764,000$ \\
\hline & CONTRACTOR INDIRECTS @ $10 \%$ & & & 476000 \\
\hline & & & & \\
\hline & & & & \\
\hline & & & & \\
\hline & TOTAL CONSTRUCTION COST & & & $5,240,000$ \\
\hline & & & & \\
\hline & & & & \\
\hline & TITLE I $\& 6 \%$ & & & 315,000 \\
\hline & TITLE I @ $14 \%$ & & & 734,000 \\
\hline & TITLE III C $8 \%$ & & & 421,000 \\
\hline & A - FIEID INSPECTION & & & \\
\hline & B-SHOP INSPECTION & & & \\
\hline & & & & \\
\hline & PROJECT AOMINISTRATION e $10 \%$ & & & 525,000 \\
\hline & & & & \\
\hline & SUB-TOTAL ENGINEERING & & & $1,995,000$ \\
\hline & & & & \\
\hline & SUB-TOTAL & & & $7,235,000$ \\
\hline & & & & \\
\hline & ESCALATION (NOT INCLUDEO) & & & \\
\hline & & & & \\
\hline & SUB-TOTAL & & & $7,235,000$ \\
\hline & & & & \\
\hline & CONTINGENCY \& $40 \%$ & & & $2,8,95,000$ \\
\hline & TOTAL JOB COST & & & $10,130,000$ \\
\hline
\end{tabular}



THE RALPH M. PARSONS COMPANY

ESTIMATE WORKSHEET

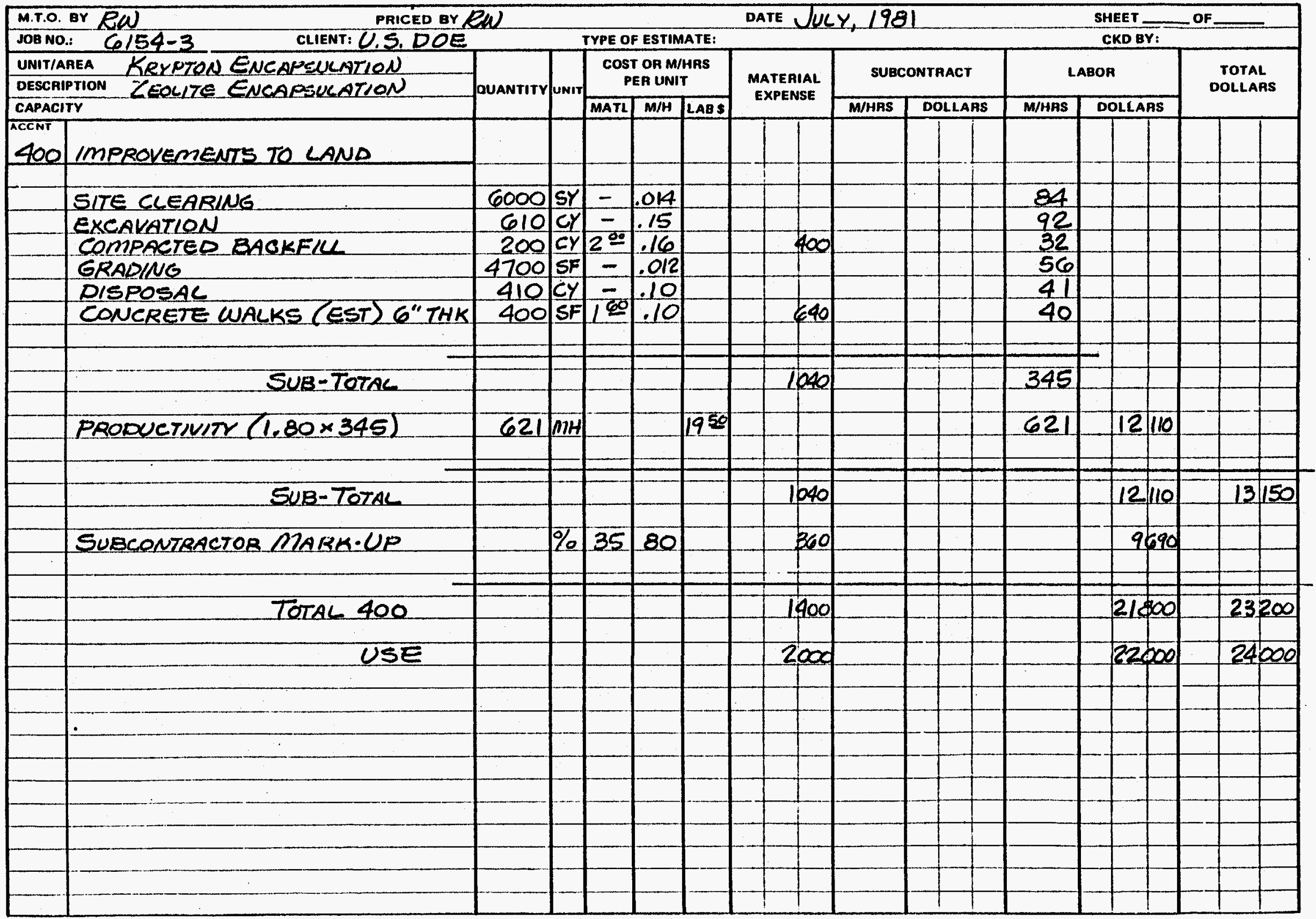




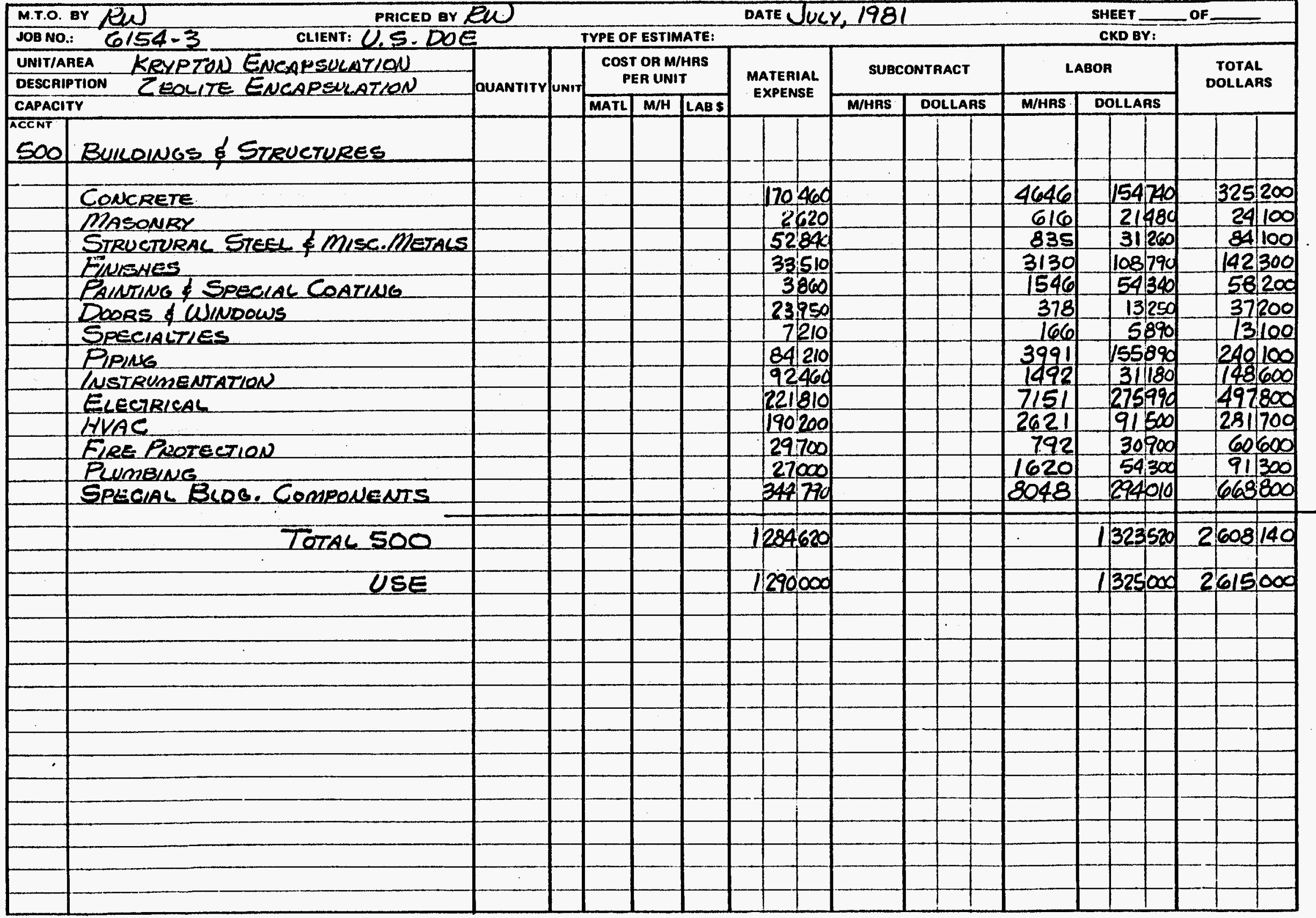


THE RALPH M. PARSONS COMPANY

ESTIMATE WORKSHEET

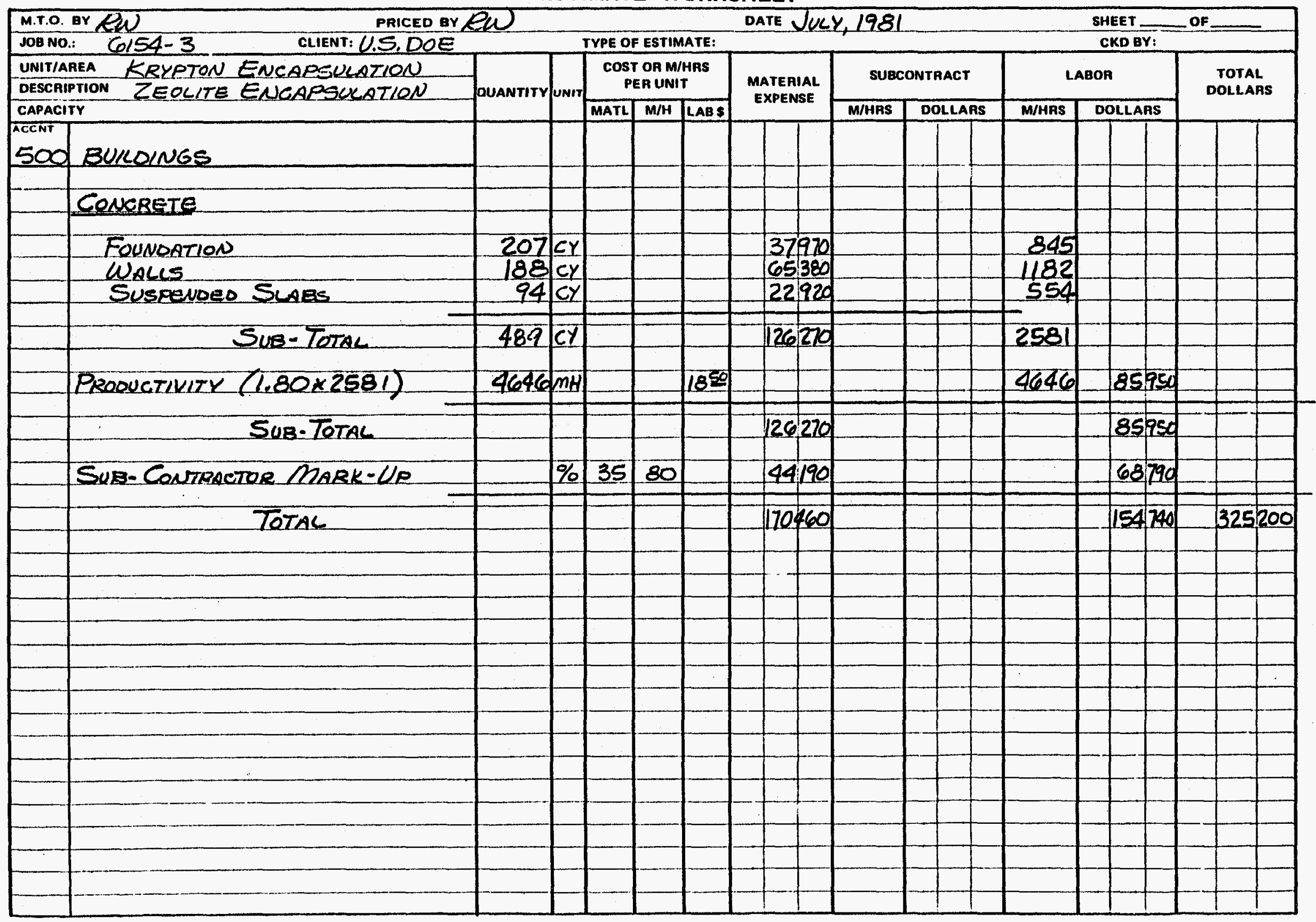


THE RALPH M. PARSONS COMPANY

ESTIMATE WORKSHEET

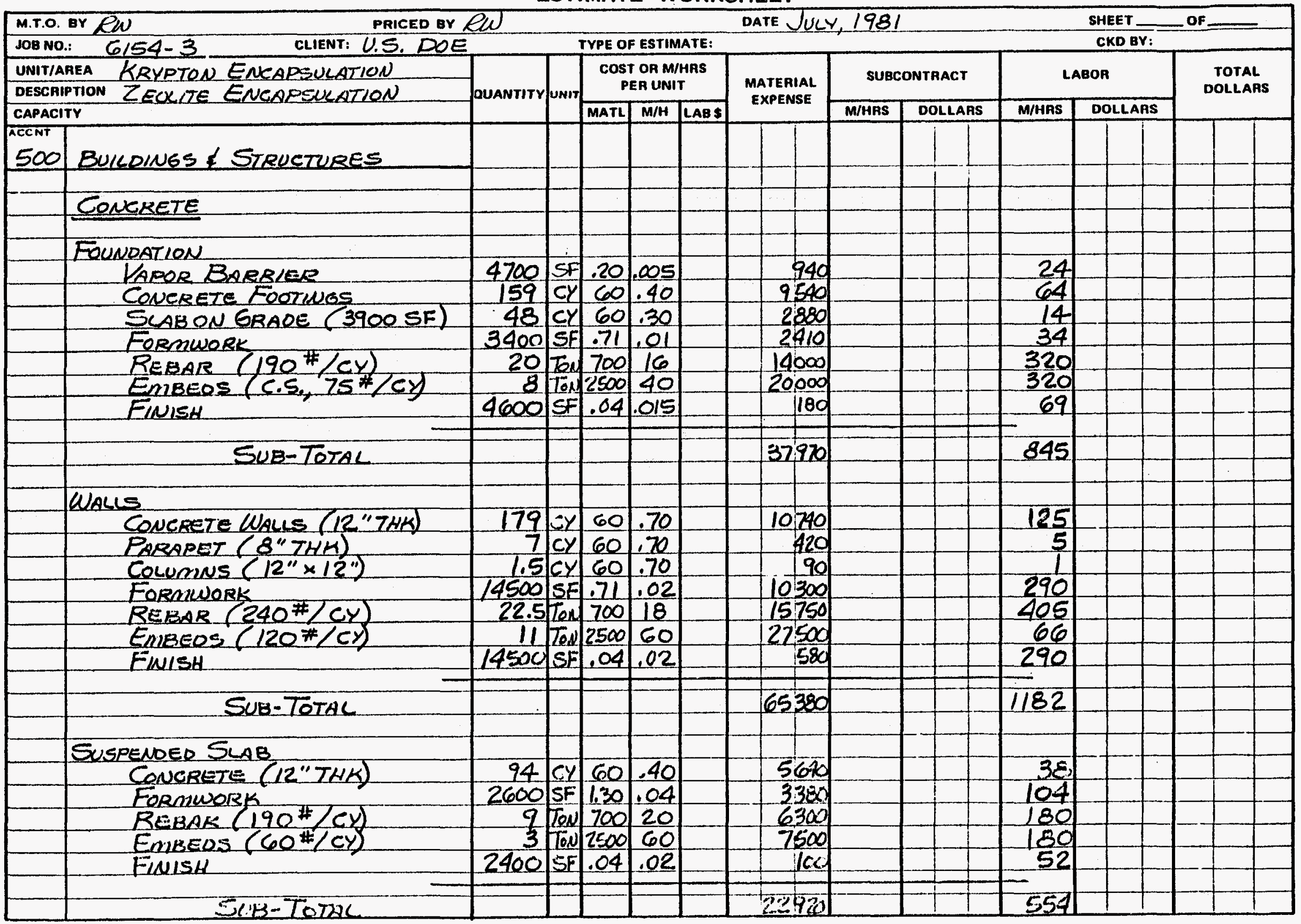


THE RALPH M. PARSONS COMPANY

ESTIMATE WORKSHEET

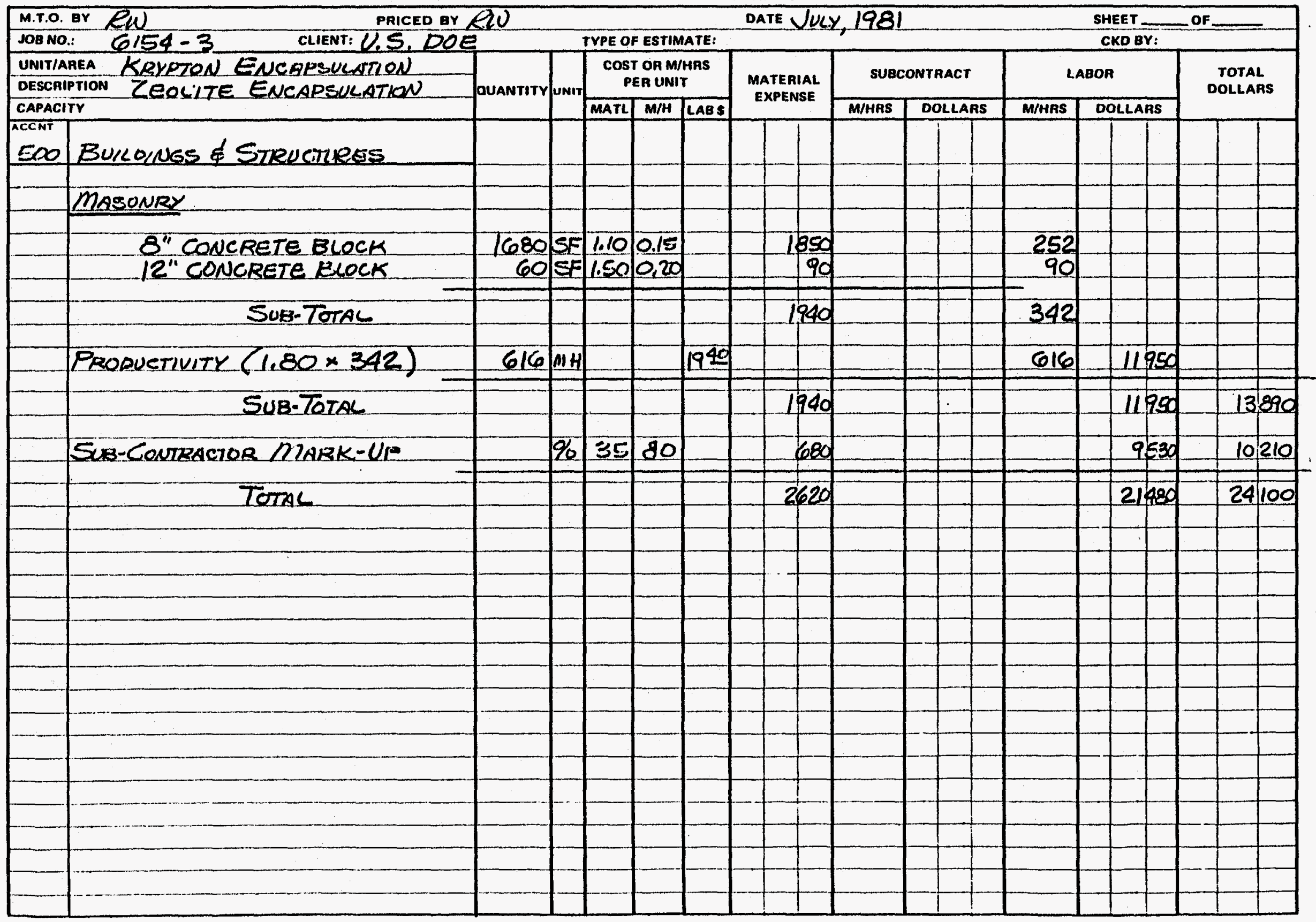


Ces 20000

THE RALPH M. PARSONS COMPANY

ESTIMATE WORKSHEET

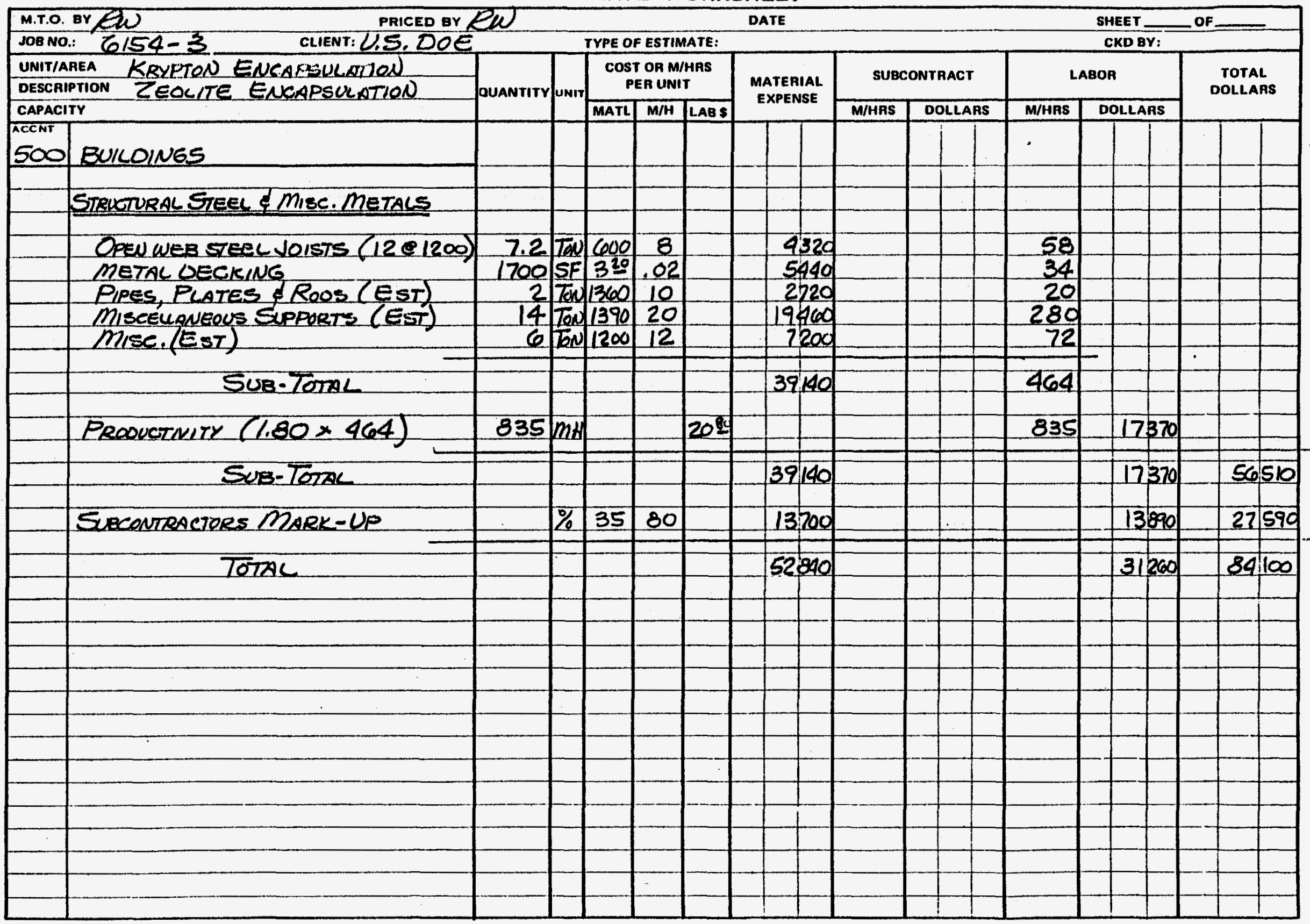


THE RALPH M. PARSONS COMPANY

ESTIMATE WORKSHEET

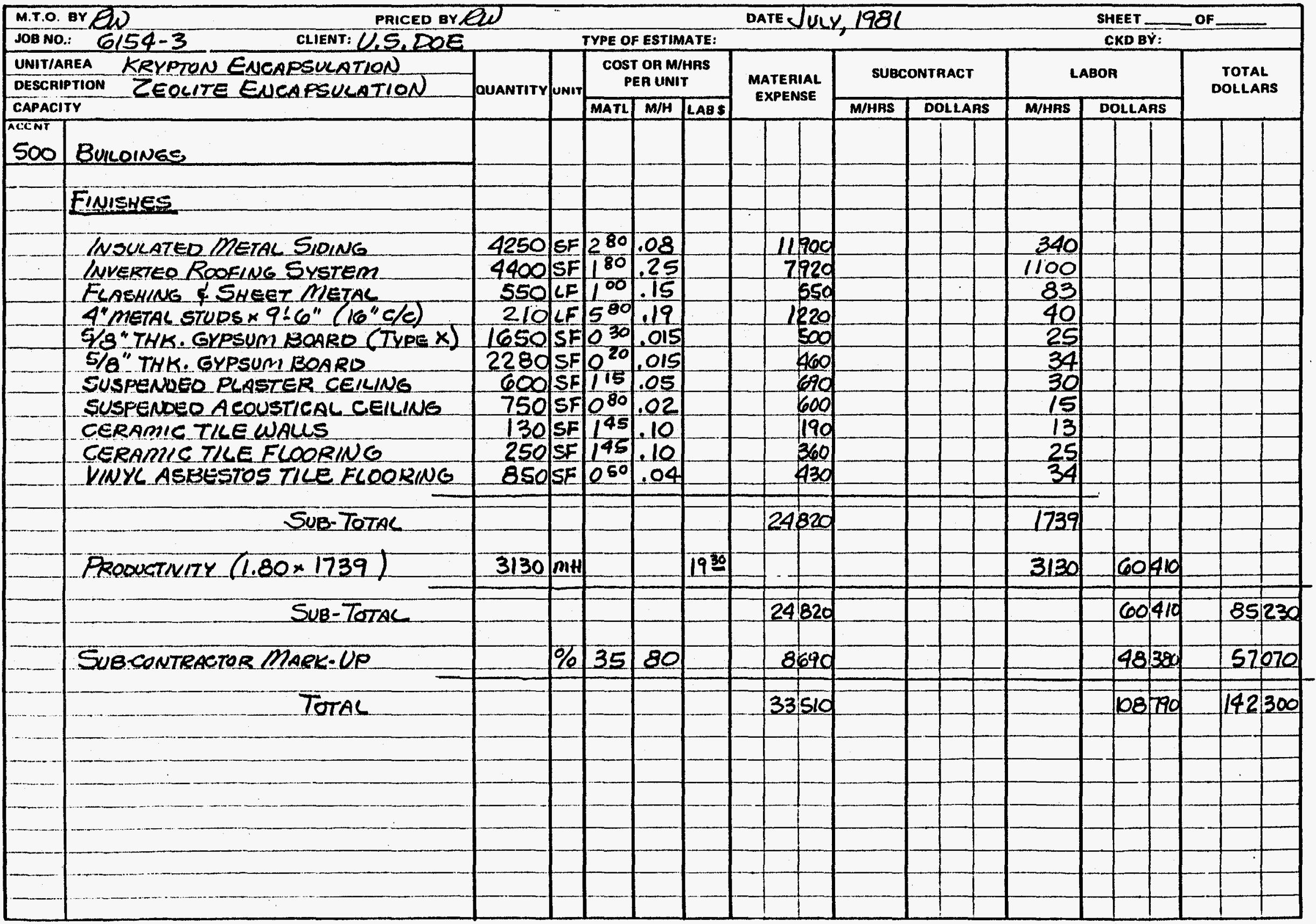




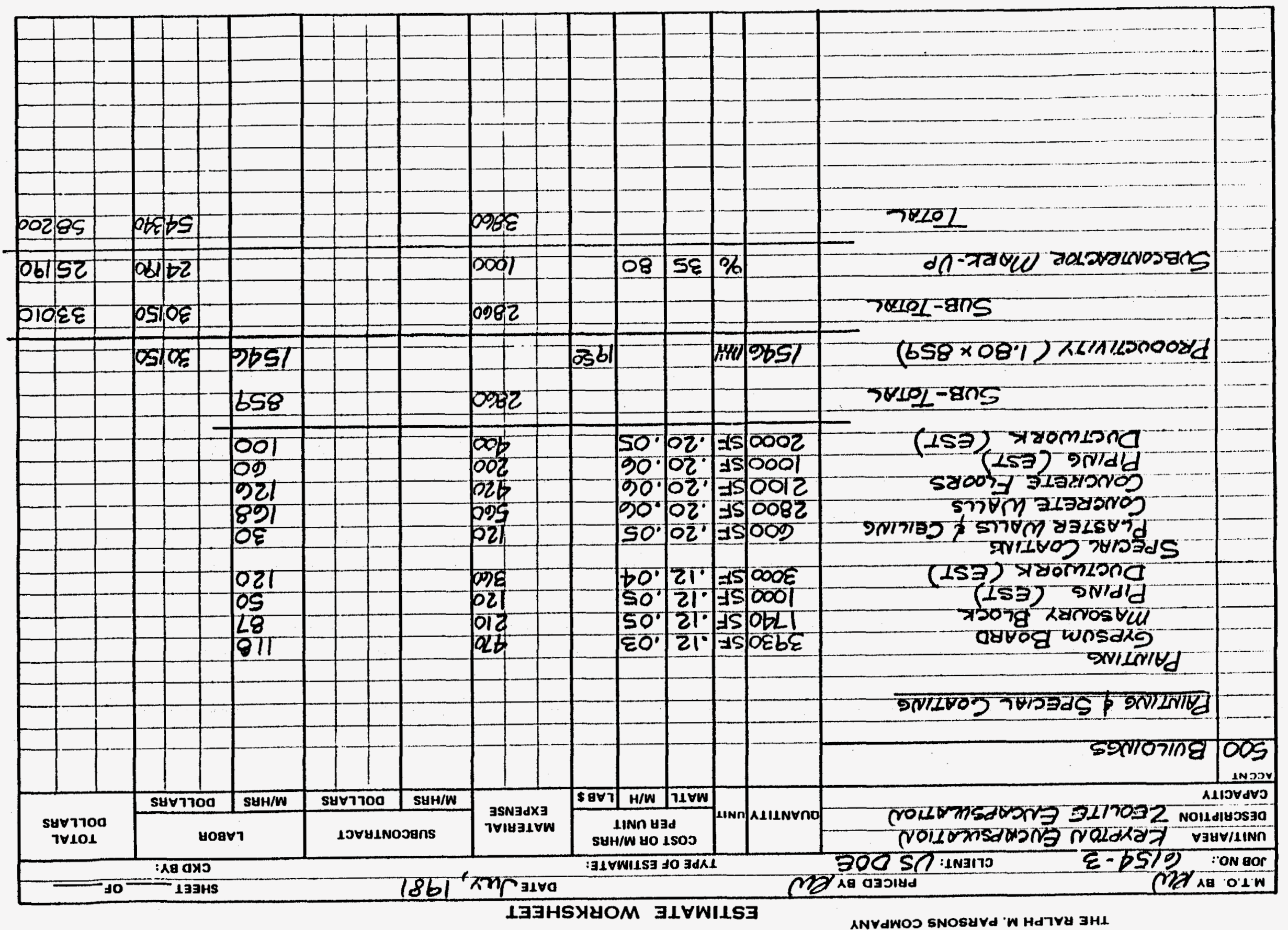


THE RALPH M. PARSONS COMPANY

ESTIMATE WORKSHEET

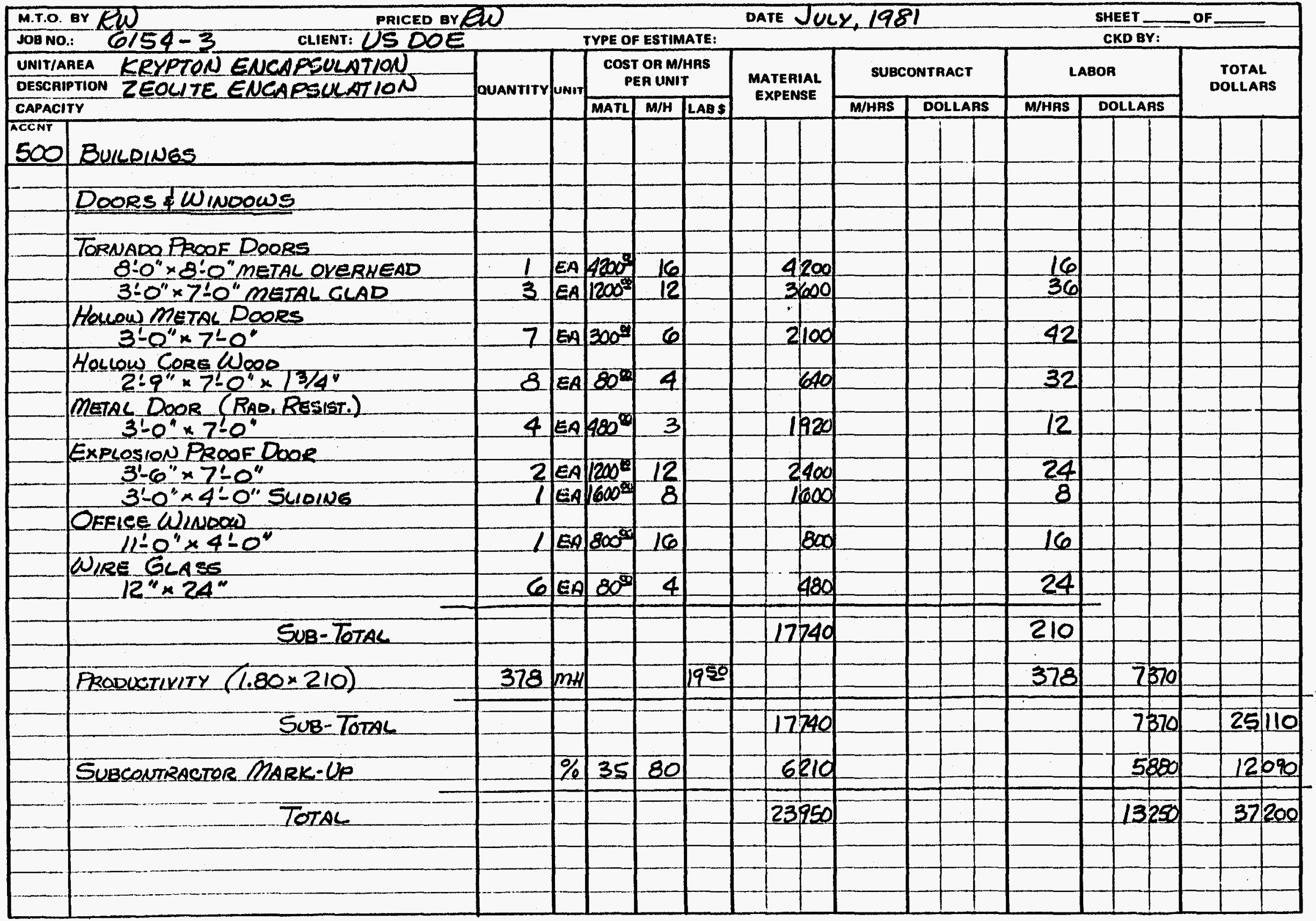


THE RALPH M. PARSONS COMPANY

ESTIMATE WORKSHEET

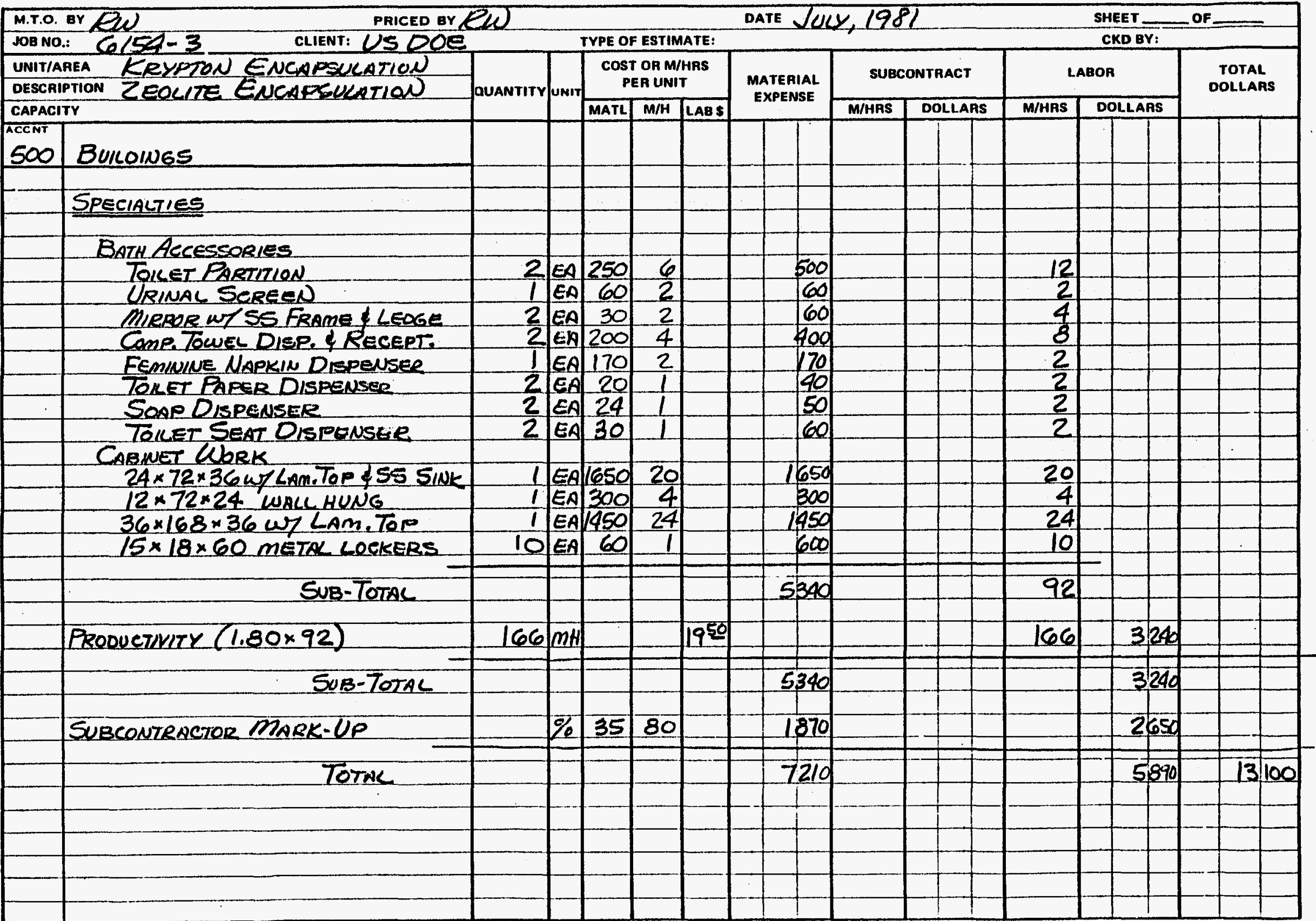


ESTIMATE WORKSHEET

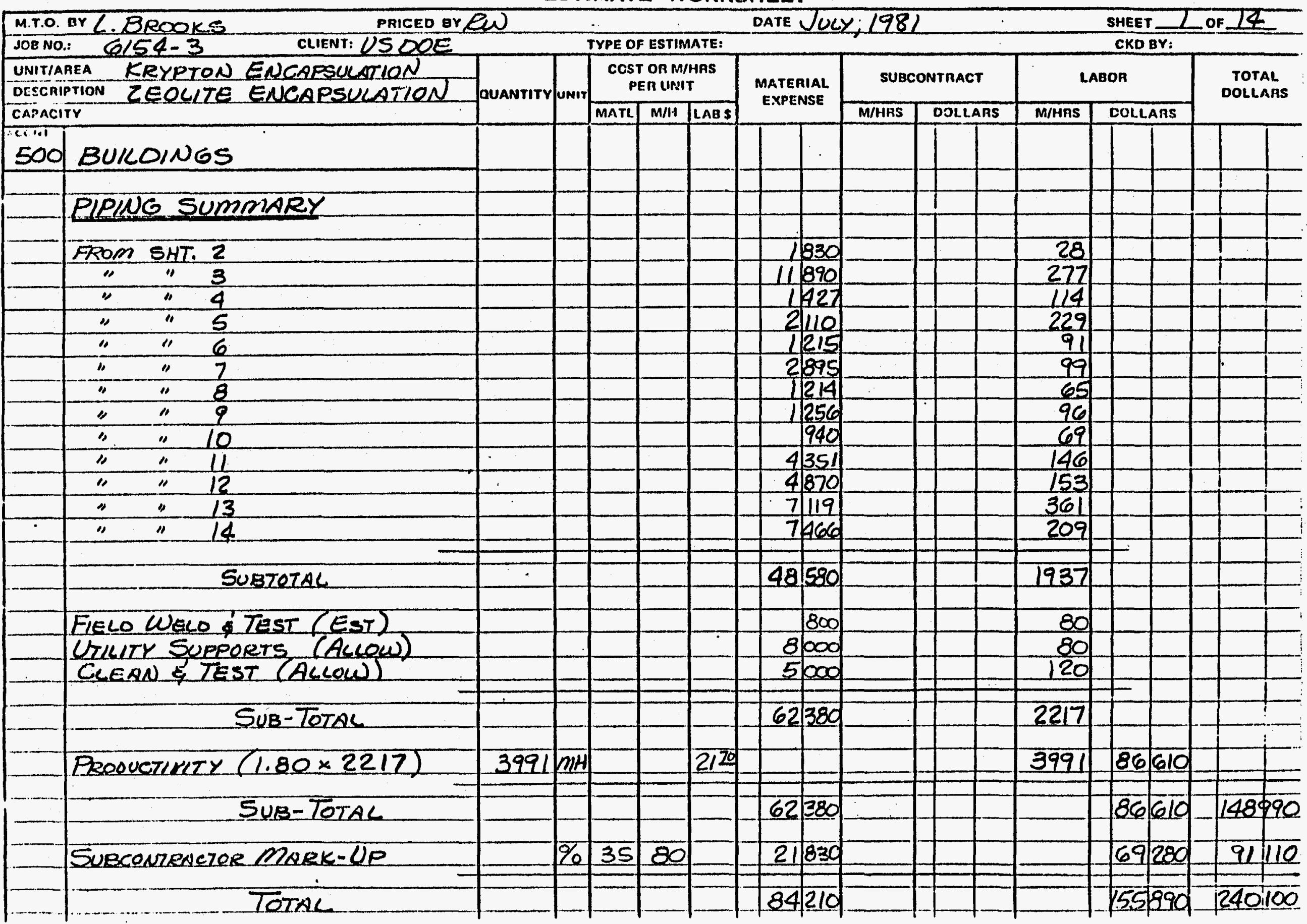


ESTIMATE WORKSHEET

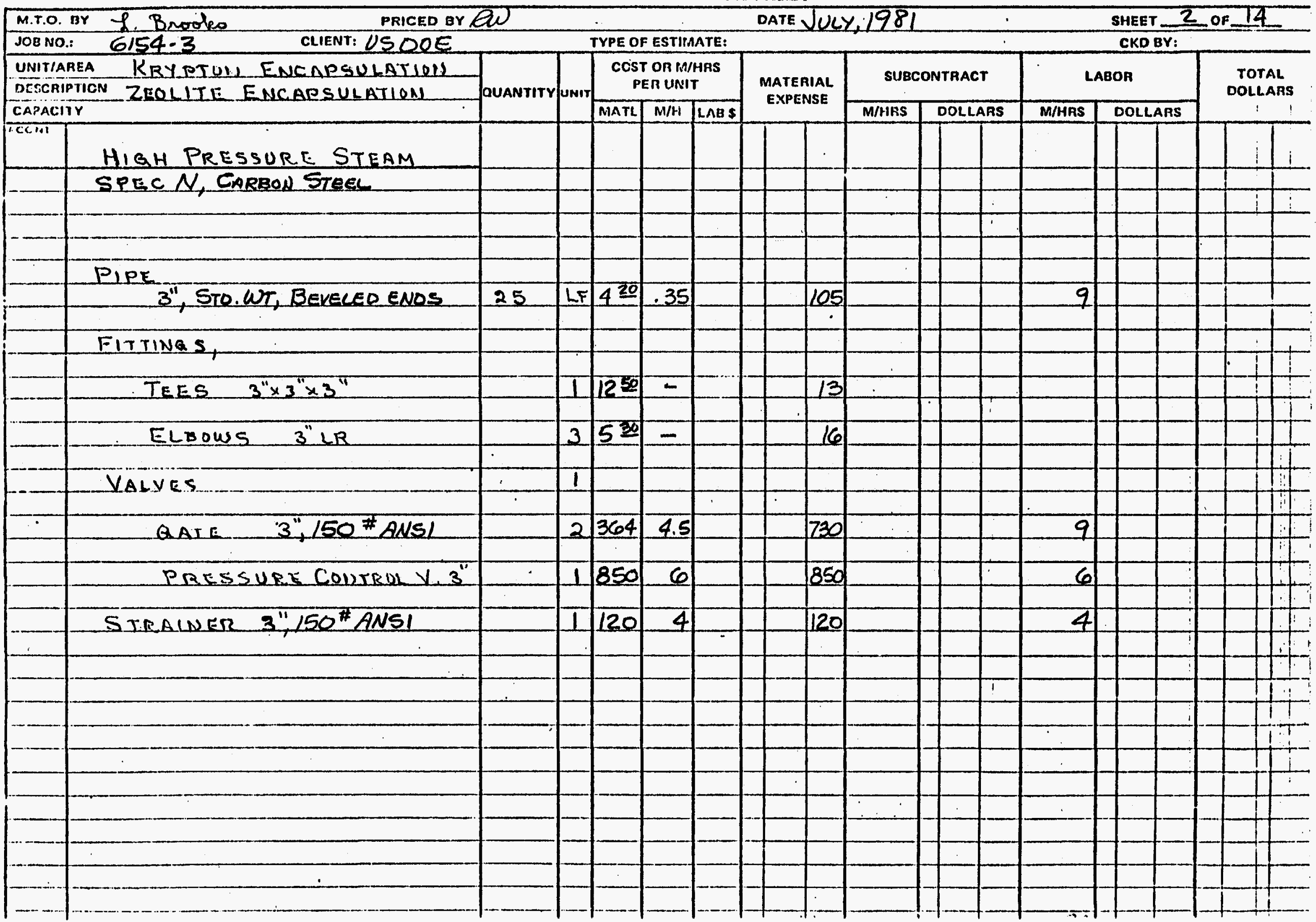




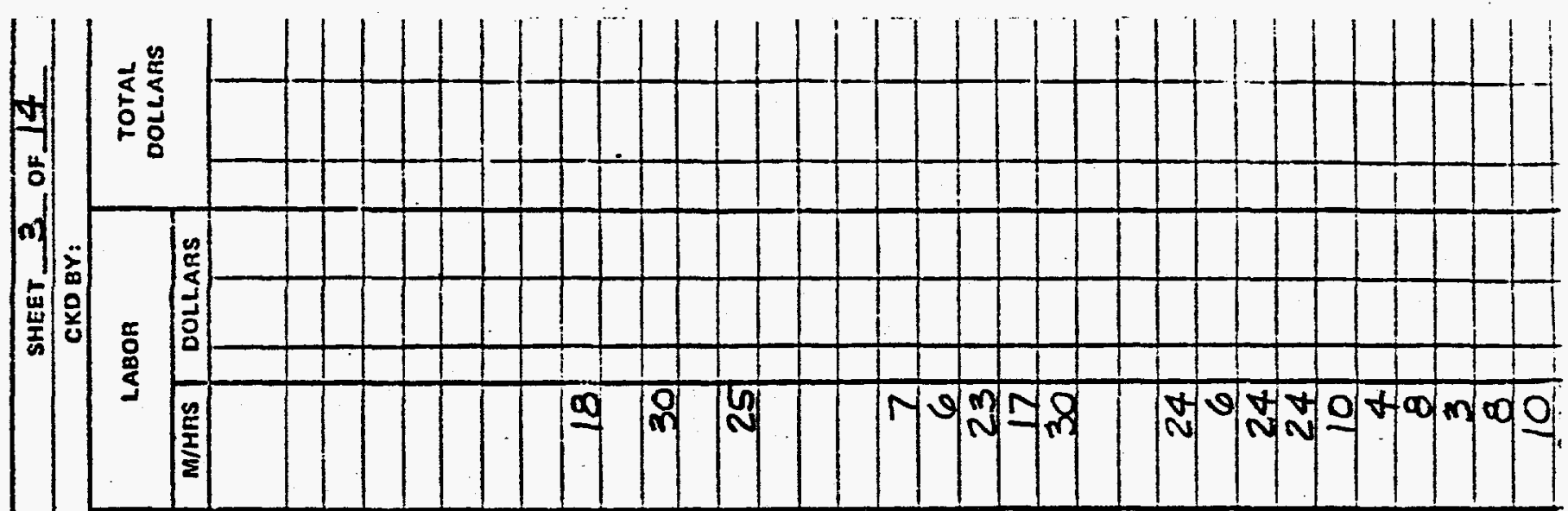

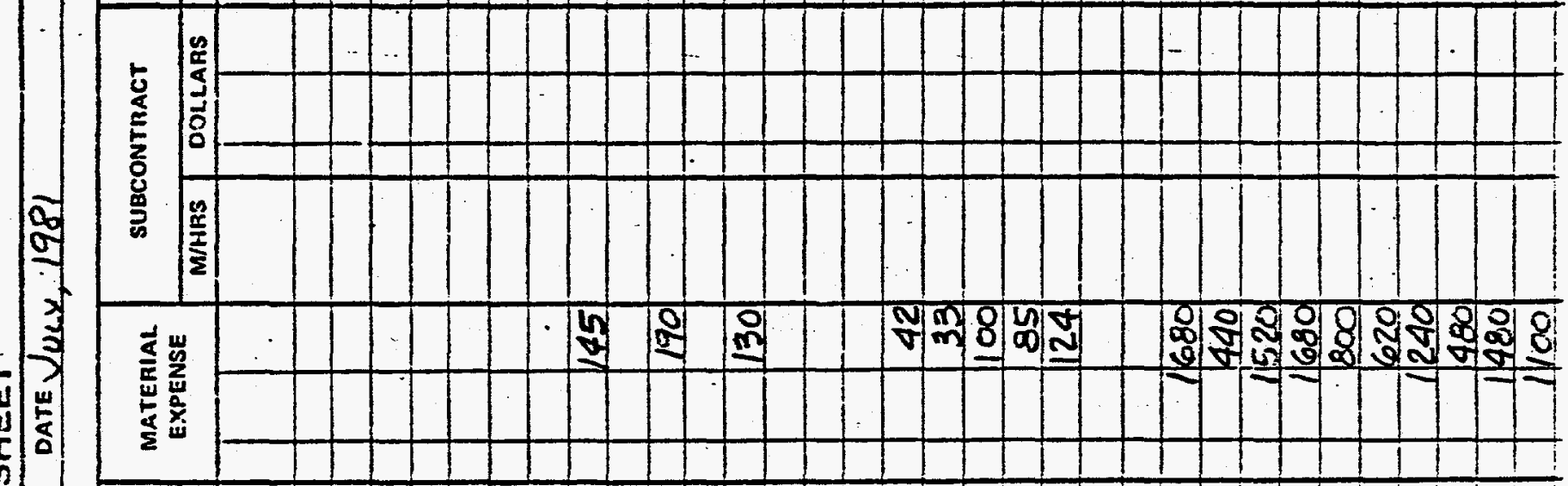

要

$\frac{5}{5}$

橧

点

㟲

w

$\sum$

崖

|

ล)

m

मmmmnसमmल

亩以 23

빙의의

영

녕 웍

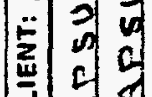

덩 영

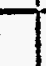

a d :

12010

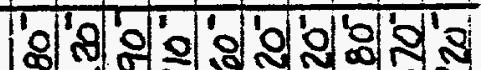

嵒 出

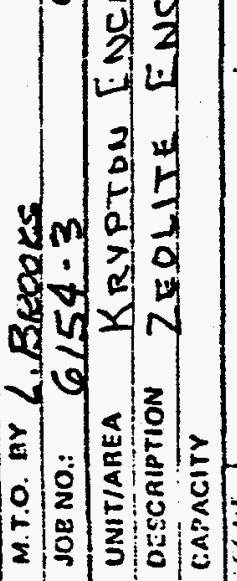

$=3040$

in

$\sum$

嵌

$=-1=-$

$x=2 \times-4=$

: 3 र 过

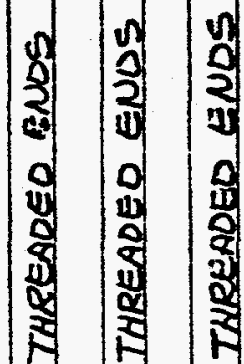

v 20

$x^{x}=$

Y

जी

4

$\sqrt{1}$

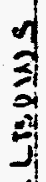

包

3)

o

en

a) 
畩

13

占

赵 总

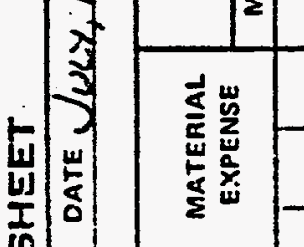

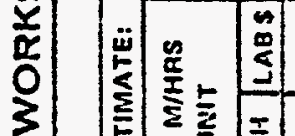

山)

5
$\Sigma$

点

\& 90

(N) 100 N

N

커

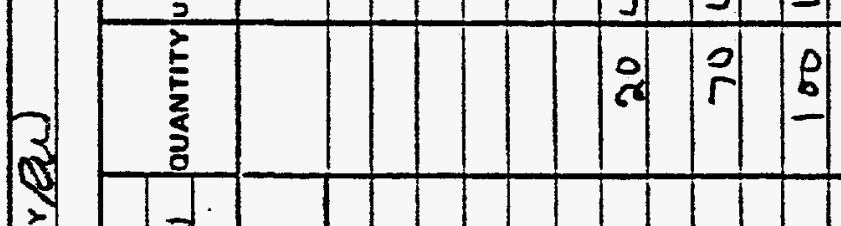

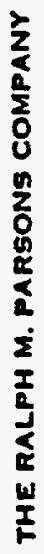

\%

v 2 경

ư

a 49

$\therefore 3$

해 $n$

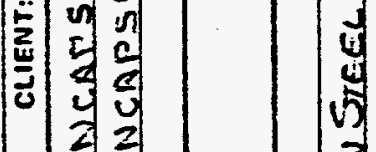

니나

ㄴ)

न न

으

\%

근

ㅇ

;

에의

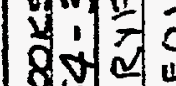

베근

की

(c)

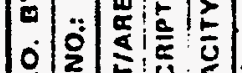

O.

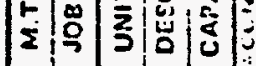

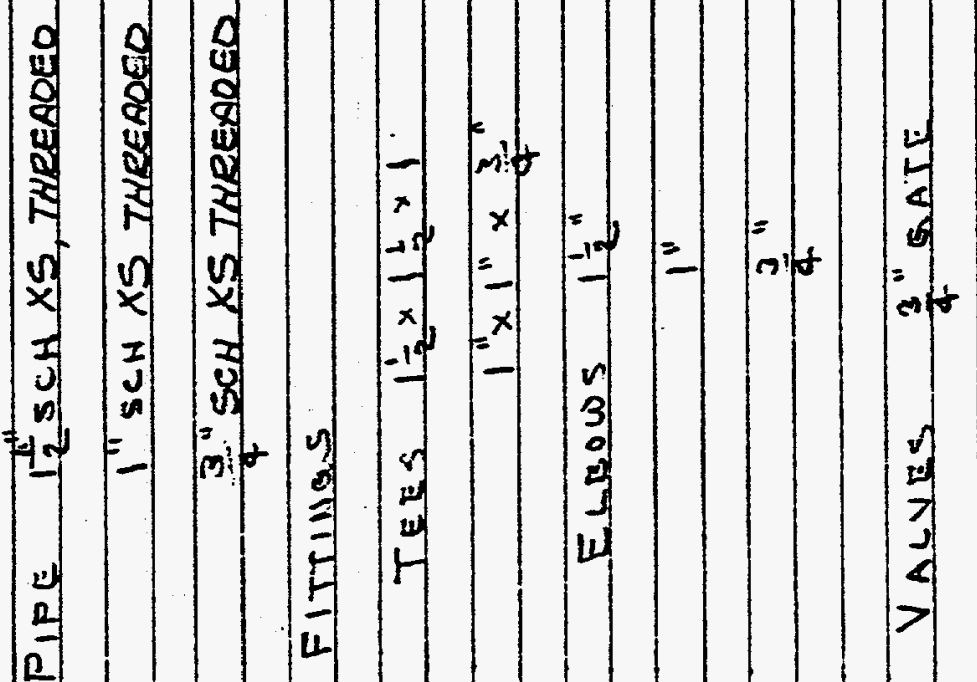




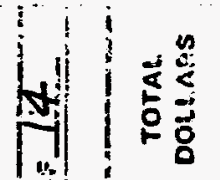

is

(n)

(1)

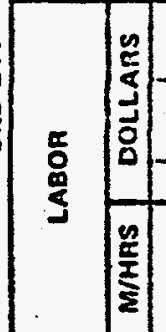

No.

In $\mathrm{N}$ a

T.

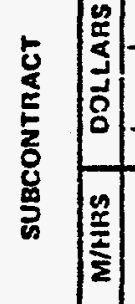

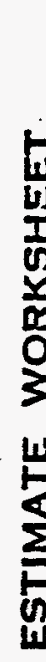

बी

屶嵌

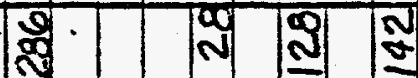

?

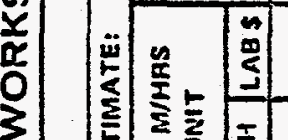

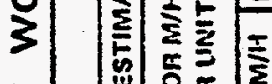

U

$\sum: \sum_{E}$

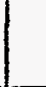

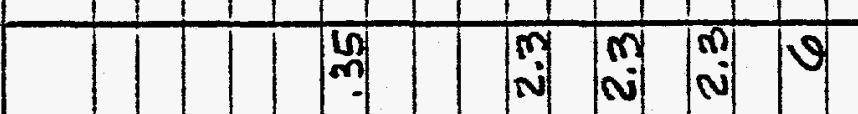

B)

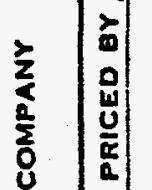

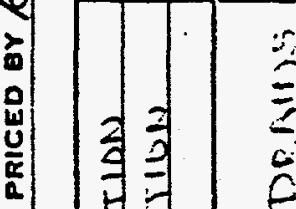

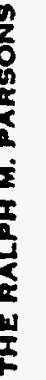

-

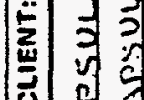

들

년

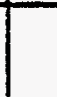

只

가 0 의

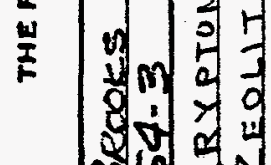

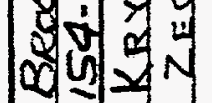

尚家

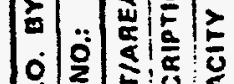

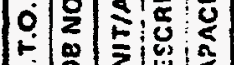

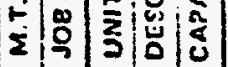




\section{ESTIMATE WORKSHEET}

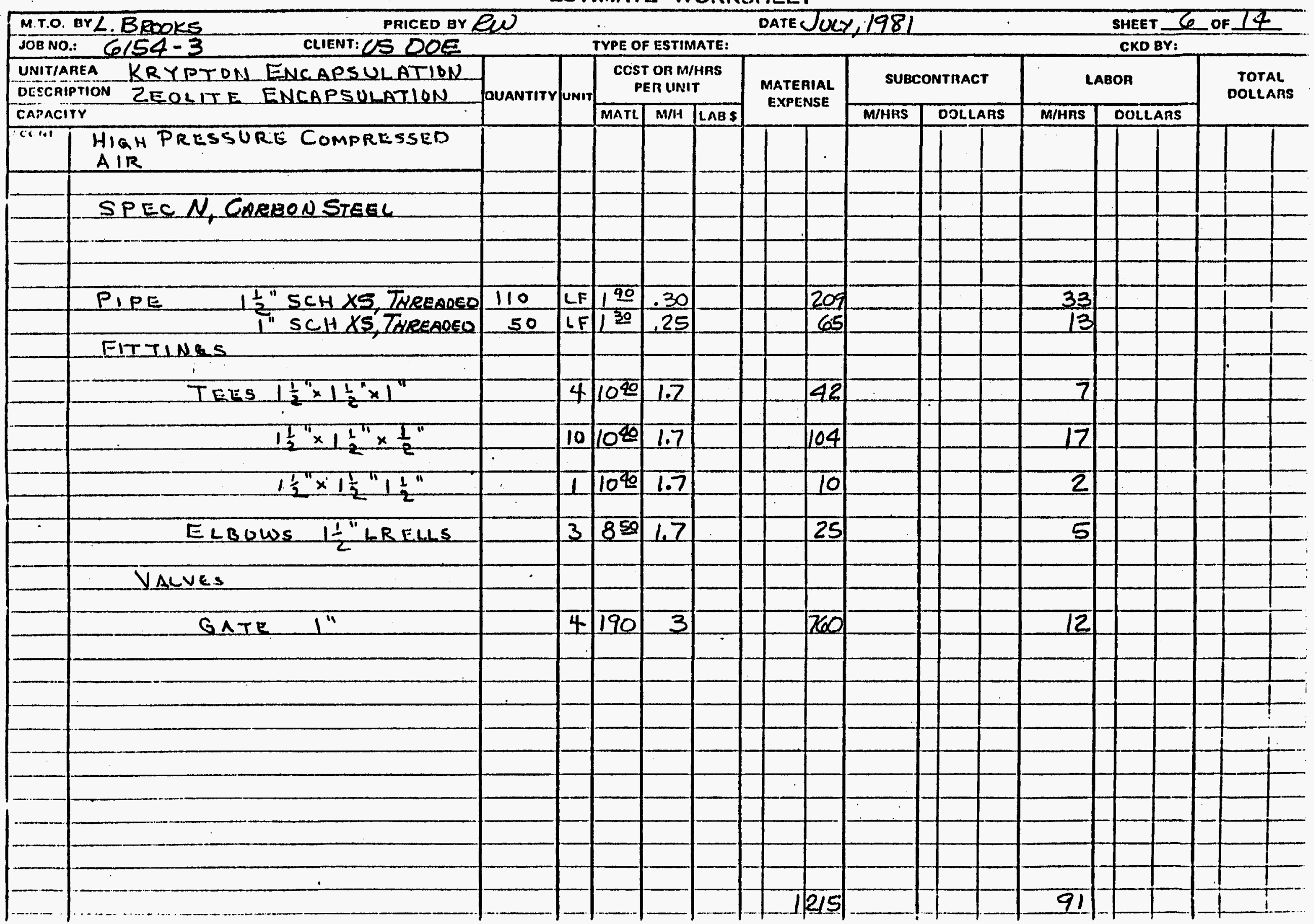




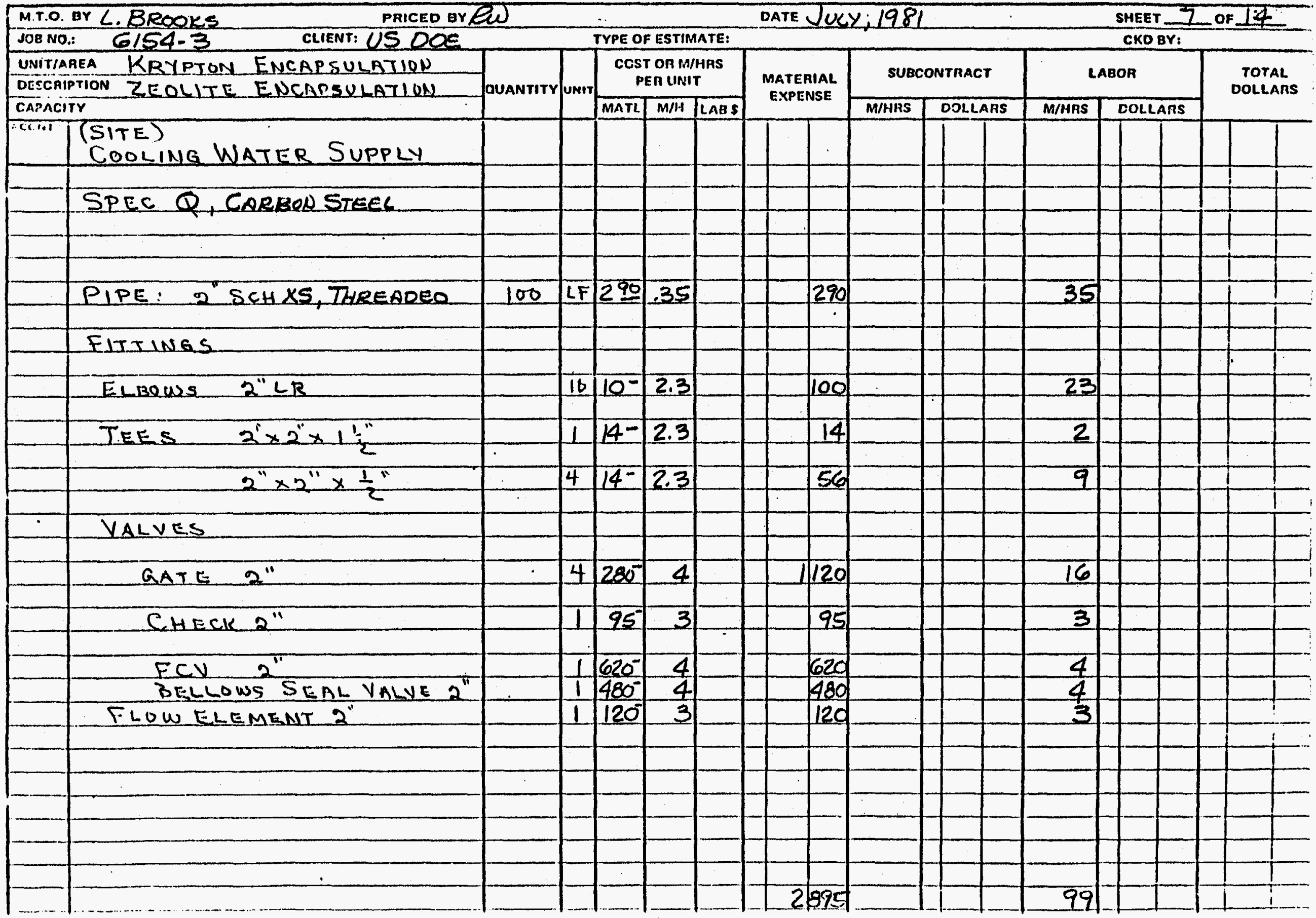




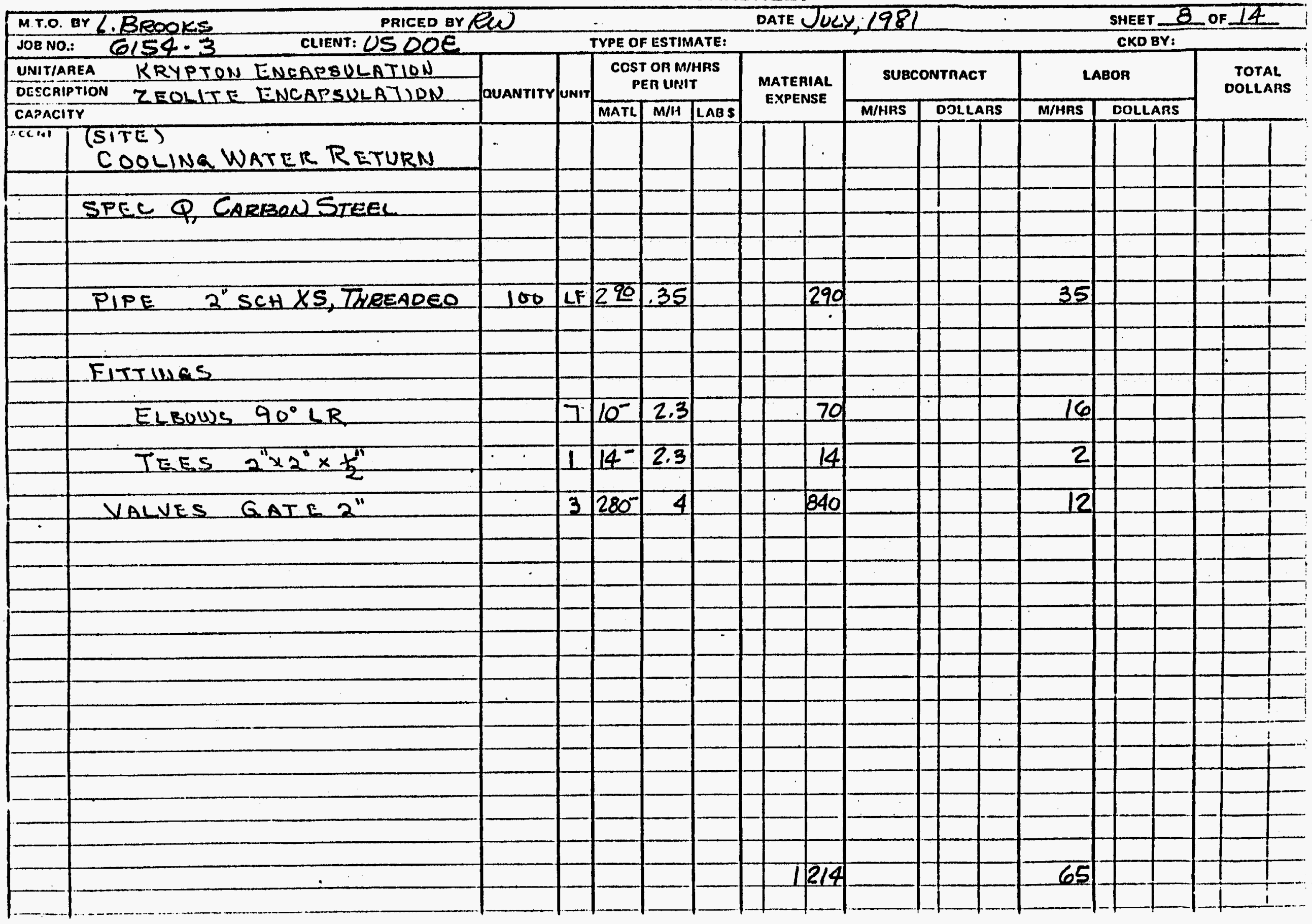




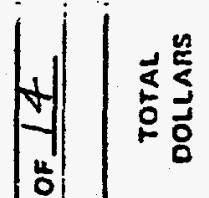
Is ल जिज

同旁

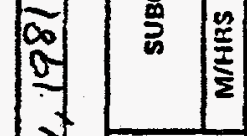

i.

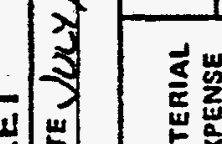

I

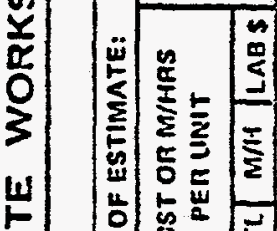

$\frac{5}{5}$

E

in

$$
\begin{array}{|l|l|}
\hline \multicolumn{2}{|c|}{} \\
\hline \frac{5}{2}
\end{array}
$$
$\frac{2}{3}$

$\approx$

9 ong

8

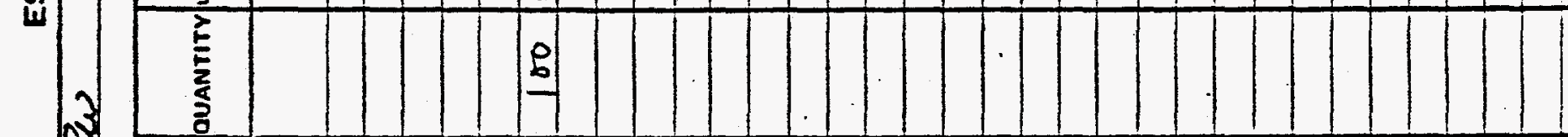

2
2
0
0
0
0
0
0
0
0
2
2
2
2
2
0

나 궁

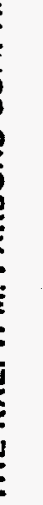

通

恼

约

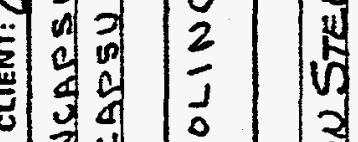

w)

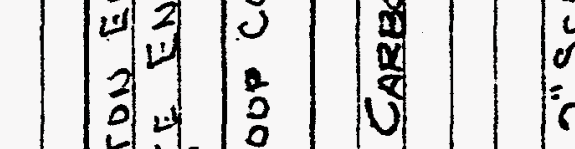

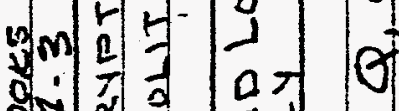

gv है ?

Q넥ㄷㄴ

v $z \quad$ zo

先 :

०)

+

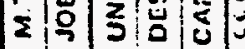


ESTIMATE WORKSHEET

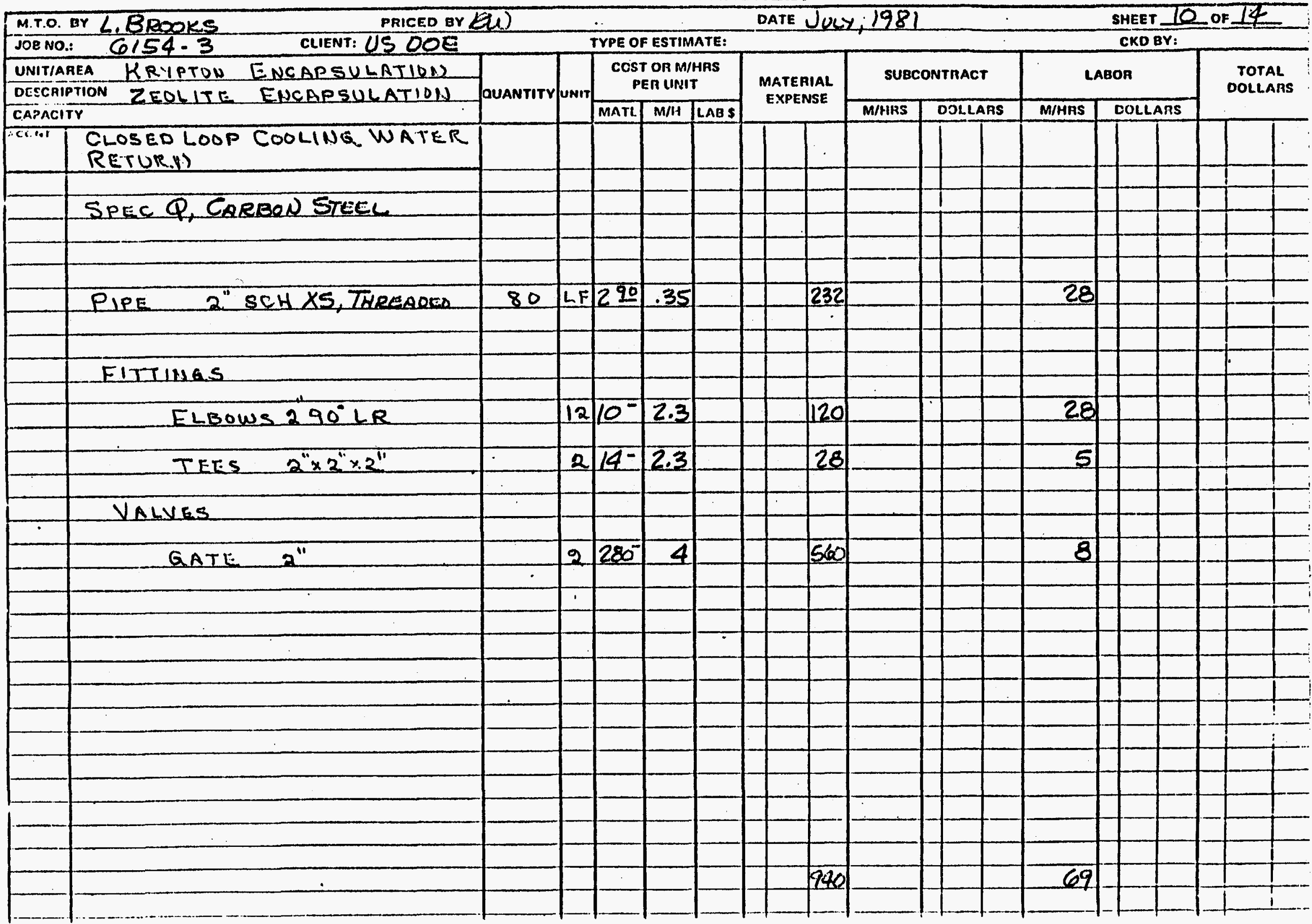




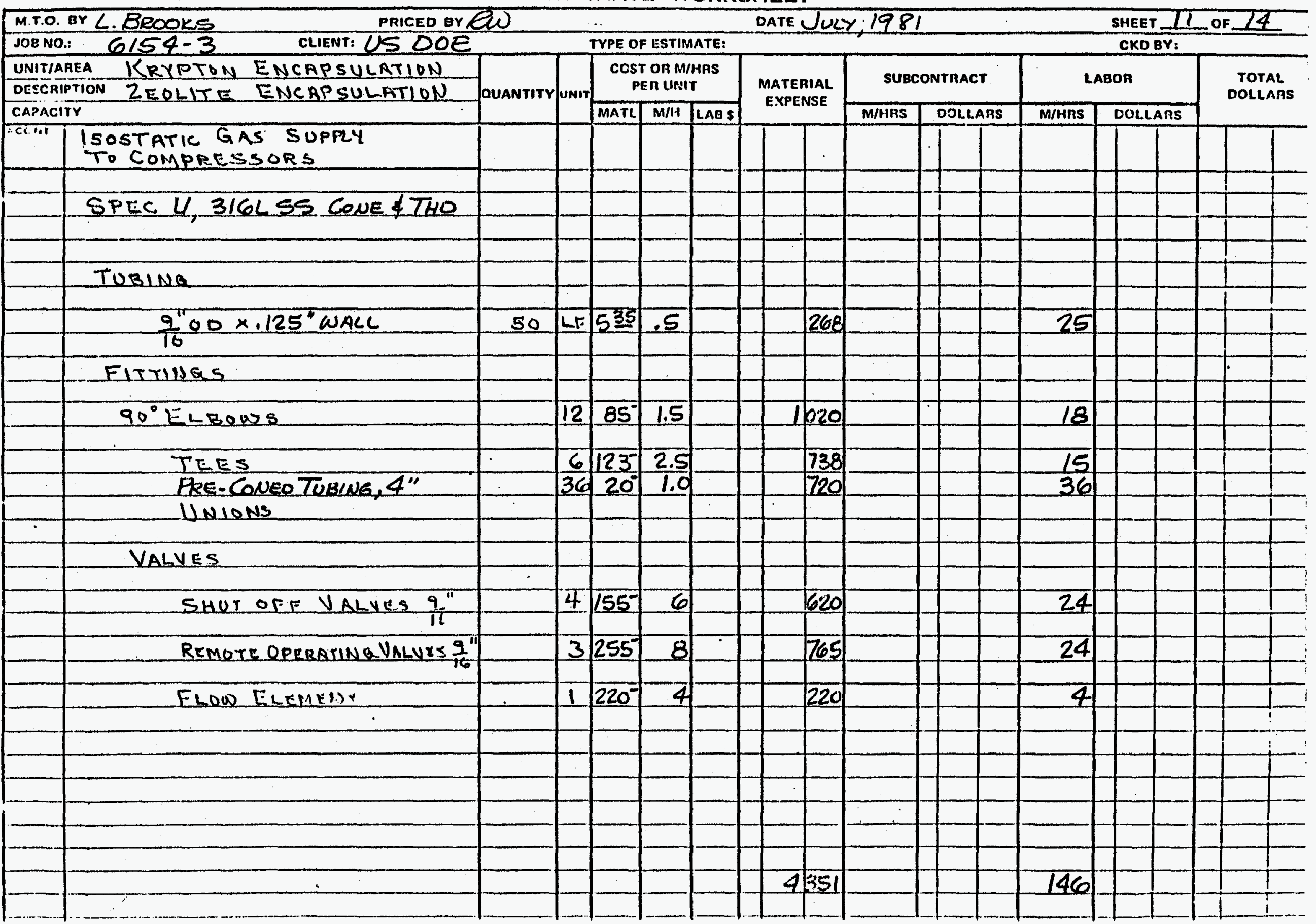




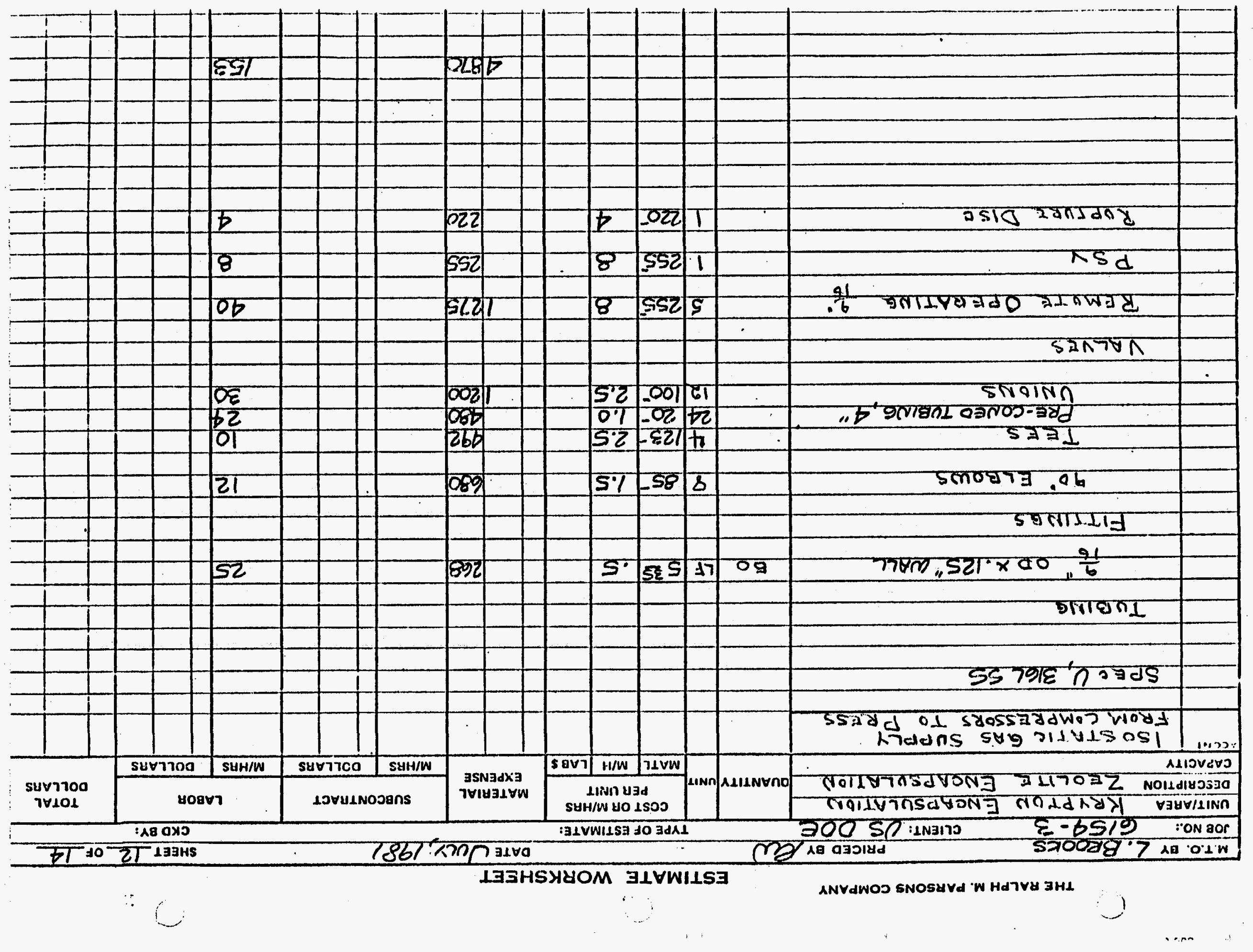




\begin{tabular}{|c|c|c|c|c|c|c|c|c|c|c|c|c|c|c|c|c|c|c|}
\hline \multirow{2}{*}{$\frac{\text { M.T.O. BY }}{\text { JOE No.: } 6 . \text { Begoks }}$} & \multicolumn{3}{|c|}{ PRICED QY $E$ W } & \multirow{2}{*}{\multicolumn{3}{|c|}{ TYPE OF ESTIMATE: }} & & \multicolumn{5}{|c|}{ DATE JUL: 1981} & \multicolumn{6}{|c|}{ SHEET 13 OF 14} \\
\hline & CLIENT: USQDE & & & & & & & & & & & & \multicolumn{6}{|c|}{ CKO BV: } \\
\hline \multirow{2}{*}{\multicolumn{2}{|c|}{$\begin{array}{l}\text { UNITIAREA KRYPTON ENCAPSULATION } \\
\text { DESCRIPTION ZTOLITE ENCAPSULATIDN } \\
\end{array}$}} & \multirow[b]{2}{*}{ QUANTITY } & \multirow{2}{*}{ Unit } & \multicolumn{3}{|c|}{$\begin{array}{l}\text { COST OR M/HAS } \\
\text { PER UNIT }\end{array}$} & \multirow{2}{*}{\multicolumn{3}{|c|}{$\begin{array}{c}\text { MATERIAL } \\
\text { EXPENSEE }\end{array}$}} & \multicolumn{3}{|c|}{ SUBCONTRACT } & \multicolumn{3}{|c|}{ LABOR } & \multirow{2}{*}{\multicolumn{3}{|c|}{$\begin{array}{l}\text { TOTAL } \\
\text { DOLLAAS }\end{array}$}} \\
\hline & & & & \multirow[t]{2}{*}{ MATL } & \multirow[t]{2}{*}{ M/H } & \multirow[t]{2}{*}{ LAB \$ } & & & & \multirow{2}{*}{ M/HRS } & \multicolumn{2}{|c|}{ DOLLARS } & \multirow{2}{*}{ M/HAS } & \multicolumn{2}{|c|}{ COLLAAS } & & & \\
\hline$c c, b+1$ & $\begin{array}{l}\text { PRESSURIZED FEED GRS } \\
\text { MIX SYSTEM }\end{array}$ & & & & & & & & & & & & & & & & & \\
\hline & 300 PSIA & & & & & & & & & & & & & & & & & \\
\hline & SPEC $V$, CARBON STEEL & & & & & & & & & & & & & & & & & \\
\hline & & & & & & & & & & & & & & & & & & \\
\hline & & & & & & & & & & & & & & & & & & \\
\hline & & & & & & & & & & & & & & & & & & \\
\hline & PIPE I" SCHXS, PLAINENDS & 250 & LF & 30 & .25 & & & & 325 & & & & 63 & & & 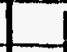 & & \\
\hline & & & & & & & & & & & & & & & & & & \\
\hline & FITTINGS & & & & & & & & & & & & & & & 7 & & \\
\hline & Flanges $300^{\circ}$ Wh RF & & 20 & 85 & 1.5 & & & & 700 & & & & 30 & & & & & \\
\hline & ELsowsl"LR ELLS & & 45 & 620 & 1.5 & & & & 279 & & & & 68 & & & _- & & \\
\hline & $1^{\prime \prime} 45^{\circ}$ ELLS & & 5 & 620 & 1.5 & & & & 31 & & & & 8 & & & & & \\
\hline & & & & & & & & & & & & & & & & & & \\
\hline & $1^{\prime \prime} \times 1^{\prime \prime} \times 1^{\prime \prime}$ & $\cdot$ & 18 & 820 & 1.5 & & & & 148 & & & & 27 & ' & & 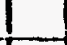 & -1 & 2 \\
\hline & $1^{\prime \prime} \times 1^{\prime \prime} \times 1^{\prime \prime}$ & & 4 & 820 & 1.5 & & & & 33 & & & & 6 & & & of & & \\
\hline & 2 & & & & & & & . & & & & & & & & & & \\
\hline & $1 \frac{1}{2} \times 1 \frac{1}{2} \times 1 \frac{1}{2}=$ & & 4 & 1040 & 1.7 & & & & 42 & & & & 7 & & & - & & \\
\hline & REOUCERG & & & & & & & & & & & & & & & ... & & \\
\hline & REDUCERS & - & 8 & 649 & 1.5 & & & & .51 & & & & 121 & & & - & & \\
\hline & VALVESI $300^{*}$ & & $F$ & Ins & 1 & & & & $a n$ & & & & 7 & & & 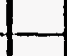 & & \\
\hline & & & 13 & 240 & 4 & & & & $200 \mid$ & & & & 201 & & & - & & \\
\hline & I" $300^{\circ}$ SOLENOIDS & & 19 & 160 & 6 & & & 3 & 640 & & & & 114 & & & 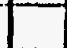 & & \\
\hline & & & & & & & & & & & & & & & & 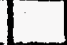 & & \\
\hline & FLOW ELEMENIS & & 3 & 90 & 2 & & & & 270 & & & & 6 & & & $\ldots$ & & \\
\hline & & & & & & & & & & & & & & & & ... & & \\
\hline & & & & & & & & & & & & & & & & - & & \\
\hline & & & & & & & & & & & & & & & & $\ldots$ & & \\
\hline & & & & & & & & & & & & & & & & -1 & & \\
\hline & & & & & & & & & & & & & & & & 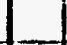 & & \\
\hline & & & & & & & & & & & & & & & & 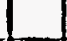 & & \\
\hline & & & & & & & & 7 & 119 & & & & 361 & & & -5 & & \\
\hline & & & & & & & & & & & & & & & & & & \\
\hline
\end{tabular}




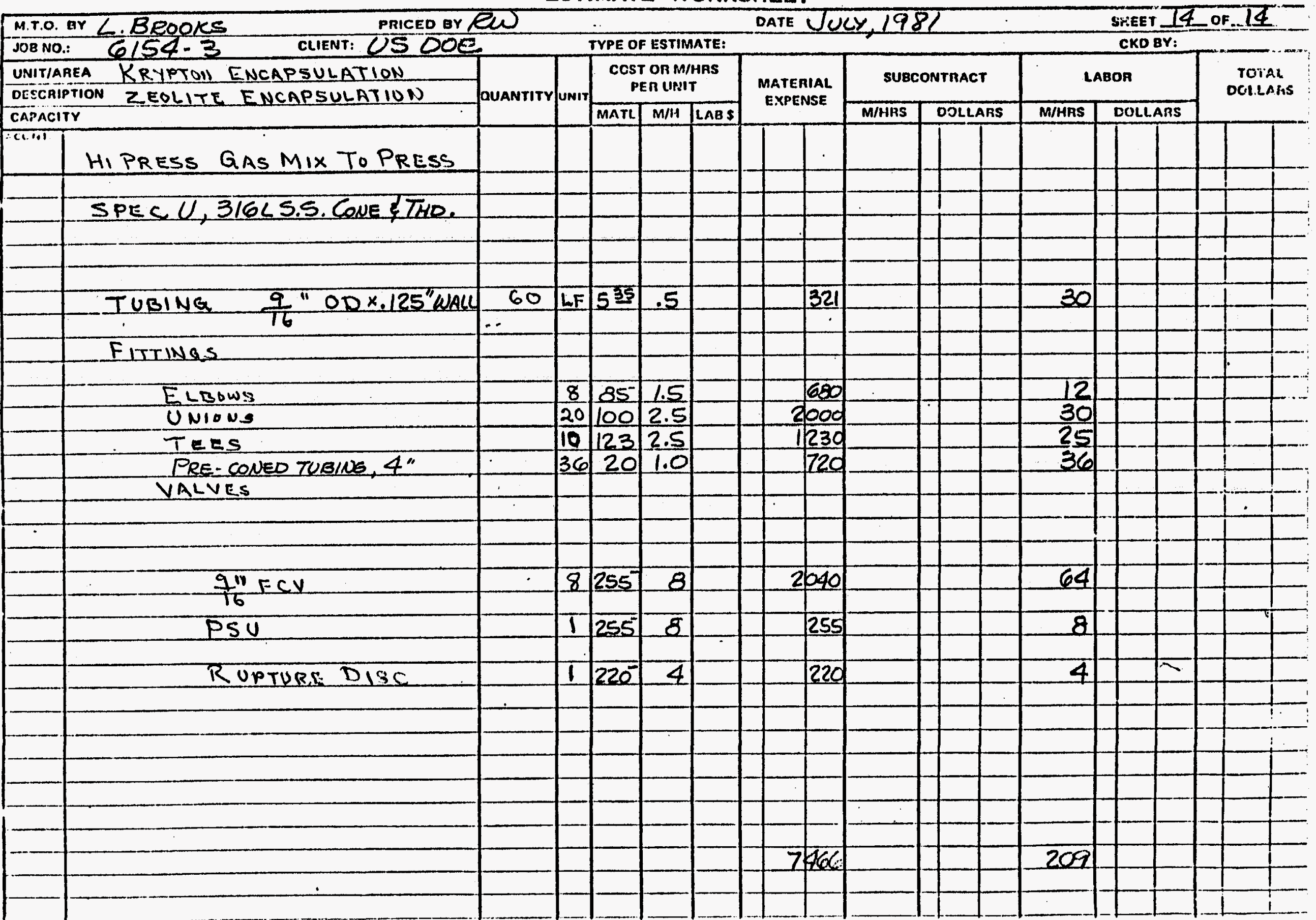


THE RALPH M. PARSONS COMPANY

ESTIMATE WORKSHEET

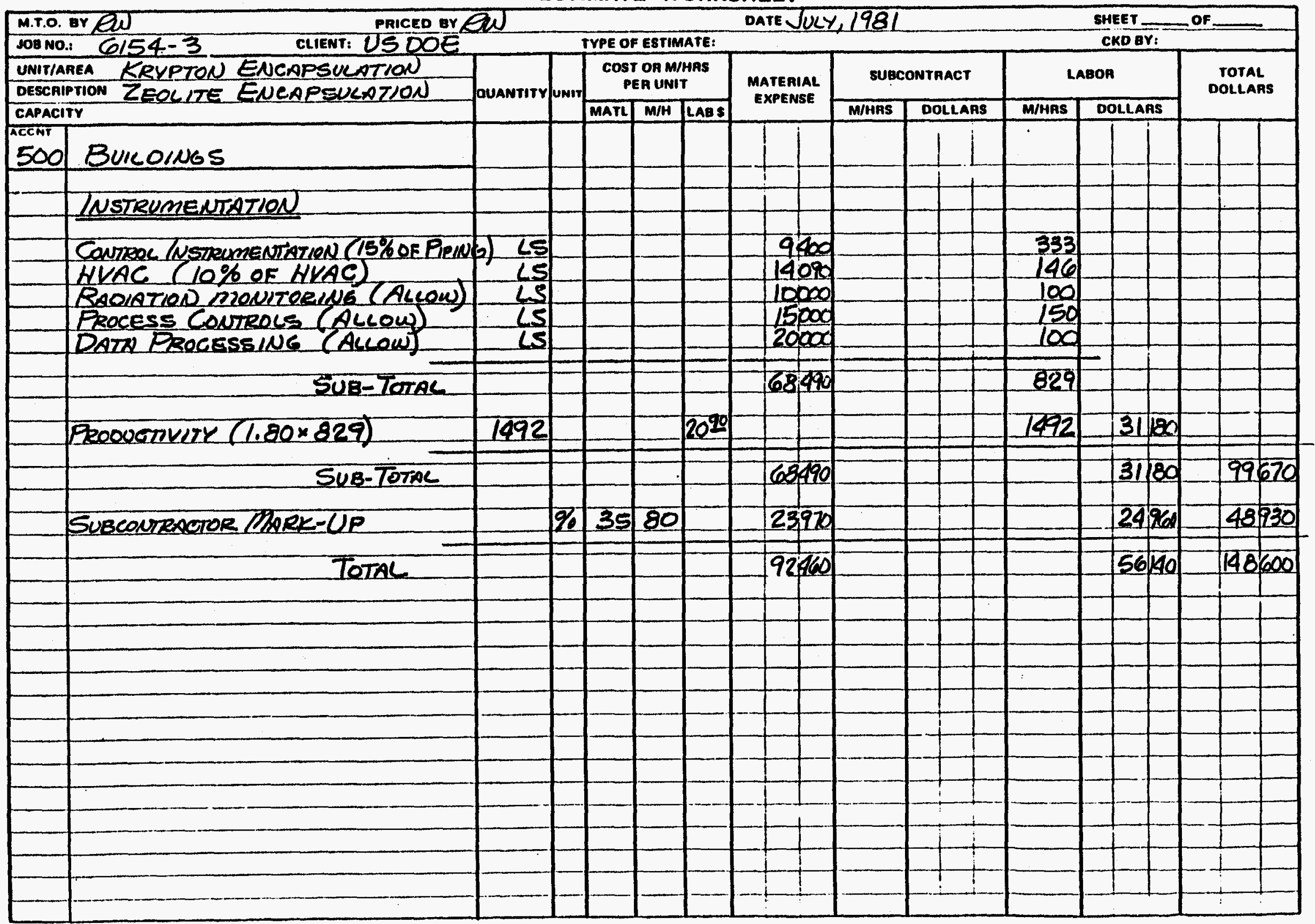


ESTIMATE WORKSHEET

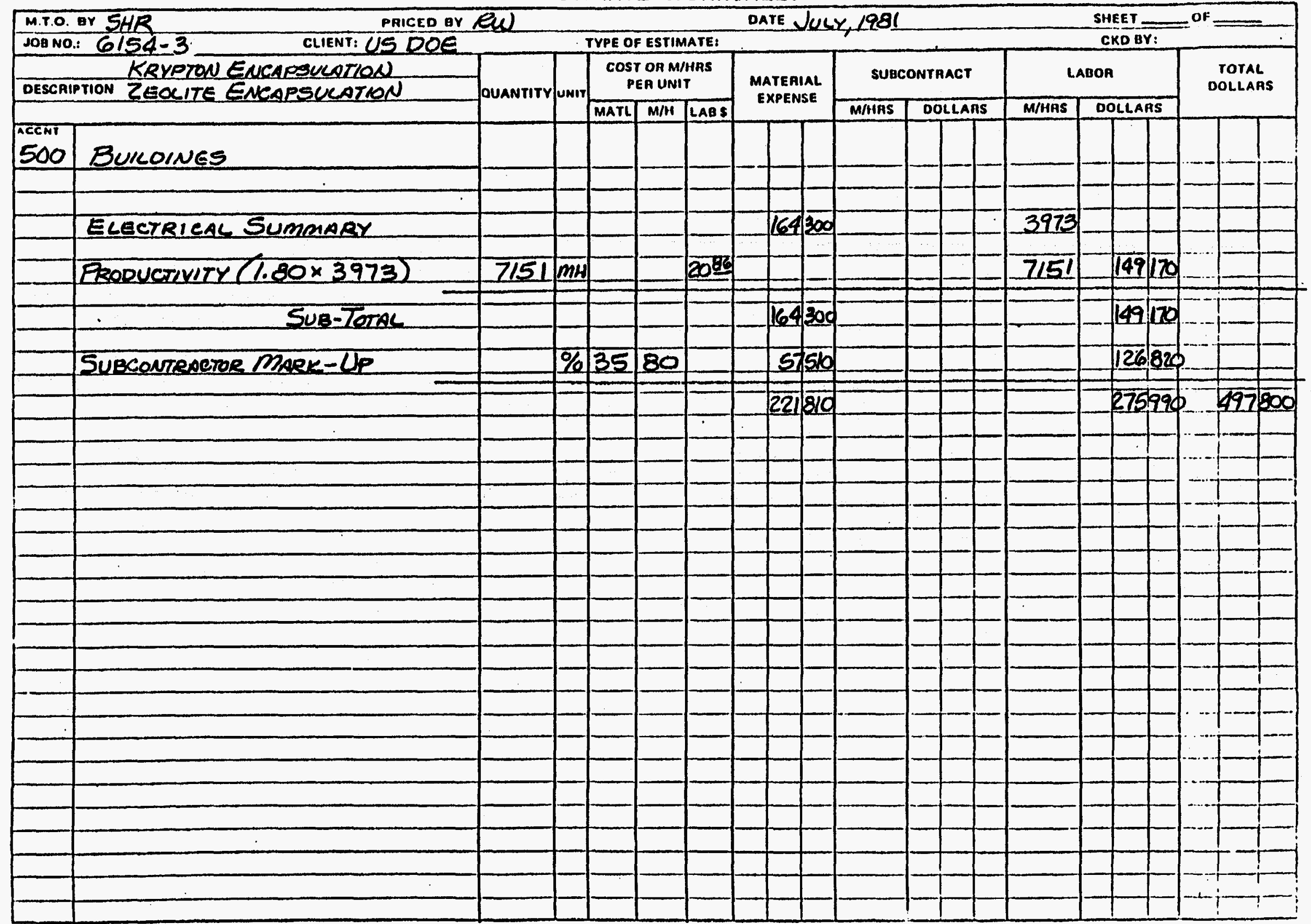



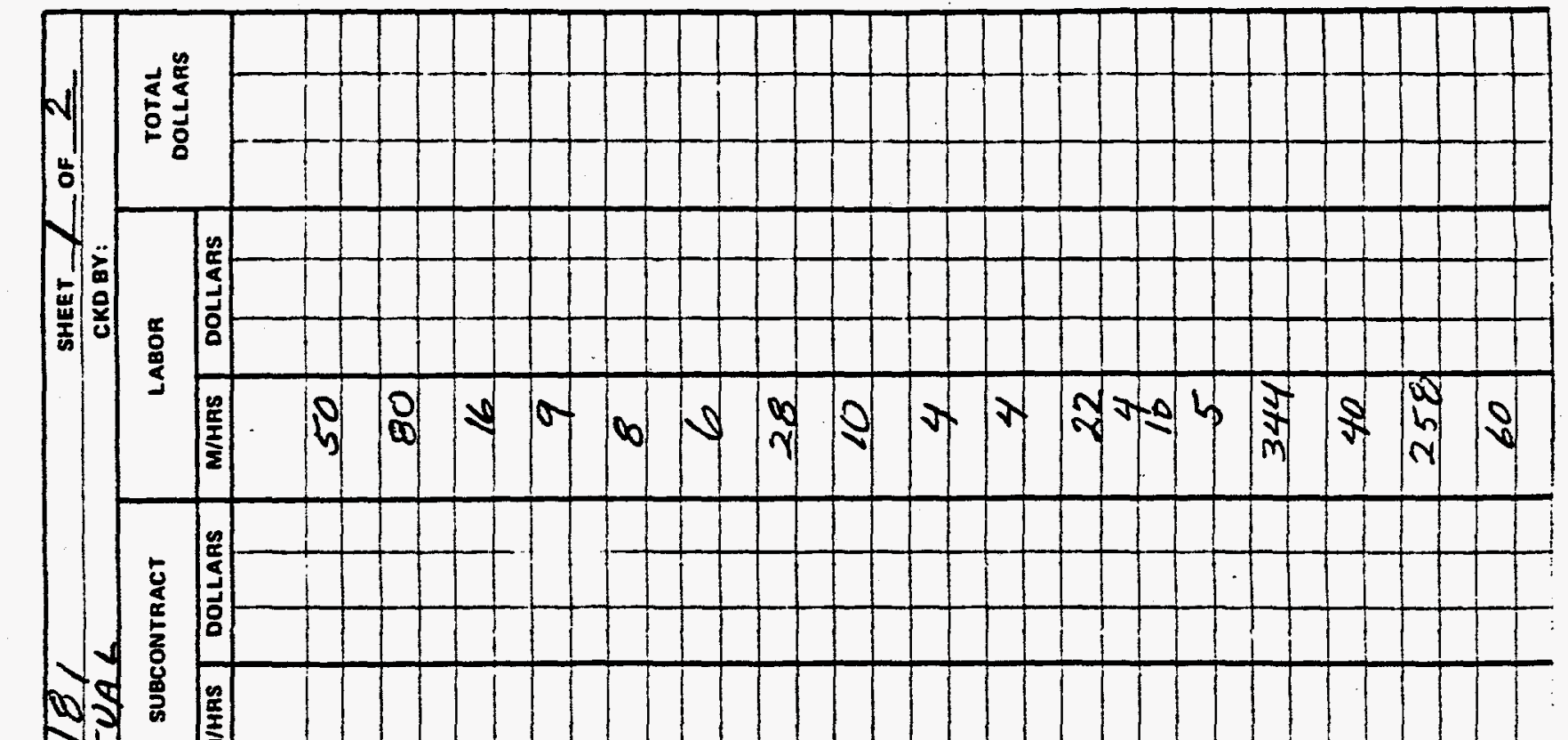

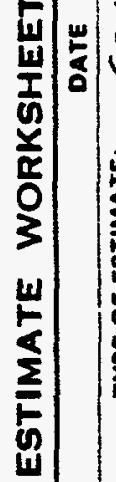

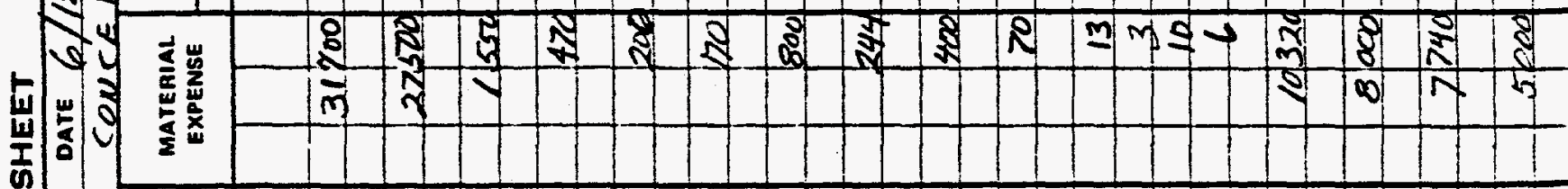

ï

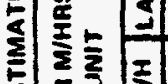

密

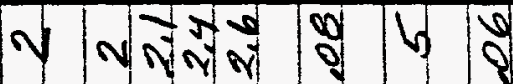

늠

岁通

(n)

है

X

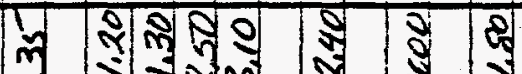

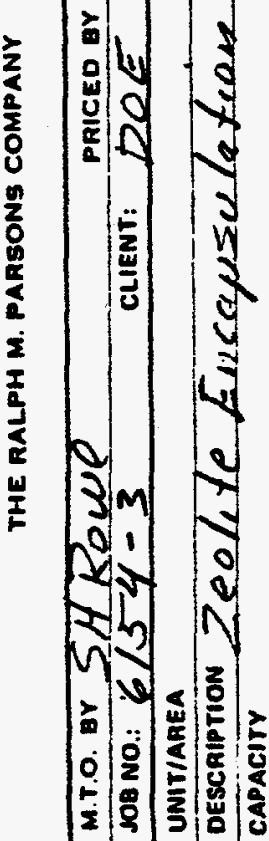

400101010

$1 \sqrt{-1}-\sqrt{ }$

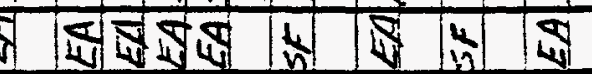

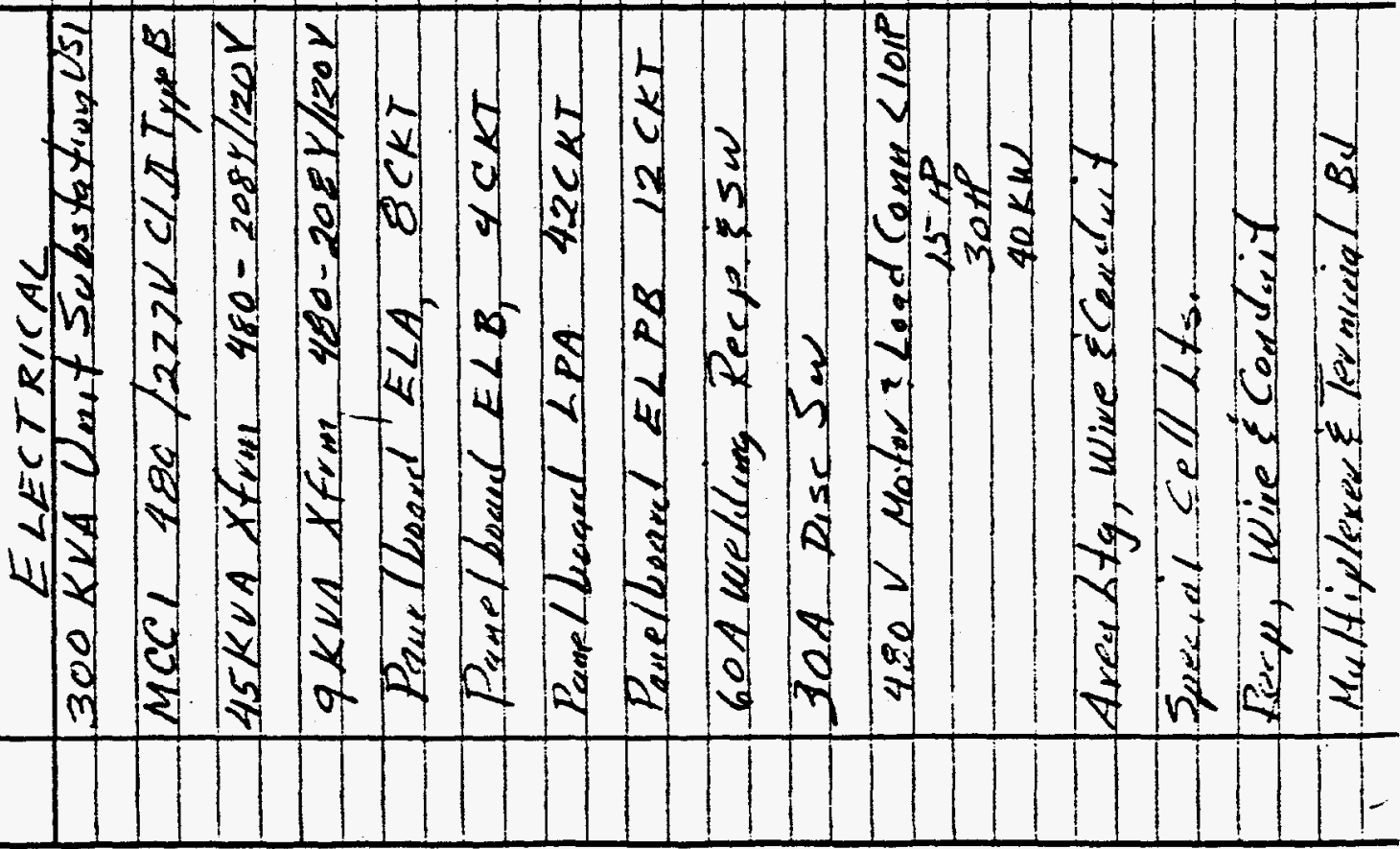


THE RALPH M. PARSONS COMPANY

ESTIMATE WORKSHEET

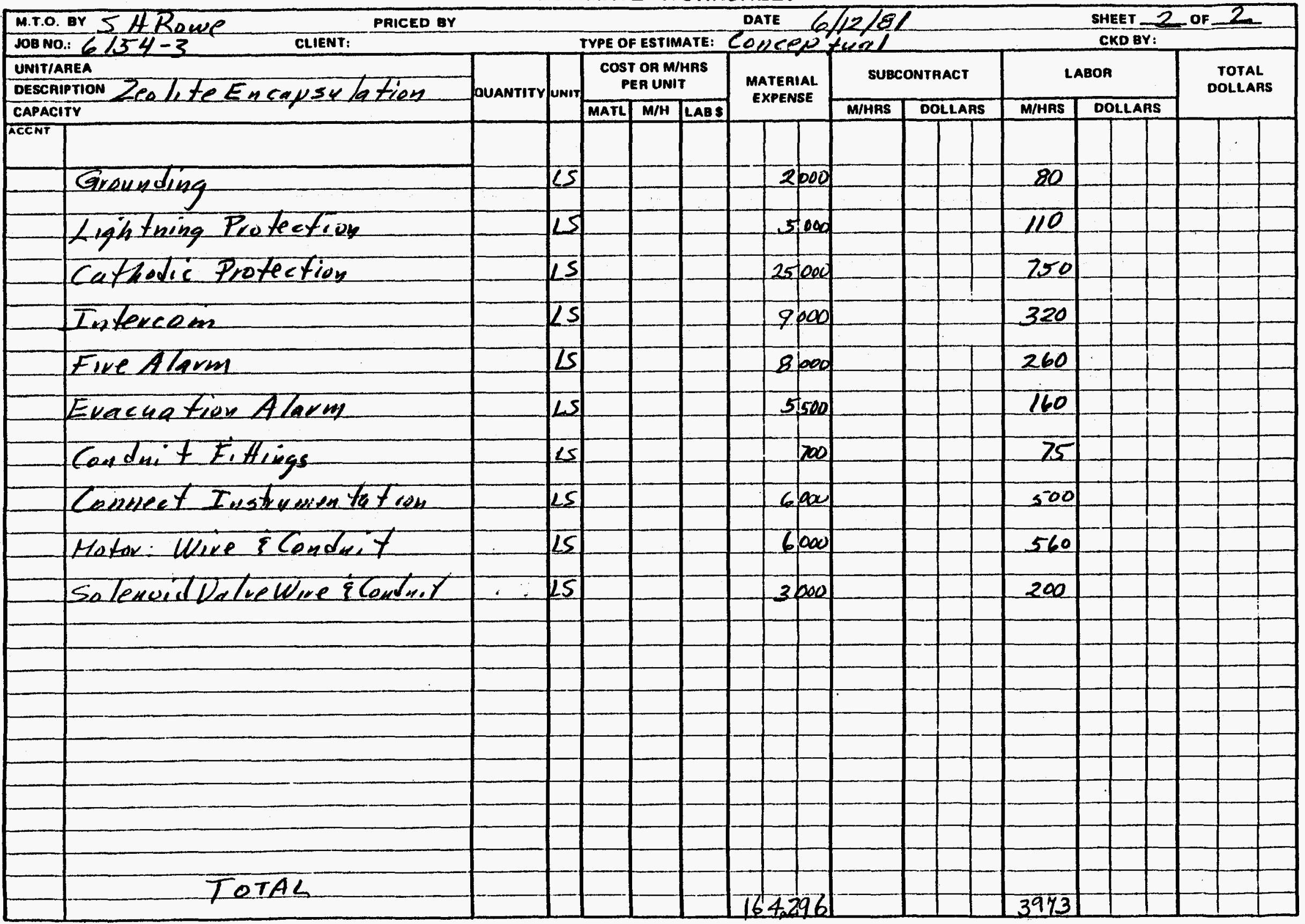


THE RALPH M. PARSONS COMPANY

ESTIMATE WORKSHEET

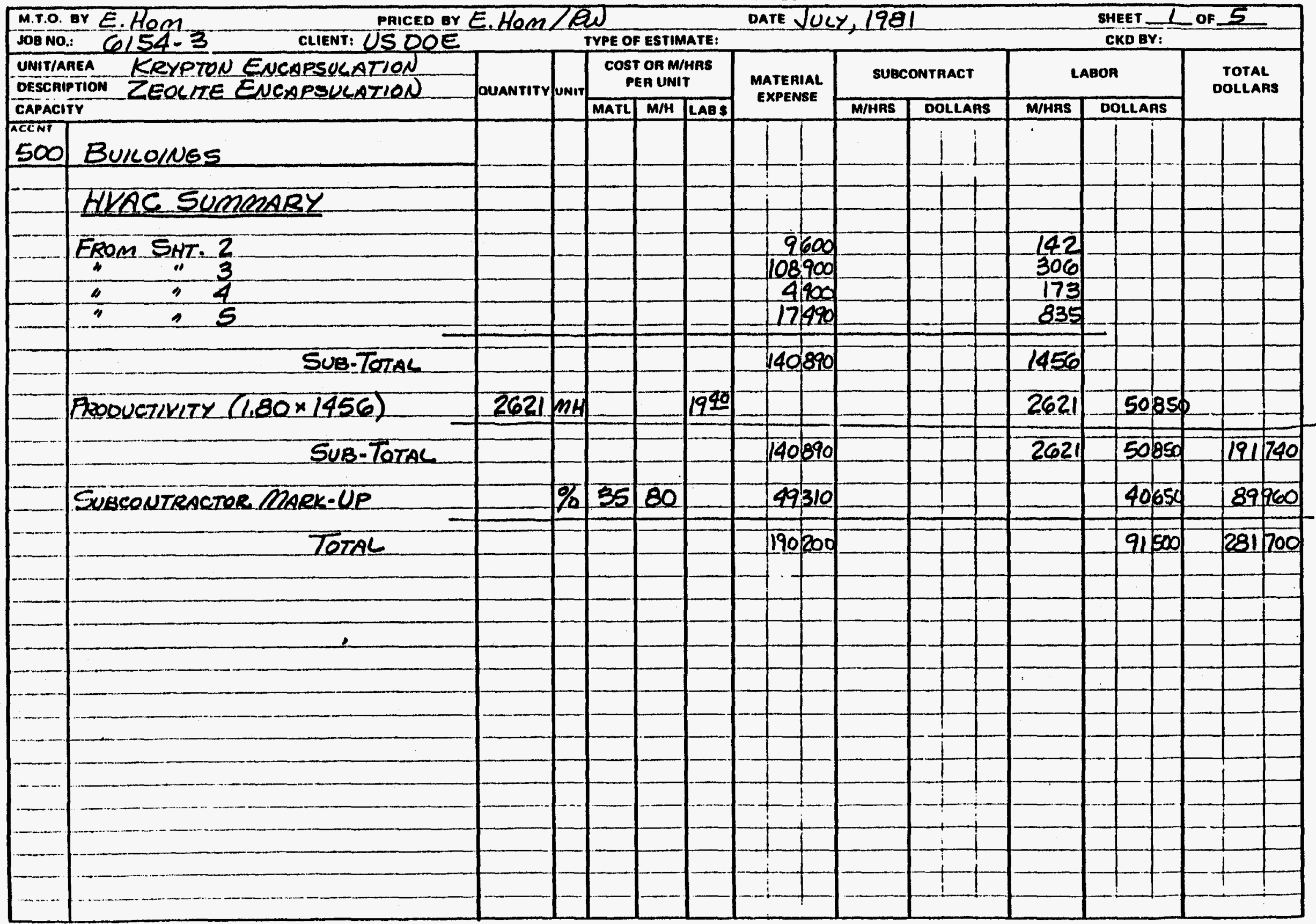


THE RALPH M. PARSONS COMPANY

ESTIMATE WORKSHEET

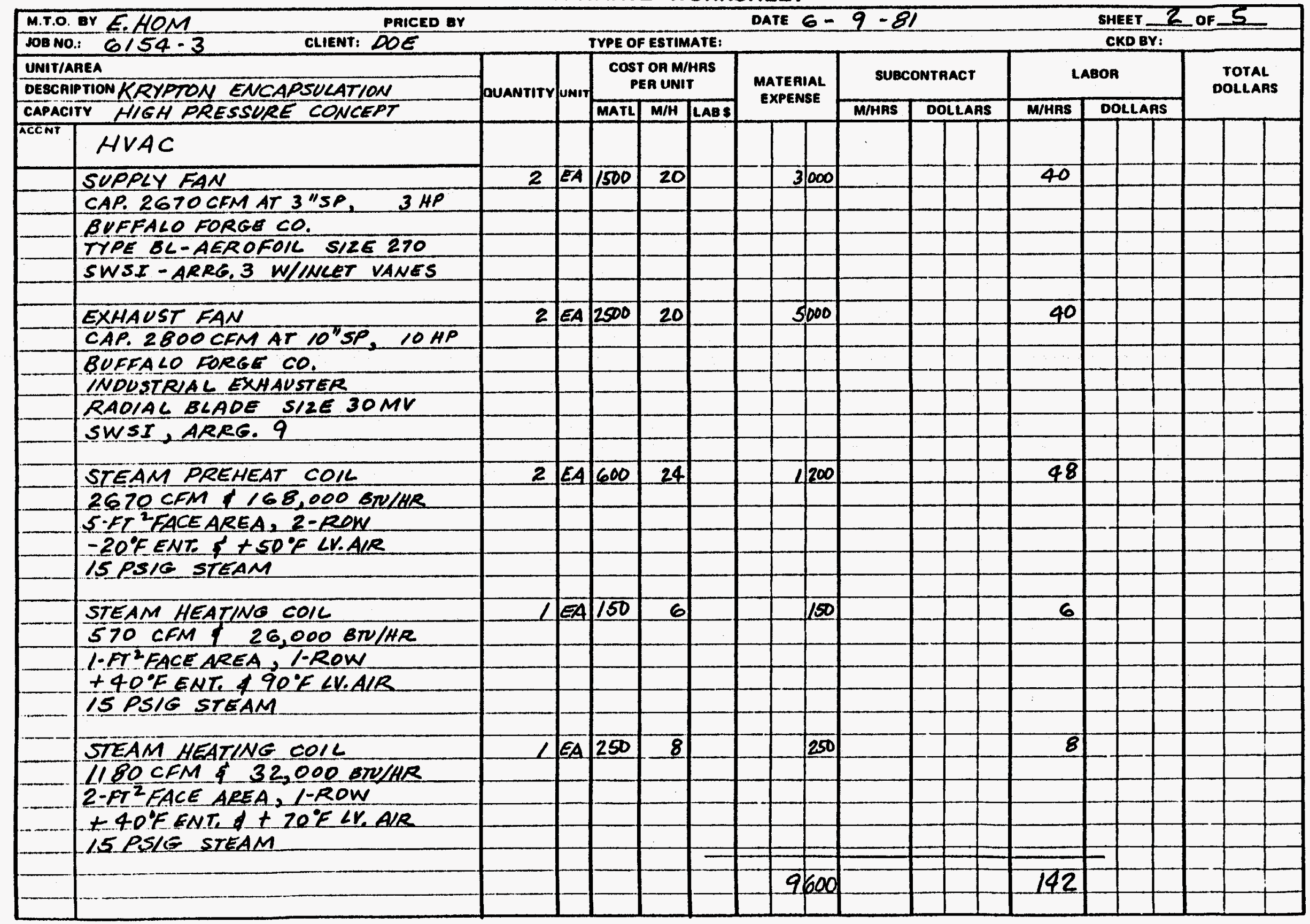


THE RALPH M. PARBONS COMPANY

ESTIMATE WORKSHEET

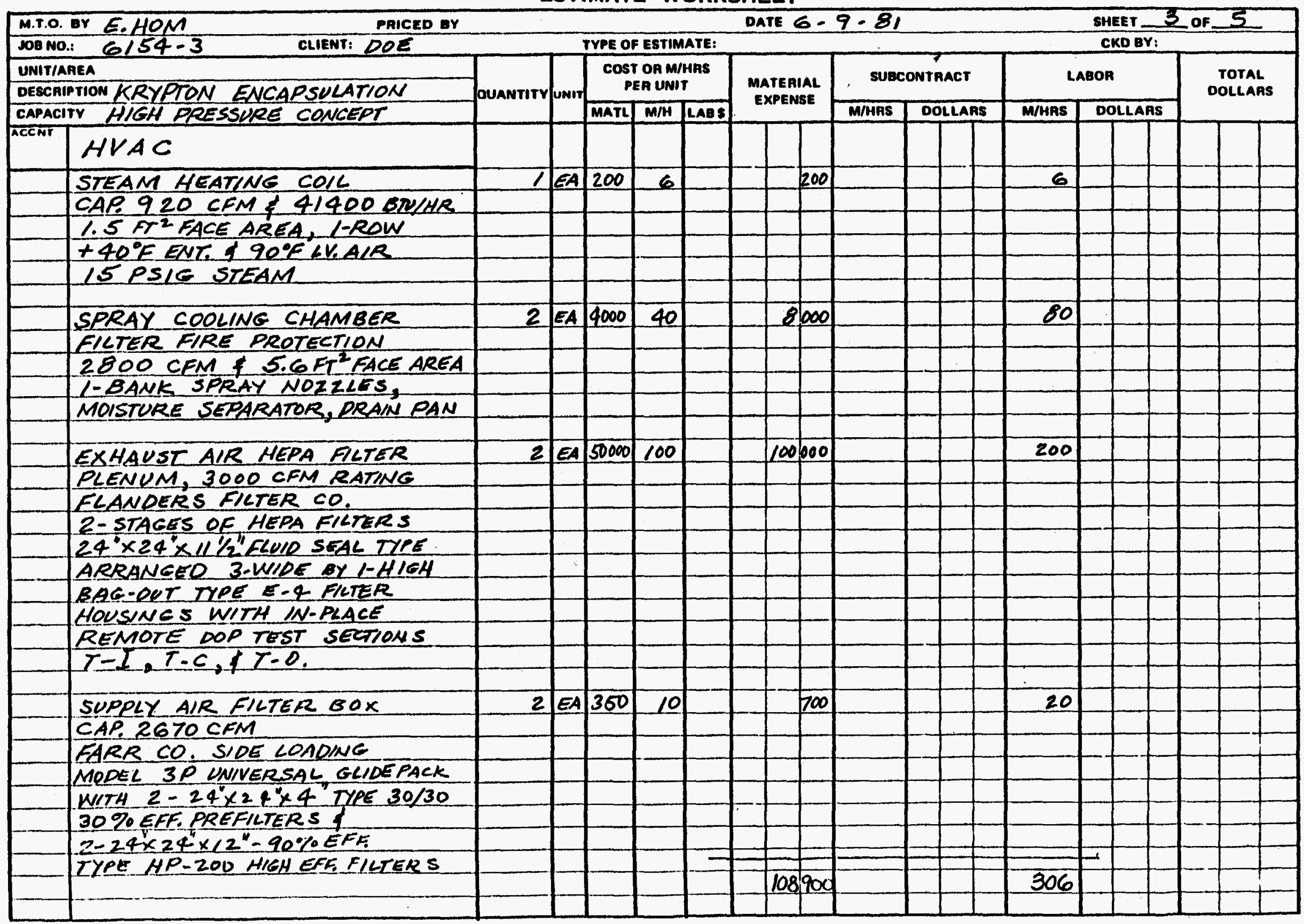


THE RALPH M. PARBONS COMPANY

ESTIMATE WORKSHEET

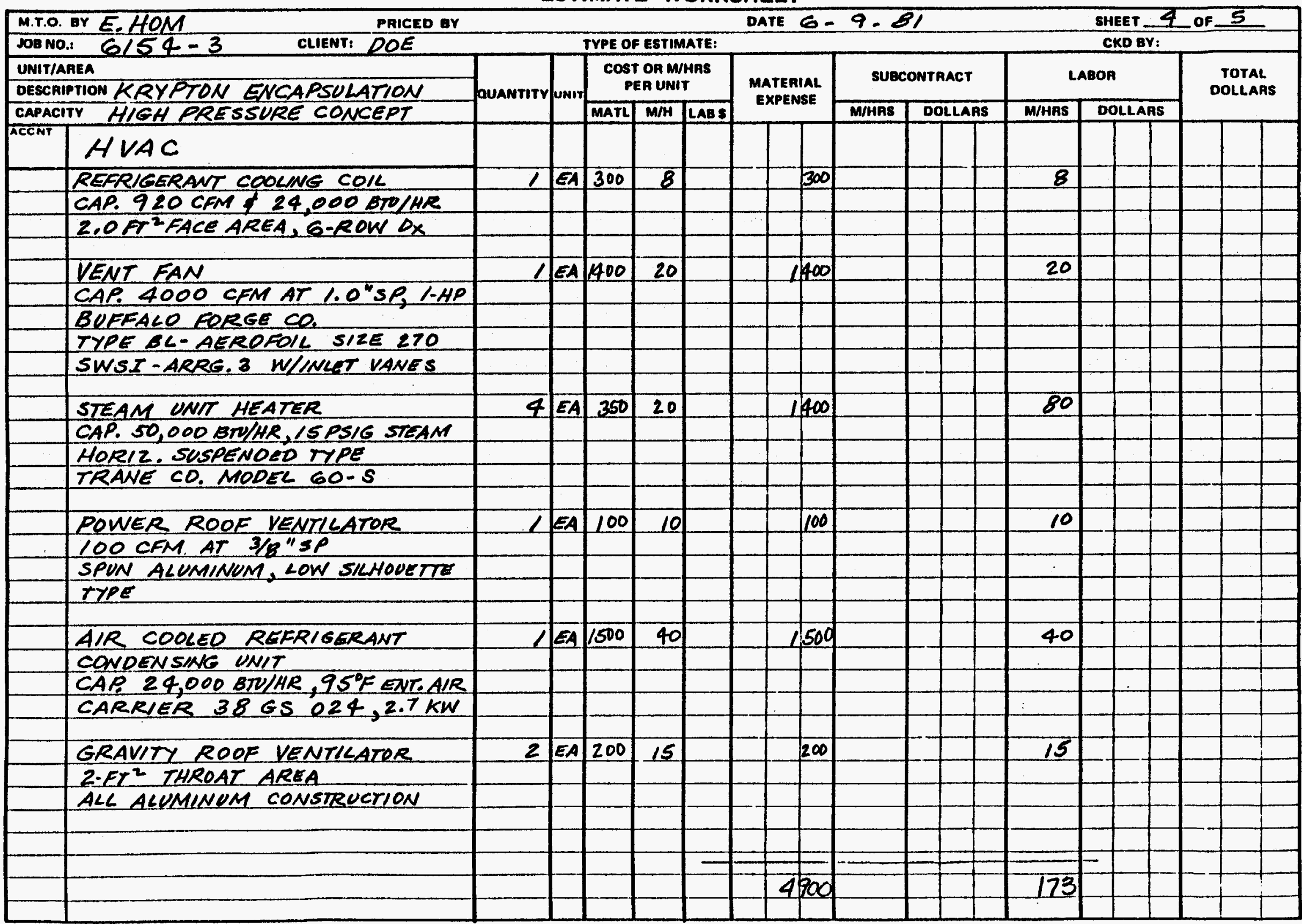




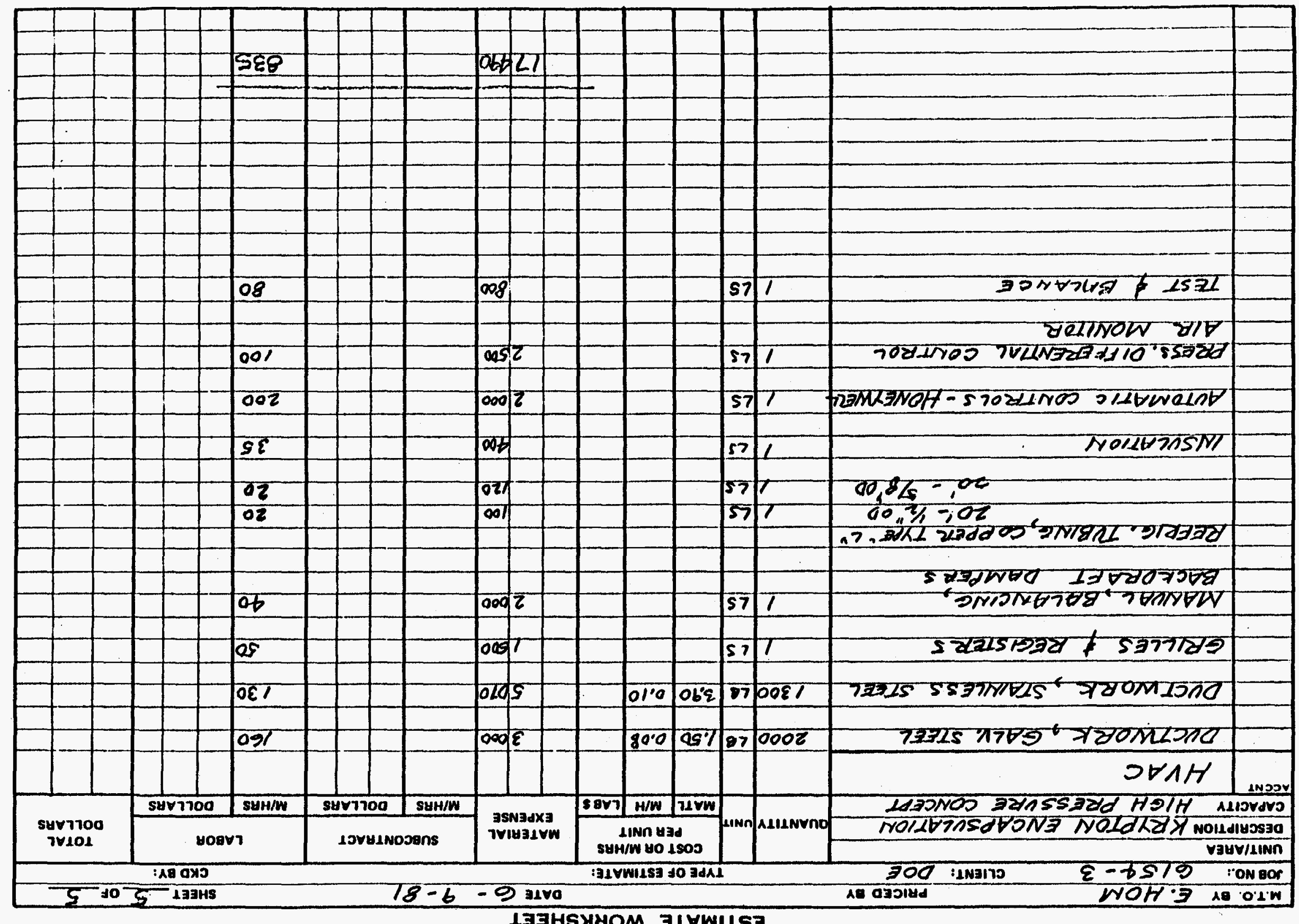

ANYdWOS SNOSUYA 'W MdTVY 3HL 
THE RALPH M. PARSONS COMPANY

ESTIMATE WORKSHEET

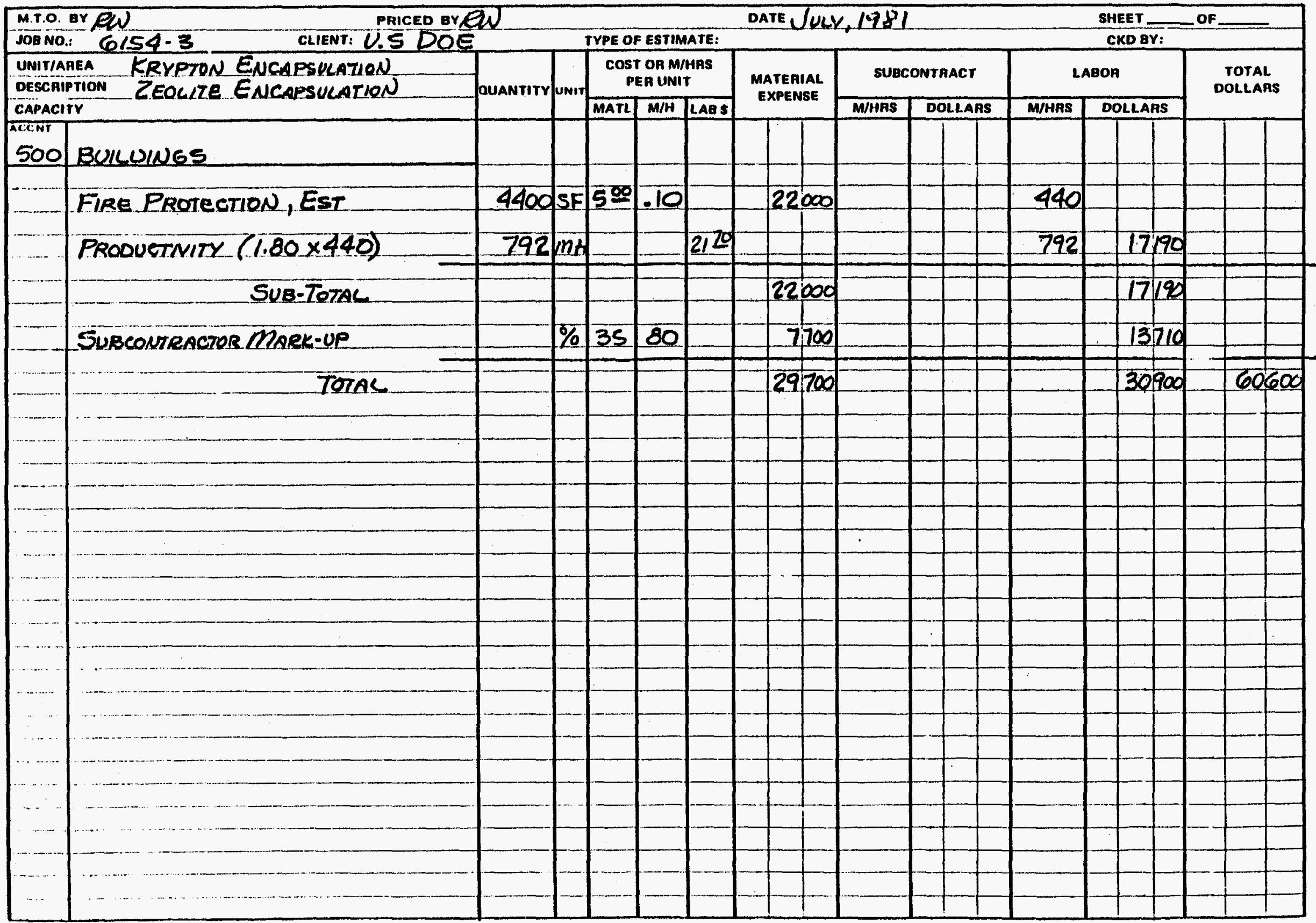


THE RALPH M. PARSONS COMPANY

ESTIMATE WORKSHEET

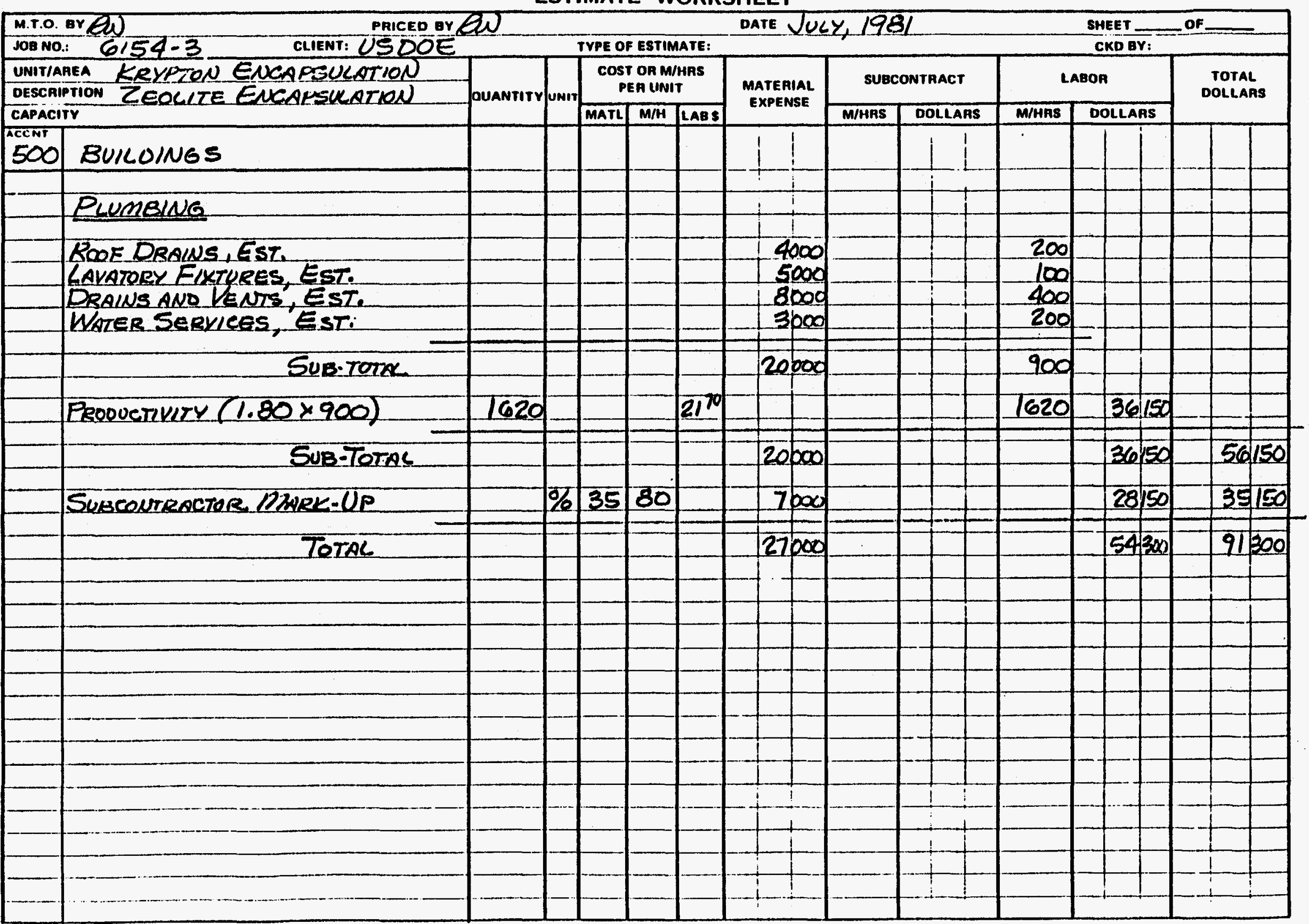




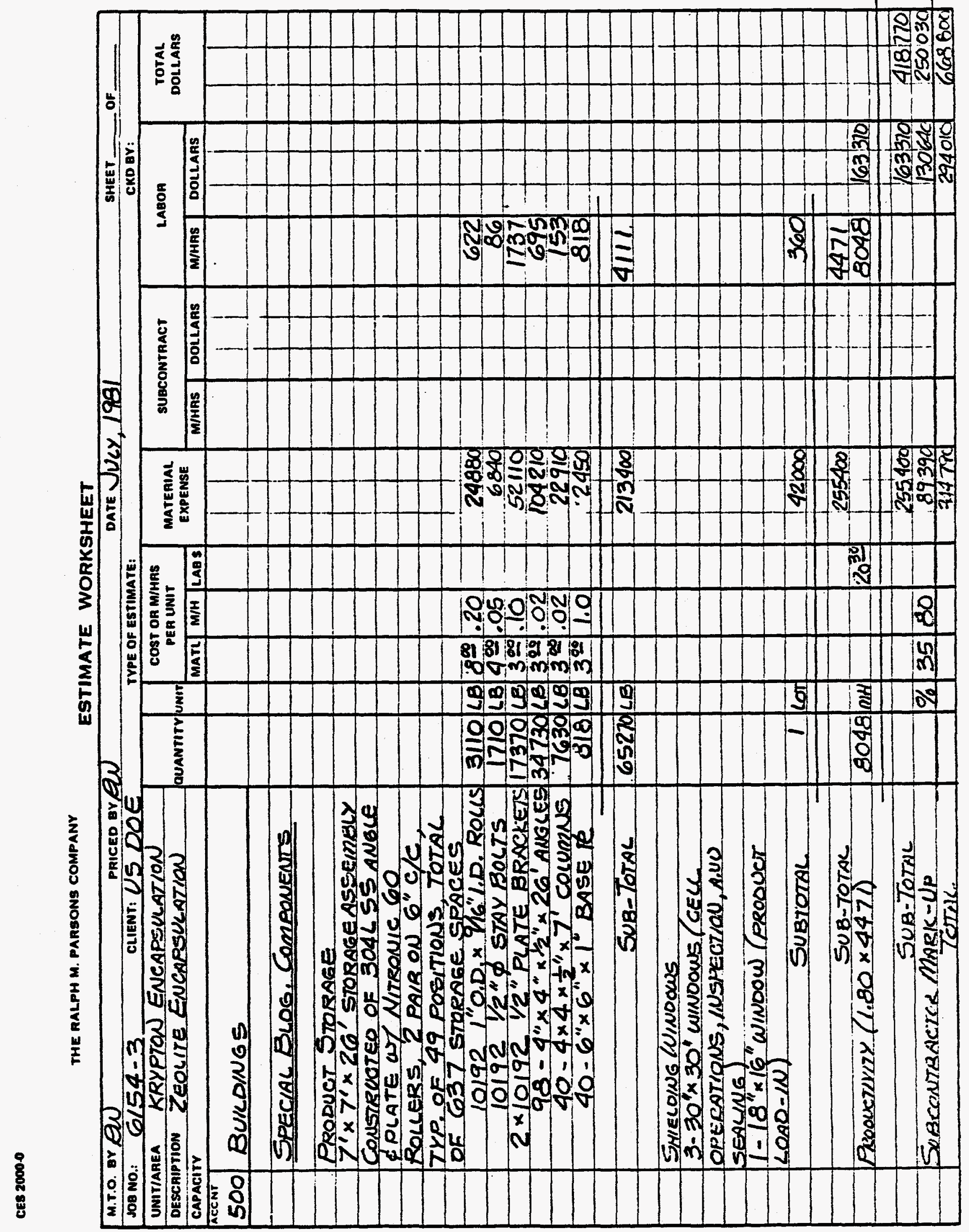




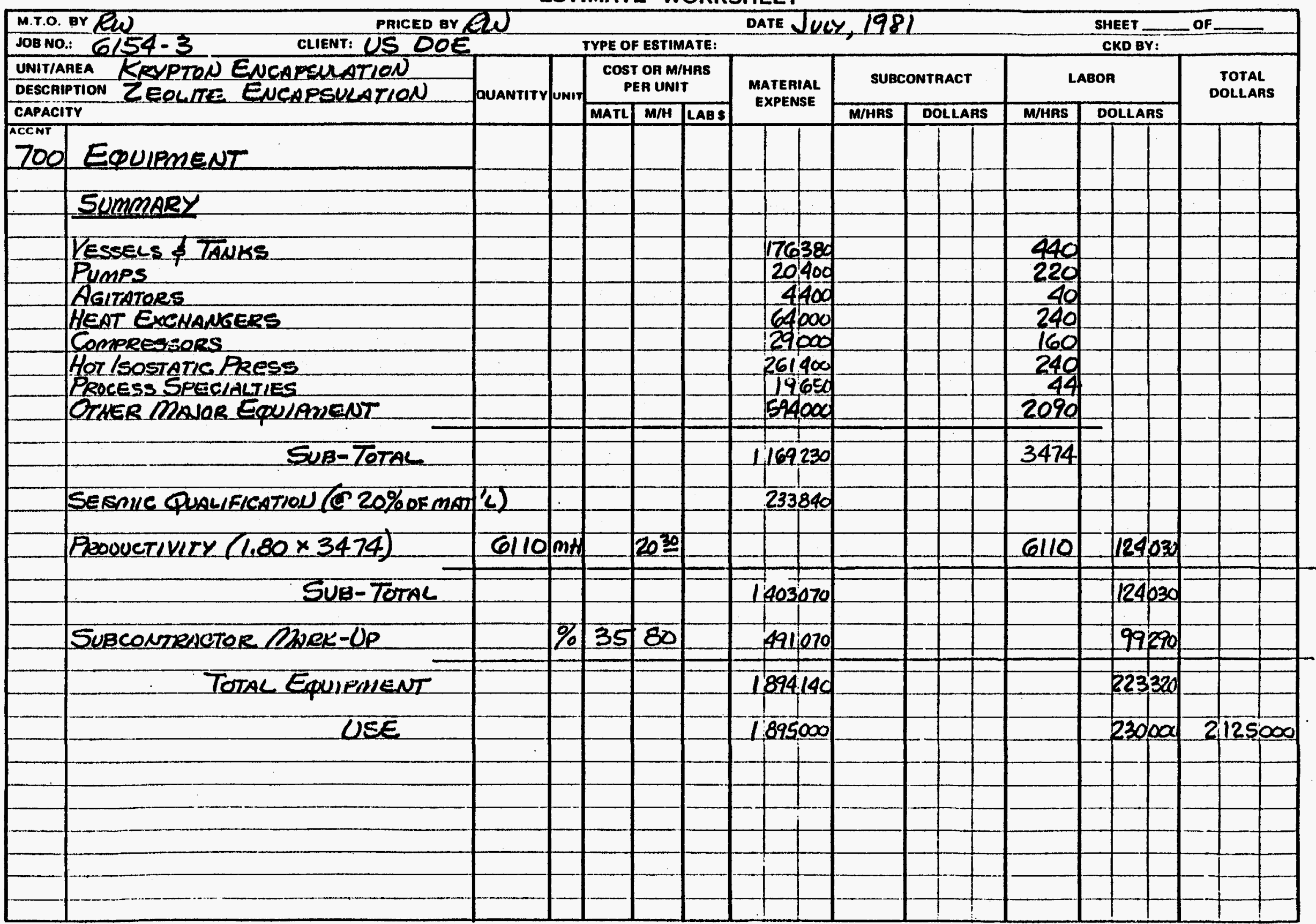




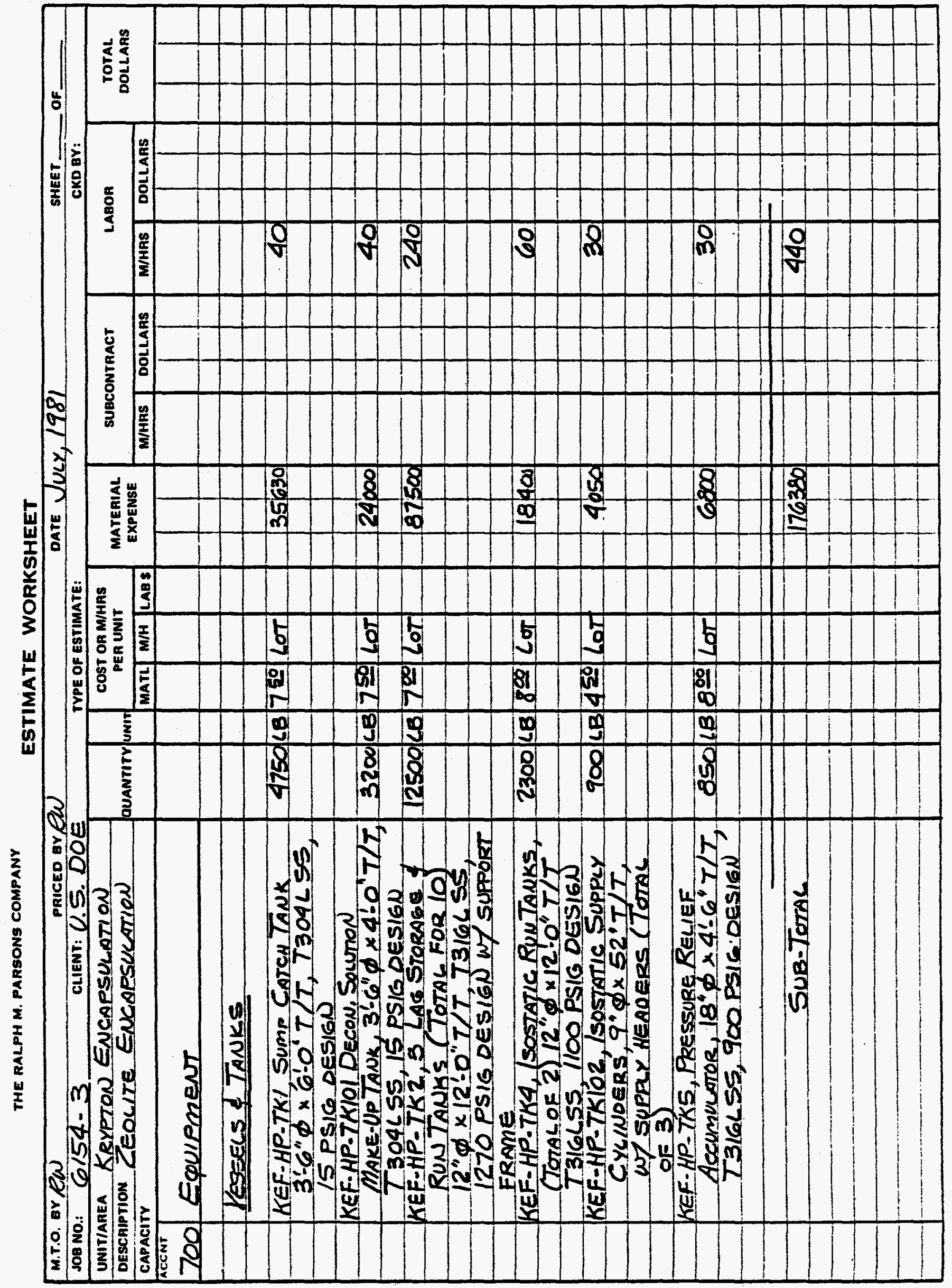


$\sqrt{2}$

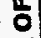

H

$\stackrel{8}{\circ}$

จ

ลู

จ

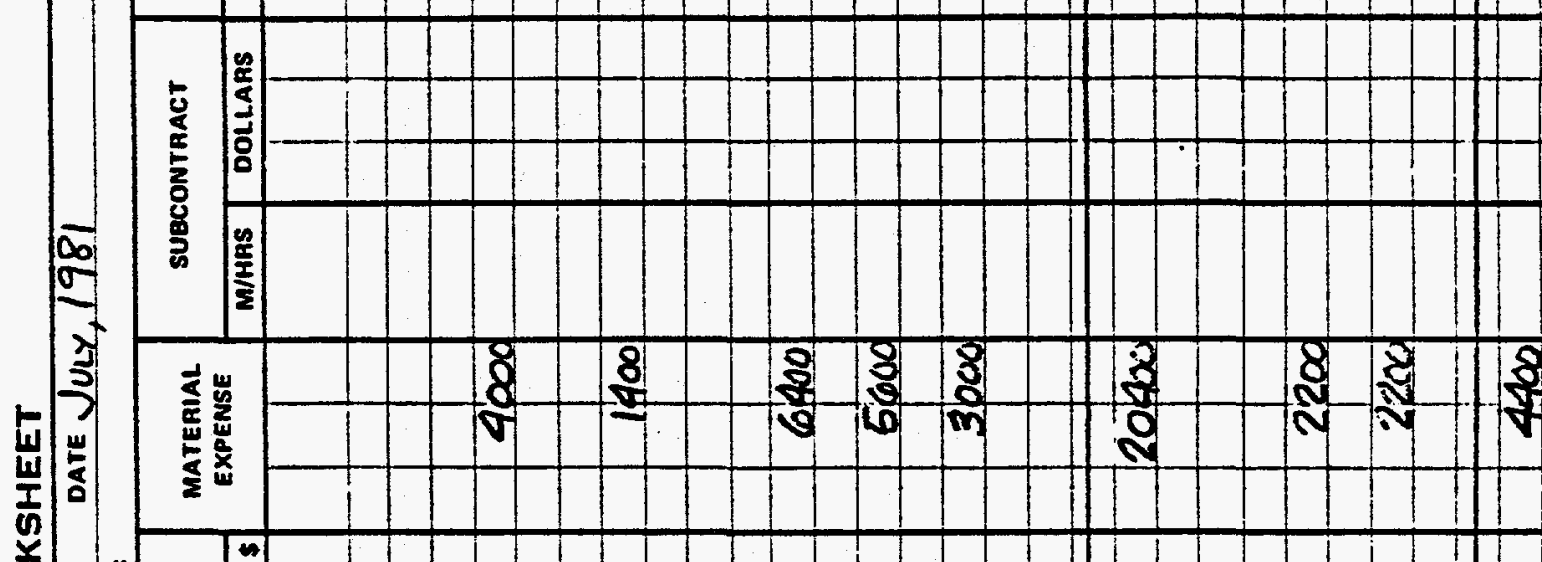

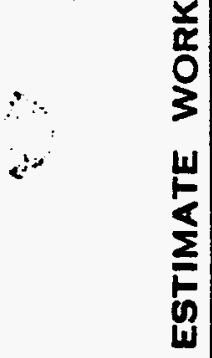

竞

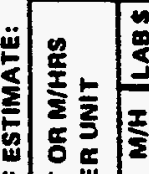

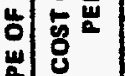

柆

高

จ

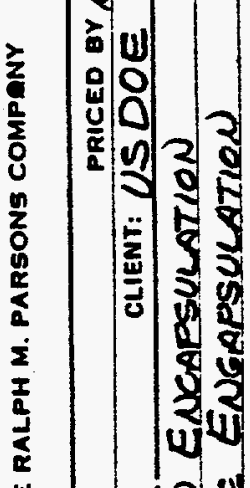

岂

7 m 3

m.

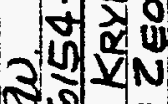

Qง z

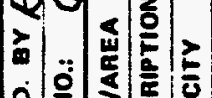

音

๑

ก

จ

\begin{tabular}{|l|l|l|}
\hline 8 & 8 \\
\hline 8 & 0 \\
\hline
\end{tabular}

$-1 \mathrm{~N}$

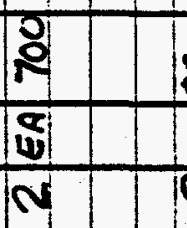

每

8

क्षै

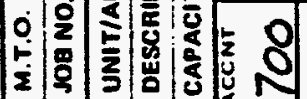

ำํำ

ơn

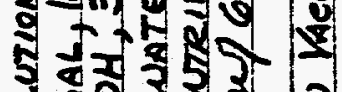

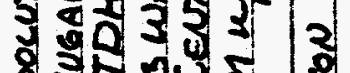

4) 북원

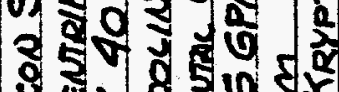

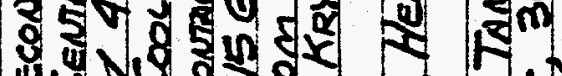

u vo a a

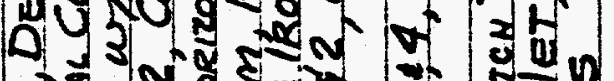

0.5

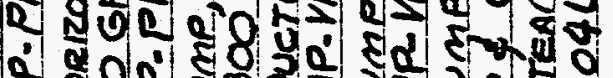

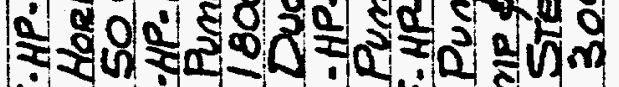

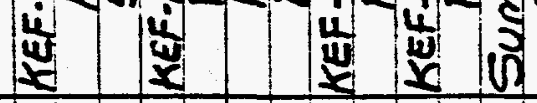

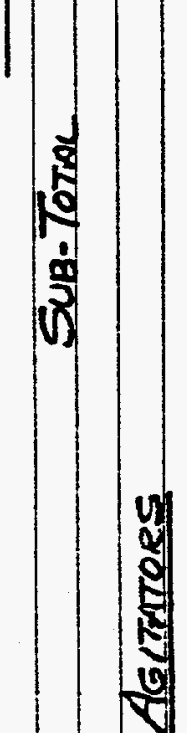

용

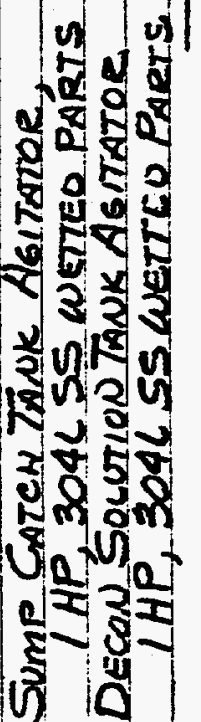




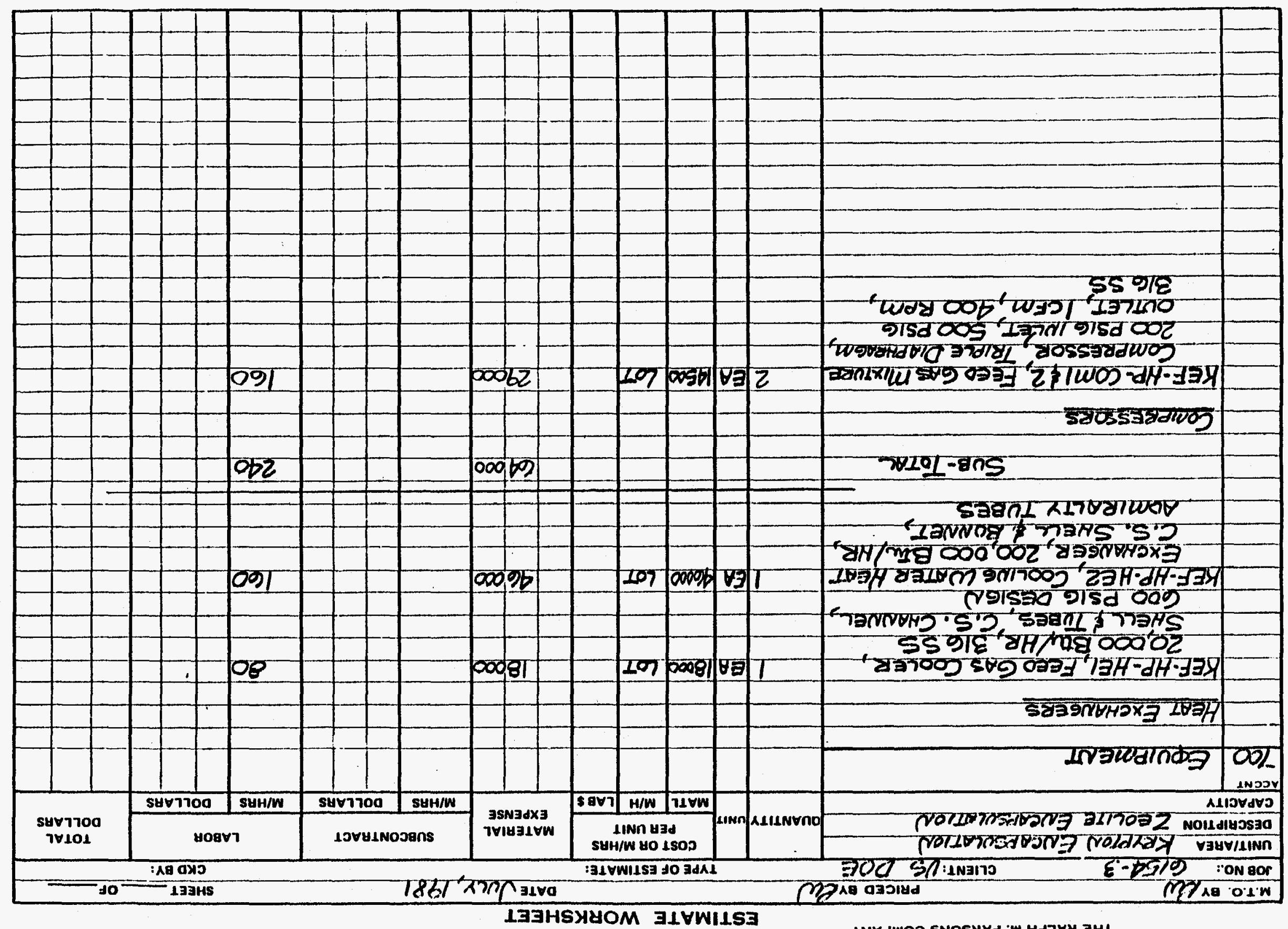

ANYdWOZ SNOSUYd 'W HdרY\& $3 H \perp$ 


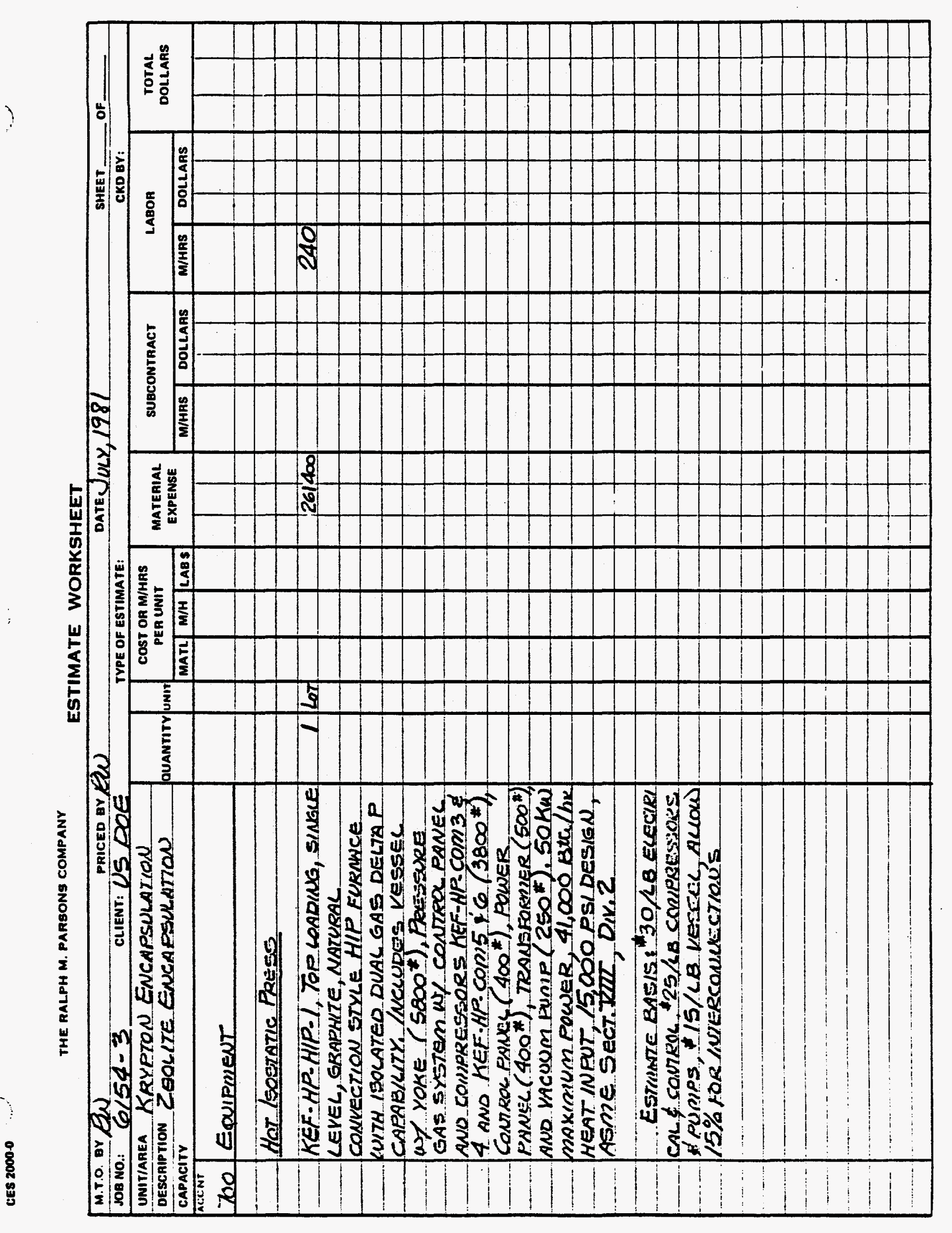




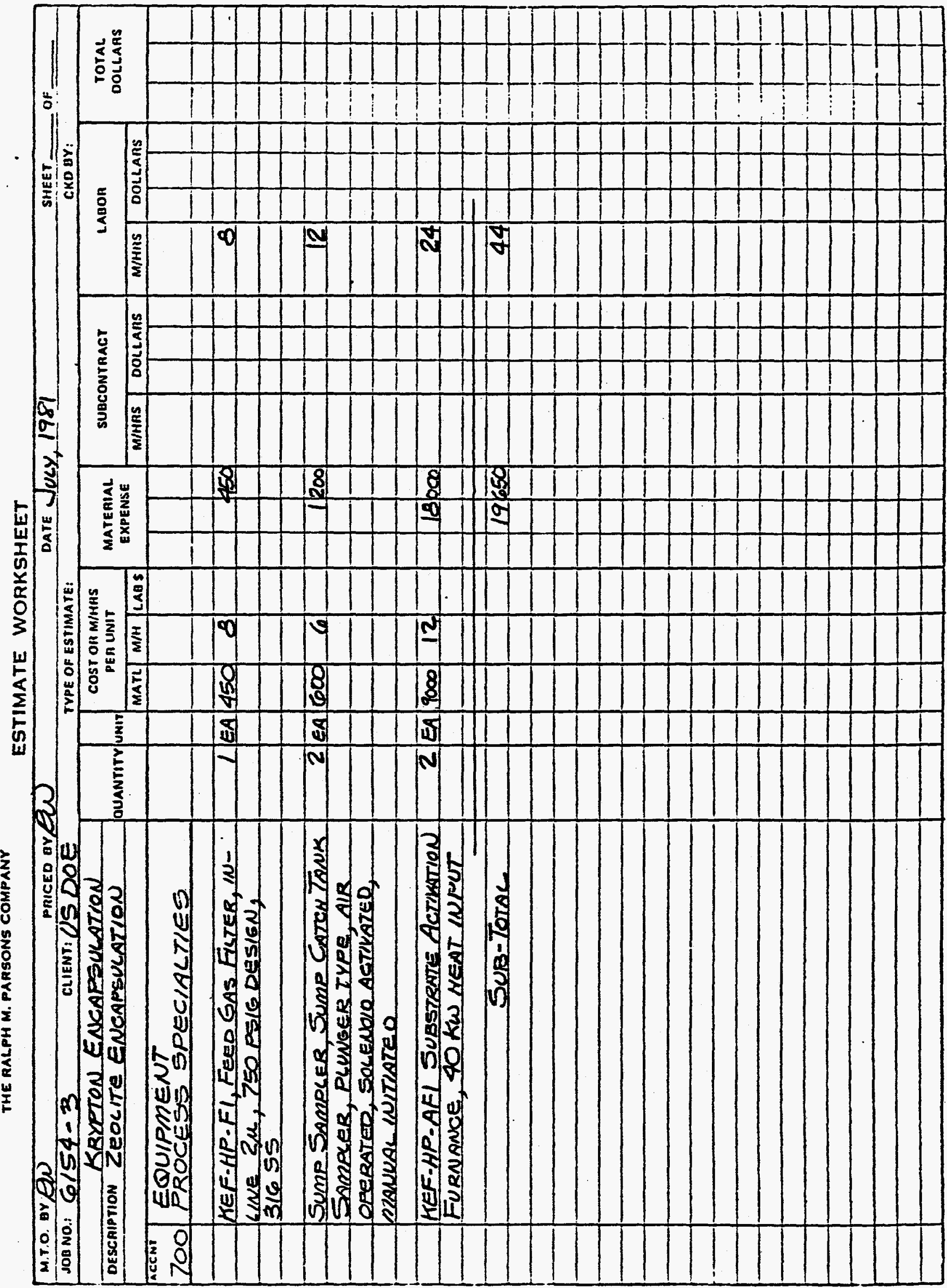


THE RALPH M. PARSONS COMPANY

ESTIMATE WORKSHEET

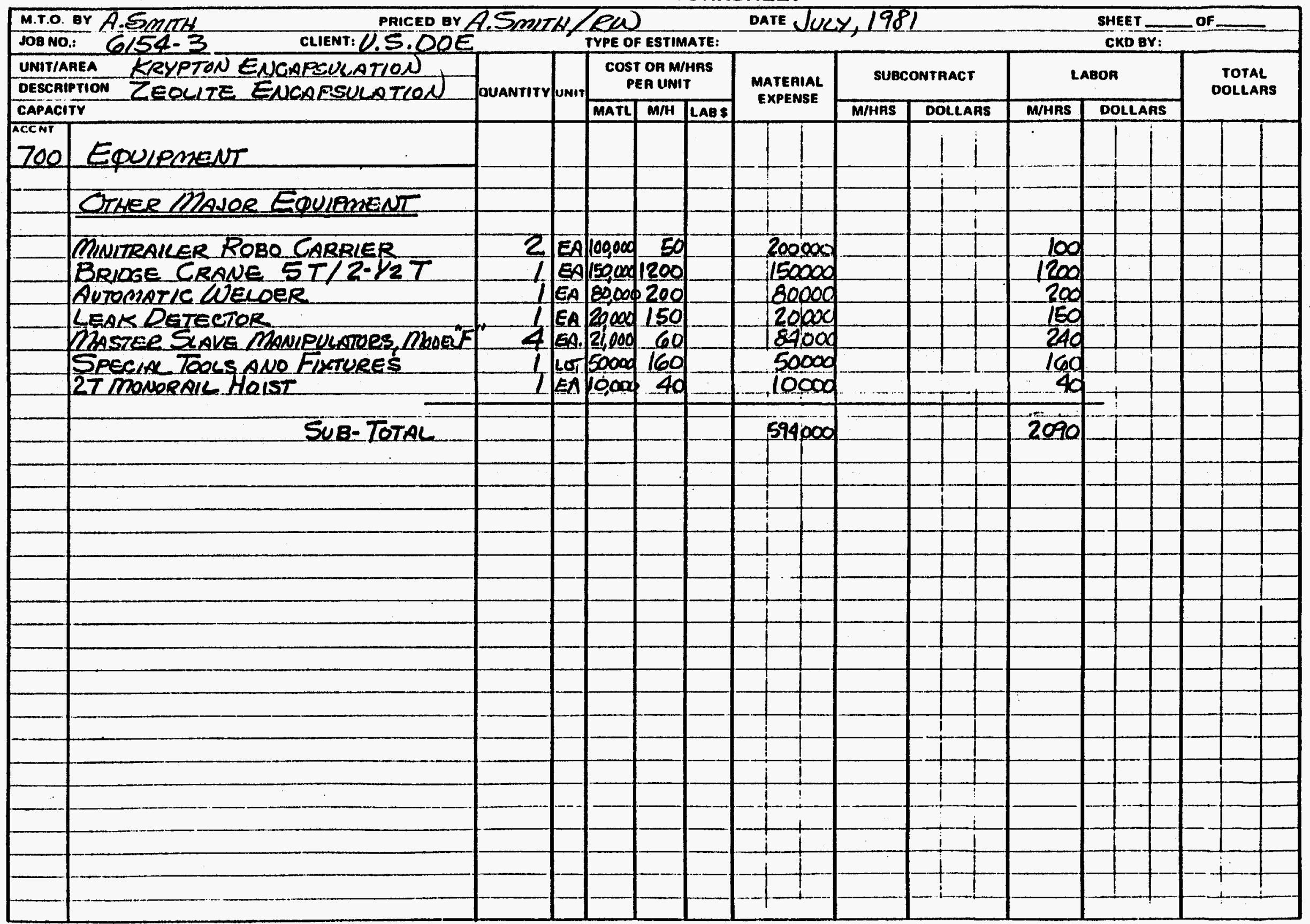

